\author{
Universidade de São Paulo \\ Instituto de Física \\ Instituto de Química \\ Instituto de Biociências \\ Faculdade de Educação
}

\title{
A CIÊNCIA COMPLEXIFICANDO O CONHECIMENTO COTIDIANO: UMA INTERVENÇÃO NA ESCOLA PÚBLICA
}

\author{
Patricia Weishaupt Bastos
}

Orientador: Prof. Dr. Cristiano Rodrigues de Mattos

São Paulo

2011 


\author{
Universidade de São Paulo \\ Instituto de Física \\ Instituto de Química \\ Instituto de Biociências \\ Faculdade de Educação
}

\title{
A CIÊNCIA COMPLEXIFICANDO O CONHECIMENTO \\ COTIDIANO: UMA INTERVENÇÃO NA ESCOLA \\ PÚBLICA
}

\section{Patricia Weishaupt Bastos}

Orientador: Prof. Dr. Cristiano Rodrigues de Mattos

Tese de doutorado apresentada ao Instituto de Física, ao Instituto de Química, ao Instituto de Biociências e a Faculdade de Educação da Universidade de São Paulo para obtenção do título de Doutor em Ensino de Ciências. 
FICHA CATALOGRÁFICA

Preparada pelo Serviço de Biblioteca e Informação

do Instituto de Física da Universidade de São Paulo

\section{Bastos, Patricia Weishaupt}

A ciência complexificando o conhecimento cotidiano: uma intervenção na escola pública - São Paulo, 2011.

Tese (Doutorado) - Universidade de São Paulo.

Faculdade de Educação, Instituto de Física, Instituto de

Química e Instituto de Biociências

Orientador: Prof. Dr. Cristiano Rodrigues de Mattos

Área de Concentração: Ensino de Ciências

Unitermos: 1.Complexidade; 2. Interdisciplinaridade; 3. Ensino

(Física) ; 4. Educação Física; 5. Escola Pública (Intervenção). 
Dedico este trabalho:

Aos meus pais

Shizg Antonio Bastos

e

Minian Helfenstens Weishaupt Bastos

Sou grata pelo apoio e incentivo.

Amo vocês. 


\section{Agradecimentos}

Para Aquele, que é onisciente, onipresente e onipotente, que conhece minha vida no mais íntimo, a quem acredito sem hesitar, a Deus.

Para aqueles, que buscam me proporcionar sempre o melhor desde que nasci, que não se afastaram de mim em nenhum instante, sempre me incentivando, mesmo que para isso precisassem abdicar de seus sonhos, aos meus pais.

Para aquele, que com seu sorriso, descontração e às vezes teimosia, me fez tentar suavizar estes anos de dedicação aos estudos, ao meu irmão.

Para aquele, que me ensinou os caminhos de como desenvolver uma pesquisa com seriedade e confiança, que sempre esteve pronto para me atender e orientar, abdicando inúmeras vezes de seus compromissos diários importantes, com intuito de atingir o melhor, ao meu mestre Prof. Dr. Cristiano.

Para aquele, que mesmo atrás do "palco", sem entender o significado de um título de doutorado, intercedeu incansavelmente em orações a Deus a meu favor, ao meu avô.

Para aquele, que sempre em momentos de angústia, me fez ponderar e analisar minhas atitudes, me encorajando a prosseguir, ao meu pastor.

Para aqueles, que me apoiaram e com seu companheirismo compartilharam de angústias, alegrias, comemorações, etc., me auxiliando nesta jornada, aos meus queridos professores, colegas e amigos.

Meus agradecimentos sinceros, a todos que me apoiaram e me incentivaram direta ou indiretamente para concretização de mais este sonho. 


\section{RESUMO}

BASTOS, P. W. A ciência complexificando o conhecimento cotidiano: uma intervenção na escola pública, 2011, 400 f. Tese (Doutorado). Instituto de Física, Instituto de Química, Instituto de Biociências e Faculdade de Educação. Universidade de São Paulo, São Paulo, 2011.

Neste trabalho mostramos que os conhecimentos da física podem ser utilizados como critérios para uma vida saudável. Isto se dá pela complexificação dos conhecimentos cotidianos com os conhecimentos da física, biomecânica e educação física para prática esportiva.

Para construir um processo de ensino-aprendizagem, em um contexto interdisciplinar, que resultasse no uso do conhecimento físico como um critério de decisão para uma vida saudável, elaboramos um conjunto de atividades de multiabordagens com base nos ciclos de aprendizagem de Lawson em suas três fases: exploração, introdução do conceito e aplicação do conceito. Um dos principais objetivos dessas atividades é possibilitar que os estudantes entendam que a prática esportiva não é sinônimo de saúde.

Os resultados obtidos após o desenvolvimento e aplicação das atividades em duas Escolas Estaduais de Ensino Médio do interior de São Paulo indicam uma complexificação do conhecimento cotidiano, por meio da apropriação de um conhecimento interdisciplinar, que antes não era identificado. Os resultados nos remeteram a importância da complexificação do conhecimento cotidiano com o conhecimento científico como forma de compreensão do seu papel na vida dos estudantes.

Palavras-chave: complexidade, interdisciplinaridade, ensino (física), educação física, escola pública (intervenção). 


\begin{abstract}
BASTOS, P. W. The science complicating the quotidian knowledge: an intervention in a public school, 2011, 400 f. Tese (Doutorado). Instituto de Física, Instituto de Química, Instituto de Biociências e Faculdade de Educação. Universidade de São Paulo, São Paulo, 2011.

In this work we show that the physics knowledge can be used as criteria for a healthy life. This goal is achieved trough complexification of the quotidian knowledge with the knowledge of physic, biomechanics and physical education for sports practice.

To build a teaching-learning process within a interdisciplinary context resulting the use of the Physics knowledge as a decision criteria for a healthy life, we planned a collection of activities based on Lawson learning cycles, using its three phases: exploration, concept introduction and concept application. One of the main objectives of these activities is allow students to know and to understand that the practice of sports is not synonymous of health.

The results we obtained after the development and the application of activities at two public high schools of São Paulo, indicated a complexification of the quotidian knowledge, through the appropriation of an interdisciplinary knowledge, which was not identified before. The results drove us to the importance of the quotidian knowledge complexification with the scientific knowledge as a way of understanding the usefulness of those subjects in students' daily life.
\end{abstract}

Keywords: complexity, interdisciplinary, teaching (physics), physical education, public school (intervention). 


\section{SUMÁRIO}

\section{Capítulo 1}

1. Introdução.

1.1. Importância da pesquisa 1

1.2. Definição do problema de pesquisa 5

1.3. Objetivo da pesquisa 11

\section{Capítulo 2}

2. Referencial teórico...................................................................................................... 13

2.1. Perfil conceitual 14

2.2. Complexificação e interdisciplinaridade 21

2.3. Pesquisa participante 27

\section{Capítulo 3}

3. Desenho de Pesquisa............................................................................................... 31

3.1.Visão geral da Pesquisa 31

3.2. Descrição da amostra 32

3.2.1. Descrição geral da amostra 33

3.2.2. Descrição detalhada da amostra 36

3.3. Pesquisadora professora 38

3.4. Questionários Preliminares 39

3.4.1. Questionário $\mathrm{Q}_{0} \quad 40$

3.4.2. Questionário $\mathrm{Q}_{1} \quad 42$

3.4.3. Questionário $\mathrm{Q}_{2}$

3.5. Construção da intervenção 45

3.5.1. PCN e Currículos 47

3.5.2. Atividades curtas de multi-abordagem e a complexificação do 52 conhecimento

3.5.3. Ciclos de Lawson 55

3.5.3.1. As fases do ciclo $\quad 56$

3.5.4. Atividade-Piloto 60

3.5.5. Intervenção e Atividade avaliatória 64

3.5.6. Plano de aula: Caderno do aluno de física + intervenção 68

3.6. Aplicação da Atividade piloto 73

3.6.1. Entraves no processo de aplicação da atividade piloto 75

3.7. Aplicação da Intervenção e da atividade avaliatória 76

3.7.1. Dificuldades apresentadas pela professora na aplicação da 79 intervenção

3.8. Coleta do diário de bordo $\quad 82$

3.8.1. Atividade piloto $\quad 82$

3.8.2. Intervenção 83

3.9. Validação da Pesquisa 84 


\section{Capítulo 4}

4. Análise de dados...................................................................................................... $\quad 88$

4.1. Respostas aos questionários preliminares $\quad 89$

4.2. Análise da Atividade piloto $\quad 99$

4.3. Análise da Intervenção 113

4.3.1. Categorização 116

$\begin{array}{ll}\text { 4.3.2. Turma } 1^{\circ} \mathrm{A}_{2} & 121\end{array}$

4.3.3. Turma $1^{\circ} \mathrm{B}_{2} \quad 141$

4.3.4. Turma $1^{\circ} \mathrm{C}_{2} \quad 159$

4.3.5. Turma $1^{\circ} \mathrm{D}_{2} \quad 175$

4.4. Reflexões: professora-pesquisadora 192

$\begin{array}{ll}\text { 4.5. Análise ao questionário de validação } & 194\end{array}$

$\begin{array}{ll}\text { 4.5.1. Turma } 1^{\circ} \mathrm{A}_{3} & 194\end{array}$

$\begin{array}{ll}\text { 4.5.2. Turma } 1^{\circ} \mathrm{B}_{3} & 201\end{array}$

4.5.3. Turma $1^{\circ} \mathrm{C}_{3} \quad 209$

4.5.4. Turma $1^{\circ} \mathrm{D}_{3} \quad 215$

4.6. Análise Final 220

4.6.1. Complexidade 220

4.6.2. Considerações preliminares sobre as ordens de aprendizado 227

4.6.3. Novos caminhos para pesquisa sobre complexificação do 228

conhecimento

\section{Capítulo 5}

5. Considerações finais......................................................................................... 233

5.1. Conclusão da pesquisa 235

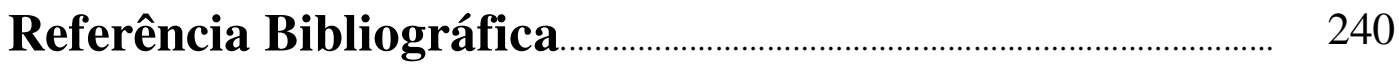

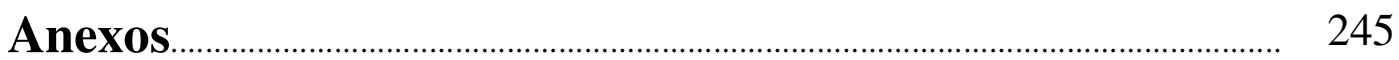




\section{SUMÁRIO - TABELAS}

\section{Capítulo 3}

3.1. Esquema do desenho de pesquisa 31

3.2. Identificação das amostras $\quad 35$

3.3. Relatos informais de alguns docentes da escola M 37

3.4. Questionário $\mathrm{Q}_{0} \quad 41$

3.5. Questionário $\mathrm{Q}_{1} \quad 43$

3.6. Questionário $\mathrm{Q}_{2} \quad 44$

3.7. Alunos que foram submetidos ao Questionário $\mathrm{Q}_{2}$. 45

3.8. Competências e habilidades do ensino de ciências da natureza (SÃO

PAULO: SE, p.38 - 39, 2008)

3.9. Proposta da disciplina física do Ensino médio (SÃO PAULO: SE, p. 49 - 50, 49

2008): $1^{\mathrm{a}}$ série - Tema: Movimentos: variações e conservações.

3.10. Proposta da disciplina educação física do Ensino médio (SÃO PAULO: SE, 51

p. 53, 2008)

3.11. Atividades piloto $\quad 62$

3.12. O ciclo de Lawson nas atividades $\quad 65$

$\begin{array}{ll}\text { 3.13. Atividades e objetivos } & 65\end{array}$

3.14. Plano de aula $\quad 70$

3.15. Desenho da aplicação da atividade piloto na escola M e G 74

3.16. Atividades dadas e turmas $\quad 75$

3.17. Participação dos alunos $\quad 75$

3.18. Questões de comparação das atividades A (Anexo $A_{3}$ - intervenção). 77

3.19. Questões de comparação das atividades $B$ (Anexo $A_{3}$ - intervenção). 79

3.20. Questionário de Validação para turma $1^{\circ} \mathrm{A}_{3}$ e $1^{\circ} \mathrm{B}_{3} \quad 85$

3.21. Questionário de Validação para turma $1^{\circ} \mathrm{C}_{3}$ e $1^{\circ} \mathrm{D}_{3} \quad 86$

\section{Capítulo 4}

4.1. Exemplos de respostas obtidas na questão 1 - escola G

4.2. Exemplos de respostas obtidas na questão 2 - escola G 89

4.3. Exemplos de respostas obtidas na questão 4 - escola $\mathrm{G} \quad 91$

4.4. : Exemplos de respostas obtidas na questão 5 - escola G 92

4.5. Exemplos de respostas obtidas na questão 6 - escola G. 92

4.6. Exemplos de respostas obtidas na questão 7 - escola pública $\mathrm{G} \quad 93$

4.7. Exemplos de respostas obtidas na escola particular $\mathrm{P} \quad 94$

4.8. Exemplos de respostas obtidas no questionário $\mathrm{Q}_{1} \quad 95$

4.9. Versão final do conjunto de atividades da intervenção 100

4.10. Respostas de algumas questões embutidas nas atividades piloto 103

$\begin{array}{lr}\text { 4.11. Diário de classe } & 122\end{array}$

4.12. Comparação de questões das atividades da intervenção - $1^{\circ} \mathrm{A}_{2}$ - escola $\mathrm{G} \quad 125$

4.13. Graus de complexidade atingidos na turma $1^{\circ} \mathrm{A}$ da escola $\mathrm{G} \quad 133$

4.14. Respostas do $1^{\circ} \mathrm{A}_{2}$ da escola $\mathrm{G}$ para atividade $3 \quad 134$

4.15. Comparação de questões das atividades 1 (antes) e 9 (depois) - $1^{\circ} \mathrm{A}_{2}$ - 135 escola $\mathrm{G}$

4.16. Comparação de questões das atividades 1 e $9-1^{\circ} \mathrm{A}_{2}-$ escola $\mathrm{G}$ 
4.17. Questionário de Opinião das aulas $-1^{\circ} \mathrm{A}_{2}-$ escola $\mathrm{G}$

4.18. Comparação de questões das atividades - $1^{\circ} \mathrm{B}_{2}$ - escola $\mathrm{G} \quad 144$

4.19. Graus de complexidade atingidos na turma $1^{\circ} \mathrm{B}$ da escola $\mathrm{G} \quad 154$

4.20. Respostas do $1^{\circ} \mathrm{B}_{2}$ da escola $\mathrm{G} \quad 155$

4.21. Comparação de questões das atividades 2 e $9-1^{\circ} B_{2}-$ escola $G \quad 155$

4.22. Questionário de Opinião das aulas $-1{ }^{\circ} \mathrm{B}_{2}$ - escola $\mathrm{G} \quad 156$

4.23. Diário de Classe - turma $1^{\circ} \mathrm{C}_{2} \quad 160$

4.24. Comparação de questões das atividades $-1^{\circ} \mathrm{C}_{2}$ - escola $\mathrm{M} \quad 163$

4.25. Graus de complexidade atingidos na turma $1^{\circ} \mathrm{C}_{2}$ da escola $\mathrm{M} \quad 169$

4.26. Respostas do $1^{\circ} \mathrm{C}_{2}$ da escola $\mathrm{M} \quad 170$

4.27 Comparação de questões das atividades 1 e 9 (técnico) $-1^{\circ} \mathrm{C}_{2}$ - escola $\mathrm{M} \quad 171$

4.28. Comparação de questões das atividades 1 e 9 (saúde) $-1^{\circ} \mathrm{C}_{2}-$ escola $\mathrm{M} \quad 171$

4.29. Questionário de Opinião das aulas $-1{ }^{\circ} \mathrm{C}_{2}-$ escola M 172

4.30. Diário de classe $\quad 175$

4.31. Comparação de questões das atividades 1 e $9-1^{\circ} \mathrm{D}_{2}$ - escola $\mathrm{M} \quad 179$

4.32. Graus de complexidade atingidos na turma $1^{\circ} \mathrm{D}$ da escola $\mathrm{M} \quad 186$

4.33. Respostas do $1^{\circ} \mathrm{D}_{2}$ da escola $\mathrm{M} \quad 187$

4.34. Comparação de questões das atividades 1 e 9 (técnico) - $1^{\circ} \mathrm{D}_{2}$ - escola $\mathrm{M} \quad 188$

4.35. Comparação de questões das atividades 1 e $9-1^{\circ} \mathrm{D}_{2}-$ escola $\mathrm{G} \quad 188$

4.36. Questionário de Opinião das aulas $-1^{\circ} \mathrm{D}_{2}-$ escola $\mathrm{G} \quad 190$

4.37. Respostas obtidas no questionário de validação $\mathrm{Q}_{3}$ - turma $1^{\circ} \mathrm{A}_{3} \quad 195$

4.38. Graus de complexidade atingidos na turma $1^{\circ} \mathrm{A}$ da escola $\mathrm{G} \quad 201$

4.39. Respostas obtidas no questionário de validação $\mathrm{Q}_{3}$ - turma $1^{\circ} \mathrm{B}_{3} \quad 202$

4.40. Graus de complexidade atingidos na turma $1^{\circ} \mathrm{B}$ da escola $\mathrm{G} \quad 209$

4.41. Respostas obtidas no questionário de validação $\mathrm{Q}_{3}$ - turma $1^{\circ} \mathrm{C}_{3} \quad 211$

4.42. Graus de complexidade atingidos na turma $1^{\circ} \mathrm{C}$ da escola $\mathrm{M} \quad 215$

4.43. Respostas obtidas no questionário de validação $\mathrm{Q}_{3}$ - turma $1^{\circ} \mathrm{D}_{3} \quad 216$

4.44. Graus de complexidade atingidos na turma $1^{\circ} \mathrm{D}$ da escola $\mathrm{M} \quad 220$

4.45. Análise Final nas duas turmas da escola $G \quad 221$

4.46. Graus de complexidade atingidos na turma $1^{\circ}$ A da escola $G \quad 222$

4.47. Graus de complexidade atingidos na turma $1^{\circ} \mathrm{B}$ da escola $\mathrm{G} \quad 223$

4.48. Análise Final nas duas turmas da escola M 224

4.49. Graus de complexidade atingidos na turma $1^{\circ} \mathrm{C}$ da escola $\mathrm{M} \quad 225$

4.50. Graus de complexidade atingidos na turma $1^{\circ} \mathrm{D}$ da escola $\mathrm{M} \quad 225$

4.51. Graus de complexidade das turmas da escola G e M 227

4.52. Ordens de Aprendizado das turmas da escola G e M 227

4.53. Respostas a questão 1 da atividade avaliatória da escola G e M 229 


\section{SUMÁRIO - FIGURAS}

\section{Capítulo 2}

2.1. Figura 2.1: Dimensões relativas à construção do conhecimento escolar partindo da hipótese de integração-enriquecimento (A: se aplica a...; G: gera; R: serve de referência) (GARCIA, 1998, p.23).

\section{Capítulo 3}

3.1.Diagrama dos ciclos de Lawson nas atividades

\section{Capítulo 4}

4.1. Questionário $\mathrm{Q}_{0}$ - Questão 3

4.2. Posições das disciplinas $-1^{\circ}$ ano. 96

4.3. Posições das disciplinas $-2^{\circ}$ ano $\quad 97$

4.4. Posições das disciplinas $-3^{\circ}$ ano 98

4.5. Posições das disciplinas 98

4.6. Posições das disciplinas total dos grupos em $1^{\circ} \mathrm{B}_{1}, 1^{\circ} \mathrm{C}_{1}$ e $1^{\circ} \mathrm{D}_{1}$

4.7. Atividade e frequência da turma $1^{\circ} \mathrm{A}_{2}$

4.8. Posições das disciplinas - turma $1^{\circ} \mathrm{A}_{2} \quad 124$

4.9. Mapa da turma $1^{\circ} \mathrm{A}_{2}$ - feito pelo aluno $\left(32, \mathrm{~A}_{2}\right) \quad 132$

4.10. Mapa da turma $1^{\circ} \mathrm{A}_{2}$ - feito pelo aluno $\left(25, \mathrm{~A}_{2}\right) \quad 133$

4.11. Complexificação do conhecimento de $1^{\circ} \mathrm{A}_{2}$

4.12. Atividade e frequência da turma $1^{\circ} \mathrm{B}_{2} \quad 142$

4.13. Posições das disciplinas - turma $\mathrm{B}_{2} \quad 143$

4.14. Mapa da turma $1^{\circ} \mathrm{B}_{2}$ - feito pelo aluno $\left(37, \mathrm{~B}_{2}\right) \quad 153$

4.15. Mapa da turma $1^{\circ} \mathrm{B}_{2}$ - feito pelo aluno $\left(24, \mathrm{~B}_{2}\right) \quad 153$

4.16. Mapa da turma $1^{\circ} \mathrm{B}_{2}$ - feito pelo aluno $\left(1, \mathrm{~B}_{2}\right) \quad 154$

4.17. Complexificação do conhecimento de $1^{\circ} \mathrm{B}_{2}$

4.18. Atividade e frequência da turma $1^{\circ} \mathrm{C}_{2} \quad 160$

4.19. Posições das disciplinas - turma $\mathrm{C}_{2} \quad 162$

4.20. Mapa da turma $1^{\circ} \mathrm{C}_{2}$ - feito pelo aluno $\left(8, \mathrm{C}_{2}\right) \quad 168$

4.21. Mapa da turma $1^{\circ} \mathrm{C}_{2}$ - feito pelo aluno $\left(31, \mathrm{C}_{2}\right) \quad 169$

4.22. Mapa da turma $1^{\circ} \mathrm{C}_{2}$ - feito pelo aluno $\left(16, \mathrm{C}_{2}\right) \quad 169$

4.23. Complexificação do conhecimento de $1^{\circ} \mathrm{C}_{2} \quad 170$

4.24. Atividade e frequência da turma $1^{\circ} \mathrm{D}_{2} \quad 177$

4.25. Posições das disciplinas - turma $\mathrm{D}_{2} \quad 178$

4.26. Mapa da turma $1^{\circ} \mathrm{D}_{2}$ - feito pelo aluno $\left(4, \mathrm{D}_{2}\right) \quad 185$

4.27. Mapa da turma $1^{\circ} \mathrm{D}_{2}$ - feito pelo aluno $\left(19, \mathrm{D}_{2}\right) \quad 186$

4.28. Complexificação do conhecimento de $1^{\circ} \mathrm{D}_{2} \quad 186$

4.29. Categorização baseado em $\mathrm{Q}_{3}-1^{\circ} \mathrm{A} \quad 201$

4.30. Categorização baseado em $\mathrm{Q}_{3}-1^{\circ} \mathrm{B} \quad 209$

4.31. Categorização baseado em $\mathrm{Q}_{3}-1^{\circ} \mathrm{C} \quad 215$

4.32. Categorização baseado em $\mathrm{Q}_{3}-1^{\circ} \mathrm{D} \quad 220$

4.33. Análise dos graus de complexidade na turma $1^{\circ} \mathrm{A} \quad 222$

4.34. Análise dos graus de complexidade na turma $1^{\circ} \mathrm{B}$ 
4.35. Análise dos graus de complexidade na turma $1^{\circ} \mathrm{C}$

4.36. Análise dos graus de complexidade na turma $1^{\circ} \mathrm{D}$

4.37. Análise das ordens de aprendizados nas turmas da escola G e M 


\section{CAPÍTULO 1}

\section{Introdução}

\subsection{Importância da Pesquisa}

Este trabalho de pesquisa resultou em uma proposta para o ensino de física, com a perspectiva de ser um suporte inovador que auxilie o professor ao ministrar o conteúdo de Mecânica desenvolvido no $1^{\circ}$ ano do Ensino Médio de acordo com o Currículo de Física do Estado de São Paulo (SEE, 2008). Com esta proposta procuramos complementar as situações de aprendizagens contidas no caderno do aluno de física - vol. 1 e $2-1^{\circ}$ ano do Ensino Médio (SEE, 2009), tendo como enfoque o êxito na aprendizagem dos conceitos de mecânica tratados no $1^{\circ}$ semestre do $1^{\circ}$ ano do Ensino Médio.

Esta proposta engloba os conceitos de mecânica da física utilizados na área de biomecânica, com o objetivo de compreender o movimento humano em determinadas habilidades praticadas em algumas modalidades esportivas, que serão explicitadas em um conjunto de nove atividades desenvolvidas para sala de aula.

Esta pesquisa visa fornecer subsídios para atuação do professor em sala de aula, de tal forma que o mesmo possa ter um acompanhamento mais detalhado da aprendizagem dos estudantes por meio da complexificação do conhecimento cotidiano aplicado ao conceito que o professor deseja trabalhar em sala de aula. No caso desta pesquisa, trabalhamos com a complexificação do conhecimento cotidiano de esporte, que será apresentada através de relações interdisciplinares entre física e educação física gradativamente a cada nova atividade inserida durante o $1^{\circ}$ semestre do $1^{\circ}$ ano do ensino médio. Baseado na evolução da complexificação do conhecimento cotidiano de esporte apresentado pelo estudante no decorrer da intervenção, mostramos que é possível o professor verificar a cada atividade proposta em sala de aula o grau de complexificação que o estudante atingiu e cruzar com seus objetivos iniciais, o que permitirá dirigir sua atividade para alcançar o sucesso na aprendizagem. Enfatizamos que também é necessário que o professor analise em suas atividades, se os "recortes" interdisciplinares efetuados possibilitam a complexificação do conhecimento cotidiano desejada. 
Leciono a disciplina de física para o ensino médio na rede pública de ensino do interior do estado de São Paulo desde que conclui o curso de Licenciatura e Bacharelado em física na Universidade Estadual Paulista - campus Rio Claro, há nove anos e durante este período percebi a necessidade de uma constante inovação no ensino de física para que sejam alcançados os objetivos destacados no Currículo do Estado de São Paulo (SEE, 2008).

Com o desejo de contribuir na área de pesquisa do ensino de física, auxiliar meus colegas professores da área para o desenvolvimento dos conteúdos de física nas aulas e propor aos estudantes um contato mais prazeroso com os conteúdos de física, decidi me empenhar no desenvolvimento de algumas atividades que atendam a heterogeneidade da sala de aula e permitam enfocar os conteúdos de física voltados para situações do cotidiano dos estudantes, que resultem em mudança de postura na tomada de decisões. Na criação destas atividades tive o cuidado em respeitar e dar mobilidade ao professor em seguir a sua sequência didática habitual.

São inúmeros os conteúdos de física que poderia escolher. Na minha dissertação de mestrado (BASTOS, 2007) concluída na Universidade de São Paulo, me detive ao tema: poluição sonora, que surgiu pela imensa utilização dos aparelhos de som eletrônicos em altos níveis sonoros na sala de aula pelos estudantes. Com o objetivo de contribuir para que os estudantes tivessem os conhecimentos necessários para obter uma vida auditiva saudável, elaborei algumas atividades para serem desenvolvidas em sala de aula concomitante ao conteúdo de acústica, que estabelecessem relações interdisciplinares entre física, fonoaudiologia e saúde.

Mas, neste trabalho optei pelo tema esporte, pela razão de inúmeras vezes escutar dos alunos que, aprender física na quadra de esportes da escola seria mais divertido. Estava nítido que os estudantes encaravam as aulas de física como enfadonhas, monótonas, etc., precisavam de uma motivação para o aprendizado dos conteúdos de física. Como seria possível compreender a física no cotidiano através do esporte? Confesso que refleti muitas vezes sobre a união de física e esporte, e porque não, física e educação física, mas como? Após intensa busca, me deparei com uma ferramenta poderosa: a biomecânica. Após me dedicar ao estudo da biomecânica através de pesquisas bibliográficas, realização de cursos, etc., foi possível com esforço construir um conjunto de atividades que relacionassem não somente física e biomecânica, mas que incluíssem mesmo que de forma simplificada elementos da educação física e saúde 
(interdisciplinaridade), estas relações e os níveis de interdisciplinaridade utilizados entre elas, serão explicitados adiante.

É importante que os estudantes tenham um primeiro contato bem sucedido com a disciplina de física para superar todos os pré-conceitos equivocados sobre a disciplina e enxerguem sua aplicação no cotidiano.

Este trabalho é relevante para pesquisa em ensino de física, pois enfocamos a aprendizagem em física como um processo de complexificação do conhecimento. Esta complexificação se dá em diferentes estágios, e se inicia quando o sujeito entra em contato com o conteúdo interdisciplinar, por meio da aplicação das atividades que estabelecem relações em níveis de interdisciplinares variados entre física, biomecânica, saúde e educação física.

Este trabalho foi elaborado na expectativa de solucionar, de forma fundamentada na pesquisa, alguns dos diversos problemas escolares que os docentes enfrentam nestes últimos anos ao ministrar a disciplina de física no primeiro ano do ensino médio, além de propiciar mais uma ferramenta para que o professor avalie aluno. Neste sentido, buscamos, nos acontecimentos cotidianos, a identificação de eventos e situações que permitam um ensino de física, mais atrativo, significativo e prazeroso e, ao mesmo tempo, com utilidade vivencial (prática) para o aluno.

Mostraremos que o conhecimento da física pode ser utilizado como um critério para uma vida saudável quando associado aos conhecimentos da educação física (biomecânica) dentro do tema motivador de esporte. Neste sentido, a focalização da realização correta dos movimentos dos atletas para alcançar alta performance é um ponto alto para se evitar lesões. Neste trabalho, ao citar vida saudável, nos referimos a saúde alcançada através da prática adequada de exercícios físicos, esportes que, por consequência, não resultará em lesões corporais.

Não pretendemos discutir em detalhes neste trabalho o conceito de saúde que envolve os aspectos sociais e mentais, ou as várias definições que a permeiam, embora sejam significativamente importantes. Aqui, relacionamos o termo saúde com a ausência de lesões. Fornecemos através do acoplamento de elementos das áreas de física, educação física, biomecânica e saúde, elementos para que os estudantes não visualizem na prática de esportes e exercícios físicos a chave certa para uma vida saudável, mas que saibam dos riscos de lesões devido a sua prática inadequada. Portanto trabalharemos com um conceito reducionista de saúde, pois está mais relacionado à ausência de doenças, especificamente lesões. 
Enfocamos neste trabalho a utilização de conceitos da Mecânica para auxiliar na compreensão do que é a realização correta de um exercício físico ou a prática adequada de um esporte, tendo como instrumento de análise, os movimentos de um atleta de em uma modalidade esportiva qualquer no desenvolvimento de habilidades esportivas. Pretendemos, assim, dar subsídios para que o estudante possa observar "criticamente" o desempenho do atleta em competições e campeonatos e analisá-los levando em consideração a otimização de movimentos corporais. Claro que não pretendemos extinguir as questões "emocionais" de uma competição, seja no preparo dos atletas, seja considerando a torcida que incentiva ou se revolta com o desempenho dos atletas e técnicos. Porém, não vamos nos aprofundar nessa perspectiva.

Nosso trabalho se refere a inserção de conhecimentos de biomecânica que permitam aos estudantes de física, no ensino médio, perceber que os atletas podem melhorar seu desempenho por meio da adequada correção dos seus movimentos.

Entre outras questões, a distinção das funções de técnico e de treinador é um tema que ajuda aos estudantes perceberem a importância dos conhecimentos de biomecânica não somente para quem faz esporte ou realiza exercícios físicos, mas para quem busca auxiliar um atleta ou uma pessoa para melhoria dos movimentos. Com isto, esperamos que os estudantes passem a olhar para seus próprios movimentos ao realizar um exercício físico ou um esporte visando evitar lesões, além, é claro, de desenvolver um olhar crítico na observação dos esportes que mais goste de assistir e torcer.

Para atingir estes objetivos gerais fizemos uma intervenção no primeiro ano do ensino médio de duas escolas públicas do estado de São Paulo, por meio de um conjunto de atividades, as quais serão apresentadas em detalhes neste trabalho. Estas intervenções tinham como objetivos específicos identificar e analisar a complexificação do conhecimento cotidiano contextualizado nos esportes ao introduzir os elementos dos conhecimentos científicos.

Estas duas escolas foram escolhidas devido a facilidade da implantação da intervenção, pois leciono física nas duas escolas aproximadamente a 9 anos e conheço o grupo de gestores, professores da escola, além das características gerais dos estudantes que as frequientam. Tenho interesse em analisar a "postura" dos estudantes frente a uma nova metodologia de ensino de física e os produtos desta intervenção, já que há algum tempo venho enfrentando muitas dificuldades em ensinar os conceitos científicos, não somente pelos infindos insucessos na aprendizagem, mas pelo grau de comprometimento dos estudantes com seus estudos. À medida que os anos passam 
percebo que a motivação pelo saber e a relação de respeito (princípios básicos de uma boa educação familiar) entre professor e aluno diminuem, suponho que isto está atrelado aos valores que a sociedade dá ao conhecimento escolar e ao professor, mas enfim, nesta pesquisa não farei um estudo em sociologia da educação.

Analisar a complexificação do conhecimento, no caso de esporte, nas três fases: implantação, processo e produto da intervenção, resultará em um novo olhar para o ensino de física nas duas escolas. Irá interferir positivamente na minha prática como pesquisadora e professora devido ao conhecimento gerado pela minha pesquisa, que poderão ser aproveitados por outros professores de física das duas instituições e por que não, aplicados a outros contextos escolares similares aos tratados nesta pesquisa.

Esta pesquisa não tem a pretensão de solucionar todos os obstáculos encontrados na sala de aula para o ensino de física nestas duas escolas, mas seus resultados corroboram para construção futura de uma teoria baseada em um instrumento de medida que associe níveis de interdisciplinaridade, graus de complexidade com o aprendizado dos conceitos científicos.

Para construção das atividades nos baseamos em Mattos \& Ferrara (2006), Rodrigues \& Mattos (2007) e Garcia (1998) que tratam da complexificação do conhecimento cotidiano através da inserção do conhecimento escolar e científico de cunho interdisciplinar.

Realizaremos um estudo de caso múltiplo, no qual sua complexidade é notória (MAZZOTTI, 2006), pois estaremos aplicando a intervenção em poucas turmas de $1^{\circ}$ ano do ensino médio de duas escolas públicas no interior do estado de São Paulo, nossa pesquisa, portanto é qualitativa e microetnográfica e pode ser classificada como uma pesquisa participante (BOGDAN \& BIKLEN, 1994), já que se trata de um estudo feito em sala de aula por uma professora-pesquisadora atentando para relação de ensinoaprendizagem de conceitos científicos.

\subsection{Definição do problema de pesquisa}

Neste trabalho temos como objetivo construir uma ferramenta que possibilite ao professor ter meios para direcionar suas aulas de acordo com a aprendizagem dos estudantes. Propomos, através de uma intervenção em sala de aula composta por um conjunto de atividades de característica interdisciplinar, verificar a complexificação do 
conhecimento cotidiano do estudante por meio de um conhecimento escolar concebido por um "recorte" realizado pelo professor, que acople os graus de complexidade (capítulo 4) a evolução na aprendizagem de conceitos científicos. Como se dá a relação entre os níveis de interdisciplinaridade e complexidade que o professor constrói, propõe em suas aulas? Como ele almeja que essa relação seja alcançada pelos estudantes? Como se dá a evolução no processo ensino-aprendizagem dos conceitos científicos aplicados ao cotidiano pelos estudantes? Podemos mapear este processo por meio de graus de complexidade na perspectiva tanto da utilização correta do ponto de vista da física do conceito, quanto na aplicação adequada do conceito em vários contextos que reflitam na aprendizagem dos estudantes durante as aulas? $\mathrm{O}$ ambiente escolar também influencia no processo ensino-aprendizagem?

Como pretendemos estudar a evolução no processo de ensino-aprendizagem dos estudantes através da progressão gradativa da complexidade por meio de graus de complexificação interligados aos níveis de interdisciplinaridades construídos pelo professor em cada atividade e atrelados a objetivos pré-determinados para cada aula ou blocos de aula na introdução de conceitos científicos, de tal forma a não rejeitar a sua utilização no cotidiano, mais fornecer sua aplicação a outros contextos e assim possibilitar uma visão ampla do conceito científico, nos basearemos em alguns referenciais teóricos que nos auxiliem a visualizar de forma coerente o andar da pesquisa e a análise dos seus avanços ou retrocessos durante sua execução, para possibilitar correções que nos façam alcançar os objetivos iniciais.

Para dar conta do estudo da evolução no processo de aprendizado dos estudantes utilizaremos à noção de perfil conceitual de Mortimer $(1995,2000)$ e como queremos entender a dinâmica na complexificação do conhecimento cotidiano durante o processo de ensino-aprendizagem através da inserção de novas zonas no perfil conceitual de um conceito e sua ampliação para utilização adequada em cada contexto em que os estudantes estiverem, nos recorreremos a ideia das ordens de aprendizado estabelecidas por Rodrigues \& Mattos (2006, 2007).

A preocupação em demonstrar aos estudantes que a realização de esportes nem sempre é sinônimo de saúde vem de situações cotidianas diversas: desde a prática de exercícios físicos e esportes até o assistir uma competição esportiva ao vivo ou pela televisão. Os argumentos que os estudantes normalmente usam para um bom desempenho dos atletas nos mostram a falta de conhecimentos sobre o movimento do corpo humano (capítulo 4). 
Além disso, a forma com que a mídia divulga a relação entre a prática de exercícios físicos, esportes, saúde e estética corporal são preocupantes. Muitos buscam a qualquer custo à forma física "perfeita", a qual supostamente envolve o excesso de exercícios físicos, muitas vezes sem orientação profissional, acarretando a prática inadequada de esportes, além das estranhas dietas alimentares, ingestão de medicamentos e até cirurgias para chegar um padrão esteticamente valorizado. Ou seja, o corpo se tornou um instrumento de valorização dos sujeitos na sociedade, virou "moda" (KOWALSKI \& FERREIRA, 2007).

Segundo Costa \& Venâncio (2004), a saúde imersa neste discurso de beleza, produz nas pessoas uma procura indiscriminada pelo exercício físico, que neste contexto se torna uma receita para a salvação. Esse modo de tratar o exercício exclui, muitas vezes, a compreensão da atividade física como forma de manutenção de saúde e bemestar.

Nesta perspectiva, uma abordagem interdisciplinar que contenha as relações entre esporte, saúde, biomecânica, educação física e física poderá ajudar os estudantes a adquirirem uma visão mais crítica e consciente da prática esportiva. A abordagem interdisciplinar utilizada neste trabalho se dá por meio de níveis de interdisciplinaridade, pois realizamos pequenos recortes em cada um dos itens citados em níveis diferentes.

Os esportes, quando praticados de forma incorreta, podem apresentar níveis de exigência física incompatíveis com a dos praticantes levando-os a situações de risco para sua saúde (LIMA \& MONSON, 2007). Assim, segundo Guedes (1999), há necessidade de incluir na escola a educação para saúde, de modo a ampliar a visão do conceito de saúde e doença. Ao atentar para o fato de que a ideia de saúde pode ser ensinada num contexto didático pedagógico, é possível, por exemplo, discutir na disciplina de educação física, aspectos da atividade física relacionados à saúde e não somente a atividades competitivas.

Neste viés, entendemos que todas as disciplinas escolares podem fornecer aos estudantes conhecimentos necessários para que os mesmos possam distinguir o que é saudável do que não é, não se detendo exclusivamente às questões de natureza biológica. Não pretendemos exaurir os vários significados do termo "educação para saúde", ou mesmo de "saúde", mas pretendemos mostrar que os conhecimentos da física podem ser utilizados como critérios para uma vida saudável.

Neste trabalho apresentamos uma forma de incluir a discussão sobre saúde, mesmo que simplificada, nas aulas de física do $1^{\circ}$ ano do ensino médio no conteúdo de 
mecânica, introduzindo conhecimentos de biomecânica contextualizados no esporte, tema de grande interesse dos estudantes. $\mathrm{O}$ ensino de biomecânica faz parte dos parâmetros curriculares nacionais de educação física (PARÂMETROS, 1997, p. 75), dada sua importância na compreensão de que todo e qualquer movimento corporal pode ser mais bem entendido com os conceitos e padrões biomecânicos, que podem ser destacados pelo professor de educação física durante as aulas (FREITAS \& COSTA, 2000).

Por outro lado, na física para o ensino médio, o conteúdo de Mecânica Clássica Newtoniana é utilizado como "o paradigma". Quase todo o conteúdo do ensino médio está referenciado nessa teoria da física, inclusive os conteúdos ligados ao eletromagnetismo, normalmente o último assunto abordado nas escolas médias. A base teórica da mecânica newtoniana é, geralmente, ensinada durante a primeira série do ensino médio, mas suas aplicações se estendem por quase todos os fenômenos físicos ensinados no ensino médio. Como sabemos, o conteúdo de mecânica é extenso (cinemática, dinâmica, estática, gravitação, hidrostática, etc.), cabendo ao professor realizar, dado o tempo limitado, um recorte pessoal do que é mais essencial para ser visto com os alunos. Esta é uma escolha difícil, principalmente quando se trata da física como um conhecimento fundamental para se entender alguns problemas cotidianos que os estudantes enfrentam. Priorizar alguns tópicos mais do que outros podem gerar lacunas que impedem a compreensão dos próprios limites da mecânica clássica, porém, atribuímos mais importância à qualidade da contextualização do que ao volume de tópicos a serem selecionados. A qualidade da contextualização se refere às analogias possíveis que, dependendo da forma como são apresentadas, se tornam muitas vezes o próprio objeto de estudo, como é caso típico da analogia hidrodinâmica da corrente elétrica (STOCKLMAYER \& TREAGUST, 1996), porém tomamos o cuidado para evitar o uso do modelo como o próprio objeto de estudo.

Dentro do ensino de física ou de qualquer outra área de conhecimento, o aprendizado correto dos conceitos faz diferença na compreensão dos fenômenos que ocorrem a nossa volta. Ao desenvolver em sala de aula o conteúdo de mecânica abrangemos conceitos como: força, energia, velocidade, impulso, etc., que já são utilizados pelos estudantes em contextos do dia-a-dia. Algumas pesquisas realizadas na área do ensino da mecânica demonstram que os estudantes estabelecem relações intuitivas entre os conceitos apresentados, o que faz com que eles dêem respostas inadequadas do ponto de vista da física (PEDUZZI, 1985). 
Segundo vários autores (p.e. MORTIMER, 2000; ITZA-ORTIZ et.al., 2003) a linguagem do cotidiano tem fortes implicações no aprendizado dos conceitos físicos, não sendo necessário que os estudantes abandonem os significados daquele conceito no cotidiano, mas deve haver uma coexistência entre o conceito físico e o conceito comum.

Muitos pesquisadores realizam trabalhos a respeito das concepções alternativas dos estudantes para os conceitos de mecânica para estabelecer pontos de partida para o ensino da Física (HOLLOW, 1985). Neste trabalho fizemos um levantamento prévio das relações que os estudantes estabelecem entre física e esporte (seção 3.4). Um dos conceitos mais estudados pelos pesquisadores em ensino de física é o conceito de força, pois além de ser central para a mecânica, a maioria dos alunos começa seus estudos em física, sem saber diferenciar o termo força, utilizado no cotidiano do seu conceito físico (ITZA-ORTIZ et. al., 2003). Muitas vezes estes erros conceituais são provenientes de um ensino em que geralmente os estudantes são forçados a memorizar fragmentos e algumas respostas prontas (HESTENES et. al, 1992). As concepções prévias dos estudantes sobre força persistem ao longo de sua escolaridade e, raramente, são superadas por quaisquer metodologias de ensino. Em parte, o fracasso do ensino dos conceitos científicos, não se deve às concepções prévias, mas pelo fato que usualmente, o ensino de Mecânica se detêm na resolução de problemas e tarefas que envolvem enormes listas de exercícios, no qual a resolução mecânica se torna inevitável (PEDUZZI, 1997).

Entendemos que o ensino de biomecânica pode permitir ao aluno uma compreensão da aplicação dos princípios da mecânica ao movimento, em particular de determinados exercícios físicos ou habilidades motoras. Pela sua natureza, os conhecimentos de biomecânica resultam de uma construção histórica de um conhecimento interdisciplinar, que podem ser associados tanto a física e a fisiologia, quanto à educação física (CORREA, 2004).

Da mesma forma, a disciplina escolar educação física pode proporcionar aos estudantes o contato com uma grande variedade de experiências de movimentos, pois todo e qualquer movimento corporal envolve conceitos e princípios biomecânicos que podem ser destacados pelo professor de maneira teórica não-formal, pois são conceitos que fazem parte da vida diária dos estudantes (FREITAS \& COSTA, 2000).

$\mathrm{Na}$ biomecânica dos esportes, por exemplo, se aplicam as leis de Newton para entender o movimento do corpo humano e aumentar a performance. Porém, muitos atletas e seus treinadores têm um pobre conhecimento dos conceitos newtonianos e, 
para se obter máxima performance do corpo humano, é necessário o uso da física e um grande entendimento das leis de Newton (PARKER, 2001). Além dos estudos em esporte de alto nível de rendimento, as pesquisas em biomecânica envolvem: esporte escolar e atividades de recreação, prevenção e reabilitação orientadas à saúde e às atividades do cotidiano e do trabalho (AMADIO \& SERRÃO, 2007).

$\mathrm{Na}$ física é comum utilizarmos o conceito de movimento e, a partir disso, construirmos uma rede complexa de conceitos e significados que muitas vezes criam barreiras para sua compreensão.

Segundo Hamil (1999), as áreas centrais de estudo do movimento do corpo humano são a cinesiologia e a biomecânica. A cinesiologia é um termo genérico usado para descrever qualquer forma de avaliação anatômica, fisiológica, psicológica ou mecânica do movimento humano. Seu conteúdo é geralmente incorporado em muitos cursos de biomecânica. Nas décadas de 1960 e 1970 a biomecânica foi desenvolvida como uma área de estudo de pós-graduação nos Estados Unidos. O conteúdo de biomecânica era extraído de uma área da física, a mecânica, estudo do movimento e efeito das forças sobre um objeto. Por outro lado, a mecânica, então usada para elaborar estruturas como pontes, máquinas, aviões, etc., teve em sua história uma larga aplicação da visão mecânica aos seres vivos (SODRÉ \& MATTOS, 2007), a qual, por fím, desembocou nos meados do século XX na biomecânica. Hoje, temos uma clara divisão dos estudos da cinesiologia e da biomecânica para análise do movimento humano.

No campo da biomecânica se estuda a funcionalidade mecânica dos órgãos, aparelhos e sistemas dos seres vivos, a sua cargabilidade mecânica, sobre os limites da sobrecarga para não gerar lesões e sobre os fatores que afetam a performance, incluindo a atividade desportiva e, portanto envolvendo, o treino em si mesmo, os meios auxiliares de treino, o equipamento desportivo e a técnica desportiva (VILAS-BOAS, 2001).

$\mathrm{Na}$ Biomecânica podemos relacionar a Física com o corpo humano e com os equipamentos esportivos, na intenção de focar a prática de esportes. Desse ponto de vista, é relevante para os estudantes reconhecer nas práticas esportivas, desenvolvidas no meio escolar, os conteúdos de biomecânica, pois além de colaborar para o aprendizado dos conceitos de mecânica, auxilia no desenvolvimento correto dos esportes. Isto nos leva a acreditar que a relação entre a educação em Física e Educação Física, pode também promover uma educação para saúde. 
É evidente a afinidade e o interesse que os estudantes apresentam ao debater sobre esportes (BETTI, 1999), pretendemos aproveitar esta motivação e propor atividades que apresentem os conceitos de mecânica aplicados aos esportes. A partir disso fica claro que é o professor quem constrói a ponte entre os conhecimentos. Integrar os conhecimentos não é uma tarefa fácil, é necessário se interar de novas áreas de conhecimento, que não são específicos da área de sua formação.

Hoje em dia está clara a relação entre esporte e saúde. A saúde e a qualidade de vida do homem podem ser preservadas e aprimoradas pela prática regular de atividade física. Para manutenção do estado de saúde é necessário cultivar um estilo de vida saudável em que a prática da atividade física regular tem contribuição relevante na medida em que promove a integração social, desenvolvimento de aptidões e qualidade de vida (COSTA, 2004). Neste trabalho não abrangeremos em detalhes o conceito de saúde e nem será nossa pretensão, mas segundo Carvalho (1996), o incremento da atividade física de uma população contribui decisivamente para saúde pública, com forte impacto na redução dos custos com tratamentos inclusive hospitalares, uma das razões de seus benefícios sociais.

Um dos impactos mais graves é o desconhecimento dos limites físicos do corpo humano e a consequente prática de esportes que leva as lesões (CARVALHO, 1996). Assim, pode-se perceber que a relação entre esporte e saúde não é tão simples quanto pensamos.

\subsection{Objetivo da Pesquisa}

Tendo como tema motivador o esporte, temos o objetivo de avaliar a complexificação dos enunciados de estudantes do ensino médio sobre o conceito de esporte ao serem submetidos a um conjunto de atividades interdisciplinares. A complexificação esperada se dá por meio da inserção de elementos discursivos da física, educação física, biomecânica e saúde ao longo das atividades. Tais elementos indicam uma compreensão da física no cotidiano, seja na abordagem do esporte de alto desempenho, seja nas atividades esportivas escolares tratadas na disciplina de educação física ou nas mídias televisivas.

Ao internalizarem estes elementos estudantes podem ter uma percepção mais adequada do seu corpo e podem mudar as formas com que praticam exercícios físicos. 
A presença de diversas áreas do conhecimento introduzidas em níveis de interdisciplinaridade diferenciados e articuladas por meio das atividades está diretamente ligada aos graus de complexificação dos discursos construídos pelos estudantes. Na nossa análise, não esquecemos da relevância das características do ambiente escolar em que os estudantes estão inseridos, já que o grau de complexificação do discurso discente não está atrelado apenas às atividades da intervenção, mas às características da escola, dos estudantes, da relação professor-aluno, isto é, a coconstituição entre ambiente e sujeitos.

Enfim, avaliaremos se a intervenção proposta como um conjunto de atividades, leva os estudantes a uma complexificação do conhecimento do conceito de esporte. Mediante as categorias estabelecidas para análise dos dados, propusemos e avaliamos os diferentes graus de complexificação atingidos pelos estudantes.

Como os dados trazem o processo de aprendizagem dos estudantes de alguns conceitos científicos, estaremos mesmo que sucintamente observando o processo de aprendizado dos estudantes no ambiente escolar (sala de aula), ou seja, em uma situação de aprender, situação dialética (aprende através de tudo que o cerca) do mundo. Este tipo de análise se encaixa na análise microgenética (VIGOTSKI, 2001; WERTSH, 1985).

Se a intervenção proposta para sala de aula visa complexificar o conhecimento cotidiano que já é complexo, através da inserção do conhecimento escolar e científico, a rede de conhecimentos intrínseca de cada estudante, contará com mais conexões que se organizaram através níveis hierárquicos diferenciados, que farão diferença na aplicação do conceito científico em diversos contextos, e para ajudar-nos a compreender este processo nos recorreremos a Bernstein (2006).

A pesquisa é descrita em ordem cronológica e apresenta todos os obstáculos enfrentados e os sucessos, além das mudanças de objetivo no decorrer da pesquisa, que faz parte da delimitação do campo da pesquisa. Inicialmente queríamos enfocar o perfil conceitual de força, em seguida, optamos pelo perfil conceitual de esporte e por último decidimos analisar a complexificação do conhecimento de esporte por meio de graus de complexidade do conhecimento, que é fundamental para uma futura análise da evolução do perfil conceitual de esporte.

No capítulo 2, apresentaremos em detalhes a utilização de alguns dos referenciais teóricos e suas interligações para o desenvolvimento e análise dos dados da pesquisa. 


\section{CAPÍTULO 2}

\section{Referencial teórico}

Esta pesquisa se alicerça em vários autores, pois buscamos referenciais teóricos que conversem entre si, ou seja, que sigam a mesma linha de raciocínio e nos auxiliem a construir, desenvolver e compreender os resultados obtidos desta pesquisa. Organizamos os autores seguindo as etapas da pesquisa, portanto teremos o referencial teórico para construção da metodologia, para construção da intervenção e para análise de dados.

Neste capítulo explanaremos alguns dos referenciais teóricos utilizados e outros no decorrer deste trabalho (seção 3.5 e 4.3). Resumidamente, enquadramos os autores no referencial teórico para:

- Construção da metodologia: Bogdan \& Biklen (1994) que darão conta de nos auxiliar na explicação da escolha em classificar a pesquisa em: qualitativa, participante e microetnográfica e Bardin (2010) para realização de uma análise categorial (análise de conteúdo - capítulo 4).

- Construção da intervenção (detalhes na seção 3.5): Mattos \& Ferrara (2006 e 2007) e Garcia (1998) que trabalham com a complexificação do conhecimento cotidiano para nos auxiliar na efetuação de um recorte responsável em um conteúdo amplo para ser inserido nas atividades, Lawson (2001) para elaboração das atividades mediante um ciclo de aprendizado que atenda as características dos estudantes e Uema (2005) para diversificar as metodologias didáticas - multi-abordagem - utilizadas nas atividades.

- Análise de dados: Mortimer (1995, 2000) para auxiliar na compreensão do perfil conceitual e na inserção de novas zonas ao perfil (objetivo estabelecido para o início da pesquisa, mas ao final como perspectiva futura), Rodrigues \& Mattos (2006, 2007) e Garcia (1998) para entendermos os níveis de complexidade e as ordens de aprendizado em que se encontram os estudantes (utilização correta do conceito no contexto adequado), Bernstein (2006) e Morais (2007) para entender os níveis hierárquicos que compõem a organização do conhecimento, Vigotski (2001) e Góes (2000) para compreendermos o processo de cognição dos estudantes em sala de aula e 
Bakhtin (2006) para estudarmos a polissemia dos vários significados atribuídos a um conceito de acordo com os contextos.

\subsection{Perfil conceitual}

A noção de perfil conceitual pretende dar conta dos múltiplos significados que são atribuídos a um mesmo conceito. Estes vários significados compõem as zonas do perfil conceitual. Portanto um conceito não possui apenas um significado que pode ser substituído por outro, mas uma gama de significados que dependem do contexto de uso. Os contextos são formados por uma grande diversidade de elementos que estão dinamicamente conectados entre si. É esta dinâmica complexa que faz no processo comunicativo, a atividade dialógica, se manifeste como uma negociação de significados. É no contexto em que os sentidos e significados manifestam-se por meio da ação comunicativa daqueles que os vivenciam (RODRIGUES \& MATTOS, 2006).

O indivíduo após um processo de aprendizagem passa a utilizar um instrumento construído por si próprio que permite a escolha da zona do perfil adequada ao contexto, através da delimitação dos significados do conceito ao contexto. A seleção da zona do perfil conceitual adequada ao contexto depende da evolução gradativa do perfil conceitual que vem de experiências que o indivíduo constrói durante o processo de aprendizagem, e isto é o que chamamos de complexificação do conhecimento.

A noção de perfil conceitual é introduzida por Mortimer (1995) que a propõe baseado na noção de perfil epistemológico de Bachelard (1984). Para Mortimer, cada indivíduo traça um perfil epistemológico para cada conceito científico, e cada zona do perfil conceitual pode ser relacionada com uma forma de pensar e com certo domínio ou contexto a que essa forma se aplica. Mortimer propõe que o perfil epistemológico corresponde a uma dimensão do perfil conceitual, que seria composto também por uma dimensão ontológica, que representaria a polissemia do conceito no seu uso cotidiano.

Bakhtin (2006) aborda em seu trabalho a polissemia (heteroglossia) do conceito e enfatiza a importância em levar o mesmo em consideração no processo de ensinoaprendizagem, pois uma palavra possui vários significados, e esses significados são determinados por seu contexto, ou seja, o número de significados de uma única palavra está relacionado a variedade de contextos possíveis, portanto além do indivíduo durante 
a aprendizagem incorporar novas zonas ao seu perfil conceitual deve estar atento aos contextos adequados do seu uso.

Rodrigues \& Mattos (2006, 2007), por outro lado usam a noção de perfil conceitual como uma representação cognitiva de um conceito. Representar o estado cognitivo por meio do perfil conceitual nos remete a definir a noção de aprendizagem como a evolução do perfil conceitual no qual, o indivíduo, em um processo de ensino, cria novas zonas ou modifica as já existentes.

Portanto o perfil conceitual dos sujeitos não é estático, está em constante mudança, a cada nova contradição entre o sabido e novos contextos, cria-se um momento de tensão das zonas, as quais podem se modificar ou ter novas zonas criadas. Ou seja, a aprendizagem é um sistema dinâmico, pois aprender um conceito é um movimento, contínuo e eterno, de re-significações frente a dinâmica da vida.

Nesse sentido, aprender um conceito é discriminar os seus contextos de uso, ou seja, tomar consciência das diferentes zonas do perfil que incluem o senso comum e o conhecimento científico é compreender a aplicação correta dentre os seus diversos significados que seja compatível ao contexto.

Assim, a ampliação de consciência do indivíduo implica em adquirir habilidades e estabelecer critérios para analisar suas próprias ideias, ou seja, para tomar consciência dos conceitos que devem ser utilizados em cada situação específica. Aqui, consciência não somente adquirir consciência do novo conceito científico, mas também da relação entre as diferentes zonas dos perfis conceituais, sabendo quando é mais conveniente usar um ou outro (MORTIMER, 1995). Neste estágio estabelece-se um grau de generalização do conceito. Segundo Vigotski (2001), a generalização do conceito se dá quando o indivíduo internaliza uma informação do seu meio social e a externaliza, associando a ela um significado que pode ser utilizado em determinados contextos específicos, processo que não se finaliza com uma abstração, mas sim, com modificação da realidade imediata, complexificando-a (PAZELLO \& MATTOS, 2010, 2011; PAZELLO, 2011).

Dessa forma, o processo de generalização é multifacetado e contínuo. As novas zonas de perfil conceitual convivem com diversas outras, incluindo desde as concepções cotidianas até as concepções científicas e escolares (RODRIGUES \& MATTOS, 2006).

Neste viés, como dissemos, podemos considerar a aprendizagem como uma dinâmica do perfil conceitual, ou seja, a inclusão de novas zonas ou ainda a consciência da correlação entre diferentes zonas do perfil. 
Ao referirmos a aprendizagem não podemos levar em consideração apenas os aspectos cognitivos, mas também os afetivos que, segundo Vigotski (2001), são indissociáveis no aprendizado de um conceito (RODRIGUES \& MATTOS 2006, 2007), por consequência, propõem uma terceira dimensão para o perfil conceitual, a dimensão axiológica.

Assim, o perfil conceitual seria composto por três dimensões: a epistemológica, a ontológica e a axiológica:

"Dimensão Epistemológica: se refere à produção do conhecimento, bem como as diversas interpretações da natureza dentro de várias correntes filosóficas. Esta dimensão trata do 'como' conheço o objeto. Esta dimensão tem origem na história e filosofia da ciência, bem como na história da construção do conhecimento humano.

Dimensão ontológica: se refere à natureza dos objetos. Esta dimensão trata do 'que' é o objeto. Está intimamente ligada com a polissemia das palavras que representam conceitos, dando várias possibilidades de significado.

Dimensão axiológica: esta dimensão não tem sido considerada em pesquisas sobre perfil conceitual. Esta se refere aos valores (e fins) atribuídos aos objetos. Esta dimensão trata do 'por que' das escolhas. Esta dimensão revela as motivações e intenções, dentro das quais o conceito é usado pelo indivíduo”. (RODRIGUES \& MATTOS, 2007, p.2).

Quando estudamos a aprendizagem como uma dinâmica do perfil conceitual, estamos considerando a dinâmica em termos dos três eixos: epistemológico, ontológico e axiológico. Essa ampliação foi tomada como uma complexificação da noção de perfil conceitual, que ainda pode ser entendido como um sistema hierárquico de perfis conceituais, no qual cada zona possui características ontológicas, epistemológicas e axiológicas. Ao conhecer as relações complexas entre os significados de um conceito e o contexto apropriado a cada situação passamos a compreender o processo da construção do conhecimento e da atividade de comunicação dos indivíduos. Através da utilização dos três eixos do perfil conceitual é possível modelar a dinâmica da relação entre contexto e zonas do perfil conceitual.

Assim, tratamos o perfil conceitual como um sistema complexo cuja estrutura foi internalizada. Esse pressuposto parte da ideia de que o mundo também é um sistema 
complexo. Essa correlação entre mundo interno e o mundo externo vem da Teoria da Atividade, na qual um dos principais fundamentos é que a consciência nasce na atividade humana (LEONTIEV, 1978). Assim, o complexo sistema de atividades e contextos no qual se dá a vivência do homem se reflete nas suas representações cognitivas, que podem ser consideradas como o perfil conceitual.

O perfil conceitual é composto por zonas, as quais refletem em significados atribuídos às palavras. Porém a atribuição de significados é feita nos contextos nos quais, por sua vez, aprendemos a atribuir significados.

A complexidade do perfil conceitual não é só representada pela polissemia das palavras, mas pela polifonia dos discursos. Um discurso é composto por enunciados que são compostos por frases, que são compostas por palavras, que são polissêmicas. Mas a incerteza dos significados se dá pela incerteza atribuída aos sentidos de cada elemento discusivo. Podemos pensar em perfis conceituais de perfis conceituais. Daí a necessidade de uma interação dialógica, princípio da construção da intersubjetividade, a qual se estabelece à medida que na própria interação discursiva vão se negociando os significados das coisas, em suma um contexto mútuo vai sendo criado (RODRIGUES \& MATTOS, 2006, 2007; DALRI et al., 2007). Assim em uma sala de aula, professor e aluno, em geral, estão em contextos diferentes, negociam significados fazendo negociações, assim estabelecendo um contexto único (RODRIGUES \& MATTOS, 2006).

Segundo Bakhtin (2006) a polifonia do discurso está sempre presente no contexto por meio da presença de várias vozes, pois o contexto também é um sistema complexo, que acolhe vários tipos de discursos que podem envolver a vida pública, institucional, artística, científica, filosófica, etc. (o cotidiano do ser humano), que são os gêneros dos discursos, por sua vez são infinitos e se estendem e se modificam na medida em que se complexificam as atividades humanas.

Ao tomarmos o mundo como um sistema complexo, conhecê-lo não pode mais ser uma tarefa de metodologias baseada em uma estrutura disciplinar do conhecimento. Como sistema complexo, o mundo apresenta diversos níveis hierárquicos em retroalimentação, no qual a representação e resolução de problemas exigem diferentes recortes epistemológicos para sua resolução (MATTOS \& FERRARA, 2002). Neste ponto, o ensino de ciências não deve revelar apenas a complexidade do mundo, mas também deixar clara a delimitação desse conhecimento, isto é, seu domínio de validade, 
para que assim o indivíduo, após adquirir um novo gênero do discurso - a ciência compreenda em quais contextos certos modelos e/ou teorias tem sentido ou não.

Deste modo visualizamos a escola como um macro-contexto onde existem vários micro-contextos associados, e é justamente no micro contexto: sala de aula, que este trabalho se propõe a analisar, ou seja, optamos por uma análise no domínio microgenético, para relatar minuciosamente as interações entre os alunos em uma sala de aula e como se dá seu aprendizado em um pequeno intervalo de tempo. Pois, todo processo humano tem gênese nas relações com o outro e com a cultura, e são essas relações que devem ser investigadas ao se examinar o curso da ação do sujeito (GÓES, 2000).

A escola possibilita ao indivíduo uma vivência social, já que propicia acesso a informação, experiências novas, etc., levando-o a um processo de desenvolvimento, composto por etapas progressivas, que possam ser percebidas pela linguagem e movimentos expressivos, ou seja, pela genética. Portanto, esse desenvolvimento psicológico do indivíduo provém da interação social, isto é, a partir da comunicação verbal ou não verbal entre duas pessoas (VIGOTSKI, 2001).

Vigotski (2001) propõe domínios genéticos (dado pelo meio social, ou seja, pelas interações dos estudantes entre si no ambiente sala de aula) relacionados ao desenvolvimento, ou seja, as etapas progressivas dos processos mentais do ser humano, que foram categorizados por Wertsch (1985) em:

- Filogenético: responsável pela base biológica, evolução e patrimônio genético da espécie.

- Sócio-cultural: constituição histórica dos grupos humanos.

- Ontogenético: desenvolvimento do indivíduo dentro de certas comunidades.

- Microgenético: transformação de um processo interpessoal em funcionamento intrapsíquico do sujeito.

Segundo Bernstein (1990) a escola possui características similares a divisão social do trabalho onde há a categoria dos agentes: adquirentes (alunos) e dos transmissores (professores) e as relações sociais envolvidas na sala de aula fazem parte das práticas desenvolvidas por eles. Desenvolvemos esta pesquisa no nível micro da sala de aula, ou seja, em um contexto comunicativo. 
Um contexto é estabelecido por meio de regras de reconhecimento e regras de realização:

"As regras de reconhecimento criam os meios que possibilitam efetuar distinções entre contextos e, assim reconhecer a peculiaridade daquele contexto. As regras de realização regulam a criação e a produção de relações especializadas internas aquele contexto” (BERNSTEIN, 1990, p.30).

Em uma sala de aula, o ápice se dá quando o estudante percebe as relações entre as zonas do perfil conceitual e associa essas zonas ao contexto adequado (RODRIGUES \& MATTOS, 2007). Em outras palavras, seguindo o modelo de reprodução e transformação cultural de Bernstein (1990), este ápice se dá quando o indivíduo consegue reconhecer o contexto e em seguida realizar um texto adequado ao contexto, ou seja, quando ocorre a fusão de contextos. Bernstein na construção deste modelo desenvolve o conceito de código que é definido não somente como o regulador entre contextos, mas também das relações que ocorrem no interior de contextos.

“Código é o regulador da relação entre contextos e gerador de princípios orientadores da produção de textos adequados a cada contexto. As modalidades específicas de código são constituídas pelos valores específicos de classificação e enquadramento. Classificação: refere-se ao grau de isolamento entre categorias de discurso, agentes, praticas, contextos e fornece regras de reconhecimento, tanto para transmissores quanto para adquirentes, para o grau de especialização de seus textos. Enquadramento: refere-se ao controle sobre a seleção sequenciamento, compassamento e regras criteriais para relação comunicativa pedagógica entre transmissor/adquirente(s) e fornece regras de realização para produção de seu texto" (BERNSTEIN, 1990, p.300).

Em uma escola (macro nível) os agentes (gestores, funcionários, docentes, discentes, etc.) desenvolvem as práticas: discursivas, de transmissão e organizacionais, que na sala de aula (micro nível) por meio de interações, se refere respectivamente a: significado, realização e contextos, e considerando essas práticas e interações que os códigos são formulados individualmente pelos estudantes. Portanto como os códigos são individuais, isso complexifica o entendimento das relações sociais e o posicionamento dos estudantes em uma sala de aula, principalmente nas hierarquias de 
comunicação, pois os discursos entre professor-aluno, aluno-aluno obedecem a hierarquias características de cada sala de aula.

"[...] qualquer contexto de interação pedagógica reflete também uma estrutura social com uma determinada organização hierárquica”

(MORAIS \& NEVES, 2007).

Tomamos o contexto da sala de aula como complexo, onde os participantes na interação pedagógica obedecem a regras que não são explícitas e requerem uma observação atenta ao comportamento do professor e dos estudantes nas aulas.

Bernstein (1990) caracteriza a estrutura social da sala de aula por meio das relações de poder e controlo que são analisadas por meio dos conceitos de enquadramento e classificação, e é isto que mede o nível do código. No capítulo 4, ao analisarmos o diário de bordo da professora (anexo A3.2.3) que a distribuição dos princípios de controlo e poder na sala de aula muitas vezes não são as mesmas em todas as aulas.

As relações de controlo e poder não são estabelecidas apenas entre professoraluno, mas entre aluno-aluno que constroem suas regras em pequenos grupos e estes com outros, que por fim constituem o "grupão" da sala de aula. Portanto existem hierarquias de contextos e a relação entre eles é regulada por um código.

Os grupos de estudantes formados em sala de aula seguem então um código, e isto se revela por auto-imagens que são muitas vezes "rotuladas" pelo pesquisador. Em uma análise, estes rótulos podem auxiliar na construção de categorias para análise dos dados tanto em grupos ou estudante por estudante, facilitando na compreensão do contexto da sala de aula (no capítulo 4, expomos grupos de estudantes com características adversas a maioria da turma).

Neste sistema caótico da sala de aula estamos interessados em analisar o processo de ensino aprendizagem dos conceitos de mecânica através da complexificação do conhecimento de esporte. Para isso, teremos que observar como se dá a comunicação e a relação entre professor-aluno e aluno-aluno, ou seja, analisar os valores de classificação e de enquadramento.

"[...] dependendo dos valores de classificação e de enquadramento que caracterizam o código regulador de um determinado contexto de comunicação são adquiridas ao nível dos sujeitos regras de reconhecimento que serão em função daqueles valores [...]” (MORAIS \& NEVES, 2007). 
Como dito anteriormente, o processo de aprendizagem alcançará sucesso quando os estudantes conseguirem reconhecer o contexto (possuir regras de reconhecimento) e em seguida realizar um texto adequado ao contexto (possuir regras de realização).

A produção do texto pode ser limitada pelas disposições sócio-afetivas do estudante em relação ao contexto, o mesmo deve ter motivação, aspiração, etc. para apresentar um bom desempenho no processo de aprendizagem (MORAIS \& NEVES, 2007). Este é o fator que caracteriza a heterogeneidade da sala de aula, pois cada estudantes possui suas próprias aspirações.

A maioria dos estudantes encontra no tema esporte motivação (resultado obtido pela aplicação de questionários prévios - seção 4.1), e embasados neste tema observaremos a geração e aquisição/transformação dos códigos no ensino de física no micro-contexto de sala de aula, em particular no ensino de mecânica.

Escolher um tema motivador é um fator importante para evolução do perfil conceitual, complexificação do conhecimento, pois irá suscitar motivação para que o indivíduo passe pelo processo de ensino-aprendizagem com disposição para incorporar novos significados ao conceito concebido em situações cotidianas, com isso os estudantes alcançarão bons resultados na aprendizagem do conceito científico. É necessário dar o peso devido que a dimensão axiológica possui no aprendizado dos sujeitos. Ao estudar a complexificação do conhecimento, não podemos apenas atentar para as dimensões: ontológica e epistemológica, mas levar em consideração o "valor" que o sujeito atribui ao conteúdo proposto pelo professor e ao contexto em questão, pois tanto as relações externas quanto as internas ao sujeito influenciam na aprendizagem.

\subsection{Complexificação e interdisciplinaridade}

É nessa conjuntura que achamos necessário buscar as interdependências entre os conhecimentos para tratar os problemas da realidade sem separá-lo do contexto em que

surgem. É importante abranger problemas relevantes para os alunos, ajudando-os a enfrentar os problemas complexos do mundo e isto pode se dar por meio da complexificação do conhecimento do cotidiano (GARCIA,1998).

"Tomar uma perspectiva da complexidade é antes de tudo uma atitude, um método, isto é, a busca das articulações e interdependências entre conhecimentos, até então divididos e compartimentados. Supõe uma 
busca de novas maneiras de formular e enfrentar os problemas, os quais precisam ser formulados e tratados sem separá-los do contexto em que surgem” (GARCIA, 1998, p.85).

Garcia (1998) propõe um recorte epistemológico que considera três tipos de conhecimento: cotidiano, escolar e científico. Para ele esses conhecimentos devem ser articulados para a construção de um conhecimento escolar complexificado. Propõe quatro hipóteses de integração do conhecimento cotidiano, escolar e científico (GARCIA, 1998, p.23). São elas:

- Hipótese da compatibilidade: considera que há continuidade entre o conhecimento cotidiano e o científico, ou seja, são epistemologicamente similares, o que fica viável a aplicação dos conhecimentos aprendidos na escola na vida cotidiana.

- Hipótese da substituição: considera que há uma descontinuidade entre o conhecimento cotidiano e científico (epistemologias diferentes), o que se entende que a função da escola é substituir as ideias intuitivas dos alunos pelas ideias científicas, na medida em que a ciência contribui com um tratamento mais complexo dos problemas sócio-ambientais.

- Hipótese da independência-coexistência: considera que as epistemologias do conhecimento científico e cotidiano não são diferentes, mas apenas são geradas e aplicadas em contextos diferentes, o que dificulta a aplicação do aprendido na escola na vida cotidiana.

- Hipótese da integração-enriquecimento do conhecimento cotidiano: considera que o conhecimento escolar se determina pela integração transformadora das colocações de diversas formas de conhecimento.

Neste trabalho adotaremos a hipótese da integração-enriquecimento do conhecimento cotidiano. Ela se refere à transformação dos conhecimentos que dão suporte ao conhecimento escolar. Assim, o conhecimento cotidiano é enriquecido por meio de sua complexificação, isto é, com a introdução de elementos do conhecimento científico. É este conhecimento complexificado que dá suporte ao conhecimento escolar. Essa hipótese,

“[...] adota um princípio de complementaridade: frente à dicotomia conhecimentos cotidianos - conhecimentos científicos, propõe a interação e evolução conjunta de ambas as formas de conhecimento, frente à dicotomia conhecimento gerais - conhecimento específicos assume que em um sistema de idéias pode haver subsistemas com 
diversos graus de coerência e generalidade. Além disso, se postula não tanto a substituição mas o enriquecimento do conhecimento cotidiano, de forma que a escola propicie uma mudança radical, a substituição de formas de pensamento cotidiano simples por outras complexas, que afete profundamente a forma de interpretar e de atuar no mundo dos sujeitos" GARCIA (1998, p.25).

Na figura 2.1 mostramos o esquema proposto por Garcia (1998, p.23), no qual se apresenta, de forma esquemática, a hipótese integração-enriquecimento. Pelo esquema se pretende mostrar as relações ente os conhecimentos cotidiano, escolar e científico. $\mathrm{O}$ contexto cotidiano gera $(\mathrm{G})$ o conhecimento cotidiano que se aplica (A) ao contexto cotidiano, o mesmo pode ser dito das relações entre o conhecimento científico e o contexto científico, e o contexto escolar e o conhecimento escolar. O destaque deste esquema está na construção do conhecimento escolar, que além das relações com o contexto escolar tem suporte dos conhecimentos cotidiano e científico. Enquanto o conhecimento científico dá referência $(\mathrm{R})$, o conhecimento escolar é enriquecido com o conhecimento cotidiano. Como um sistema complexo, as retroalimentações ocorrem, por exemplo, o conhecimento escolar se aplicando (A) ao contexto cotidiano.

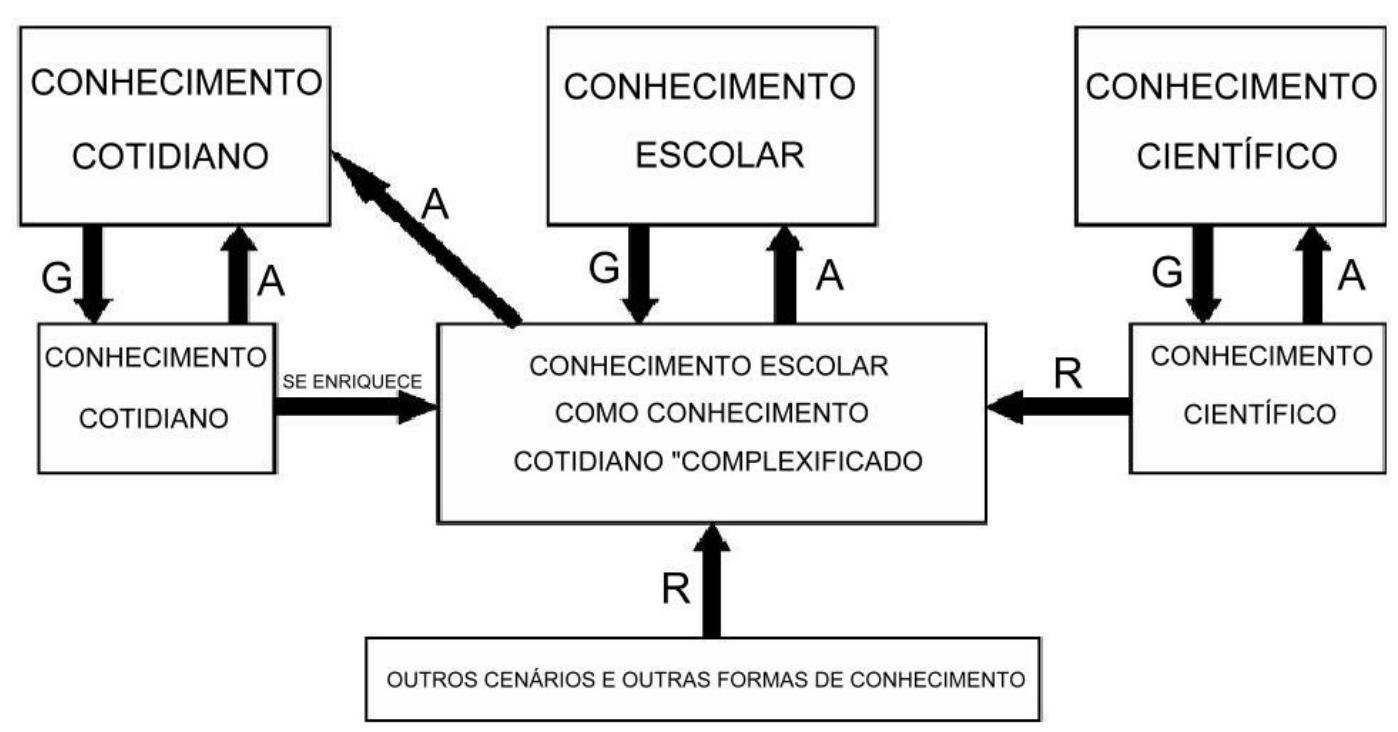

Figura 2.1: Dimensões relativas à construção do conhecimento escolar partindo da hipótese de integração-enriquecimento (A: se aplica a...; G: gera; R: serve de referência) (GARCIA, 1998, p.23).

Sabemos que a complexidade das retroalimentações entre os níveis hierárquicos pode ser ainda maior como, por exemplo, considerar as influências do conhecimento 
escolar sobre o conhecimento no contexto científico, mas neste trabalho utilizamos o modelo apresentado na figura 2.1 para representar o conhecimento escolar.

Junto da hipótese do enriquecimento do cotidiano vem o postulado do pluralismo cognitivo, no qual se afirma que existem diferentes formas de pensamento, coexistentes no sujeito, que se utilizam prioritariamente em uma ou outra situação, ou seja, dependem das demandas do contexto. Da mesma forma, pode-se afirmar que o conhecimento cotidiano, presente no meio social cotidiano dos alunos, são uma fonte de ideias, devendo ser um referente contínuo do conhecimento escolar.

Não basta, situar os conteúdos de ensino em um referencial crítico, mas também é necessário assegurar que os alunos atribuam significados aos conhecimentos que consideramos pertinentes, que insuflem o desejo de um processo de ensino-aprendizado para a construção do conhecimento compartilhado. Assim, ao considerar a organização e a construção do conhecimento escolar pretendemos uma aprendizagem que permita a passagem de formas de pensamento simples para outras mais complexas (GARCIA, 1998).

Para nós, então, a escola deve converter-se em um lugar de reflexão sobre as relações entre os indivíduos e o meio, como um veículo de mudança social, tendo como objetivo educativo básico o enriquecimento do cotidiano (GARCIA, 1998). Nesse contexto, o aluno deve conseguir construir através das atividades escolares, noções mais complexas que permitam uma melhor compreensão, sensibilização e atuação diante de uma situação problema do cotidiano.

Mas para isso, é necessário determinar o conhecimento escolar já pensando na integração didática das diferentes formas de conhecimento, em particular, do conhecimento cotidiano e do científico. $\mathrm{Na}$ escola podemos propor problemas que são cotidianos na medida em que afetam nossa vida, mas que por sua complexidade requerem em seu tratamento a participação de outras formas de conhecimento.

Do nosso ponto de vista, o papel do professor deveria ser o de facilitar as conexões entre as disciplinas escolares, possibilitando ao aluno resolver problemas interdisciplinares. Isto significa que o professor deveria fornecer os elementos necessários para permitir ao aluno reconhecer e resolver problemas da vida ao seu redor. Mas, na formação de professores, não são apresentadas referências sobre esse tipo de construção de conhecimento, o que associado à falta de hábito do estudo, leva professores a preferirem à abordagem multidisciplinar a interdisciplinar. 
Daí a importância de se buscar articulações e interdependências entre os diversos níveis de conhecimento, cujas interações são complexas, compostas por sub-sistemas que são produzidos por recursividade (processos cíclicos que supõe regeneração e renovação), que apresentam diversos níveis hierárquicos de organização. É na apresentação de exemplos interdisciplinares, integrando cotidiano e científico, que os professores podem se apropriar das representações que dão conta das situações complexas do cotidiano. Por isso é mais adequado adotar um enfoque de complementaridade:

"Reconhecer a existência tanto de estruturas conceituais próprias de cada âmbito do conhecimento como estruturas gerais comuns, que dão coerência à visão de mundo que cada sujeito possui" (GARCIA, 1998, p.78).

Visão corroborada do ponto de vista cognitivo quando consideramos perfil conceitual. Mortimer considera fundamental a consciência do perfil conceitual para que o indivíduo se aproprie das formas enunciativas significativas em cada contexto, o que Rodrigues \& Mattos (2007) chamam de terceira ordem de aprendizado.

Para chegar a essa consciência tomamos como necessário elaborar conexões entre as disciplinas para resolução de problemas interdisciplinares. A criação científica tem se embebido das ideias de vários campos de conhecimento, originando campos disciplinares novos, gerando múltiplos conceitos utilizados em várias áreas, o que nos remete a buscar interdependências e articulações entre os conhecimentos para entender o mundo.

Na perspectiva complexa os elementos correspondentes da realidade se explicam como partes do sistema ou como sistemas em si mesmos, os quais estão interrelacionados, de maneira que qualquer um deles não poderá ser visto de forma isolada, senão através de sua posição e de sua função na organização do conjunto. Analisando sob a perspectiva da complexidade se pretende construir pontes entre os conhecimentos compartimentados, elaborar conceitos que potencializem a heurística interdisciplinar e integradora (GARCIA, 1998).

Assim, na educação escolar é necessário oferecer aos alunos e professores em formação mecanismos para utilizar os conhecimentos de forma inter-relacionada e possibilitar a atuação sobre a complexidade do cotidiano. É este argumento que fundamenta nossa proposta de trabalho, no qual pretendemos apresentar uma articulação entre conhecimentos da física e biomecânica, não como meros elementos prescritivos ou 
informativos, mas formativos para uma educação para saúde. Isto implica em escolher diferentes instrumentos conceituais e metodológicos dos diferentes campos do saber que relacionados ou integrados, ajudem a resolver os problemas do cotidiano.

Devemos possibilitar ao aluno/professor que construa através de atividades escolares representações complexas que lhe permitam uma melhor compreensão de seu cotidiano. Para isso, o conhecimento escolar não pode ser a redução ou simplificação de uma disciplina científica, mas sim uma proposta de modelagem dos problemas que afetam a vida dos alunos, mesmo que, por sua complexidade, requeiram em seu tratamento a participação de outras formas de conhecimento. Para isso, devemos conectar a rede de conteúdos complexos às ideias dos alunos. Este movimento não é o de uma substituição de formas de pensar o senso comum, por formas de pensar científico, nem o de considerá-lo um conhecimento superior ao cotidiano, mas enriquecer o conhecimento cotidiano complexificando-o com o conhecimento científico (GARCIA, 1998).

Nossa intenção é permitir que os estudantes estabeleçam relações entre seu cotidiano e os conhecimentos escolares. Ao começarmos a analisar o currículo escolar e a planejar a construção de "pontes" com o cotidiano, já percebemos a dificuldade na tarefa de complexificar este conhecimento para transformá-lo em um conhecimento escolar que explique e ajude a compreender o cotidiano.

É o professor quem escolhe o tema e define como explicá-lo de modo a atender certas expectativas do aluno. A partir desses pressupostos consideramos fundamental à função do professor no estabelecimento das pontes entre o conhecimento científico e cotidiano, ou seja, na construção de um conhecimento escolar que desperte interesse nos alunos fazendo com que os mesmos atribuam sentido ao que aprendem.

É notório que a integração de fenômenos do cotidiano do aluno ao conteúdo curricular ajuda a complexificar o conhecimento, pois aumentam o número de conexões na rede de significados, entre os níveis de organização dos elementos que formam o sistema de representação. Concebemos o conhecimento como uma estrutura complexa, com diferentes níveis hierárquicos interagindo em retro-alimentação, isto é, a pandisciplinaridade (MATTOS \& FERRARA, 2002).

Ao propor um tema em sala de aula o professor deve pensar em enquadrá-lo em termos dos problemas vivenciados pelos estudantes (fator sócio-afetivo), já visualizando outras formas de conhecimento que irão auxiliá-los a entender as situações do cotidiano complexo. 
A escolha do tema e como será desenvolvido em sala de aula traz mesmo que implicitamente os anseios do professor (dimensão axiológica) que sofre também influência do seu relacionamento com os estudantes. Atrelado a complexificação de um conhecimento do cotidiano há a complexidade do contexto da sala de aula, que se revelam no código construído através da relação professor-aluno e aluno-aluno, proveniente da fusão de contextos dos mesmos, que durante o processo de ensinoaprendizagem devem ser superadas para que os estudantes apresentem como resultado a produção de um texto adequado ao contexto.

É necessário que o professor tenha claro, em sua intervenção, o grau de complexidade que o estudante deve atingir, pois segundo Garcia (1998), a complexificação se processa pelas articulações e interdependências entre os conhecimentos e é o fio condutor da intervenção educativa. É preciso que o professor apresente aos estudantes as ligações entre os conhecimentos - o estudante não constrói por si próprio - para que haja uma mudança de contexto com uso do significado correto do conceito.

"O contexto é um fator fundamental para compreensão dos significados do conhecimento ensinado" (DALRI, et. al, 2007, p.4).

\subsection{Pesquisa Participante}

Uma pesquisa qualitativa se desenvolve pela observação participante, no qual as notas de campo têm importância fundamental, pois nas mesmas além de constar todos os dados da pesquisa, os pesquisadores reconhecem e levam em consideração a subjetividade e o efeito da mesma nos dados (BOGDAN \& BIKLEN, 1994).

A pesquisa se passa em duas escolas de ensino médio, e se desenvolve restritamente no contexto da sala de aula (delimitado previamente). Devido a pesquisa se estender a um pequeno grupo de estudantes realizaremos um estudo de caso, no qual se faz necessário entender também o ambiente da sala de aula, e isso só possível através de uma pesquisa participante. Para responder a questão de pesquisa, optamos por obter os dados por meio de questionários que serão analisados qualitativamente para propiciar mais detalhes para conclusão da pesquisa (análise de conteúdo).

A pesquisa participante, assim como a pesquisa-ação, caracteriza-se pela interação entre pesquisadores e membros das situações investigadas. Há autores que 
empregam as duas expressões como sinônimas (GIL, 2002). A partir disso, utilizaremos as duas expressões, com significado que esteja de acordo com as características deste trabalho.

A pesquisa participante tem como característica o envolvimento do pesquisador com os participantes (cunho social), é um processo de troca. Em pesquisas na área educacional, temos o próprio pesquisador, como alvo de estudo, abrindo margem a muitas críticas. É requerida uma atenção redobrada por parte do pesquisador, e embasamento teórico que o auxilie na análise dos dados. Não se pode perder a objetividade, ou seja, perder e distorcer os objetivos iniciais da pesquisa.

"[...] o projeto de pesquisa-ação precisa ser articulado dentro de uma problemática com um quadro de referência teórica adaptado aos diferentes setores: educação, organização, comunicação, saúde, trabalho, moradia, vida política e sindical, lazer, etc. O papel da teoria consiste em gerar idéias, hipóteses ou diretrizes para orientar a pesquisa e as interpretações" (THIOLLENT, 1947, p.55).

Este tipo de pesquisa é dinâmica, pois busca solucionar rapidamente problemas de ordem social, que requerem durante toda a pesquisa tomada de decisões, de consciência, ações, negociações, solução de conflitos, etc.(THIOLLENT, 1947).

A pesquisa participante como metodologia, entendida como primordial na área das ciências sociais foi, e é hoje com menos intensidade, alvo de críticas por não seguir fielmente a teorias e métodos como as pesquisas de cunho tradicionalmente científico. Contudo a pesquisa participante não deixa de ser uma investigação científica, pois possui objetivos claros de aquisição do conhecimento que obedece a expectativa científica (THIOLLENT, 1947).

"Do ponto de vista científico, a pesquisa-ação é um proposta metodológica e técnica que oferece subsídios para organizar a pesquisa social aplicada sem os excessos da postura convencional ao nível da observação, processamento de dados, experimentação, etc. Com ela se introduz uma maior flexibilidade na concepção e na aplicação dos meios de investigação concreta" (THIOLLENT, 1947, p.24).

No campo educacional é comum termos o pesquisador como o próprio professor da sala de aula onde se dará a pesquisa, o que requer um controle metodológico maior, não se pode perder a precisão e o objetivo para que os resultados não sejam ambíguos. 
Ser professor-pesquisador traz um diferencial a pesquisa participante pela facilidade na realização de ajustes que farão a pesquisa progredir (flexibilidade da pesquisa).

"Com a orientação metodológica da pesquisa-ação, os pesquisadores em educação estariam em condição de produzir informações $e$ conhecimentos de uso mais efetivo, inclusive no nível pedagógico. Tal orientação contribuiria para o esclarecimento das micro-situações escolares e para a definição de objetivos de ação pedagógica e de transformações mais abrangentes" (THIOLLENT, 1947, p.75).

Neste viés, a troca do olhar de professora para pesquisadora e vice-versa, favorece a intervenção em sala de aula e enriquece a análise de dados. A resposta à aplicação da intervenção, a possibilidade da utilização de recursos didáticos e autorização da administração é mais rápida, facilitando no bom andamento da pesquisa. A presença de uma segunda pessoa (o pesquisador) na sala de aula pode interferir no comportamento dos alunos no cotidiano escolar. A prática professor - pesquisador possibilita uma auto-reflexão de suas ações como professor em sala de aula. A composição em cada aula de um diário de bordo e a sua análise com o olhar de pesquisador facilita modificações e inserções imediatas nas intervenções (atividades). Essa dinâmica ajuda no bom andamento da pesquisa.

Sabemos que ser professor - pesquisador e vice-versa não é $100 \%$ vantajoso, pois em algumas descrições de ambiente, de comportamento, etc. podem ser suprimidos alguns pontos relevantes para análise de dados, que devido a convivência diária na escola sejam comuns. Um outro ponto importante é dificuldade em realizar uma autoanálise de comportamento em sala de aula e posicionamento em situações adversas. Não há uma pesquisa neutra, pois toda pesquisa é permeada por expectativas do pesquisador, mas deixamos em evidência que durante toda pesquisa efetuamos avaliação realista dos objetivos inicialmente propostos. Mas sempre visando compreender mais o processo da inserção da intervenção do que propriamente o resultado final da sua aplicação.

Nesta pesquisa encontramos algumas características de uma pesquisa microetnográfica e participante (BOGDAN \& BIKLEN, 1994). É microetnográfica, pois dá conta de descrever minuciosamente um ambiente pequeno no estudo de um contexto e uma intervenção específica e seus participantes, embora não conste o período de estranhamento (adaptação dos estudantes e do professor com o pesquisador), o que caracteriza uma pesquisa mais rápida que atende a situações imediatas. E é participante, pois o pesquisador não apenas se insere no grupo para mera observação, mas participa 
da situação a ser investigada, visando manter o equilíbrio entre pesquisadora e professora não fugindo dos objetivos-alvo da investigação.

Segundo Thiollent (1985) a pesquisa participante não se limita a aceitação dos pesquisadores no meio pesquisado (observação participante), mas é explicitada dentro da situação de investigação, tomando cuidados para que haja reciprocidade por parte das pessoas e grupos implicados na situação de pesquisa.

De acordo com Campos (1984) a pesquisa participante auxilia a rever as práticas de pesquisa e as práticas escolares e a entender as relações entre os principais atores: o aluno e o professor, e a entender a teia de relações existentes entre diretor, funcionário, inspetor, etc. Quando se trata do processo de aprendizagem (processo especifico da ação escolar) o envolvimento é mais nítido na ralação professor-aluno, o que não exclui um grau mínimo de participação da escola como um todo.

A investigação - ação (gerada por investigação científica) voltada para educação, se, planejada, auto-refletida e refletida, pode potencializar os seres humanos a interpretar a realidade a partir de suas próprias práticas, concepções e valores, projetando novas ações, revelando um alto potencial transformador (BASTOS \& GRABAUSKA, 1998).

Segundo Engel (2000) podemos enumerar algumas características da pesquisaação:

i - o processo de pesquisa é um processo de aprendizagem para todos os participantes, ii - o pesquisador é um participante social que intervém numa situação com finalidade de verificar se o novo procedimento é eficaz ou não,

iii - o pesquisador procura diagnosticar um problema específico numa situação específica, com o fim aplicar na prática os resultados, iv - as modificações introduzidas na prática são constantemente avaliadas no decorrer do processo de intervenção, trazendo redefinições e mudanças de direção, gerando benefícios ao processo,

$\mathrm{v}$ - as fases finais da pesquisa são usadas para aprimorar os resultados das fases anteriores.

Encontramos as características descritas acima no decorrer desta pesquisa, pois vários ajustes são realizados ao longo do desenvolvimento da intervenção que somente são possíveis devido a maleabilidade que um professor - pesquisador possui, garantindo mais proximidade dos objetivos da pesquisa à realidade do ambiente escolar. 


\section{CAPÍTULO 3}

\section{Desenho de Pesquisa}

\subsection{Visão geral da Pesquisa}

Neste trabalho procuramos estabelecer relações interdisciplinares entre física, educação física, saúde, esporte e biomecânica. Este recorte pretende aproveitar a identificação explícita dos adolescentes com os exercícios físicos e esportes. Toda pesquisa se desenvolveu no Ensino Médio (seção 3.2.1), mas com ênfase no $1^{\circ}$ ano devido a correspondência entre o conteúdo do currículo do estado de São Paulo (SEE, 2008) e o conteúdo da intervenção realizada. A intervenção se deu em sala de aula por meio de um conjunto de atividades, cujo objetivo foi o de ensinar aos estudantes a compreender o conceito de saúde mesmo que reducionista numa perspectiva interdisciplinar, coordenando conhecimentos da física, educação física e biomecânica. Nas atividades desenvolvemos os conteúdos de mecânica voltados ao estudo dos movimentos para gerar um melhor desempenho na prática esportiva. Não abrangemos a parte nutricional (alimentação) e nem discutimos os diversos conceitos que permeiam a definição de saúde e qualidade de vida. Reforçamos que neste trabalho, a noção de saúde está relacionada apenas com a ausência de doenças. Aqui a prática esportiva saudável é aquela que não causa lesões fisiológicas.

$\mathrm{Na}$ tabela 3.1, a seguir, estão mostradas todas as fases da pesquisa, que se deram nos anos de 2007, 2008, 2009 e 2010.

Tabela 3.1: Esquema do desenho de pesquisa

\begin{tabular}{|c|c|c|c|}
\hline Ano & Avaliação & Objetivo & Descrição \\
\hline 2007 & $\begin{array}{l}\text { Questionário } \\
\text { Prévio } 0\left(\mathrm{Q}_{0}\right)\end{array}$ & $\begin{array}{l}\text { Delimitar os objetivos da pesquisa, } \\
\text { através do levantamento da concepção } \\
\text { prévia dos estudantes sobre a relação } \\
\text { entre esporte e física. }\end{array}$ & $\begin{array}{l}\text { Questionário com } 7 \\
\text { questões }\end{array}$ \\
\hline \multirow{2}{*}{2008} & $\begin{array}{l}\text { Questionário } \\
\text { Prévio } 1\left(\mathrm{Q}_{1}\right)\end{array}$ & $\begin{array}{l}\text { Completar os dados obtidos em } \mathrm{Q}_{0} \text { para } \\
\text { diminuirmos algumas respostas } \\
\text { inconclusivas }\end{array}$ & $\begin{array}{l}\text { Questionário com } 8 \\
\text { questões }\end{array}$ \\
\hline & $\begin{array}{l}\text { Questionário } \\
\text { Prévio } 2\left(\mathrm{Q}_{2}\right)\end{array}$ & $\begin{array}{l}\text { Analisar se houve interferências na } \\
\text { citação das disciplinas relacionadas ao } \\
\text { esporte em } \mathrm{Q}_{0}\end{array}$ & $\begin{array}{l}\text { Questionário com } 2 \\
\text { questões }\end{array}$ \\
\hline
\end{tabular}




\begin{tabular}{|l|l|l|l|l|}
\hline 2009 & $\begin{array}{l}\text { Atividades } \\
\text { piloto }\end{array}$ & $\begin{array}{l}\text { Testar o conteúdo das atividades para } \\
\text { realizar as adequações necessárias }\end{array}$ & $\begin{array}{l}10 \text { Atividades (vide } \\
\text { anexo A2) }\end{array}$ \\
\hline $\mathbf{2 0 1 0}$ & $\begin{array}{l}\text { Intervenção }+ \\
\text { Verificar a complexificação do } \\
\text { Ativ. } \\
\text { Avaliatória }\end{array}$ & $\begin{array}{l}9 \text { Atividades (vide } \\
\text { anexo A3) + } \\
\text { Atividade Avaliatória }\end{array}$ \\
\hline $\mathbf{2 0 1 0}$ & $\begin{array}{l}\text { Questionário de } \\
\text { validação* }\left(\mathrm{Q}_{3}\right)\end{array}$ & $\begin{array}{l}\text { Confirmar o resultado favorável obtido } \\
\text { na análise de dados }\end{array}$ & $\begin{array}{l}\text { Questionário } \\
\text { composto de } \\
\text { questões }\end{array}$ \\
\hline
\end{tabular}

*Sentido de corroboração aos dados obtidos na intervenção.

No terceiro bimestre de 2007 e no primeiro bimestre de 2008, por meio de alguns questionários preliminares, fizemos um mapeamento da concepção prévia dos estudantes do $3^{\circ}$ ano do ensino médio da escola estadual $\mathrm{G}$ a respeito das relações entre esporte, saúde e física, para nos auxiliar a delimitar os objetivos da pesquisa. Aplicamos um dos questionários preliminares - sem muitas pretensões - também em uma escola particular (P) (que utiliza método apostilado) apenas para ter um parâmetro de comparação de como os conceitos físicos são citados e explicados em outras situações de ensino. Durante o $2^{\circ}$ semestre de 2008 e o $1^{\circ}$ bimestre de 2009 , construímos um conjunto de nove atividades e mais uma avaliação final abrangendo o conteúdo de mecânica relacionado a esporte, saúde, educação física, biomecânica e física, com intuito de realizar inicialmente um teste, para fazermos às adequações necessárias as condições reais da escola e dos estudantes. No quarto bimestre de 2009, aplicamos estas atividades, que nomeamos de atividades piloto, em duas escolas de ensino médio: escola estadual G ( 2 turmas de $1^{\circ}$ ano) e escola estadual M (3 turmas de $1^{\circ}$ ano). Como se tratou de um teste, o conteúdo do caderno do aluno de física do $1^{\circ}$ ano do $4^{\circ}$ bimestre não casou com o conteúdo contido nas atividades piloto (proposta para ser aplicada no $1^{\circ}$ e $2^{\circ}$ bimestre). No $1^{\circ}$ e $2^{\circ}$ bimestre de 2010 aplicamos as atividades reestruturadas, que denominamos de intervenção e uma atividade de avaliação nas mesmas escolas: escola estadual G ( 2 turmas de $1^{\circ}$ ano) e escola estadual M ( 2 turmas de $1^{\circ}$ ano) e no $3^{\circ}$ bimestre um questionário de validação.

\subsection{Descrição da Amostra}

Toda a descrição da amostra está baseada nas observações realizadas durante o período da pesquisa e nos relatos da professora que atua nas duas escolas há 9 anos, portanto conhece os problemas intrínsecos da escola e as características dos estudantes 
que tempos frequentam, embora a cada ano surjam novidades quanto ao comportamento dos estudantes.

\subsubsection{Descrição geral da Amostra}

As amostras selecionadas são compostas de estudantes da escola $\mathrm{G}$ e escola $\mathrm{M}$ na cidade de São Roque, no interior do estado de São Paulo, com exceção de uma turma de 9 alunos de uma escola particular (P) de Mairinque (município vizinho de São Roque).

A escola G (localizada no Jardim Villaça - bairro um pouco afastado do centro da cidade, a beira da Rodovia Raposo Tavares) e escola M (localizada no centro da cidade) atendem a demanda de alunos de vários bairros da cidade, com diversas condições financeiras, mas em geral são alunos que possuem baixo poder aquisitivo. Ao mesmo tempo em que apresentam um padrão de consumo suficiente para desfrutar de celulares de custo alto, notebooks, etc., muitos estudantes trabalham meio-período para auxiliar suas famílias e suprir seus gastos pessoais. São adolescentes comuns, que adoram frequentar festas e se divertir, e que no contexto escolar não demonstram prazer em estudar e não vêem no estudo uma forma de melhorar de vida. Apesar disso, relatam posteriormente à saída da escola, que perderam oportunidade de estudar (baseado em relatos da professora).

A escola particular de Ensino Médio (sistema apostilado) se localiza no centro da cidade de Mairinque (interior do estado de São Paulo - a 4 km de São Roque). Esta escola atende a alunos de médio a alto poder aquisitivo, com intuito de preparar o aluno para prestar vestibular de uma universidade estadual ou federal.

A escola $\mathrm{M}$ é a maior escola da cidade (comporta 22 turmas por período) com quase 60 anos de existência e atende a maioria dos bairros da cidade (afastados e próximos da escola), pois é localizado no centro da cidade e, por conseqüência, o público recebido é muito heterogêneo (em termos de condições financeiras e grau de conhecimento). A escola fica próxima a biblioteca municipal, de várias lan houses, do único shopping da cidade, etc., portanto há vários lugares para os estudantes ficarem antes e depois das aulas e até para cabularem as aulas. Os modos de comportamento dos alunos dentro da escola são diversos, e diferem de período para período, mas de uma forma geral é necessário o apoio das rondas policiais escolares para ajudar a conter os alunos relacionados com "ações" ilícitas. Muitos alunos em busca da sonhada 
"liberdade", não vivida no ensino fundamental, escolhem a esta escola do centro, embora seja mais perto a escola $\mathrm{G}$.

A escola $\mathrm{G}$ é uma escola pequena (comporta 9 salas por período), com quase 50 anos de existência, que recebe os estudantes de algumas escolas municipais que se encontram mais próximas da Rodovia Raposo Tavares. O ponto de ônibus é em frente à escola, portanto as chances são menores de cabular as aulas. Os gestores e funcionários da escola conhecem pelo nome todos os alunos e muitas vezes os pais, o que facilita um controle maior do comportamento dos estudantes.

O grupo gestor das duas escolas G e M é similar quanto à exigência, e de certa forma possuem os mesmos problemas embora as quantidades de alunos por período sejam bem diferentes uma da outra. Os recursos disponíveis para os professores na escola M são: lousa, giz, data-show e um notebook (para uso de toda escola) que vivem sempre com problemas pelo fato de que não há uma sala fixa para os equipamentos. Já na escola $\mathrm{G}$, os recursos disponíveis para os professores são: lousa, giz, biblioteca, DVD, TV, data-show e um notebook (para uso de toda escola) com sala adequada para uso.

Não foi realizada uma seleção criteriosa das turmas que iriam participar da pesquisa, simplesmente escolhemos as turmas que a professora-pesquisadora lecionava. A amostra do questionário preliminar foi composta em 2007 de 3 turmas de terceiro ano (da manhã) da escola G, e uma turma de segundo ano (da manhã) da escola particular. Em 2008, a amostra foi composta de seis turmas de segundo ano, 4 turmas de terceiro ano (da manhã) e 3 turmas de primeiro ano (da tarde) da escola G. Assim, amostra total de $2007+2008$ é composta por 333 alunos, cujas idades variam entre 15 e 20 anos de idade (tabela 3.2.).

A amostra das atividades piloto foi composta em 2009 de 2 turmas de $1^{\circ}$ ano (da tarde) da escola $\mathrm{G}\left(1^{\circ} \mathrm{A}_{1}\right.$ e $\left.1^{\circ} \mathrm{B}_{1}\right)$ e 3 turmas de $1^{\circ}$ ano (da tarde) da escola $\mathrm{M}\left(1^{\circ} \mathrm{C}_{1}, 1^{\circ} \mathrm{D}_{1}\right.$ e $\left.1^{\circ} \mathrm{E}_{1}\right)$. Assim, amostra total de 2009 é composta por 125 alunos, cujas idades variam entre 15 e 18 anos de idade (tabela 3.2.).

A amostra da intervenção foi composta em 2010 de 2 turmas de $1^{\circ}$ ano (da tarde) da escola $\mathrm{G}\left(1^{\circ} \mathrm{A}_{2}\right.$ e $\left.1^{\circ} \mathrm{B}_{2}\right)$ e 2 turmas de $1^{\circ}$ ano (da tarde) da escola $\mathrm{M}\left(1^{\circ} \mathrm{C}_{2}\right.$ e $\left.1^{\circ} \mathrm{D}_{2}\right)$. Assim, amostra total de 2010 é composta por 156 alunos, cujas idades variam entre 15 e 18 anos de idade (tabela 3.2.).

O período da manhã se estende das $7 \mathrm{~h}$ as $12 \mathrm{~h}$ e 20 min e o período da tarde se estende das $13 \mathrm{~h}$ as $18 \mathrm{~h}$ e $20 \mathrm{~min}$ em ambas escolas públicas. 
Tabela 3.2: Identificação das amostras.

\begin{tabular}{|c|c|c|c|}
\hline Avaliação & Ano/bimestre & Aluno/série/período & $\begin{array}{l}\text { Questionário/ } \\
\text { escola/ no de } \\
\text { questões }\end{array}$ \\
\hline \multirow[b]{4}{*}{$\begin{array}{l}\text { Questionário } \\
\text { Preliminar (Q) }\end{array}$} & $2007 / 3^{\circ}$ & $\begin{array}{l}1 \text { ao } 80 / 3^{\circ} \text { ano } \mathrm{A}_{0}, \mathrm{~B}_{0} \mathrm{e} \\
\mathrm{C}_{0} / \text { manhã }\end{array}$ & $\mathrm{Q}_{0} / \mathrm{G} / 7$ \\
\hline & $2007 / 3^{\circ}$ & $\begin{array}{l}81 \text { ao } 90 / 2^{\circ} \text { ano } \mathrm{A}_{0} / \\
\text { manhã }\end{array}$ & $\mathrm{Q}_{0} / \mathrm{P} / 7$ \\
\hline & $2008 / 1^{\circ}$ & $\begin{array}{l}1 \text { ao } 27 / 2^{\circ} \text { ano } B_{0} / \\
\text { manhã }\end{array}$ & $\mathrm{Q}_{1} / \mathrm{G} / 8$ \\
\hline & $2008 / 1^{\circ}$ & $\begin{array}{l}1 \text { ao } 68 / 1^{\circ} \text { ano } \mathrm{A}_{0}, \mathrm{~B}_{0} \mathrm{e} \\
\mathrm{C}_{0} / \text { tarde } \\
1 \text { ao } 148 / 2^{\circ} \text { ano } \mathrm{C}_{0}, \mathrm{D}_{0}, \\
\mathrm{E}_{0}, \mathrm{~F}_{0}, \mathrm{G}_{0} / \text { manhã } \\
1 \text { ao } 62 / 3^{\circ} \text { ano } \mathrm{D}_{0}, \mathrm{E}_{0}, \mathrm{~F}_{0}, \\
\mathrm{G}_{0} / \text { manhã }\end{array}$ & $\mathrm{Q}_{2} / \mathrm{G} / 2$ \\
\hline \multirow{2}{*}{$\begin{array}{l}\text { Atividades Piloto } \\
\text { (AP) }\end{array}$} & $2009 / 4^{\circ}$ & $\begin{array}{l}1 \text { ao } 53 / 1^{\circ} \text { ano } A_{1} \text { e } B_{1} / \\
\text { tarde }\end{array}$ & - / G / - \\
\hline & $2009 / 4^{\circ}$ & $\begin{array}{l}1 \text { ao } 72 / 1^{\circ} \text { ano } C_{1}, D_{1} e \\
E_{1} / \text { tarde }\end{array}$ & - / M / - \\
\hline \multirow{2}{*}{$\begin{array}{l}\text { Intervenção (I) + } \\
\text { Atividade } \\
\text { Avaliatória (AV) }\end{array}$} & $2010 / 1^{o}$ e $2^{o}$ & $\begin{array}{l}1 \text { ao } 41 / 1^{\circ} \text { ano } A_{2} / \text { tarde } \\
1 \text { ao } 41 / 1^{\circ} \text { ano } B_{2} / \text { tarde }\end{array}$ & - / G / - \\
\hline & $2010 / 1^{o}$ e $2^{o}$ & $\begin{array}{l}1 \text { ao } 37 / 1^{\circ} \text { ano } \mathrm{C}_{2} / \text { tarde } \\
1 \text { ao } 37 / 1^{\circ} \text { ano } D_{2} / \text { tarde }\end{array}$ & $-/ \mathrm{G} /-$ \\
\hline $\begin{array}{l}\text { Validação da } \\
\text { Pesquisa }\left(\mathbf{Q}_{3}\right)^{*}\end{array}$ & $2010 / 1^{\circ}$ e $2^{o}$ & $\begin{array}{l}1 \text { ao } 41 / 1^{\circ} \text { ano } A_{3} / \text { tarde } \\
1 \text { ao } 41 / 1^{\circ} \text { ano } B_{3} / \text { tarde } \\
1 \text { ao } 37 / 1^{\circ} \text { ano } C_{3} / \text { tarde } \\
1 \text { ao } 37 / 1^{\circ} \text { ano } D_{3} / \text { tarde }\end{array}$ & $\mathrm{Q}_{3} / \mathrm{G}, \mathrm{M} / 7$ \\
\hline
\end{tabular}

* As turmas $\mathrm{A}_{2}=\mathrm{A}_{3}, \mathrm{~B}_{2}=\mathrm{B}_{3}, \mathrm{C}_{2}=\mathrm{C}_{3}$ e $\mathrm{D}_{2}=\mathrm{D}_{3}$ são equivalentes.

Utilizaremos para facilidade da leitura dos dados as notações: $G$ para a escola estadual G, M para a escola estadual M, P para a única escola particular, Q para os questionários preliminares, AP para atividade piloto, I para intervenção, AV para atividade avaliatória, V para validação, sub-índice 0 para as turmas de 2007 e 2008 submetidas ao questionário preliminar, sub-índice 1 para as turmas de 2009 submetidas 
as atividades piloto, sub-índice 2 para as turmas de 2010 submetidas a intervenção e sub-índice 3 para as turmas de 2010 submetidas ao questionário de validação, que são equivalentes em composição as turmas de sub-índice 2 .

\subsubsection{Descrição detalhada da Amostra}

A descrição detalhada da amostra se revela mediante o processo de pesquisa e está acoplada aos relatos da professora em junção as observações da pesquisadora.

$\mathrm{Na}$ escola $\mathrm{M}$, com relação ao período da tarde, no qual desenvolvemos a pesquisa (por meio de relatos informais), os docentes descrevem o período como "difícil de lidar", devido à falta de motivação e descomprometimento dos estudantes com os estudos, pois percebem que os mesmos não encaram o estudo como um aliado para melhorar de vida. Além disso, se queixam do mau comportamento dos estudantes (não condizente com uma sala de aula). Segundo os docentes desta escola, os estudantes não se importam com: notas baixas, excesso de faltas, punições mais severas vindas do quadro de gestores da escola, etc. talvez por terem adquirido a tão sonhada "liberdade", não desfrutada até então. Todos os estudantes frequentaram o ensino fundamental em escolas pequenas de bairro municipal, onde "todo mundo conhece todo mundo" e os responsáveis são mais presentes na escola.

Em reuniões pedagógicas da escola ou mesmo na hora de trabalho pedagógico coletivo (HTPC), há uma preocupação dos educadores e gestores em entender: por que os alunos se recusam a estudar e se comportam inadequadamente na sala de aula? Nestas reuniões os professores falam sobre algumas questões enfrentadas em sala de aula e "trocam figurinhas", pedem opiniões ao coordenador e esporadicamente ao diretor que frequenta muito pouco estas reuniões. Várias questões são levantadas para discussão, mas é raro quando são obtidas respostas que mostrem a atitude a ser tomada diante dos estudantes em sala de aula e no contexto escolar geral. Os docentes salientam nas reuniões a facilidade e o apoio que os estudantes desfrutam para estudar, pois recebem do Governo do Estado de São Paulo, cadernos, livros, caderno do aluno, mochila, passe de ônibus, merenda, etc., mas todos estes incentivos ao estudo, não refletem em mudança da postura dos estudantes em relação a escola, pois continuam através de atitudes no cotidiano da sala de aula não valorizando o estudo e a escola. 
Na tabela 3.3, escolhemos alguns trechos, advindos da coleta de conversas informais nas reuniões de professores de disciplinas distintas, que caracterizam os alunos e o corpo docente da escola, fornecendo uma descrição mais completa da amostra:

Por meio dos relatos informais citados na tabela 3.3, identificamos alguns dos problemas atuais apresentados na escola M (que nos parecem plausível de generalização nas escolas da rede pública) e as dificuldades enfrentadas pelo professor em sala de aula, mas também, é nítida a preocupação dos docentes em buscar meios para superar os vários obstáculos originados nas aulas.

Tabela 3.3: Relatos informais de alguns docentes da escola M.

\begin{tabular}{|c|l|}
\hline Professor & Relato \\
\hline A & $\begin{array}{l}\text { "No ano passado os alunos se intimidavam pelas faltas, pois os pais na } \\
\text { reunião de pais se preocupavam mais com as faltas do que com as notas, } \\
\text { mas neste ano os alunos não se importam com nada, está difícil trabalhar } \\
\text { na sala de aula, será que devo mudar meus valores?". }\end{array}$ \\
\hline B & $\begin{array}{l}\text { "Percebo que é preciso saber o que o aluno espera da escola, motivá-lo, } \\
\text { mas tenho medo, pois acho que ele não quer nada da escola. Não sei se há } \\
\text { valores... é difícil ir contra os meus valores, será que devo abandoná-los? E } \\
\text { faço o que na escola?". }\end{array}$ \\
\hline C & $\begin{array}{l}\text { "Sinto que nada mais funciona, tenho que fazer coisas que não concordo } \\
\text { como dar visto no caderno e na apostila e espremer para ver se sai nota, } \\
\text { não querem fazer absolutamente nada!". }\end{array}$ \\
\hline D & $\begin{array}{l}\text { "A sala de aula tem de tudo menos alunos interessados nos conteúdos. } \\
\text { Dizem que a maioria vence, então talvez os conteúdos sejam inadequados } \\
\text { a esta nova geração, mas está no Currículo do Estado de São Paulo". }\end{array}$ \\
\hline E & $\begin{array}{l}\text { "Puxa, tenho uma sala de 40 alunos e dentre eles um deficiente físico, } \\
\text { auditivo, não dou conta de tudo isso, o que faço? preciso dar atenção } \\
\text { adequada aos deficientes". }\end{array}$ \\
\hline F & $\begin{array}{l}\text { "Nós precisamos moldá-los no primeiro ano do ensino médio, há de ter } \\
\text { uma forma de fazê-los entender as regras, o celular e o cigarro é lei federal, } \\
\text { mas eles não obedecem". }\end{array}$ \\
\hline
\end{tabular}

Por meio de observações em sala de aula durante a pesquisa, notamos que intimidar os estudantes através de notas ou faltas não causa efeito, há um descomprometimento dos estudantes com a aprendizagem. Comportamentos como: sair da sala de aula sem autorização, dizer em voz alta palavras torpes, andar pela sala de aula gritando, se comunicar com alunos que estão no pátio ou em outra sala de aula, se 
dirigir ao professor de maneira agressiva, desprezar o material doado e a proposta de aula dada pelo professor, recusar a desenvolver as atividades propostas pelo professor, utilizar de aparelhos eletrônicos em sala de aula, fazem parte da rotina. Diante disto, as possíveis ameaças formuladas pelo professor para alcançar seu objetivo de aprendizagem são vãs, é necessário buscar novas estratégias que consigam atingir com sucesso os estudantes e que resultem em motivação para buscar o conhecimento.

$\mathrm{Na}$ escola $\mathrm{G}$ através de relatos informais, averiguamos que as discussões dos professores nas reuniões pedagógicas e HTPC (hora de trabalho pedagógico coletivo) são similares as da escola $M$, pois os docentes se queixam da falta de interesse dos estudantes para o estudo, e do aproveitamento insatisfatório. Mas em termos de comportamento disciplinar em sala de aula é mais ameno que na escola M.

\subsection{Professora - pesquisadora}

Em todas as etapas da pesquisa a professora das turmas analisadas é a própria pesquisadora. A professora leciona na rede pública de ensino do interior de São Paulo desde janeiro de 2002, tendo cargo efetivo nas duas únicas escolas públicas de ensino médio da cidade de São Roque, portanto o "ambiente escolar" (administração, corpo docente e funcionários) das duas escolas já é conhecido. Quanto às características dos alunos que frequentam a escola de certa forma a professora conhece, embora a mesma dê relatos de que a cada ano os alunos chegam ao ensino médio com mais defasagens de conteúdo e, além disso, sem limites de comportamento, e modificação nítida de valores dados à escola como um todo.

A nosso ver a troca do olhar de professora para pesquisadora e vice-versa, favorece a intervenção em sala de aula, enriquece e ao mesmo tempo dificulta a análise de dados. A resposta à aplicação da intervenção, a possibilidade da utilização de recursos didáticos e autorização da administração é mais rápida e dinâmica, facilitando no bom andamento da pesquisa. A presença de uma segunda pessoa (o pesquisador) na sala de aula pode interferir no comportamento dos alunos do cotidiano escolar. A prática professor - pesquisador possibilita uma auto-reflexão de suas ações como professor em sala de aula, através da composição em cada aula de um diário de bordo, que ao ser analisado com o olhar de pesquisador facilita em modificações e inserções imediatas nas intervenções. 
Sabemos que ser professora - pesquisadora e vice-versa não é absolutamente vantajoso, pois em algumas descrições de ambiente, de comportamento, etc. podem ser suprimidos alguns pontos relevantes para análise de dados, que devido à convivência diária na escola sejam comuns. Um outro ponto importante é a dificuldade em realizar uma auto-análise de comportamento na sala de aula e posicionamento em situações adversas.

Segundo Bardin (2010) não há como um investigador realizar uma pesquisa sem demonstrar seus sentimentos, pois sempre há uma alegria quando o estudo realizado confirma ou infirma uma hipótese (desde que se obtenham resultados), ou permite que se siga por outro caminho, com outros olhares. Não há uma pesquisa neutra, pois toda pesquisa é permeada por expectativas do pesquisador, mas deixamos em evidência que durante toda pesquisa efetuamos avaliação realista dos objetivos inicialmente propostos. Mas sempre visando compreender mais o processo da inserção da intervenção do que propriamente o resultado final da sua aplicação.

\subsection{Questionários preliminares}

Nesta seção apresentaremos todos os questionários preliminares, que formam um conjunto de três questionários aplicados anteriormente à atividade piloto e a intervenção. Nestes questionários mostraremos as concepções prévias dos estudantes com relação à física e os esportes. Estes questionários nos auxiliaram no levantamento do perfil conceitual dos estudantes a respeito da relação entre física e esporte (objetivo inicial da pesquisa), com enfoque na observação de como os estudantes utilizam os conceitos de física vistos no primeiro ano do ensino médio. Restringimos-nos ao conteúdo do primeiro ano do ensino médio, pois pelo Currículo do Estado de São Paulo (SÃO PAULO: SEE, 2008) é nesta série que temos o conteúdo de mecânica, no qual pretendemos interligá-los com o tema: esporte, para auxiliar na aprendizagem de alguns conceitos físicos de mecânica e resultar em uma vida saudável (sem lesões provenientes do exercício físico) pela mudança de postura quanto à prática de esportes.

Tabela 3.1: Esquema do desenho de pesquisa.

\begin{tabular}{|l|l|l|l|}
\hline Ano & Avaliação & Objetivo & Descrição \\
\hline
\end{tabular}




\begin{tabular}{|c|c|c|c|}
\hline 2007 & $\begin{array}{l}\text { Questionário } \\
\text { Prévio } 0\left(\mathrm{Q}_{0}\right)\end{array}$ & $\begin{array}{l}\text { Delimitar os objetivos da pesquisa, } \\
\text { através do levantamento da concepção } \\
\text { prévia dos estudantes sobre a relação } \\
\text { entre esporte e física. }\end{array}$ & $\begin{array}{l}\text { Questionário com } 7 \\
\text { questões. }\end{array}$ \\
\hline \multirow{2}{*}{2008} & $\begin{array}{l}\text { Questionário } \\
\text { Prévio } 1\left(\mathrm{Q}_{1}\right)\end{array}$ & $\begin{array}{l}\text { Completar os dados obtidos em } \mathrm{Q}_{0} \text { para } \\
\text { diminuirmos algumas } \\
\text { inconclusivas. }\end{array}$ & $\begin{array}{l}\text { Questionário com } 8 \\
\text { questões. }\end{array}$ \\
\hline & $\begin{array}{l}\text { Questionário } \\
\text { Prévio } 2\left(\mathrm{Q}_{2}\right)\end{array}$ & $\begin{array}{l}\text { Analisar se houve interferências na } \\
\text { citação das disciplinas relacionadas ao } \\
\text { esporte em } \mathrm{Q}_{0} \text {. }\end{array}$ & $\begin{array}{l}\text { Questionário com } 2 \\
\text { questões. }\end{array}$ \\
\hline 2009 & $\begin{array}{l}\text { Atividades } \\
\text { piloto }\end{array}$ & $\begin{array}{l}\text { Testar o conteúdo das atividades para } \\
\text { realizar as adequações necessárias. }\end{array}$ & $\begin{array}{l}10 \text { Atividades (vide } \\
\text { anexo A2). }\end{array}$ \\
\hline 2010 & $\begin{array}{l}\text { Intervenção } \\
\text { Ativ. } \\
\text { Avaliatória }\end{array}$ & $\begin{array}{l}\text { Verificar a complexificação do } \\
\text { conhecimento de esportes. }\end{array}$ & $\begin{array}{l}9 \text { Atividades (vide } \\
\text { anexoA3) }+1 \\
\text { Atividade } \\
\text { Avaliatória. }\end{array}$ \\
\hline 2010 & $\begin{array}{l}\text { Questionário de } \\
\text { validação* }\left(Q_{3}\right)\end{array}$ & $\begin{array}{l}\text { Confirmar o resultado favorável obtido } \\
\text { na análise de dados. }\end{array}$ & $\begin{array}{l}\text { Questionário } \\
\text { composto de } \\
\text { questões. }\end{array}$ \\
\hline
\end{tabular}

*Sentido de corroboração aos dados obtidos na intervenção.

\subsubsection{Questionário $Q_{0}$}

Priorizamos realizar o levantamento de dados em uma das escolas públicas do Estado de São Paulo na cidade de São Roque - escola G. Para ter um parâmetro de comparação quanto a metodologia de ensino, em termos de analisar se a extensão de conteúdos resulta na aplicabilidade - sem ajuda do professor - dos conhecimentos de física vistos na escola no cotidiano dos estudantes, aplicamos um questionário em uma escola particular P de ensino médio na cidade de Mairinque. Na tabela 3.2 mostramos a ordem em que os questionários foram aplicados e também a quantidade de alunos que foram submetidos à pesquisa.

Devemos levar em conta as ideias prévias dos alunos para delimitar os objetivos e para organizar os conteúdos. Com este intuito decidimos levantar os conceitos prévios dos alunos sobre a inserção dos esportes na aprendizagem dos conteúdos de mecânica. Foi aplicado um questionário $\mathrm{Q}_{0}$ constituído por sete questões. Nossa hipótese inicial era de que os alunos não conseguiriam aplicar os conceitos de mecânica vistos ao longo do ensino médio na prática de esportes. Também não conseguiriam visualizar a aplicação da física no seu cotidiano, além utilizar conceitos como força, equilíbrio, velocidade, etc., de forma mais ligada ao senso comum, e como consequência, não conseguiriam relacionar os conceitos da física com os esportes. Afinal o tema, de 
mecânica é um conteúdo regularmente abordado pelos professores da escola pública, que geralmente enfocam somente a parte de cinemática escalar (MRU e MRUV) e dinâmica (apenas as três leis de Newton), deixando de lado cinemática vetorial, estática, hidrostática e gravitação universal.

Os dados foram coletados em três turmas de $3^{\mathrm{a}}$ série do Ensino Médio da escola G em São Roque, no período da manhã, no $3^{\circ}$ bimestre de 2007 , e em uma turma de $2^{\circ}$ ano de uma escola particular em Mairinque, no período da manhã, no $4^{\circ}$ bimestre de 2007, na qual a professora que atuou nas salas em questão é a própria pesquisadora. A superposição de papéis, a nosso ver, não acarretou em deformação da amostragem, dado que a situação de aula era conhecida e o questionário foi aplicado como atividade livre extra.

Optamos também por aplicar o questionário $\mathrm{Q}_{0}$ em uma turma da escola particular para verificar se há alguma diferença de resultados, pois sabemos que é um ensino apostilado, no qual o conteúdo de mecânica é abordado em detalhes e há quatro aulas de física semanais e apenas 10 alunos por sala, enquanto na escola pública apenas duas aulas semanais com em média 35 a 45 alunos por sala. Aplicamos então o questionário $\mathrm{Q}_{0}$ contendo sete questões aos estudantes da $3^{\mathrm{a}}$ série $\mathrm{A}_{0}, \mathrm{~B}_{0}$ e $\mathrm{C}_{0}$ do ensino médio da escola $\mathrm{G}$, em um total de 80 alunos, cujas idades variavam entre 17 e 20 anos de idade $\left(\mathrm{Q}_{0 \mathrm{G}}\right)$ e em uma turma de $2^{\mathrm{a}}$ série da escola particular, em um total de 10 alunos $\left(\mathrm{Q}_{\mathrm{OP}}\right)$. O objetivo deste questionário era determinar se os alunos conseguem aplicar os conceitos de mecânica nos esportes e em suas atividades diárias. Na tabela 3.4 mostramos as questões que compõem o questionário $\mathrm{Q}_{0}$ :

Tabela 3.4: Questionário $\mathrm{Q}_{0}$. 1) Na sua concepção, qual a importância do esporte na vida do ser humano? Comente.

Objetivo da questão: Nesta questão queríamos identificar a concepção de vida saudável para os alunos vinculada à prática esportiva e como se dá esta relação, com a hipótese que não relacionariam com o social e o mental, apenas com ausência de doenças.

2) Qual modalidade de esporte que você pratica? (pode ser semanalmente, ou até mensalmente). Quais são as habilidades necessárias para desempenhá-lo com sucesso? Explique.

Objetivo da questão: Nesta questão, queríamos identificar se os alunos desenvolvem atividades físicas regularmente, já que é um dos itens para uma vida saudável e se realmente conhecem as habilidades necessárias para praticar o esporte de forma correta.

3) De todas as disciplinas, coloque em ordem a que mais relaciona com esporte. Não se esqueça de nenhuma disciplina. 
Objetivo da questão: Nesta questão queríamos saber se os alunos conseguem perceber a aplicação das disciplinas escolares nos esportes.

4) Relacionando agora o assunto "esporte" diretamente a física enumere pelo menos seis modalidades esportivas e a respectiva aplicação da física nas mesmas. Para facilitar use o modelo de tabela:

\begin{tabular}{|l|l|c|} 
Modalidade esportiva & Física (conteúdo) & $\begin{array}{c}\text { Explique a relação da modalidade } \\
\text { esportiva com a física }\end{array}$ \\
\hline
\end{tabular}

Objetivo da questão: Nesta questão abordamos diretamente os objetivos de pesquisa. Queríamos verificar se os alunos conseguem aplicar os conceitos de mecânica vistos ao longo do ensino médio.

5) Quais tipos de esportes podem ser desenvolvidos em uma academia de ginástica? Em quais deles em sua opinião é evidente a aplicação dos conceitos da física?

Objetivo da questão: Como alguns adolescentes cultuam o corpo, frequentam ou já frequentaram academias de ginástica, através desta questão queríamos observar se os alunos conseguem visualizar os conceitos de mecânica com os equipamentos de musculação, ou com as aulas de gasto calórico desenvolvido nas mesmas.

6) A introdução do tópico: "A física dos esportes", auxiliaria você no aprendizado dos conteúdos de física? De que forma?

Objetivo da questão: Durante as aulas os alunos geralmente questionam qual aplicação do conteúdo visto no dia-a-dia, sendo que alguns sempre citam a quadra de esportes como um lugar de aplicação da física, portanto nesta questão buscamos levantar algumas informações sobre isto.

7) Continue a frase (com pelo menos cinco linhas). Nas minhas atividades diárias percebo que a física está sempre presente, como por exemplo, ...

Objetivo da questão: Nesta questão queríamos analisar como os alunos aplicam os conceitos físicos no cotidiano.

\subsubsection{Questionário $Q_{1}$}

Após um breve estudo dos dados obtidos pelo questionário $\mathrm{Q}_{0}$ formulamos um novo questionário, para averiguar com mais cuidado alguns conceitos físicos de mecânica. Aplicamos o questionário $\mathrm{Q}_{1}$ contendo oito questões (tabela 3.5) aos estudantes da $2^{\mathrm{a}}$ série $\mathrm{B}_{0}$ do ensino médio do período da manhã no $1^{\circ}$ bimestre de 2008 , da escola G, em São Roque, em um total de 27 alunos, cujas idades variavam entre 17 e 20 anos de idade. É relevante ressaltar que o questionário foi aplicado no período de recuperação através de um jornal proposto pela Secretaria da Educação do Estado de 
São Paulo, cujo conteúdo tratava de MRU e MRUV, além de alguns tópicos sobre pressão e ondas.

Tabela 3.5: Questionário $\mathrm{Q}_{1}$

1 - Dos conteúdos de física que foram abordados no ano passado, qual the chamou mais atenção? Dê uma explicação convincente?

Objetivo da questão: Nesta questão queríamos que os alunos ressaltassem quais os conteúdos de mecânica despertam mais interesse.

2 - Dentre os conteúdos do ano passado selecione dois e descreva como cada um se relaciona com o seu dia-a-dia?

Objetivo da questão: Nesta questão queríamos observar se os alunos conseguem relacionar a física com o seu cotidiano sem a ajuda do professor.

\section{3 - Em quais conteúdos você teve mais dificuldade? Por quê?}

Objetivo da questão: Nesta questão queríamos verificar quais tópicos apresentam mais dificuldades no aprendizado para que futuramente possamos dar mais ênfase nas atividades.

4 - Construa uma frase ou uma historinha utilizando palavras relacionadas à física e aos esportes, de no mínimo 5 linhas.

Objetivo da questão: Nesta questão queríamos observar se os alunos conseguem aplicar os conceitos de física na construção de uma frase.

5 - Uma área muito utilizada para avaliar o desempenho na prática esportiva é a biomecânica. Nela são utilizados muitos conceitos da Física desenvolvidos na primeira série do ensino médio. Enumere pelo menos seis atividades esportivas (lembre-se do pan 2007 e que temos nesse ano as olimpíadas).

Objetivo da questão: Nesta questão queríamos apenas saber as modalidades esportivas preferidas pelos alunos, para termos alguns parâmetros para construção das atividades.

6 - Explique qual a relação dessas atividades esportivas com os conceitos aprendidos no primeiro ano.

Objetivo da questão: Nesta questão queríamos analisar se os alunos se lembram dos conteúdos visto em bimestres anteriores, e se os conceitos foram aprendidos de forma correta.

7 - O número de medalhas da ginástica olímpica e a natação no Pan2007 foi o maior dentre todos os esportes, fazendo com que estas modalidades tivessem muito sucesso. Descreva como a Física pode ser aplicada nestes dois esportes.

Objetivo da questão: Nesta questão queríamos analisar a forma de uso de alguns conceitos de mecânica. 
8 - Quase todo brasileiro é fanático por futebol, será que a física está presente no futebol? Faça uma breve explicação.

Objetivo da questão: Nesta questão queríamos verificar se os alunos realmente enxergam a relação da física com o futebol ou se apenas é citado sem significado nenhum.

\subsubsection{Questionário $Q_{2}$}

Ao querer relacionar a física com o esporte, como já dissemos precisamos analisar os conceitos prévios e verificar se os alunos realizam ou idealizam a relação com a disciplina, para isso propomos um último questionário preliminar para analisar em posições, quais disciplinas na concepção dos alunos têm mais relação com o esporte. Aplicamos o questionário $\mathrm{Q}_{2}$ (tabela 3.6) contendo duas questões aos estudantes da $1^{\mathrm{a}}$ série $\left(A_{0}, B_{0}, C_{0}\right)$ do ensino médio no período da tarde, $2^{a}$ série $\left(C_{0}, D_{0}, E_{0}, F_{0}, G_{0}\right)$ e $3^{\circ}$ ano $\left(D_{0}, E_{0}, F_{0}, G_{0}\right)$ do ensino médio do período da manhã no $1^{\circ}$ bimestre de 2008 , da escola G, em São Roque, em um total de 278 alunos, cujas idades variavam entre 14 e 20 anos de idade (conforme a tabela 3.7). É relevante que o questionário foi aplicado na primeira aula do período por professores de disciplinas diferentes, para evitar alguns problemas de caráter "bajulador".

Tabela 3.6: Questionário $\mathrm{Q}_{2}$.

Por favor, responda as questões em detalhes.

1) Na sua concepção, qual a importância do esporte na vida do ser humano? Comente.

Objetivo da questão: Esta questão tem o mesmo objetivo da questão 1 do questionário $\mathrm{Q}_{0}$, pois queríamos obter mais dados dos estudantes sobre a relação: saúde e esporte. Precisamos analisar o que os alunos pensam sobre os benefícios e malefícios da prática de esportes.

2) De todas as disciplinas, coloque em ordem a que mais relaciona com esporte. Não se esqueça de nenhuma disciplina (G, H, A, EF, FIL, I, P, F, M, B, Q).

Objetivo da questão: Nesta questão queríamos saber se os alunos conseguem perceber a aplicação das disciplinas escolares nos esportes. Esperamos que já tenham previamente a noção de que física está diretamente relacionada ao esporte. 
Tabela 3.7: Alunos que foram submetidos ao Questionário $\mathrm{Q}_{2}$

\begin{tabular}{|c|c|c|c|}
\hline Série & Período & $\mathbf{N}^{0}$ de alunos & Disciplina \\
\hline $1^{\circ} \mathrm{A}_{0}$ & \multirow{3}{*}{ Tarde } & 23 & Artes A \\
\hline $1^{\circ} \mathrm{B}_{0}$ & & 19 & Artes A \\
\hline $1^{\circ} \mathrm{C}_{0}$ & & 25 & Língua Portuguesa P \\
\hline $2^{\circ} \mathrm{C}_{0}$ & \multirow{9}{*}{ Manhã } & 23 & Artes A \\
\hline $2^{\circ} \mathrm{D}_{0}$ & & 28 & Matemática M \\
\hline $2^{\circ} \mathrm{E}_{0}$ & & 22 & Química Q \\
\hline $2^{\circ} \mathrm{F}_{0}$ & & 26 & Filosofia FIL \\
\hline $2^{\circ} \mathrm{G}_{0}$ & & 29 & Física F \\
\hline $3^{\circ} \mathrm{D}_{0}$ & & 22 & Matemática M \\
\hline $3^{\circ} \mathrm{E}_{0}$ & & 17 & História H \\
\hline $3^{\circ} \mathrm{F}_{0}$ & & 25 & Matemática M \\
\hline $3^{\circ} \mathrm{G}_{0}$ & & 19 & Inglês I \\
\hline
\end{tabular}

\subsection{Construção da intervenção}

É importante em toda intervenção na sala de aula levar em consideração as concepções prévias dos estudantes a respeito do conceito a ser abrangido em sala de aula. Não queremos desvalorizar a concepção já existente, ou pregar a mudança (substituição) de um conceito, mas introduzir novas zonas ao perfil conceitual dos indivíduos (complexificar o conhecimento), o que acarretará em uma gama de aplicações deste conceito, que dependerá das situações, ou seja, dos contextos de uso, no qual podemos avaliar o grau de complexificação atingido pelo estudante.

Como estamos inseridos em uma sala de aula heterogênea, sabemos que a evolução de perfil conceitual de cada estudante, a complexificação do conhecimento é diferente, mas esperamos que os estudantes a cada aquisição de um novo significado para o conceito, tomem consciência do seu perfil conceitual para consequentemente associar os significados aos contextos de uso respectivos. 
O intuito da intervenção não é desprezar o conhecimento cotidiano ou considerar o científico como superior, mas enriquecer o conhecimento cotidiano (GARCIA, 1998) e mostrar para o aluno que um conceito pode ter vários significados que são dependentes do contexto.

Tivemos o cuidado neste trabalho em verificar se os estudantes são capazes de aplicar os conceitos vistos na intervenção em novas situações relacionadas a outras modalidades esportivas. Tanto as concepções prévias como as novas concepções a respeito de um conceito podem conviver pacificamente, sendo usados em contextos independentes e não relacionados, portanto não é necessário negar suas concepções prévias (MORTIMER, 2000).

Para a construção da intervenção recorremos ao tema esporte para despertar o interesse dos estudantes pela disciplina de física logo na primeira série inicial do ensino médio. Optamos por este tema pelo fato dos estudantes apresentarem alto grau de afinidade e interesse (seção 4.1).

Com este tema podemos abranger todo conteúdo de mecânica e, além disso, enfocar a prática esportiva saudável utilizando recursos similares aos apresentados por Bastos (2007) e Bastos \& Mattos (2009). Mas, por que especificamente integrar mecânica e esporte? A escolha surgiu a partir de algumas hipóteses (analisadas posteriormente no capítulo 4):

1) da identificação dos alunos com os esportes e da empolgação com as aulas de educação física (talvez seja pelo fato de fazer exercícios físicos ou simplesmente sair um pouco da sala de aula), embora tenham diferentes gostos quanto às diversas modalidades esportivas,

2) do risco em sofrer lesões pela forma inadequada de praticar exercícios físicos, esportes, etc., que está diretamente associado à falta de conhecimentos em biomecânica, 3) da forma com que os estudantes relacionam esporte, saúde e beleza e seguem alguns padrões de beleza estabelecidos pela mídia (COSTA \& VENÂNCIO, 2004),

4) da maneira com que os estudantes julgam o desempenho de um atleta e as atitudes do técnico em competições esportivas,

5) da relação que os alunos estabelecem entre física e esporte, mesmo que erroneamente, utilizando termos como: velocidade, aceleração, tempo, força, etc., 6) da importância em mostrar que a física pode ser utilizada para contribuir para uma vida saudável. 


\subsubsection{PCN e Currículos}

Segundo o Currículo do Estado de São Paulo para a disciplina de física (SÃO PAULO: SE, 2008) é preciso dar um significado ao que é ensinado nas aulas de física, explicitando o seu sentido já no momento do aprendizado e ao mesmo tempo desenvolver algumas competências e habilidades (tabela 3.8).

Tabela 3.8: Competências e habilidades do ensino de ciências da natureza (SÃO PAULO: SE, p.38-39, 2008).

\begin{tabular}{|c|c|c|c|}
\hline $\begin{array}{c}\text { Competências } \\
\text { gerais }\end{array}$ & \multicolumn{3}{|c|}{ Habilidades gerais e específicas } \\
\hline $\begin{array}{l}\text { - Representar } \\
\text { - Comunicar-se } \\
\text { - Conviver }\end{array}$ & $\begin{array}{l}\text { - Ler e expressar-se } \\
\text { com textos, cifras, } \\
\text { ícones, gráficos, } \\
\text { tabelas e fórmulas. } \\
\text { - Converter uma } \\
\text { linguagem em outra. }\end{array}$ & $\begin{array}{l}\text { - Registrar medidas } \\
\text { e observações. } \\
\text { - Descrever } \\
\text { situações. } \\
\text { - Planejar e fazer } \\
\text { entrevistas. }\end{array}$ & $\begin{array}{l}\text { - Sistematizar dados. } \\
\text { - Elaborar relatórios. } \\
\text { - Participar de } \\
\text { reuniões. } \\
\text { - Argumentar. } \\
\text { - Trabalhar em grupo. }\end{array}$ \\
\hline $\begin{array}{l}\text { Investigar e } \\
\text { intervir em } \\
\text { situações reais. }\end{array}$ & $\begin{array}{l}\text { - Formular questões. } \\
-\quad \text { Realizar } \\
\text { observações. } \\
\text { - Selecionar } \\
\text { variáveis. } \\
\text { - } \quad \text { Estabelecer } \\
\text { relações. }\end{array}$ & $\begin{array}{l}\text { - Interpretar, propor } \\
\text { e fazer } \\
\text { experimentos. } \\
\text { - Fazer e verificar } \\
\text { hipóteses. }\end{array}$ & $\begin{array}{l}\text { - Diagnosticar e } \\
\text { enfrentar problemas, } \\
\text { individualmente ou } \\
\text { em equipe. }\end{array}$ \\
\hline $\begin{array}{l}\text { Estabelecer } \\
\text { conexões e dar } \\
\text { contexto }\end{array}$ & $\begin{array}{l}\text { Relacionar } \\
\text { informações } \\
\text { processos com seus } \\
\text { contextos e diversas } \\
\text { áreas } \\
\text { conhecimento }\end{array}$ & $\begin{array}{l}\text { Identificar } \\
\text { dimensões sociais, } \\
\text { éticas e estéticas em } \\
\text { questões técnicas e } \\
\text { científicas. }\end{array}$ & 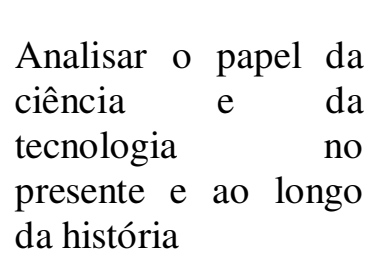 \\
\hline
\end{tabular}

Propomos através de uma intervenção (composta de um conjunto de atividades) - que contemplem a maioria das habilidades e competências enumeradas na tabela 3.8 mostrar que a física pode servir como um critério para uma vida saudável. Para isso as atividades elaboradas exploram as relações interdisciplinares entre física, saúde, esporte, biomecânica e educação física para fornecer uma nova visão sobre a prática de esportes e de exercícios físicos. 
Com esta intervenção esperávamos que os estudantes alcançassem um entendimento maior quanto ao conteúdo de mecânica abrangido no $1^{\circ}$ semestre do $1^{\circ}$ ano do Ensino Médio da rede pública de ensino do Estado de São Paulo, no qual o tema é: Movimentos - variações e conservações.

Optamos por fazer um recorte interdisciplinar visando ajudar o estudante a complexificar seu conhecimento cotidiano em relação a esporte e saúde. Similarmente encontramos nos cadernos de física do aluno do $1^{\circ}$ ano do Ensino Médio (vol. 1 e 2) um recorte do conteúdo de mecânica, feito por razões que desconhecemos, mas que de algum modo buscam o aprendizado de alguns conceitos de mecânica elegidos a priori. $\mathrm{Na}$ intervenção acoplamos estes conceitos a prática esportiva com objetivo de formar uma cadeia coerente e conectada para proporcionar sucesso no aprendizado.

O Currículo do Estado de São Paulo para o ensino de física contextualiza o conteúdo de mecânica no $1^{\circ}$ ano do ensino médio da seguinte forma:

"A Mecânica pode corresponder às competências que possibilitam, por exemplo, analisar movimentos de coisas que observamos, identificando suas causas, sejam carros, aviões, foguetes ou mesmo movimentos das águas de um rio ou dos ventos, sejam sistemas nos quais os movimentos dependem da ampliação de forças, como as ferramentas e os utensílios. Também pode compor esse espaço a análise de sistemas que requerem ausência de movimento, ou seja, o equilíbrio, como o de uma estante de livros, de uma escada de apoio ou de um malabarista.

A Mecânica deve propiciar a compreensão de leis de regularidades, expressas nos princípios de conservação, como os das quantidades de movimento e da energia, e também dar elementos para que os estudantes tomem consciência da evolução tecnológica relacionada às formas de transporte ou do aumento da capacidade produtiva do ser humano" (SÃO PAULO: SE, p.46 - 47, 2008).

Seguindo, portanto, o Currículo do Estado de São Paulo para o ensino de física, as atividades da intervenção foram elaboradas e organizadas de acordo com os conteúdos que estão apresentados na tabela 3.9. 
Tabela 3.9: Proposta da disciplina física do Ensino médio (SÃO PAULO: SE, p. 49 - 50, 2008): $1^{\mathrm{a}}$ série - Tema: Movimentos: variações e conservações.

\begin{tabular}{|c|c|c|}
\hline \multicolumn{2}{|c|}{ Conteúdos gerais } & Conteúdos específicos \\
\hline \multirow{3}{*}{ 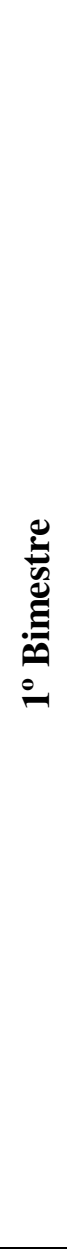 } & $\begin{array}{l}\text { Grandezas do } \\
\text { movimento: } \\
\text { identificação, } \\
\text { caracterização } \\
\text { e estimativa } \\
\text { de valores }\end{array}$ & $\begin{array}{l}\text { - Movimentos que se realizam no cotidiano e as grandezas } \\
\text { relevantes para sua observação (distância percorrida, } \\
\text { percurso, velocidade, massa, tempo, etc.). } \\
\text { - Características comuns e formas de sistematizar os } \\
\text { movimentos (segundo trajetórias, variações de velocidade } \\
\text { etc.). } \\
\text { - Estimativas e escolha de procedimentos adequados para } \\
\text { realização de medidas (por exemplo, uma estimativa do } \\
\text { tempo de percurso entre duas cidades por diferentes meios } \\
\text { de transporte ou da velocidade média de um entregador de } \\
\text { compras). }\end{array}$ \\
\hline & $\begin{array}{l}\text { Quantidade } \\
\text { de } \\
\text { movimento } \\
\text { linear: } \\
\text { variação e } \\
\text { conservação }\end{array}$ & $\begin{array}{l}\text { - Modificações nos movimentos como consequência de } \\
\text { interações (por exemplo, para que um carro parado passe a } \\
\text { se movimentar, é necessária uma interação com o piso). } \\
\text { - Causas da variação de movimentos, associadas às } \\
\text { intensidades das forças e ao tempo de duração das interações } \\
\text { (por exemplo, os dispositivos de segurança). } \\
\text { - Conservação da quantidade de movimento e a identificação } \\
\text { de forças para fazer análises, previsões e avaliações de } \\
\text { situaçôes cotidianas que envolvem movimentos. }\end{array}$ \\
\hline & & $\begin{array}{l}\text { - As leis de Newton na análise de partes de um sistema de } \\
\text { corpos. } \\
\text { - Relação entre as leis de Newton e a lei da conservação da } \\
\text { quantidade de movimento. }\end{array}$ \\
\hline \multirow[b]{2}{*}{ 莺 } & $\begin{array}{l}\text { Trabalho e } \\
\text { energia } \\
\text { mecânica }\end{array}$ & $\begin{array}{l}\text { - Trabalho de uma força como medida da variação do } \\
\text { movimento, inclusive nas situações envolvendo atrito. } \\
\text { - Formas de energia mecânica e sua associação aos } \\
\text { movimentos reais. } \\
\text { - Avaliação dos riscos da alta velocidade em veículo por meio } \\
\text { dos parâmetros envolvidos na variação do movimento. }\end{array}$ \\
\hline & $\begin{array}{l}\text { Equilíbrio } \\
\text { estático e } \\
\text { dinâmico }\end{array}$ & $\begin{array}{l}\text { - Condições necessárias para a manutenção do equilíbrio de } \\
\text { objetos, incluindo situações no ar ou na água. } \\
\text { - Processos da amplificação de forças em ferramentas, } \\
\text { instrumentos ou máquinas. } \\
\text { - Processos físicos e a conservação do trabalho mecânico. } \\
\text { - Evolução histórica dos processos de utilização do trabalho } \\
\text { mecânico (como por exemplo, na evolução dos meios de } \\
\text { transporte ou de máquinas mecânicas) e suas implicações na } \\
\text { sociedade. }\end{array}$ \\
\hline
\end{tabular}


Através das atividades buscamos complementar as situações de aprendizagem do caderno do aluno de física de ensino médio - $1^{\text {a }}$ série - volume 1 e 2 , para instigar o interesse do aluno pela física através de situações do cotidiano que lhe tragam prazer em aprender, visto que, são alunos da primeira série do ensino médio que estão tendo o primeiro contato com a disciplina de física (mal divulgada por alunos que já cursaram o ensino médio pela sua dificuldade no aprendizado). Procuramos apresentar os conceitos físicos com um enfoque diferenciado que tenha aplicabilidade no cotidiano dos estudantes e que sejam utilizados futuramente.

As situações de aprendizagem do caderno do aluno de física já estabelecem algumas relações com o cotidiano do aluno, mas as atividades que propomos as complementam, pois estão baseadas na construção de um conhecimento interdisciplinar, o que pode corroborar para o sucesso no aprendizado dos conteúdos de mecânica.

Ao utilizarmos nas atividades algumas modalidades esportivas (que são trabalhadas em educação física), como um artifício para despertar a motivação nos estudantes, esperamos produzir um interesse maior pelo estudo da física, além de mostra-la não apenas como aplicação de fórmulas matemáticas, mas mostrar que seus conhecimentos podem ser utilizados como um critério para uma vida saudável.

É de suma importância que os professores façam as pontes interdisciplinares para que os estudantes apliquem os conhecimentos no seu cotidiano. A atividade 2 leva o estudante a discutir tópicos como: saúde e beleza física, saúde e esportes, que estão diretamente ligados o Currículo do Estado de São Paulo para o ensino de educação física $-1^{\circ}$ semestre do $1^{\circ}$ ano (tabela 3.10 ), no qual encontramos grande ênfase em temas como: "Os adolescentes e jovens são atingidos por um bombardeio de imagens e enunciados que propõem um padrão de beleza corporal" (SÃO PAULO: SE, p. 41, 2008).

O Currículo de Educação Física do Estado de São Paulo (S.E., 2008) traz várias modalidades esportivas que são abrangidas nas atividades da intervenção que propomos, possibilitando um diálogo interdisciplinar entre os conteúdos de física e educação física. Este diálogo pode ser utilizado por ambos os professores para resultar no êxito de aprendizado dos estudantes, evidenciando a ligação real entre as diversas áreas do conhecimento (que não devem ser abordadas de forma isolada como apresentada na grade curricular atual do Ensino Médio).

Neste trabalho o nível de interdisciplinaridade entre educação física e física relacionada ao caderno do aluno do $1^{\circ}$ ano do ensino médio não é integral (100\%), mas 
durante as atividades tratamos de temas que no global estão relacionados a educação física. Durante a aplicação das atividades não é necessário que os estudantes realizem na prática os movimentos de cada habilidade esportiva mencionada nas atividades, pois focamos o alto desempenho dos atletas.

Tabela 3.10: Proposta da disciplina educação física do Ensino médio (SÃO PAULO: SE, p. 53, 2008).

\begin{tabular}{|c|c|c|}
\hline \multicolumn{2}{|c|}{ Conteúdos gerais } & Conteúdos específicos \\
\hline \multirow{2}{*}{ 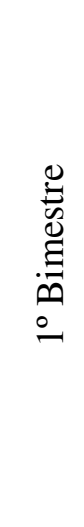 } & Esporte & $\begin{array}{l}\text { - Sistemas de jogo e táticas em uma modalidade coletiva já } \\
\text { conhecida pelos alunos } \\
\text { - A importância dos sistemas de jogo e táticas no desempenho } \\
\text { esportivo e na apreciação do esporte como espetáculo. }\end{array}$ \\
\hline & $\begin{array}{l}\text { Corpo, } \\
\text { saúde e } \\
\text { beleza }\end{array}$ & $\begin{array}{l}\text { - Padrões e estereótipos de beleza corporal } \\
\text { - Indicadores que levam a construção de representações sobre } \\
\text { corpo e beleza } \\
\text { - Medidas e avaliação da composição corporal } \\
\text { - Índice de massa corpórea }\end{array}$ \\
\hline \multirow[b]{2}{*}{ 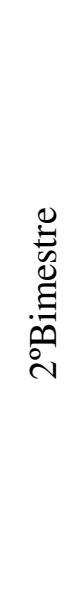 } & Esporte & $\begin{array}{l}\text { - Modalidade individual: atletismo, ginástica artística ou } \\
\text { ginástica rítmica }\end{array}$ \\
\hline & $\begin{array}{l}\text { Corpo, } \\
\text { saúde e } \\
\text { beleza }\end{array}$ & $\begin{array}{l}\text { - Corpo e beleza em diferentes períodos históricos } \\
\text { - Padrões de beleza e suas relações com contextos históricos e } \\
\text { culturais } \\
\text { - Interesses mercadológicos envolvidos no estabelecimento de } \\
\text { padrões de beleza corporal } \\
\text { - Produtos e práticas alimentares e de exercícios físicos } \\
\text { associados a busca de padrões de beleza } \\
\text { - Consumo e gasto calórico: alimentação, exercício físico e } \\
\text { obesidade. }\end{array}$ \\
\hline
\end{tabular}

Encontramos no PCN+ do Ensino Médio de Educação Física (2002) a proposta de temas a serem discutidos em sala de aula como: esporte, padrões de beleza, saúde corporal, papel do esporte, dor e lesão, e vários outros impostos pela mídia e pelo contexto atual, colocando na responsabilidade do professor estar atento a esses temas e rever cientificamente estas questões. Além disso, diz que o professor deve assegurar a autonomia do aluno em relação a prática da atividade física, pois após o término do ensino médio o jovem e o adulto devem ter condições de saber porque, para que e como realizar as suas atividades físicas se assim desejarem sem a necessidade de um acompanhamento profissional. 
Com isto percebemos a necessidade do ensino de biomecânica no ensino médio, para que o estudante tenha uma autonomia para analisar seus movimentos no jogo, no esporte, na luta, na ginástica, na atividade rítmica, etc.

Nas atividades da intervenção enfocamos com mais ênfase a importância da ciência na prática esportiva, na prevenção de lesões, na explicação dos movimentos e funcionamento do corpo humano, sendo imprescindível tanto em física quanto em educação física (disciplinas que escolhemos) abranger os conhecimentos de biomecânica no Ensino Médio. Lembramos que as questões sobre a definição de saúde não são vistas em detalhes (visão reducionista de saúde).

\subsubsection{Atividades curtas de multi-abordagem e complexificação do conhecimento}

Partindo do pressuposto de que as salas de aulas são heterogêneas e a metodologia de ensino deve atender a todos os estudantes e por consequência motiválos, adotamos para construção destas atividades, as atividades curtas de multiabordagens (UEMA, 2005), pois proporciona ao professor abranger um conceito de várias formas, além de se adequar a realidade de uma escola pública.

As atividades curtas de multi-abordagens podem ser elaboradas utilizando leituras, discussão de textos, demonstrações, experiências, exposição oral, exercícios, equações matemáticas, filmes, etc., ou seja, são diversificadas para atender a necessidade da maioria dos estudantes. A escolha das formas didáticas dependerá das relações inter ou intradisciplinares que o professor quer fazer. Embora as atividades elaboradas tenham características interdisciplinares não é necessária a participação de professores de outra áreas (mas nada impede que seja feito), pois a ponte interdisciplinar pode ser feita por um único professor, basta somente haver empenho em estudar os conteúdos que não são específicos da sua área de formação, pois o objetivo é que os alunos se apropriem do conhecimento interdisciplinar que apresentamos.

As atividades curtas de multi-abordagens permitem mobilidade suficiente para se encaixar na grade curricular atual, no qual se tem apenas 2 aulas de física por semana, cada uma com 50 minutos de duração. Assim o professor pode intercalar as formas didáticas de acordo com o tempo disponível para não comprometer o currículo, além de poder utilizá-las como atividades extra-classe.

A intervenção é composta por nove atividades com duração de 1 até 3 aulas cada atividade, dependendo do tópico a ser abrangido. Assim, se fez necessário nomeá-las de 
"atividades de multi-abordagens", desconsiderando "curtas" do seu nome original. No contexto apresentado por Uema (2005), as atividades tinham curta duração e no total, as atividades não ultrapassavam quatro horas de duração.

Com essa intervenção pretendemos auxiliar o estudante, na análise dos benefícios e das consequências para sua saúde, quando estão desenvolvendo exercícios físicos, praticando esportes, etc., possibilitando um novo olhar quanto aos julgamentos referentes ao desempenho de um atleta em qualquer modalidade esportiva, evidenciando todos os conhecimentos que são necessários para intervir em seu treinamento e que devem estar diretamente ligados as atitudes tomadas pelo técnico esportivo, ou seja, um técnico (profissional) bem instruído, é ideal para reduzir os riscos de lesões dos atletas durante a prática do esporte. Nosso objetivo não é entrar em detalhes na discussão da formação de um técnico esportivo, apenas queremos que os estudantes visualizem na biomecânica uma ferramenta primordial para realização bem sucedida de um esporte.

Nestas atividades procuramos integrar o conhecimento de física (conteúdo de mecânica) com o de educação física e esporte (biomecânica) através de uma abordagem interdisciplinar (a relação estabelecida entre esses conhecimentos se dará em níveis de interdisciplinaridade diferenciados) para fornecer critérios que possibilitem uma avaliação sobre o que é uma vida saudável com relação à prática de exercícios físicos, que levará a uma complexificação do conhecimento cotidiano. Ou seja, procuramos incorporar no conhecimento do cotidiano do aluno o conhecimento científico, que favorecerá o surgimento de formas de pensamento complexo e o abandono de outras formas mais simples ou lineares, normalmente atribuídas à lógica disciplinar que o conhecimento científico na escola propicia (GARCIA,1998).

Tanto o conhecimento científico quanto o conhecimento cotidiano, compõem-se em um conjunto de conteúdos conectados entre si em uma trama, sendo o objetivo das atividades reconectar estas tramas de conteúdos, fazer novos recortes na pandisciplinaridade (MATTOS \& FERRARA, 2002), permitindo que os estudantes possam reelaborar suas ideias.

Portanto, a ideia de perfil conceitual (MORTIMER, 1995, 2000) é um pressuposto que suporta a escolha do método de ensino proposto, pois a complexificação do conhecimento implica na necessidade de uma complexificação nas suas representações mentais. A noção de perfil conceitual que adotamos permite compreender a coabitação de concepções representadas pelas zonas dos perfis conceituais dos estudantes. Ou seja, o estudante não abandona suas concepções prévias 
para substituí-las pela concepção complexificada, mas atribui modifica ou cria novas zonas dos perfis conceituais que estão em jogo no processo educacional, delimitando mais claramente os contextos de uso destes conceitos. Assim, quanto mais complexo o contexto a que se referem os conceitos, mais complexa deve ser a representação do perfil conceitual. Tal complexidade se dá em todas as suas dimensões, sejam as dimensões ontológicas, epistemológicas ou axiológicas (RODRIGUES \& MATTOS, 2006). A relação entre zona de perfil conceitual e contexto é fundamental, sendo necessária a explicitação dos contextos de uso das zonas dos perfis conceituais para que os estudantes compreendam os enunciados, numa situação dialógica, de forma correta.

Mattos \& Rodrigues (2007) propõem três ordens aprendizagem, as quais permitem uma melhor análise da relação entre perfil conceitual e conceito de aprendizagem. A aprendizagem de $1^{a}$ ordem consiste na simples aquisição de uma nova zona do perfil conceitual à custa do redimensionamento ou modificação das préexistentes. Nesta ordem de aprendizado a pessoa não percebe a relação entre contexto e zona do perfil conceitual eleita para uso. A aprendizagem de $2^{a}$ ordem consiste no estabelecimento das zonas que formam o perfil conceitual. O indivíduo ainda não percebe a relação entre zona do perfil e seu contexto de uso. Apesar disso, as zonas do perfil estão mais bem delimitadas. A aprendizagem de $3^{a}$ ordem consiste na tomada de consciência das relações entre a zona do perfil conceitual e seus possíveis contextos de uso, ou seja, o estudante consegue organizar as zonas e cria prioridade de significados para uso do conceito segundo o contexto de uso.

Posteriormente, espera-se que o estudante chegue ao que Rodrigues \& Mattos (2006) chamam de $3^{a}$ ordem de aprendizado, situação cognitiva na qual o aluno teria consciência de todas as zonas de um perfil conceitual correlacionando cada uma delas a um contexto específico de uso (meta-consciência ${ }^{1}$ ).

\footnotetext{
${ }^{1}$ São vários significados para um mesmo conceito dependendo do contexto, portanto o aluno tem várias "consciências" para dar conta de todas as zonas do perfil conceitual.
} 


\subsubsection{Ciclos de Lawson}

As atividades de multi-abordagens foram construídas segundo os ciclos de aprendizagem de Lawson (2001).

Neste trabalho apresentaremos uma intervenção composta por nove atividades que abrangem os três tipos de ciclos de aprendizagem: descritivo, empírico-abdutivo e hipotético-preditivo. As atividades obedecem a uma estrutura hierárquica de ciclos e sub-ciclos, na qual grupos de três atividades, constituídas com as três etapas do ciclo de aprendizagem (exploração, introdução do conceito e aplicação do conceito), podem ser concebidos como atividades maiores de exploração, introdução do conceito e aplicação do conceito (figura 3.1).

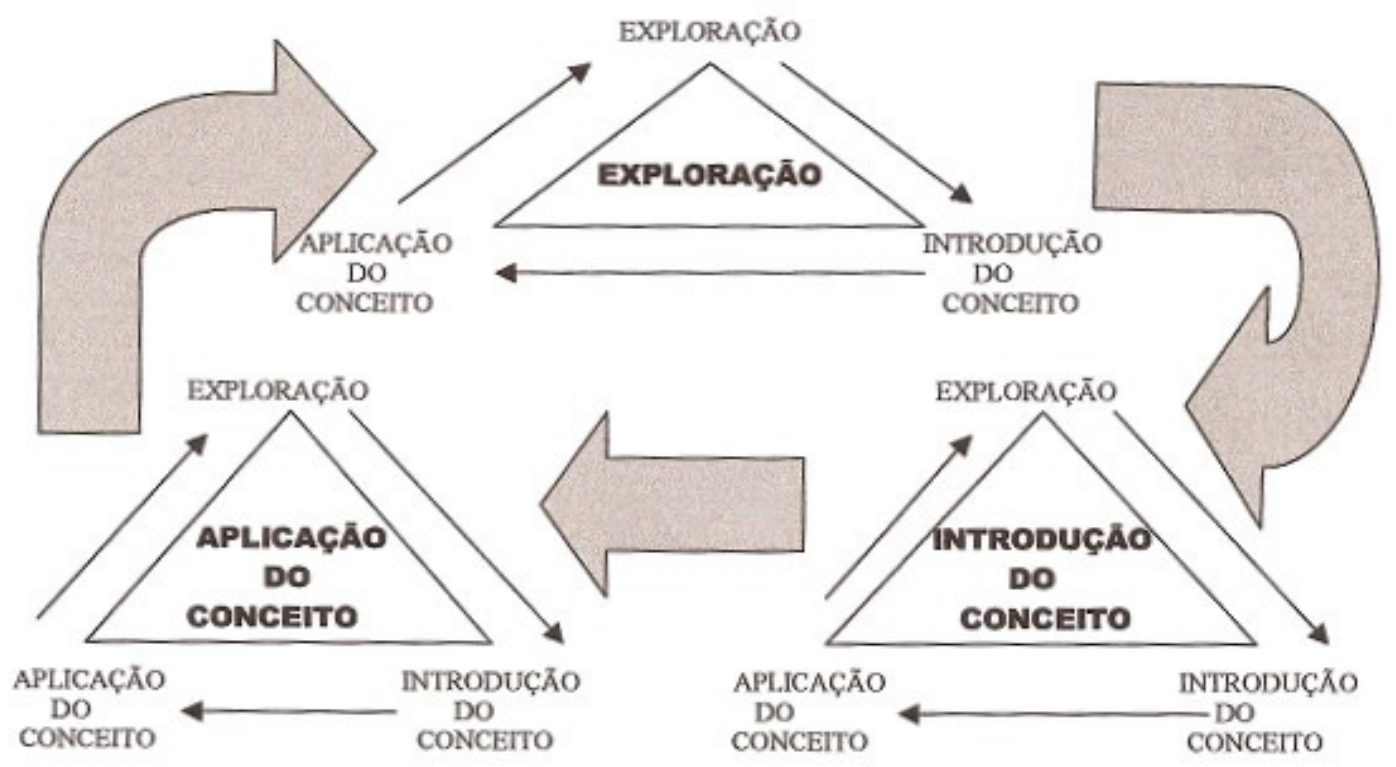

Figura 3.1: Diagrama do ciclo de Lawson nas atividades.

Acreditamos que os ciclos de aprendizagem de Lawson são mais adequados ao objetivo da intervenção, pois são compostos de fases (exploração, introdução do conceito e aplicação do conceito) que permitem um processo de ensino-aprendizagem no qual o estudante constrói o conhecimento de forma crítica. Pesquisas têm dado respaldo a efetivação dos ciclos de aprendizagem em levar os estudantes a pensar criativamente e criticamente, bem como facilitar o entendimento dos conceitos científicos, desenvolvendo atitudes positivas em relação à ciência e, assim, desenvolvendo habilidades para observar processos científicos e argumentar sobre eles (LAWSON, 1995 apud MISHENO \& LAWSON, 1999, p.24). Este ciclo envolve os 
estudantes na investigação significativa, tendo como objetivo melhorar suas habilidades de reflexão e ajudar aos estudantes a construírem conceitos significativos, sempre seguindo o processo através de palavras chave como: se, logo, portanto (MUSHENO \& LAWSON, 1999).

Segundo Lawson (1989), o ciclo de aprendizagem em si é um método de ensino que pretende ser coerente com a ordem em que as pessoas espontaneamente constroem o conhecimento e permite aos estudantes examinar e adequar seus conceitos prévios, a partir da argumentação e do teste. Os ciclos de aprendizagem são mais divulgados em aplicações de laboratório, entretanto Lawson (1989) afirma sua eficácia em explorações que envolvem leitura e outras atividades não-manipulativas.

O ciclo de aprendizagem se divide em três fases, obrigatoriamente consecutivas: exploração, introdução do conceito e aplicação do conceito. Fizemos uma adaptação no original no que diz respeito a fase de "introdução do conceito", pois Lawson utiliza “introdução do termo". Deixamos claro que ao contrário de Lawson não tomamos a palavra conceito como um grau elevado de abstração ou dotado de um significado único, mas como algo que já tem um significado para o aluno em um determinado contexto. Nosso objetivo é ampliar o perfil conceitual deste conceito por meio da complexificação do conhecimento, ou seja, permitir que o aluno alcance a $3^{\mathrm{a}}$ ordem de aprendizado (RODRIGUES \& MATTOS, 2007). Acreditamos que obteremos êxito aplicando um conjunto de atividades que obedecem os ciclos de aprendizagem de Lawson.

\subsubsection{As fases do ciclo}

$\mathrm{Na}$ fase de exploração os estudantes aprendem através de suas ações e reações a uma nova situação. Nesta $1^{\text {a }}$ fase eles exploram novas situações com o mínimo de orientação, o que traz um aumento de questões ou complexificações, pois não conseguem compreende-la com seus caminhos habituais de pensamento e começam a identificar modelos de regularidade no fenômeno observado.

$\mathrm{Na}$ fase de introdução do conceito começa a introdução de um novo conceito ou de conceitos específicos quando são usados para referir aos modelos descobertos durante a exploração. O conceito pode ser introduzido pelo professor, pelo livro-texto, um filme ou outro meio. Este passo deve seguir sempre à exploração e ter relação direta 
com o padrão descoberto durante a atividade de exploração. Nesta $2^{\mathrm{a}}$ fase o estudante deve ser encorajado a identificar mais de um modelo como possível, antes de ser revelado à classe o modelo correto, mas devemos ter em mente que esperar que o estudante descubra todo o modelo da ciência é irreal.

$\mathrm{Na}$ fase de aplicação do conceito os estudantes aplicam o novo conceito ou os novos modelos de pensamento para adicionar exemplos. Nesta $3^{\text {a }}$ fase é necessário para alguns estudantes entenderem a dimensão da aplicabilidade do novo conceito. Sem inúmeras aplicações, o significado do conceito pode ficar restrito. Muitos estudantes podem abstrair os conceitos para diversas situações. Esta fase ajuda o estudante na reorganização conceitual.

Segundo Lawson (1989), o ciclo de aprendizagem em suas três fases pode ser classificado em: descritivo, empírico abdutivo e hipotético preditivo.

No ciclo de aprendizagem descritivo os estudantes descobrem e descrevem um padrão empírico dentro de um contexto específico (exploração). O professor fornece o nome (introdução do conceito), e o padrão é então identificado em contextos adicionais. Este ciclo é chamado de descritivo porque os estudantes e professores estão descrevendo suas observações sem atentar para explicação de suas observações. Neste ciclo respondemos a questão “Qual?”, mas não suscitamos a questão causal "Por quê?

No ciclo de aprendizagem empírico abdutivo os estudantes novamente descobrem e descrevem um padrão empírico em um contexto específico (exploração), mas caminham para generalização das possíveis causas deste padrão. Isto requer o uso de analogias (abdução) para utilizar os conceitos aprendidos em outros contextos para o contexto atual (introdução do conceito). Os conceitos podem ser introduzidos pelos estudantes, professores ou ambos. Com a orientação do professor, os estudantes analisam através dos dados obtidos durante a fase de exploração para verificar se as causas hipotetizadas são consistentes com estes dados ou com outros fenômenos conhecidos (aplicação do conceito). Em outras palavras as observações são feitas de forma descritiva, mas este tipo de ciclo vai além, pois busca generalizar e testar inicialmente a causa do fenômeno.

No ciclo de aprendizagem hipotético preditivo, apresentamos inicialmente uma questão causal, no qual os estudantes são questionados para gerar explicações possíveis ao fenômeno. É dado um tempo para o estudante deduzir as consequências lógicas destas explicações e explicitamente esboçar e realizar experimentos para testá-las (exploração). As análises dos resultados experimentais permitem que algumas hipóteses 
sejam refutadas, algumas sejam descartadas e conceitos sejam introduzidos (introdução do conceito). Finalmente os conceitos relevantes e os padrões razoáveis são abordados e discutidos e podem ser aplicados em outras situações (aplicação do conceito). Neste ciclo temos a generalização e o teste das hipóteses alternativas através da comparação de deduções lógicas com os resultados empíricos.

Neste trabalho apresentamos a combinação dos três ciclos de aprendizagem de Lawson: o descritivo, empírico abdutivo e o hipotético preditivo. As atividades apresentam uma estrutura hierárquica de ciclos e sub-ciclos, na qual grupos de três atividades, constituídas com as três etapas (exploração, introdução do conceito e aplicação do conceito), podem ser concebidos como atividades maiores de exploração, introdução do conceito e aplicação do conceito, sendo que o ciclo maior que envolve os sub-ciclos são governados pelo ciclo hipotético preditivo (tabela 3.12). Em todos os ciclos inicialmente o professor identifica os conceitos a serem tratados e os fenômenos que envolvem o padrão sobre o qual o conceito está baseado e na fase de aplicação do conceito outros fenômenos são discutidos e explorados que envolvem o mesmo conceito.

O ciclo de aprendizagem hipotético preditivo governa o conjunto das nove atividades. Na fase de exploração os estudantes exploram o fenômeno levantado por uma questão causal dada pelos próprios estudantes ou pelo professor. Em uma discussão na classe, hipóteses são lançadas e ditas pelos estudantes para trabalhar em grupos para deduzir suas implicações e esboçar experimentos ou esta ação é feita em discussão em classe. Os estudantes conduzem os experimentos. Na fase de introdução do conceito os dados são comparados e analisados, conceitos são introduzidos e conclusões tiradas. Este ciclo, portanto possibilita aos estudantes adquirirem habilidades em formular questões, levantar as hipóteses, prever, colher dados e concluir, através de deduções (se...e...então), induções, inferências e comparações.

O ciclo de aprendizagem descritivo é aplicado nas atividades 1,2 e 3, pois se enquadra nos seguintes passos dados por Lawson (1989): na fase de exploração o estudante explora o fenômeno e tenta descobrir e descrever o padrão. $\mathrm{Na}$ fase de introdução do conceito os estudantes informam os dados que eles obtiveram e eles/ou o professor descreve o padrão, o professor em seguida introduz o(s) conceito(s) para se referir ao padrão.

A partir da atividade 4 até a atividade 9, aplicamos duas vezes o ciclo de aprendizagem empírico abdutivo, pois se enquadram nos seguintes passos dados por 
Lawson (1989): na fase de exploração o professor coloca uma questão descritiva e uma causal. Os estudantes coletam dados para responder a questão descritiva e os expõem no quadro negro. A questão descritiva é rendida e a questão causal é levantada. Hipóteses e alternativas são antecipadas para responder a questão causal e os dados já obtidos são examinados por um teste inicial. Na fase de introdução do conceito, são introduzidos os conceitos que dizem respeito ao fenômeno explorado e a explicação mais plausível é hipotetizada.

Observe que o ciclo de aprendizagem descritivo somente requer a descrição dos padrões (exemplo: seriação, classificação, conservação) enquanto o ciclo de aprendizagem hipotético dedutivo exige o uso de padrões de alta a ordem (exemplo: controle de variáveis, razões correlatas, razões hipotéticas dedutivas). O ciclo empírico abdutivo é o intermediário e requer a descrição dos padrões, mas geralmente envolve um modelo de alta ordem.

Como as atividades foram construídas para complementar o caderno de física do aluno do $1^{\circ}$ ano do ensino médio - vol. 1 e 2, as atividades são intercaladas com as situações de aprendizagem propostas no mesmo (e algumas inserções de conteúdo feitas a critério do professor). Dentro das situações de aprendizagem há: experiências, lições de casa, pesquisas individuais, etc., que podem ser realizadas em casa ou na sala de aula, conforme a preferência do professor. Entre as fases do ciclo de aprendizagem de Lawson é permitido adicionar atividades que envolvam outras metodologias, contanto que obrigatoriamente seja seguida a ordem: exploração, introdução do conceito e aplicação do conceito. Enfim, as atividades não foram elaboradas para atrapalhar o currículo, mas para diversificar e auxiliar na aprendizagem dos conceitos de mecânica abrangidos por ele.

Dentro das situações de aprendizagem do caderno de física do aluno (vol. 1 e 2 $1^{\text {a }}$ série do ensino médio) - que envolvem na maioria das vezes situações exemplificadas com carros - procuramos identificar os ciclos de aprendizagem de Lawson e entrelaçar com as atividades (tabela 3.11). Observe na tabela 3.14 que os ciclos associados ao caderno de física do aluno são empíricos abdutivos, pois a todo o momento analogias são feitas para relacionar o conteúdo de mecânica com aplicações no dia a dia, embora não seja na área de esportes, auxilia no ciclo de aprendizagem como um todo, pois intensifica a aplicação da mecânica em outras situações, dando uma visão mais ampla ao estudante, possibilitando-os a estabelecer mais conexões. 
É dada liberdade para o professor selecionar dentro das situações de aprendizagem os tópicos que serão feitos em aula ou extra-classe, podendo também inserir outros tópicos que a seu critério sejam relevantes para o aprendizado do conceito em questão.

Salientamos que o tópico de hidrostática não foi tratado nas atividades, pois não faz parte do currículo do Estado de São Paulo, o que reduziu o número de esportes que puderam ser tratados nas atividades.

\subsubsection{Atividade Piloto}

Tabela 3.1: Esquema do desenho de pesquisa.

\begin{tabular}{|c|c|c|c|}
\hline Ano & Avaliação & Objetivo & Descrição \\
\hline 2007 & $\begin{array}{l}\text { Questionário } \\
\text { Prévio } 0\left(\mathrm{Q}_{0}\right)\end{array}$ & $\begin{array}{l}\text { Delimitar os objetivos da pesquisa, } \\
\text { através do levantamento da concepção } \\
\text { prévia dos estudantes sobre a relação } \\
\text { entre esporte e física. }\end{array}$ & $\begin{array}{l}\text { Questionário com } 7 \\
\text { questões }\end{array}$ \\
\hline \multirow{2}{*}{2008} & $\begin{array}{l}\text { Questionário } \\
\text { Prévio } 1\left(\mathrm{Q}_{1}\right)\end{array}$ & $\begin{array}{l}\text { Completar os dados obtidos em } \mathrm{Q}_{0} \text { para } \\
\text { diminuirmos } \quad \text { algumas } \\
\text { inconclusivas. }\end{array}$ & $\begin{array}{l}\text { Questionário com } 8 \\
\text { questões }\end{array}$ \\
\hline & $\begin{array}{l}\text { Questionário } \\
\text { Prévio } 2\left(\mathrm{Q}_{2}\right)\end{array}$ & $\begin{array}{l}\text { Analisar se houve interferências na } \\
\text { citação das disciplinas relacionadas ao } \\
\text { esporte em } \mathrm{Q}_{0} \text {. }\end{array}$ & $\begin{array}{l}\text { Questionário com } 2 \\
\text { questões }\end{array}$ \\
\hline 2009 & $\begin{array}{l}\text { Atividades } \\
\text { piloto }\end{array}$ & $\begin{array}{l}\text { Testar o conteúdo das atividades para } \\
\text { realizar as adequações necessárias. }\end{array}$ & $\begin{array}{l}10 \text { Atividades (vide } \\
\text { anexo A2) }\end{array}$ \\
\hline 2010 & $\begin{array}{l}\text { Intervenção }+ \\
\text { Ativ. } \\
\text { Avaliatória }\end{array}$ & $\begin{array}{l}\text { Verificar a complexificação do } \\
\text { conhecimento de esportes. }\end{array}$ & $\begin{array}{l}9 \text { Atividades (vide } \\
\text { anexoA3) }+1 \\
\text { Atividade } \\
\text { Avaliatória }\end{array}$ \\
\hline 2010 & $\begin{array}{l}\text { Questionário de } \\
\text { validação* }\left(\mathrm{Q}_{3}\right)\end{array}$ & $\begin{array}{l}\text { Confirmar o resultado favorável obtido } \\
\text { na análise de dados. }\end{array}$ & $\begin{array}{l}\text { Questionário } \\
\text { composto de } \\
\text { questões }\end{array}$ \\
\hline
\end{tabular}

*Sentido de corroboração aos dados obtidos na intervenção.

As atividades da intervenção foram construídas visando não abranger muitas aulas. A ideia é de que fossem incluídas durante o $1^{\circ}$ e $2^{\circ}$ bimestre do $1^{\circ}$ ano do Ensino Médio, no qual o conteúdo de mecânica deve ser ministrado. As atividades, de uma forma geral, foram diversificadas com aulas práticas, discussões, aulas expositivas, aplicação de cálculos e conceitos. Em sua maioria podem ser adaptadas à realidade da escola em que o professor leciona, já que os materiais utilizados são de fácil acesso. 
O papel do professor é crucial quando lidamos com atividades baseadas em conhecimento interdisciplinar. O pressuposto do qual partimos é de que é o professor que apresenta exemplo de pontes entre os diferentes conhecimentos disciplinares e ajuda ao estudante a compreender sua necessidade para dar conta da complexidade do fenômeno estudado. No nosso caso, o professor exemplificou as relações entre a física e esporte, o que exige do professor estudos preliminares sobre estes dois ramos do saber e reflexões sobre suas relações. Baseado nesse pressuposto, não há exigência de que o professor seja um especialista em todos os ramos de conhecimento, mas que tenha construído conhecimentos suficientes sobre este novo conhecimento complexificado, para construir o conhecimento escolar. Assim, o pressuposto adotado implica que não se deve esperar que a construção do conhecimento interdisciplinar venha exclusivamente ou que comece a partir do aluno.

No decorrer das atividades tivemos o cuidado em fornecer, além de fontes de pesquisa diferenciadas facilitar o trabalho na sala de aula, questões que possibilitassem ao aluno refletir sobre a prática de exercícios físicos, esporte e saúde, ou seja, criar conflitos entre suas atitudes e o recomendável para uma vida saudável.

Conforme escolha já apresentada, desenvolvemos atividades multi-abordagem, nas quais procuramos atender as variadas aptidões individuais dos alunos, combinando cálculos, textos, aulas práticas, debates, etc., sempre visando a maior participação dos alunos nas aulas, pois suas contribuições são muito importantes para o sucesso das atividades.

Reconhecer a existência tanto de estruturas conceituais próprias de cada âmbito do conhecimento como estruturas gerais comuns, que dão coerência à visão de mundo que cada sujeito possui e cada comunidade (GARCIA, 1998, p.78), é do ponto de vista da complexidade, fundamental.

Sabemos que, ao aplicarmos as atividades em mais de uma classe, não nos é possível indicar que os estudantes terão os mesmos comportamentos. As reações são diversas, além de fatores comuns da sala de aula como: indisciplina, dificuldades, dúvidas etc., e para contornar imprevistos é fundamental a experiência em sala de aula do professor. Para isso, deixamos livre a condução das atividades, não prescrevendo métodos de como agir na sala de aula, mas apenas estabelecendo rigor quanto a ordem: exploração do conceito, introdução do conceito e aplicação do conceito que o ciclo de aprendizagem de Lawson segue. 
Os dados analisados dos questionários preliminares (seção 4.1) nos auxiliaram a elaborar o conjunto de nove atividades de multi-abordagens e mais uma avaliação para compor a intervenção segundo os ciclos de aprendizagem de Lawson (1989) - descritivo e empírico-abdutivo - em suas três fases (figura 3.1 e tabela 3.11), e estabelecer nossos objetivos dentro de cada atividade, mas não eliminou a seguinte dúvida: Qual(is) conceito(s) focar para análise da dinâmica do perfil conceitual? Pensamos em força, em energia, em velocidade, peso, etc.

Decidimos aplicar um pré-teste das atividades da intervenção, que chamamos de atividades piloto (anexo A2), por várias razões, dentre elas para verificar:

i) sua adequação a realidade dos alunos da $1^{\mathrm{a}}$ série;

ii) se as atividades (textos, comentários, exercícios, etc., ou seja, seu formato) não são maçantes e desmotivantes para os alunos;

iii) se é mais proveitoso serem propostas individualmente ou em grupo;

iv) se cada atividade colabora para aprendizagem mais efetiva dos conceitos nela inseridos;

v) se a escolha do ciclo de Lawson está adequada ao andamento da atividade;

vi) se gera interesse e discussões sobre os conceitos;

vii) o tempo de aplicação de cada atividade;

viii) a qualidade das questões formuladas, etc.

Sabemos que a aplicação de uma intervenção é um processo dinâmico, ou seja, cada aplicação funcionará como um piloto, pois necessitará de ajustes, já que é totalmente dependente da interação professor - estudante, pois nas atividades encontramos as intenções do professor que necessariamente devem estar unidas às dificuldades de aprendizagem dos alunos.

Tabela 3.11: Atividades piloto.

\begin{tabular}{|c|c|c|c|c|c|}
\hline$\frac{0}{\circlearrowright}$ & $\begin{array}{l}\text { Fases } \\
\text { do } \\
\text { Ciclo }\end{array}$ & Atividade & Objetivo & 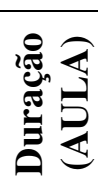 & 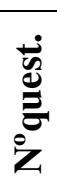 \\
\hline 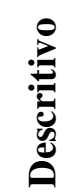 & 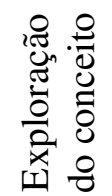 & $\begin{array}{l}1 \text { - Você pode } \\
\text { ser um } \\
\text { treinador? }\end{array}$ & $\begin{array}{l}\text { Mostrar a necessidade de buscar } \\
\text { "conhecimento" para opinar corretamente } \\
\text { sobre a prática de uma habilidade } \\
\text { esportiva. }\end{array}$ & 1 & 10 \\
\hline
\end{tabular}




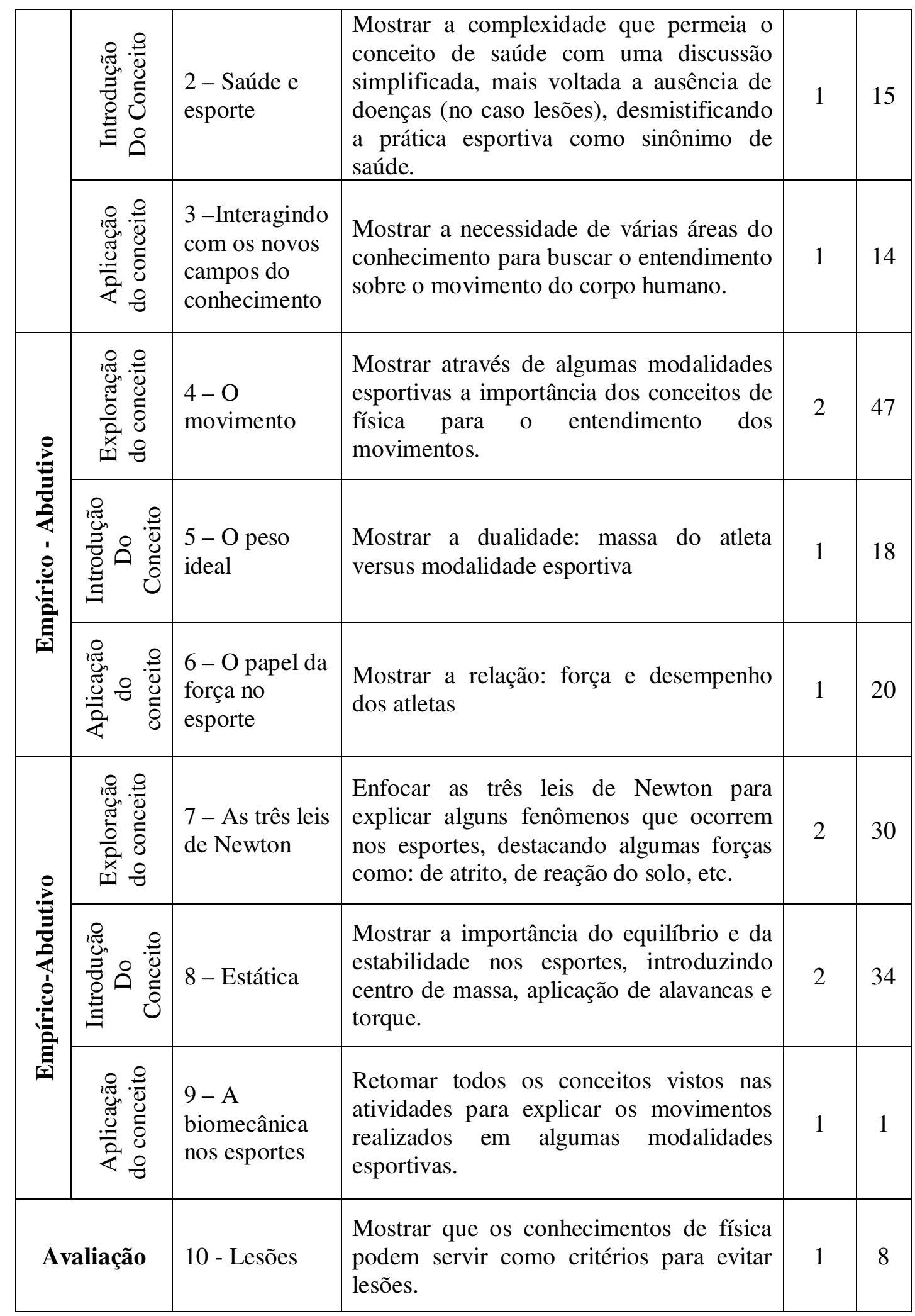

De acordo com Bernstein (1990), é o professor que define um contexto de significados na sala de aula através de regras de enquadramento que segundo os relatos 
da professora foram fornecidas no primeiro dia de aula, além disso, também há regras que ultrapassam a sala de aula. $\mathrm{O}$ enquadramento diz respeito as comunicações que abrange professor, aluno, espaço, conteúdo de aprendizagem, escola, família, etc.

A partir disso o professor deve acompanhar detalhadamente o processo de evolução da ideias dos estudantes para que possa realizar ajustes nas atividades (tempo e modificação das questões): o programado, o que ocorre na sala de aula, as dificuldades dos estudantes, etc.

\subsubsection{Intervenção e Atividade Avaliatória}

Após aplicação e da análise das atividades piloto (seção 4.2), fizemos inúmeras correções nas atividades da intervenção e observamos que no geral o conjunto de atividades se encaixa no ciclo hipotético-preditivo, o que não torna necessário a avaliação final, pois durante as atividades os estudantes chegam a conclusões, que são condizentes com os objetivos propostos inicialmente.

Com a análise dos dados (capítulo 4), redefinimos e delimitamos nossos objetivos iniciais de análise do perfil conceitual, e decidimos não focar somente os conceitos específicos de mecânica, mas analisar o perfil conceitual de esporte em termos da complexificação do conhecimento de esporte, que em nosso ponto de vista abrange tanto os conceitos físicos de mecânica como de saúde mesmo que reducionista, que nos possibilita a análise da utilização dos conceitos da física como um critério para uma vida saudável.

A intervenção (anexo A3), após modificações ficou com formato indicado na tabela 3.12. É nítido que diminuímos o número de questões, para otimizar o tempo e realizar a junção com as situações de aprendizagem contidas no caderno do aluno do $1^{\circ}$ ano - vol. 1 e 2.

A cada atividade foram estabelecidos a priori alguns objetivos (tabela 3.13) para nos orientar no êxito da aplicação das atividades. Mas, tínhamos como objetivo geral que ao final das atividades os alunos utilizassem os conhecimentos da física, para auxiliar na prática esportiva adequada, sem riscos a saúde (aparecimento de lesões). Então após a intervenção decidimos elaborar uma atividade avaliatória (anexo A3) para complementar os dados obtidos pela atividade 9. Analisamos se os estudantes através das atividades conseguiram gradualmente adquirir noções mais complexas que lhes 
permitissem uma melhor compreensão sobre os cuidados que devem ser tomados ao realizar os movimentos na prática esportiva.

Tabela 3.12: O ciclo de Lawson nas atividades.

\begin{tabular}{|c|c|c|c|c|c|c|}
\hline ن를 & $\begin{array}{l}\text { Fases } \\
\text { do } \\
\text { Ciclo }\end{array}$ & $\begin{array}{c}\text { Composição } \\
\text { dos } \\
\text { Ciclos }\end{array}$ & $\begin{array}{l}\text { Fases do } \\
\text { Subciclo }\end{array}$ & Atividade & Duração & 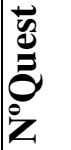 \\
\hline \multirow{9}{*}{ 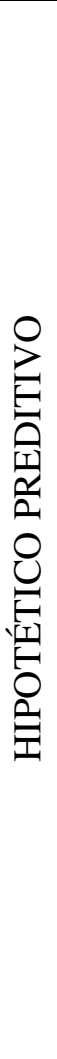 } & \multirow{3}{*}{ 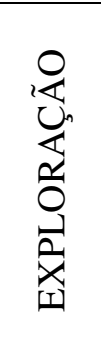 } & \multirow{3}{*}{ 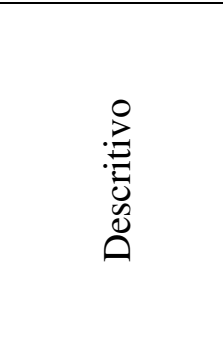 } & Exploração & $\begin{array}{l}1 \text { - Você pode ser um } \\
\text { técnico? }\end{array}$ & 1 aula & 12 \\
\hline & & & $\begin{array}{l}\text { Introdução } \\
\text { do conceito }\end{array}$ & 2 - Saúde e esporte & 1 aula & 13 \\
\hline & & & $\begin{array}{l}\text { Aplicação do } \\
\text { conceito }\end{array}$ & $\begin{array}{l}3 \text { - Interagindo com os } \\
\text { novos campos do } \\
\text { conhecimento }\end{array}$ & 1 aula & 7 \\
\hline & \multirow{3}{*}{ 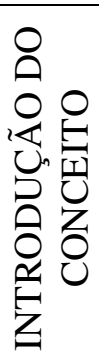 } & \multirow{3}{*}{ 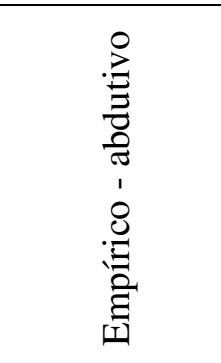 } & Exploração & $4-\mathrm{O}$ movimento & 3 aulas & 18 \\
\hline & & & $\begin{array}{l}\text { Introdução } \\
\text { do conceito }\end{array}$ & $5-\mathrm{O}$ peso ideal & 2 aulas & 9 \\
\hline & & & $\begin{array}{l}\text { Aplicação do } \\
\text { conceito }\end{array}$ & $\begin{array}{l}6 \text { - O papel da força no } \\
\text { esporte }\end{array}$ & 1 aulas & 7 \\
\hline & \multirow{3}{*}{ 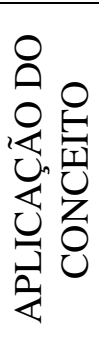 } & \multirow{3}{*}{ 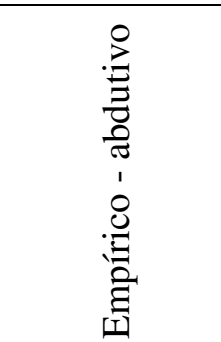 } & Exploração & $\begin{array}{l}7-\text { As três leis de } \\
\text { Newton e os esportes }\end{array}$ & 2 aulas & 17 \\
\hline & & & $\begin{array}{l}\text { Introdução } \\
\text { do conceito }\end{array}$ & $\begin{array}{l}8-\text { Do movimento ao } \\
\text { equilíbrio: alavancas no } \\
\text { corpo humano }\end{array}$ & 2 aulas & 11 \\
\hline & & & $\begin{array}{l}\text { Aplicação do } \\
\text { conceito }\end{array}$ & 9 - Lesões e esportes & 1 aula & 11 \\
\hline
\end{tabular}

Tabela 3.13: Atividades e objetivos.

\begin{tabular}{|l|l|}
\hline \multicolumn{1}{|c|}{ ATIVIDADE } & \multicolumn{1}{c|}{ OBJETIVO } \\
\hline $\begin{array}{l}\text { 1- Você pode ser } \\
\text { um técnico? }\end{array}$ & $\begin{array}{l}\text { Mostrar a necessidade de buscar "conhecimento" para opinar } \\
\text { corretamente sobre a prática de uma habilidade esportiva. }\end{array}$ \\
\hline 2- Saúde e esporte & $\begin{array}{l}\text { Mostrar a complexidade que permeia o conceito de saúde, e } \\
\text { relacioná-lo somente a prática esportiva, reduzindo o conceito } \\
\text { de saúde a ausência de lesões, pois realizar exercícios físicos } \\
\text { não é sinônimo de saúde. }\end{array}$ \\
\hline $\begin{array}{l}\text { 3- Interagindo com } \\
\text { os novos campos do } \\
\text { conhecimento }\end{array}$ & $\begin{array}{l}\text { Mostrar a necessidade de várias áreas do conhecimento para } \\
\text { buscar o entendimento sobre o movimento do corpo humano. }\end{array}$ \\
\hline
\end{tabular}




\begin{tabular}{|l|l|}
\hline $\begin{array}{l}\text { 4-O movimento } \\
\text { (velocidade média, } \\
\text { aceleração) }\end{array}$ & $\begin{array}{l}\text { Mostrar através de algumas modalidades esportivas a } \\
\text { importância dos conceitos de física para o entendimento dos } \\
\text { movimentos. }\end{array}$ \\
\hline $\begin{array}{l}5-\text { O peso ideal } \\
\text { (massa e peso) }\end{array}$ & $\begin{array}{l}\text { Mostrar a dualidade: massa do atleta versus modalidade } \\
\text { esportiva }\end{array}$ \\
\hline $\begin{array}{l}\text { 6- O papel da força } \\
\text { no esporte }\end{array}$ & Mostrar a relação: força e desempenho dos atletas \\
\hline $\begin{array}{l}\text { N- As três leis de } \\
\text { Newton }\end{array}$ & $\begin{array}{l}\text { Enfocar as três leis de Newton para explicar alguns fenômenos } \\
\text { que ocorrem nos esportes, destacando algumas forças como: de } \\
\text { atrito, de reação do solo, etc. }\end{array}$ \\
\hline $\begin{array}{l}\text { 8- Do movimento } \\
\text { ao equilíbrio: } \\
\text { alavanca no corpo } \\
\text { humano }\end{array}$ & $\begin{array}{l}\text { Mostrar a importância do equilíbrio e da estabilidade nos } \\
\text { esportes, introduzindo centro de massa, aplicação de alavancas } \\
\text { e torque. }\end{array}$ \\
\hline 9- Lesões e esportes & $\begin{array}{l}\text { Retomar todos os conceitos vistos nas atividades para explicar } \\
\text { os movimentos realizados em algumas modalidades esportivas } \\
\text { e mostrar que os conhecimentos de física podem servir como } \\
\text { critérios para evitar lesões. }\end{array}$ \\
\hline
\end{tabular}

A complexificação do conhecimento dos estudantes durante o processo de aplicação das atividades é gradual e pode ser programado pelo professor, que tem mobilidade para realizar ajustes nas atividades desde que siga a ordem no ciclo de Lawson. Segundo Garcia (1998) a evolução das ideias dos estudantes é espiral, pois é uma evolução conjunta do processo ensino-aprendizagem e cada atividade tem por objetivo fazer com que os estudantes se elevem no grau de complexificação que está diretamente ligado aos níveis de interdisciplinaridade entre física, esporte, educação física, biomecânica e saúde, propostos em cada uma delas:

Atividade 1: EXPLORAÇÃO (concepções prévias)

Verificar o nível de interdisciplinaridade estabelecido pelos estudantes ao tratar de esportes, o que permite ao professor organizar os conteúdos nas atividades.

Atividade 2: INTRODUÇÃO DO CONCEITO (conceito de saúde)

Interdisciplinaridade: educação física, saúde e esporte.

Única atividade focada para discussão simplificada de saúde e qualidade de vida relacionada a esportes e prática de exercícios físicos. Durante as atividades focamos o conceito de saúde enfatizando a ausência de doenças, já que utilizamos os conceitos de biomecânica para prevenção de lesões. Nesta atividade encontramos alguns elementos 
abrangidos no caderno de educação física do aluno vol. 1 e 2 e podemos fazer pontes entre saúde, qualidade de vida com o conteúdo de esporte, corpo, saúde e beleza.

Atividade 3: APLICAÇÃO DO CONCEITO ( aplicação na biomecânica)

Interdisciplinaridade: biomecânica, física, saúde e esporte.

Atividade para que o estudante conheça a área de estudo da biomecânica e como está relacionada a física, saúde e ao esporte.

Estas três atividades compõem o ciclo descritivo de Lawson, pois os estudantes conhecem o conteúdo a ser estudado por descrição textual e fazem parte da fase de exploração do ciclo global hipotético-preditivo.

Atividade 4: EXPLORAÇÃO (explorando alguns conceitos mais conhecidos pelos estudantes para entender os movimentos).

Interdisciplinaridade: esporte e física.

Contato com conceitos de velocidade, aceleração, distância, tempo aplicados ao entendimento dos movimentos em alguns esportes.

Atividade 5: INTRODUÇÃO DO CONCEITO (conceitos não utilizados pelos alunos, que envolvem os explorados anteriormente).

Interdisciplinaridade: esporte, física e educação física.

Contato com os conceitos de peso e massa corporal.

Atividade 6: APLICAÇÃO DO CONCEITO (aplicação em algumas habilidades esportivas).

Interdisciplinaridade: esporte e física.

Entender alguns esportes que envolvem impulso e quantidade de movimento que utilizam todos os conceitos vistos anteriormente.

Estas 3 atividades compõem o ciclo empírico-abdutivo de Lawson, pois os estudantes criam hipóteses para entender os esporte abrangidos nas atividades e não apenas em descreve-los. Fazem parte da fase de introdução do conceito do ciclo global hipotético-preditivo. 
Atividade 7: EXPLORAÇÃO (visualização dos movimentos nos esportes)

Interdisciplinaridade: física e esporte.

Explorar os movimentos em alguns esportes e os conceitos físicos envolvidos.

Atividade 8: APLICAÇÃO DO CONCEITO (novos conceitos para possibilitar o entendimento global e os objetivos do esporte) Interdisciplinaridade: física, esporte e educação física.

A partir dos conceitos envolvidos em estática, entender alguns esportes específicos como ginástica artística, rítmica, etc. que fazem parte do caderno do aluno de educação física do $1^{\circ}$ ano do ensino médio, vol. 1 e 2.

\section{Atividade 9: APLICAÇÃO DO CONCEITO}

Interdisciplinaridade: física, esporte, biomecânica, saúde e educação física.

Verificar o grau de complexidade atingido pelos estudantes após o processo de intervenção.

Estas 3 atividades compõem o ciclo empírico-abdutivo de Lawson, pois os estudantes criam hipótese para entender os esporte abrangidos nas atividades e não apenas em descreve-los. Fazem parte da fase da aplicação do conceito do ciclo global hipotético-preditivo.

As nove atividades compõem o ciclo hipotético-preditivo, pois os estudantes formulam hipóteses para entender os movimentos nos esportes selecionados nas atividades e através de comparações, deduções, etc. com o estudo dos conceitos de mecânica envolvidos tiram suas conclusões, que são vistas nas repostas obtidas pela atividade 9.

\subsubsection{Plano de aula: Caderno do aluno de física + Intervenção}

Como a intervenção é uma forma de complementar o caderno do aluno de física do $1^{\circ}$ ano - vol. 1 e 2 (SEE, 2009), elaboramos um plano de aula que desse conta de entrelaçar este dois materiais. Como a intervenção segue os ciclos de Lawson e as atividades de multi-abordagem, buscamos característica na sequência didática do caderno do aluno de física que estivessem de acordo com os ciclos de aprendizagem de Lawson. Sabemos que as situações de aprendizagem dos cadernos do aluno de física 
não foram elaboradas com base nos ciclos de Lawson e nas atividades de multiabordagem.

Ao analisar a sequência didática do caderno do aluno de física, observamos que as situações de aprendizagem obedecem de uma forma geral às fases do ciclo de aprendizagem de Lawson e as atividades de multi-abordagem.

Isto permitiu que construíssemos um plano de aula (tabela 3.14) que utiliza os três diferentes tipos de ciclo de aprendizagem. Neste plano de aula mostramos como enquadramos as situações de aprendizagem com os ciclos de Lawson.

$\mathrm{O}$ anexo (A3.1) traz as atividades que apresentam alguns vídeos, propostas de atividades de campo, experiências, textos, etc., como também encontramos nos cadernos do aluno.

No plano de aula, prevemos o tempo de duração de cada atividade e de cada situação de aprendizagem do caderno de física, para permitir que a professora possa comparar o andamento real do curso com o ideal e não extrapolar o tempo previsto. 
Tabela 3.14 Plano de aula.

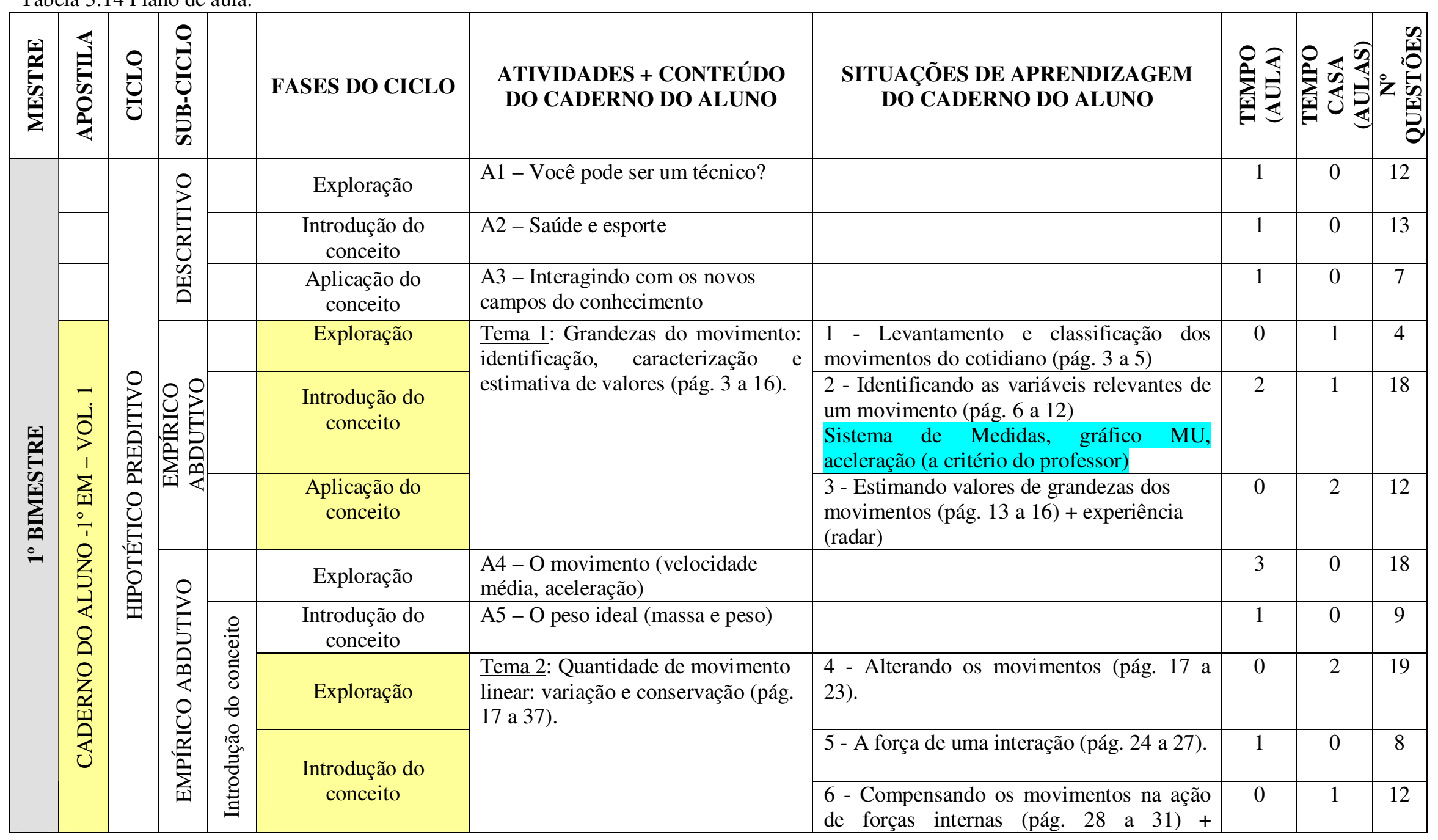




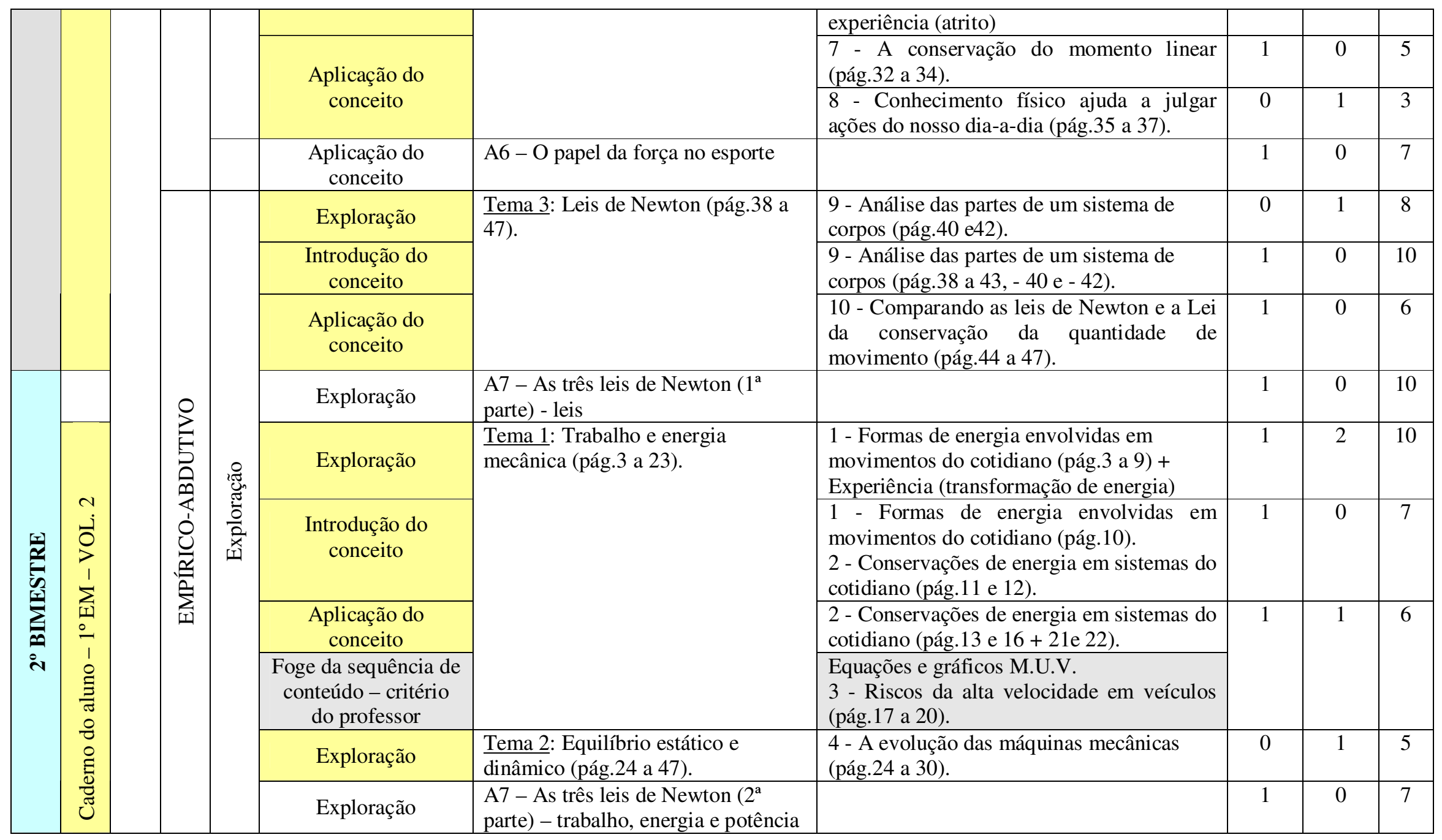




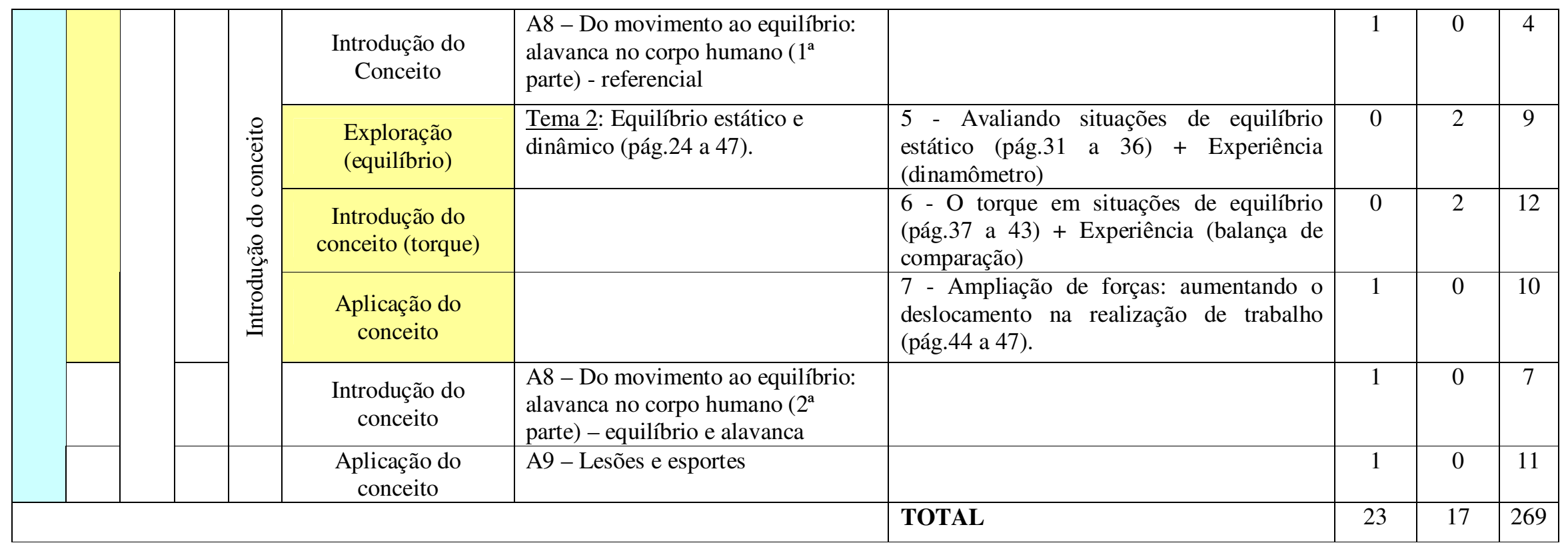




\subsection{Aplicação da atividade piloto}

As atividades-piloto foram aplicadas nos estudantes da $1^{\mathrm{a}}$ série do ensino médio do período da tarde de duas escolas estaduais na cidade de São Roque. Na escola G aplicamos em duas turmas $\left(\mathrm{A}_{1}\right.$ e $\left.\mathrm{B}_{1}\right)$ em um total de 53 estudantes e na escola $\mathrm{M}$ aplicamos em três turmas $\left(\mathrm{C}_{1}, \mathrm{D}_{1}\right.$ e $\left.\mathrm{E}_{1}\right)$ em um total de 72 estudantes, no $4^{\circ}$ bimestre de 2009. Optamos por aplicar em duas escolas, para verificar se haveria diferenças significativas de resultados.

Não fizemos uma escolha criteriosa das turmas que iríamos introduzir as atividades da intervenção, simplesmente aplicamos em todas as turmas de primeiro ano que a professora lecionava em 2009, que de certa forma ajudou nas correções feitas nas atividades durante sua aplicação.

A professora que atuou nas salas em questão para aplicação das atividades piloto é a própria pesquisadora. A superposição de papéis, a nosso ver, não acarretou em deformação da amostragem.

Primeiramente as atividades foram introduzidas nas três turmas da escola M. As turmas são heterogêneas em grau de conhecimento, disciplina e organização. No dia-adia os alunos não se organizam em fileiras, mas formam pequenos grupos com as carteiras de acordo com afinidades, mas no geral é um "grupão". Nas três primeiras atividades foi proposta aos alunos a formação de grupos de no máximo quatro pessoas (alguns optaram em dupla, outros em trio, outros individual), sendo livre a consulta a livros e caderno, valorizando principalmente a opinião dos estudantes (anexo A2 diário de bordo - atividades piloto). Os alunos ficaram a vontade na organização dos grupos na sala, pois segundo a professora interferir na "organização bagunçada" deles é iniciar conflitos (discussões) desnecessários.

Na escola $\mathrm{G}$, iniciamos a aplicação das atividades piloto duas semanas depois, sendo excelente, pois já sabíamos antemão as dúvidas que iam aparecer e pudemos ajeitar e apresentar as questões já com algumas correções (anexo A2.2).

As atividades foram aplicadas de acordo com a tabela 3.15, apresentada na próxima página.

Nas turmas $A_{1}$ e $E_{1}$ não foi possível terminar a aplicação das atividades piloto devido a imprevistos no calendário escolar, como reunião de pais e mestres, conselho de classe, etc. 
Tabela 3.15: Desenho da aplicação da atividade piloto na escola M e G.

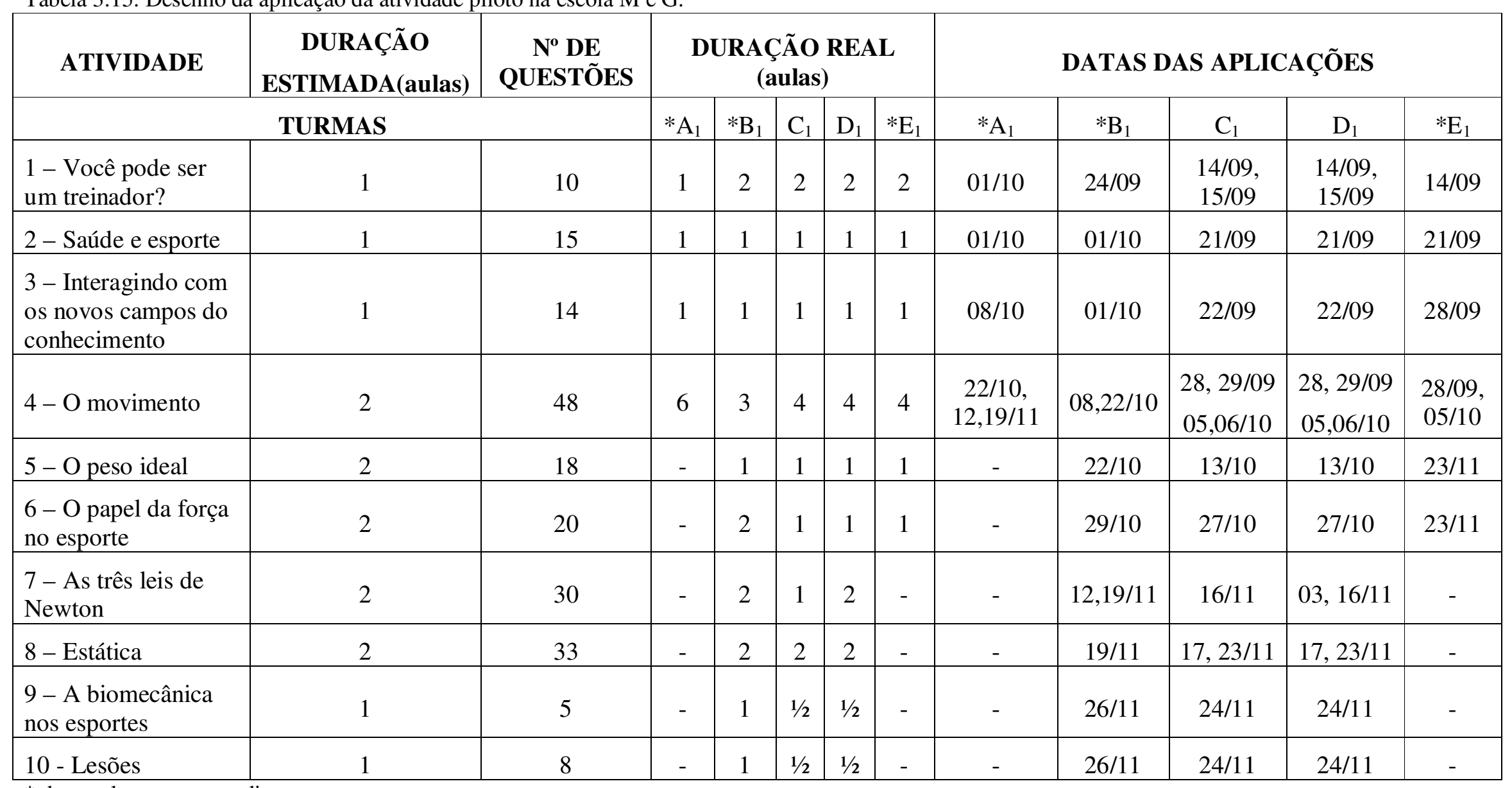

* duas aulas no mesmo dia 


\subsubsection{Entraves no processo de aplicação da atividade piloto}

Como as atividades foram aplicadas no $4^{\circ}$ bimestre, nos deparamos com vários fatores que influenciaram no andamento das atividades, como por exemplo:

1 - o assunto contido no caderno de física do aluno do $1^{\circ}$ ano do ensino médio - vol. 3 (Sistema Solar e origem do Universo) não era condizente com o conteúdo das atividades (mecânica), que foi visto no $1^{\circ}$ semestre;

2 - intervalos de tempo grandes entre as atividades devido ao número reduzido de aulas, tendo em vista a ocorrência de imprevistos como: reuniões internas da escola, "paredões" (consenso mútuo dos alunos de ausência em um dia pré-determinado) dos alunos devido aos feriados, etc.;

3 - alguns alunos que começaram a escolher as atividades que iriam fazer do $4^{\circ}$ bimestre, por estarem aprovados ou retidos pelas notas e faltas.

Devido ao fator número 2, não pudemos terminar as dez atividades em todas as turmas (observe a tabela 3.16) e devido ao fator 3 tivemos uma diminuição significativa dos alunos presentes nas aulas.

Tabela 3.16: Atividades dadas e turmas.

\begin{tabular}{|c|c|c|c|}
\hline Turma & $\mathbf{N}^{\mathbf{0}}$ de alunos & Atividades dadas & Análise de dados \\
\hline $\mathrm{A}_{1 \mathrm{G}}$ & 26 & 1 até 5 & não \\
\hline $\mathrm{B}_{1 \mathrm{G}}$ & 27 & 1 até 10 & $\operatorname{sim}$ \\
\hline $\mathrm{C}_{1 \mathrm{M}}$ & 39 & 1 até 10 & $\operatorname{sim}$ \\
\hline $\mathrm{D}_{1 \mathrm{M}}$ & 33 & 1 até 10 & $\operatorname{sim}$ \\
\hline $\mathrm{E}_{1 \mathrm{M}}$ & 37 & 1 até 5 & não \\
\hline
\end{tabular}

Portanto a amostra para análise do início, durante e fim das atividades é composta no total de 99 alunos, sendo que dentre estes, alguns não responderam as atividades até o final (tabela 3.17).

Tabela 3.17: Participação dos alunos.

\begin{tabular}{|c|c|c|}
\hline Turma & Ativ. 1 & Avaliação \\
\hline $\mathrm{B}_{1 \mathrm{G}}$ & 27 & 21 \\
\hline $\mathrm{C}_{1 \mathrm{M}}$ & 39 & 30 \\
\hline $\mathrm{D}_{1 \mathrm{M}}$ & 33 & 14 \\
\hline
\end{tabular}




\subsection{Aplicação da Intervenção e da atividade avaliatória}

Tabela 3.1: Esquema do desenho de pesquisa.

\begin{tabular}{|c|c|c|c|}
\hline Ano & Avaliação & Objetivo & Descrição \\
\hline 2007 & $\begin{array}{l}\text { Questionário } \\
\text { Prévio } 0\left(\mathrm{Q}_{0}\right)\end{array}$ & $\begin{array}{l}\text { Delimitar os objetivos da pesquisa, } \\
\text { através do levantamento da concepção } \\
\text { prévia dos estudantes sobre a relação } \\
\text { entre esporte e física. }\end{array}$ & $\begin{array}{l}\text { Questionário com } 7 \\
\text { questões }\end{array}$ \\
\hline \multirow{2}{*}{2008} & $\begin{array}{l}\text { Questionário } \\
\text { Prévio } 1\left(\mathrm{Q}_{1}\right)\end{array}$ & $\begin{array}{l}\text { Completar os dados obtidos em } \mathrm{Q}_{0} \text { para } \\
\text { diminuirmos algumas respostas } \\
\text { inconclusivas. }\end{array}$ & $\begin{array}{l}\text { Questionário com } 8 \\
\text { questões }\end{array}$ \\
\hline & $\begin{array}{l}\text { Questionário } \\
\text { Prévio } 2\left(\mathrm{Q}_{2}\right)\end{array}$ & $\begin{array}{l}\text { Analisar se houve interferências na } \\
\text { citação das disciplinas relacionadas ao } \\
\text { esporte em } \mathrm{Q}_{0} \text {. }\end{array}$ & $\begin{array}{l}\text { Questionário com } 2 \\
\text { questões }\end{array}$ \\
\hline 2009 & $\begin{array}{l}\text { Atividades } \\
\text { piloto }\end{array}$ & $\begin{array}{l}\text { Testar o conteúdo das atividades para } \\
\text { realizar as adequações necessárias. }\end{array}$ & $\begin{array}{l}10 \text { Atividades (vide } \\
\text { anexo A2) }\end{array}$ \\
\hline 2010 & $\begin{array}{l}\text { Intervenção } \\
\text { Ativ. } \\
\text { Avaliatória }\end{array}$ & $\begin{array}{l}\text { Verificar a complexificação do } \\
\text { conhecimento de esportes. }\end{array}$ & $\begin{array}{l}9 \text { Atividades (vide } \\
\text { anexoA3) }+1 \\
\text { Atividade } \\
\text { Avaliatória }\end{array}$ \\
\hline 2010 & $\begin{array}{l}\text { Questionário de } \\
\text { validação* }\left(\mathrm{Q}_{3}\right)\end{array}$ & $\begin{array}{l}\text { Confirmar o resultado favorável obtido } \\
\text { na análise de dados }\end{array}$ & $\begin{array}{l}\text { Questionário } \\
\text { composto de } \\
\text { questões }\end{array}$ \\
\hline
\end{tabular}

*Sentido de corroboração aos dados obtidos na intervenção.

Para a intervenção, a priori estabelecemos algumas metas quanto ao tempo de aplicação (tabela 3.14) da sequência didática do caderno do aluno e das atividades da intervenção, que sofreram algumas modificações devido a própria complexidade característica de uma escola pública como: reuniões e atividades escolares marcadas de última hora, comportamento e a disposição dos estudantes em cada aula, suspensão de aulas devido aos jogos da seleção de futebol brasileira na copa, etc. (anexo A3).

As atividades da intervenção foram aplicadas nos estudantes da $1^{\mathrm{a}}$ série do ensino médio do período da tarde de duas escolas estaduais na cidade de São Roque. Na escola $G$ aplicamos em duas turmas $\left(A_{2}\right.$ e $\left.B_{2}\right)$ em um total de 82 estudantes e na escola $\mathrm{M}$ aplicamos em duas turmas $\left(\mathrm{C}_{2}\right.$ e $\left.\mathrm{D}_{2}\right)$ em um total de 74 estudantes, no $1^{\mathrm{o}}$ e $2^{\mathrm{o}}$ bimestre de 2010. Optamos por aplicar em duas escolas, para verificar se haveria diferenças significativas de resultados e utilizar quatro salas para analisar em conjunto o processo de ensino-aprendizagem com características particulares de cada classe, que são gritantes (capitulo 4). A nosso ver a variedade de classes e todos os possíveis 
detalhamentos minuciosos do contexto sala de aula e dos estudantes são importantes para análise dos dados.

No início da aplicação da intervenção foram coletados alguns dados prévios a partir de algumas questões das atividades 1, 2 e 3 que servirão para compararmos com algumas questões da atividade 9 (última) e da atividade avaliatória (tabela 3.18), para analisarmos a complexificação do conhecimento de esporte. Observe as questões escolhidas na tabela abaixo:

Tabela 3.18: Questões de comparação das atividades (Anexo A3-intervenção).

\section{Atividade 1}

1) Quais são as maiores responsabilidades de um técnico de qualquer modalidade esportiva?

Objetivo da questão: Nesta questão queríamos analisar se os estudantes citam como responsabilidade do técnico o estudo dos movimentos do atleta para maior performance.

6) Seu conhecimento atual é suficiente para que você faça bons apontamentos (comentários) para auxiliar um atleta? Que conhecimentos estão te faltando?

Objetivo da questão: Nesta questão queríamos analisar se os estudantes citam a ciência como uma aliada para maior performance (conhecer biomecânica).

\section{Atividade 2}

4)Praticar alguma modalidade esportiva ou fazer exercício físico resulta em saúde? Por quê?

Objetivo da questão: Nesta questão queríamos analisar se os estudantes somente relacionam esporte somente como benéfico a saúde, sem levar em consideração que a sua prática inadequada causa lesões.

10) Leia o texto abaixo e responda:

a) Qual é a ligação entre saúde e esporte? Comente.

b) Qualquer pessoa no momento em que quiser, pode praticar esporte? Por quê?

c) Quais os cuidados que devemos ter ao praticar exercícios físicos?

Objetivo da questão: É verificar se os estudantes de alguma forma citam a importância do auxílio de profissionais adequados com intuito evitarem lesões futuras.

\section{Atividade 3}

4-De que forma a "Ciência" pode ajudar um técnico a melhorar o desempenho de um atleta?

Objetivo da questão: Nesta questão queríamos analisar se os estudantes já estabelecem a relação da ciência com o esporte.

5- Leia o texto abaixo e responda: 
c)Complete a frase: A biomecânica pode ajudar a....

d)A biomecânica pode ajudar a corrigir os movimentos de um atleta para melhorar seu desempenho? De que forma?

Objetivo da questão: Mostrar aos estudantes que existe uma área do conhecimento específica para o estudo dos movimentos de um atleta com intuito de evitar lesões e melhorar a performance.

\section{Atividade 9}

2) Que cuidados devemos ter ao iniciar uma atividade física?

3) Qual é a ligação entre saúde e esporte? Comente

4) Praticar alguma modalidade esportiva ou fazer exercício físico é sinônimo de saúde? Por quê?

5) Qual a importância da biomecânica para prática esportiva?

6) Qualquer pessoa no momento que quiser, pode praticar esporte? Por quê?

7) Quais os cuidados que devemos ter ao praticar exercícios físicos?

8) Por que uma compreensão básica dos princípios mecânicos básicos ajudará o atleta a ter um melhor desempenho?

12) Quais são as maiores responsabilidades de um técnico de qualquer modalidade esportiva?

13) Depois destas atividades você é capaz de analisar mais criticamente o desempenho de um atleta?

Objetivo geral das questões abaixo: Analisar se de alguma forma os alunos introduziram novas zonas ao perfil conceitual de esporte, e conseguem aplicar o conhecimento interdisciplinar apresentado na intervenção para analisar criticamente a relação entre a prática esportiva e saúde, e o papel da biomecânica nesta relação.

\section{Atividade avaliatória}

Objetivo da questão: Analisar se os estudantes passaram a utilizar os conceitos vistos na intervenção como uma forma de se ter uma vida saudável.

1 - Formule um texto, uma frase ou uma história que contenha obrigatoriamente (no singular ou plural) as palavras: biomecânica, esporte, saúde, física, lesão, corpo e vida.

Pela tabela 3.19 comparamos as questões das atividades iniciais e finais com as questões indicadas na tabela 3.18 enfocam mais a relações entre física, esporte, educação física, biomecânica e saúde e permitem analisar se após a intervenção houve a complexificação do conhecimento cotidiano a respeito de esporte.

Observaremos as respostas dos estudantes a estas questões, atentando para o encadeamento das ideias e suas respectivas justificativas, e a inclusão de novas ideias ao argumentar sobre esporte, saúde, educação física, física e biomecânica. 
Tabela 3.19: Questões de comparação das atividades (Anexo A3 - intervenção).

\begin{tabular}{|c|c|c|c|c|}
\hline Atividade 1 & Atividade 2 & Atividade 3 & Atividade 9 & Atividade Avaliatória \\
\hline Questão 1 & & & Questão 12 & \multirow{8}{*}{ Questão 1} \\
\hline \multirow[t]{7}{*}{ Questão 6} & & & Questão 13 & \\
\hline & Questão 4 & & Questão 4 & \\
\hline & Questão 10a & & Questão 3 & \\
\hline & Questão $10 \mathrm{~b}$ & & Questão 6 & \\
\hline & Questão 10c & & Questão 7 e 2 & \\
\hline & & Questão 4, 5c, 5d & Questão 8 & \\
\hline & & Questão $4,5 c, 5 d$ & Questão 5 & \\
\hline
\end{tabular}

\subsubsection{Dificuldades apresentadas pela professora na aplicação da intervenção}

A intervenção foi proposta aos alunos como uma forma de complementar o conteúdo do caderno do aluno de física, com objetivo de facilitar o aprendizado dos conceitos físicos. As atividades da intervenção tiveram o mesmo peso das outras atividades avaliatórias dadas pela professora.

Não houve modificações nas sequências das fases do ciclo de aprendizagem de Lawson, mas devido a frequência dos alunos nas aulas e a imprevistos como: reunião de pais conselhos de classe, etc., a professora alterou a ordem das atividades do caderno de física do alunos (Anexo 3.2.3 diário de bordo), excluiu algumas tarefas de classe e de casa e deixou os experimentos propostos no caderno de física do aluno (v. 1 e 2) para serem feitos nas férias de julho e entregues em agosto (processo dinâmico). Mas, diferentemente do piloto das atividades durante a aplicação, não incluímos ou retiramos questões ou conteúdos das atividades de intervenção. Em ambas as escolas foi aplicada a intervenção na íntegra, exceto pelo fato de que na escola $G$ foi possível passar todos os vídeos (no data-show) sugeridos nas atividades da intervenção, mas na escola M a professora foi obrigada a excluir as questões apresentadas nas atividades de intervenção que necessitavam assistir o vídeo, embora durante as aulas a professora descrevesse por gestos as modalidades esportivas contidas na intervenção para os estudantes de acordo com as dúvidas apresentadas.

Durante a intervenção, segundo os relatos da professora, os estudantes incluíram facilmente a intervenção como parte do conteúdo de física do semestre, sendo que , 
muitas vezes, preferiam responder as atividades da intervenção ao invés das atividades do caderno de física do aluno.

Mas, como dissemos anteriormente, as atividades de intervenção estão entrelaçadas com o caderno do aluno. Os conceitos físicos (suas definições) e algumas de suas aplicações no cotidiano do aluno estão contidos no caderno de física do aluno e são importantes para aplicação dos mesmos nas modalidades esportivas tratadas nas atividades de intervenção. Portanto, é necessário que o professor mescle adequadamente os dois materiais, e para isso é importante que o professor conheça e esteja a vontade com o conteúdo do material que irá utilizar. Não defendemos a ideia de que o professor seja o detentor do conhecimento e tenha a obrigação de se especializar nos conteúdos de biomecânica, mas é imprescindível um estudo adequado para que consiga estabelecer pontes entre os conhecimentos interdisciplinares para mostrar aos estudantes suas correlações e aplicações no seu dia-a-dia.

Durante toda a intervenção a professora passou por situações adversas, não previstas, mas para superá-las não utilizou qualquer receita pronta, contamos com o bom senso e a experiência para contorná-las e atingir o alvo proposto para aula. É papel do professor, demarcar um tempo para conclusão de cada atividade, pois é ele que conhece o ritmo dos estudantes com que está trabalhando.

Pelos relatos da professora notamos que a disposição, a motivação do professor para trabalhar com os estudantes sofre picos como também o comportamento dos estudantes frente às atividades (anexo A3.2.3), mas o professor com objetivos claros para cada aula e seguindo, da melhor maneira possível, provavelmente obterá sucesso na aplicação e um bom índice de aprendizado.

Em cada atividade da intervenção proposta, encontramos os estudantes estabelecendo hipóteses entre si e propiciando discussões sobre os diversos pontos de vista, já que embora as atividades fossem propostas individualmente, os estudantes tinham liberdade para discutí-las uns com os outros e realizá-las em grupos, desta forma não houve interferência no ambiente sala de aula, visto que os alunos não seguem a disposição em fileiras, eles praticamente se "amontoam" em blocos de afinidades que por sua vez forma um "grupão" bem coeso, são bem unidos como grupo, e defendem praticamente os mesmos ideais e seguem um comportamento semelhante.

$\mathrm{Da}$ mesma forma que discutem os assuntos inerentes as atividades de intervenção, apresentam picos de discussão, e é comum perderem o foco durante as aulas e passarem a discutirem assuntos diversos. Existe uma mescla de situações que 
dependem do dia, o rendimento e o aprendizado está diretamente atrelado a disposição dos estudantes em aprender e como o professor apresenta a proposta para aula. Cabe ao professor encaminhar a atividade, não enfadonhamente, mas garantindo o cronograma por ele elaborado para execução de cada atividade.

A intervenção, como dito anteriormente, foi aplicada em duas escolas diferentes não somente em espaço físico ou corpo docente, mas principalmente em grupo gestor, clientela de alunos e acesso aos recursos didáticos disponíveis em cada escola. $\mathrm{Na}$ escola $\mathrm{G}$ o acesso aos recursos didáticos como televisão, data-show, livros, materiais escolares, etc. são livres, o professor possui total autonomia para solicitar e utilizar todos os recursos didáticos que a escola possui da maneira que lhe aprouver. Além disso, a movimentação dos alunos para o pátio ou quadra não é vetado, há acessoria dos inspetores para assegurar que todos os alunos permaneçam no local desejado pelo professor.

Já na escola M, o professor encontra grandes dificuldades para utilizar os recursos didáticos (são do mesmo tipo da escola G), pois nunca estão operando adequadamente ou nunca estão montados na sala, mesmo agendando antecipadamente o material. A equipe gestora estabelece várias regras para utilização dos recursos, intimidando o professor ao seu uso e não apóia a saída dos alunos da sala de aula. Estes lados tão distintos das duas escolas, mesmo estando na mesma cidade, abala, de certa forma, a motivação, tanto do professor quanto dos estudantes, pois o recurso que se diz público não faz jus à palavra.

$\mathrm{Na}$ escola $\mathrm{G}$ há também problemas de indisciplina, mas não são tão acentuados quanto na escola M no ano letivo de 2010. O professor com sua experiência em sala de aula consegue atenuá-los e desenvolver sua proposta de aula e chegar nos seus objetivos.

Segundo os relatos da professora, ao analisar a questão de comportamento adequado em sala de aula, ou seja, valores que esperamos já estar embutidos nos alunos, que fazem parte da constituição do caráter individual através da convivência familiar, é notável a diferença entre as duas escolas pela maneira de tratar o professor, de se portar em sala, da importância dada ao conhecimento.

Além destes aspectos citados, há grandes diferenças no comportamento dos estudantes, que por sua vez se modifica a cada ano, pois todos os anos as escolas recebem novos alunos para $1^{\text {a }}$ série do ensino médio vindo das escolas municipais de bairros diversos da cidade. 


\subsection{Coleta do diário de bordo}

A superposição do papel de pesquisadora e professora não acarretou problemas quanto à coleta de dados e aplicação das atividades, ao contrário auxiliou, tendo em vista que a direção da escola e funcionários já eram conhecidos, possibilitando a previsão à respeito das dificuldades e facilidades apresentadas ao aplicarmos os questionário e as atividades. Isto também forneceu subsídios para algumas modificações rápidas ao aplicar as atividades, pois a cada sala a receptividade era diferente, e por consequência o modo diferenciado de introduzir as atividades.

Caso a superposição de papéis não ocorresse seria necessário um tempo maior para que a inserção de um pesquisador na sala de aula não interferisse no comportamento dos alunos e para que o mesmo pudesse conhecer o comportamento habitual deles, interagindo de forma natural.

\subsubsection{Atividade piloto}

No diário de bordo da atividade encontramos relatos do comportamento dos alunos frente às atividades. Nestes relatos são enfocados os problemas quanto à interpretação das questões, questões ambíguas, disposição dos textos, dificuldade de aprendizagem dos conceitos, tempo de duração, ou seja, é dado mais atenção as relações de ensino e aprendizagem que os estudantes estabelecem com as atividades. A seguir mostramos alguns diálogos entre aluno-aluno e professora-aluno contidos nas anotações do diário de bordo da professora na atividade piloto (anexo A2), para fornecer detalhes das características das aulas.

O papel do professor na intervenção é o de mediador, orientando os alunos nas atividades, com objetivo de fazer os alunos alcançarem a aprendizagem. Observe no diálogo descrito a seguir que durante a aplicação da atividade piloto a professora atuou como mediadora, apenas encaminhando o raciocínio dos estudantes e não forneceu as respostas de imediato:

Diálogo 1 - Assunto: velocidade média (anexo A2: atividade piloto 4 - questão 1 a 4):

Aluno (A): Não entendi a questão 1

Professora(P): Vamos ler juntos e devagar 
A: Ah entendi então são $10 \mathrm{~m} / \mathrm{s}$, na questão 2 acho que $5 \mathrm{~m} / \mathrm{s}$, mas e a questão 3?

P: Então se você faz com velocidade de $5 \mathrm{~m} / \mathrm{s}$, significa que você faz 5 metros em 1 segundo, então 100metros em ....

\section{A: Ah entendi}

No diário de bordo (anexo A2) estão expressos as dúvidas dos estudantes na aula e alguns diálogos entre eles, que nos levam a analisar como se dá a construção do conhecimento em uma sala de aula (observe no diálogo 2 e 3 abaixo), em que nos dias atuais é muito difícil encontrar e manter os alunos alinhados em fileiras e em silêncio durante a aula, realizando as atividades tranquilamente. É preciso entender a "bagunça organizada" e aproveitá-la em prol da aprendizagem

Diálogo 2 - Assunto: quantidade de movimento (anexo A2: atividade piloto 4 - questão 14 a 24), momento de análise da colisão do maratonista Vanderley com o padre fantasiado

A1: O Vanderley, pois o fantasiado é gordo

A2: Mas o Vanderley está correndo

A1: Mas foi de lado...

Diálogo 3 - Assunto: Saúde, beleza e alimentação (anexo A2: atividade piloto 2 questão 1 a 4) - Momento da discussão de saúde e alimentação

A1: Eu sou magra, mas só como merda

A2: Esqueci qual alimento é saudável, mesmo...verdura é?

\subsubsection{Intervenção}

Abaixo destacamos alguns trechos do diário de bordo da professora (anexo A3) para exemplificar o conteúdo do mesmo e sua importância na análise de dados (capítulo 4).

No diário de bordo, a professora se queixa da indisciplina em algumas salas: "Depois do intervalo é sempre difícil, mas passei na lousa 5 exercícios sobre velocidade média, a maioria dos alunos não fizeram, olhei todos os cadernos $e$ apostilas, dei um sermão, cobrei as atividades atrasadas, enfim...” (diário de bordo, anexo A3); e, também, da falta de interesse em participar da aula: “... mas é muito difícil estão em uma fase em que não se interessam por nada e não querem fazer nada..." (diário de bordo, anexo A3). Para reverter este quadro a professora insiste e 
persiste durante as aulas realizando até simulações: "Articulei alguns exemplos simulando colisões entre mim (professora) e um aluno, um ginasta e um lutador de sumo" (diário de bordo, anexo A3.2.3).

Havia momentos em que a professora se dizia cansada de "remar contra a maré" se manifestando desanimada: "Desta vez estou cansada, entrei calada e sai muda, apenas coloquei na lousa o que deveriam fazer" (diário de bordo, anexo A3.2.3).

No decorrer da aplicação da intervenção a professora realizou modificações pertinentes para o desenvolvimento das atividades encontrando soluções rápidas ("Estava indecisa se aplicaria a atividade 3 pela quantidade de alunos que havia na sala, então na primeira parte da aula passei alguns exercícios sobre velocidade média e também conversões de medidas" - diário de bordo, anexo A3.2.3).

As modificações na atividade, realizadas pela professora, colaboraram para efetivar bons resultados, pois auxilia na preparação de um ambiente favorável para o aprendizado, além de deixá-los mais receptivos para o assunto a ser abordado.

\subsection{Validação da pesquisa $\left(Q_{3}\right)$}

Tabela 3.1: Esquema do desenho de pesquisa.

\begin{tabular}{|c|c|c|c|}
\hline Ano & Avaliação & Objetivo & Descrição \\
\hline 2007 & $\begin{array}{l}\text { Questionário } \\
\text { Prévio } 0\left(\mathrm{Q}_{0}\right)\end{array}$ & $\begin{array}{l}\text { Delimitar os objetivos da pesquisa, } \\
\text { através do levantamento da concepção } \\
\text { prévia dos estudantes sobre a relação } \\
\text { entre esporte e física. }\end{array}$ & $\begin{array}{l}\text { Questionário com } 7 \\
\text { questões }\end{array}$ \\
\hline \multirow{2}{*}{2008} & $\begin{array}{l}\text { Questionário } \\
\text { Prévio } 1\left(\mathrm{Q}_{1}\right)\end{array}$ & $\begin{array}{l}\text { Completar os dados obtidos em } \mathrm{Q}_{0} \text { para } \\
\text { diminuirmos } \\
\text { inconclusivas }\end{array}$ & $\begin{array}{l}\text { Questionário com } 8 \\
\text { questões }\end{array}$ \\
\hline & $\begin{array}{l}\text { Questionário } \\
\text { Prévio } 2\left(\mathrm{Q}_{2}\right)\end{array}$ & $\begin{array}{l}\text { Analisar se houve interferências na } \\
\text { citação das disciplinas relacionadas ao } \\
\text { esporte em } \mathrm{Q}_{0}\end{array}$ & $\begin{array}{l}\text { Questionário com } 2 \\
\text { questões }\end{array}$ \\
\hline 2009 & $\begin{array}{l}\text { Atividades } \\
\text { piloto }\end{array}$ & $\begin{array}{l}\text { Testar o conteúdo das atividades para } \\
\text { realizar as adequações necessárias }\end{array}$ & $\begin{array}{l}10 \text { Atividades (vide } \\
\text { anexo A2) }\end{array}$ \\
\hline 2010 & \begin{tabular}{|l|} 
Intervenção + \\
Ativ. \\
Avaliatória
\end{tabular} & $\begin{array}{l}\text { Verificar a complexificação do } \\
\text { conhecimento de esportes }\end{array}$ & $\begin{array}{l}9 \text { Atividades (vide } \\
\text { anexoA3) }+1 \\
\text { Atividade } \\
\text { Avaliatória }\end{array}$ \\
\hline 2010 & $\begin{array}{l}\text { Questionário de } \\
\text { validação* }\left(\mathrm{Q}_{3}\right)\end{array}$ & $\begin{array}{l}\text { Confirmar o resultado favorável obtido } \\
\text { na análise de dados }\end{array}$ & $\begin{array}{l}\text { Questionário } \\
\text { composto de } \\
\text { questões }\end{array}$ \\
\hline
\end{tabular}

*Sentido de corroboração aos dados obtidos na intervenção. 
Não utilizamos o termo validação no sentido rigoroso de cunho metodológico, mas no sentido de corroboração dos dados obtidos na intervenção.

O objetivo do questionário de validação era o de confirmar o resultado obtido na análise de dados (seção 4.3) e complementá-los mediante a verificação de como os estudantes articulam a biomecânica, educação física, esporte, saúde e física, e a aplicação dos conceitos de mecânica em outra modalidade esportiva diferente da abrangida nas intervenções.

Para finalizar decidimos aplicar um questionário nas quatro turmas em que aplicamos a intervenção. O questionário de validação engloba não somente questões relacionadas a esporte, biomecânica, educação física, física e saúde, mas contém duas questões relacionadas com a montagem do mapa da sala, no qual os estudantes desenham a posição das carteiras na sala de aula determina a localização de todos. Estas duas questões que envolvem o mapeamento da sala de aula, foram propostas devido aos estudantes mudarem de grupos e trocarem as posições das carteiras, o que impossibilita a professora de mapear com precisão, a sala. Apenas os estudantes que convivem por mais tempo juntos conseguem fazer essa identificação de forma detalhada.

O questionário de validação foi proposto com questões diferenciadas para as turmas mediante sua aplicação e análise das respostas. Como o questionário foi aplicado com defasagem de turma para turma, foi possível realizar algumas modificações, até que obtivéssemos detalhes de como os estudantes unem os conteúdos de educação física e física. Abaixo apresentamos as questões do questionário de validação e seus objetivos.

O questionário de validação é composto de 7 questões para turma $1^{\circ} \mathrm{A}_{3}$ e $1^{\circ} \mathrm{B}_{3}$ da escola G (tabela 3.20).

Tabela 3.20: Questionário de Validação para turma $1^{\circ} \mathrm{A}_{3}$ e $1^{\circ} \mathrm{B}_{3}$

1 - Faça um mapeamento da sua sala colocando a posição real das carteiras e identificando os alunos por número.

Objetivo da questão: Obter o mapeamento da sala, para comparar com as possíveis respostas idênticas obtidas na atividade 9 da intervenção e na atividade avaliatória.

2 - Agora que temos um mapa da sala, dê as coordenadas para inspetora localizar um de seus colegas (a sua escolha).

Objetivo da questão: Confirmar a lógica do mapa feito pelo estudante

3 - Qual é a relação existente entre a disciplina de física e educação física? O que tem em comum?

Objetivo da questão: Analisar se os estudantes percebem a relação interdisciplinar entre física e educação física 
4 - Dos assuntos (conteúdos) que você estudou na matéria de educação física, quais deles podem ser utilizados para entender, explicar a matéria de física do $1^{\mathrm{o}}$ e $2^{\mathrm{o}}$ bimestre? De que forma? Dê exemplos.

Objetivo da questão: Analisar se os estudantes reconhecem a aplicação da educação física na física.

5 - Formule uma pergunta para fazer ao professor de educação física que contenha os conhecimentos da matéria de educação física e física.

Objetivo da questão: Analisar se os estudantes sabem utilizar, em conjunto, os conceitos das duas áreas.

6 - De tudo que foi visto na matéria de física no $1^{\circ}$ e $2^{\circ}$ bimestre, quais podem ser aplicados nas aulas de educação física? Como? De que forma?

Objetivo da questão: Analisar se os estudantes sabem utilizar em conjunto os conceitos das duas áreas.

7 - Formule uma questão para professora de física responder, bem difícil, que contenha o conteúdo de física e educação física.

Objetivo da questão: Analisar como os estudantes articulam os conceitos das duas disciplinas

O questionário de validação é composto de 7 questões para turma $1^{\circ} \mathrm{C}_{3} \mathrm{e} 1^{\circ} \mathrm{D}_{3}$ da escola M (tabela 3.21).

Tabela 3.21: Questionário de Validação para turma $1^{\circ} \mathrm{C}_{3}$ e $1^{\circ} \mathrm{D}_{3}$

1 - Faça um mapeamento da sua sala colocando a posição real das carteiras e identificando os alunos por número.

Objetivo da questão: Obter o mapeamento da sala, para comparar com as respostas idênticas obtidas na atividade 9 da intervenção e na atividade avaliatória.

2 - Agora que temos um mapa da sala, dê as coordenadas para inspetora localizar um de seus colegas (a sua escolha).

Objetivo da questão: Confirmar a lógica do mapa feito pelo estudante

3 - Qual é a relação existente entre a disciplina de física e educação física? O que tem em comum?

Objetivo da questão: Analisar se os estudantes percebem a relação interdisciplinar entre física e educação física

4 - Dos assuntos (conteúdos) que você estudou na matéria de educação física, quais deles podem ser utilizados para entender, explicar a matéria de física do $1^{\mathbf{o}}$ e $2^{\mathrm{o}}$ bimestre? De que forma? Dê exemplos.

Objetivo da questão: Analisar se os estudantes reconhecem a aplicação da educação física na física.

5 - Formule uma pergunta para fazer ao professor de educação física contenha os conhecimentos da matéria de educação física e física. 
Objetivo da questão: Analisar se os estudantes sabem utilizar em conjunto os conceitos das duas áreas.

6 - De tudo que foi visto na matéria de física no $1^{\circ}$ e $2^{\circ}$ bimestre, quais podem ser aplicados nas aulas de educação física? Como? De que forma?

Objetivo da questão: Analisar se os estudantes sabem utilizar em conjunto os conceitos das duas áreas.

7 - Formule uma questão para professora de física responder, bem difícil, que contenha o conteúdo de física e educação física.

Objetivo da questão: Analisar como os estudantes articulam os conceitos das duas disciplinas

No próximo capítulo realizaremos a análise dos dados obtidos pelos questionários prévios, atividade-piloto, intervenção e questionário de validação.

\section{Escolha metodológica para transcrição}

Optamos pela transcrição direta dos dados obtidos por meio das respostas dos estudantes (ipsis litteris). O uso incorreto ou incomum de pontuação, ortografia ou forma de escrita presente nas citações diretas provém de seu autor original [sic]. 


\section{CAPÍTULO 4}

\section{Análise de dados}

Neste capítulo serão apresentados os dados coletados com todos os instrumentos de avaliação dos estudantes. Como vimos no quadro do "desenho de pesquisa" (seção 3.1.) aplicamos um questionário preliminar no ano de 2007 que consistia de um conjunto de 7 questões $\left(\mathrm{Q}_{0}\right)$; e para complementar os dados obtidos no ano de 2008 aplicamos dois questionários preliminares: um de 8 questões $\left(\mathrm{Q}_{1}\right)$ e um de 2 questões $\left(Q_{2}\right)$. No ano de 2009, iniciamos a intervenção (conjunto de atividades), mas com uma versão piloto (AP) composta de 10 atividades (seção 3.5.4), como um meio de testar e posteriormente ajustar as atividades. No ano de 2010, aplicamos a versão definitiva da intervenção (I) - seção 3.5.5 - e uma atividade avaliatória (AV), das quais selecionamos um conjunto de questões para análise das respostas e que nos auxiliaram para analisar a complexificação do conhecimento de esporte. Ainda em 2010, aplicamos um questionário que denominamos de questionário de validação $\left(\mathrm{Q}_{3}\right)$ para auxiliar na conclusão dos resultados obtidos pela análise de dados da intervenção e obter o mapeamento de posição dos estudantes nas salas.

A seguir apresentamos a análise dos questionários preliminares, da atividade piloto (AP), da intervenção (I) e do questionário de validação $\left(\mathrm{Q}_{3}\right)$.

Tabela 3.1: Esquema do desenho de pesquisa.

\begin{tabular}{|c|c|c|c|}
\hline Ano & Avaliação & Objetivo & Descrição \\
\hline 2007 & $\begin{array}{l}\text { Questionário } \\
\text { Prévio } 0\left(\mathrm{Q}_{0}\right)\end{array}$ & $\begin{array}{l}\text { Delimitar os objetivos da pesquisa, através } \\
\text { do levantamento da concepção prévia dos } \\
\text { estudantes sobre a relação entre esporte e } \\
\text { física. }\end{array}$ & $\begin{array}{l}\text { Questionário com } 7 \\
\text { questões }\end{array}$ \\
\hline \multirow{2}{*}{2008} & $\begin{array}{l}\text { Questionário } \\
\text { Prévio } 1\left(\mathrm{Q}_{1}\right)\end{array}$ & $\begin{array}{lcr}\text { Completar os } & \text { dados obtidos } & \text { em } \text { Q }_{0} \text { para } \\
\text { diminuirmos } & \text { algumas } & \text { respostas } \\
\text { inconclusivas. } & & \end{array}$ & $\begin{array}{l}\text { Questionário com } 8 \\
\text { questões }\end{array}$ \\
\hline & $\begin{array}{l}\text { Questionário } \\
\text { Prévio } 2\left(\mathrm{Q}_{2}\right)\end{array}$ & $\begin{array}{l}\text { Analisar se houve interferências na citação } \\
\text { das disciplinas relacionadas ao esporte em } \mathrm{Q}_{0}\end{array}$ & $\begin{array}{l}\text { Questionário com } 2 \\
\text { questões }\end{array}$ \\
\hline 2009 & $\begin{array}{l}\text { Atividades piloto } \\
\text { (AP) }\end{array}$ & $\begin{array}{l}\text { Testar o conteúdo da } \\
\text { as adequações necess }\end{array}$ & $\begin{array}{l}10 \text { Atividades (vide } \\
\text { anexo A2) }\end{array}$ \\
\hline 2010 & $\begin{array}{l}\text { Intervenção }{ }^{+} \\
\text {Ativ. Avaliatória }\end{array}$ & $\begin{array}{l}\text { Verificar a complexificação do conhecimento } \\
\text { de esportes. }\end{array}$ & $\begin{array}{l}9 \quad \text { Atividades } \quad \text { (vide } \\
\text { anexoA3) }+1 \\
\text { Atividade Avaliatória }\end{array}$ \\
\hline 2010 & $\begin{array}{l}\text { Questionário de } \\
\text { validação* }\left(\mathrm{Q}_{3}\right)\end{array}$ & $\begin{array}{l}\text { Confirmar o resultado favorável obtido na } \\
\text { análise de dados. }\end{array}$ & $\begin{array}{l}\text { Questionário composto } \\
\text { de } 7 \text { questões }\end{array}$ \\
\hline
\end{tabular}

*Sentido de corroboração aos dados obtidos na intervenção. 


\subsection{Respostas aos questionários preliminares}

\section{Questionário $Q_{0}$}

Ao analisar o questionário $\mathrm{Q}_{0}$ obtivemos dados importantes para auxiliar na construção da intervenção. Abaixo faremos uma análise detalhada das 8 questões propostas no questionário $\mathrm{Q}_{0}$.

Na questão 1, a maioria dos alunos vê na prática esportiva um meio para o ser humano ter uma vida saudável. Na maioria das respostas, observamos o conceito de saúde apenas relacionado à ausência de doenças. Em outras respostas os alunos focam o social com grande importância, tendo no esporte uma perspectiva de mudança de vida, talvez seja por alguns casos relatados na mídia. O importante é destacar que o esporte para os alunos é definido como algo que sempre traz benefícios tanto no aspecto mental, físico ou social. Para eles o esporte é reflexo de segurança, garra, diversão, etc., em nenhum momento percebem que a prática de esportes de forma errônea pode trazer malefícios à saúde.

Tabela 4.1: Exemplos de respostas obtidas na questão 1 - escola G.

\begin{tabular}{|c|l|}
\hline Identificação* & \multicolumn{1}{|c|}{ Resposta } \\
\hline$\left(\mathrm{Q}_{0 \mathrm{G}}, 1,62\right)$ & $\begin{array}{l}\text { "Além de ser gostoso, é bom de fazer, faz muito bem a saúde e te } \\
\text { ajuda a prevenir doenças". }\end{array}$ \\
\hline$\left(\mathrm{Q}_{0 \mathrm{G}}, 1,19\right)$ & $\begin{array}{l}\text { "O esporte é bom para manter a saúde do ser humano. Uma pessoa } \\
\text { que pratica esporte, dificilmente vai ter problemas físicos, cardíacos". }\end{array}$ \\
\hline$\left(\mathrm{Q}_{0 \mathrm{G}}, 1,67\right)$ & $\begin{array}{l}\text { "É muito importante para manter a saúde não sofrer de obesidade e } \\
\text { também para o coração". }\end{array}$ \\
\hline$\left(\mathrm{Q}_{0 \mathrm{G}}, 1,80\right)$ & $\begin{array}{l}\text { "Acredito que é benefício para sua saúde, pois a pessoa acaba } \\
\text { adquirindo uma estabilidade com o corpo e com isso ajuda a evitar } \\
\text { algumas doenças". }\end{array}$ \\
\hline
\end{tabular}

*(questionário, questão, aluno).

$\mathrm{Na}$ questão 2 percebemos que os alunos têm pouco conhecimento das habilidades necessárias para ter um excelente desempenho na prática esportiva.

Tabela 4.2: Exemplos de respostas obtidas na questão 2 - escola G.

\begin{tabular}{|c|l|}
\hline Identificação* & \multicolumn{1}{|c|}{ Respostas } \\
\hline$\left(\mathrm{Q}_{0 \mathrm{G}}, 2,06\right)$ & $\begin{array}{l}\text { "Semanalmente na escola prático futsal, vôlei e queimada e as } \\
\text { habilidades necessárias é fazer um aquecimento para seu corpo". }\end{array}$ \\
\hline
\end{tabular}




\begin{tabular}{|c|l|}
\hline$\left(\mathrm{Q}_{0 \mathrm{G}}, 2,14\right)$ & $\begin{array}{l}\text { "Caminhada é para desempenhá-la com sucesso é necessário estar } \\
\text { bem alongado e com uma roupa adequada". }\end{array}$ \\
\hline$\left(\mathrm{Q}_{0 \mathrm{G}}, 2,15\right)$ & $\begin{array}{l}\text { "Bem particularmente pratico duas atividades físicas semanalmente, } \\
\text { uma delas é a caminhada, procuro caminhar todos os dias pelo menos } \\
\text { que estar bem alongados e com uma roupa bem própria para a } \\
\text { caminhada, e outra atividade que faço é andar todos os dias de bike e } \\
\text { para exercer essa atividade com sucesso, temos que estar com uma } \\
\text { roupa adequada e procurar andar em um lugar plano". }\end{array}$ \\
\hline$\left(\mathrm{Q}_{0 \mathrm{G}}, 2,23\right)$ & $\begin{array}{l}\text { "Eu gosto de praticar futebol para praticá-lo é necessário muito } \\
\text { equilíbrio e habilidade quanto mais rápido você for melhor e precisa } \\
\text { de muita força nas pernas para chutar" }\end{array}$ \\
\hline$\left(\mathrm{Q}_{0 \mathrm{G}}, 2,39\right)$ & $\begin{array}{l}\text { "Eu pratico o vôlei e para desempenhá-lo melhor e sendo bem ágil, ter } \\
\text { um bom salto e ser bem flexível”. }\end{array}$ \\
\hline$\left(\mathrm{Q}_{0 \mathrm{G}}, 2,51\right)$ & $\begin{array}{l}\text { "Dança, ter equilíbrio ter elasticidade corporal, ter bom } \\
\text { condicionamento e resistência física”. }\end{array}$ \\
\hline$\left(\mathrm{Q}_{0 \mathrm{G}}, 2,76\right)$ & \begin{tabular}{l} 
"Vôlei e basquete, alongar e saber jogar". \\
\hline
\end{tabular}
\end{tabular}

*(questionário, questão, aluno)

Na questão 3, a maioria dos alunos identifica em primeiro lugar a disciplina de educação física como relacionada aos esportes (figura 4.1). Mas, obtemos a física em segundo lugar, o que implica que os alunos já estabelecem algumas relações interdisciplinares entre a física e o esporte. É claro que o questionário foi aplicado numa aula de física, talvez isso tenha levado os alunos a opinarem por física, mas durante o trabalho mostraremos o resultado desta questão aplicado por professores de outras disciplinas.

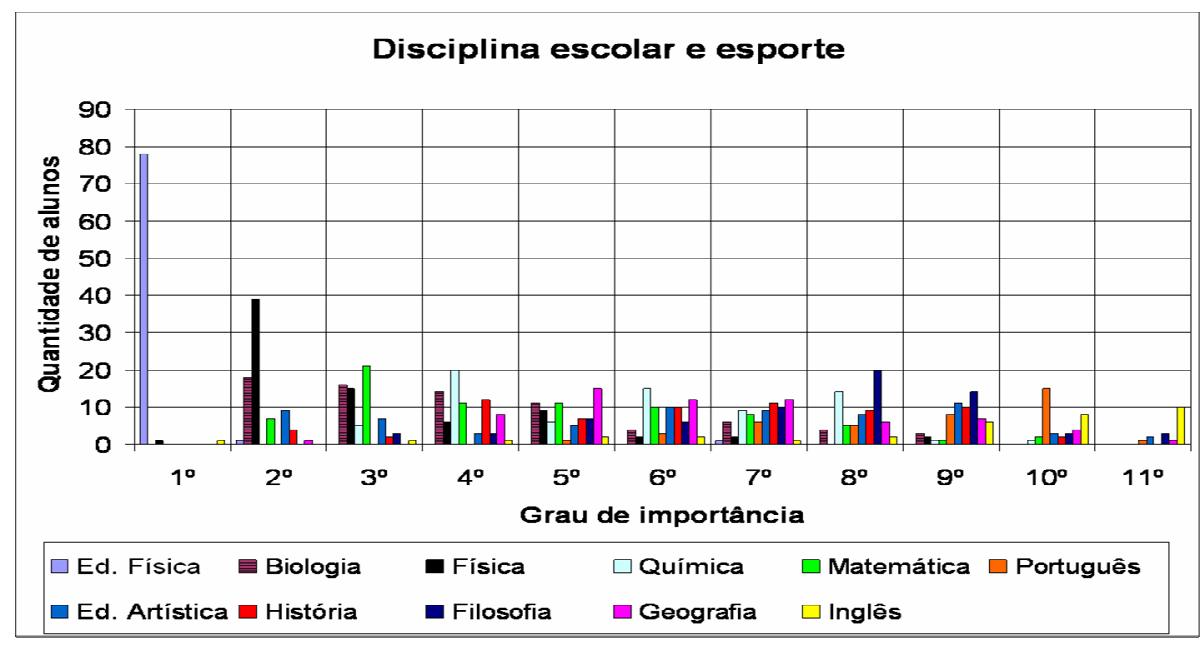

Figura 4.1: Questionário $\mathrm{Q}_{0}$ - Questão 3. 
Tabela 4.3: Exemplos de respostas obtidas na questão 4 - escola G.

\begin{tabular}{|c|c|}
\hline Identificaçãa* & Respostas \\
\hline$\left(\mathrm{Q}_{0 \mathrm{G}}, 4,01\right)$ & $\begin{array}{l}\text { "Corrida: distância, medida dos quilômetros percorridos } \\
\text { Salto: altura, medida da altura alcançada } \\
\text { Futebol: distância, medida da distância para se acertar o gol } \\
\text { Ciclismo: velocidade, medida da velocidade alcançada } \\
\text { Levantamento de peso: força } \\
\text { Natação: força". }\end{array}$ \\
\hline$\left(\mathrm{Q}_{0 \mathrm{G}}, 4,08\right)$ & $\begin{array}{l}\text { "Ginástica rítmica: acústica, trabalha o corpo com o ritmo musical } \\
\text { Tiro: óptica, necessita ter uma boa visão e boa mira } \\
\text { Corrida: energia, dinâmica, ele atinge o máximo de energia no seu } \\
\text { corpo para correr e pegar velocidade } \\
\text { Arremesso de peso: força, usa a força para lançar o objeto a distância } \\
\text { Salto na caixa de areia: velocidade, necessita de muita velocidade para } \\
\text { saltar e ganhar com maior pulo". }\end{array}$ \\
\hline$\left(\mathrm{Q}_{0 \mathrm{G}}, 4,59\right)$ & $\begin{array}{l}\text { "Hipismo: cinemática, tem que se concentrar no obstáculo } \\
\text { Atletismo: velocidade, a física marca a velocidade que o atleta quer } \\
\text { chegar } \\
\text { Ginástica: força, tem que ter força e equilíbrio } \\
\text { Vôlei: equilíbrio, tem que ter equilíbrio } \\
\text { Basquete: distância, tem que saber a distância da cesta } \\
\text { Futebol: peso, tem que ter peso da bola". }\end{array}$ \\
\hline$\left(\mathrm{Q}_{0 \mathrm{G}}, 4,74\right)$ & $\begin{array}{l}\text { "Salto em distância: concentração e impulso, você precisa pesar e ter } \\
\text { impulso e velocidade para acontecer o salto } \\
\text { Ginástica: equilíbrio e impulso, você usa o equilíbrio para ter } \\
\text { concentração nos saltos } \\
\text { Levantamento de peso: força, você usa para realizar os exercícios com } \\
\text { resultado } \\
\text { Ciclismo: força e equilíbrio, você usa o equilíbrio para andar e força } \\
\text { também } \\
\text { Vôlei: altura, você tem que ter o tamanho certo para jogar } \\
\text { Handball: impulso e força, quando você corre você vai pegando } \\
\text { impulso e ai você arremessa". }\end{array}$ \\
\hline
\end{tabular}

Na questão 4, a maioria dos alunos não sabe explicar o esporte através dos conceitos físicos (tabela 4.3). Mesmo citando velocidade, tempo, distância e força, que são mais trabalhados durante o $1^{\circ}$ ano do ensino médio os alunos não tem clara sua 
aplicação nos esportes e nem mesmo do conceito em si, apenas tem o senso comum de dizer que se há movimento deve haver velocidade, distância, etc.

$\mathrm{Na}$ questão 5, a maioria das respostas corrobora com os dados obtidos na questão 4 (tabela 4.4), os alunos não conseguem aplicar os conceitos físicos no cotidiano, especificamente no tema esporte.

Tabela 4.4: Exemplos de respostas obtidas na questão 5 - escola G.

\begin{tabular}{|c|l|}
\hline Identificação* & \multicolumn{1}{c|}{ Respostas } \\
\hline$\left(\mathrm{Q}_{0 \mathrm{G}}, 5,13\right)$ & $\begin{array}{l}\text { "Academia de ginástica: box, alongamento, levantamento de peso, } \\
\text { karate, judô. Na minha opinião em todos está evidente as aplicações } \\
\text { da física". }\end{array}$ \\
\hline$\left(\mathrm{Q}_{0 \mathrm{G}}, 5,16\right)$ & $\begin{array}{l}\text { "Box, karate, levantamento de peso, no levantamento de peso, onde o } \\
\text { atleta aplica a lei da força e da velocidade”. }\end{array}$ \\
\hline$\left(\mathrm{Q}_{0 \mathrm{G}}, 5,38\right)$ & $\begin{array}{l}\text { "Levantamento de peso, corrida, ginástica. A ginástica envolve } \\
\text { gravidade, a corrida velocidade, aceleração, distância e o } \\
\text { levantamento de peso, força, mas todos os esportes envolvem física". }\end{array}$ \\
\hline$\left(\mathrm{Q}_{0 \mathrm{G}}, 5,46\right)$ & $\begin{array}{l}\text { "Levantamento de peso: o levantamento de peso é evidente porque } \\
\text { temos que usar nossa força para levantá-lo". }\end{array}$ \\
\hline$\left(\mathrm{Q}_{0 \mathrm{G}}, 5,61\right)$ & $\begin{array}{l}\text { "Alguns esportes como judô levantamento de peso, entre outros o } \\
\text { levantamento de peso porque tem que ter equilíbrio". }\end{array}$ \\
\hline$\left(\mathrm{Q}_{0 \mathrm{G}}, 5,72\right)$ & $\begin{array}{l}\text { "Qualquer tipo de ginástica, levantamento de peso, corrida, } \\
\text { levantamento de peso, pois envolve dinâmica, você precisa de } \\
\text { impulso, força e não fica parado". }\end{array}$ \\
\hline$\left(\mathrm{Q}_{0 \mathrm{G}}, 5,79\right)$ & $\begin{array}{l}\text { "Levantamento de peso, ginástica aeróbica: lei da gravidade, } \\
\text { acústica". }\end{array}$ \\
\hline
\end{tabular}

*(questionário, questão, aluno)

Na questão 6, a maioria dos alunos opinou a favor da união da física com os esportes, de maneira a facilitar a aprendizagem, embora não tenham entendimento dos conteúdos envolvidos e da sua aplicação.

Tabela 4.5: Exemplos de respostas obtidas na questão 6 - escola G.

\begin{tabular}{|c|l|}
\hline Identificação* & \multicolumn{1}{c|}{ Respostas } \\
\hline$\left(\mathrm{Q}_{0 \mathrm{G}}, 6,08\right)$ & $\begin{array}{l}\text { "Bom de forma que aprendêssemos, a saber, fazer cálculos sobre } \\
\text { velocidade, como conseguem fazer piruetas e outros movimentos. Daí } \\
\text { começa a surgir a curiosidade sobre tudo isso". }\end{array}$ \\
\hline$\left(\mathrm{Q}_{0 \mathrm{G}}, 6,15\right)$ & $\begin{array}{l}\text { "Bem me ajudará no aspecto de ver e também perceber, a força, a } \\
\text { velocidade, a distância, o tempo, etc., pois cada esporte tem alguma } \\
\text { dessas coisas relacionadas é usado nele, e também é utilizado na } \\
\text { física". }\end{array}$ \\
\hline
\end{tabular}




\begin{tabular}{|c|l|}
\hline$\left(\mathrm{Q}_{0 \mathrm{G}}, 6,26\right)$ & $\begin{array}{l}\text { "Sim descobrindo exatamente os conceitos da física no dia-a-dia, e } \\
\text { nos esportes comuns". }\end{array}$ \\
\hline$\left(\mathrm{Q}_{0 \mathrm{G}}, 6,42\right)$ & $\begin{array}{l}\text { "Só se for para falar de gravidade. A física influencia muito no } \\
\text { esporte, nós que não percebemos". }\end{array}$ \\
\hline$\left(\mathrm{Q}_{0 \mathrm{G}}, 6,45\right)$ & $\begin{array}{l}\text { "Sim acho que se fosse ensinado física com esporte, ou em qualquer } \\
\text { outra coisa que envolva prática, em que os alunos participem mais do } \\
\text { que apenas copiar lição, acho que despertaria mais o interesse deles e } \\
\text { seria fácil de aprender pois teríamos exemplo e contato. Não sei se é } \\
\text { possível, mas seria muito produtivo". }\end{array}$ \\
\hline$\left(\mathrm{Q}_{0 \mathrm{G}}, 6,79\right)$ & $\begin{array}{l}\text { "Sim auxiliaria, pois seria uma maneira mais interessante e mais fácil } \\
\text { de aprender". }\end{array}$ \\
\hline
\end{tabular}

*(questionário, questão, aluno)

$\mathrm{Na}$ questão 7 observamos que os alunos estabelecem conexões estranhas da física com o cotidiano, não tem claro a definição dos conceitos simples mais utilizados em mecânica.

Tabela 4.6: Exemplos de respostas obtidas na questão 7 - escola pública G.

\begin{tabular}{|c|c|}
\hline Identificaçãa* & Respostas \\
\hline$\left(\mathrm{Q}_{0 \mathrm{G}}, 7,04\right)$ & $\begin{array}{l}\text { "Na escola como ir passear, ter um exercício a ser realizado, medir } \\
\text { altura, a cintura, há também de ver que o peso, comer alguma, } \\
\text { observar as coisas ao redor, ou simplesmente assistir a um programa } \\
\text { relacionado a física". }\end{array}$ \\
\hline$\left(\mathrm{Q}_{0 \mathrm{G}}, 7,13\right)$ & $\begin{array}{l}\text { "Sou um jogador de vôlei e aplico muita força para sacar a bola e no } \\
\text { bloqueio aplicamos a teoria que tudo vai com velocidade e ocorre o } \\
\text { atrito com a mesma intensidade". }\end{array}$ \\
\hline$\left(\mathrm{Q}_{0 \mathrm{G}}, 7,16\right)$ & $\begin{array}{l}\text { "Na aula de educação física, no jogo de futebol, onde aplicamos a lei } \\
\text { da velocidade, a lei de que toda ação gera uma reação com o chute e a } \\
\text { defesa do goleiro, com o tempo que esse mesmo goleiro tem que } \\
\text { calcular para pegar a bola em tempo correto evitando assim o gol, ou } \\
\text { no basquete, onde calcularmos sem perceber a distância da cesta e a } \\
\text { velocidade que temos que jogar a bola para que ela caia dentro da } \\
\text { mesma marcando pontos". }\end{array}$ \\
\hline$\left(\mathrm{Q}_{0 \mathrm{G}}, 7,74\right)$ & $\begin{array}{l}\text { "Quando vou caminhar eu perco calorias e quando corro também, pois } \\
\text { os batimentos aumentam, a ginástica também porque você pega } \\
\text { impulso, usa a força e envolve um pouco de tudo". }\end{array}$ \\
\hline$\left(\mathrm{Q}_{0 \mathrm{G}}, 7,67\right)$ & $\begin{array}{l}\text { "No futebol quando chuto a bola, nas competições de ginástica } \\
\text { artística percebemos que deve ter equilíbrio e força, assim na maioria } \\
\text { dos esportes a física está presente e podemos aprender com maior } \\
\text { facilidade". }\end{array}$ \\
\hline
\end{tabular}




\begin{tabular}{|c|l|}
\hline & $\begin{array}{l}\text { "Quando acordamos e nos espreguiçamos, nosso corpo estava } \\
\text { contraído e ao esticá-lo ele relaxa ao tomarmos banho vemos o } \\
\text { contraste entre a temperatura do corpo com a água, dependendo do } \\
\text { tempo, se está calor queremos água mais fria, e se está frio, a água } \\
\text { mais quente, ao varrermos a casa, a força que empregamos na } \\
\text { vassoura, ao andarmos, corrermos, ao praticarmos esporte”. }\end{array}$ \\
\hline "Quando estou caminhando atrasada para o trabalho e tenho que \\
aumentar a velocidade porque a distância parece não diminuir, ao \\
contrário do tempo e ao mesmo tempo minha visão conseguir \\
enxergar meu chefe voando (como se não houvesse gravidade) em \\
direção ao meu pescoço".
\end{tabular}

*(questionário, questão, aluno)

Os alunos da escola particular apresentam respostas similares ao da escola pública, apenas citam mais conteúdos, mas não conseguem desenvolver com certeza a aplicação dos conceitos físicos na prática esportiva.

Tabela 4.7: Exemplos de respostas obtidas na escola particular P

\begin{tabular}{|c|c|}
\hline Identificação* & Respostas \\
\hline$\left(\mathrm{Q}_{0 \mathrm{P}}, 1,86\right)$ & $\begin{array}{l}\text { "A importância do esporte em nossa vida é muito grande, pois só } \\
\text { através dele podemos manter boa qualidade de vida, com saúde, } \\
\text { alegria e principalmente disposição em superar desafios". }\end{array}$ \\
\hline$\left(\mathrm{Q}_{0 \mathrm{P}}, 1,84\right)$ & $\begin{array}{l}\text { "O esporte para saúde física e mental. Um físico bom aumenta a auto- } \\
\text { estima de qualquer pessoa, consequentemente, aumenta também o } \\
\text { bem-estar psicológico". }\end{array}$ \\
\hline$\left(\mathrm{Q}_{0 \mathrm{P}}, 2,88\right)$ & $\begin{array}{l}\text { "Eu pratico musculação, para eu desempenhá-la com sucesso preciso } \\
\text { estar bem descansado, bem alimentado e com um bom preparo físico } \\
\text { para aguentar fazer bem e certo os exercícios". }\end{array}$ \\
\hline$\left(\mathrm{Q}_{0 \mathrm{P}}, 4,81\right)$ & $\begin{array}{l}\text { "Formula 1: mecânica, funcionamento dos carros } \\
\text { Arremesso de peso: força de intensidade, aplicação da força } \\
\text { Corrida: velocidade, aplicação da velocidade, corrida". }\end{array}$ \\
\hline$\left(\mathrm{Q}_{0 \mathrm{P}}, 4,90\right)$ & $\begin{array}{l}\text { "Hafiting: hidrostática, o projeto do trajeto } \\
\text { Fórmula 1: cinemática, planejamento na pista } \\
\text { Bang jump: pêndulo, para não acontecer acidentes". }\end{array}$ \\
\hline$\left(\mathrm{Q}_{0 \mathrm{P}}, 5,87\right)$ & "Musculação, os aparelhos que estimulam o corpo a força". \\
\hline$\left(\mathrm{Q}_{0 \mathrm{P}}, 6,82\right)$ & $\begin{array}{l}\text { "Pois a parte teórica não é suficiente, para sabermos onde aplicar por } \\
\text { exemplo no esporte". }\end{array}$ \\
\hline$\left(\mathrm{Q}_{0 \mathrm{P}}, 7,86\right)$ & $\begin{array}{l}\text { "no cálculo das distâncias percorridas a pé ou de carro, na academia, } \\
\text { nas questões de eletricidade e termodinâmica". }\end{array}$ \\
\hline
\end{tabular}




\begin{tabular}{|l|l|}
\hline$\left(\mathrm{Q}_{0 \mathrm{P}}, 7,90\right)$ & $\begin{array}{l}\text { "andando de moto o efeito centrífugo que age sobre a moto, a } \\
\text { cinemática que está presente em trajetos feitos de carro, na academia } \\
\text { os aparelhos que ajudam a desenvolver o princípio da tração. Em } \\
\text { todas nossas atividades diárias está presente os conceito físicos } \\
\text { aprendidos em sala de aula”. }\end{array}$ \\
\hline
\end{tabular}

*(questionário, questão, aluno)

São várias as evidências que nos mostram que os alunos não conseguem unir os conteúdos de física vistos na escola com o cotidiano. A falta de conhecimento para aplicar os conceitos no cotidiano resulta muitas vezes em desmotivação.

\section{Questionário $Q_{1}$}

Em uma análise geral podemos observar com este questionário que os alunos por si, não conseguem estabelecer conexões do conteúdo aprendido na escola com as ações no cotidiano, mesmo porque muitos conceitos não são aprendidos de forma correta e ao tentar aplicar no seu cotidiano causam distorções, equívocos, que são semelhantes a qualquer indivíduo que nunca viu física na vida. Isso nos faz pensar: onde está a diferença em quem passou pelo ensino médio em relação a uma pessoa que tem pouco grau de estudo? Nas respostas dos alunos, vemos que os mesmos sabem que a física está diretamente relacionada aos esportes, mas não tem potencial argumentativo, talvez porque os conceitos abrangidos durante as aulas, foram superficiais, apenas para resolver os exercícios e esquecidos devido à velha frase: "Para que vai servir isso na minha vida?".

Tabela 4.8: Exemplos de respostas obtidas no questionário $\mathrm{Q}_{1}$.

\begin{tabular}{|c|l|}
\hline Identificação* & \multicolumn{1}{c|}{ Respostas } \\
\hline$\left(\mathrm{Q}_{1}, 1,19\right)$ & $\begin{array}{l}\text { "Movimento Uniformemente variado, porque ele aborda quase todas } \\
\text { as fórmulas que aprendi”. }\end{array}$ \\
\hline$\left(\mathrm{Q}_{1}, 2,15\right)$ & $\begin{array}{l}\text { "Força: quando estou parada, para me mover, para escrever tenho } \\
\text { ação de uma força. Cinemática: venho de ônibus até a escola, sei qual } \\
\text { é o seu trajeto, mais não me importa com o tempo, a velocidade". }\end{array}$ \\
\hline$\left(\mathrm{Q}_{1}, 3,18\right)$ & $\begin{array}{l}\text { "Quase todos, porque eu tinha preguiça de estudar, mas se me dessem } \\
\text { a fórmula eu resolvia, mas para achar a fórmula era muito difícil". }\end{array}$ \\
\hline$\left(\mathrm{Q}_{1}, 4,5\right)$ & $\begin{array}{l}\text { "Uma pessoa de massa 70 kg prática beisebol, ao arremessar a bolas a } \\
\text { pessoa com uma velocidade de 30km/h e esbarra em outro jogador, } \\
\text { com a força que exerceu sobre ele, ele é arremessado para trás, pois } \\
\text { toda ação tem uma reação". }\end{array}$ \\
\hline
\end{tabular}




\begin{tabular}{|c|l|}
\hline$\left(\mathrm{Q}_{1}, 4,10\right)$ & $\begin{array}{l}\text { "A física é muito presente nos esportes que praticamos. Está no } \\
\text { contato entre pessoas e objetos, por exemplo, quando a gente joga } \\
\text { bola, o contato entre a bola e as pessoas faz com a bola é chamado } \\
\text { força ou explicando mais detalhadamente quando a superfície dos } \\
\text { corpos se tocam". }\end{array}$ \\
\hline$\left(\mathrm{Q}_{1}, 5,23\right)$ & "Futebol, natação, vôlei, judô, basquete e salto em vara". \\
\hline$\left(\mathrm{Q}_{1}, 6,22\right)$ & $\begin{array}{l}\text { "A velocidade tem muito a ver com a física na parte de velocidade } \\
\text { pois é com essas formulas físicas que conseguimos chegar a uma } \\
\text { velocidade certa de um atleta". }\end{array}$ \\
\hline$\left(\mathrm{Q}_{1}, 7,11\right)$ & "Movimentação do corpo e força". \\
\hline$\left(\mathrm{Q}_{1}, 8,27\right)$ & $\begin{array}{l}\text { "Sim pois no futebol, pois sempre iremos usar a aceleração força entre } \\
\text { outras coisas no futebol que estão relacionados a física”. }\end{array}$ \\
\hline
\end{tabular}

*(questionário, questão, aluno)

\section{Questionário $Q_{2}$}

O questionário $\mathrm{Q}_{2}$ nos auxiliou a verificar se já faz parte do perfil conceitual dos estudantes a relação dos esportes com a física.

Para obtermos mais dados, a questão 1 propicia discussões sobre algumas relações da saúde com o esporte (visto que já aplicamos esta questão no Questionário $\mathrm{Q}_{0}$ ). Nossa insistência nessa relação é devido ao fato de pretendermos destinar uma atividade para discutir o conceito de saúde relacionado ao esporte, fundamentalmente na relação entre a prática esportiva e os benefícios e malefícios que podem acarretar à saúde.

Para facilitar a análise da questão 2, construímos alguns gráficos que nos auxiliam a visualizar as sequências das disciplinas por grau de importância:

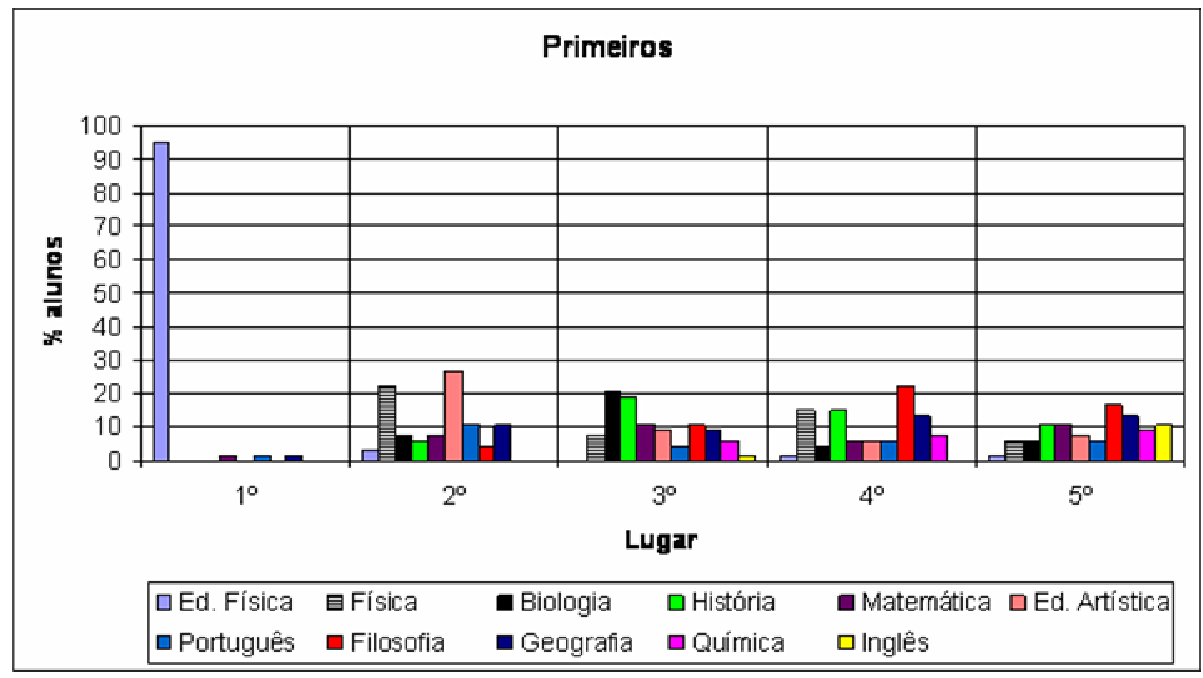

Figura 4.2: Posições das disciplinas $-1^{\circ}$ ano. 
O gráfico da figura 4.2 foi construído com os dados do $1^{\circ}$ ano do ensino médio. Nas salas o questionário foi aplicado por dois professores: de educação artística e de português. Observe que os alunos relacionam esporte primeiramente com a educação física, e em segundo lugar com a educação artística, no qual podemos atribuir este fato pela influência dos professores que estavam na sala (tabela 3.7), mas em terceiro e quarto lugar aparece à física e a biologia. A partir disso podemos aproveitar estas conexões prévias - os perfis conceituais pré-estabelecidos - para introduzirmos os conceitos que permeiam a física e os esportes.

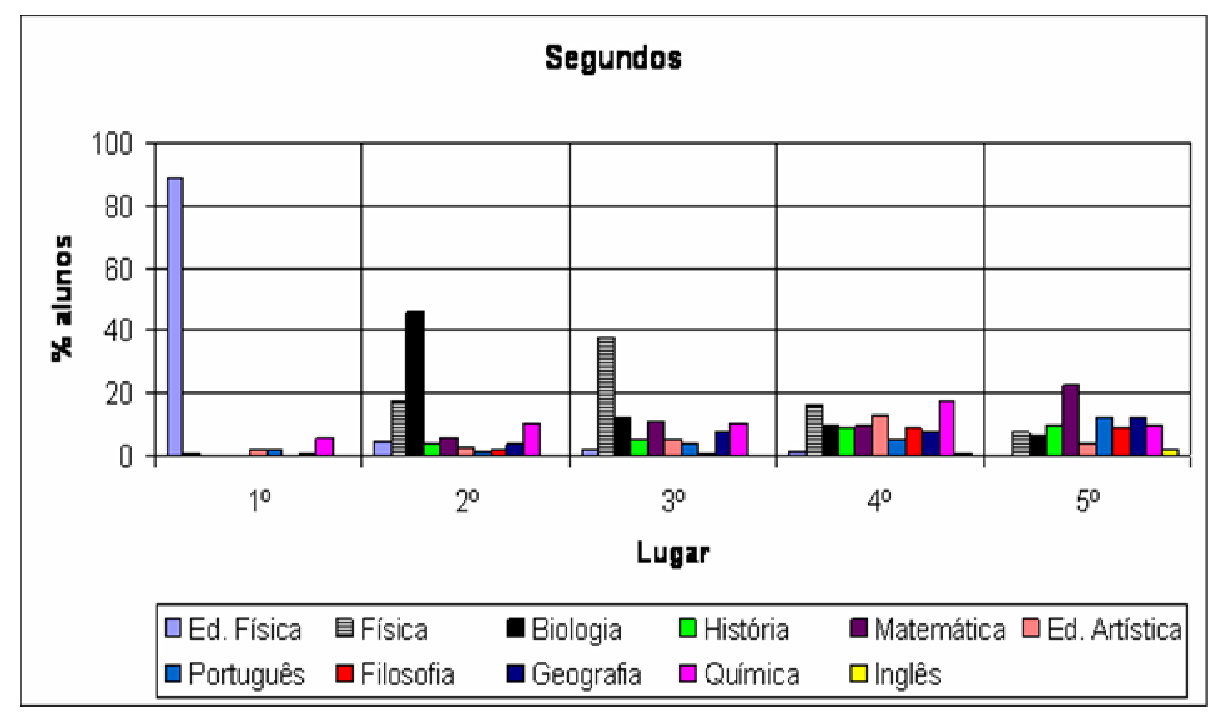

Figura 4.3: Posições das disciplinas $-2^{\circ}$ ano.

$\mathrm{Na}$ figura 4.3, percebemos que os segundos anos estabelecem por prioridade a educação física, e em segundo e terceiro lugar, a biologia e a física. Nas cinco salas de segundos anos tivemos professores de educação artística, português, matemática, química, filosofia, física e inglês, que, como é mostrado no gráfico não influenciaram na obtenção dos dados. 


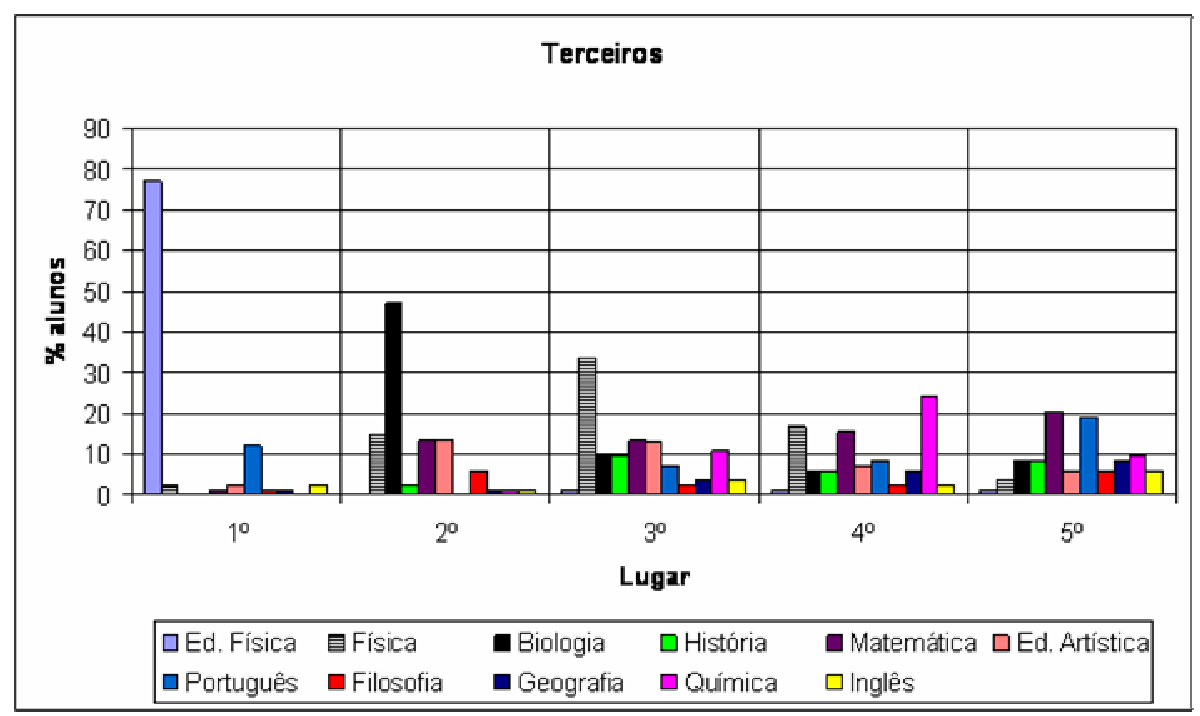

Figura 4.4: Posições das disciplinas $-3^{\circ}$ ano.

$\mathrm{Na}$ figura 4.4 temos os dados dos terceiros anos, no qual vemos similaridade com aqueles representados na figura 4.3. Os professores que aplicaram o questionário eram de matemática, história e inglês, no qual pelo gráfico podemos ver que não influenciaram nos dados.

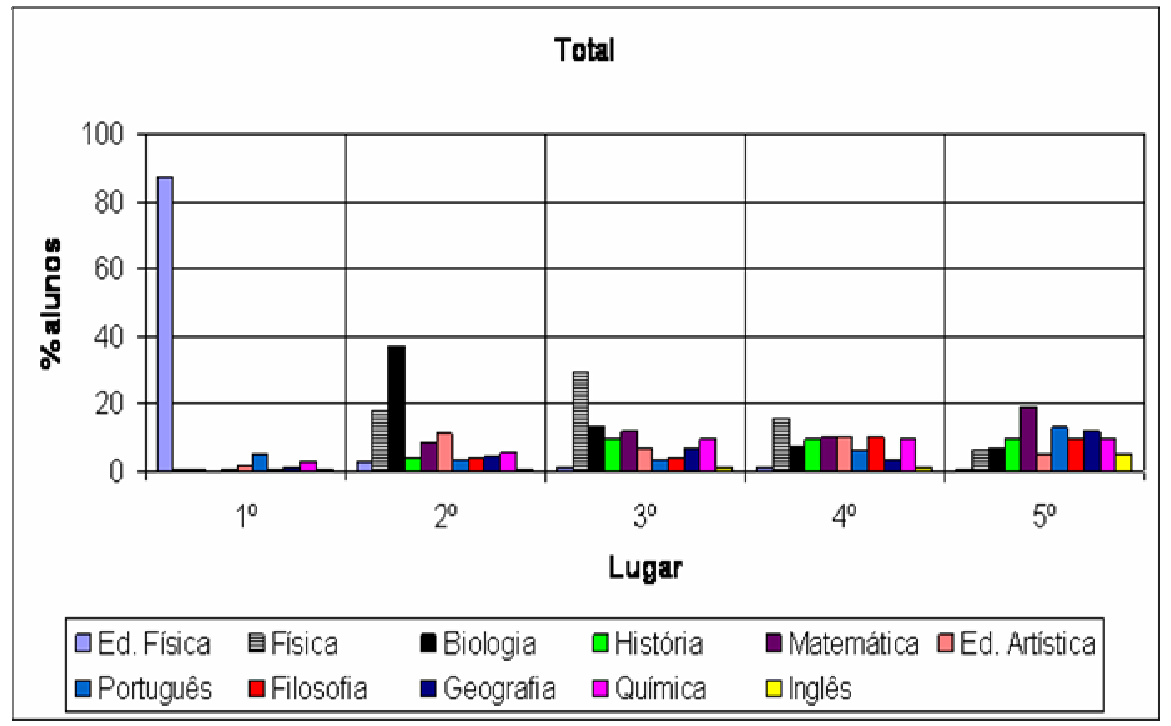

Figura 4.5: Posições das disciplinas.

Na figura 4.5 percebemos que temos a educação física em primeiro lugar, a biologia em segundo lugar e a física em terceiro lugar. Este resultado é animador, pois nos dão fortes indícios de que a dimensão epistemológica ligada à física está incluída no perfil conceitual do aluno, o que facilita na introdução dos conceitos físicos nos esportes. 
Após a análise dos questionários prévios, pudemos nos nortear para planejar as intervenções (atividades) para o ensino e aprendizagem dos conceitos físicos de mecânica. Nosso interesse é introduzir conceitos de biomecânica tendo os esportes como elemento motivador, permitindo que o aluno visualize certas aplicações da física no seu cotidiano. Assim, pretendemos que sejam ampliadas as percepções de como a física pode, por meio da biomecânica ampliar a consciência dos benefícios ou malefícios que o esporte pode trazer à saúde do praticante, seja ao adquirir boa forma física, seja pela possibilidade de lesões devido a prática esportiva inadequada.

A principal ideia é a de aproveitar as experiências que os alunos tem nos seus momentos de lazer, de exercícios físicos ou na realização de esportes e buscar estabelecer relações com a física. Queremos que os alunos desfrutem dos conhecimentos da física, não apenas momentaneamente, mas que os acompanhe durante toda sua vida e que faça a diferença em suas atitudes frente ao seu cotidiano.

\subsection{Análise da atividade piloto}

Não fizemos uma escolha criteriosa das turmas em que iríamos aplicar as atividades. Simplesmente as aplicamos em todas as turmas de primeiro ano em que a professora-pesquisadora lecionava em 2009. Esse procedimento de certa forma, possibilitou as correções feitas nas atividades durante sua aplicação.

A professora que atuou nas salas em questão para aplicação das atividades piloto é a própria pesquisadora. A superposição de papéis, a nosso ver, não acarretou em deformação da amostragem.

A intenção inicial era manter grupos de 4 alunos, mas devido à má distribuição quanto à participação nas resoluções das questões, passamos para formação de duplas, de forma a garantir maior participação de todos os alunos nas atividades.

Durante a aplicação das atividades a professora não interferiu nas respostas dos alunos, apenas encaminhou o raciocínio quando os mesmos a procuravam para esclarecer dúvidas, que iam desde a não compreensão das perguntas e dos conceitos envolvidos nas atividades até dúvidas sobre as questões do caderno de física do aluno do $4^{\circ}$ bimestre. À medida que as atividades estavam sendo desenvolvidas a professora corrigia as lições de casa do caderno de física vol.4 dos alunos (Anexo A2.2).

Após a aplicação das atividades em cada turma, era notável nas atividades, além da presença de questões ambíguas e de palavras pouco utilizadas pelos alunos, a má 
disposição dos textos para o entendimento do aluno (muitos deixavam de ler os textos), o grande número de questões desnecessárias, falta de algumas questões cabíveis ao desenvolvimento do tema, da ausência de experimentos e de vídeos que auxiliassem no entendimento do aluno. Em função disso, tivemos de reorganizar a duração de cada atividade, o número de atividades, o número ideal de questões para cada atividade, etc.

Na escola G, iniciamos a aplicação das atividades piloto duas semanas depois. Isso se mostrou uma medida excelente, pois foi possível, antemão, prever as dúvidas que iam aparecer e, assim, pudemos apresentar as questões já com algumas correções. $\mathrm{Na}$ aplicação da atividade 4, antes de iniciá-la, resolvemos desenvolver uma atividade experimental no pátio, para facilitar o desenvolvimento da atividade, já que na escola M, esta atividade se estendeu por muitas aulas devido a falta de entendimento na leitura das questões, embora tivesse muitas questões.

Após a análise dos dados obtidos nas atividades piloto, fizemos inúmeras correções, desde a exclusão de questões até a introdução de outras, chegando a um conjunto de nove atividades em definitivo (tabela 4.9).

Tabela 4.9: Versão final do conjunto de atividades da intervenção.

\begin{tabular}{|c|c|c|c|c|}
\hline Ciclo & $\begin{array}{c}\text { Fases do } \\
\text { ciclo }\end{array}$ & $\begin{array}{l}\text { Sub- } \\
\text { Ciclo }\end{array}$ & $\begin{array}{l}\text { Fases do } \\
\text { Sub-ciclo }\end{array}$ & Atividade \\
\hline \multirow{9}{*}{ 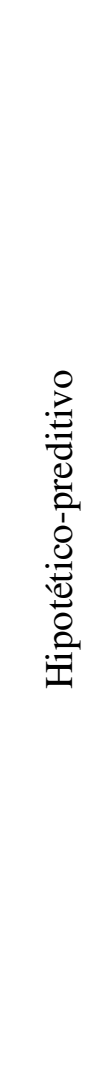 } & \multirow{3}{*}{ 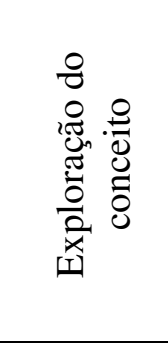 } & \multirow{3}{*}{ 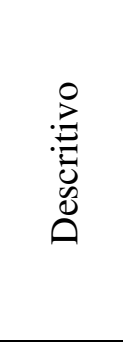 } & $\begin{array}{l}\text { Exploração } \\
\text { do conceito }\end{array}$ & 1 - Você pode ser um técnico? \\
\hline & & & $\begin{array}{l}\text { Introdução } \\
\text { do Conceito }\end{array}$ & 2 - Saúde e esporte \\
\hline & & & $\begin{array}{l}\text { Aplicação do } \\
\text { conceito }\end{array}$ & $\begin{array}{l}3 \text { - Interagindo com os novos } \\
\text { campos do conhecimento }\end{array}$ \\
\hline & \multirow{3}{*}{ 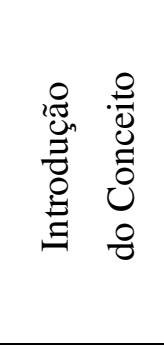 } & \multirow{3}{*}{ 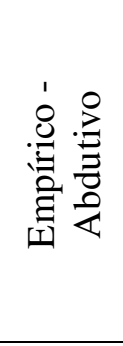 } & $\begin{array}{l}\text { Exploração } \\
\text { do conceito }\end{array}$ & $\begin{array}{l}4 \text { - O movimento (velocidade média, } \\
\text { aceleração) }\end{array}$ \\
\hline & & & $\begin{array}{l}\text { Introdução } \\
\text { do Conceito }\end{array}$ & $5-\mathrm{O}$ peso ideal (massa e peso) \\
\hline & & & $\begin{array}{l}\text { Aplicação do } \\
\text { conceito }\end{array}$ & 6 - O papel da força no esporte \\
\hline & \multirow{3}{*}{ 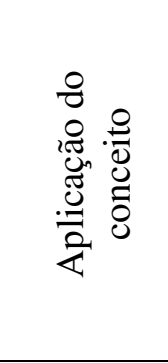 } & \multirow{3}{*}{ 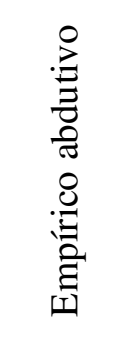 } & $\begin{array}{l}\text { Exploração } \\
\text { do conceito }\end{array}$ & 7 - As três leis de Newton \\
\hline & & & $\begin{array}{l}\text { Introdução } \\
\text { do Conceito }\end{array}$ & $\begin{array}{l}8 \text { - Do movimento ao equilíbrio: } \\
\text { alavanca no corpo humano }\end{array}$ \\
\hline & & & $\begin{array}{l}\text { Aplicação do } \\
\text { conceito }\end{array}$ & 9 - Lesões e esportes \\
\hline
\end{tabular}


Percebemos que no geral o conjunto de atividades se encaixa no ciclo hipotéticopreditivo, o que não torna necessário a avaliação final, pois durante as atividades já percebemos os estudantes chegando a suas próprias conclusões, que são condizentes com os objetivos propostos inicialmente. Encontramos indícios no diário de bordo (anexo A2.2) da professora que confirmam o novo ciclo de aprendizagem em todas as atividades. A seguir mostraremos alguns trechos de diálogos (citados no diário de bordo) de algumas atividades:

- Atividade 1: os alunos criaram hipóteses ao estabelecer os conhecimentos que um técnico deve possuir, observe os trechos do diálogo 1 e 2 .

\section{Diálogo 1}

A: Sei lá, mas acho que deve ter faculdade de educação física, mas que matérias?

A1: Acho que de jogos

A:Ah deve ter coisas do corpo humano também

A1: Mas será que é só isso?

A: Talvez biologia...

\section{Diálogo 2}

A2: Ah um técnico deve ser sido um jogador antes, e só conhecer o esporte e dar dicas de jogadas e pronto.

A3: Será que ele faz algum curso?

Nos diálogos 1 e 2 os estudantes, antes de responder a questão 10 da atividade piloto 1, tentam chegar a um consenso, levantando hipóteses sobre as disciplinas importantes que um técnico deve ter cursado para coordenar um time ou um atleta.

- Atividade 2: os estudantes suscitam discussões sobre saúde e qualidade de vida e suas relações com beleza, prática de esportes, etc, observe o diálogo 3 e 4 .

\section{Diálogo 3}

A4: Corpo magro acho que não é saúde, veja, eu só como porcaria, mas sou seca, será que tenho boa saúde? Não como bem.

A5: Mas você é magra

A4: Mas não faço exercícios, então será que tenho saúde? 


\section{A5: Acho que sim você não está doente}

Diálogo 4

A6: Para ter qualidade de vida, preciso ser rico

A7: Ah, mas ser rico, acho que não é só isso!

A6: $O$ rico se alimenta bem, vai ao médico...

No diálogo 3 e 4, os estudantes tentam construir juntos os parâmetros que justifiquem uma pessoa saudável, para chegar em um consenso na elaboração das respostas às questões 1 a 6 da atividade piloto 2 .

- Atividade 4: os estudantes levantaram hipóteses sobre velocidades:

\section{Diálogo 5}

A8: Ah, o padre sai ganhando, porque ele é gordo.

A9: Mas e a velocidade dele?

No diálogo 5 os estudantes estão levantando hipóteses para responder as questões 14 a 24 da atividade piloto 4 , no qual o objetivo é analisar as quantidades de movimento em uma colisão.

Como a atividade piloto foi aplicada em sala de aula em grupos, não pudemos analisar detalhadamente a complexificação do conhecimento de esporte individual ou em grupo, pois como os estudantes mudavam de grupos a cada 3 atividades (isso porque a professora insistia em manter o mesmo grupo a cada 3 atividades seguidas) para completar o ciclo de aprendizagem de Lawson, não conseguimos comparar respostas individuais ou em grupo e citar as respostas por grupo ou por aluno. Aliás, pelo diário de bordo da professora, verificamos que os estudantes não gostam de manter o mesmo grupo, pois no decorrer das atividades, fazem muitas reclamações um dos outros por várias razões: porque um deles conversa demais, ou porque só um escreve, ou porque um não faz nada, etc. Mesmo assim, escolhemos algumas respostas de grupos aleatórios (tabela 4.10), para analisar (mesmo sendo um piloto) se obtivemos indícios que nos mostram que os estudantes utilizam a física nos esportes, relacionando a prevenção de lesões. 
Tabela 4.10: Respostas de algumas questões embutidas nas atividades piloto.

\begin{tabular}{|c|c|}
\hline Atividade & Questões \\
\hline 1 & $\begin{array}{l}\text { Q.1 - Qual é a função de um técnico de qualquer modalidade esportiva? } \\
\text { Q.4 - São comuns algumas frases por parte de um torcedor, como: "bata } \\
\text { mais fraco", “jogue com vontade", "ataque”, etc. Será que estes tipos de } \\
\text { comentários auxiliam o atleta para correção de seus movimentos? Por quê? } \\
\text { Q.6 - Depois de responder estas questões: } \\
\text { a) Seu conhecimento atual é suficiente para que você faça bons } \\
\text { apontamentos (comentários) para auxiliar o atleta? Por quê? } \\
\text { b) Que conhecimentos estão te faltando? }\end{array}$ \\
\hline 2 & $\begin{array}{l}\text { Q.2 - Complete a frase: Para uma pessoa para ser considerada saudável são } \\
\text { necessários... } \\
\text { Q.8 - Qual é a relação entre saúde e esporte? Comente. } \\
\text { Q.9 - Qualquer pessoa no momento em que quiser, pode praticar esporte? } \\
\text { Por quê? } \\
\text { Q.10 - A prática esportiva sempre resulta em saúde? Por quê? }\end{array}$ \\
\hline 10 & $\begin{array}{l}\text { Q.1 - Praticar alguma modalidade esportiva ou fazer exercício físico é } \\
\text { sinônimo de saúde? Por quê? } \\
\text { Q.2 - Que cuidados devemos ter ao iniciar uma atividade física? } \\
\text { Q.5 - Agora você pode dizer qual é a maior responsabilidade de um } \\
\text { treinador? }\end{array}$ \\
\hline & Questão - Exemplos de respostas das turmas* \\
\hline $1-1^{\circ} \mathrm{D}_{1}$ & $\begin{array}{l}1 \text { - "Organizar, orientar e treinar seus atletas". } \\
4 \text { - "Sim, pois os jogadores tentam melhorar o que estão errando". } \\
6 \mathrm{a} \text { - "Não, pois falta conhecimento sobre tática". } \\
6 \mathrm{~b} \text { - "Falta aprender a montar um esquema tático". }\end{array}$ \\
\hline $2-1^{\circ} \mathrm{D}_{1}$ & $\begin{array}{l}2 \text { - "Alimentação balanceada, praticar exercícios físicos". } \\
8 \text { - "Todas pessoas que praticam esporte tem saúde". } \\
9 \text { - "Não, pois se a pessoa tiver uma doença grave". } \\
10 \text { - "Sim, porque faz com que o corpo entre em forma". }\end{array}$ \\
\hline $10-1^{\circ} \mathrm{D}_{1}$ & $\begin{array}{l}1 \text { - "Contribui para que a saúde seja melhor". } \\
2 \text { - "Não podemos passar do nosso limite". } \\
5 \text { - "Ele tem que saber qual o desempenho de cada jogador e qual } \\
\text { movimento é mais eficiente ou não". }\end{array}$ \\
\hline $1-1^{\circ} \mathrm{C}_{1}$ & $\begin{array}{l}1 \text { - "É comandar os atletas". } \\
4 \text { - "Sim porque mexe com o psicológico". } \\
6 \text { - "Sim porque não tem segredo para ajudar". }\end{array}$ \\
\hline
\end{tabular}




\begin{tabular}{|c|c|}
\hline & $6 \mathrm{~b}$ - "nenhum". \\
\hline $2-1^{\circ} \mathrm{C}_{1}$ & $\begin{array}{l}2 \text { - "Boa alimentação fazer exercícios físicos e ter hábitos saudáveis". } \\
8 \text { - "Praticar esporte é essencial para saúde". } \\
9 \text { - "Não porque as vezes a pessoa tem algum problema e não sabe". } \\
10 \text { - "Sim, porque ela faz bem para nós'. }\end{array}$ \\
\hline $10-1^{\circ} \mathrm{C}_{1}$ & $\begin{array}{l}\text { 1- "Sim porque quase } 100 \% \text { que praticar exercício tem uma ótima saúde". } \\
2 \text { - "Temos que ter cuidado para realizarmos o exercício, para não sofrer } \\
\text { lesões e não causar danos a saúde". } \\
5 \text { - "O treinador deve ensinar seus atletas a movimentar de maneira } \\
\text { correta". }\end{array}$ \\
\hline $1-1^{\circ} \mathrm{B}_{1}$ & $\begin{array}{l}1 \text { - "Treinar a equipe". } \\
4 \text { - "Pode ajudar ou deixar o atleta nervoso". } \\
6 \mathrm{a} \text { - "Sim tenho noção das estratégias". } \\
6 \mathrm{~b} \text { - "Saber jogar". }\end{array}$ \\
\hline $2-1^{\circ} \mathrm{B}_{1}$ & $\begin{array}{l}2 \text { - "Alimentação balanceada, praticar esporte". } \\
8 \text { - "Você pratica esporte tem saúde". } \\
9 \text { - "Não porque a pessoa pode estar cansada ou doente". } \\
10 \text { - "Sim, porque ela faz bem para nós". }\end{array}$ \\
\hline $10-1^{\circ} \mathrm{B}_{1}$ & $\begin{array}{l}1 \text { - "Sim para uma saúde melhor". } \\
2 \text { - "Temos que ter um preparo e fazer alguns exames antes para não } \\
\text { provocar lesões e problemas graves de saúde". } \\
5 \text { - "Deixar o atleta na melhor forma diminuindo contusões". }\end{array}$ \\
\hline
\end{tabular}

* não é possível identificar os alunos, pois fizeram as atividades com grupos não-fixos.

Os resultados favoráveis (expostos na tabela 4.10) obtidos pelas atividades piloto, nos estimularam a continuar seguindo a pesquisa pelo mesmo caminho, com os mesmos objetivos estabelecidos a priori para intervenção, pois os estudantes demonstraram apropriação do conhecimento interdisciplinar entre física, saúde, biomecânica, educação física e esporte, mesmo que em graus de complexidade diferentes.

No geral as respostas às questões inseridas no meio das atividades nas duas escolas foram similares, e nos levaram a realizar inúmeras correções. Como dissemos anteriormente, não conseguimos separar as respostas de cada estudante ou de cada grupo e comparar suas respostas no início, durante e no final das atividades, pois ao conjunto de três atividades os grupos são modificados, conforme o desejo (afinidades) dos estudantes. Apenas estabelecemos que os grupos deveriam ser mantidos por três 
atividades sequenciais, para obedecer o ciclo de Lawson nas fases de: exploração, introdução do conceito e aplicação do conceito que são obrigatórias.

Abaixo colocamos algumas das modificações realizadas nas atividades por questão a partir do posicionamento dos estudantes durante as atividades (retirado do diário de bordo da professora A2.2), como por exemplo, quando os estudantes tinham as seguintes reclamações: não entendi a questão, os textos são difíceis, já respondi isso um monte de vezes, a questão é antes do texto, etc. O leitor pode recorrer ao anexo A3.1 para verificar as todas as modificações realizadas, em detalhes, da atividade piloto para a intervenção.

\section{- Atividade Piloto 1}

Questão 1: Qual é a função de um técnico de qualquer modalidade esportiva?

Esta questão foi modificada, pois muitos estudantes se referiam apenas a uma única função do técnico, como por exemplo: "Treinar os atletas", "Comandar o time”, "Preparar o atleta", "Fazer o time vencer".

Com relação a Questão n5 : Siga então os seguintes passos:

a) Escolha uma modalidade esportiva

b) Determine os objetivos desta modalidade

c) Cite algumas características especiais desta modalidade

d) Enumere algumas características que os atletas de elite desta modalidade possuem.

e) Elabore no mínimo três frases que os técnicos podem aplicar no treino dos atletas, para incentivar e corrigir alguns movimentos.

Inteiramente reformulada em termos de disposição e vocabulário, pois os estudantes, por exemplo não sabiam o significado de "atleta de elite", então substituímos por "bom atleta" e retiramos a solicitação de que citassem frases de incentivo aos atletas, que poderiam ser ditas pelo técnico, tendo em vista que queríamos apenas frases para corrigir os movimentos, porém os alunos não compreenderam assim:

"Vôlei-Tenha calma, preste atenção”.

"Futebol-Continue time, precisamos ganhar, vamos força de vontade, passe a bola”.

"Futebol - Vamos jogar com toda força e garra, nós somos brasileiros não desistimos nunca, o importante não é competir, é ganhar”.

"Futebol - Você consegue, você pode fazer melhor, marcação".

Com relação a Questão n 6 : Depois de responder estas questões:

a) Seu conhecimento atual é suficiente para que você faça bons apontamentos (comentários) para auxiliar o atleta? Por quê?

c) Que conhecimentos estão te faltando? 
d) Será que algumas das disciplinas (I, P, G, H, M, Q, B, etc.) que você tem na escola te podem auxiliar para instruir (ajudar) um atleta?

e) Cite pelo menos três disciplinas, e explique como ela será útil para análise de uma prática esportiva. Você pode seguir a tabela abaixo

\begin{tabular}{|l|l|l|}
\hline Disciplina & Conteúdo específico da disciplina & Auxilia porque.... \\
\hline & & \\
\hline & & \\
\hline & & \\
\hline
\end{tabular}

Também inteiramente modificada devido a sua má formulação. Os estudantes não conseguiam compreender o que estávamos pedindo. A palavra "instruir" levou os estudantes a um contexto oposto ao que esperávamos, pois ao invés de citarem as disciplinas, levando em consideração os seus conhecimentos para um bom desempenho do atleta na modalidade esportiva escolhida, a maioria dos estudantes interpretou em termos dos conhecimentos necessários para um bom relacionamento do atleta com a mídia e com as pessoas, observe algumas respostas e a figura 4.6:

"Língua Portuguesa - para não falar errado, Inglês - para se comunicar quando for jogar fora do país, Educação física - para prática esportiva”

“Língua Portuguesa - gramática para se comunicar bem, Inglês - para se comunicar no estrangeiro, Educação física - para ter uma boa preparação física”.

"Língua Portuguesa - para ser culto ao falar, Inglês - para falar outra língua, Biologia - para saber o limite do corpo”.

Alguns estudantes citaram a disciplina de história, expondo a necessidade do atleta em saber a história da modalidade esportiva que pratica e sociologia para saber viver em grupo e na sociedade.

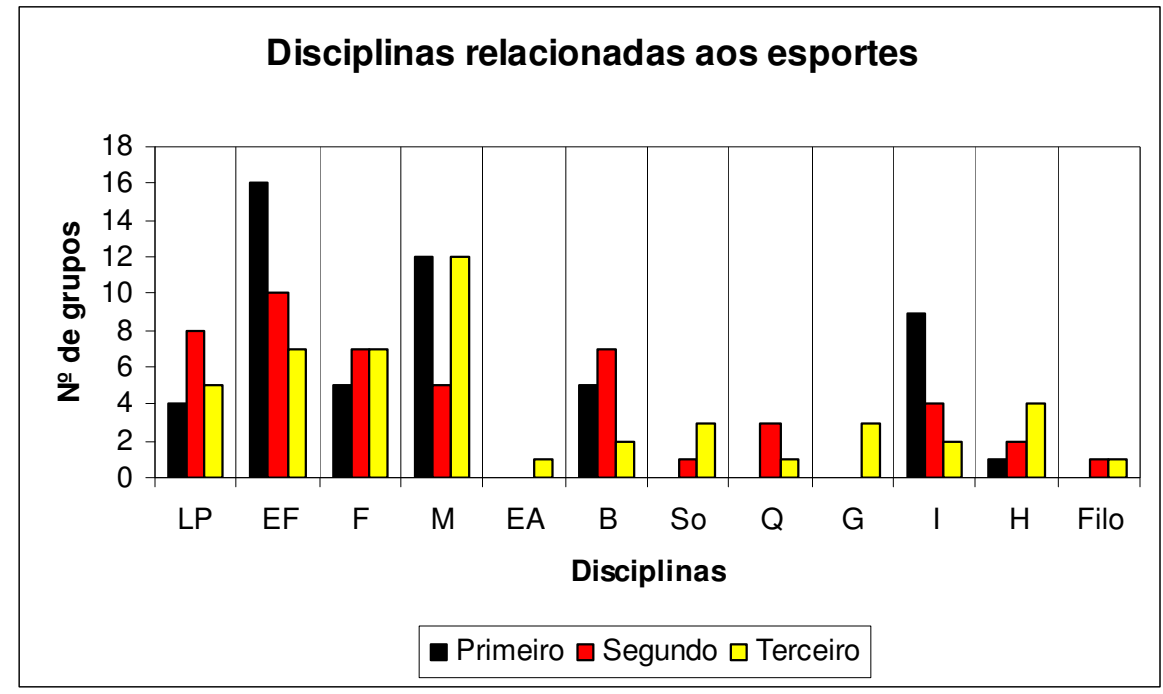

Figura 4.6: Posições das disciplinas total dos grupos em $1^{\circ} \mathrm{B}_{1}, 1^{\circ} \mathrm{C}_{1}$ e $1^{\circ} \mathrm{D}_{1}$. 
Com relação as questões 7, 8 e 9: 7) Será que é possível um técnico dominar as várias áreas necessárias do conhecimento para treinar um atleta adequadamente e corrigir os possíveis erros?, 8)Um técnico necessita do auxilio de outros profissionais para ajudar em sua análise sobre o desempenho do atleta? e 9)Cite alguns profissionais que fazem parte de uma equipe técnica e dê suas funções.

Novamente totalmente modificadas, pois a maioria dos estudantes apenas responderam sim ou não, o que nos impossibilita a análise. Tivemos um equívoco nas respostas, pois todos os estudantes interpretaram diferentemente o termo "equipe técnica" confundindo com equipe de arbitragem e componentes do time.

Mantivemos a questão 10 e adicionamos outras questões que nos possibilitaram ter parâmetros de comparação para complexificação do conhecimento de esporte, pois foram recolocadas na última atividade (9), no qual buscamos similaridades e diferenças nas respostas.

\section{- Atividade Piloto 2}

A atividade foi inteira modificada, algumas questões foram excluídas, outras modificadas e trocadas de ordem.

Pretendíamos com esta atividade, obter parâmetros que pudessem ser comparados com os resultados obtidos ao final das aplicações de todas as atividades, em termos de analisar se o perfil conceitual da ligação entre saúde e esporte sofreu modificações ou se manteve o mesmo após a inserção dos conhecimentos de mecânica.

Do modo que foram apresentadas às questões, tanto em formulação quanto em disposição e sequência com o texto, não atenderam nossos objetivos em obter dados que evidenciem a relação entre prática esportiva e saúde. As questões "soaram” aos alunos de forma repetitiva, então as repostas se mantiveram praticamente iguais durante toda atividade.

$\mathrm{Na}$ análise das respostas observamos também que os estudantes não tinham conhecimento suficiente para argumentar sobre qualidade de vida e saúde (observe a seguir na questão 4), pois desconheciam o seu significado, então propomos a obrigatoriedade da leitura do texto primeiramente (antes pelo tamanho e a disposição do texto muitos não faziam a leitura). Além disso, os estudantes tiveram dificuldade em entender as palavras: relacione e manutenção. 
Lembramos que utilizamos nas atividades a definição de saúde apenas como a ausência de lesões, mas na atividade 2 , mesmo que brevemente possibilitamos ao estudante o contato com as várias vertentes da definição de saúde e qualidade de vida, para que pudessem conhecer e argumentar mais sobre o assunto.

Questão 4: Uma pessoa dita como "saudável" necessariamente possui boa qualidade de vida? Por quê?

"Sim, porque para ser saudável precisa ter uma boa qualidade de vida"

"Sim, pois se a pessoa é saudável, ela se alimenta adequadamente, faz atividade física regularmente, e tem uma boa qualidade de vida”.

"Qualidade de vida é sinônimo de uma pessoa saudável"

Questão 5: Relacione qualidade de vida com saúde.

"Qualidade de vida se é bem de vida ou não e saúde se tem uma saúde boa ou ruim".

"Qualidade de vida seria as condições com o que você vive no dia-a-dia, a saúde seria seu interior estando bem”.

"Quem tem qualidade de vida tem saúde".

"Qualidade de vida é renda financeira e saúde é cuidar do corpo”.

As questões 8, 9 e 10 se mantiveram com poucas modificações, pois apresentaram resultados satisfatórios. As respostas dadas pelos estudantes se adequaram ao contexto desejado, cujo objetivo era analisar a concepção prévia sobre a relação entre esporte e saúde.

Questão 8: Qual é a relação entre saúde e esporte? Comente

"Quando praticamos esporte a nossa saúde melhora”.

"Saúde é o bem estar exercido pelo esporte”.

"Para praticar esporte precisa ter uma saúde boa".

Questão 9: Qualquer pessoa no momento em que quiser, pode praticar esporte? Por quê?

"É só ter força de vontade".

"Sim, porque o esporte é para todos".

"Sim porque para o esporte não tem idade".

Questão 10: A prática esportiva sempre resulta em saúde? Por quê?

"Sim, pois ajuda a melhorar o funcionamento dos órgãos”.

“Sim, porque faz bem a saúde e fortalece o corpo”.

"Sim a prática de esporte ajuda nós a melhorar a saúde”.

As questões 12, 13 e 14, foram inadequadas, pois os estudantes estavam dispostos em grupos e as perguntas tinham caráter individual, então gerou confusões, 
pois tinham que se basear em apenas uma pessoa do grupo para respondê-la. Estas questões continuam, mas com outra formulação e em outra disposição na atividade, mesmo porque decidimos que as atividades seriam aplicadas individualmente para evitar vários problemas.

Questão 12: O que você deve analisar ao comprar um calçado para prática de esportes?

"Se é bom e durável"

"Ser confortável"

"Se não sai do pé e o solado é bom"

"Confortável e resistente"

Observamos que os alunos desconhecem a importância de um calçado adequado para atividade física e sua influência no aparecimento de lesões.

- Atividade Piloto 3

Nesta atividade a ordem das questões foram modificadas e alguns textos foram excluídos e outros compactados para que os estudantes fizessem a leitura dos textos e pudessem argumentar mais a respeito de cada questão. A intenção é que os estudantes se inteirassem da existência de uma área da ciência para o estudo do movimento do corpo humano, que auxilia diretamente no melhor desempenho dos esportes, além de conhecer um pouco dos cientistas que se envolveram no estudo do corpo humano.

Percebemos, por algumas respostas na questão 8 e pelo diário de bordo da professora, que os estudantes não leram o texto pelo tamanho e pela sua má colocação na atividade.

Questão 8: Complete a frase: A biomecânica pode ajudar a.... "Não sei"

"Descobrir os movimentos do corpo"

"Ao ser humano ultrapassar seus limites"

"Na parte da mecânica"

"A vida"

“A aceleração"

- Atividade Piloto 4 
Esta atividade foi toda reformulada, pois os estudantes apresentaram muita dificuldade de raciocínio devido à má interpretação das questões e a falta da visualização prática (no cotidiano) através de algum experimento. A parte experimental foi realizada apenas em duas turmas $\left(1 \mathrm{~A}_{1}, 1 \mathrm{~B}_{1}\right)$ devido a dificuldade apresentada pelas outras três turmas $\left(1 \mathrm{C}_{1}, 1 \mathrm{D}_{1}, 1 \mathrm{E}_{1}\right)$ no entendimento dos cálculos de velocidade (relato pela professora) verificados nas respostas dos estudantes. A atividade nas duas turmas que realizaram os experimentos fluiu melhor (diário de bordo - anexo A2.2).

Alguns gráficos apresentaram problemas, pois para sua interpretação era necessário que fossem coloridos e isso não foi possível devido aos poucos recursos didáticos e financeiros disponíveis. Muitas questões estavam confusas e mal dispostas impossibilitando seu entendimento, principalmente na questão 6.

Muitas questões possibilitavam respostas através de sim ou não, sem criar margem para a argumentação que era justamente o que precisávamos para chegar às conclusões na análise dos dados.

Enfim, essa atividade apresentou muitas falhas devido a sua enorme extensão (48 questões). Prevíamos duas aulas para seu término, mas necessitamos de cinco aulas. Portanto excluímos várias questões após analisar as respostas, pois se revelaram desnecessárias e repetitivas e dividimos a atividade em duas partes, para não haver uma quebra na sequência da atividade.

Com relação a questão 6: Desafio: Preciso fazer uma comparação da velocidade entre três atletas em provas diferentes para saber qual dos atletas obteve maior velocidade durante o percurso. Frank Caldeira em 2005 completou a Maratona de São Silvestre em 44min06s e Ronaldo Costa em 1998 completou a Maratona em Berlim em 2h06min05s. O queniano Eliud Kipchoge na Corrida Espanhola de São Silvestre em Madri $(10 \mathrm{~km})$ completou a prova em 26min54s. Qual deles teve maior velocidade? Explique seu raciocínio.

A professora fez uma explicação geral na lousa sobre velocidade média e conversões das unidades de tempo e distância, pois a maioria dos estudantes elegia o corredor mais rápido apenas pela análise da grandeza tempo e não levavam em conta a distância e, quando recorriam aos cálculos, não faziam as transformações de unidades devidas, por isso optamos em colocar no início das atividades algumas perguntas com conversões de unidade simples para estimular o raciocínio e relembrar o conteúdo. 
A cada aula de aplicação desta atividade especificamente a professora corrigia as questões para que o aluno tivesse um retorno e oportunidade de entender seus erros e corrigi-los, pois durante as aulas eram muitos os alunos para serem atendidos.

Segundo a professora esta atividade foi muito cansativa, pois os alunos demonstraram muitas dificuldades tanto para entenderem as perguntas quanto para aplicar os conceitos já vistos nos bimestres anteriores.

\section{- Atividade Piloto 5}

Nesta atividade não precisamos fazer alterações nas questões, apenas mudamos a ordem dos textos, para nos assegurarmos de que os estudantes fizessem a leitura, pois segundo os relatos da professora, os estudantes não apresentaram interesse pela leitura.

- Atividade Piloto 6

Fizemos várias modificações nesta atividade, pois as questões iniciais levaram os alunos a consultar o livro de física e a copiar algumas definições, impossibilitando nossa análise. Optei por utilizar palavras sinônimas e a explicar outras que os estudantes demonstraram não entender, para evitar confusões ao responderem (por exemplo: interação, colisão).

Eliminei todos os gráficos desta atividade, pois observamos que a maioria dos estudantes não respondeu, visto que deixaram a atividade com extensão exagerada sem necessidade. Os gráficos contidos na atividade não faziam parte dos gráficos utilizados comumente na sala de aula, então se faziam necessárias explicações à parte, para sua interpretação. Mas enfim pudemos alcançar nossos objetivos, citados anteriormente, sem os mesmos.

\section{- Atividade Piloto 7}

Nesta atividade excluímos algumas questões e em outras buscamos palavras sinônimas para facilitar o entendimento. Fizemos alterações na disposição dos textos para forçar a leitura, e dividimos a atividade em duas partes para estar de acordo com o conteúdo do caderno do aluno de física v.1 e 2, além de diminuir o número de questões que realmente estava em excesso. 
No diário de bordo, a professora cita várias vezes algumas questões e gráficos em que a maioria dos estudantes demonstrou dificuldade em interpretar. Dentre estas questões e gráficos verificamos sua significância para o alcance dos nossos objetivos citados anteriormente e optamos por exclusão ou adaptação.

\section{- Atividade Piloto 8}

Apenas modificamos o formato da atividade, e a dividimos em duas partes para separar os conteúdos e não causar desinteresse nos alunos devido sua extensão, mas mesmo assim, a parte de estática requerem bastante ilustração e abrangem vários conceitos novos dos estudantes.

- Atividade Piloto 9 e 10

Os estudantes responderam rapidamente as atividades 9 e 10, então resolvemos fazer uma junção (2 em 1) e caracterizá-la como avaliação (aplicação dos conceitos aprendidos), focando mais as relações entre: biomecânica, esporte e saúde Retiramos todos os textos da atividade 10 e introduzindo questões que forneciam dados de comparação com as questões das primeiras atividades, para possibilitar a análise da complexificação do conhecimento de esporte, que não foi possível com as poucas questões propostas nas atividades piloto.

Como dito anteriormente e exemplificados nos diálogos 1 a 5 , durante a aplicação da atividade piloto, observamos nos diálogos dos estudantes descritos pelo diário de bordo da professora (anexo A2.2), que os estudantes formulavam as hipóteses e discutiam diferentes pontos de vista sobre os assuntos abordados. Isso nos leva a enquadrar as atividades não apenas no ciclo empírico-abdutivo, mas no ciclo hipotéticopreditivo de Lawson.

Como a aplicação das atividades-piloto ocorreu com defasagem de uma escola para outra, possibilitou acertos imediatos. O objetivo do piloto era justamente realizar acertos para se aproximar do ideal, que era o de levar os estudantes ao contexto desejado. Durante sua aplicação aconteceram modificações de uma turma para outra, e principalmente, de uma escola para outra, para que ajustássemos o conteúdo das questões inseridas nas atividades do público alvo. Portanto as aplicações de cada atividade foram concomitantes com alterações, exclusões e formulações de novas 
questões nas atividades. E isso, foi imprescindível para que formássemos um conjunto final de atividades que seguissem os objetivos iniciais de estabelecer uma ponte interdisciplinar entre esporte, saúde, educação física, biomecânica e física.

Enfatizamos que todas as modificações foram embasadas nas dificuldades apresentadas pelos estudantes ao responderem cada atividade e nas dificuldades enfrentadas pela professora durante sua execução.

Um dos maiores obstáculos encontrados nas atividades foi à dificuldade dos estudantes em interpretar as questões, no qual uma das causas se deve a escassez de vocabulário, que procede da falta de leitura habitual dos estudantes (obtido por relato da professora). Então, frequentemente, os alunos ignoravam os textos propostos pelas atividades. Observamos que quando o aluno solicitava a professora para solucionar alguma dúvida relacionada a interpretação da questão, a fala da professora e a resposta do estudante se repetia: (Prof.) "Você já fez a leitura do texto? (Aluno) Não”. Talvez pelo fato de conter nas atividades algumas questões ambíguas, mal formuladas, desnecessárias aos objetivos propostos nas atividades. Destacamos que a professora durante toda a aplicação das atividades-piloto, fez poucas colocações aos estudantes sobre as questões, fez papel de mediadora na aplicação das atividades e, portanto para esclarecer os questionamentos dos estudantes apenas encaminhou o raciocínio. Aliás, observamos nas aulas que os estudantes interagiram muito entre si, e juntos construíram o conhecimento. Repetidamente, os alunos preferiam solucionar suas dúvidas com outros estudantes e em último caso pedir auxílio ao professor.

Por consequência, procuramos editorar as atividades alterando a extensão e a disposição dos textos, na meta de impor a leitura dos textos, que possui papel essencial no desenvolvimento das atividades, pois, também, contribuía para dosar a interferência do professor na elaboração do raciocínio dos estudantes.

\subsection{Análise da Intervenção}

Como dissemos na seção 3.7 escolhemos analisar as atividades iniciais (Atividades 1, 2, 3) e as finais (Atividade 9 e Avaliatória) para verificar o grau de complexificação do conhecimento cotidiano dos alunos sobre esporte.

Nas atividades 4, 5, 6, 7 e 8 inserimos os conceitos físicos do conteúdo de mecânica citados na proposta curricular do estado de São Paulo e relacionados diretamente às várias modalidades esportivas. Mediante os relatos da professora (diário 
de bordo, anexo A3.2.3) os alunos apresentaram dificuldades com as operações matemáticas, que infelizmente não puderam ser solucionadas nestas poucas atividades e nem era este o objetivo da intervenção. Durante a aplicação da intervenção os estudantes demonstraram apropriação dos conceitos físicos, o que será explicitado posteriormente neste trabalho. As atividades não exigiam a utilização intensa da matemática, embora seja notável sua utilização na física, mas não podemos fazer da matemática uma barreira para o ensino de física, seja em qualquer série e conteúdo. Através das atividades que propomos, é possível ensinar os conceitos físicos de mecânica com utilização de algumas operações matemáticas básicas e alcançar êxito, ou seja, levar os estudantes a aprendizagem.

Buscamos elementos dentro dos conteúdos da primeira série do ensino médio que motivem os estudantes, e que os façam estabelecer relações com o seu cotidiano. Tomamos o tema esporte como elemento facilitador para a aprendizagem dos conceitos físicos em sala de aula. Encontrar temas que despertem a motivação dos estudantes em aprender é essencial, pois se depender do ambiente físico da sala de aula, é desanimador, há décadas encontramos somente carteiras e cadeiras impróprias ás estaturas dos alunos, um quadro negro, giz e nada mais.

Mesmo assim, neste ambiente, podemos encontrar alunos que resistem a esta situação e se empenham para aprender, mas a maioria se entrega a situação do descaso e embarcam no ritmo da desmotivação em aprender. Isto nos dá indícios de uma desestruturação da escola pública que envolve vários aspectos, talvez pelos valores dados pela sociedade atual ao conhecimento, resultando na perda de identidade da escola na sociedade, e acentuando a desvalorização do professor.

As atividades da intervenção foram propostas para serem realizadas individualmente, mas isso, não foi possível, pois nas duas escolas a disposição das carteiras não é em fileiras, mas em pequenos grupos ou "grupões" formados pelos próprios alunos.

$\mathrm{Na}$ escola $\mathrm{G}$, as carteiras são posicionadas de acordo com grupos, que são formadas por afinidades entre os estudantes e são fixos em todas as aulas, com poucas variações ocorridas quando muitos alunos do grupo faltam ou se desentendem por algum motivo desconhecido. Já na escola $\mathbf{M}$, embora as salas sejam organizadas por pequenos grupos eles se alteram a cada aula, as vezes com mais alunos por grupo, as vezes com menos, as vezes preferem sentar sozinhos, enfim é um sistema cuja dinâmica é muito complexa. 
Salientamos que nas turmas das duas escolas, embora haja pequenos grupos, todos se comunicam muito bem, e formam o "grupão da sala de aula", bem unidos nas decisões.

Segundo a professora, a mesma permite que os alunos permaneçam organizados desta forma, porque: “... a partir do momento em que há controle, há descontentamento, desafio por desobedecer às regras, e isto influencia na construção do conhecimento, contudo não deixo isto solt, pois está inserido em regras impostas previamente na $1^{a}$ aula...” (Anexo A3.2.3). A professora tem o controle da turma implicitamente, há uma negociação de comportamento na sala, os estudantes entendem e aceitam as regras por ela estabelecidas. Cada uma das salas possui uma dinâmica diferenciada para resolução das atividades e isto está diretamente relacionada à relação professora-aluno e a composição dos grupos. Durante as aulas a professora fala pouco e faz algumas anotações na lousa sobre as atividades da aula e deixa os alunos à vontade para realizar a atividade, circula entre as carteiras e atende a dúvida dos estudantes nas carteiras ou em sua mesa, no restante permanece sentada aplicando visto no caderno do aluno de física, organizando o diário, etc.

Pela aplicação da atividade piloto, observamos que a medida que interferimos no processo de formação dos grupos causamos desmotivação e o grau de discussão decai no grupo, aparentemente nessa situação os estudantes precisam ter autonomia para criarem um ambiente que lhes pareçam mais propício para construção do conhecimento, embora, o que pareça, para olhos externos ao ambiente, uma bagunça, para os estudantes é um modo de organização, é desta forma que se sentem bem, buscando suas afinidades.

Ao analisarmos os dados verificamos que os alunos possuem respostas similares em algumas questões e em outras não e em muitas vezes modificam a resposta através de palavras sinônimas, e isto, está relacionado a organização dos grupos na aula, que por sua vez é dependente do dia. As respostas dos alunos às questões, nos mostram, muitas vezes, que é uma cópia, que podemos chamar de "consciente", pois o conhecimento é construído em grupo e cada estudante reescreve as conclusões alcançadas no grupo. Os estudantes revelam uma dinâmica diferenciada em cada questão, sabem o que é passível de compartilhar (copiar) ou não.

Para aplicar a intervenção nos baseamos no plano de aula (tabela 3.14), que durante o processo, devido a imprevistos tiveram algumas mudanças diferenciadas (anexo A3) para cada turma, mas em nenhum momento foi modificado o ciclo de 
aprendizagem de Lawson proposto nas suas fases de: exploração do conceito, introdução do conceito e aplicação do conceito.

A professora concluiu com os estudantes durante o período de aplicação da intervenção em ambas as escolas, as páginas 3 a 13, 16 a 20, 22 a 34, 36 a 38, 40, 42 e 43 do caderno de física do aluno vol.1 (São Paulo: SEE, 2009) e as páginas 7 a 10, 10 a 16, 20 a 29, 41, 42, 44 a 46 do caderno de física do aluno vol.2 (São Paulo: SEE, 2009), sendo que os roteiros de experimentação foram destinados como atividade extra-classe, para que não fosse extrapolado em demasiado o tempo previsto de aplicação da intervenção.

\subsubsection{Categorização}

Ao analisar os dados foi necessário formular categorias que auxiliassem a agrupar as respostas, segundo os objetivos referentes a complexificação do conhecimento cotidiano dos estudantes sobre esporte. Estas categorias são exemplificadas e ficam mais fáceis de entender por meio das tabelas 4.12, 4.18, 4.24, 4.31, 4.37, 4.39, 4.41 e 4.43 .

Segundo Bardin (2010), analisar um conteúdo é encontrar uma técnica de análise adequada ao domínio e aos objetivos pretendidos em uma investigação, que é passível de modificação mediante ao tipo de interpretação que se deseja, desde que esteja atrelado aos objetivos. A análise de conteúdo tem utilização em um campo amplo: comunicações (escrito, oral, icônico e outros códigos semióticos) e, portanto é adaptável aos documentos e objetivos do investigador, podendo ocorrer de diversas formas.

Coletamos uma grande quantidade de dados escritos, embora tenhamos também dados do contexto da sala de aula coletados, por meio do diário de bordo da professora, mas que não são suficientes para realizarmos uma análise do discurso que requer outros cuidados para coleta de dados. Optamos por coletar apenas dados escritos para não desobedecer regras impostas pelo grupo gestor da escola $\mathrm{M}$ e $\mathrm{G}$ (contrato didático), quanto a utilização de aparelhos eletrônicos na sala de aula (Anexo 3.2.3 ). Apenas com o material textual que é independente da interferência da professora, realizamos uma análise categorial para compreensão do processo de ensino-aprendizagem (CAREGNATO \& MUTTI, 2006).

Como dito, neste trabalho utilizaremos, portanto, uma análise categorial, pois permite a classificação dos elementos de significação constitutivo na mensagem, no 
qual podemos introduzir uma ordem segundo certos critérios de categorização estabelecidos, ou seja, que se adaptam a realidade da investigação, deixando o procedimento mais sistemático e objetivo. Para a categorização, condensamos os dados e buscaremos fornecer uma visão simplificada da classificação na categorias estabelecidas permitindo entender mais os dados. Para se ter êxito nas categorias formuladas (grelha de categorias - Bardin, 2010, p. 147), nas categorias formuladas devemos encontrar, nos dados obtidos, algumas qualidades, como: exclusão mútua, homogeneidade, pertinência, objetividade, fidelidade e produtividade. Estas qualidades são encontradas gradativamente na elaboração das categorias e na classificação dos dados nas categorias.

Uma análise categorial que segue os critérios mencionados é extremamente importante neste caso, pois ao isolarmos e repartirmos os elementos por uma organização, segundo Garcia (1998), conseguimos caracterizar os diferentes graus de complexidade que os estudantes se encontram, o que nos possibilita descrever as correspondentes dificuldades de aprendizagem que enfrentam. Assim, o grau de complexidade em que o estudante se encontra fornece ao professor quais objetivos foram alcançados em cada atividade, pois mostra a evolução do conhecimento e o desenvolvimento das estruturas cognitivas.

À cada atividade esperamos que os estudantes complexifiquem o conhecimento sobre o esporte gradualmente. Com isso, ao final das atividades, esperamos medir o grau de complexidade em que o estudante se encontra. Lembramos que o nível inicial de complexidade do estudante foi explorado nos questionários preliminares, no qual, na maioria dos casos, encontramos o nível zero de complexificação voltada tanto para articulação de conceitos quanto de contexto.

Como falamos em graus, decidimos adotar números para simplificar a análise dos dados. A categorização partiu do pressuposto que a complexificação do conhecimento pode dar-se em duas vertentes: tanto na coordenação quanto na articulação de conceitos trabalhados, que estarão inclusa como parte nova do discurso dos estudantes e na utilização de contextos variados plausíveis aos estudantes. Acreditamos que a complexificação do conhecimento pode ser construída por vários caminhos, não atrelado apenas às disciplinas, mas aos contextos que permeiam a aprendizagem, indo ao encontro da utilização do termo pan-disciplinaridade (MATTOS \& FERRARA, 2006). 
Portanto, para representar as duas vertentes da complexificação do conhecimento recorremos a um par ordenado $(x, y)$, onde $x$ será o grau devido a complexificação, referente a articulação dos conceitos, e $y$, o grau referente ao contexto de uso destes conceitos. O par ordenado não está vinculado na construção de um gráfico no plano cartesiano, mas foi uma forma de fornecer uma visão geral do grau de articulação de conceitos e contexto em que os estudantes se encontram - tabela 4.45 e 4.48 .

Para a coordenada $x$ utilizaremos:

- Grau 0: não houve complexificação do conhecimento cotidiano, apenas adiciona novos conceitos abrangidos nas aulas, mas não estabelece relações entre eles, permanece atribuindo aos conceitos significados do cotidiano.

- Grau 1: há complexificação do conhecimento cotidiano, pois o estudante agrega novos elementos no seu discurso, de forma a utilizar e articular os conceitos abrangidos nas aulas de física. Isto se dá a partir das relações adequadas e coerentes, por exemplo, entre as palavras: desempenho, limite, lesão, biomecânica, saúde, etc.

- Grau 2: há complexificação do conhecimento cotidiano, pois além do estudante agregar novos conceitos abrangidos nas aulas de física ao seu discurso, ele reconhece o a relação de interdisciplinaridade com a educação física, e utiliza termos novos que não foram utilizados nas aulas de física, tais como: handball, voleiball, futsal, basquete, flexibilidade, alongar, alimentação, ginástica (salto carpado), composição corporal, rúgbi, futebol americano, massa corporal, IMC (índice de massa corpórea), beleza, etc.

Para a coordenada $y$ utilizaremos:

- Grau 0: Não respondeu, que pode ser por falta no dia, transferência de classe ou escola.

- Grau 1: As respostas permeiam apenas o contexto formal da sala de aula e da escola.

- Grau 2: Nas respostas encontramos aplicação dos conceitos desenvolvidos na escola (sala de aula), no cotidiano como, por exemplo, nas respostas de alguns estudantes encontramos citações sobre o "tira-teima" no "globo esporte", tênis adequado a prática esportiva, máquinas para auxiliar no movimento das pessoas e prótese biomecânica.

As categorias citadas acima foram utilizadas na análise conjunta das questões na atividade 9 e da atividade avaliatória com o questionário de validação $\left(\mathrm{Q}_{3}\right)$, para que pudéssemos ter uma visão global das ideias dos estudantes e não nos apoiarmos em apenas um conjunto de dados isolados (um questionário apenas). Portanto o grau 2 será utilizado apenas na análise final (tabela 4.45 e 4.48). Lembramos que o estudante estará 
enquadrado no grau 2 para coordenada $x$ se adicionar na sua resposta, a algumas das questões selecionadas (tabela 3.19) alguns conceitos trabalhados na disciplina de educação física e estará no grau 2 na coordenada $y$ se em sua resposta aplicar os conceitos em um contexto fora da escola.

$\mathrm{Na}$ análise separada da atividade 9 e da atividade avaliatória e do questionário de validação, utilizamos apenas a coordenada $\mathrm{x}$, ou seja, o grau devido a complexificação referente a articulação dos conceitos:

- Grau 0: Não houve complexificação do conhecimento de esporte, apenas utilizou os conceitos desenvolvidos nas aulas, sem estabelecer relações, e continua utilizando os conceitos com significados atribuídos por ele no cotidiano

- Grau 1: Ocorre a complexificação do conhecimento de esporte, através das articulações entre os conceitos vistos nas atividades.

Lembramos que o grau 2 referente à coordenada $x$, e à coordenada $y$, somente serão utilizados na análise final quando faremos o cruzamentos dos dados (atividade 9 mais atividade avaliatória e do questionário de validação).

Utilizamos, mesmo que, com qualidade distinta dos graus 0,1 e 2, os graus - 1 e -2, para nos auxiliar na análise da participação dos estudantes nas atividades da intervenção. Optamos por nomear como grau -1 e -2 para facilitar na visualização dos dados. Os graus -1 e -2 são utilizados com mesma definição, tanto para coordenada $x$ quanto para coordenada $y$ :

- Grau - 2: Não respondeu, ou porque faltou, ou porque se transferiu de classe ou de escola.

- Grau -1: Fora do perguntado, ou dados insuficientes para classificação nas categorias propostas.

Esta categorização elaborada com base em graus de complexificação, pode ser atrelada às ordens de aprendizado propostas por Mattos \& Rodrigues (2007), pois em função da relação: pensamento e palavra, proposto por Vygotski (2001), podemos dizer que os graus de complexificação atingidos nos discursos dos estudantes revelam uma dinâmica do perfil conceitual dos estudantes, uma evolução no grau de complexificação do conhecimento cotidiano sobre o esporte.

Esta dinâmica do perfil conceitual se dá à medida em que os estudantes complexificam o conhecimento cotidiano (agregam novos conceitos e aplicam de forma adequada em diversos contextos). Ensinamos aos estudantes conhecimentos científicos (epistemológicos) que os auxiliam a ampliar suas visões sobre a prática esportiva, 
capacitando-os a complexificarem seus conhecimentos prévios (cotidianos - dimensão ontológica) sobre esporte. Isto resulta na modificação da percepção dos estudantes sobre o valor e fim da prática de exercícios físicos e na sua visualização de esportes de competição (dimensão axiológica). Lembramos que a dimensão axiológica é de suma importância, pois faz parte da escolha do tema: esporte, pois segundo Bernstein (1990) o indivíduo deve apresentar uma pré-disposição, uma motivação para evoluir na aprendizagem.

Os graus de complexificação, definidos acima, em pares ordenados (tabela 4.45 e 4.48), podem ser relacionados às ordens de aprendizado (MATTOS \& RODRIGUES, 2007), da seguinte forma (seção 3.5.2):

- $1^{\text {a }}$ ordem: diz respeito aos pares ordenados $(0,1)$ e $(0,2)$.

Nesta classificação o estudante apenas utiliza alguns conceitos vistos nas aulas, com o sentido utilizado anterior às atividades, tanto no contexto da sala de aula quanto exterior à ela.

- $2^{\mathrm{a}}$ ordem: diz respeito aos pares ordenados $(1,1),(2,1),(1,2)$.

Nesta classificação o estudante utiliza e articula os conceitos abrangidos nas atividades. Mas com limitações, alguns reconhecem que o conhecimento é interdisciplinar (o conceito pode ser utilizado em outras áreas), mas não aplicam no contexto fora da escola, outros não reconhecem a interdisciplinaridade mas aplicam os conceitos da física no contexto fora da escola.

- $3^{\text {a }}$ ordem: diz respeito ao par ordenado $(2,2)$.

Nesta classificação o estudante reconhece a utilização dos conceitos vistos nas aulas de física, por meio das atividades em outras disciplinas e consegue aplicar fora do contexto escolar, ou seja além de incluir no seu discurso os novos conceitos vistos, consegue aplicá-los adequadamente em outros contextos (fora da sala de aula).

Para que o estudante seja enquadrado na ordem máxima de aprendizagem é necessário um amadurecimento das ideias do estudante, tanto em termos da utilização dos novos conceitos, quanto na aplicação adequada nos contextos.

Os pares $(-2,0),(-1,2),(-1,-1)$ não fazem parte desta análise em termos das ordens de aprendizado (qualidade distinta), pois tem origem duvidosa, já que faz parte dos estudantes que não responderam as questões ou que responderam de forma incompleta ou fora do proposto.

O estudante alcança o grau máximo de complexidade quando produz um texto adequado ao contexto (BERNSTEIN, 1990). Segundo Garcia (1998), os estudantes 
enfrentam dificuldades durante o processo de transição do simples ao complexo e quando situamos a evolução das ideias dos estudantes por meio de um gradiente de complexificação progressiva, conduzimos com mais destreza a intervenção.

As categorias definidas em graus de complexidade nos possibilitam justamente observar esse gradiente de complexificação do conhecimento, o que nos permite analisar futuramente a dinâmica do perfil conceitual de esporte, obtendo retorno quanto ao estágio de aprendizado em que o estudante se encontra possibilitando a interferência adequada do professor durante o processo de aprendizagem.

A análise de dados deste trabalho se dá através de três olhares que a todo o momento se cruzam:

- Contexto escolar: descrição das características de cada escola envolvida, situando-a na cidade e na comunidade em questão.

- Contexto da sala de aula: observação das relações estabelecidas entre alunoprofessor, aluno-aluno, alunos-gestores, professores-gestores, etc.

- Aprendizagem: processo de complexificação do conhecimento a partir de uma intervenção em um cenário complexo como no macro da escola e no micro da sala de aula.

Além das categorias já apresentadas também categorizamos os estudantes por grupos A, B, C, etc. de similaridade, que possuem características gritantes que se destacam na turma, e por grupos de afinidade distribuídos na sala de aula (obtido por uma mapa da sala de aula feito pelos estudantes - posições dos estudantes na sala de aula), que serão descritos adiante. Estas categorias e os mapas nos auxiliaram na compreensão do processo de ensino-aprendizagem e por consequência na classificação dos estudantes de acordo com as categorias elaboradas, nos dando indícios de como e com quem, um estudante pode aprender no contexto da sala de aula

\subsubsection{Turma $1^{\circ} \mathrm{A}_{2}$}

A turma $1^{\circ} \mathrm{A}_{2}$, referente a escola $\mathrm{G}$ é composta por 41 alunos, sendo que dentre eles analisamos as respostas de apenas 32 alunos, pois, no decorrer do semestre tivemos algumas transferências de classe e de escola e alguns abandonos de curso. Nesta turma eram ministradas duas aulas consecutivas no mesmo dia, às segundas-feiras, a $5^{\mathrm{a}}$ e $6^{\mathrm{a}}$ aula do período da tarde.

A aplicação da intervenção na turma $1^{\circ} \mathrm{A}_{2}$ seguiu inicialmente o plano de aula (tabela 3.14) que prevê o término da intervenção em junho (fim do $1^{\circ}$ semestre), mas 
durante a aplicação tivemos mudanças devido a imprevistos já citados. Observe na tabela 4.11 o diário de classe da professora.

Durante o processo de aplicação das atividades contabilizamos 48 aulas de física, mas ministramos para intervenção 38 aulas. A diferença de 10 aulas inclui reunião de pais com alunos, palestras, jogo da copa assistido na escola, campeonato de futebol entre as turmas da escola, etc. Lembramos que no plano de aula (tabela 3.14) estabelecemos 23 aulas para toda a intervenção, mas verificamos que cada turma segue um ritmo de realização de tarefas.

Tabela 4.11: Diário de classe.

\begin{tabular}{|c|c|}
\hline DATA & CONTEÚDO - $\mathbf{1}^{\circ} \mathrm{A}_{2}$ \\
\hline $22 / 02$ & Apresentação \\
\hline $01 / 03$ & Atividade $1+$ caderno 1 (p. 3 a 5$)$ \\
\hline $08 / 03$ & Ativ. $2+$ cad. 1 (p. 6 e 7$)$ \\
\hline $15 / 03$ & Veloc. Média + cad. 1 (p. 8 a 11) \\
\hline $22 / 03$ & Exercícios de Veloc. Média + ativ. 3 \\
\hline $29 / 03$ & Ativ. $4+$ ativ. de corrida no pátio \\
\hline $05 / 04$ & Ativ. 4 \\
\hline $12 / 04$ & Colisões + ativ. 4 \\
\hline $19 / 04$ & Cad. 1 (p. 17 a 20) + Acel. média + Ativ. 4 \\
\hline $26 / 04$ & Cad. 1 (p. 21 a 23$)+$ Ativ. 5 \\
\hline $03 / 05$ & Cad. 1 (p. 24 a 27$)+$ Ativ. 5 \\
\hline $24 / 05$ & Cad. 1 (p. 32 a 37,40 a 43) \\
\hline $31 / 05$ & Ativ. $6+$ cad. 2 (p. 7 a 10$)$ \\
\hline $14 / 06$ & Cad. 2 (p. 10 a 16, 20 a 26) + Em + Pot \\
\hline $21 / 06$ & Cad. 2 (p. 44 a 47$)+$ Ativ. 7 \\
\hline $05 / 07$ & Ativ. 8 \\
\hline $02 / 08$ & Cad. 3 + término Ativ. 8 + Ativ. 9 \\
\hline $09 / 08$ & Cad. 3 + término Ativ. 9 \\
\hline $23 / 08$ & Cad.3 + Ativ. Av. \\
\hline
\end{tabular}

Na figura 4.7, observamos que a média dos alunos presentes, equivale aos alunos frequentes durante toda a intervenção na turma $1^{\circ} \mathrm{A}_{2}$, ou seja, os estudantes são os mesmos, não revezam a presença nas aulas. É relevante destacar a baixa frequência no 
dia 5 de julho, que foi antecedente às férias de julho, mas superada depois das férias em agosto.

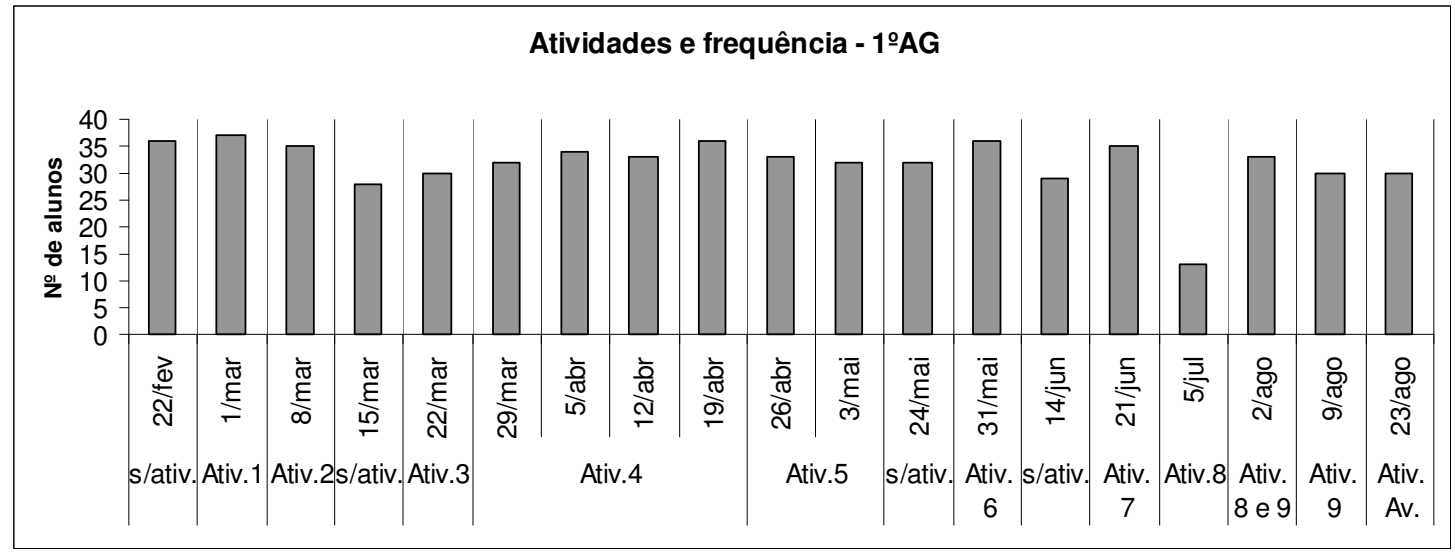

Figura 4.7: Atividade e frequência da turma $1^{\circ} \mathrm{A}_{2}$

$\mathrm{Na}$ atividade 1 com a questão 7, os estudantes descrevem as disciplinas escolares que mais identificam com o esporte. Com isso, pudemos verificar se os estudantes já estabelecem alguma relação entre a disciplina de física e o esporte. Observe na figura 4.8 que a disciplina de educação física aparece em $1^{\circ}$ lugar, a disciplina de física em $2^{\circ}$ lugar e a disciplina de matemática em $3^{\circ}$ lugar. Mas, mesmo com a modificação realizada na questão após a atividade piloto, continuamos com alguns estudantes citando as disciplinas de inglês, língua portuguesa entre outras pelo fato de serem primordiais para comunicação do atleta no Brasil e em outros paises.

Questão 7: Será que algumas das disciplinas (I, P, G, H, M, Q, B, F, EF, EA, Fil, So) que você tem na escola podem ajudar um atleta a ter um bom desempenho? Cite pelo menos quatro disciplinas (coloque em ordem de importância), e explique como ela será útil para análise de uma prática esportiva. Para facilitar complete a tabela abaixo:

\begin{tabular}{|l|l|l|l|}
\hline & Disciplina & $\begin{array}{l}\text { Conteúdo (matéria) } \\
\text { específico da disciplina }\end{array}$ & Auxilia ... \\
\hline Exemplo & Artes & Técnicas de Pintura & $\begin{array}{l}\text { Dar harmonia as cores no } \\
\text { quadro }\end{array}$ \\
\hline $1^{a}$ & & & \\
\hline $2^{a}$ & & & \\
\hline $3^{a}$ & & & \\
\hline $4^{a}$ & & & \\
\hline
\end{tabular}




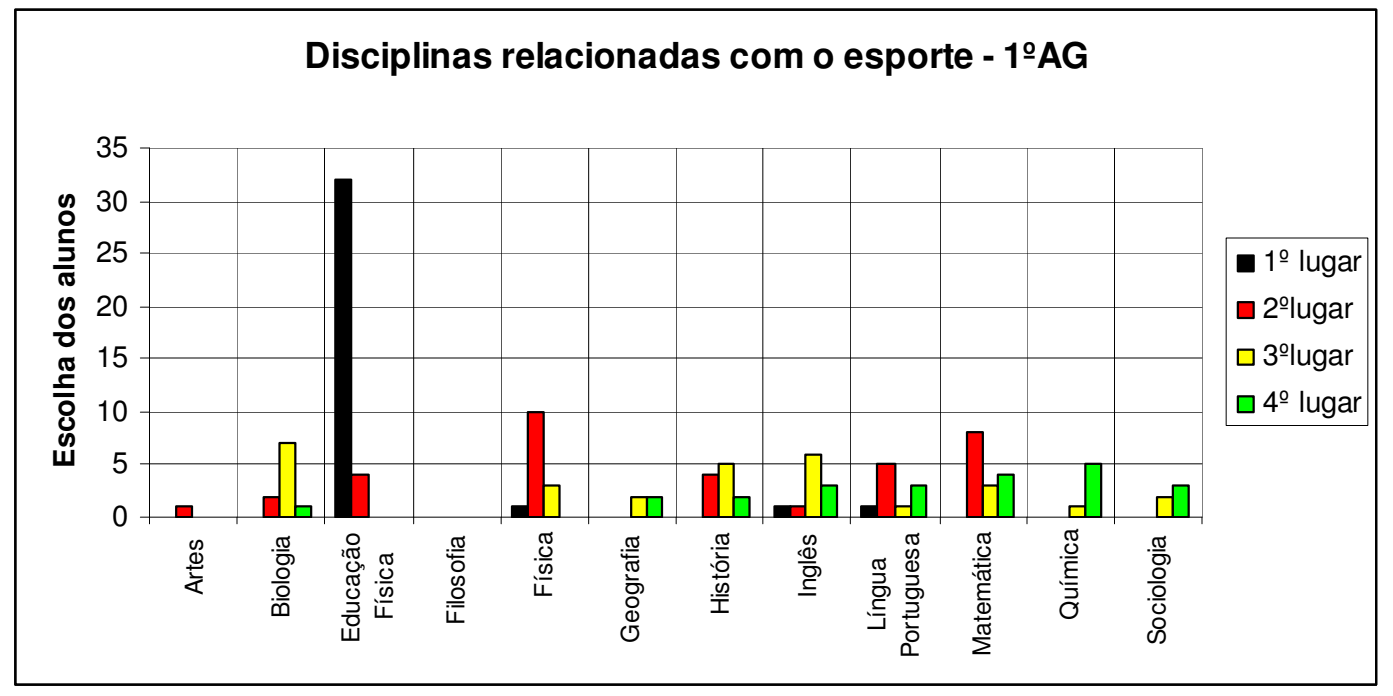

Figura 4.8: Posições das disciplinas - turma $1^{\circ} \mathrm{A}_{2}$

Mostramos nas tabelas 4.12 a 4.16 algumas respostas dos alunos de algumas questões e atividades selecionadas (tabela 3.19), cujo é possível analisar a complexificação do conhecimento de esporte.

A tabela 4.12 traz a quantidade: de atividades entregues, atividades que faltaram, de faltas dos estudantes durante o período de aplicação da intervenção e as respostas dos estudantes a questão 5 e 8 da atividade 9 e a questão 1 da atividade avaliatória, que nos informam sobre a complexificação do conhecimento de esporte. 
Tabela 4.12: Comparação de questões das atividades da intervenção - $1^{\circ} \mathrm{A}_{2}$ - escola G.

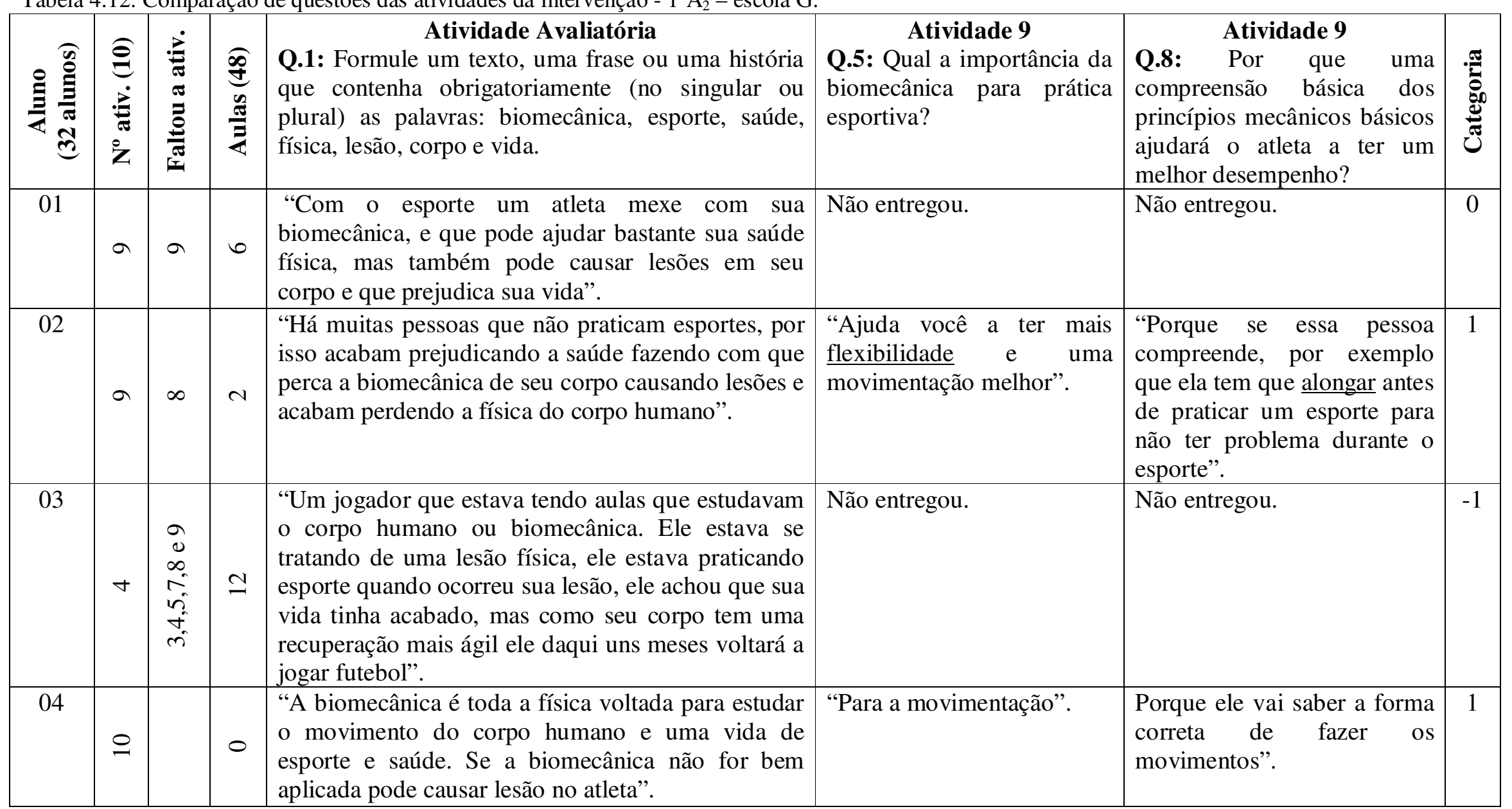




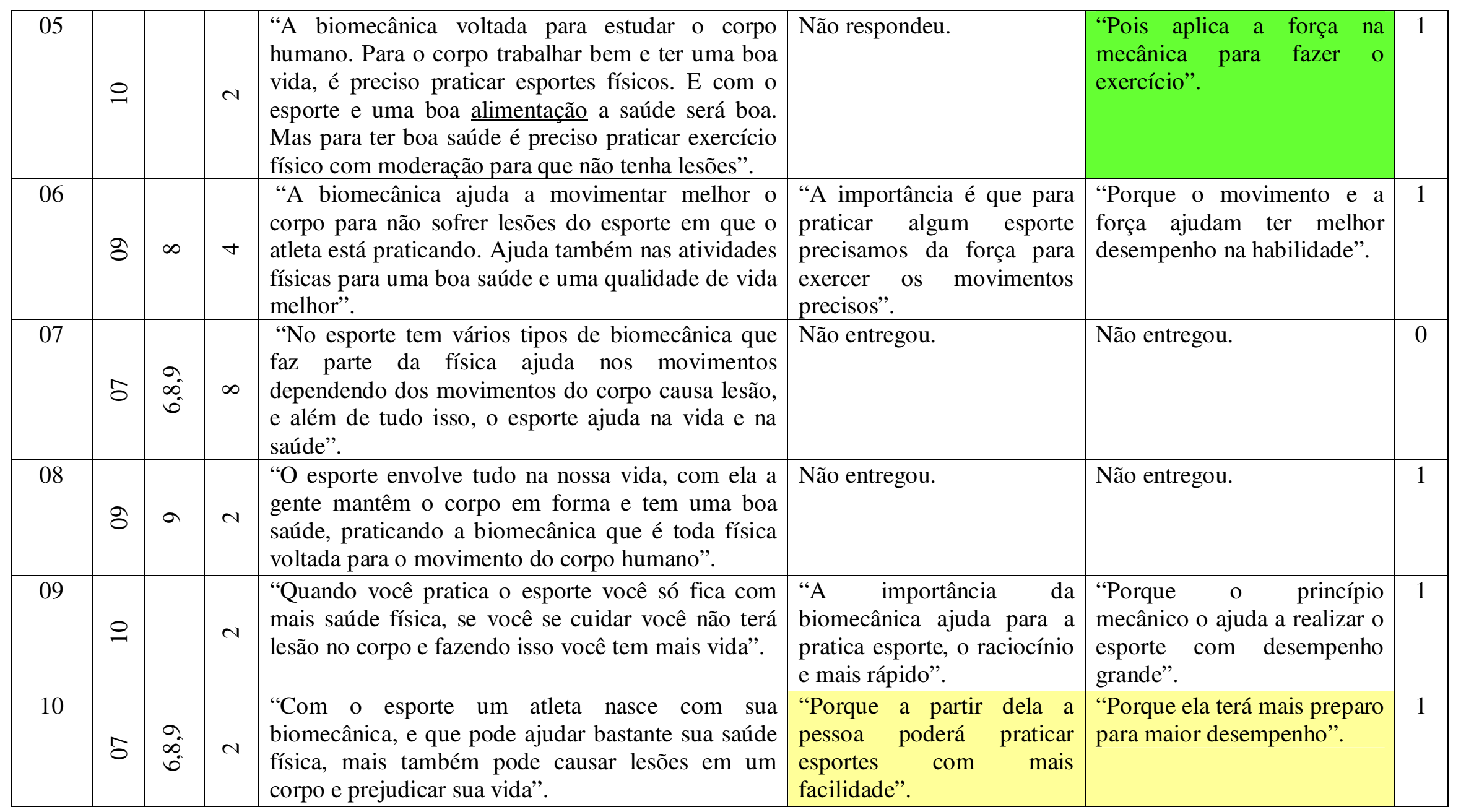




\begin{tabular}{|c|c|c|c|c|c|c|c|}
\hline 12 & $\stackrel{0}{-}$ & & $\forall$ & $\begin{array}{l}\text { "A biomecânica ajuda a tratar de uma pessoa com } \\
\text { uma lesão que sofreu em algum esporte, e com essa } \\
\text { lesão a pessoa ficou com o corpo machucado e } \\
\text { depois vai ficar com uma boa saúde e uma vida } \\
\text { melhor". }\end{array}$ & $\begin{array}{l}\text { "Tratar de lesões } \\
\text { condicionamento }\end{array}$ & $\begin{array}{l}\text { "Porque com a mecânica os } \\
\text { especialistas poderiam criar } \\
\text { máquinas que ajudasse no } \\
\text { desempenho dos atletas". }\end{array}$ & 1 \\
\hline 14 & 8 & $\infty$ & $\forall$ & $\begin{array}{l}\text { "Para se ter uma vida saudável, uma boa saúde, a } \\
\text { pessoa deve praticar esportes, mas para isso deve } \\
\text { conhecer bem seu corpo, seus limites. Deve aquecer } \\
\text { antes de começar qualquer atividade física para } \\
\text { evitar supostas lesões que poderão ocorrer com a } \\
\text { pessoa e saber bem sobre biomecânica, conhecendo } \\
\text { os movimentos do corpo". }\end{array}$ & $\begin{array}{l}\text { "Trabalha com } \quad \text { o } \\
\text { movimento do corpo na } \\
\text { capacidade, limites, etc.". }\end{array}$ & $\begin{array}{l}\text { "Porque ele saberá o limite } \\
\text { do seu corpo". }\end{array}$ & 1 \\
\hline 15 & $\stackrel{\infty}{\circ}$ & $\overbrace{0}^{\infty}$ & 으 & $\begin{array}{l}\text { "A biomecânica sempre nos ajuda a entender e } \\
\text { trabalhar o corpo. Também devemos praticar muitas } \\
\text { atividades físicas para manter sua saúde estável. O } \\
\text { esporte também nos ajuda bastante na vida desde } \\
\text { que não aconteça nenhuma lesão". }\end{array}$ & $\begin{array}{l}\text { "A biomecânica ajuda a } \\
\text { facilitar os movimentos } \\
\text { durante algum esporte". }\end{array}$ & $\begin{array}{l}\text { "Por que se essa pessoa } \\
\text { compreender, por exemplo, } \\
\text { que ela tem que alongar antes } \\
\text { de praticar um esporte para } \\
\text { não ter problemas durante o } \\
\text { esporte". }\end{array}$ & 1 \\
\hline 16 & s & 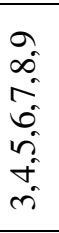 & $\nabla$ & $\begin{array}{l}\text { "Um jogador de futebol como todo o esporte tem } \\
\text { que ter muita saúde, ele precisa ter uma } \\
\text { biomecânica bem aprimorada, um jogador de } \\
\text { futebol pode sofrer várias lesões, física ou mental, e } \\
\text { ter uma vida boa". }\end{array}$ & Não entregou. & Não entregou. & -1 \\
\hline 17 & $\stackrel{\infty}{\circ}$ & $\stackrel{\infty}{\infty}$ & 6 & $\begin{array}{l}\text { "Em todo esporte existe a biomecânica que faz } \\
\text { parte da física e que ajuda a saúde, faz bem para o } \\
\text { corpo e para vida, mas tem que ter o máximo de } \\
\text { cuidado para não sofrer lesões graves". }\end{array}$ & Não entregou. & Não entregou. & 1 \\
\hline
\end{tabular}




\begin{tabular}{|c|c|c|c|c|c|c|c|}
\hline 18 & I & $\begin{array}{l}\hat{0} \\
\infty \\
\hat{b} \\
\hat{n} \\
m\end{array}$ & $\stackrel{0}{=}$ & $\begin{array}{l}\text { "Era uma vez um rapaz que tinha um grave } \\
\text { problema no corpo: uma lesão praticando rúgbi. O } \\
\text { problema afetou na biomecânica e seu problema de } \\
\text { saúde ficou muito conhecido e repercutiu o mundo } \\
\text { todo e os estudantes de física se interessaram nele } \\
\text { para estudá-los para ver como ele se movimentou } \\
\text { para conseguir melhorar em sua vida". }\end{array}$ & Não entregou. & Não entregou . & 0 \\
\hline 20 & 8 & $\dot{z}$ & $\sim$ & Não entregou. & $\begin{array}{lrrr}\text { "Porque a partir } & \text { dela a } \\
\text { pessoa poderá } & \text { praticar } \\
\text { esportes } & \text { com } & \text { mais } \\
\text { facilidade" } & & \end{array}$ & $\begin{array}{l}\text { "Porque ela terá mais preparo } \\
\text { para mais desempenho" }\end{array}$ & 1 \\
\hline 21 & 8 & $n$ & 으 & $\begin{array}{l}\text { "Um atleta estava fazendo exercício de física e ai lê } \\
\text { começou a lembrar o que a professora dele falou } \\
\text { sobre biomecânica e sobre corpo humano, então o } \\
\text { atleta foi ao médico ver como ele estava a saúde } \\
\text { dele e ver se ele precisava fazer algum esporte, } \\
\text { então o medico falou que sim então quando ele } \\
\text { estava fazendo o esporte e acabou acontecendo uma } \\
\text { lesão no joelho e ficou pensando na vida e na } \\
\text { morte". }\end{array}$ & $\begin{array}{l}\text { "Que a física estuda os } \\
\text { movimentos e isso ajuda a } \\
\text { pratica esportiva para você } \\
\text { fazer os esportes". }\end{array}$ & $\begin{array}{l}\text { "Ele poderá saber sobre seus } \\
\text { movimentos e isso ajudará no } \\
\text { desempenho dele". }\end{array}$ & 1 \\
\hline
\end{tabular}




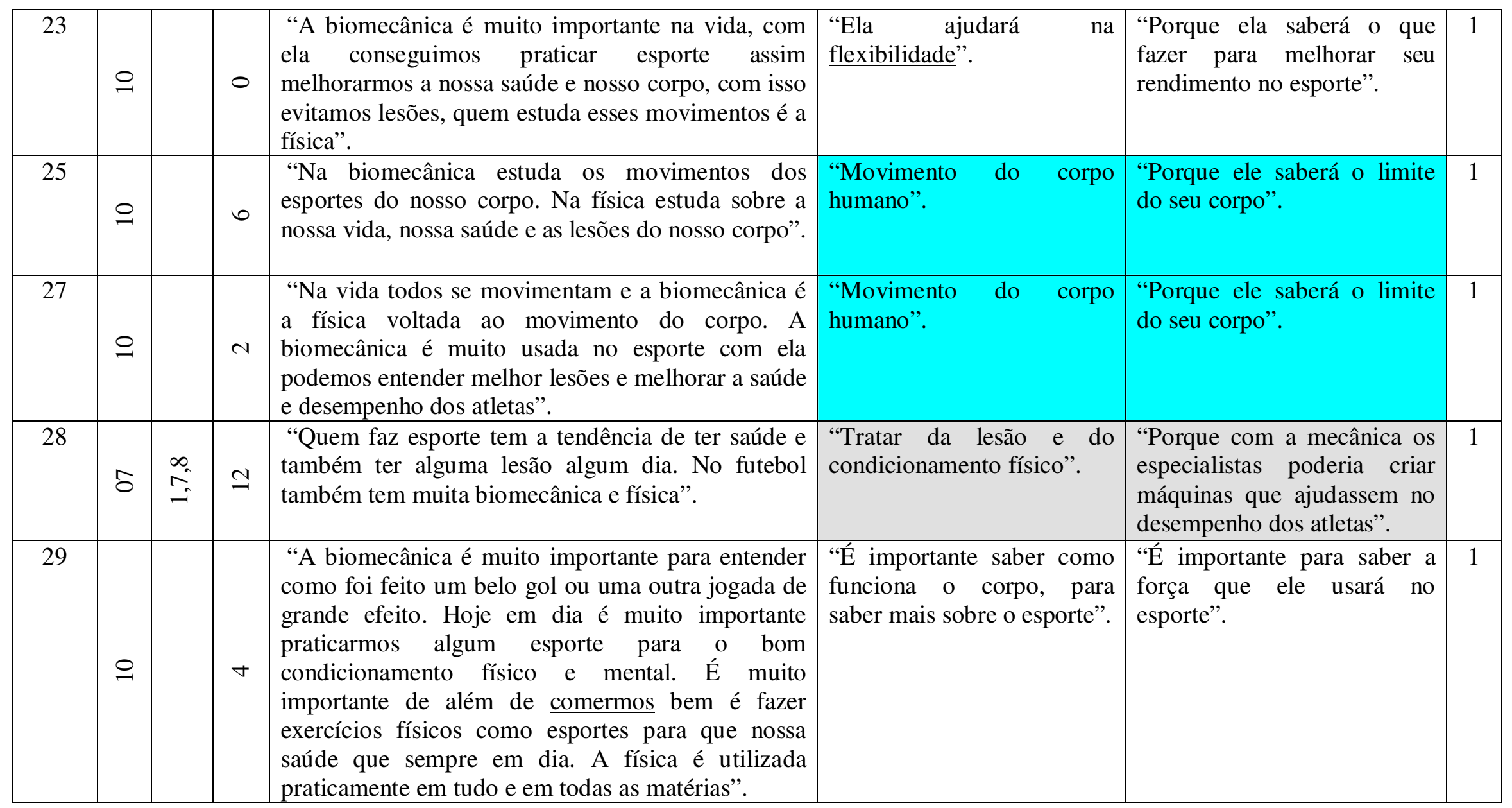




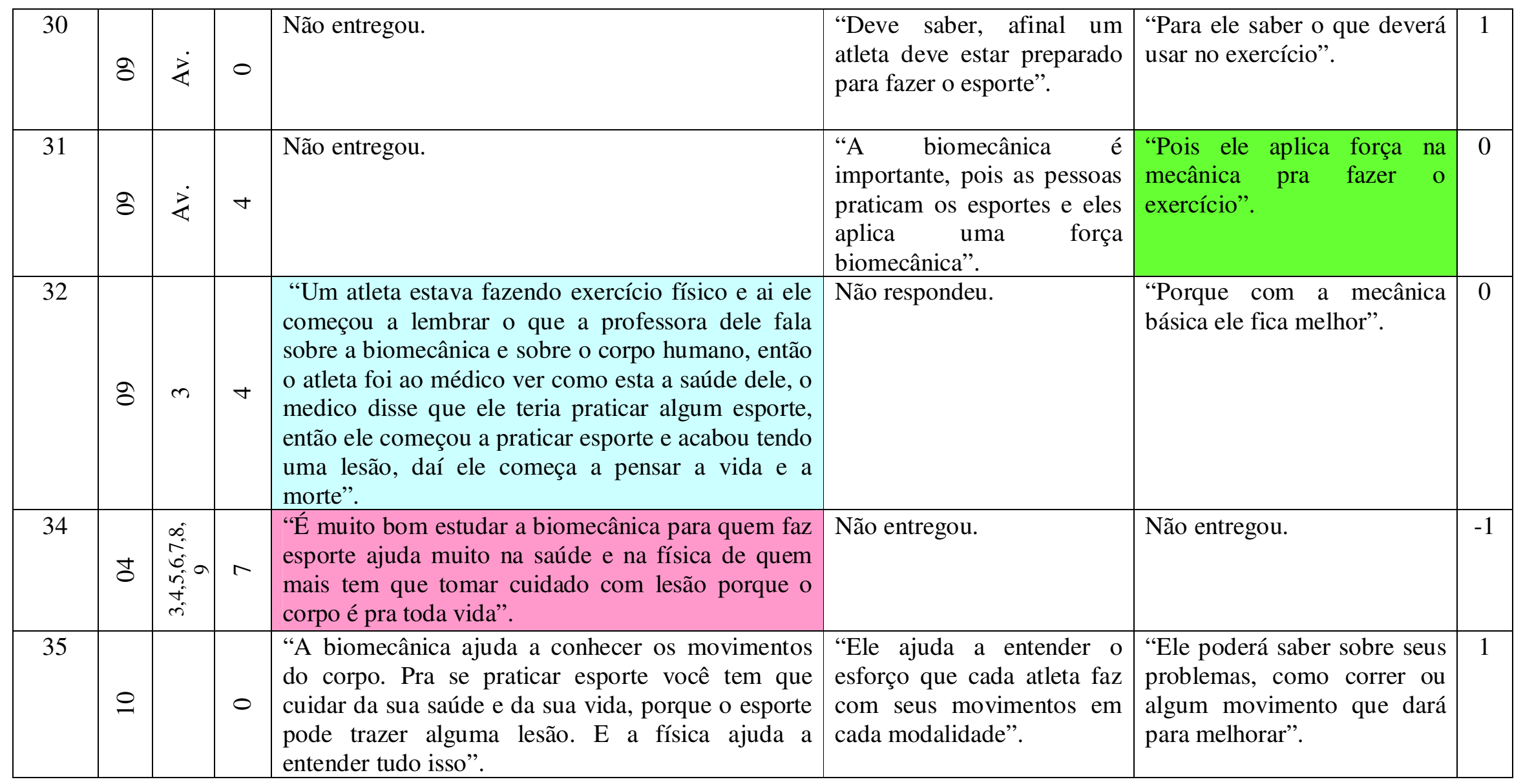




\begin{tabular}{|c|c|c|c|c|c|c|c|}
\hline 38 & 8 & $\infty$ & $\nabla$ & $\begin{array}{l}\text { "O esporte hoje em dia está sendo cada vez mais } \\
\text { comum na vida das pessoas. Através disso existe } \\
\text { também a biomecânica que estuda o movimento do } \\
\text { corpo humano. Além do esporte fazer bem para o } \\
\text { corpo humano é fundamental para a saúde do ser } \\
\text { humano, praticando de acordo com a necessidade } \\
\text { física de cada um, para que não ocorra nenhuma } \\
\text { lesão". }\end{array}$ & $\begin{array}{l}\text { "Movimento do corpo } \\
\text { humano". }\end{array}$ & $\begin{array}{l}\text { "Porque ele saberá o limite } \\
\text { do seu corpo". }\end{array}$ & 1 \\
\hline 39 & 으 & & 0 & $\begin{array}{l}\text { "É muito bom estudar a biomecânica para quem } \\
\text { faz esportes ajuda muito na saúde e na física de } \\
\text { quem pratica, mas tem que tomar cuidado com } \\
\text { lesão, porque o corpo é para toda vida". }\end{array}$ & $\begin{array}{l}\text { "A importância é que ajuda } \\
\text { a correr o tanto necessário } \\
\text { para cada esporte que o } \\
\text { atleta fizer". }\end{array}$ & $\begin{array}{l}\text { "Porque isso acha o tênis } \\
\text { certo que o atleta deve usar". }\end{array}$ & 1 \\
\hline 40 & J & $\begin{array}{l}\hat{a} \\
\infty \\
\hat{\theta} \\
\dot{\sigma} \\
\hat{i}\end{array}$ & 6 & $\begin{array}{l}\text { "A biomecânica é importante entender como } \\
\text { funciona a trajetória que a bola faz. O futebol é um } \\
\text { esporte muito bom que incentiva as pessoas a } \\
\text { participarem dele. É muito bom cuidar da saúde } \\
\text { comendo uma boa alimentação e fazendo } \\
\text { exercícios. A física estuda todo movimento do } \\
\text { homem. Em todo esporte você pode sofrer lesão. } \\
\text { Toda pessoa faz muito bem cuidar do corpo. É } \\
\text { importante na vida termos muita saúde". }\end{array}$ & & & 1 \\
\hline
\end{tabular}


As cores iguais na tabela 4.12 mostram as respostas similares dos estudantes, que após o mapeamento da sala (figura 4.9 e 4.10) percebemos que é por organização das carteiras (grupos), embora com pouca frequência os estudantes troquem de carteira e de grupo, mas por relatos da professora podemos dizer que é uma construção coletiva do conhecimento (A3.2.3). Embora as atividades fossem propostas individualmente os estudantes desta turma responderam as atividades em grupos, de acordo com o posicionamento das carteiras, que estão relacionados as afinidades entre os estudantes. De acordo com o mapeamento feito pelos estudantes e com os dados representados na tabela 4.12, observamos que os estudantes $\left(10, \mathrm{~A}_{2}\right)$ e $\left(20, \mathrm{~A}_{2}\right)-\left(28, \mathrm{~A}_{2}\right)$ e $\left(12, \mathrm{~A}_{2}\right)-$ $\left(31, \mathrm{~A}_{2}\right)$ e $\left(5, \mathrm{~A}_{2}\right)-\left(25, \mathrm{~A}_{2}\right)$ e $\left(26, \mathrm{~A}_{2}\right.$ - é o 27 no mapeamento da sala) sentam juntos, o que afirma o compartilhamento de respostas de acordo com grupos de afinidade.

\section{Mapeamento da turma $1^{\circ} \mathrm{A}_{2}$}

O mapeamento foi obtido pela respostas de 30 estudantes ao questionário de validação $\left(\mathrm{Q}_{3}\right)$ - seção 3.9. Ao analisar o mapa da classe elaborado pelos estudantes, a maioria nos surpreenderam, pois representaram as carteiras em posição de fileiras (figura 4.10), o que não é real, mas tivemos alguns estudantes que ilustraram em detalhes a sala de aula (figura 4.9 e 4.10 ), observe que um mapa complementa o outro.

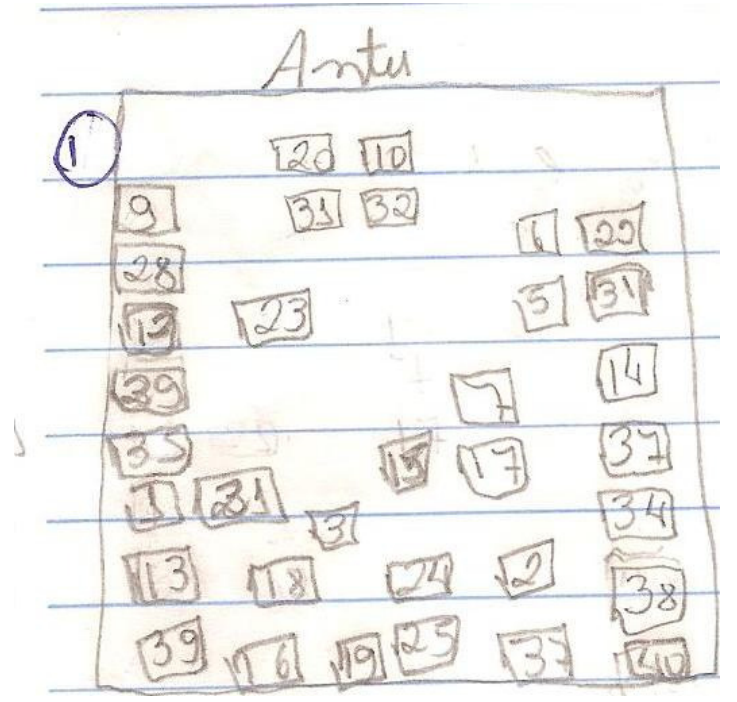

Figura 4.9: Mapa da turma $1^{\circ} \mathrm{A}_{2}$ - feito pelo aluno (32, $\left.\mathrm{A}_{2}\right)$. 


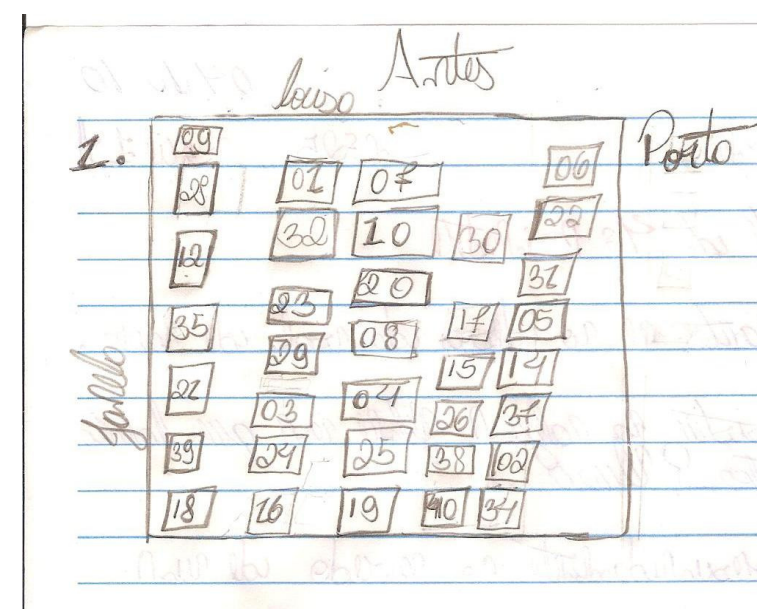

Figura 4.10: Mapa da turma $1^{\circ} \mathrm{A}_{2}$ - feito pelo aluno $\left(25, \mathrm{~A}_{2}\right)$.

\section{Classificação}

De acordo com as categorias elaboradas a posteriori, pudemos mapear a complexificação do conhecimento de esporte e verificar que a maioria dos estudantes conseguiu relacionar esporte e física ( tabela abaixo).

Tabela 4. 13: Graus de complexidade atingidos na turma $1^{\circ} \mathrm{A}$ da escola $\mathrm{G}$.

\begin{tabular}{|c|c|}
\hline Grau de complexidade & Porcentagem (\%) \\
\hline Grau -2 & 22 \\
\hline Grau -1 & 7,3 \\
\hline Grau 0 & 12,2 \\
\hline Grau 1 & 58,3 \\
\hline
\end{tabular}

Observe a figura 4.11:

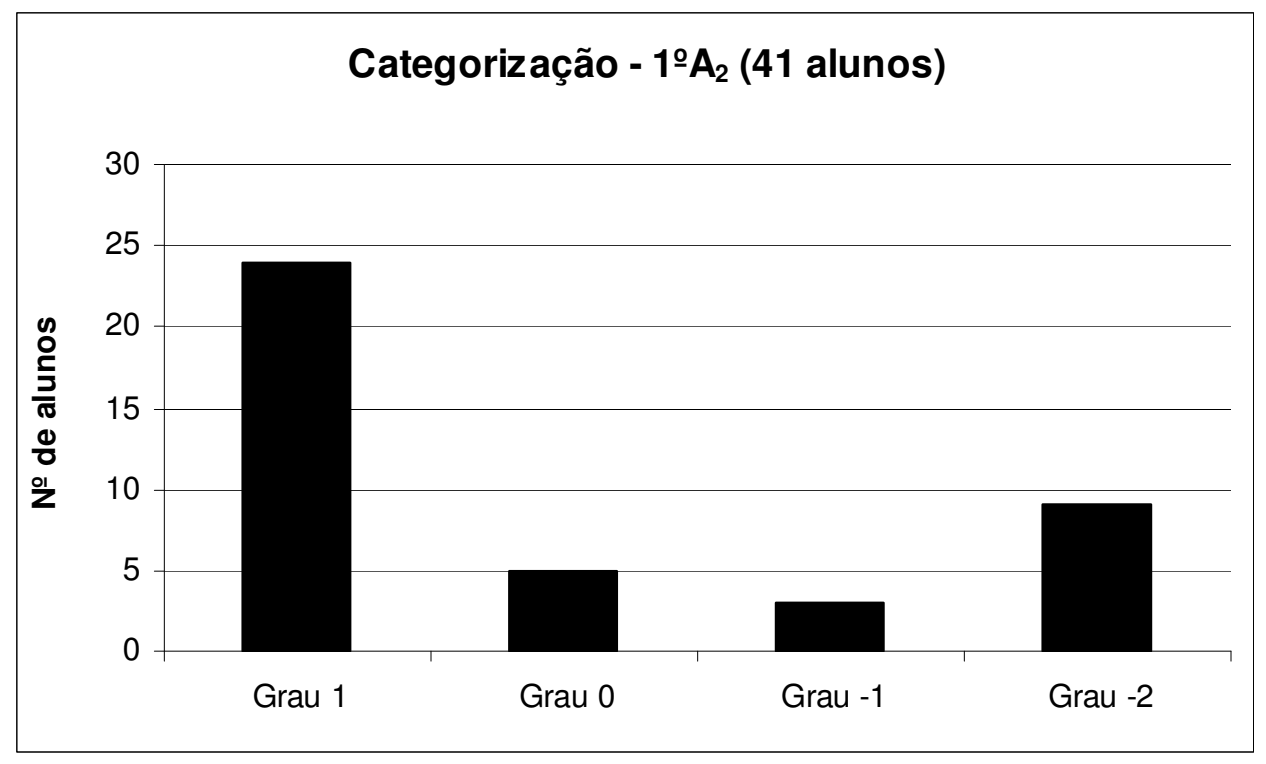

Figura 4.11: Complexificação do conhecimento de $1^{\circ} \mathrm{A}_{2}$. 
Os estudantes tiveram o primeiro contato com a palavra biomecânica na atividade 3 da intervenção. Depois o termo biomecânica apareceu implícito nas outras atividades e explícito na atividade 9. Na atividade 3 contém um texto que explica o que é, e para que serve a biomecânica e nesta atividade os estudantes tinham que responder a algumas questões. Os estudantes nestas questões apenas transcreveram trechos do texto nas respostas (tabela 4.14).

Tabela 4.14: Respostas do $1^{\circ} \mathrm{A}_{2}$ da escola $\mathrm{G}$ para atividade 3 .

\section{Atividade 3}

Q.4: De que forma a "ciência" pode ajudar um técnico a melhorar o desempenho de um atleta?

Q.5c: Complete a frase: A biomecânica pode ajudar a....

Q.5d: A biomecânica pode ajudar a corrigir os movimentos de um atleta para melhorar seu desempenho? De que forma?

\begin{tabular}{|c|l|}
\hline Aluno & \multicolumn{1}{c|}{ Resposta } \\
\hline \multirow{3}{*}{05} & $\begin{array}{l}\text { (Q.4) "Com as informações do corpo humano". } \\
(\mathrm{Q} .5 \mathrm{c}) \text { "Ajuda nas habilidades e movimento do corpo humano". } \\
(\mathrm{Q} .5 \mathrm{~d}) \text { "Pode ter uma opinião melhor do atleta". }\end{array}$ \\
\hline \multirow{2}{*}{13} & $\begin{array}{l}\text { (Q.4) "No modo, tênis, posição, etc.". } \\
\text { (Q.5c) "Ajuda a explicação da mecânica aos sistema biológicos". } \\
\text { (Q.5d) "Sim, porque estuda os movimentos e assim pode encontrar a maneira } \\
\text { mais correta para o atleta". }\end{array}$ \\
\hline 38 & $\begin{array}{l}\text { (Q.4) "Descobrindo a capacidade física do atleta". } \\
(\mathrm{Q} .5 \mathrm{c}) \text { "Avaliar o efeito da força sobre os atletas". } \\
\text { (Q.5d) "Sim estimulante o movimento muscular do corpo". }\end{array}$ \\
\hline
\end{tabular}

Se compararmos com as respostas obtidas na questão 1 da atividade avaliatória (tabela 4.12), os dados da tabela 4.14 corroboram e fornecem mais evidências da complexificação do conhecimento de esporte dos estudantes.

Para completar os dados, na turma $1^{\circ} \mathrm{A}_{2}$ atentamos para outras questões de outras atividades da intervenção que possibilitassem analisar se o estudante aplica as novas zonas do perfil conceitual de esporte em outro contexto. A tabela 4.15 trás a comparação das respostas a questão 1 da atividade 1 que se repete na questão 12 da atividade 9. Verificamos que os estudantes passam a aplicar os conceitos contidos na intervenção que antes não eram relevantes, pois associavam o técnico esportivo apenas à vitória da competição (que também faz parte da responsabilidade de um técnico), e 
agora atentam também para o desempenho (movimentos corretos) associado a saúde do atleta (ausência de lesões).

Observe que dentre as repostas o estudante 6, continua falando de vitória, mas também engloba outros fatores (complexifica o conhecimento) demonstrando não somente as zonas novas do perfil conceitual de esporte, mas englobando com as já existentes.

Tabela 4.15: Comparação de questões das atividades 1 (antes) e 9 (depois) - $1^{\circ} \mathrm{A}_{2}$ - escola G.

\begin{tabular}{|c|c|c|}
\hline & $\begin{array}{c}\text { Atividade 1 } \\
\text { Q.1: Quais são as maiores } \\
\text { responsabilidades de um técnico de } \\
\text { qualquer modalidade esportiva? }\end{array}$ & $\begin{array}{c}\text { Atividade } 9 \\
\text { Q.12: Quais são as maiores } \\
\text { responsabilidades de um técnico de } \\
\text { qualquer modalidade esportiva? }\end{array}$ \\
\hline Aluno & Resposta & Resposta \\
\hline 02 & "Coordenar a sua equipe para vitória". & $\begin{array}{l}\text { "É que ele deve aperfeiçoar o atleta } \\
\text { para não ter nenhuma lesão". }\end{array}$ \\
\hline 04 & $\begin{array}{l}\text { "Comandar o time, deixando-os } \\
\text { prontos para o que vier". }\end{array}$ & $\begin{array}{l}\text { "Ficar atento no rendimento dos } \\
\text { atletas, resolver os problemas } \\
\text { individualmente". }\end{array}$ \\
\hline 06 & $\begin{array}{l}\text { "Acompanhar a saúde do atleta e saber } \\
\text { lidar com eles e com a modalidade } \\
\text { esportiva". }\end{array}$ & $\begin{array}{l}\text { "Todo técnico treina o atleta para } \\
\text { vencer, mas aplica todas as técnicas } \\
\text { precisas para que o atleta tenha um } \\
\text { bom desempenho". }\end{array}$ \\
\hline 15 & $\begin{array}{l}\text { "Primeiramente coordenar o time, a } \\
\text { posição de acordo com cada jogador, e } \\
\text { dar dura no time que só assim ele irá } \\
\text { ter resultado". }\end{array}$ & $\begin{array}{l}\text { "Treinar seu atleta para que não } \\
\text { tenha erros na hora de praticar o } \\
\text { esporte seja qual for". }\end{array}$ \\
\hline 20 & $\begin{array}{l}\text { "Saber coordenar seu time e os } \\
\text { jogadores e conhecer bem a } \\
\text { modalidade que ele vai coordenar com } \\
\text { seu time". }\end{array}$ & $\begin{array}{l}\text { "Ele tem que analisar o desempenho } \\
\text { e a técnica do atleta". }\end{array}$ \\
\hline 22 & $\begin{array}{l}\text { "De treinar bem sua equipe para } \\
\text { demonstrar que ele é um bom técnico". }\end{array}$ & $\begin{array}{l}\text { "É treinar seu atleta para vencer e } \\
\text { também aplicar todas as técnicas } \\
\text { precisas para que seu atleta tenha um } \\
\text { bom desempenho". }\end{array}$ \\
\hline 30 & $\begin{array}{l}\text { "Ele tem que dar o melhor de si para } \\
\text { vencer sempre, caso seu atleta perca, } \\
\text { toda responsabilidade cairá no } \\
\text { técnico". }\end{array}$ & $\begin{array}{l}\text { "Fazer o atleta ter um bom } \\
\text { desempenho". }\end{array}$ \\
\hline 31 & $\begin{array}{l}\text { "Ensinar e ver os erros que são } \\
\text { cometidos, como exemplo no futebol, o } \\
\text { técnico deve ter a capacidade de } \\
\text { ensinar e criticar seus jogadores". }\end{array}$ & $\begin{array}{l}\text { "Saber o que fazer, ensinar e o mais } \\
\text { importante, cuidado com a saúde". }\end{array}$ \\
\hline 35 & $\begin{array}{l}\text { "Ele tem que ter compromisso com } \\
\text { seus atletas e saber o que vai passar e } \\
\text { tem que ter calma". }\end{array}$ & $\begin{array}{l}\text { "Ele tem que falar onde o atleta está } \\
\text { errando e o que ele deve fazer certo". }\end{array}$ \\
\hline
\end{tabular}


A prática esportiva está diretamente relacionada à saúde, mas não podemos apenas associá-la à benefícios, pois sua prática inadequada trás lesões ao ser humano, portanto temos que atentar para os movimentos adequados a prática esportiva escolhida. Visando analisar se o estudante compreendeu a relação saúde e esporte fizemos a comparação de algumas questões da atividade 2 com a atividade 9 e verificamos que o estudante complexifica o conhecimento de esporte, adicionando ao seu perfil conceitual novos conceitos.

Tabela 4.16: Comparação de questões das atividades 1 e 9 - $1^{\circ} \mathrm{A}_{2}$ - escola $\mathrm{G}$.

\begin{tabular}{|c|c|c|}
\hline & $\begin{array}{c}\text { Atividade } 2 \\
\text { Q.10b: Qualquer pessoa no momento } \\
\text { em que quiser, pode praticar esporte? } \\
\text { Por quê? } \\
\text { Q10c: Quais os cuidados que devemos } \\
\text { ter ao praticar exercícios físicos? }\end{array}$ & $\begin{array}{c}\text { Atividade } 9 \\
\text { Q.2: Que cuidados devemos ter ao } \\
\text { iniciar uma atividade física? } \\
\text { Q.7: Quais os cuidados que } \\
\text { devemos ter ao praticar exercícios } \\
\text { físicos? }\end{array}$ \\
\hline Aluno & Resposta & Resposta \\
\hline 04 & $\begin{array}{l}\text { (Q.10b) "Sim porque não vai prejudicar } \\
\text { a pessoa". } \\
\text { (Q.10c) "Fazer aquecimento antes". }\end{array}$ & $\begin{array}{l}\text { (Q.2) "Se alongar antes". } \\
\text { (Q.7) "Cuidado para não se esforçar } \\
\text { demais e causar alguma lesão". }\end{array}$ \\
\hline 22 & $\begin{array}{l}\text { (Q.10b) "depende se a pessoa não tiver } \\
\text { um preparo ela tem que praticar aos } \\
\text { poucos". } \\
\text { (Q.10c) "Pegar leve e sempre fazer } \\
\text { alongamentos". }\end{array}$ & $\begin{array}{l}\text { (Q.2) "Se alonga antes de praticar } \\
\text { qualquer atividade física e tomar } \\
\text { cuidado quando estiver praticando o } \\
\text { esporte para não ter lesões". } \\
\text { (Q.7) "Ter cuidado para não } \\
\text { sofrermos uma lesão durante o } \\
\text { exercício físico". }\end{array}$ \\
\hline 29 & $\begin{array}{l}\text { (Q.10b) "Sim qualquer pessoa pode } \\
\text { praticar esporte mesmo sendo gordo, } \\
\text { magro, porque para o esporte não tem } \\
\text { idade peso e tamanho é sempre bom". } \\
\text { (Q.10c) "Não fazer exercícios físicos } \\
\text { em excesso porque pode trazer } \\
\text { problemas cardíacos". }\end{array}$ & $\begin{array}{l}\text { (Q.2) "Ter um preparo físico, } \\
\text { treinamento e } \underline{\text { alongamento". }} \\
\text { (Q.7) "Tomar cuidado com lesões e } \\
\text { mal alimentação e mal preparo } \\
\text { físico". }\end{array}$ \\
\hline
\end{tabular}

\section{Relação física e educação física}

$\mathrm{Na}$ tabela 4.12 sublinhamos algumas palavras que evidenciam que alguns estudantes associam os conteúdos da disciplina de educação física aos de física. $\mathrm{O}$ professor de educação física desta turma nos relatou por entrevista informal que em suas aulas insiste em falar da importância do alongamento antes de qualquer atividade física para evitar lesões. Além disso, está apresentando modalidades esportivas que não são 
comuns aos estudantes como rúgbi e futebol americano citadas pelos estudantes. Nas respostas ao questionário de validação (seção 4.5) percebemos que a maioria dos estudantes passou a construir a ponte interdisciplinar entre física e educação física.

\section{Relação professora-aluno}

Para obtermos mais informações sobre o relacionamento da turma $1^{\circ} \mathrm{A}_{2}$ com a professora e avaliar a metodologia utilizada na intervenção + caderno de física vol. 1 e 2, elaboramos um questionário com 10 questões, que denominamos de questionário de opinião. Nesta turma pedimos para os estudantes não se identificassem, com objetivo de deixá-los mais livres para colocarem suas opiniões. Esse questionário foi aplicado pela professora eventual de língua portuguesa da escola, observe a tabela 4.17:

Tabela 4.17: Questionário de Opinião das aulas - $1^{\circ} \mathrm{A}_{2}$ - escola G.

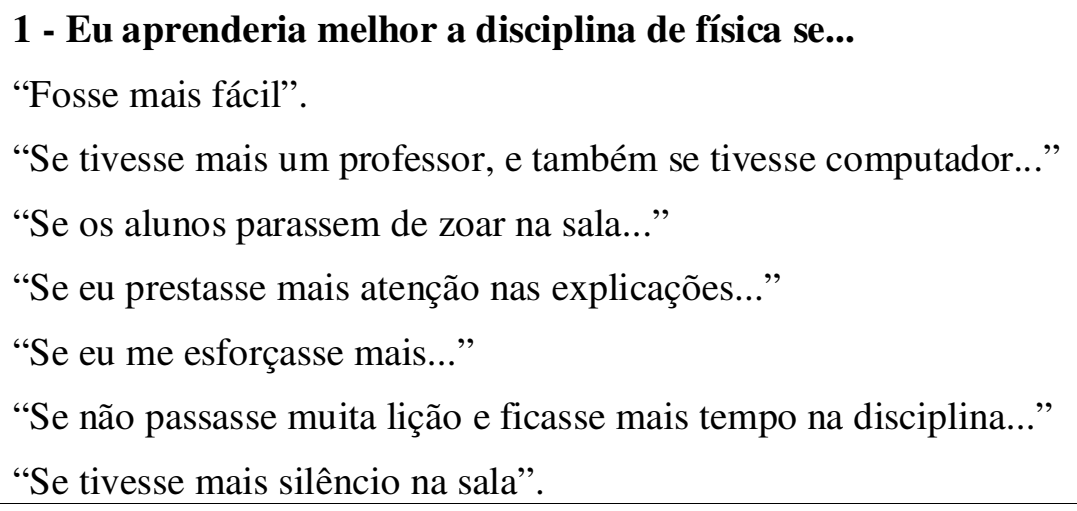

"É boa porque a gente não precisa copiar muita coisa, mas também é ruim porque as perguntas são difíceis e complicadas e tem muitas contas". 
"Mais ou menos, não aprendo muito com a apostila e sim com a explicação da professora".

"Legal, gostei das experiências, mas mesmo assim acho que certas experiências são ruins porque eles falam para conseguir alguns materiais que são difíceis de achar".

"Mais fáceis de entender que as lições da lousa".

"Complicada pois há algumas atividades que não consigo entender".

"Boa, porque não precisa copiar da lousa".

"Boa, mas precisamos da ajuda do professor para responder".

"Não gosto muito da apostila".

\section{4 - A professora de física é...}

"gente boa às vezes, mas às vezes ela é chata porque quer passar prova quando algum aluno interrompe quando ela está explicando".

"legal, mas ela passa lição muito rápido..."

"legal, pois deixa terminar as lições depois..."

"muito organizada com trabalhos e notas..."

"é nervosa se ela tiver explicando e a sala bagunçando, ela já passa prova..."

“...legal. Não grita, não xinga e não manda o aluno para fora...”

"...é chata, nunca falta..."

5 - A professora de física devia...

"Conversar mais com os alunos..."

"Tirar alguns alunos da sala..."

"Passar menos lição..."

"Dar mais atividades da apostila..."

"Fazer mais atividade de interação..."

6 - Eu gosto da escola porque...

"Vai ser alguma coisa importante na minha vida..."

"Porque aprendo coisas novas e encontro pessoas diferentes".

"É um lugar que posso ficar um pouco longe de casa e ver os amigos".

"Porque posso ver meus amigos".

"Fico longe de casa".

\section{7 - Eu odeio a escola porque...}

"Eu não odeio a escola..."

"Por causa de matemática..."

"As vezes não tenho vontade de vir, é muito tempo..."

"É muito barulho, calor..."

"Pela falta de respeito dos alunos..." 


\section{8 - Eu não gosto quando a professora de física...}

“Começa a passar lição sem falar nada, ela entra e já passa lição...”

"Dá muita coisa, ai não dá tempo de fazer..."

"Fala que vai passar prova..."

"Passa muita lição na lousa, ao invés da apostila".

"Passa lição na lousa com letra pequena e rápido..."

"Passa ao mesmo tempo lição na lousa, da apostila e do caderninho, não dá tempo..."

\section{9 - Para melhorar as aulas de física a professora deve...}

"Ser mais autoritária com os alunos..."

"Fazer menos conta..."

"Dar um jeito nos alunos que atrapalham a aula..."

"Deixar um pouco a lousa..."

"Passar menos lição..."

10 - Um bom aluno, deve nas aulas de física...

"Prestar atenção..."

"Fazer a lição..."

"Respeitar o professor..."

"Fazer todas as atividades da lousa, da apostila e do caderninho".

"Calar a boca e fazer o que a professora passa".

Pudemos perceber pelos relatos dos estudantes no questionário de opinião (tabela 4.17) que a professora possui um comportamento atípico aos demais professores que lecionam na escola $\mathrm{G}$ e $\mathrm{M}$, pois é muito centrada no conteúdo das aulas, não se permitindo estabelecer conversas paralelas ao conteúdo, e isto gera aplicação de atividades em demasiado aos estudantes, que se sentem sufocados. Mas ao mesmo tempo em que a professora exige muitas atividades, também é um pouco flexível quanto ao prazo de entrega das atividades. Percebemos que no contrato didático estabelecido no primeiro dia de aula (anexo A3.2.3) é bastante citado, que a conversa na hora da explicação resulta em prova. Os estudantes também reclamam dos alunos do grupo B (indisciplinados), mas o que impera é o fato das excessivas atividades por aula.

Para comparação temos um curto relato da professora sobre sua relação com a sala: “Meu relacionamento é bom, me estresso bem pouco nesta sala, a maioria estão preocupados em desenvolver as tarefas, mas claro que há alunos bagunceiros, o que 
de certa forma, descontraem a sala. Ficam quietos nas minhas explicações, embora conversem muito alto durante a realização das tarefas" (Anexo A3.2.3).

Nesta fala da professora percebemos que ela não enxerga os alunos do grupo B como o principal problema da turma (oposto aos estudantes), pois no global a turma inteira é falante durante as aulas, mas isso não impede que a professora mantenha uma boa relação com a turma.

Quanto ao caderno de física do aluno, a maioria dos estudantes (dentre os que aprovam e reprovam) enfatizam a facilidade em não ter que copiar na lousa, e outros adicionam a importância do professor para o entendimento das situações de aprendizagem.

Quanto às atividades de intervenção, os estudantes (dentre os que aprovam e reprovam) enfatizam a extensão das atividades e das questões e a dificuldade em interpretar tanto os textos quanto as questões, mas elogiam quanto à facilidade em entender o conteúdo.

\section{Casos Particulares}

- Alunos do grupo A

$\mathrm{Na}$ turma $1^{\circ} \mathrm{A}_{2}$, encontramos a classe de alunos que enquadramos no grupo $\mathrm{A}$. Esta categoria de estudantes serve para enquadrar os alunos que estão em sala de aula (corpo presente), mas ao mesmo tempo tão longe (atenção voltada a outros assuntos). Encontram-se quietos em sala de aula não interagem com outros estudantes, não participam da aula, mas fazem as atividades, estão apáticos. Muitas vezes esta característica vem junto com a dificuldade de aprendizado, como é o caso do aluno $\left(7, \mathrm{~A}_{2}\right)$ e $\left(17, \mathrm{~A}_{2}\right)$ - sentam juntos - fig. 4.9 e 4.10 embora tenhamos nos surpreendido com o aluno $\left(17, \mathrm{~A}_{2}\right)$ que ficou classificado no grau 1 de complexidade.

- Alunos do grupo B

$\mathrm{Na}$ turma $1^{\circ} \mathrm{A}_{2}$, encontramos também a classe de alunos que nomeamos de “alunos do grupo B". Esta categoria de estudantes serve para enquadrar os alunos que estão sempre presentes na sala de aula, mas preferem conversar, tirar a concentração dos outros alunos, enfim bagunçar e por consequência não consegue assimilar os conteúdos das aulas, portanto não possuem a habilidade de, ao mesmo tempo, bagunçar e prestar 
atenção nas aulas. Temos como exemplo os alunos $\left(3, \mathrm{~A}_{2}\right),\left(15 \mathrm{~A}_{2}\right),\left(16 \mathrm{~A}_{2}\right),\left(18, \mathrm{~A}_{2}\right)$, $\left(34, \mathrm{~A}_{2}\right)$ sentam próximos - fig. 4.9 e 4.10 que foram enquadrados na categoria 0 , exceto pelo aluno $\left(15, \mathrm{~A}_{2}\right)$ que foi classificado no grau 1 de complexidade.

\subsubsection{Turma $1^{\circ} B_{2}$}

A turma $1^{\circ} B_{2}$, referente a escola $\mathrm{G}$ é composta por 41 alunos, sendo que dentre eles analisamos as respostas de apenas 36 alunos, pois no decorrer do semestre tivemos algumas transferências de classe e de escola e alguns abandonos de curso. Nesta turma eram ministradas duas aulas consecutivas no mesmo dia as segundas-feiras, a $3^{\mathrm{a}}$ e $4^{\mathrm{a}}$ aula do período da tarde.

A aplicação da intervenção na turma $1^{\circ} \mathrm{B}_{2}$ seguiu inicialmente o plano de aula (tabela 3.14) que prevê o término da intervenção em junho (fim do $1^{\circ}$ semestre), mas durante a aplicação sofreram mudanças devido a imprevistos no calendário escolar, a frequência dos estudantes na aula, reuniões internas, etc. Como a turma $1^{\circ} \mathrm{B}_{2}$ tem as 2 aulas de física no mesmo dia da semana como a turma $1^{\circ} \mathrm{A}_{2} \mathrm{o}$ diário de classe da professora é similar (tabela 4.11).

Durante a aplicação das atividades contabilizamos 48 aulas de física, mas ministramos a intervenção em 38 aulas. A diferença de 10 aulas inclui: reunião de pais com alunos, palestras, jogo da copa assistido na escola, campeonato de futebol entre as turmas da escola, etc. Lembramos que no plano de aula (tabela 3.14) estabelecemos 23 aulas para toda a intervenção, mas verificamos que esta turma segue um ritmo mais lento na realização de tarefas.

$\mathrm{Na}$ figura 4.12 observamos que a média dos alunos presentes, equivale aos alunos frequentes durante toda a intervenção na turma $1{ }^{\circ} \mathrm{B}_{2}$, ou seja, os estudantes são os mesmo, não revezam a presença nas aulas. É relevante destacar uma frequência um pouco baixa no dia 5 de julho, devido a data anteceder as férias de julho, porém foi recuperada em seguida. 


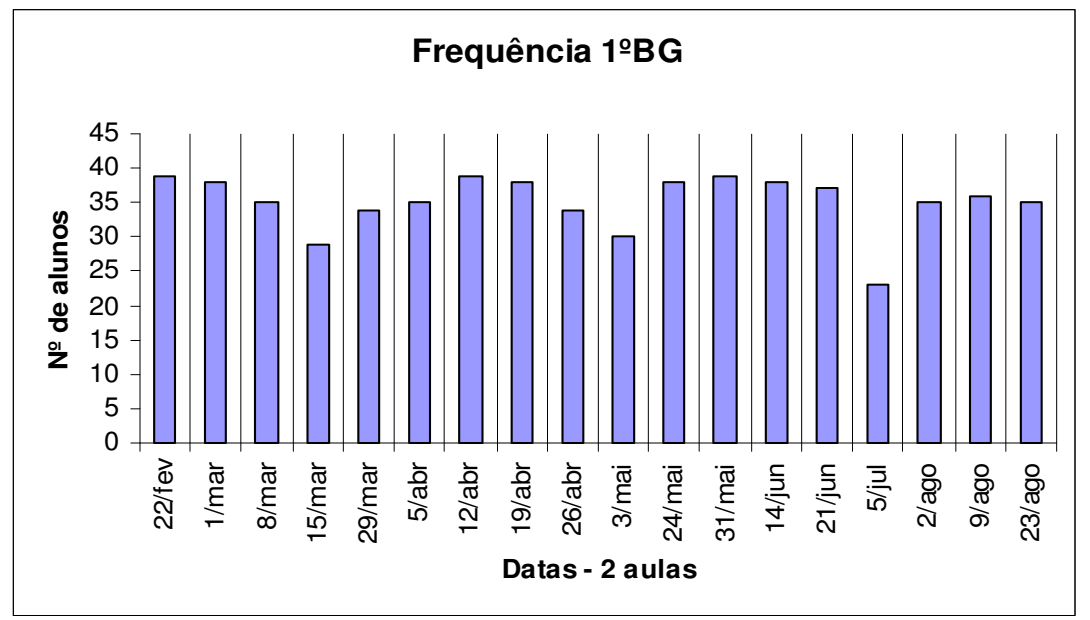

Figura 4.12: Atividade e frequência da turma $1^{\circ} \mathrm{B}_{2}$.

$\mathrm{Na}$ atividade 1, com a questão 7, os estudantes descrevem as disciplinas escolares que mais identificam com o esporte, pudemos verificar se os estudantes já estabelecem alguma relação entre a disciplina de física e o esporte. Observe na figura 4.13 que a disciplina de educação física aparece em $1^{\circ}$ lugar, a disciplina de matemática em $2^{\circ}$ lugar e a disciplina de física em $3^{\circ}$ lugar. Mas mesmo com a modificação realizada na questão após a atividade piloto, continuamos com alguns estudantes citando as disciplinas de inglês, língua portuguesa entre outras primordiais para comunicação do atleta no Brasil e em outros paises. Observe que nesta turma há um número razoável de estudantes citando a disciplina de sociologia, pois os estudantes alegam que os atletas devem se relacionar bem entre si, saber viver em sociedade.

Questão 7: Será que algumas das disciplinas (I, P, G, H, M, Q, B, F, EF, EA, Fil, So) que você tem na escola podem ajudar um atleta a ter um bom desempenho? Cite pelo menos quatro disciplinas (coloque em ordem de importância), e explique como ela será útil para análise de uma prática esportiva. Para facilitar complete a tabela abaixo:

\begin{tabular}{|l|l|l|l|}
\hline & Disciplina & $\begin{array}{l}\text { Conteúdo } \\
\text { específico da disciplina }\end{array}$ & Auxilia ... \\
\hline Exemplo & Artes & Técnicas de Pintura & $\begin{array}{l}\text { Dar harmonia as cores no } \\
\text { quadro }\end{array}$ \\
\hline $1^{a}$ & & & \\
\hline $2^{a}$ & & & \\
\hline $3^{a}$ & & & \\
\hline $4^{a}$ & & & \\
\hline
\end{tabular}




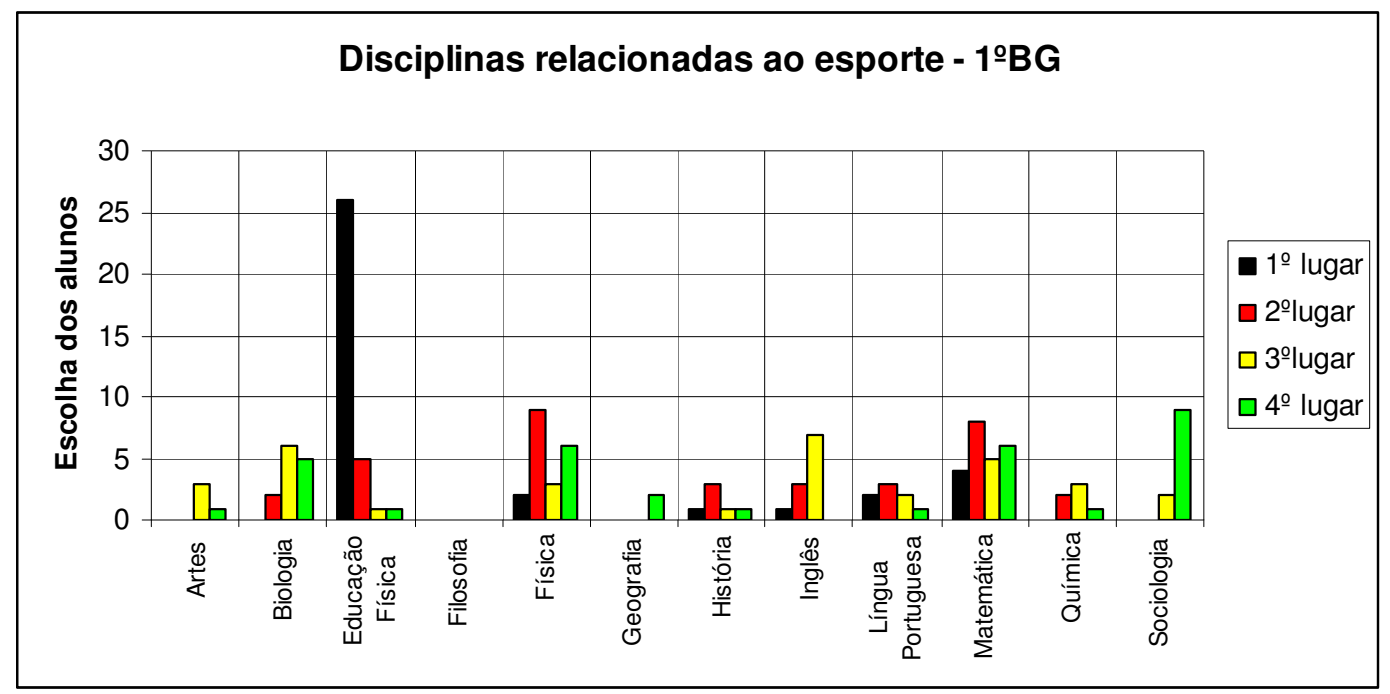

Figura 4.13: Posições das disciplinas - turma $\mathrm{B}_{2}$.

Mostramos nas tabelas 4.18. a 4.21 algumas respostas dos alunos de algumas questões e atividades selecionadas (tabela 3.19), cujo é possível analisar a complexificação do conhecimento de esporte.

A tabela 4.18 traz a quantidade: de atividades entregues, atividades que faltaram, de faltas durante o período de aplicação da intervenção e as respostas dos estudantes a questão 5 e 8 da atividade 9 e a questão 1 da atividade avaliatória, que nos informam sobre a complexificação do conhecimento de esporte. 
Tabela 4.18: Comparação de questões das atividades $-1^{\circ} \mathrm{B}_{2}-$ escola $\mathrm{G}$.

\begin{tabular}{|c|c|c|c|c|c|c|c|}
\hline 冚畩 & 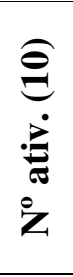 & 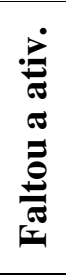 & 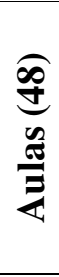 & $\begin{array}{l}\text { Atividade Avaliatória } \\
\text { Q.1: Formule um texto, uma frase ou uma história } \\
\text { que contenha obrigatoriamente (no singular ou } \\
\text { plural) as palavras: biomecânica, esporte, saúde, } \\
\text { física, lesão, corpo e vida. }\end{array}$ & $\begin{array}{l}\text { Atividade } 9 \\
\text { Q.5: Qual a importância da } \\
\text { biomecânica para prática } \\
\text { esportiva? }\end{array}$ & $\begin{array}{l}\text { Atividade } 9 \\
\text { Q.8: Por que uma } \\
\text { compreensão básica dos } \\
\text { princípios mecânicos básicos } \\
\text { ajudará o atleta a ter um } \\
\text { melhor desempenho? }\end{array}$ & שֶ \\
\hline 01 & $\stackrel{\infty}{\circ}$ & $\begin{array}{l}\gtrless \\
i\end{array}$ & 0 & Não entregou. & $\begin{array}{l}\text { "Ajuda a melhorar os } \\
\text { movimentos do corpo, } \\
\text { evitando várias lesões". }\end{array}$ & Não respondeu. & 0 \\
\hline 02 & 8 & $\nabla$ & 0 & $\begin{array}{l}\text { "A biomecânica tem grande importância na física e } \\
\text { é usada para melhorar os movimentos de um atleta e } \\
\text { evitar lesões. Assim o atleta pode praticar seus } \\
\text { esportes, ter mais saúde e vida". }\end{array}$ & $\begin{array}{l}\text { "Ajuda a melhorar os } \\
\text { movimentos do corpo na } \\
\text { prática esportiva, evitando } \\
\text { lesões". }\end{array}$ & $\begin{array}{l}\text { "Porque ele irá conhecer } \\
\text { melhor o seu corpo e suas } \\
\text { limitações". }\end{array}$ & 1 \\
\hline 04 & $\stackrel{0}{ }$ & & $\infty$ & $\begin{array}{l}\text { "O corpo de um atleta que pratica esporte, } \\
\text { geralmente tem saúde, através da física pode dar } \\
\text { vida para um atleta que com uma lesão perde parte } \\
\text { do corpo, perna braço, etc. entra a parte da } \\
\text { biomecânica que dá mobilidade a essa parte } \\
\text { colocando a parte do corpo". }\end{array}$ & $\begin{array}{l}\text { "Muitas e muitas pessoas } \\
\text { perdem alguma parte do } \\
\text { corpo e com a ajuda da } \\
\text { biomecânica } \\
\text { continuar a pode } \\
\text { esporte". }\end{array}$ & "Ele sabe até aonde pode ir". & 1 \\
\hline 05 & $\stackrel{\infty}{\circ}$ & $\stackrel{n}{i}$ & $\nabla$ & $\begin{array}{l}\text { "A Andressa foi da um dible na Gabriela e a } \\
\text { Gabriela sofreu uma lesão muito grave. A Cássia } \\
\text { tem uma saúde muito boa e se ela continua assim a } \\
\text { vida dela vai ser muito boa e então o corpo dela } \\
\text { ainda melhor. Mas a Cássia se fazer muita física ela } \\
\text { fica doente". }\end{array}$ & $\begin{array}{l}\text { "Porque ajuda a melhorar } \\
\text { os movimentos do corpo". }\end{array}$ & Não respondeu. & 1 \\
\hline
\end{tabular}




\begin{tabular}{|c|c|c|c|c|c|c|c|}
\hline 06 & 은 & & N & $\begin{array}{l}\text { "A biomecânica faz parte da nossa vida são os } \\
\text { nossos movimentos. Para se ter saúde é preciso } \\
\text { praticar esportes, atividade física, ter alimentação } \\
\text { balanceada entre outras coisas. Isso serve para se ter } \\
\text { um corpo saudável e uma vida longa. Só tome } \\
\text { cuidado com o esforço na hora da prática de } \\
\text { exercícios físicos para não ter contusões e lesões". }\end{array}$ & $\begin{array}{l}\text { "Ajuda a melhorar os } \\
\text { movimentos do corpo na } \\
\text { prática esportiva, evitando } \\
\text { lesões". }\end{array}$ & $\begin{array}{l}\text { "Porque ele irá conhecer } \\
\text { melhor o seu corpo e suas } \\
\text { limitações". }\end{array}$ & 1 \\
\hline 07 & 으 & & $\infty$ & $\begin{array}{l}\text { "Biomecânica para melhorar o funcionamento do } \\
\text { corpo praticando vários tipos de esporte para ajudar } \\
\text { também com a saúde, praticar atividade física, } \\
\text { também ajuda com o nosso corpo, mas antes temos } \\
\text { que se alongar, para não ter lesão. Fazer e praticar } \\
\text { atividade física nos ajuda a ter uma vida saudável". }\end{array}$ & $\begin{array}{l}\text { "É importante porque } \\
\text { assim para saber se o atleta } \\
\text { está preparado para } \\
\text { competir". }\end{array}$ & $\begin{array}{l}\text { "Porque dirá se o atleta está } \\
\text { em condição de fazer a } \\
\text { modalidade". }\end{array}$ & 1 \\
\hline 08 & $\stackrel{\infty}{\circ}$ & $\begin{array}{l}\dot{\psi} \\
\text { in } \\
\text { i }\end{array}$ & 6 & Não entregou. & $\begin{array}{l}\text { "Pois a biomecânica } \\
\text { envolve toda a parte de } \\
\text { movimento que mais } \\
\text { agilidade ao praticar o } \\
\text { esporte". }\end{array}$ & $\begin{array}{l}\text { "Porque ele aprenderá melhor } \\
\text { o seu deslocamento no } \\
\text { esporte". }\end{array}$ & 1 \\
\hline 10 & $\stackrel{\circ}{\circ}$ & $\vec{m}$ & $\infty$ & $\begin{array}{l}\text { "Para praticar esporte você deve ter uma saúde para } \\
\text { sofrer nenhuma lesão no corpo e acabar } \\
\text { prejudicando sua vida, isto tudo está incluído na } \\
\text { biomecânica e na física". }\end{array}$ & $\begin{array}{l}\text { "Porque a biomecânica } \\
\text { ajuda a melhorar o } \\
\text { movimento do corpo". }\end{array}$ & Não respondeu. & 1 \\
\hline
\end{tabular}




\begin{tabular}{|c|c|c|c|c|c|c|c|}
\hline 11 & $\stackrel{\infty}{\circ}$ & $\hat{n}$ & $\nabla$ & $\begin{array}{l}\text { "Os esportes são ótimos para o corpo e a saúde, mas } \\
\text { que se praticada incorretamente pode ocasionar } \\
\text { lesões sérias na vida da pessoa e que se tiver um } \\
\text { bom estudo da biomecânica do corpo, pode ajudar } \\
\text { muito no condicionamento físico de um atleta". }\end{array}$ & $\begin{array}{l}\text { "Para obter um } \\
\text { conhecimento melhor do } \\
\text { corpo e como ele funciona } \\
\text { e tornar a condição física } \\
\text { cada vez melhor ao praticar } \\
\text { esportes". }\end{array}$ & $\begin{array}{l}\text { "Porque se obter um } \\
\text { conhecimento melhor do } \\
\text { corpo pode ajudar a corrigir } \\
\text { movimentos errados". }\end{array}$ & 1 \\
\hline 12 & $\stackrel{0}{ }$ & & 0 & $\begin{array}{l}\text { "O futebol é um esporte que faz um jogador ter } \\
\text { movimentos que se requer saúde e estrutura física } \\
\text { no corpo, porque senão leva muita lesão e pode } \\
\text { prejudicar sua vida". }\end{array}$ & $\begin{array}{l}\text { "Importante, pois num } \\
\text { levantamento de peso é } \\
\text { preciso levar o peso até o } \\
\text { antebraço e depois a } \\
\text { cabeça". }\end{array}$ & $\begin{array}{l}\text { "Porque saberá calcular um } \\
\text { movimento que o ajudará na } \\
\text { ação que ele quer fazer e } \\
\text { evitará uma lesão". }\end{array}$ & 1 \\
\hline 13 & 8 & $n$ & 6 & $\begin{array}{l}\text { "A biomecânica é utilizada na física e no esporte e } \\
\text { ajuda a melhorar os movimentos e evitar lesões e } \\
\text { assim praticar esportes para ter um corpo com saúde } \\
\text { e bastante vida". }\end{array}$ & $\begin{array}{l}\text { "Ajuda a melhorar os } \\
\text { movimentos do corpo na } \\
\text { prática esportiva, evitando } \\
\text { lesões". }\end{array}$ & $\begin{array}{l}\text { "Porque ele irá conhecer } \\
\text { melhor o seu corpo e suas } \\
\text { limitação". }\end{array}$ & 1 \\
\hline 14 & 8 & - & $\infty$ & $\begin{array}{l}\text { "A biomecânica é muito importante para o esporte. } \\
\text { No esporte o preparo físico e a saúde é muito } \\
\text { importante. Batedores de falta usam a física para } \\
\text { fazer gols de faltas, existe algumas lesões que } \\
\text { podem tirar os atletas dos esportes. Na vida o corpo } \\
\text { é fundamental para o esporte". }\end{array}$ & $\begin{array}{l}\text { "Ajuda a melhorando os } \\
\text { movimentos do corpo, } \\
\text { evitando lesões". }\end{array}$ & $\begin{array}{l}\text { "Porque ele irá conhecer } \\
\text { melhor o seu corpo e suas } \\
\text { limitações". }\end{array}$ & 1 \\
\hline 15 & $\stackrel{0}{ }$ & & 6 & $\begin{array}{l}\text { "Na física explica a importância da bioquímica para } \\
\text { nossa saúde e o quanto a saúde é boa para o esporte } \\
\text { pro corpo e pra vida também nos ajuda a se curar } \\
\text { mais rápido das lesões". }\end{array}$ & $\begin{array}{l}\text { "É importante para manter } \\
\text { sua resistência". }\end{array}$ & $\begin{array}{l}\text { "Porque dirá se o atleta está } \\
\text { em condição de fazer a } \\
\text { modalidade". }\end{array}$ & -1 \\
\hline
\end{tabular}




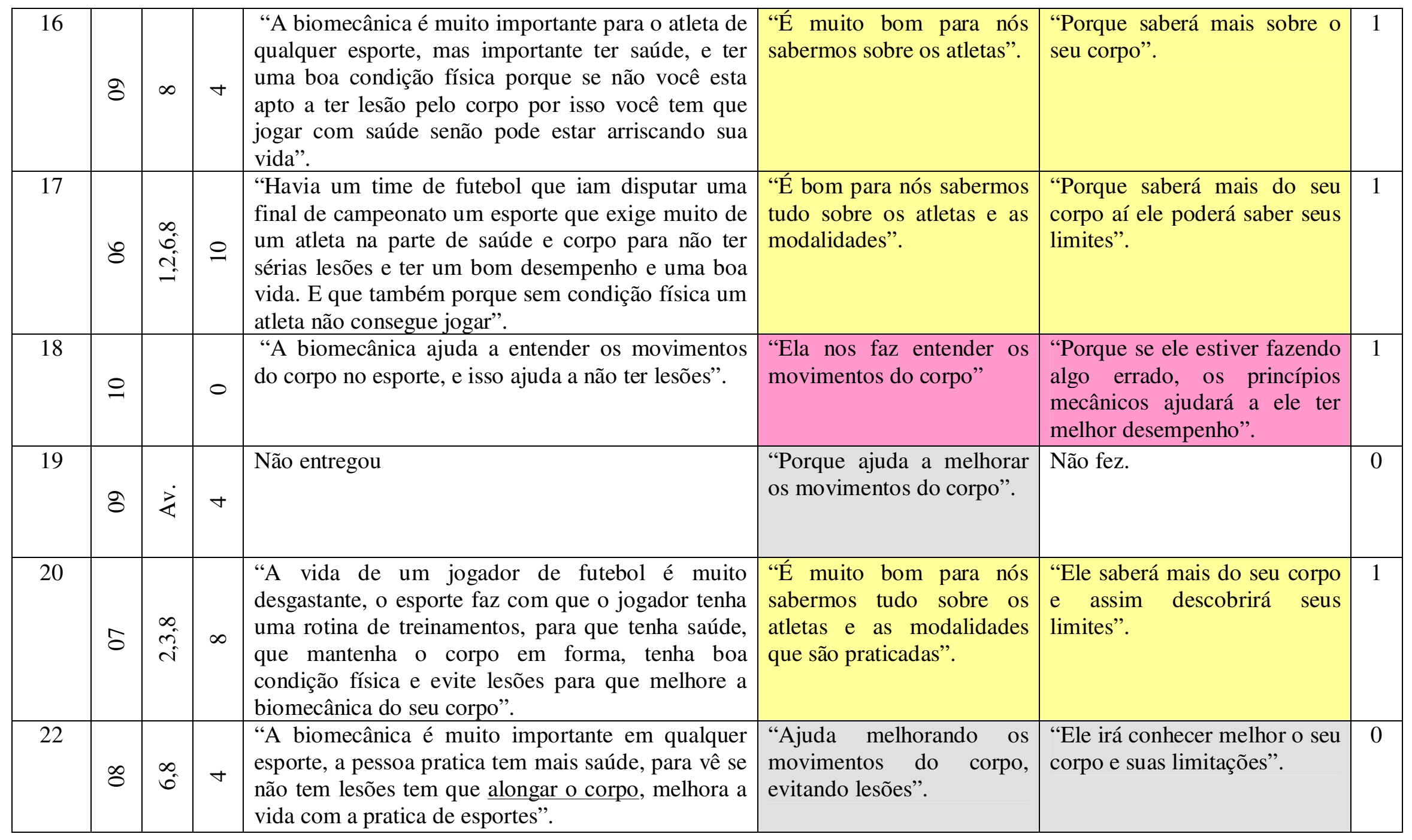




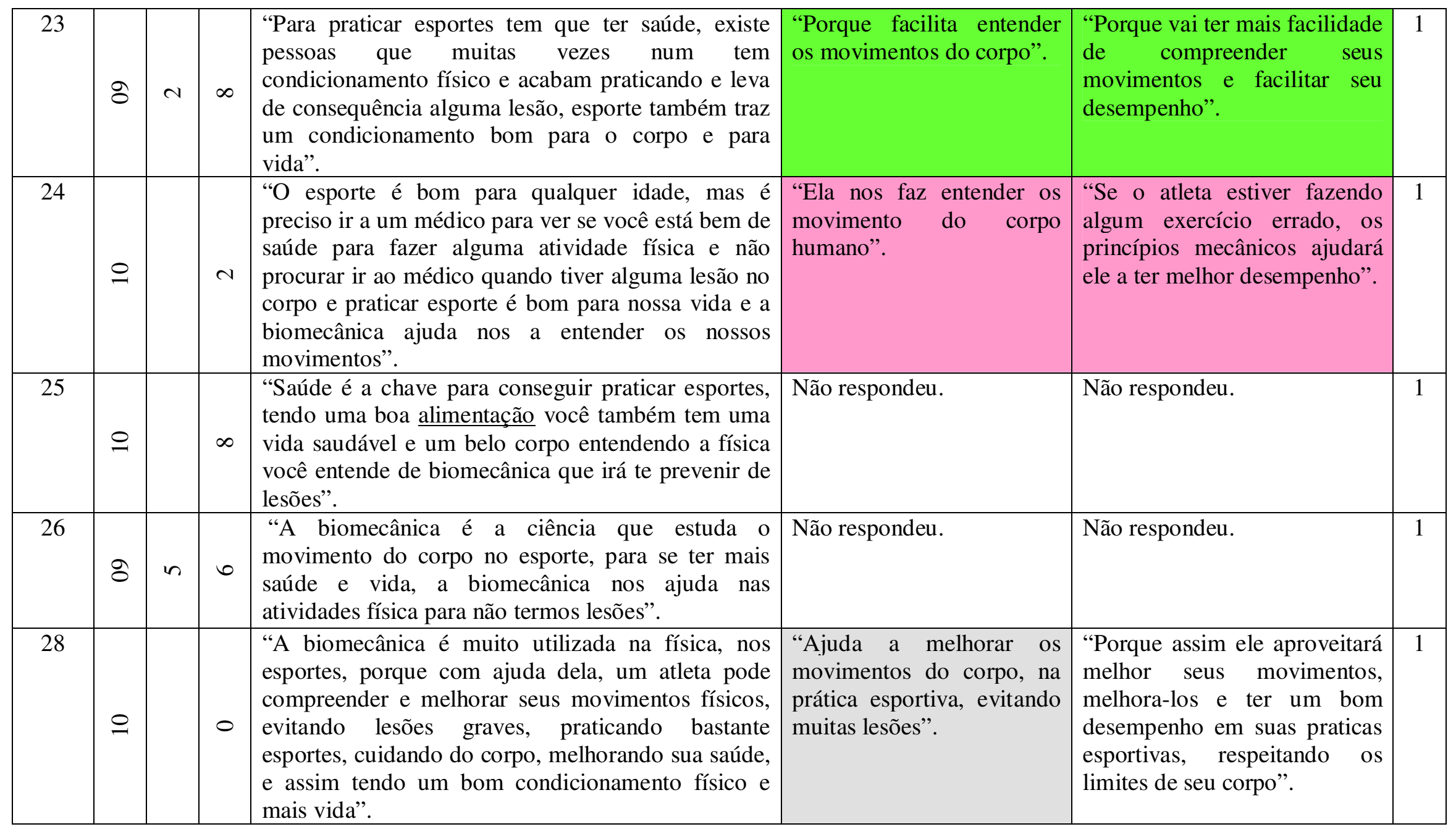




\begin{tabular}{|c|c|c|c|c|c|c|c|}
\hline 30 & s & $\begin{array}{l}\infty \\
\stackrel{+}{i}\end{array}$ & $\nabla$ & $\begin{array}{l}\text { "A biomecânica é muito importante para uma } \\
\text { pessoa praticar esporte e não ter lesões, mas é } \\
\text { importante ter uma boa saúde e cuidar do corpo e } \\
\text { ter uma boa vida e uma boa parte física ai sim você } \\
\text { poderá praticar esportes e se assegurar que não terá } \\
\text { lesões". }\end{array}$ & $\begin{array}{l}\text { "Para nós sabermos tudo } \\
\text { sobre os atletas e as } \\
\text { modalidades que } \\
\text { praticadas". }\end{array}$ & $\begin{array}{l}\text { "Porque ele saberá mais sobre } \\
\text { o seu corpo e assim descobrirá } \\
\text { seus limites". }\end{array}$ & 1 \\
\hline 31 & 8 & $n$ & 으 & $\begin{array}{l}\text { "Biomecânica para melhorar o funcionamento do } \\
\text { corpo praticamos vários tipos de esportes, para } \\
\text { ajudar também na nossa saúde e praticamos várias } \\
\text { atividades física, antes de praticar qualquer } \\
\text { exercício físico alongamos antes evitamos vários } \\
\text { tipos de lesão no nosso corpo e assim não } \\
\text { prejudicamos nossa vida". }\end{array}$ & $\begin{array}{l}\text { "É importante para manter } \\
\text { sua resistência". }\end{array}$ & $\begin{array}{l}\text { "Porque diria se o atleta está } \\
\text { em condição de fazer a } \\
\text { modalidade". }\end{array}$ & 1 \\
\hline 32 & 8 & $\infty$ & $N$ & $\begin{array}{l}\text { "No esporte temos que ter bastante saúde para } \\
\text { melhorar a condição física e evitar lesões futuras } \\
\text { durante a vida". }\end{array}$ & Não respondeu. & Não respondeu. & -1 \\
\hline 34 & 8 & $\checkmark$ & $\simeq$ & $\begin{array}{l}\text { "A biomecânica e a física fazem parte do dia-a-dia } \\
\text { do corpo de um atleta. Dependendo do esporte se } \\
\text { pode causar uma lesão muito forte e pode afastar o } \\
\text { atleta do que ele mais gosta de fazer. E pode levar a } \\
\text { vida toda para melhorar e voltar a praticar seu } \\
\text { esporte". }\end{array}$ & $\begin{array}{l}\text { "É bom para sabermos tudo } \\
\text { sobre os atletas e suas } \\
\text { modalidades". }\end{array}$ & $\begin{array}{l}\text { "Porque irá orientá-lo como se } \\
\text { movimentar em determinado } \\
\text { esporte para não se lesionar". }\end{array}$ & 1 \\
\hline
\end{tabular}




\begin{tabular}{|c|c|c|c|c|c|c|c|}
\hline 35 & $\hat{0}$ & $\begin{array}{l}\infty \\
i \\
i\end{array}$ & $\nabla$ & $\begin{array}{l}\text { "O atleta precisa ter uma boa condição física para } \\
\text { praticar esportes e precisa alongar os músculos para } \\
\text { uma boa biomecânica sem lesões e precisa também } \\
\text { de se alimentar muito bem para ter uma vida cheia } \\
\text { de saúde". }\end{array}$ & $\begin{array}{l}\text { "É muito bom para } \\
\text { sabermos sobre os atletas". }\end{array}$ & $\begin{array}{l}\text { "Porque ele sabe o que está } \\
\text { fazendo e o estado do seu } \\
\text { corpo". }\end{array}$ & 1 \\
\hline 36 & 으 & & 0 & $\begin{array}{l}\text { "A biomecânica no esporte é considerada um tipo } \\
\text { de física, que ajuda na saúde do ser humano, mas } \\
\text { deve ser feito com orientação de um profissional, } \\
\text { para não ocasionar uma lesão, ou qualquer outro } \\
\text { dano ao nosso corpo". }\end{array}$ & $\begin{array}{l}\text { "É importante para quase } \\
\text { tudo, sem ela seria mais } \\
\text { difícil de praticar esporte". }\end{array}$ & Não respondeu. & 1 \\
\hline 37 & $\stackrel{0}{ }$ & & 0 & $\begin{array}{l}\text { "A saúde de nossos corpos dependem muito da } \\
\text { maneira que nós cuidamos deles: se alimentando, } \\
\text { praticando esportes, tentando manter sempre a } \\
\text { calma, etc., tudo isso pra viver uma vida saudável. } \\
\text { Mas cuidado: pegue sempre um exercício que dê ao } \\
\text { seu limite, senão lesões sérias podem ser causadas. } \\
\text { Para isso, saber qual exercício seria o melhor para } \\
\text { você, por que não estudar um pouco de física, hein? } \\
\text { Assim você pode conhecer melhor a biomecânica } \\
\text { de seu corpo e seus benefícios". }\end{array}$ & $\begin{array}{l}\text { "Ajuda a melhorar os } \\
\text { movimentos do corpo, na } \\
\text { prática esportiva, evitando } \\
\text { lesões". }\end{array}$ & $\begin{array}{l}\text { "Ele irá conhecer melhor o seu } \\
\text { corpo e suas limitações". }\end{array}$ & 1 \\
\hline
\end{tabular}




\begin{tabular}{|c|c|c|c|c|c|c|c|}
\hline 40 & 8 & 充 & $\infty$ & Não entregou. & $\begin{array}{l}\text { "Porque facilita a entender } \\
\text { os movimento do corpo". }\end{array}$ & $\begin{array}{l}\text { "Porque ele vai ter mais } \\
\text { facilidade de compreender } \\
\text { sues movimentos e facilitar } \\
\text { seu desempenho". }\end{array}$ & 1 \\
\hline
\end{tabular}


As cores iguais na tabela 4.18 mostram respostas iguais dos estudantes, o que, após o mapeamento da sala, percebemos que é por organização das carteiras (grupos), embora, com pouca frequência, os estudantes troquem de carteira e de grupo, mas por relatos da professora podemos dizer que é uma construção coletiva do conhecimento, são que eles discutem entre si as respostas das questões. Embora as atividades fossem propostas individualmente os estudantes desta turma responderam as atividades em grupos, de acordo com o posicionamento das carteiras, que estão relacionados as afinidades entre os estudantes.

De acordo com o mapeamento feito pelos estudantes (fig. 4.14 a 4.16) e com os dados apresentados na tabela 4.18, observamos que os alunos com respostas similares sentam juntos ou bem próximos, o que afirma o compartilhamento de respostas de acordo com grupos de afinidade. Salientamos que os alunos $\left(18, \mathrm{~B}_{2}\right),\left(24, \mathrm{~B}_{2}\right.$ - no mapeamento da sala é 23$)$ e $\left(40, \mathrm{~B}_{2}\right),\left(23, \mathrm{~B}_{2}\right.$ - no mapeamento da sala é 24$)$ trabalham em grupo e segundo os relatos da professora são alunos que cumprem com todos os deveres escolares. O restante de alunos $\left(01, \mathrm{~B}_{2}\right),\left(02, \mathrm{~B}_{2}\right),\left(05, \mathrm{~B}_{2}\right),\left(06, \mathrm{~B}_{2}\right),\left(09, \mathrm{~B}_{2}\right),\left(10, \mathrm{~B}_{2}\right)$, $\left(13, B_{2}\right),\left(14, B_{2}\right),\left(22, B_{2}\right),\left(28, B_{2}\right),\left(37, B_{2}\right)$ possuem respostas similares pela constituição de grupos e pelo auxílio do aluno do "grupo C”(classificação explicada posteriormente).

\section{Mapeamento da turma $1^{\circ} \mathbf{B}_{2}$}

O mapeamento foi obtido pela respostas dos 27 estudantes ao questionário de validação $\left(\mathrm{Q}_{3}\right)$ - seção 4.5. Ao analisar o mapa da classe elaborado pelos estudantes, a maioria nos surpreendeu, pois representaram as carteiras em posição de fileiras (figura 4.16), o que não é real, mas tivemos alguns estudantes que ilustraram em detalhes a sala de aula (figura 4.14 e 4.15), observe que um mapa complementa o outro. 


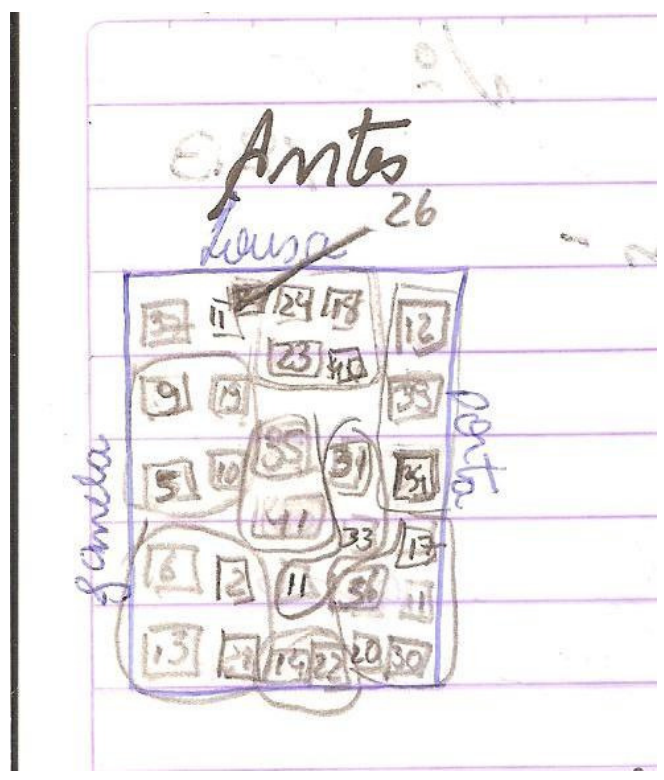

Figura 4.14: Mapa da turma $1^{\circ} \mathrm{B}_{2}$ - feito pelo aluno $\left(37, \mathrm{~B}_{2}\right)$.

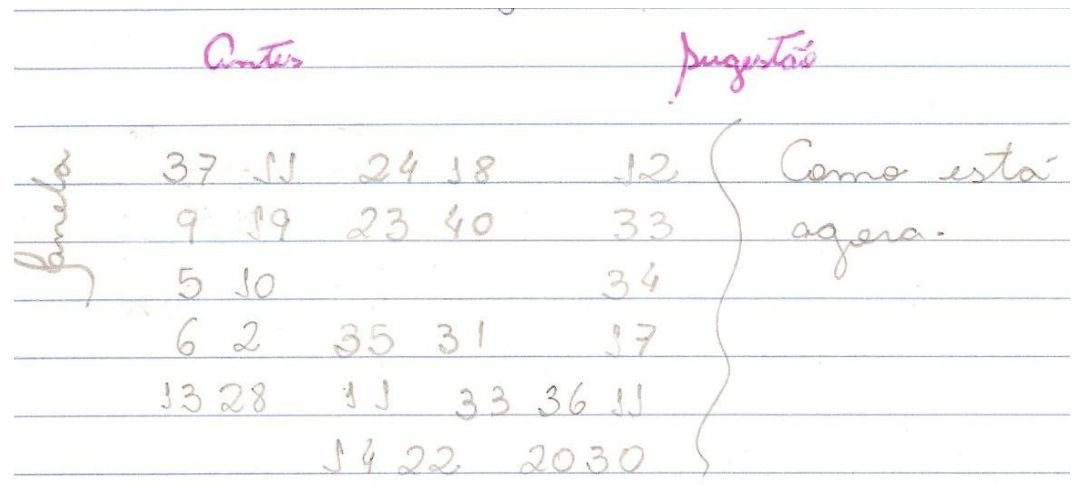

Figura 4.15: Mapa da turma $1^{\circ} \mathrm{B}_{2}$ - feito pelo aluno $\left(24, \mathrm{~B}_{2}\right)$.

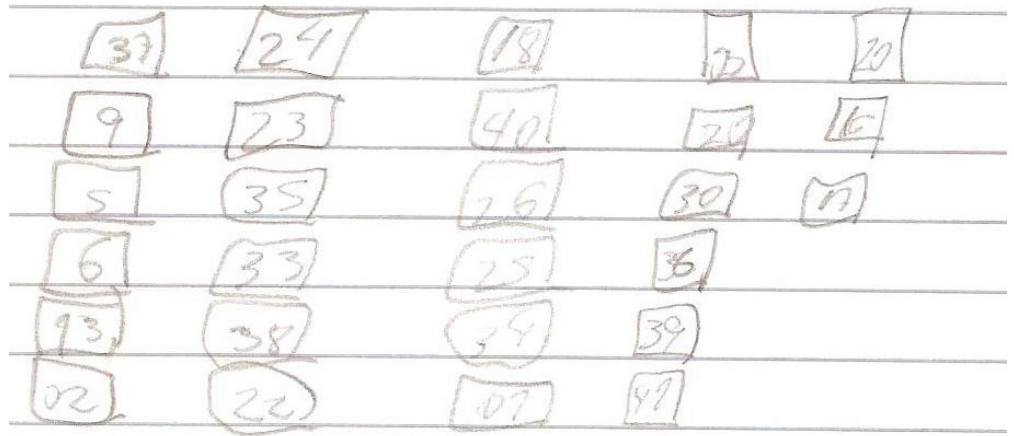

Figura 4.16: Mapa da turma $1^{\circ} \mathrm{B}_{2}$ - feito pelo aluno $\left(1, \mathrm{~B}_{2}\right)$. 


\section{Classificação}

De acordo com as categorias elaboradas a posteriori, pudemos mapear a complexificação do conhecimento de esporte e verificar que a maioria dos estudantes conseguiu relacionar esporte e física (tabela abaixo).

Tabela 4. 19: Graus de complexidade atingidos na turma $1^{\circ} \mathrm{B}$ da escola $\mathrm{G}$.

\begin{tabular}{|c|c|}
\hline Grau de complexidade & Porcentagem $(\%)$ \\
\hline Grau -2 & 12,2 \\
\hline Grau -1 & 7,3 \\
\hline Grau 0 & 9,8 \\
\hline Grau 1 & 70,7 \\
\hline
\end{tabular}

Observe a figura 4.17:

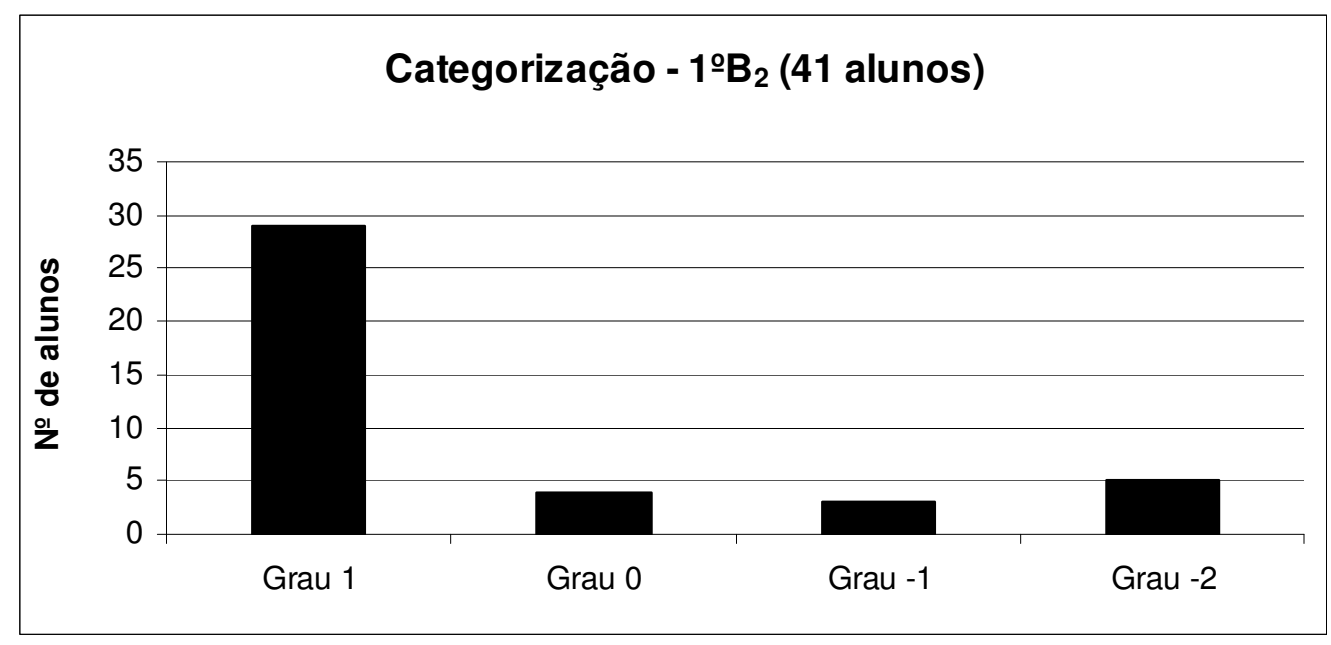

Figura 4.17: Complexificação do conhecimento de $1^{\circ} \mathrm{B}_{2}$.

Os estudantes tiveram o primeiro contato com a palavra biomecânica na atividade 3 da intervenção e depois o termo apareceu somente na atividade 9, mas estava implícito nas outras atividades. Na atividade 3 contém um texto que explica o que é e para que serve a biomecânica e nesta atividade os estudantes tinham que responder a algumas questões, perceba que os estudantes apenas transcreveram trechos do texto nas respostas (tabela 4.20). Comparando com as respostas obtidas na questão 1 da atividade avaliatória, estes dados nos fornecem mais evidências da complexificação do conhecimento de esporte dos estudantes. 
Tabela 4.20: Respostas do $1^{\circ} \mathrm{B}_{2}$ da escola G.

\begin{tabular}{|c|c|}
\hline \multicolumn{2}{|c|}{ 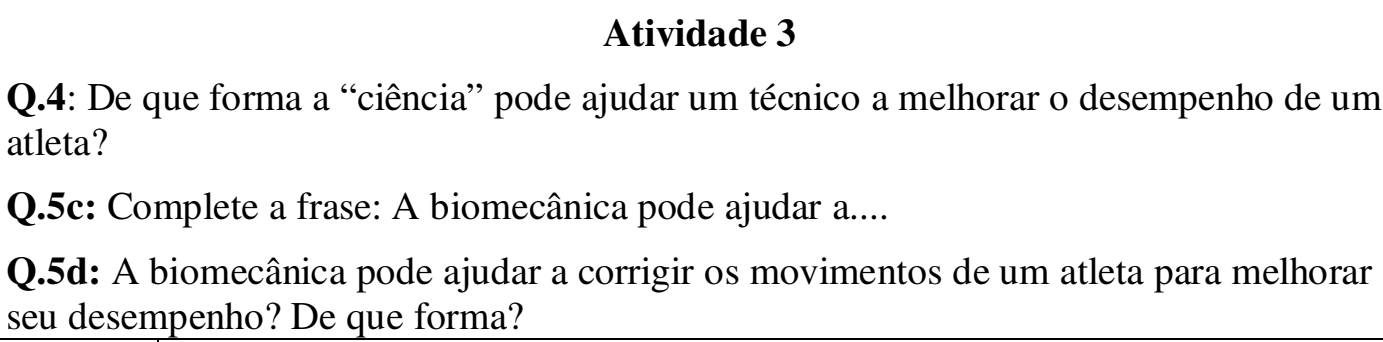 } \\
\hline Aluno & Resposta \\
\hline 13 & $\begin{array}{l}\text { (Q.4) "Pode sim...". } \\
\text { (Q.5c) "Pode ajudar a avaliar um movimento de um organismo vivo e sua } \\
\text { força". } \\
\text { (Q.5d) "Sim avaliando o efeito das forças na pessoa". }\end{array}$ \\
\hline 24 & $\begin{array}{l}\text { (Q.4) "No desenvolvimento deles". } \\
\text { (Q.5c) "Avaliar o efeito da força sobre as pessoas". } \\
\text { (Q.5d) "Sim dependendo dos movimentos dele". }\end{array}$ \\
\hline 41 & $\begin{array}{l}\text { (Q.4) "Estudando os efeitos das forças e a resistência". } \\
\text { (Q.5c) "O movimento". } \\
\text { (Q.5d) "Sim, no movimento". }\end{array}$ \\
\hline
\end{tabular}

Nesta turma, a maioria dos alunos não terminou até o fim a atividade 9 , portanto as questões de comparação sobre as responsabilidades de um técnico (ativ.1 - Q.1 com ativ.9 - Q.12) não puderam ser realizadas. Até onde, a maioria dos estudantes responderam, conseguimos comparar algumas questões da atividade 9 , com a atividade 2 cujo tema é saúde. Essa comparação visa analisar se o estudante compreendeu a relação: saúde e esporte.

Tabela 4.21: Comparação de questões das atividades 2 e $9-1^{\circ} \mathrm{B}_{2}-$ escola $\mathrm{G}$.

\begin{tabular}{|c|c|c|}
\hline$\stackrel{\varrho}{\Xi}$ & $\begin{array}{l}\text { Atividade } 2 \\
\text { Q.10b: Qualquer pessoa no momento em } \\
\text { que quiser, pode praticar esporte? Por } \\
\text { quê? } \\
\text { Q10c: Quais os cuidados que devemos } \\
\text { ter ao praticar exercícios físicos? }\end{array}$ & $\begin{array}{l}\text { Atividade } 9 \\
\text { Q.2: Que cuidados devemos ter ao } \\
\text { iniciar uma atividade física? } \\
\text { Q.7: Quais os cuidados que devemos } \\
\text { ter ao praticar exercícios físicos? }\end{array}$ \\
\hline 28 & $\begin{array}{l}\text { (10b) "sim, porque é bem saudável". } \\
\text { (10c) "Ter cuidados com a alimentação e } \\
\text { o corpo". }\end{array}$ & $\begin{array}{l}\text { (q.2) "Se alongar, consultar um } \\
\text { médico". } \\
\text { (q.7) "Cuidados com o corpo, a } \\
\text { alimentação e movimentos bruscos do } \\
\text { corpo para não ter sérias lesões". }\end{array}$ \\
\hline 08 & Não entregou. & $\begin{array}{l}\text { (q.2) "Sempre antes de praticar um } \\
\text { esporte fazer alongamentos". }\end{array}$ \\
\hline
\end{tabular}




\begin{tabular}{|l|l|l|}
\hline $37 *$ & $\begin{array}{l}\text { (q. 7) "Precisamos ter cuidado para } \\
\text { não sofrer lesões". }\end{array}$ \\
\hline $\begin{array}{l}\text { (10b) "Sim, o esporte se adapta a a } \\
\text { qualquer idade". }\end{array}$ & $\begin{array}{l}\text { (q.2) "Se alongar, consultar um } \\
\text { médico". } \\
\text { (10c) "Cuidados em não ir além do nosso } \\
\text { (q. 7) "Precisamos tomar cuidado para } \\
\text { limite, cuidados com lesões dependendo } \\
\text { do esporte e cuidado com a alimentação, } \\
\text { pois os dois andam ligados". }\end{array}$ & $\begin{array}{l}\text { não se exceder e acabar tendo lesões, } \\
\text { devemos tomar líquido e ter uma boa } \\
\text { alimentação". }\end{array}$ \\
\hline
\end{tabular}

*aluno posteriormente classificado como pertencente ao Grupo C

\section{Relação física e educação física}

$\mathrm{Na}$ tabela 4.18 sublinhamos algumas palavras que evidenciam que alguns estudantes associam os conteúdos da disciplina de educação física aos de física. O professor de educação física desta turma nos relatou por entrevista informal que, em suas aulas, insiste em falar da importância do alongamento antes de qualquer atividade física para evitar lesões.

Nas respostas ao questionário de validação $\mathrm{Q}_{3}$ (seção 4.5) percebemos que a maioria dos estudantes passaram a construir a ponte interdisciplinar entre física e educação física. Como o questionário é composto por 7 questões em uma delas o estudante demonstra apropriação da relação física e educação física

\section{Relação professora-aluno}

Para obtermos mais informações sobre o relacionamento da turma $\mathrm{B}_{2}$ com a professora e avaliar a metodologia utilizada na intervenção + caderno de física vol. 1 e 2, elaboramos um questionário com 10 questões, que denominamos de questionário de opinião. Nesta turma pedimos para os alunos não se identificassem, com objetivo de deixá-los mais livres para colocarem suas opiniões. O questionário foi aplicado pela professora eventual de língua portuguesa da escola, observe a tabela 4.22.

Tabela 4.22: Questionário de Opinião das aulas $-1^{\circ} \mathrm{B}_{2}$ - escola G.

\section{1 - Eu aprenderia melhor a disciplina de física se...}

"Se todos colaborassem não fazendo bagunça..."

"Se passasse mais vídeos..."

"Se me esforçasse mais..."

"Se fizesse mais aulas práticas..."

"Se eu prestasse mais atenção..."

2 - As atividades do caderninho são....

"Algumas são chatas, mas aí a professora ajuda e os colegas também ai fica legal..."

"Legais, aprendi muita coisa que não sabia..."

"Fáceis, mas as vezes difíceis, como as contas de velocidade..." 


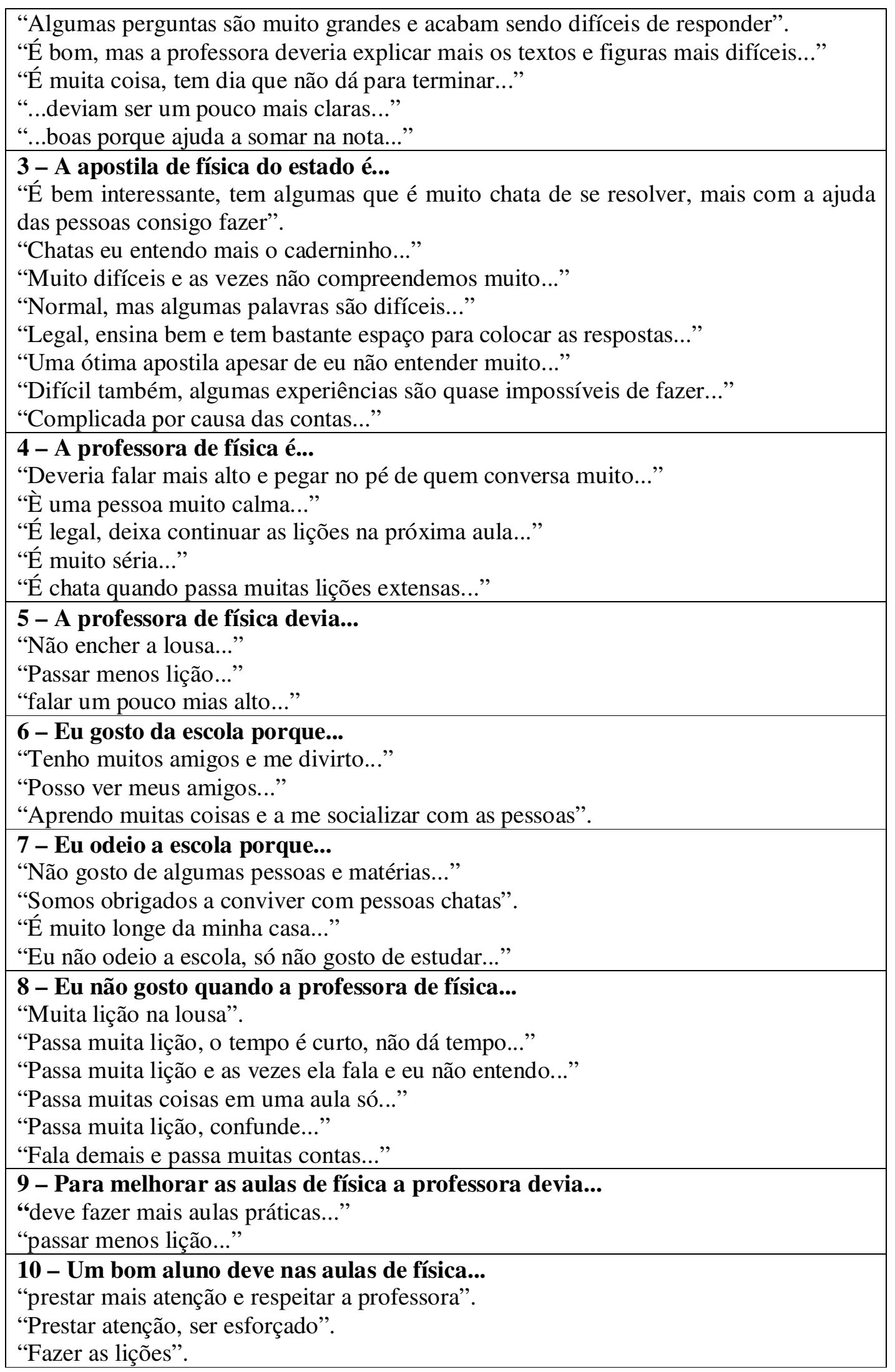


Pudemos perceber pelos relatos dos estudantes no questionário de opinião que a professora possui um comportamento atípico aos demais professores, pois é muito centrada no conteúdo das aulas, e isto gera aplicação de atividades em demasiado aos estudantes, que se sentem sufocados. Mas ao mesmo tempo em que exige muitas atividades, também é um pouco flexível quanto ao prazo de entrega das atividades. Apesar de ser agitada e ansiosa para o desenvolvimento dos conteúdos, os alunos enfatizam a calma da professora, mas o que impera é o fato das excessivas atividades por aula.

Para comparação temos um curto relato da professora sobre sua relação com a sala: "Gosto muito desta sala, a maioria dos alunos são interessados em realizar as tarefas, me perguntam muito a respeito do conteúdo, embora sejam muitas vezes inseguros. Nesta sala, há um monitor voluntário que me auxilia bastante. Durante as tarefas conversam entre si de vários assuntos, mas não se esquecem dos deveres do dia" (Anexo A3.2.3).

Percebemos por esta fala que a professora se sente muito bem nesta turma para desenvolver seu trabalho.

Quanto ao caderno de física do aluno, a maioria dos estudantes (dentre os que aprovam e reprovam) enfatizam a dificuldade em entender as atividades e a importância da ajuda dos colegas e do professor para realizar as situações de aprendizagem.

Quanto as atividades de intervenção, os estudantes (dentre os que aprovam e reprovam) enfatizam a extensão das atividades e das questões e a dificuldade em interpretar tanto os textos quanto as questões, e enfatizam a necessidade da ajuda dos colegas e da professora.

\section{Casos Particulares}

- Alunos do grupo C

Na turma $1^{\circ} B_{2}$, encontramos um aluno $\left(37, B_{2}\right)$ que nomeamos de "aluno C". Esta categoria de estudantes serve para enquadrar os alunos que são diferentes a grande maioria dos estudantes, pois sente prazer em ajudar o professor nos seus afazeres, explica a matéria para os alunos que não entenderam (monitor), estuda em casa, formula questões relevantes na aula, etc. 


\section{- Alunos do grupo D}

Na turma $1^{\circ} \mathrm{B}_{2}$, encontramos também a classe de alunos pertencentes ao grupo D. Esta categoria de estudantes serve para enquadrar os estudantes que são frequentes nas aulas, gostam de conversar em seu grupo durante as aulas (aparentemente não estão prestando atenção), e escolhem as atividades para realizar, mas quando dão devolutivas, mostram algum retorno positivo. Este é o caso dos estudantes $\left(30, \mathrm{~B}_{2}\right),\left(17, \mathrm{~B}_{2}\right),\left(20, \mathrm{~B}_{2}\right)$, $\left(35, \mathrm{~B}_{2}\right)$ - parecem dispersos- que trabalham em grupo (mapeamento - fig.4.14 a 4.16) e apresentam algum retorno, se encaixando no grau 1 de complexidade.

\subsubsection{Turma $1^{\circ} \mathrm{C}_{2}$}

A turma $1^{\circ} \mathrm{C}_{2}$, referente a escola $\mathrm{M}$ é composta por 37 alunos, sendo que dentre eles analisamos as respostas de apenas 27 alunos, pois no decorrer do semestre tivemos algumas transferências de classe e de escola e alguns abandonos de curso. Além disso, nesta turma estão inseridos dois deficientes auditivos (D.A.) e uma professora intérprete. Nesta turma eram ministradas duas aulas intercaladas, mas no mesmo dia as quintas-feiras, a $3^{\mathrm{a}}$ e $5^{\mathrm{a}}$ aula do período da tarde.

A aplicação da intervenção na turma $1{ }^{\circ} \mathrm{C}_{2}$ seguiu inicialmente o plano de aula (tabela 3.14) que prevê o término da intervenção em junho (fim do $1^{\circ}$ semestre), mas durante a aplicação sofreram mudanças devido a imprevistos no calendário escolar, a frequência dos estudantes na aula, reuniões internas, etc., observem na tabela 4.23 o diário de classe da professora.

No período de aplicação das atividades contabilizamos 44 aulas, mas ministramos as atividades da intervenção em 42 aulas. A diferença de 2 aulas pode ser devido a reunião de pais com alunos ou reunião de professores. Lembramos que no plano de aula (tabela 3.14) estabelecemos 23 aulas para toda a intervenção. E nesta turma excedeu em 19 aulas o previsto e por análise do diário de bordo da professora verificamos que o ritmo de realização de tarefas desta turma é mais lento, pois são falantes e preguiçosos para realizar as atividades. Durante a intervenção vários alunos se atrasavam no cumprimento das atividades, então acumulavam atividades. 
Tabela 4.23: Diário de Classe - turma $1^{\circ} \mathrm{C}_{2}$.

\begin{tabular}{|c|l|}
\hline Data $-\mathbf{n}^{\mathbf{0} a u l a s}$ & \multicolumn{1}{|c|}{ Conteúdo $-\mathbf{1}^{\mathbf{0}} \mathbf{C}_{\mathbf{2}}$} \\
\hline $18 / 02-2$ & Apresentação \\
\hline $25 / 02-2$ & Ativ. 1 + cad. 1 (p. 3, 4 e 5) \\
\hline $04 / 03-2$ & Ativ. 2 + S.I. (Sist. Intern.) + cad. 1 (p. 6 e 7) \\
\hline $11 / 03-2$ & Ativ. 3 + Ex. sobre unidades e deslocamento \\
\hline $18 / 03-2$ & Veloc. Média + exercícios \\
\hline $25 / 03-2$ & Ativ.4 (quadra) + cálculos \\
\hline $01 / 04-2$ & Ativ. 4+ cad. 1 (p. 3 a 12, 16) \\
\hline $08 / 04-2$ & Ativ. 4 \\
\hline $15 / 04-2$ & Ativ. 4 + Am + ex. \\
\hline $22 / 04-2$ & Cad.(p. 17 a 20, 22 e 23)+ P = m.g \\
\hline $29 / 04-2$ & Ex. peso + ativ. 5 \\
\hline $06 / 05-2$ & Cad. 1 (p. 24 a 26, 32 a 37) \\
\hline $13 / 05-2$ & Cad. 1 (p. 27, 38 a 43) + 3 leis \\
\hline $20 / 05-2$ & Ativ. 6 + Ativ. 7 \\
\hline $27 / 05-2$ & Ativ. 7 \\
\hline $10 / 06-2$ & Em + cad. 2 (p. 7 a 16) \\
\hline $17 / 06-2$ & Pot. + cad. 2 (p. 24 a 27) + Ativ. 7 \\
\hline $24 / 06-2$ & Torque + cad. 2 (p. 42 a 46) + Ativ. 7 \\
\hline $01 / 07-2$ & Ativ. 8 \\
\hline $05 / 08-2$ & Cad. 3 + Exp. Cad. 2 p/ entregar + Ativ. 9 \\
\hline $12 / 08-2$ & Ativ. Avaliatória + Ativ. pessoal \\
\hline & \\
\hline
\end{tabular}

Na figura 4.18, temos uma relevante variação na frequência dos estudantes nas aulas, mas mesmo assim temos um grupo de alunos (média dos alunos nas aulas) que são frequentadores assíduos durante toda intervenção, ou seja, estes estudantes não revezam a presença nas aulas.

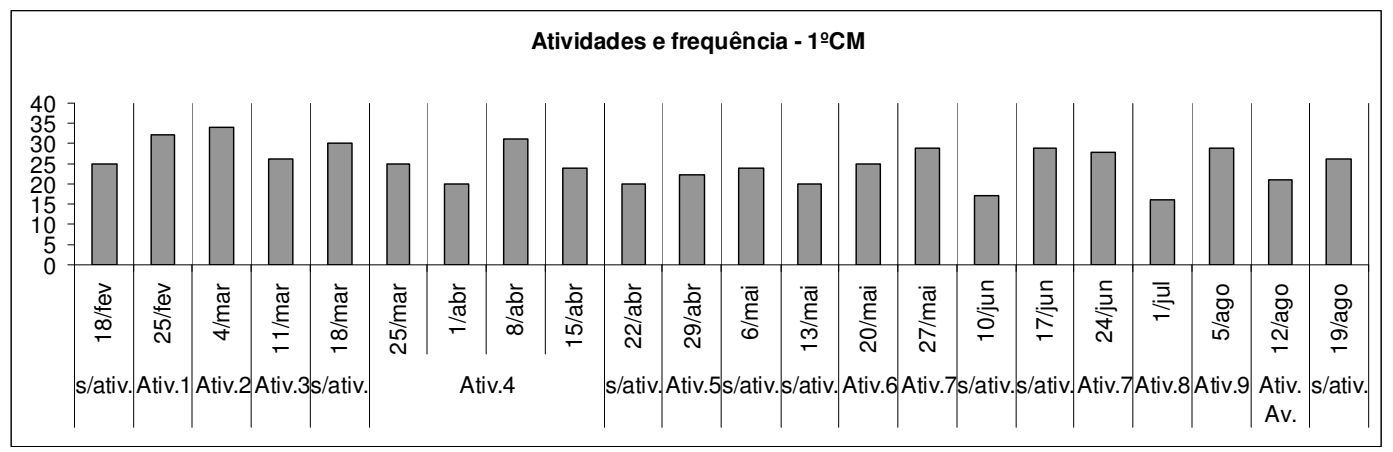

Figura 4.18: Atividade e frequência da turma $1^{\circ} \mathrm{C}_{2}$.

$\mathrm{Na}$ atividade 1, com a questão 7 , os estudantes descrevem as disciplinas escolares que mais identificam com o esporte, pudemos verificar se os estudantes já estabelecem alguma relação entre a disciplina de física e o esporte. Observe na figura 
4.19 que a disciplina de matemática aparece em $1^{\circ}$ lugar, à disciplina de educação física em $2^{\circ}$ lugar e a disciplina de língua portuguesa em $3^{\circ}$ lugar e a turma a disciplina de física aparece em $4^{\circ}$ lugar. Portanto a dimensão epistemológica ligada à física não está incluída no perfil conceitual do aluno.

Acreditamos que a disciplina de matemática aparece em $1^{\circ}$ lugar, pela figura 4.19 da professora de ciências exatas, e pela ausência da disciplina de física entre as primeiras acreditamos ser devido ao ensino municipal de $6^{\circ}$ a $9^{\circ}$ ano do ensino fundamental, no qual o professor de ciências pode enfatizar uma das 3 disciplinas: química, biologia e física conforme sua formação e afinidade com o conteúdo, observe o relato: "Durante a aula uma aluna se queixou que não poderia responder a questão sete, pois nunca tinha tido biologia, química e física. Diante disso expliquei que deveria recorrer aos conhecimentos que já possuía" (Anexo A3.2.3).

Questão 7: Será que algumas das disciplinas (I, P, G, H, M, Q, B, F, EF, EA, Fil, So) que você tem na escola podem ajudar um atleta a ter um bom desempenho? Cite pelo menos quatro disciplinas (coloque em ordem de importância), e explique como ela será útil para análise de uma prática esportiva. Para facilitar complete a tabela abaixo:

\begin{tabular}{|l|l|l|l|}
\hline & Disciplina & $\begin{array}{l}\text { Conteúdo } \\
\text { específico da disciplina }\end{array}$ & Auxilia ... \\
\hline Exemplo & Artes & Técnicas de Pintura & $\begin{array}{l}\text { Dar harmonia as cores no } \\
\text { quadro }\end{array}$ \\
\hline $1^{a}$ & & & \\
\hline $2^{a}$ & & & \\
\hline $3^{a}$ & & & \\
\hline $4^{a}$ & & & \\
\hline
\end{tabular}

Como há apenas 3 escolas estaduais de ensino médio para atender toda demanda de estudantes advindos das escolas de bairro do município, temos turmas bastante heterogêneas, causando disparidade nos dados de turma a turma ou de escola para escola. 


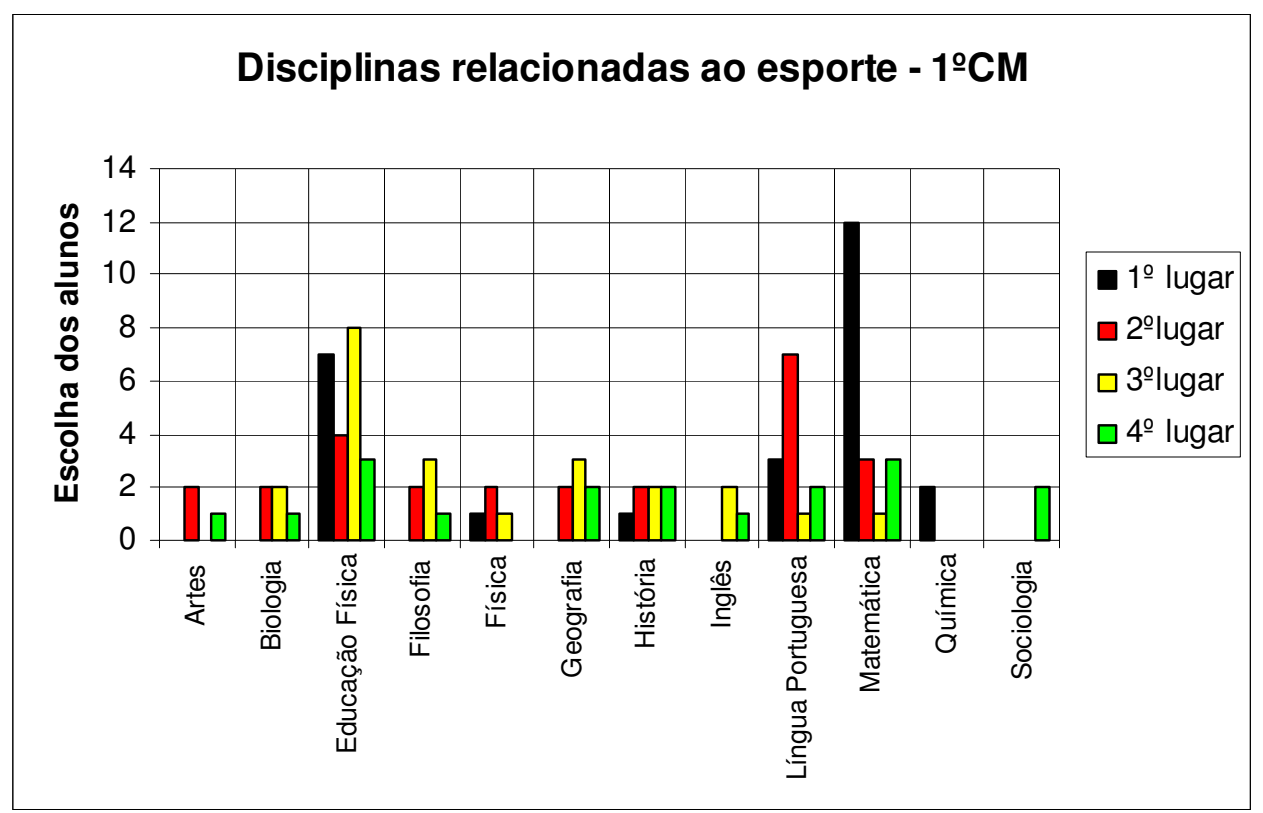

Figura 4.19: Posições das disciplinas - turma $\mathrm{C}_{2}$.

Abaixo mostramos nas tabelas 4.24, 4.26, 4.27 e 4.28 respostas dos alunos a algumas questões e atividades selecionadas (tabela 3.19), onde é possível analisar a complexificação do conhecimento de esporte.

A tabela 4.24 traz a quantidade de: atividades entregues, atividades que faltaram, faltas durante o período de aplicação da intervenção e as respostas dos estudantes a questão 5 e 8 da atividade 9 e a questão 1 da atividade avaliatória, que nos informam sobre a complexificação do conhecimento de esporte. 
Tabela 4.24: Comparação de questões das atividades $-1^{\circ} \mathrm{C}_{2}-$ escola $\mathrm{M}$.

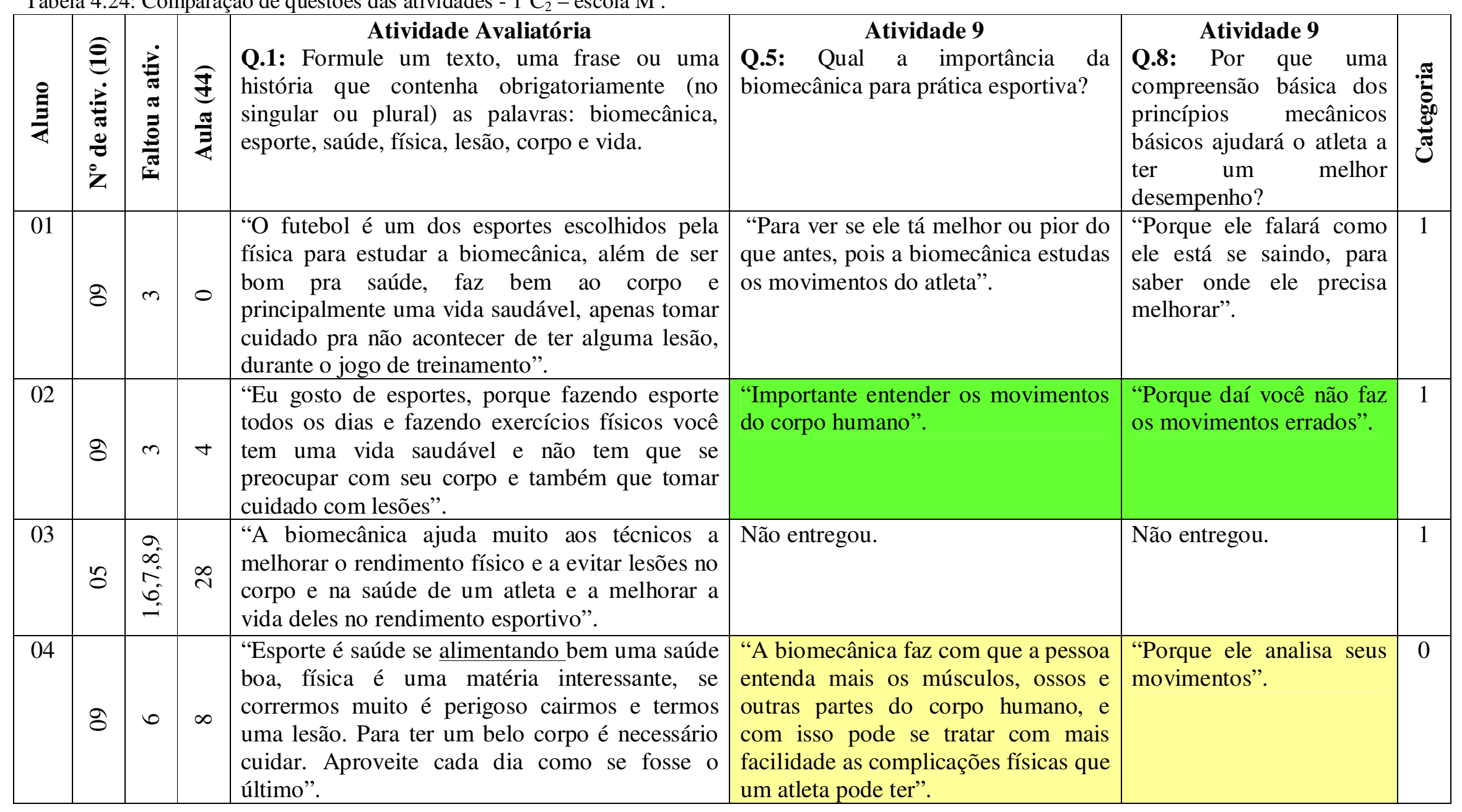




\begin{tabular}{|c|c|c|c|c|c|c|c|}
\hline 07 & 8 & $\begin{array}{l}0 \\
\tilde{n} \\
\stackrel{n}{i}\end{array}$ & ণ & $\begin{array}{l}\text { "A física tem um dos seus conceitos que á } \\
\text { biomecânica que estuda o movimento de cada } \\
\text { atleta, independente do esporte, o esporte é } \\
\text { muito bom, pois a pessoa fica com um corpo } \\
\text { bonito, saudável, mas pode acontecer lesões } \\
\text { fatais trazendo estragos a vida". }\end{array}$ & $\begin{array}{l}\text { "É importante porque a biomecânica } \\
\text { é o movimento". }\end{array}$ & $\begin{array}{l}\text { "Porque daí você não faz } \\
\text { os movimentos errados". }\end{array}$ & 1 \\
\hline 08 & $\infty$ & $\begin{array}{l}0 \\
i\end{array}$ & $\underline{0}$ & $\begin{array}{l}\text { "O futebol é um esporte muito bom que traz uma } \\
\text { bela aparência e ainda um corpo belo e uma } \\
\text { saúde incomparável, só que existe probabilidade } \\
\text { de ocorrer alguma lesão e também pode ser } \\
\text { estudado a biomecânica". }\end{array}$ & $\begin{array}{l}\text { "Porque observa seu corpo e vê qual } \\
\text { atividade você pode fazer". }\end{array}$ & $\begin{array}{l}\text { "Porque ele analisa seus } \\
\text { movimentos". }\end{array}$ & 1 \\
\hline 09 & $\stackrel{\infty}{\circ}$ & $\begin{array}{l}0 \\
i n\end{array}$ & $\simeq$ & $\begin{array}{l}\text { "O esporte pode ser praticado por qualquer } \\
\text { pessoa que tenha saúde física e a biomecânica } \\
\text { não deve ser feita por pessoas que tenham lesão } \\
\text { corporal e que não tenha uma vida ruim". }\end{array}$ & $\begin{array}{l}\text { "Importante entender os movimentos } \\
\text { do corpo humano". }\end{array}$ & $\begin{array}{l}\text { "Porque daí você não faz } \\
\text { os movimentos errados". }\end{array}$ & 1 \\
\hline 11 & $\stackrel{0}{-}$ & & \pm & $\begin{array}{l}\text { "A nossa vida, o esporte físico é bastante } \\
\text { importante para nossa saúde. Ao praticar algum } \\
\text { esportes é preciso alongar o corpo. E a } \\
\text { biomecânica e esportes estão sempre ligados um } \\
\text { ao outro". }\end{array}$ & $\begin{array}{l}\text { "Ajuda o atleta a melhorar a sua } \\
\text { saúde e o condicionamento". }\end{array}$ & $\begin{array}{l}\text { "Força, instabilidade, } \\
\text { equilíbrio, } \quad \text { precisão, } \\
\text { melhora no futebol, tendo } \\
\text { assim melhor empenho". }\end{array}$ & 1 \\
\hline 13 & 8 & N & $\forall$ & $\begin{array}{l}\text { "A física é uma matéria muito legal de estudar } \\
\text { sobre a biomecânica do modo dos movimentos } \\
\text { do corpo. Com a física você pode calcular por } \\
\text { exemplo no futebol que é um esporte muito..." }\end{array}$ & “Ajuda como fazer os movimentos". & Não fez. & 1 \\
\hline
\end{tabular}




\begin{tabular}{|c|c|c|c|c|c|c|}
\hline 15 & $\stackrel{ }{\circ}$ & $N$ & $\begin{array}{l}\text { "A nossa vida ela é muito importante para nós } \\
\text { termos uma boa saúde devemos praticar esportes } \\
\text { usamos muito a biomecânica, nós também } \\
\text { devemos praticar adequadamente para não } \\
\text { ocorrer leões e prejudicar a saúde". }\end{array}$ & $\begin{array}{l}\text { "Ajuda a trabalhar a saúde e } \\
\text { condicionamento". }\end{array}$ & $\begin{array}{l}\text { "Força, estabilidade, } \\
\text { precisão, melhorando o } \\
\text { tempo mais } \\
\text { desempenho". }\end{array}$ & 1 \\
\hline 16 & $\stackrel{ }{\circ}$ & 0 & $\begin{array}{l}\text { "Nosso corpo necessita de movimentos para } \\
\text { podermos realizar determinado esporte que fará } \\
\text { bem a nossa saúde, assim podemos ter uma vida } \\
\text { saudável. A física está presente em tudo até na } \\
\text { vida profissional dos técnico, professores, etc., } \\
\text { que devem compreender o atleta se ele está } \\
\text { pronto para realizar alguma atividade física ou se } \\
\text { ele sofreu alguma lesão". }\end{array}$ & $\begin{array}{l}\text { "Importante entender os movimentos } \\
\text { do corpo humano". }\end{array}$ & $\begin{array}{l}\text { "Porque daí você não faz } \\
\text { movimentos errados". }\end{array}$ & 1 \\
\hline 17 & 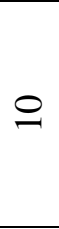 & 0 & $\begin{array}{l}\text { "A biomecânica estuda os movimentos do corpo. } \\
\text { Na nossa vida, os esporte é fundamental, pois ele } \\
\text { ajuda não só na saúde física, quanto mental mais } \\
\text { também é preciso cuidados para não acarretar } \\
\text { lesões". }\end{array}$ & $\begin{array}{l}\text { "Para fazer os movimentos certos } \\
\text { sem causar luxações ou dores". }\end{array}$ & $\begin{array}{l}\text { "A pessoa não faz } \\
\text { movimentos errados e não } \\
\text { se machuca". }\end{array}$ & 1 \\
\hline 19 & 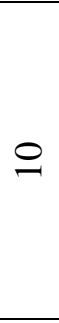 & 0 & $\begin{array}{l}\text { "Um praticante de esporte, ou um atleta, tem boa } \\
\text { saúde. Os dois devem fazer um alongamento } \\
\text { antes de praticar, senão é perigoso ocorrer lesões } \\
\text { no seu corpo. O correto é o atleta estudar toda a } \\
\text { parte de biomecânica, ou seja, todos os tipos de } \\
\text { movimento da física, assim seria melhor para se } \\
\text { ter a vida saudável que ele necessita". }\end{array}$ & $\begin{array}{l}\text { "É que no esporte necessita de } \\
\text { velocidade, gravidade, etc., e } \\
\text { mecânica é tudo isso". }\end{array}$ & $\begin{array}{l}\text { "Para melhorar os saltos, } \\
\text { por exemplo". }\end{array}$ & 1 \\
\hline 21 & $\stackrel{ }{\circ}$ & $N$ & $\begin{array}{l}\text { "Eu adoro biomecânica, porque através dela eu } \\
\text { descobri vários tipos de esportes e praticando os } \\
\text { esportes podemos ter uma saúde saudável e } \\
\text { física e não tem perigo de lesões e os corpos não } \\
\text { causa dor e a vida fica uma beleza". }\end{array}$ & $\begin{array}{l}\text { "Importante entender o movimentos } \\
\text { do corpo humano". }\end{array}$ & $\begin{array}{l}\text { "Porque dai você não faz } \\
\text { o movimento errado". }\end{array}$ & 1 \\
\hline
\end{tabular}




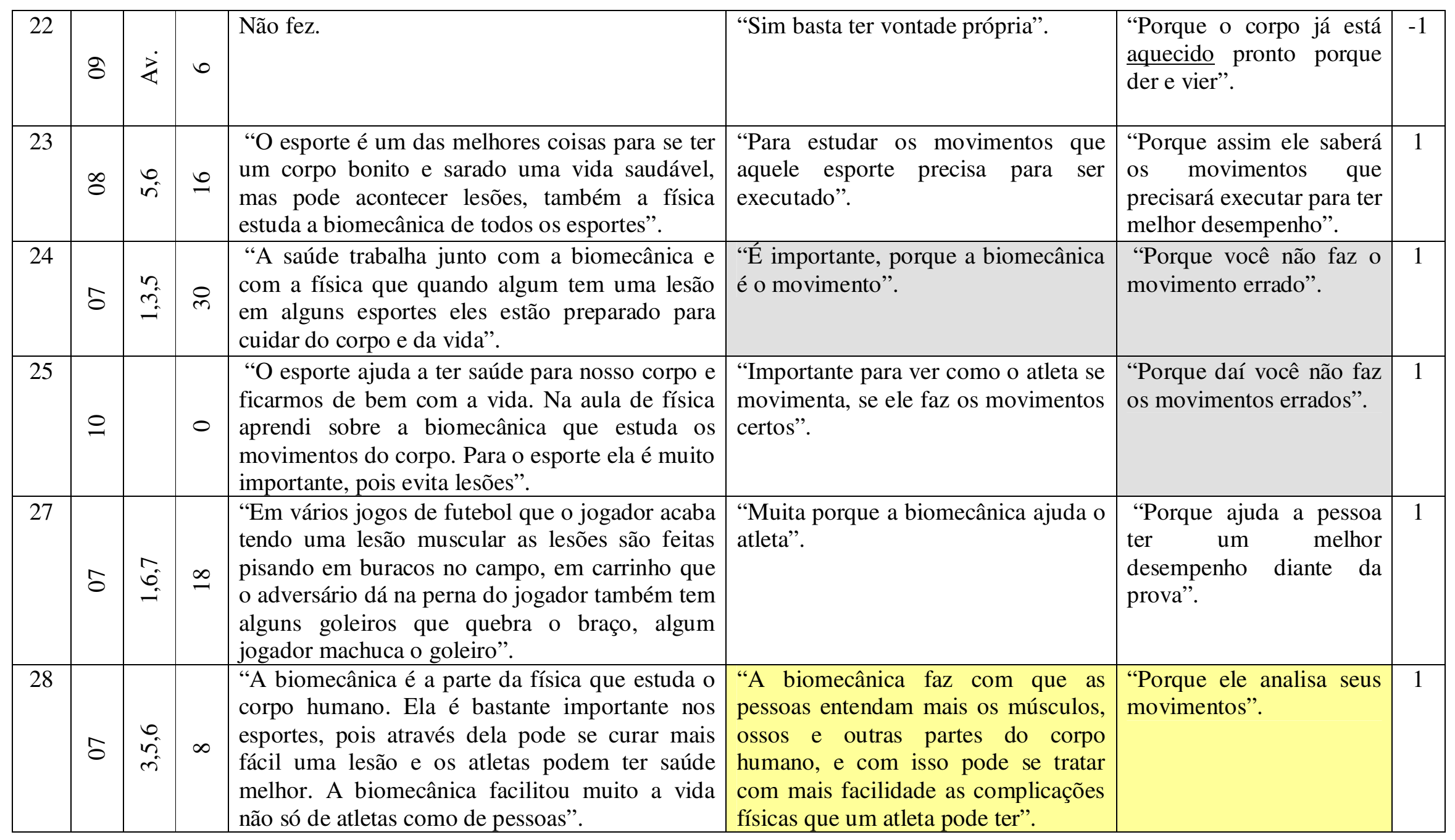




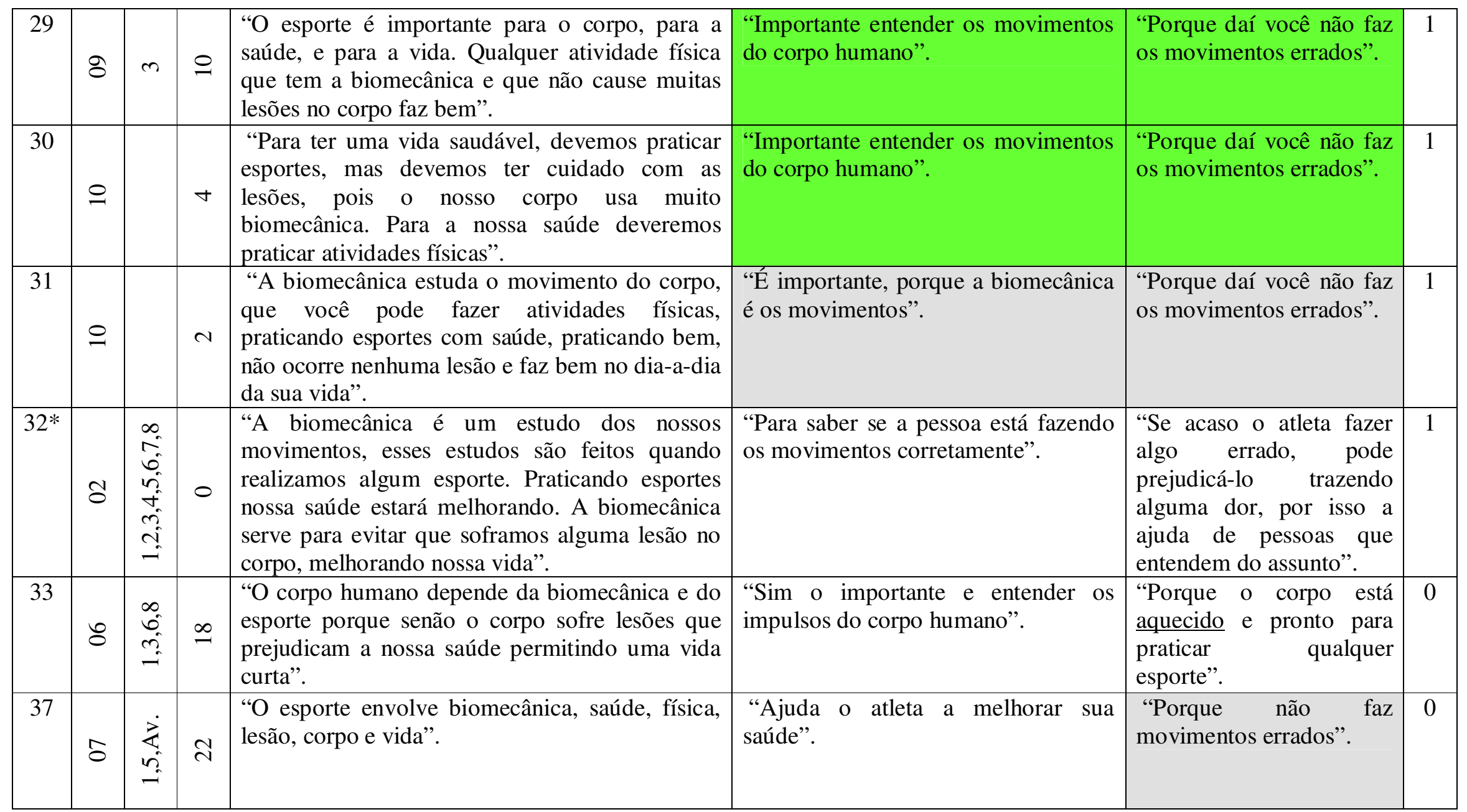

*Aluna nova - transferência de classe 
As cores iguais na tabela 4.24 mostram respostas iguais dos estudantes, que a percebemos que é por organização das carteiras (grupos), embora alguns estudantes troquem de grupo, ou seja, a disposição das carteiras na sala de aula muda, mas podemos dizer que é uma forma de organização para construir coletivamente o conhecimento. Embora as atividades fossem propostas individualmente os estudantes desta turma responderam as atividades em grupos, de acordo com o posicionamento das carteiras, que estão relacionados às afinidades entre os estudantes.

Relacionando as respostas idênticas na tabela 4.24 com as figuras 4.20 a 4.22 , identificamos grupos relacionados a posição: os alunos $\left(02, \mathrm{C}_{2}\right),\left(09, \mathrm{C}_{2}-10\right.$ no mapeamento da sala), $\left(16, \mathrm{C}_{2}\right),\left(21 \mathrm{C}_{2}\right),\left(29, \mathrm{C}_{2}-28\right.$ no mapeamento da sala $),\left(30, \mathrm{C}_{2}-29\right.$ no mapeamento da sala) compartilham as respostas, embora não sentem em grupo fechado, mas fiquem espalhados. Os alunos $\left(11, \mathrm{C}_{2}\right),\left(15, \mathrm{C}_{2}\right)$ trabalham sempre juntos e segundo o relato da professora são bons alunos.

Os alunos (07, $\left.\mathrm{C}_{2}\right),\left(24, \mathrm{C}_{2}\right.$ - aluno do "grupo E" - descrito a seguir) compartilharam informações com o aluno $\left(31, \mathrm{C}_{2}\right)$ embora sentem em lugares afastados. Os alunos $\left(04, \mathrm{C}_{2}\right),\left(12, \mathrm{C}_{2}\right)$ não estejam representados na figura (faltaram no dia do mapeamento da sala) sentam juntos e compartilharam informações com o aluno $\left(27, \mathrm{C}_{2}\right)$.

\section{Mapeamento da turma $1^{\circ} \mathrm{C}_{2}$}

O mapeamento foi obtido pela respostas dos 21 estudantes ao questionário de validação $\left(\mathrm{Q}_{3}\right)$ - seção 4.4. Ao analisar o mapa da classe elaborado pelos estudantes, a maioria nos surpreenderam, pois representaram as carteiras em posição de fileiras (figura 4.21 e 4.22), o que não é real, mas tivemos alguns estudantes que ilustraram em detalhes a sala de aula (figura 4.20), observe que um mapa complementa o outro.

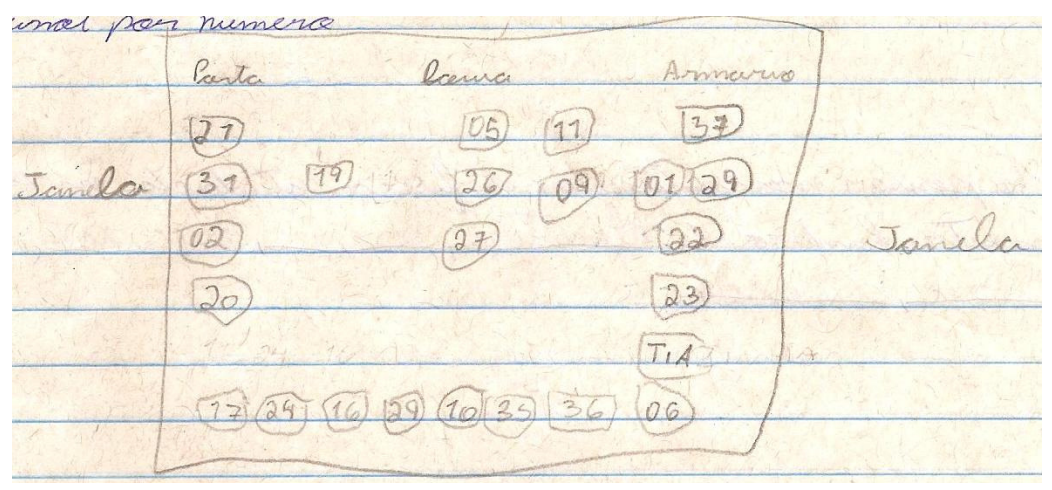

Figura 4.20: Mapa da turma $1^{\circ} \mathrm{C}_{2}$ - feito pelo aluno $\left(8, \mathrm{C}_{2}\right)$. 


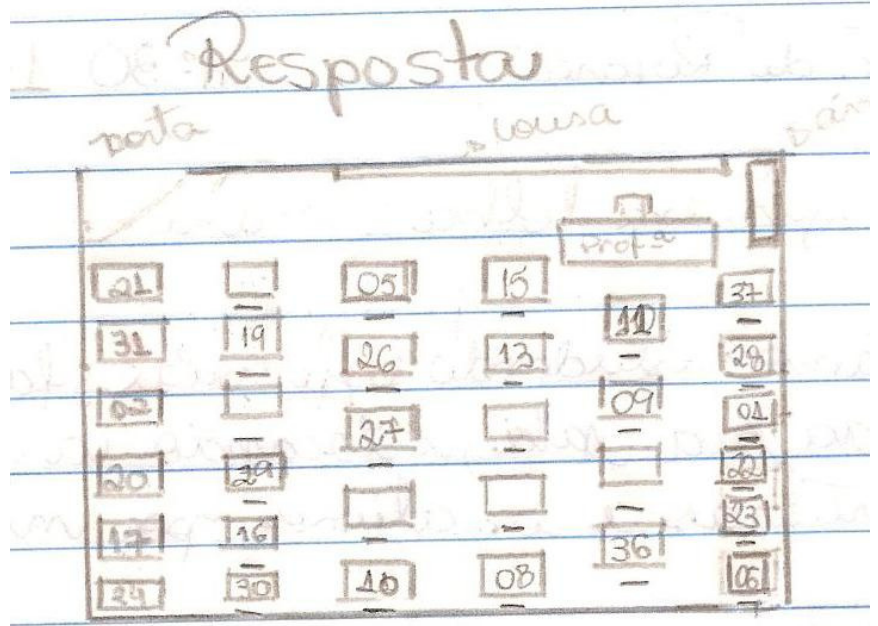

Figura 4.21: Mapa da turma $1{ }^{\circ} \mathrm{C}_{2}$ - feito pelo aluno $\left(31, \mathrm{C}_{2}\right)$.

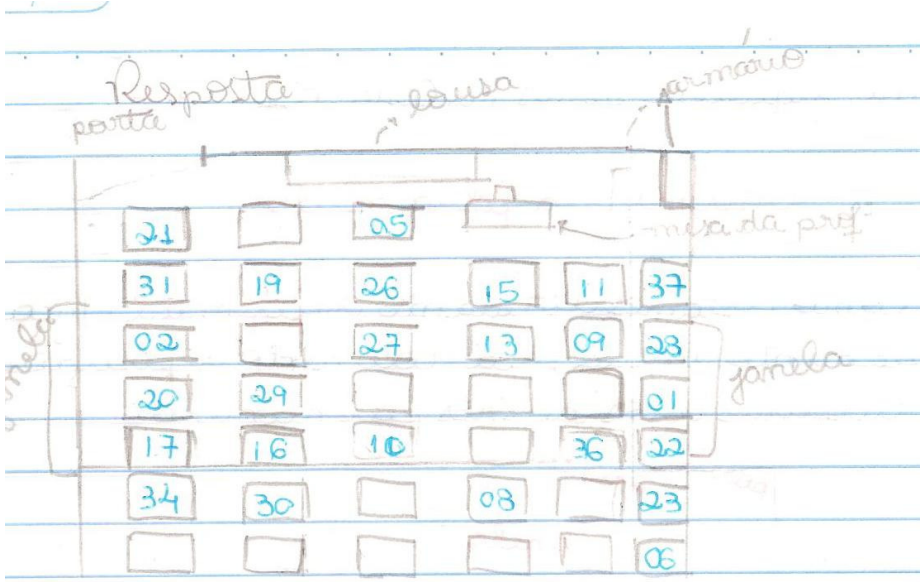

Figura 4.22: Mapa da turma $1^{\circ} \mathrm{C}_{2}$ - feito pelo aluno $\left(16, \mathrm{C}_{2}\right)$.

\section{Classificação}

De acordo com as categorias elaboradas a posteriori, pudemos mapear a complexificação do conhecimento de esporte e verificar que a maioria dos estudantes conseguiu relacionar esporte e física (tabela abaixo).

Tabela 4. 25: Graus de complexidade atingidos na turma $1^{\circ} \mathrm{C}$ da escola $\mathrm{M}$.

\begin{tabular}{|c|c|}
\hline Grau de complexidade & Porcentagem (\%) \\
\hline Grau -2 & 27 \\
\hline Grau -1 & 2,7 \\
\hline Grau 0 & 10,8 \\
\hline Grau 1 & 59,4 \\
\hline
\end{tabular}


Observe a figura 4.23:

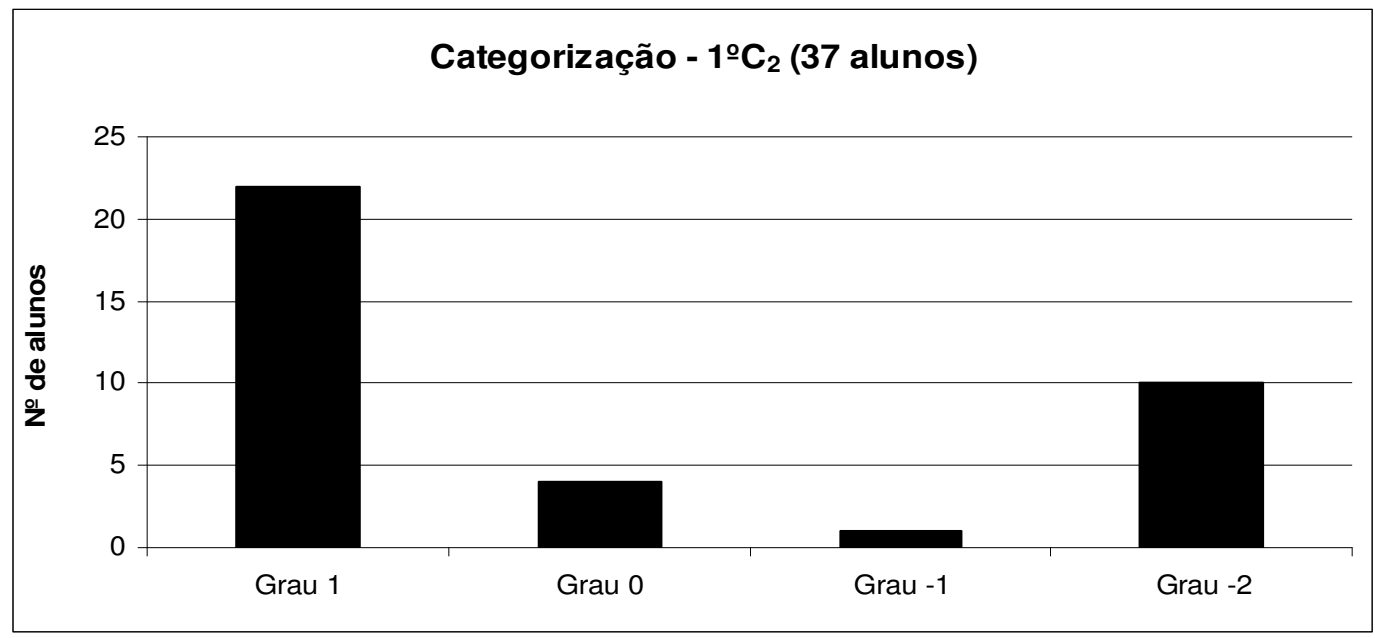

Figura 4.23: Complexificação do conhecimento de $1^{\circ} \mathrm{C}_{2}$.

Os estudantes tiveram o primeiro contato com a palavra biomecânica na atividade 3 da intervenção e depois o termo apareceu somente na atividade 9, mas estava implícito nas outras atividades. $\mathrm{Na}$ atividade 3 contém um texto que explica o que é e para que serve a biomecânica e nesta atividade os estudantes tinham que responder a algumas questões, perceba que os estudantes apenas transcreveram trechos do texto nas respostas (tabela 4.26). Comparando com as respostas obtidas na questão 1 da atividade avaliatória, estes dados nos fornecem mais evidências da complexificação do conhecimento de esporte dos estudantes.

Tabela 4.26: Respostas do $1^{\circ} \mathrm{C}_{2}$ da escola $\mathrm{M}$.

\begin{tabular}{|l|l|}
\hline \multirow{2}{*}{ Q.4: De que forma a "ciência" pode ajudar um técnico a melhorar o desempenho } \\
de um atleta? \\
Q.5c: Complete a frase: A biomecânica pode ajudar a.... \\
Q.5d: A biomecânica pode ajudar a corrigir os movimentos de um atleta para \\
melhorar seu desempenho? De que forma?
\end{tabular}


(Q.5d) "Sim da forma que ela monitora os movimentos".

Para completar os dados, na turma $1^{\circ} \mathrm{C}_{2}$ atentamos a outras questões de outras atividades da intervenção que possibilitassem analisar se o estudante aplica as novas zonas do perfil conceitual de esporte em outro contexto. A tabela 4.27 trás a comparação da resposta a questão 1 da atividade 1 que se repete na questão 12 da atividade 9. Verificamos que os estudantes passam a aplicar os conceitos contidos na intervenção, que antes não eram relevantes, pois associavam o técnico apenas a vitória da competição (que faz parte da responsabilidade de um técnico), e agora atentam também para o desempenho (movimentos corretos) associado a saúde do atleta.

Tabela 4.27: Comparação de questões das atividades 1 e 9 (técnico) $-1^{\circ} \mathrm{C}_{2}-$ escola M.

\begin{tabular}{|l|l|l|}
\hline Aluno & \multicolumn{1}{|c|}{ Atividade 1 } & \multicolumn{1}{|c|}{ Atividade 9 } \\
& $\begin{array}{l}\text { Q.1: Quais são as maiores } \\
\text { responsabilidades de um técnico de } \\
\text { qualquer modalidade esportiva? } \\
\text { Q.6: Seu conhecimento atual é suficiente } \\
\text { para que você faça bons apontamentos } \\
\text { (comentários) para auxiliar um atleta? Que } \\
\text { conhecimentos estão te faltando? }\end{array}$ & $\begin{array}{l}\text { de qualquer as maiores } \\
\text { esportiva? }\end{array}$ \\
\hline 11 & $\begin{array}{l}\text { (Q.1) "Preparar o time de todas as formas, } \\
\text { assim fazendo com um time melhor". } \\
\text { (Q.6) "De todas as características e forma } \\
\text { de jogar". }\end{array}$ & $\begin{array}{l}\text { (Q.12) "O treinador precisa ter } \\
\text { conhecimento em física e } \\
\text { conseguir identificar também a } \\
\text { partir de exames". }\end{array}$ \\
\hline 22 & $\begin{array}{l}\text { (Q.6) "Falta ser um bom técnico". } \\
\text { (Q.12) "Sim deve prestar atenção } \\
\text { no movimento do atleta". }\end{array}$ \\
\hline
\end{tabular}

Nesta turma não realizamos a comparação de algumas questões da atividade 2 com a atividade 9, pois pela análise não conseguimos verificar os graus de complexidade, que neste caso seria associar prática esportiva a saúde com conhecimento de que a prática inadequada de esporte trás lesões ao ser humano, pois muitos estudantes não haviam respondido a todas as questões das atividades, como por exemplo o aluno $\left(11, \mathrm{C}_{2}\right)$, observe na tabela 4.28:

Tabela 4.28: Comparação de questões das atividades 1 e 9 (saúde) - $1^{\circ} \mathrm{C}_{2}-$ escola M.

\begin{tabular}{|l|l|l|}
\hline Aluno & Atividade 2 & Atividade 9 \\
\hline 11 & $\begin{array}{l}\text { (10b) não respondeu } \\
\text { (10c) não respondeu }\end{array}$ & $\begin{array}{l}\text { (Q.2) “Tem que primeiramente alongar e fazer o } \\
\text { aquecimento". } \\
\text { (Q.7) “Tomar cuidado com a saúde e usado para não } \\
\text { se lesionar". }\end{array}$ \\
\hline
\end{tabular}

\section{Relação física e educação física}

$\mathrm{Na}$ tabela 4.24 sublinhamos algumas palavras que evidenciam que alguns estudantes associam os conteúdos da disciplina de educação física aos de física. $\mathrm{O}$ 
professor de educação física desta turma nos relatou por entrevista informal que em suas aulas insiste em falar da importância do alongamento antes de qualquer atividade física para evitar lesões e que no $2^{\circ}$ bimestre passou uma reportagem sobre os movimentos da ginasta Daiane dos Santos ao realizar o salto "Duplo Twist Carpado".

Nas respostas ao questionário de validação percebemos que a maioria dos estudantes passou a construir a ponte interdisciplinar entre física e educação física, sendo que a estudante $\left(27, \mathrm{C}_{2}\right)$ cita o salto duplo "Duplo Twist Carpado" visto na aula de educação física. Como o questionário é composto por 7 questões, analisamos sem em uma delas, o estudante demonstra apropriação da relação física e educação física.

\section{Relação professora-aluno}

Para obtermos mais informações sobre o relacionamento da turma $\mathrm{C}_{2}$ com a professora, e avaliar a metodologia utilizada na intervenção + caderno de física vol. 1 e 2, elaboramos um questionário com 10 questões, que denominamos de questionário de opinião, que nesta turma pedimos para os alunos não se identificarem, com objetivo de deixá-los mais livres para se expressar (aplicado pela própria professora da turma), observe a tabela 4.29 .

Tabela 4.29: Questionário de Opinião das aulas $-1{ }^{\circ} \mathrm{C}_{2}-$ escola M.

\begin{tabular}{l} 
1 - Para eu aprender a matéria de física a professora deve... \\
"Explicar bem a matéria para todos..." \\
"Explicar muitas vezes e passar menos lição..." \\
"Deve chamar atenção quando eu não estiver prestando atenção..." \\
"Ter muita paciência..." \\
\hline 2- Eu odeio quando a professora de física... \\
"Passa muita lição..." \\
"Passa lição na lousa e briga com os alunos por causa da bagunça..." \\
"Não odeio, somente não gosto quando ela entope a gente de muitas lições..." \\
"Dá muitas páginas do caderninho pra responder..." \\
"Vem com muita lição, não sabemos em qual prestamos atenção, caderninho, lousa e \\
apostila..." \\
"Começa a tagarelar e eu não entendo nada". \\
"Passa muita matéria em pouco tempo de responder, e as perguntas são complicadas". \\
"Acumula diversos tipos de lição em uma aula". \\
"Não manda os alunos ficarem quietos na hora da lição". \\
3 - Para melhorar as aulas de física a professora deve... \\
"Não passar muita lição..." \\
"Controlar mais os alunos..." \\
"ser mais simpática, conversar mais com os alunos..." \\
4 - Para eu compreender a matéria devo... \\
"prestar atenção nas aulas..." \\
"me esforçar prestar atenção..."
\end{tabular}


5 - Como seria um professor ideal?

"Um professor que tenha paciência e explique de um jeito que nós entenda".

"Compreensivo, que saiba explicar".

"Que dê aula interessante e engraçada".

6 - Como seria um aluno ideal?

"Que seja educado, que preste atenção e faça as lições".

"O aluno que vem para escola aprender e não para encontrar os amigos".

"Que não fizesse bagunça e prestasse atenção".

7 - Eu gosto da escola porque...

"Aprendo coisas novas, não fico em casa sozinha, como comida, me divirto..."

"Vejo os amigos e aprendo alguma coisa".

"Faço novas amizades".

8 - Eu odeio a escola porque...

"Eu não odeio a escola".

"Há matérias e professores chatos".

"Faço muita lição".

\section{9 - As atividades do caderninho foram....}

"Muito difícil por causa que era muitas perguntas difíceis.."

"Chatas, mas não posso reclamar, porque também foram úteis, mas quando a professora passa o caderninho ela geralmente passa muitas perguntas aí é chato".

"Muito cansativas".

"ruins, não entendo nada..."

"Difíceis de responder as questões chatas e trabalhosas".

"Muito complicadas".

"Até que legais".

"Difíceis e muitas perguntas para pouco tempo..."

"Mais ou menos tinha lições super fácil e lógica, mas algumas meio estranhas que não conseguia compreender direito".

"Repetitivas, chatas, mas ensinaram algo".

"Diferentes, um pouco difíceis, mas dá para aprender algo".

"Difíceis por entrarem no assunto rápido e textos complexos".

"Essenciais para que eu aprendesse sobre muitos assuntos de física. Alguns exercícios foram difíceis e chatos, mas me ajudaram a entender muitas coisas".

10 - O caderno do aluno de física é...

"Muito difícil de responder".

"Complicadas, mas são legais..."

"Uma coisa sem palavra porque tem que trazer, se esquece tira um negativo e tem coisa muito difícil de se entender".

"Legais eu gosto fazer lição nelas são bem interessantes e melhor do que ficar copiando e respondendo atividades".

"boas, mas deveriam ser mais fáceis pois estamos começando estudar física este ano e precisamos de uma coisa básica antes de ir mais fundo com a matéria".

"complicada e confusa..."

Pudemos perceber pelos relatos dos estudantes no questionário de opinião que a

professora possui um comportamento atípico aos demais professores, pois é muito centrada no conteúdo das aulas, não estabelece conversas paralelas ao conteúdo, e isto gera aplicação de atividades em demasiado aos estudantes, que se sentem sufocados. 
Para comparação temos um curto relato da professora sobre sua relação com a sala: "Meu relacionamento nesta sala é mediano, pois sei que irá ser muito desgastante as duas aulas, devido ao trabalho paralelo que irei fazer com os D.A.'s e a falta de controle dos outros alunos com as conversas e com suas cobranças incessantes de atendimento instantâneo, não possuem a paciência da espera e são inseguros, precisam de confirmação constante a suas respostas. Isso me deixa irritada e cansada" (Anexo 3.2.3).

Percebemos neste discurso que a professora não enxerga os alunos do grupo B como o principal problema da turma (oposto aos estudantes), pois no global a turma inteira é falante durante as aulas, mas a maioria dos estudantes são inseguros e precisam da ajuda da professora apenas para confirmar a resposta, embora já tenham a resposta em mãos elaboradas por eles próprios. Mas nesta turma além dos alunos relatarem que se sentem sufocados com muitas atividades por aula, a professora se sente do mesmo jeito, pois tem que fornecer atenção devida aos deficientes auditivos e sanar a ansiedade dos alunos com as dúvidas que surgem, mas de uma forma geral isso não impede que a professora mantenha uma boa relação com a turma.

Quanto ao caderno de física do aluno, a maioria dos estudantes (dentre os que aprovam e reprovam) enfatiza a dificuldade em realizar as tarefas e a facilidade em não precisar copiar as lições da lousa.

Quanto as atividades de intervenção, os estudantes (dentre os que aprovam e reprovam) enfatizam a extensão das atividades e das questões e a dificuldade em interpretar tanto os textos quanto as questões.

\section{Casos Particulares}

- Alunos do grupo E

Esta categoria de estudantes serve para enquadrar os alunos que circulam na sala de aula em busca de respostas corretas, segundo seus critérios. Estes alunos implicitamente durante as aulas prestam atenção e sabem escolher a melhor resposta, como é o caso do aluno $\left(7, \mathrm{C}_{2}\right)$ e $\left(24, \mathrm{C}_{2}\right)$.

- Alunos do grupo C

$\mathrm{Na}$ turma encontramos dois alunos no grupo $\mathrm{C}$ : o aluno (32, $\mathrm{C}_{2}$ - aluno novato transferido de outra turma) que embora tenha participado apenas da atividade 9 e da 
atividade avaliatória se enquadra no grau 1 de complexidade e o aluno $\left(3, \mathrm{C}_{2}\right)$ que ficou ausente durante 5 atividades num total de 28 faltas, mas que é classificado também no grau 1 de complexidade. Os dois alunos estão inseridos no mesmo grupo (mapeamento), e interagem um com os outros o que gera a construção do conhecimento com o "estudante mais capaz" que esteve presente em todas as atividades.

\subsubsection{Turma $1^{\circ} \mathrm{D}_{2}$}

A turma $1^{\circ} \mathrm{D}_{2}$, referente a escola $\mathrm{M}$ é composta por 37 alunos, sendo que dentre eles analisamos as respostas de apenas 28 alunos, pois no decorrer do semestre tivemos algumas transferências de classe e de escola e alguns abandonos de curso. Nesta turma as duas aulas eram ministradas em dias diferentes, na terça-feira a $1^{\text {a }}$ aula e na quintafeira a $4^{\text {a }}$ aula do período da tarde.

A aplicação da intervenção na turma $1^{\circ} \mathrm{D}_{2}$ seguiu inicialmente o plano de aula (tabela 3.14) que prevê o término da intervenção em junho (fim do $1^{\circ}$ semestre), mas durante a aplicação sofreram mudanças devido a imprevistos no calendário escolar, a frequência dos estudantes na aula, reuniões internas, etc., observe na tabela 4.30 o diário de classe da professora.

Tabela 4.30: Diário de classe.

\begin{tabular}{|c|c|}
\hline $\begin{array}{c}\text { Data - } \\
\text { noaulas }\end{array}$ & Conteúdo $-1^{\circ} \mathbf{D}_{2}$ \\
\hline $18 / 02-2$ & Apresentação \\
\hline $23 / 02-1$ & Atividade 1 \\
\hline $25 / 02-1$ & Término ativ. $1+$ cad. 1 (p. 3,4 e 5) \\
\hline $02 / 03-1$ & Atividade 2 \\
\hline $04 / 03-1$ & S.I. (Sist. Internacional.)+ cad. 1 (p. 6 e 7$)$ \\
\hline $09 / 03-1$ & Ex. sobre unidades e deslocamento \\
\hline $11 / 03-1$ & Ativ. 3 \\
\hline $16 / 03-1$ & Veloc. Média \\
\hline $18 / 03-1$ & Ex. Veloc. Média \\
\hline $23 / 03-1$ & Lições atrasadas \\
\hline $25 / 03-1$ & Ativ.4 (quadra) \\
\hline $30 / 03-1$ & Ativ. $4+$ cad. 1 (p. 16) \\
\hline $01 / 04-1$ & cad. 1 (p. 8 e 12) + ex. Veloc. Média \\
\hline $06 / 04-1$ & Ativ. 4 \\
\hline $08 / 04-1$ & Ativ. 4 \\
\hline $13 / 04-1$ & $\mathrm{Am}+\mathrm{ex}$ \\
\hline $15 / 04-1$ & Ativ. 4 \\
\hline $20 / 04-1$ & cad.1 (p. 17 a 20) \\
\hline $22 / 04-1$ & Lições atrasadas \\
\hline $27 / 04-1$ & cad. 1 (p. 21 a 24) $+\mathrm{P}=\mathrm{m} . \mathrm{g}$ \\
\hline $29 / 04-1$ & Ativ. 5 \\
\hline
\end{tabular}




\begin{tabular}{|c|c|}
\hline $04 / 05-1$ & Ativ. 5 \\
\hline $06 / 05-1$ & cad. 1 (p. 24 a 26) \\
\hline $13 / 05-1$ & cad. 1 (p. 32 a 37) \\
\hline $18 / 05-1$ & 3 leis de Newton \\
\hline $20 / 05-1$ & Ativ. 6 \\
\hline $24 / 05-1$ & Ativ. 7 \\
\hline $27 / 05-1$ & Ativ. 7 \\
\hline $01 / 06-1$ & Cad. 2 (p. 7 a 10) \\
\hline $10 / 06-1$ & Em + cad. 2 (p. 11 a 16) \\
\hline $17 / 06-1$ & Pot. + cad. 2 (p. 24 a 27) \\
\hline $22 / 06-1$ & Torque + cad. 2 (p. 42 a 46$)$ \\
\hline $24 / 06-1$ & Ativ. 7 \\
\hline $29 / 06-1$ & Ativ. $7+$ Ativ. 8 \\
\hline $01 / 07-1$ & Ativ. 8 \\
\hline $03 / 08-1$ & Cad. 3 + Exp. Cad. 2 p/ entregar em setembro + Ativ. 9 \\
\hline $05 / 08-1$ & Ativ. 9 \\
\hline $10 / 08-1$ & Ativ. avaliatória \\
\hline $24 / 08-1$ & Cad. $3+$ Ativ. pessoal \\
\hline
\end{tabular}

Durante a aplicação das atividades contabilizamos 45 aulas, mas ministramos a intervenção em 40 aulas. A diferença de 5 aulas inclui reunião de pais com alunos, reunião de professores, interrupção do inspetor, atividades do caderno do aluno de física vol.3 (não incluso na intervenção), etc. Lembramos que no plano de aula (tabela 3.14) estabelecemos 23 aulas para toda a intervenção, e esta turma excedeu em 17 aulas o previsto. A dinâmica desta sala é bem atípica, os estudantes têm um ritmo bem lento para entrega de atividades (sempre atrasados na entrega de atividades), por serem falantes e não dar a atenção devida ao professor, além disso, as duas aulas de física são ministradas na $1^{\mathrm{a}}$ aula (entrada) e na $4^{\mathrm{a}}$ aula (depois do intervalo) o que corrobora para o atraso, pois não demoram menos de $20 \mathrm{~min}$ para se organizarem em sua "bagunça organizada" e imprevisível, é praticamente um sistema caótico.

$\mathrm{Na}$ figura 4.24, observamos picos de alta frequência, mas temos uma média de alunos frequentes na maioria das atividades da intervenção, ou seja, ficamos com um grupo de estudantes que não revezam a presença nas aulas. Acreditamos que nos dias em que há baixa frequência os estudantes decidem cabular a aula em grupo, exceto pelo dia 20/04 que antecedeu o feriado. 


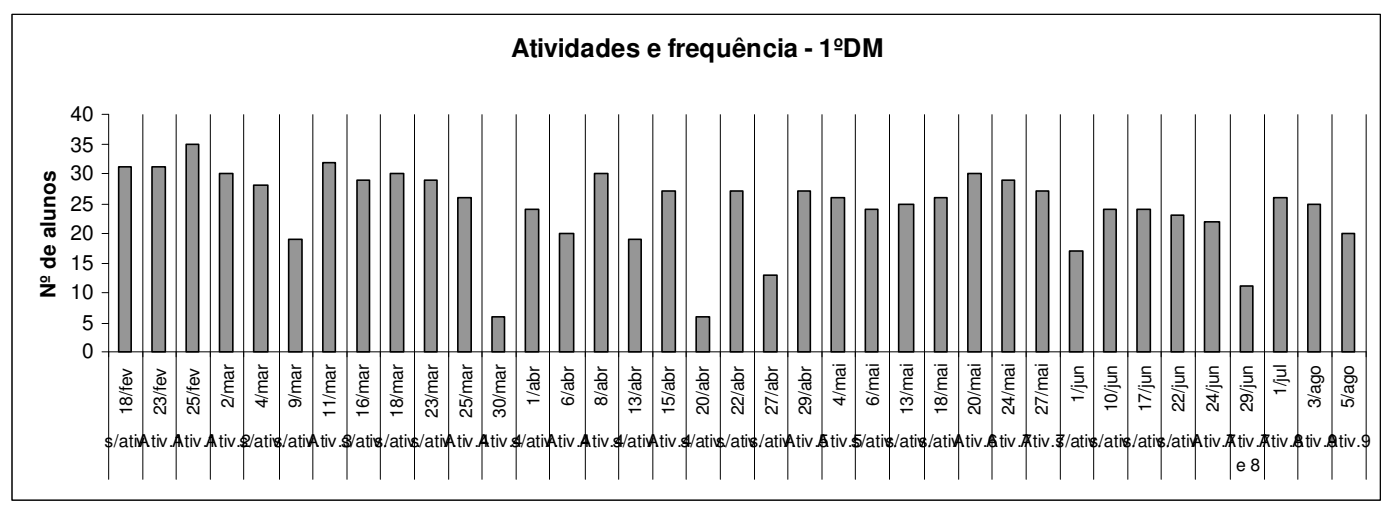

Figura 4.24: Atividade e frequência da turma $1^{\circ} \mathrm{D}_{2}$.

$\mathrm{Na}$ atividade 1, com a questão 7 , os estudantes descrevem as disciplinas escolares que mais identificam com o esporte, pudemos verificar se os estudantes já estabelecem alguma relação entre a disciplina de física e o esporte. Observe na figura 4.25 que a disciplina de educação física aparece em $1^{\circ}$ lugar, a disciplina de língua portuguesa em $2^{\circ}$ lugar e a disciplina de matemática em $3^{\circ}$ lugar. Mas mesmo com a modificação realizada na questão após a atividade piloto, continuamos com alguns estudantes citando as disciplinas de inglês, língua portuguesa entre outras, que segundo eles são primordiais para comunicação do atleta no Brasil e em outros paises.

Questão 7: Será que algumas das disciplinas (I, P, G, H, M, Q, B, F, EF, EA, Fil, So) que você tem na escola podem ajudar um atleta a ter um bom desempenho? Cite pelo menos quatro disciplinas (coloque em ordem de importância), e explique como ela será útil para análise de uma prática esportiva. Para facilitar complete a tabela abaixo:

\begin{tabular}{|l|l|l|l|}
\hline & Disciplina & $\begin{array}{l}\text { Conteúdo } \\
\text { específico da disciplina }\end{array}$ & Auxilia ... \\
\hline Exemplo & Artes & Técnicas de Pintura & $\begin{array}{l}\text { Dar harmonia as cores no } \\
\text { quadro }\end{array}$ \\
\hline $1^{a}$ & & & \\
\hline $2^{a}$ & & & \\
\hline $3^{a}$ & & & \\
\hline $4^{a}$ & & & \\
\hline
\end{tabular}

Observe que a disciplina de física nunca aparece em primeiro lugar e a explicação para isso encontra-se em um questionamento realizado pela aluna $\left(8, \mathrm{D}_{2}\right)$ : “Como que eu vou saber se tem a ver com física, nem sei o que é física?” durante a aplicação da atividade 1. Acreditamos que no contexto geral muitos professores de ciências do $9^{\circ}$ ano do ensino fundamental municipal escolhem por comodidade ou afinidade enfocar química ou biologia ou física; isso resulta em salas heterogêneas de $1^{\circ}$ ano do ensino médio. Essa mesma situação ocorreu no questionário $\mathrm{Q}_{2}$ (figura 4.2) referente ao $1^{\circ}$ ano do ensino médio, mas é relevante destacar que não ocorre nas outras 
séries do ensino médio (fig.4.3 e 4.4), pois já tiveram contato com a disciplina de física nos anos anteriores.

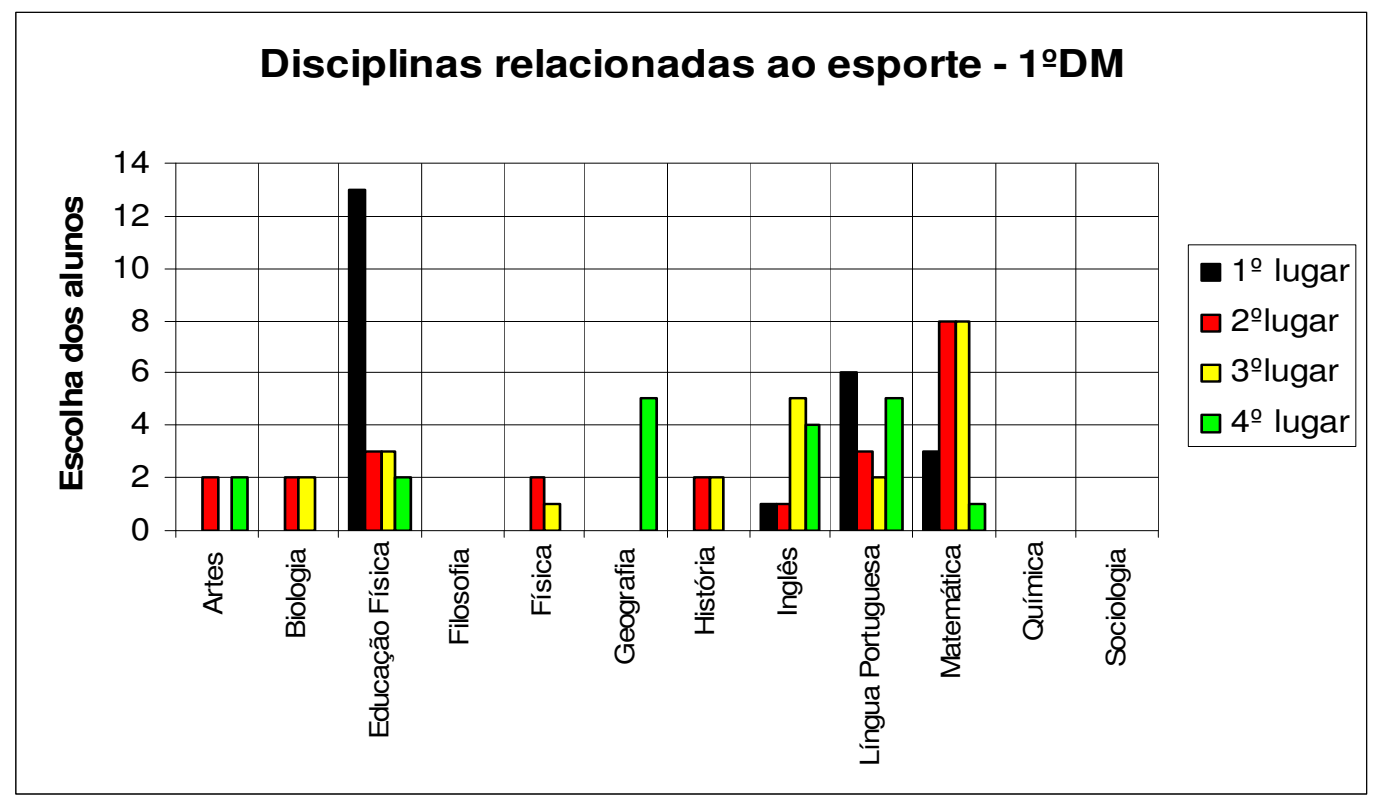

Figura 4.25: Posições das disciplinas - turma $\mathrm{D}_{2}$

Mostramos nas tabelas 4.31, 4.33, 4.34 e 4.35 algumas respostas dos alunos de algumas questões e atividades selecionadas (tabela 3.19), cujo é possível analisar a complexificação do conhecimento de esporte.

A tabela 4.31 traz a quantidade de atividades entregues, atividades que faltaram, faltas durante o período de aplicação da intervenção e as respostas dos estudantes a questão 5 e 8 da atividade 9 e a questão 1 da atividade avaliatória, que nos informam sobre a complexificação do conhecimento de esporte. 
Tabela 4.31: Comparação de questões das atividades 1 e $9-1^{\circ} \mathrm{D}_{2}-$ escola $\mathrm{M}$.

\begin{tabular}{|c|c|c|c|c|c|c|c|}
\hline 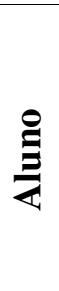 & 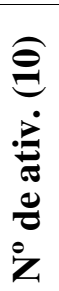 & 离 & $\frac{10}{2}$ & $\begin{array}{l}\text { Atividade Avaliatória } \\
\text { Q.1: Formule um texto, uma frase ou uma história que } \\
\text { contenha obrigatoriamente (no singular ou plural) as } \\
\text { palavras: biomecânica, esporte, saúde, física, lesão, } \\
\text { corpo e vida. }\end{array}$ & $\begin{array}{l}\text { Atividade } 9 \\
\text { Q.5: Qual a importância da } \\
\text { biomecânica para prática } \\
\text { esportiva? }\end{array}$ & $\begin{array}{l}\text { Atividade } 9 \\
\text { Q.8: Por que uma } \\
\text { compreensão básica dos } \\
\text { princípios mecânicos } \\
\text { básicos ajudará o atleta a ter } \\
\text { um melhor desempenho? }\end{array}$ & 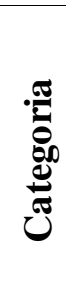 \\
\hline 02 & 5 & $\hat{i}$ & 6 & $\begin{array}{l}\text { "Porque o atleta tem que comer bem e fazer exercício, } \\
\text { tem que ter uma boa alimentação e tem que se aquecer } \\
\text { antes de qualquer jogo". }\end{array}$ & $\begin{array}{l}\text { "É importante para pratica } \\
\text { de um esporte porque sem a } \\
\text { biomecânica nós não } \\
\text { poderíamos } \\
\text { movimentar". }\end{array}$ & $\begin{array}{l}\text { "Porque se ele conhecer } \\
\text { esses princípios mecânicos } \\
\text { fará com, que ele tome } \\
\text { cuidado para não se } \\
\text { lesionar". }\end{array}$ & 1 \\
\hline 03 & 8 & $\checkmark$ & $r$ & $\begin{array}{l}\text { "Para ter saúde tem que se alimentar bem fazer muito } \\
\text { esporte como fazer jogar futebol". }\end{array}$ & "Não sei”. & “Sim”. & -1 \\
\hline 04 & $\stackrel{\infty}{\circ}$ & $\begin{array}{l}\infty \\
\forall\end{array}$ & - & $\begin{array}{l}\text { "A biomecânica estuda a saúde física e movimentos do } \\
\text { corpo dos atletas, evitando lesões e outros acidentes } \\
\text { contribuindo para uma vida saudável". }\end{array}$ & $\begin{array}{l}\text { "É } \quad \text { o estudo da } \\
\text { movimentação dos corpos". }\end{array}$ & $\begin{array}{l}\text { "Porque se ele conhecer } \\
\text { esses princípios mecânicos } \\
\text { fará com ele tome cuidado } \\
\text { para não se lesionar e } \\
\text { aumentar seu desempenho". }\end{array}$ & 1 \\
\hline 05 & $\infty$ & $\begin{array}{l}\infty \\
\forall\end{array}$ & $\simeq$ & $\begin{array}{l}\text { "Para ter um corpo com uma boa saúde e uma boa } \\
\text { condição física você precisa praticar esportes e estudar } \\
\text { os movimentos que você tem que fazer com a } \\
\text { biomecânica para não ter lesões e viver uma vida } \\
\text { saudável". }\end{array}$ & $\begin{array}{l}\text { "É que com a biomecânica } \\
\text { você estará um pouco ciente } \\
\text { dos movimentos que você } \\
\text { deve fazer para praticar } \\
\text { aquele esporte". }\end{array}$ & $\begin{array}{l}\text { "Porque estará orientado o } \\
\text { que é preciso fazer ou quais } \\
\text { os movimentos que são } \\
\text { precisos para praticar aquele } \\
\text { esporte". }\end{array}$ & 1 \\
\hline
\end{tabular}




\begin{tabular}{|c|c|c|c|c|c|c|c|}
\hline 06 & $\stackrel{\infty}{\infty}$ & $\ddot{\gamma}$ & 6 & $\begin{array}{l}\text { "Para ter um corpo bom constante que vida e uma boa } \\
\text { alimentação, para não ocorrer lesão e claro que } \\
\text { biomecânica ajuda". }\end{array}$ & "Não sei”. & “Não sei”. & -1 \\
\hline 10 & 8 & $\begin{array}{l}\infty \\
\infty \\
\infty\end{array}$ & 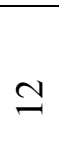 & $\begin{array}{l}\text { "Biomecânica estuda o corpo e sem movimentos como } \\
\text { no esporte ligado a saúde e na física, obtendo o melhor } \\
\text { momento da vida e também para evitar lesão". }\end{array}$ & Não entregou. & Não entregou. & 0 \\
\hline 12 & 8 & $\begin{array}{l}\infty \\
\dot{m} \\
\dot{m}\end{array}$ & $=$ & $\begin{array}{l}\text { "Para qualquer esporte a saúde física e biomecânica e } \\
\text { importante para o corpo e a vida para não ter lesões no } \\
\text { esporte e durante o dia-a-dia". }\end{array}$ & $\begin{array}{l}\text { "É o estudo da } \\
\text { movimentação do corpo". }\end{array}$ & $\begin{array}{l}\text { "Porque se ele conhecer } \\
\text { esses princípios se sairá } \\
\text { melhor". }\end{array}$ & 1 \\
\hline
\end{tabular}




\begin{tabular}{|c|c|c|c|c|c|c|c|}
\hline 13 & $\infty$ & $n$ & r & $\begin{array}{l}\text { "A biomecânica é muito importante na física pois ela } \\
\text { auxilia o esporte, a saúde, o corpo e a vida de um atleta } \\
\text { com ou sem lesão". }\end{array}$ & $\begin{array}{l}\text { "É } \quad \text { o } \quad \text { estudo } \quad \text { da } \\
\text { movimentação dos corpos". }\end{array}$ & $\begin{array}{l}\text { "Porque se ele conhecer } \\
\text { esses princípios mecânicos } \\
\text { fará com ele tome cuidado } \\
\text { para não se lesionar e } \\
\text { aumentar seu desempenho". }\end{array}$ & 1 \\
\hline 14 & $\Xi$ & 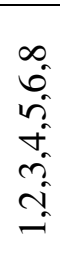 & $\underline{0}$ & $\begin{array}{l}\text { "O esporte é uma coisa que faz bem pra todos e para o } \\
\text { bem estar de todos, é bom para o corpo e para saúde e } \\
\text { para a vida. A biomecânica estuda tudo isso (O } \\
\text { movimento do corpo), ajuda a descobrir o que causa a } \\
\text { lesão. Quem pratica esporte é feliz e de bem coma } \\
\text { vida". }\end{array}$ & $\begin{array}{l}\text { "É importante para praticar } \\
\text { de um esporte porque sem a } \\
\text { biomecânica nos não } \\
\text { podemos nos movimentar". }\end{array}$ & $\begin{array}{l}\text { "Porque se ele conhecer } \\
\text { esses princípios mecânicos } \\
\text { fará com que ele tome } \\
\text { cuidado para não se } \\
\text { lesionar". }\end{array}$ & 1 \\
\hline 15 & $\stackrel{ }{-}$ & & N & $\begin{array}{l}\text { "A biomecânica é o estudo do corpo e da vida que } \\
\text { envolve o esporte e a saúde dentro da física para } \\
\text { prevenir lesões". }\end{array}$ & $\begin{array}{l}\text { "Estuda os movimentos do } \\
\text { corpo humano". }\end{array}$ & $\begin{array}{l}\text { "Porque se ele conhecer } \\
\text { esses princípios fará com } \\
\text { que ele tome cuidado em } \\
\text { não se lesionar e aumente } \\
\text { seu desempenho". }\end{array}$ & 1 \\
\hline 17 & $\hat{0}$ & $\begin{array}{l}\infty \\
i \\
\forall\end{array}$ & $\infty$ & $\begin{array}{l}\text { "A biomecânica estuda o corpo e seus movimentos } \\
\text { como no esporte ligado a saúde e na física, obtendo o } \\
\text { melhor momento da vida e também para evitar lesões". }\end{array}$ & Não entregou. & Não entregou. & 1 \\
\hline
\end{tabular}




\begin{tabular}{|c|c|c|c|c|c|c|c|}
\hline 19 & 8 & $n$ & $\forall$ & $\begin{array}{l}\text { "A biomecânica é o estudo do corpo da vida que em } \\
\text { sobre o esporte e a saúde dentro da física para prevenir } \\
\text { lesões". }\end{array}$ & \begin{tabular}{lcr|} 
"Porque & estuda & o \\
movimento & do & corpo \\
humano". & &
\end{tabular} & $\begin{array}{l}\text { "Porque se ele souber ele } \\
\text { evitará lesões". }\end{array}$ & 1 \\
\hline 22 & 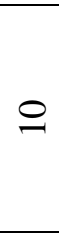 & & $=$ & $\begin{array}{l}\text { "A biomecânica estuda muito o corpo e a vida, você } \\
\text { precisa de uma boa saúde física e praticar bastante } \\
\text { esportes para prevenir lesões". }\end{array}$ & $\begin{array}{l}\text { "Estuda os movimentos do } \\
\text { corpo humano". }\end{array}$ & $\begin{array}{l}\text { "Porque se ele conhecer } \\
\text { esses princípios mecânico } \\
\text { fará com que ele tome } \\
\text { cuidado em não se lesionar e } \\
\text { aumentar seu desempenho". }\end{array}$ & 1 \\
\hline 23 & 8 & $\nabla$ & 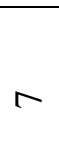 & $\begin{array}{l}\text { "Para ter um corpo ou uma vida saudável se deve } \\
\text { praticar educação física, esporte e principalmente para } \\
\text { não ocorrer lesão e é claro que a biomecânica ajuda". }\end{array}$ & $\begin{array}{l}\text { "Porque na biomecânica se } \\
\text { começa o esporte com } \\
\text { cronômetros". }\end{array}$ & $\begin{array}{l}\text { "Porque os atletas estudam a } \\
\text { compreensão e isso ajuda". }\end{array}$ & 1 \\
\hline 24 & 8 & $n$ & $r$ & $\begin{array}{l}\text { "A biomecânica ajuda os atletas de qualquer esporte } \\
\text { para ajudar o corpo e não ter lesões e ter uma saúde e } \\
\text { vida melhor fazendo exercícios físicos" }\end{array}$ & $\begin{array}{l}\text { "É muito importante pois } \\
\text { através dela saberemos o } \\
\text { que fazer com o corpo". }\end{array}$ & $\begin{array}{l}\text { "para sabermos } \text { quais } \\
\text { movimentos fazer com o } \\
\text { corpo". }\end{array}$ & 1 \\
\hline 25 & $\hat{0}$ & $\ddot{n}$ & $\infty$ & $\begin{array}{l}\text { "Biomecânica é muito com para o corpo, saúde física e } \\
\text { toda a vida, praticar esportes é bom só que com } \\
\text { cuidados para evitar lesões". }\end{array}$ & Não entregou. & Não entregou. & 1 \\
\hline 26 & 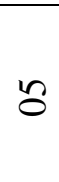 & 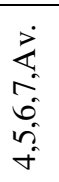 & $m$ & Não entregou. & $\begin{array}{l}\text { "Estuda os movimentos do } \\
\text { corpo humano". }\end{array}$ & $\begin{array}{l}\text { "porque ele sabe a } \\
\text { capacidade do seu corpo". }\end{array}$ & 1 \\
\hline
\end{tabular}




\begin{tabular}{|c|c|c|c|c|c|c|c|}
\hline 27 & 으 & & $n$ & $\begin{array}{l}\text { "O esporte deve fazer parte da nossa vida, pois nos } \\
\text { proporciona uma corpo e uma saúde estável. Através da } \\
\text { biomecânica podemos ter uma ideia de atividades } \\
\text { físicas que podemos fazer e evitar lesões". }\end{array}$ & $\begin{array}{l}\text { "É muito importante, pois } \\
\text { através da biomecânica } \\
\text { sabemos quais movimentos } \\
\text { podem ser feitos com o } \\
\text { corpo". }\end{array}$ & $\begin{array}{l}\text { "Porque ele terá uma noção } \\
\text { melhor nos exercícios que } \\
\text { pode fazer em cada parte do } \\
\text { corpo". }\end{array}$ & 1 \\
\hline 28 & 8 & $\infty$ & $\infty$ & $\begin{array}{l}\text { "A biomecânica é muito necessária no esporte, porque } \\
\text { você tem que ter um bom porte físico e preparo físico } \\
\text { também, e principalmente saúde, porque senão tiver } \\
\text { preparo físico, você dever ter uma lesão. Tipo o futebol } \\
\text { você tem que aquecer seu corpo para futebol porque o } \\
\text { futebol é o seu principal trabalho na vida se você é } \\
\text { jogador de futebol". }\end{array}$ & $\begin{array}{l}\text { "Nós precisamos muito da } \\
\text { biomecânica porque nós se } \\
\text { movimenta muito". }\end{array}$ & $\begin{array}{l}\text { "Para o atleta ser melhor no } \\
\text { seu esporte". }\end{array}$ & 1 \\
\hline 32 & 今 & $\begin{array}{l}\sum_{1} \\
\infty \\
\infty\end{array}$ & 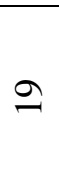 & Não entregou. & $\begin{array}{l}\text { "É muito importante porque } \\
\text { necessário para os } \\
\text { movimentos". }\end{array}$ & $\begin{array}{l}\text { "Porque a pessoa já } \\
\text { conhecerá como começar o } \\
\text { esporte". }\end{array}$ & 0 \\
\hline 33 & 8 & n & $\infty$ & $\begin{array}{l}\text { "Biomecânica estuda o corpo e seus movimentos como } \\
\text { no esporte ligado a saúde e na física obtendo o melhor } \\
\text { momento de vida e também para cuidar lesões". }\end{array}$ & $\begin{array}{l}\text { "Estuda os movimentos do } \\
\text { corpo humano". }\end{array}$ & $\begin{array}{l}\text { "Porque se ele conhecer } \\
\text { esses princípios fará com } \\
\text { que ele tome cuidado em } \\
\text { não se lesionar e aumente } \\
\text { seu desempenho". }\end{array}$ & 1 \\
\hline 34 & 으 & & r & $\begin{array}{l}\text { "Para ajudar você com as atividades físicas tem que ter } \\
\text { uma boa alimentação e para ter um bom corpo, pratique } \\
\text { muito esporte, e esteja uma boa saúde para não ter uma } \\
\text { lesão pratique todos os dias". }\end{array}$ & $\begin{array}{l}\text { "Pois ajuda a melhorar no } \\
\text { desempenho do atleta". }\end{array}$ & $\begin{array}{l}\text { "Pois ajuda a melhorar no } \\
\text { desempenho do atleta". }\end{array}$ & 1 \\
\hline
\end{tabular}




\begin{tabular}{|c|c|c|c|c|c|c|c|}
\hline 35 & J & 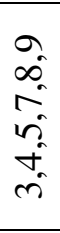 & \pm & $\begin{array}{l}\text { "O esporte em nossa vida é muito importante alem de } \\
\text { incluir a biomecânica da saúde, mas não podemos } \\
\text { esquecer de fazer alongamentos quando for fazer } \\
\text { qualquer atividade física pois as vezes o nosso corpo } \\
\text { pode não estar acostumado e pode haver lesão". }\end{array}$ & Não entregou. & Não entregou. & 0 \\
\hline 37 & 으 & & $\infty$ & $\begin{array}{l}\text { "A biomecânica é muito importante na física pois ela } \\
\text { auxilia o esporte a saúde e o corpo e a vida de um atleta } \\
\text { com ou sem lesão". }\end{array}$ & $\begin{array}{l}\text { "É } \quad \text { o estudo da } \\
\text { movimentação do corpo". }\end{array}$ & $\begin{array}{l}\text { "Porque se ele conhecer } \\
\text { esses princípios fará com } \\
\text { que ele tome cuidado em } \\
\text { não se lesionar e aumente } \\
\text { seu desempenho". }\end{array}$ & 1 \\
\hline
\end{tabular}

*aluno novato - transferência de período 
As cores iguais na tabela 4.31 mostram as respostas iguais dos estudantes, no qual não conseguimos distinguir o caráter da associação, mas percebemos que eles compartilham e constroem coletivamente o conhecimento ou em pequenos grupos ou em "grupões". A disposição das carteiras e a organização de grupos se alteram de aula para aula, embora tenhamos grupos que permanecem no mesmo lugar, como: os grupos: $\left(12, \mathrm{D}_{2}\right),\left(15, \mathrm{D}_{2}\right),\left(04, \mathrm{D}_{2}\right)$ e $\left(13, \mathrm{D}_{2}\right),\left(37, \mathrm{D}_{2}\right)$ e $\left(03, \mathrm{D}_{2}\right),\left(06, \mathrm{D}_{2}\right),\left(23, \mathrm{D}_{2}\right),\left(34, \mathrm{D}_{2}\right)$. É interessante que esses grupos não geram sempre respostas iguais para todos (tabela $4.31)$.

\section{Mapeamento da turma $1^{\circ} \mathrm{D}_{2}$}

O mapeamento foi obtido pela respostas dos 16 estudantes ao questionário de validação $\left(\mathrm{Q}_{3}\right)$ - seção 4.6. É relevante destacar que durante a elaboração do mapa, os estudantes alegaram que fariam à representação do dia, pois a maioria troca de lugar todos os dias, apenas alguns alunos permanecem juntos e no mesmo lugar. Ao analisar o mapa da classe elaborado pelos estudantes, a maioria iniciou a ilustração representando as carteiras em posição de fileiras, mas com a insistência da professora para o mapeamento real da sala de aula, obtemos as figuras 4.26 e 4.27

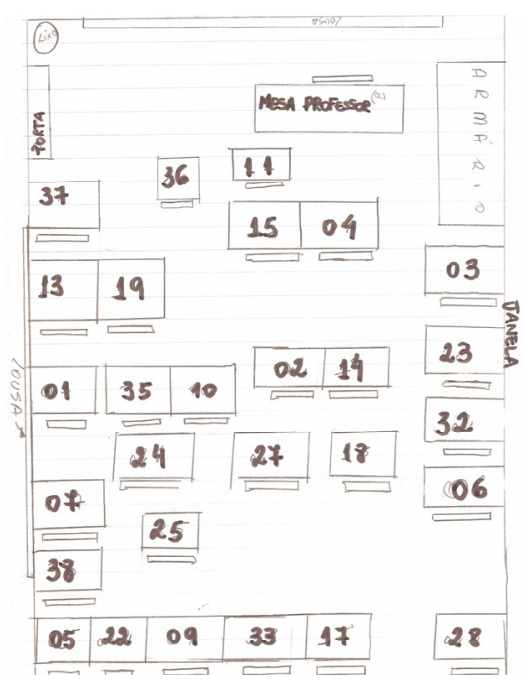

Figura 4.26: Mapa da turma $1^{\circ} \mathrm{D}_{2}$ - feito pelo aluno $\left(4, \mathrm{D}_{2}\right)$. 


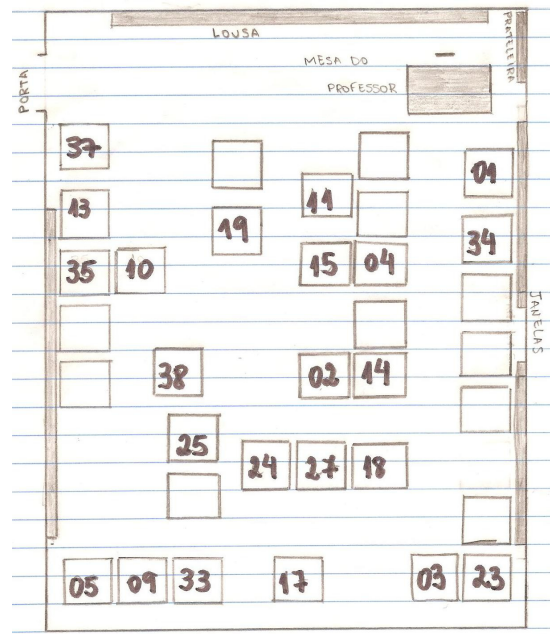

Figura 4.27: Mapa da turma $1^{\circ} \mathrm{D}_{2}$ - feito pelo aluno $\left(19, \mathrm{D}_{2}\right)$.

\section{Classificação}

De acordo com as categorias elaboradas a posteriori, pudemos mapear a complexificação do conhecimento de esporte e verificar que a maioria dos estudantes conseguiu relacionar esporte e física (tabela abaixo).

Tabela 4. 32: Graus de complexidade atingidos na turma $1^{\circ} \mathrm{D}$ da escola $\mathrm{M}$.

\begin{tabular}{|c|c|}
\hline Grau de complexidade & Porcentagem (\%) \\
\hline Grau -2 & 24,3 \\
\hline Grau -1 & 5,4 \\
\hline Grau 0 & 10,8 \\
\hline Grau 1 & 59,5 \\
\hline
\end{tabular}

Observe a figura 4.28:

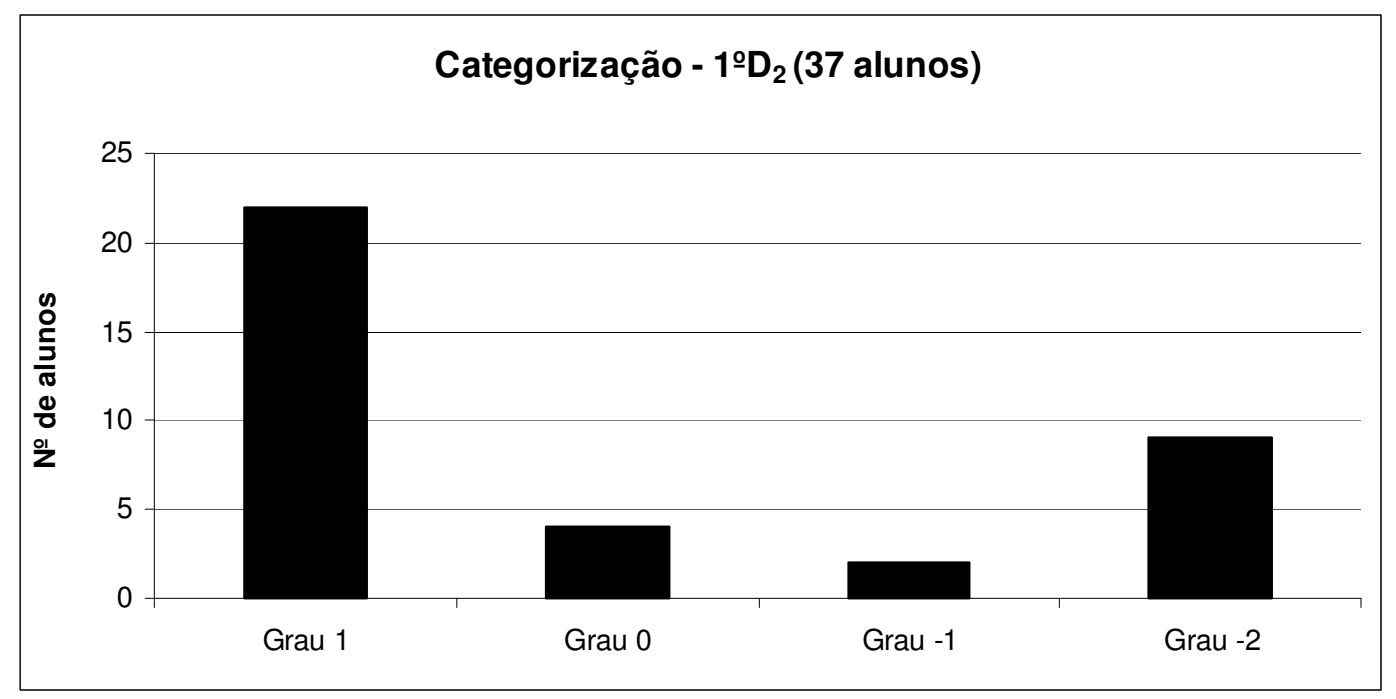

Figura 4.28: Complexificação do conhecimento de $1^{\circ} \mathrm{D}_{2}$. 
Os estudantes tiveram o primeiro contato com a palavra biomecânica na atividade 3 da intervenção e depois o termo apareceu somente na atividade 9, mas estava implícito nas outras atividades. Na atividade 3 contém um texto que explica o que é e para que serve a biomecânica e nesta atividade os estudantes tinham que responder a algumas questões, perceba que os estudantes apenas transcreveram trechos do texto nas respostas (tabela 4.33). Comparando com as respostas obtidas na questão 1 da atividade avaliatória, estes dados nos fornecem mais evidências da complexificação do conhecimento de esporte dos estudantes.

Tabela 4.33: Respostas do $1^{\circ} \mathrm{D}_{2}$ da escola M.

\begin{tabular}{|l|l|}
\hline \multirow{2}{*}{} & $\begin{array}{l}\text { Q.4: De que forma a "ciência" pode ajudar um técnico a melhorar o desempenho } \\
\text { de um atleta? }\end{array}$ \\
Q.5c: Complete a frase: A biomecânica pode ajudar a.... \\
Q.5d: A biomecânica pode ajudar a corrigir os movimentos de um atleta para \\
melhorar seu desempenho? De que forma?
\end{tabular}

Para completar os dados, na turma $1^{\circ} \mathrm{D}_{2}$ atentamos a outras questões de outras atividades da intervenção que possibilitassem analisar se o estudante aplica as novas zonas do perfil conceitual de esporte em outro contexto. A tabela 4.34 trás a comparação das respostas a questão 1 da atividade 1 que se repete na questão 12 da atividade 9. Verificamos que os estudantes passam a aplicar os conceitos contidos na intervenção que antes não eram relevantes, pois associavam o técnico apenas a vitória da competição (que faz parte da responsabilidade de um técnico), e agora atentam também para o desempenho (movimentos corretos) associado a saúde do atleta. 
Tabela 4.34: Comparação de questões das atividades 1 e 9 (técnico) - $1^{\circ} \mathrm{D}_{2}-$ escola $\mathrm{M}$.

\begin{tabular}{|c|c|c|}
\hline \multirow[b]{2}{*}{$\stackrel{g}{\rightleftarrows}$} & Atividade 1 & de 9 \\
\hline & $\begin{array}{l}\text { Q.1: Quais são as maiores } \\
\text { responsabilidades de um técnico de } \\
\text { qualquer modalidade esportiva? } \\
\text { Q.6: Seu conhecimento atual é } \\
\text { suficiente para que você faça bons } \\
\text { apontamentos (comentários) para } \\
\text { auxiliar um atleta? Que conhecimentos } \\
\text { estão te faltando? }\end{array}$ & $\begin{array}{l}\text { Q.12: Quais são as maiores } \\
\text { responsabilidades de um técnico de } \\
\text { qualquer modalidade esportiva? }\end{array}$ \\
\hline 05 & $\begin{array}{l}\text { (Q.6) "Não eu acho que ainda falta } \\
\text { mais pesquisas no futebol". }\end{array}$ & $\begin{array}{l}\text { (Q.12) "É claro que sim, porque eu } \\
\text { aprendi que com a biomecânica, eu sei o } \\
\text { que é preciso para o atleta ir bem no } \\
\text { esporte e os movimentos que ele tem } \\
\text { que realizar". }\end{array}$ \\
\hline 27 & $\begin{array}{l}\text { (Q.1) "As responsabilidades são fazer } \\
\text { com que o time entrem na mesma } \\
\text { sintonia na hora do jogo, e levar o time } \\
\text { pra frente trazendo vitória". }\end{array}$ & $\begin{array}{l}\text { (Q.12) "Uma das maiores } \\
\text { responsabilidades além de treina-lo } \\
\text { corretamente, é o cuidado para que ele } \\
\text { não tenha nenhuma lesão". }\end{array}$ \\
\hline 34 & $\begin{array}{l}\text { (Q.1) "É ensinar como fazer a } \\
\text { modalidade". }\end{array}$ & $\begin{array}{l}\text { (Q. 12) "As responsabilidades são ter } \\
\text { mais cuidado para não ter nenhuma } \\
\text { lesão no corpo". }\end{array}$ \\
\hline 37 & $\begin{array}{l}\text { (Q.1) "Desenvolver seu esporte com } \\
\text { responsabilidade, força de vontade, ter } \\
\text { uma boa saúde, aprender a respeitar..." }\end{array}$ & $\begin{array}{l}\text { (Q.12) "Preparar um atleta corrigindo } \\
\text { seus erros". }\end{array}$ \\
\hline
\end{tabular}

A prática esportiva está diretamente relacionada a saúde, mas não podemos apenas associá-la a benefícios, pois sua prática inadequada trás lesões ao ser humano, portanto temos que atentar aos movimentos adequados a prática esportiva escolhida. Visando analisar se o estudante compreendeu a relação saúde e esporte fizemos a comparação de algumas questões da atividade 2 com a atividade 9 e verificamos que o estudante adiciona ao seu perfil conceitual novos conceitos.

Tabela 4.35: Comparação de questões das atividades 1 e $9-1^{\circ} \mathrm{D}{ }_{2}-$ escola G.

\begin{tabular}{|c|l|l|}
\hline \multirow{5}{*}{\begin{tabular}{|l|}
\multicolumn{1}{|c|}{ Atividade 2 } \\
Q.10b: Qualquer pessoa no momento em \\
que quiser, pode praticar esporte? Por quê? \\
Q10c: Quais os cuidados que devemos ter ao \\
praticar exercícios físicos?
\end{tabular}} & $\begin{array}{l}\text { Q.2: Que cuidados devemos ter ao } \\
\text { iniciar uma atividade física? } \\
\text { Q.7: Quais os cuidados que } \\
\text { devemos ter ao praticar exercícios } \\
\text { físicos? }\end{array}$ \\
\hline 15 & $\begin{array}{l}\text { (Q10b) "Nem sempre, porque a atividade } \\
\text { física tem que ser moderada" } \\
\text { (Q10c) "Os cuidados são: fazer } \\
\text { alongamentos, beber bastante água, não ficar } \\
\text { para não gerar contusões, como o } \\
\text { preparo físico". }\end{array}$ \\
\hline
\end{tabular}




\begin{tabular}{|c|c|c|}
\hline 24 & $\begin{array}{l}\text { (Q10b) "Não na maior parte dos esportes é } \\
\text { preciso ter recomendação médica". } \\
\text { (Q10c) "Ver se podemos praticar esse } \\
\text { exercício físico e ver nosso limite". }\end{array}$ & $\begin{array}{l}\text { antes das atividades físicas e ter } \\
\text { uma boa alimentação". } \\
\text { (Q.7) "Ter cuidado para não ter } \\
\text { lesões". }\end{array}$ \\
\hline 26 & $\begin{array}{l}\text { (Q10b) "Não porque muitas tem problemas } \\
\text { de saúde". } \\
\text { (Q10c) "Alimentação saudável e fazer } \\
\text { alongamentos". }\end{array}$ & $\begin{array}{l}\text { (Q.4) "Porque pode fazer mal para } \\
\text { o seu corpo". } \\
\text { (Q.7) "Não forçar muito para não } \\
\text { ter nenhum tipo de lesão". }\end{array}$ \\
\hline 27 & $\begin{array}{l}\text { (Q10b) "Sim, porque o esporte faz muito } \\
\text { bem a qualquer pessoa". } \\
\text { (Q10c) "Muitos cuidados mais } \\
\text { principalmente aquelas pessoas que tem } \\
\text { problema de coração, asma, e outras doenças } \\
\text { que podem ser fatais". }\end{array}$ & $\begin{array}{l}\text { (Q.6) "Sim, mas é preciso ter } \\
\text { cuidado com lesões, e se possível } \\
\text { fazer alongamentos antes". } \\
\text { (Q.7) "Cuidados para que não } \\
\text { cause lesões no corpo". }\end{array}$ \\
\hline 37 & $\begin{array}{l}\text { (Q10b) "Não tem que passar por avaliação } \\
\text { médica". } \\
\text { (Q10c) "Não passar dos limites" }\end{array}$ & $\begin{array}{l}\text { (Q.2) "Primeiramente teria que } \\
\text { haver um alongamento". } \\
\text { (q.7) "Cuidados como verificar se } \\
\text { a saúde está instável, tomando } \\
\text { cuidado para não haver lesões". }\end{array}$ \\
\hline
\end{tabular}

\section{Relação física e educação física}

Na tabela 4.31 e 4.35 sublinhamos algumas palavras que evidenciam que alguns estudantes associam os conteúdos da disciplina de educação física aos de física. O professor de educação física desta turma nos relatou por entrevista informal que em suas aulas insiste em falar da importância do alongamento antes de qualquer atividade física para evitar lesões, e que no $2^{\circ}$ bimestre passou uma reportagem sobre os movimentos da ginasta Daiane dos Santos ao realizar o salto Duplo Twist Carpado.

Nas respostas ao questionário de validação percebemos que a maioria dos estudantes passam a construir a ponte interdisciplinar entre física e educação física. Como o questionário é composto por 7 questões em uma delas o estudante demonstra apropriação da relação física e educação física.

\section{Relação professora-aluno}

Para obtermos mais informações sobre o relacionamento da turma $\mathrm{D}_{\mathbf{2}}$ com a professora, e avaliar a metodologia utilizada na intervenção + caderno de física vol. 1 e 2, elaboramos um questionário com 10 questões, que denominamos de questionário de opinião - que nesta turma pedimos para os alunos se identificarem, pois segundo a 
professora são muito espontâneos em dar opiniões - no qual foi aplicado pela própria professora da turma, observe a tabela 4.36.

Tabela 4.36: Questionário de Opinião das aulas $-1^{\circ} \mathrm{D}_{2}$ - escola G.

\begin{tabular}{|c|c|}
\hline Aluno & Resposta \\
\hline \multicolumn{2}{|c|}{1 - Eu gosto da escola porque... } \\
\hline 02 & "Vejo meus amigos e amigas". \\
\hline 12 & "aprendo, conheço pessoas..." \\
\hline 19 & "....porque a comida é boa e posso conversar". \\
\hline \multicolumn{2}{|c|}{2 - Eu odeio a escola porque... } \\
\hline 23 & "tem pessoas que se acham e professores insuportáveis". \\
\hline 33 & "passam muita lição". \\
\hline 18 & "levam a gente para a diretoria". \\
\hline \multicolumn{2}{|c|}{3 - O caderno do aluno de física é... } \\
\hline 02 & "Facilita na hora de fazer lição". \\
\hline 04 & $\begin{array}{l}\text { "Boa ideia o uso da apostila, pois é mais fácil do que ficar copiando a } \\
\text { a lição e ainda economiza caderno". }\end{array}$ \\
\hline 15 & $\begin{array}{l}\text { "É muito difícil, para quem veio da } 8^{\mathrm{a}} \text { série sem saber nada de física, é } \\
\text { muito complicada". }\end{array}$ \\
\hline 27 & $\begin{array}{l}\text { "Muito boa, mas contem exercícios muito difíceis de fazer sozinho e é } \\
\text { preciso ajuda da professora". }\end{array}$ \\
\hline 28 & "É boa, mas difícil de entender". \\
\hline 33 & "Ajuda a gente a aprender melhor física". \\
\hline \multicolumn{2}{|c|}{ 4- As atividades do caderninho... } \\
\hline 02 & "São muito difíceis de raciocinar". \\
\hline 04 & $\begin{array}{l}\text { "É um complemento muito bom, pois alem da apostila o caderninho é } \\
\text { muitas vezes até mais fácil de fazer e compreender". }\end{array}$ \\
\hline 07 & $\begin{array}{l}\text { "É muito grande e morro de preguiça de responder e ler, mas tenho } \\
\text { que ganhar nota". }\end{array}$ \\
\hline 12 & "É bem interessante para nos estimular". \\
\hline 13 & "Não consigo entender, mas com paciência vai". \\
\hline 15 & $\begin{array}{l}\text { "Algumas atividades são bem fáceis, sobre esportes e exercícios } \\
\text { envolvendo física e tem alguns que tem que fazer algumas contas, } \\
\text { mas são poucas essas, é mais fácil do que da apostila". }\end{array}$ \\
\hline 23 & "Nós expressamos nossas opiniões". \\
\hline 27 & "São legais pois além de aprender nos informa bastante coisas". \\
\hline \multicolumn{2}{|c|}{5 - O que a professora deveria fazer para eu aprender? } \\
\hline 19 & "a professora não deve fazer nada, o esforço depende de mim..." \\
\hline 05 & "...passar lição com mais calma..." \\
\hline 02 & "...me dar mais atenção..." \\
\hline \multicolumn{2}{|c|}{6 - Eu odeio quando a professora de física... } \\
\hline 02 & "Já chega na sala passando lição". \\
\hline 04 & $\begin{array}{l}\text { "Começa a nos sobrecarregar, dando várias coisas para fazer e } \\
\text { entregar na mesma aula, coisas da apostila, do caderninho, na lousa". }\end{array}$ \\
\hline 05 & "Chega na sala e já passa lição". \\
\hline 07 & "Fala para não copiar a lição do colega". \\
\hline 12 & "Passa muita coisa de uma só vez". \\
\hline 15 & "Passa contas com números enormes". \\
\hline
\end{tabular}




\begin{tabular}{|l|l|}
\hline \multicolumn{2}{|l|}{ 7 - Para eu se um bom aluno devo... } \\
\hline 02 & "parar de bagunçar". \\
\hline 04 & "...cumprir com as minhas obrigações...” \\
\hline 15 & "prestar atenção nas aulas, fazer as lições..." \\
\hline $\mathbf{8}-$ As aulas de física são... \\
\hline 33 & "bem aproveitadas". \\
\hline 03 & "boas para eu aprender". \\
\hline 27 & $\begin{array}{l}\text { "muito corridas, sempre tem atividades para fazer e entregar na } \\
\text { mesma aula". }\end{array}$ \\
\hline $\mathbf{9}-$ Em termos de comportamento minha sala é... \\
\hline 05 & $\begin{array}{l}\text { "Nota dez, porque nos comportamos bem é claro com os professores } \\
\text { que nos respeitam, aí sim nos respeitamos". }\end{array}$ \\
\hline 13 & "Horrível, a maioria das pessoas não obedecem os professores..." \\
\hline 04 & "melhorou, mas é muita bagunça". \\
\hline 07 & "péssima, todos falam demais, só zoam, adoro essa classe é a melhor". \\
\hline
\end{tabular}

Pudemos perceber pelos relatos dos estudantes no questionário de opinião que a professora possui um comportamento atípico aos demais professores, pois é muito centrada no conteúdo das aulas, e isto gera aplicação de atividades em demasiado aos estudantes, que se sentem sufocados.

Para comparação temos um curto relato da professora sobre sua relação com a sala: "Eu praticamente "rezo" antes de entrar nesta sala, pois serei ignorada, chegarão atrasados na aula, falaram alto de assuntos diversos, etc. Tento não demonstrar o meu desânimo e principalmente não fazer escândalos quanto a disciplina, finjo que não é comigo e atendo sempre com calma aos poucos que me perguntam alguma coisa. Mesmo assim, os alunos dizem que gostam de mim, agora só basta saber por quê?" (Anexo A3.2.3).

Percebemos neste discurso que a turma $1^{\circ} \mathrm{D}_{2}$ é atípica as demais, possuem um comportamento incoerente excessivo para uma sala de aula, e isto é confirmado pelas respostas a questão 9 do questionário de opinião. Notemos que em termos de análise pelas categorias, a maioria dos estudantes se enquadra no grau 1 de complexidade. Podemos simplificar a sala com a frase: "Parece, mas não é".

Quanto ao caderno de física do aluno, a maioria dos estudantes (dentre os que aprovam e reprovam) enfatiza a dificuldade em realizar as tarefas, e outros adicionam a importância do professor para o entendimento das situações de aprendizagem.

Quanto as atividades de intervenção, a maioria dos estudantes (dentre os que aprovam e reprovam) enfatiza a extensão das atividades e a dificuldade em interpretar as questões, mas elogiam por poder expressar sua opinião nas questões. 


\section{Casos Particulares}

- Alunos do grupo E

Na turma $1^{\circ} \mathrm{D}_{2}$, encontramos a classe de alunos que nomeamos de "alunos E". Esta categoria de estudantes serve para enquadrar os alunos que circulam na sala de aula em busca de respostas corretas, segundo seus critérios. Este aluno implicitamente durante as aulas presta atenção e sabe escolher a melhor resposta, como é o caso do aluno $\left(22, \mathrm{D}_{2}\right),\left(33, \mathrm{D}_{2}\right)$.

- Aluno do grupo A

Na turma $1^{\circ} \mathrm{D}_{2}$, encontramos a classe de alunos que nomeamos de "alunos $\mathrm{A}$ ". Esta categoria de estudantes serve para enquadrar os alunos que estão em sala de aula (corpo presente), mas ao mesmo tempo tão longe (atenção voltada a outros assuntos). Encontram-se quietos em sala de aula não interagem com outros estudantes a não ser em seu grupo, não participam da aula, mas fazem as atividades, estão apáticos. Muitas vezes esta característica vem junto com a dificuldade de aprendizado, como é o caso do aluno $\left(6, \mathrm{D}_{2}\right)$ e $\left(3, \mathrm{~A}_{2}\right)$.

\subsection{Reflexões: professora-pesquisadora}

Abaixo apresento algumas reflexões sobre o entrelaçamento entre os papéis de pesquisadora e professora durante a pesquisa.

\section{Como professora:}

- Prefiro que os alunos faltosos façam as atividades que perderam mesmo que seja fora da ordem, pois sei que precisarão desta nota na média final,

- Sempre tenho que fornecer uma "segurança" (continue, muito bem, etc.) para o estudante continuar respondendo as atividades,

- Prefiro sempre realizar as atividades do caderno do aluno de física, pois tenho prazo para o seu término,

- Altero a sequência das atividades do caderno do aluno, cada vez que, após dar uma atividade em outra sala, vejo que seria melhor ter procedido de outra forma para alcançar o aprendizado. E muitas vezes, analiso o número de alunos para iniciar um tópico novo (para não perderem muita coisa), 
- Às vezes dou uma corridinha básica com o conteúdo se percebo que não dará para fechar o bimestre, e acabo suprimindo algumas "coisas".

- Muitas vezes explico o conteúdo através de exemplos corriqueiros, articulando gestualmente, procurando alcançar a rede de significados internos dos estudantes, visando facilitar o aprendizado. Ao tentar me aproximar da linguagem dos estudantes, receio que muitas vezes aumente ou suprima aspectos significativos dos conteúdos de física, mas que mediante a situação são meramente justificados, pois faz parte da fase de negociação de significados.

- Fico irritada e inconformada pelos estudantes não memorizarem as fórmulas e quando escrevo no quadro não lembram o significado de cada incógnita. Após exemplificar gestualmente, ou por vídeo, ou por atividade de campo (ativ. 4) através da atividades propostas o uso do conceito, fica mais fácil retomar os conceitos. Por exemplo, o conceito de velocidade média quando pergunto dizem que não sabem do que se trata, mas se pergunto: o que fizeram na atividade realizada no pátio (anexo A3.2.3 no diário de bordo - ativ.4), rapidamente os estudantes abstraem e iniciam os cálculos matemáticos.

Claro que muitas vezes uso de conveniência particular, se percebo que o assunto traz muito desgaste, ou muitos alunos não conseguem entender, ou estou cansada e desanimada, ou percebo que é polêmico e não domino muito bem o assunto, simplesmente evito em tocar no assunto, tudo é questão de experiência

em sala de aula.

Como pesquisadora:

Preocupa-me a sequência das atividades elaboradas, com o tempo destinado a cada uma delas, ou seja, com o planejamento prévio e com o comportamento dos alunos em cada uma das atividades. Além disso, me atento para interpretação que o aluno faz de cada questão e em que contexto ela o remete, para futuramente alterar a questão ou suprimí-la, de acordo com a análise dos dados.

Muitas vezes faço alterações imediatas (sem alterar o ciclo de aprendizagem de Lawson) nas questões de uma sala para outra para facilitar no entendimento, é claro que tenho mobilidade para fazer alterações instantâneas, pois sou também a professora. Os estudantes são imprevisíveis, hora demonstram empolgação ao realizar as atividades e hora não querem saber de responder, então o tempo para cada atividade oscila muito e precisa da cobrança incessante do professor, ficando nítido que o aspecto motivacional interfere muito no comportamento dos alunos frente às atividades. 


\subsection{Análise ao questionário de validação}

Como dissemos o questionário de validação contém duas questões relacionadas ao mapeamento da sala de aula, as mesmas já foram utilizadas para análise da intervenção.

Nesta seção analisaremos as questões relacionadas a física e educação física e categorizaremos segundo as categorias anteriores em graus de complexidade: 0, 1, 2 e 1, - 2, para validar os dados obtidos pela análise de algumas questões da intervenção. Lembramos que categorizamos no grau 1 se em algumas das questões o estudante demonstrou uma complexificação do conhecimento de esporte.

\subsubsection{Turma $1^{\circ} \mathrm{A}_{3}$}

Nesta turma o questionário de validação foi aplicado pela professora eventual de língua portuguesa, no qual dentre os 32 alunos frequentes somente 23 alunos responderam o questionário. As respostas similares foram identificadas por cores (tabela 4.33) e mostram que são equivalentes a grupos de afinidade distribuídos pela sala de aula. Destacamos as respostas dos estudantes $\left(05, \mathrm{~A}_{3}\right),\left(09, \mathrm{~A}_{3}\right),\left(35, \mathrm{~A}_{3}\right)$ que adicionam o esporte abrangido nas aulas de educação física pelo professor, o rúgbi e o futebol americano. 
Tabela 4.37: Respostas obtidas no questionário de validação $\mathrm{Q}_{3}-$ turma $1^{\circ} \mathrm{A}_{3}$.

\begin{tabular}{|c|c|c|c|c|c|c|}
\hline$\frac{\stackrel{g}{\Xi}}{z}$ & $\begin{array}{l}\text { Q.3: Qual é a relação } \\
\text { existente entre a disciplina de } \\
\text { física e educação física? O } \\
\text { que tem em comum? }\end{array}$ & $\begin{array}{l}\text { Q.4: Dos assuntos } \\
\text { (conteúdos) que você } \\
\text { estudou na matéria de } \\
\text { educação física, quais } \\
\text { deles podem ser } \\
\text { utilizados para entender, } \\
\text { explicar a matéria de } \\
\text { física do } 1^{\circ} \text { e } 2^{\circ} \\
\text { bimestre? De que forma? } \\
\text { Dê exemplos. }\end{array}$ & $\begin{array}{l}\text { Q.5: Formule uma } \\
\text { pergunta para fazer ao } \\
\text { professor de educação } \\
\text { física contenha os } \\
\text { conhecimentos da } \\
\text { matéria de educação } \\
\text { física e física. }\end{array}$ & $\begin{array}{l}\text { Q.6: De tudo que foi visto } \\
\text { na matéria de física no } 1^{\circ} \\
\mathrm{e} 2^{\circ} \text { bimestre, quais } \\
\text { podem ser aplicados nas } \\
\text { aulas de educação física? } \\
\text { Como? De que forma? }\end{array}$ & $\begin{array}{l}\text { Q.7: Formule uma } \\
\text { questão para } \\
\text { professora de física } \\
\text { responder, bem } \\
\text { difícil, que contenha } \\
\text { o conteúdo de física } \\
\text { e educação física. }\end{array}$ & Uू⿻ \\
\hline 01 & $\begin{array}{l}\text { "O nome e o estudo de } \\
\text { movimento das forças". }\end{array}$ & $\begin{array}{l}\text { "Os movimentos, força, } \\
\text { as contas, etc.". }\end{array}$ & $\begin{array}{l}\text { "Para fazer um gol a } \\
\text { longa distância é } \\
\text { necessário aplicar um } \\
\text { pouco mais de força?". }\end{array}$ & $\begin{array}{l}\text { "'Movimentos, } \\
\text { tempo, fazendo } \\
\text { esporte que precise } \\
\text { utilizar os itens citados". }\end{array}$ & $\begin{array}{l}\text { "Como uma pessoa } \\
\text { chuta a bola por } \\
\text { cima da barreira e } \\
\text { ela faz uma curva } \\
\text { impressionante e } \\
\text { entra no gol?". }\end{array}$ & 0 \\
\hline
\end{tabular}




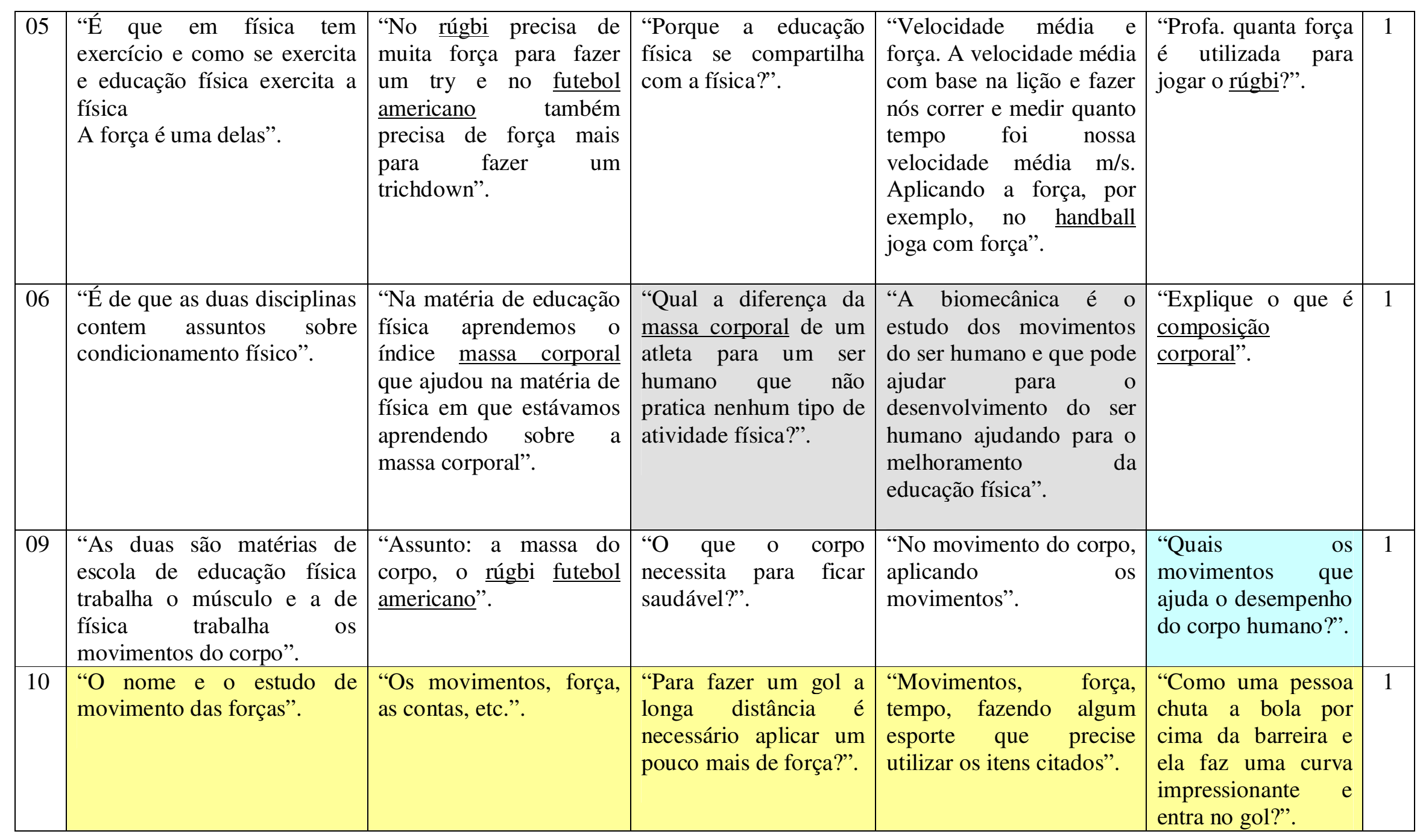




\begin{tabular}{|c|c|c|c|c|c|c|}
\hline 14 & $\begin{array}{l}\text { "O estudo dos movimentos } \\
\text { corporais que realizamos }\end{array}$ & $\begin{array}{l}\text { "Os movimentos } \\
\text { corporais, aplicando } \\
\text { como funciona cada } \\
\text { movimento por exemplo, } \\
\text { quando chutamos uma } \\
\text { bola, correndo". }\end{array}$ & $\begin{array}{l}\text { "Se uma pessoa corre } \\
250 \mathrm{~m} \text { em } 25 \mathrm{~s} \text {. Qual é a } \\
\text { velocidade média que } \\
\text { ele fez em } \mathrm{km} / \mathrm{h} \text { ?". }\end{array}$ & $\begin{array}{l}\text { "A energia mecânica, a } \\
\text { energia cinética potencial } \\
\text { fazendo exercícios que } \\
\text { façam isso. Por exemplo, } \\
\text { levantandoro peso } \\
\text { correndo". }\end{array}$ & $\begin{array}{lr}\text { "Qualquer } & \text { pessoa } \\
\text { pode começar a } \\
\text { fazer } & \text { exercícios, } \\
\text { quando } & \text { bem } \\
\text { entender, } & \text { sem } \quad \text { se } \\
\text { alongar, } & \text { sem } \\
\text { conhecer } & \text { seus } \\
\text { limites?". } & \\
\end{array}$ & 1 \\
\hline 15 & $\begin{array}{l}\text { "As duas matérias tem em } \\
\text { comum porque cada uma } \\
\text { delas falam um pouco do } \\
\text { corpo como: força, } \\
\text { movimentos físicos, saúde". }\end{array}$ & $\begin{array}{l}\text { "Os assuntos como força, } \\
\text { força brusca, os } \\
\text { movimentos que fazemos } \\
\text { com o corpo e outros". }\end{array}$ & $\begin{array}{l}\text { "Quando tentamos } \\
\text { mover um peso } \\
\text { bruscamente, nosso } \\
\text { corpo sofre com esse } \\
\text { movimento de peso e } \\
\text { quando pegamos este } \\
\text { mesmo peso } \\
\text { vagarosamente } \\
\text { acontece o mesmo com } \\
\text { nosso corpo"? }\end{array}$ & $\begin{array}{l}\text { "A lição de movimentos } \\
\text { de pesos, e o que acontece } \\
\text { com o corpo durante a } \\
\text { força que você está } \\
\text { fazendo. Indicando o jeito } \\
\text { certo para não dar mal } \\
\text { jeito no corpo e nem } \\
\text { provocar tensões bruscas } \\
\text { nos músculos". }\end{array}$ & & 1 \\
\hline 19 & $\begin{array}{l}\text { "Não tem nada em comum, } \\
\text { física estuda os movimentos } \\
\text { que o ser humano faz, e a } \\
\text { educação física faz esporte". }\end{array}$ & $\begin{array}{l}\text { "A questão de força, por } \\
\text { exemplo, a força que } \\
\text { você usa para diminuir o } \\
\text { atrito desse objeto". }\end{array}$ & 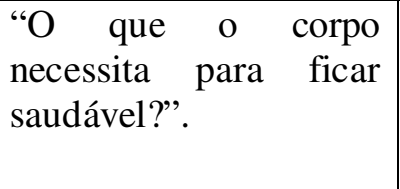 & $\begin{array}{l}\text { "No movimento do corpo } \\
\text { aplica do movimento". }\end{array}$ & $\begin{array}{lr}\text { "Guiar } & \text { os } \\
\text { movimentos que } & \\
\text { ajuda o desempenho } & \\
\text { do corpo humano?". }\end{array}$ & 0 \\
\hline 21 & $\begin{array}{l}\text { "Movimentos, de estudar } \\
\text { sobre os movimentos e } \\
\text { força". }\end{array}$ & $\begin{array}{l}\text { "Os movimentos, as } \\
\text { contas e as forças que } \\
\text { utilizar no movimento". }\end{array}$ & $\begin{array}{l}\text { "Dê exemplos de como } \\
\text { uma pessoa pula de } \\
\text { uma distância para } \\
\text { outra ela não cai e nem } \\
\text { se machuca?". }\end{array}$ & $\begin{array}{l}\text { "A força que se aplica em } \\
\text { um movimento, como por } \\
\text { exemplo vai chutar uma } \\
\text { bola, fazendo com } \\
\text { treinamento de chutes a } \\
\text { distância". }\end{array}$ & $\begin{array}{l}\text { "Como uma pessoa } \\
\text { chuta uma bola e faz } \\
\text { a bola ir direto na } \\
\text { trave e ainda faz ela } \\
\text { passar pela barreira } \\
\text { de jogadores?". }\end{array}$ & 1 \\
\hline
\end{tabular}




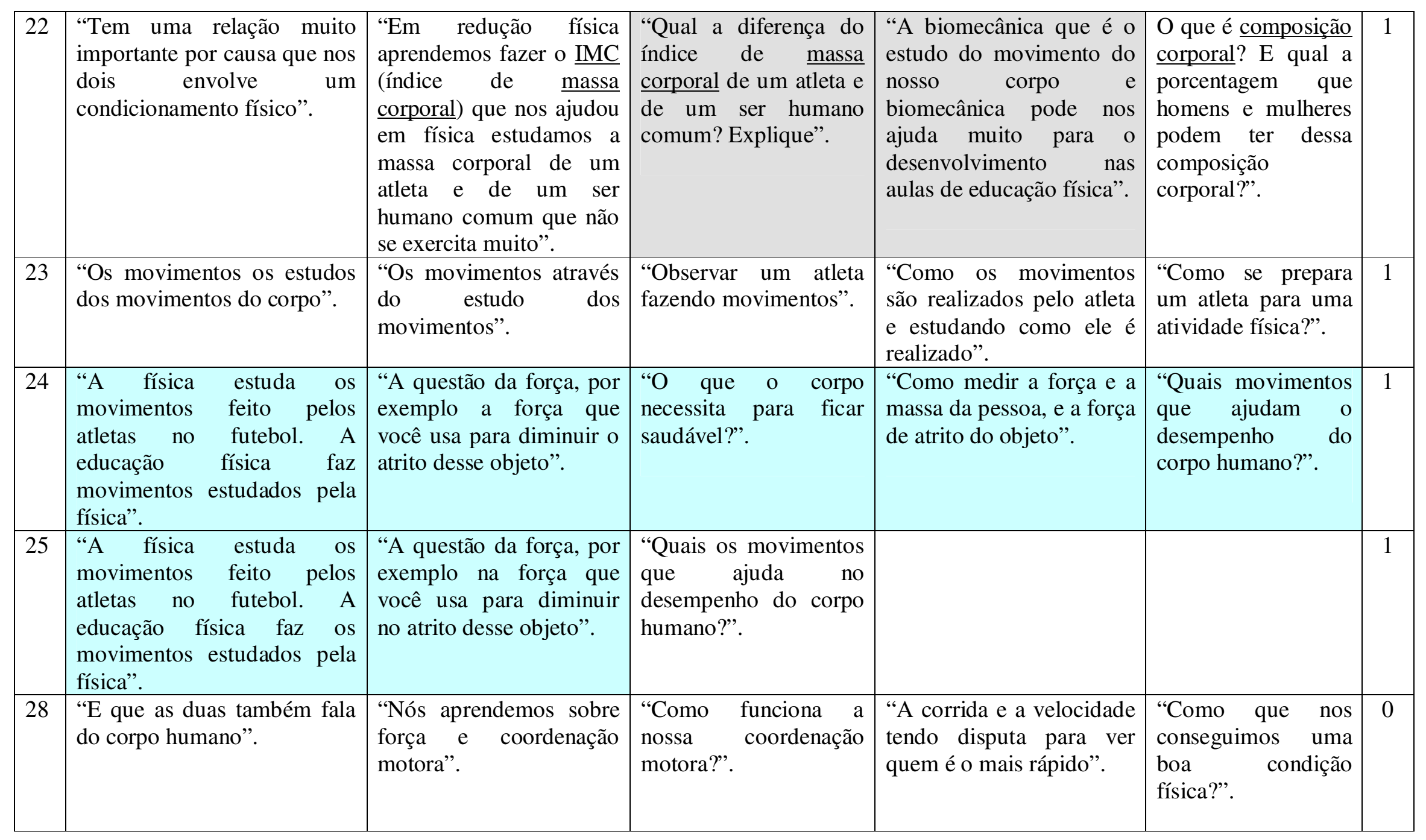




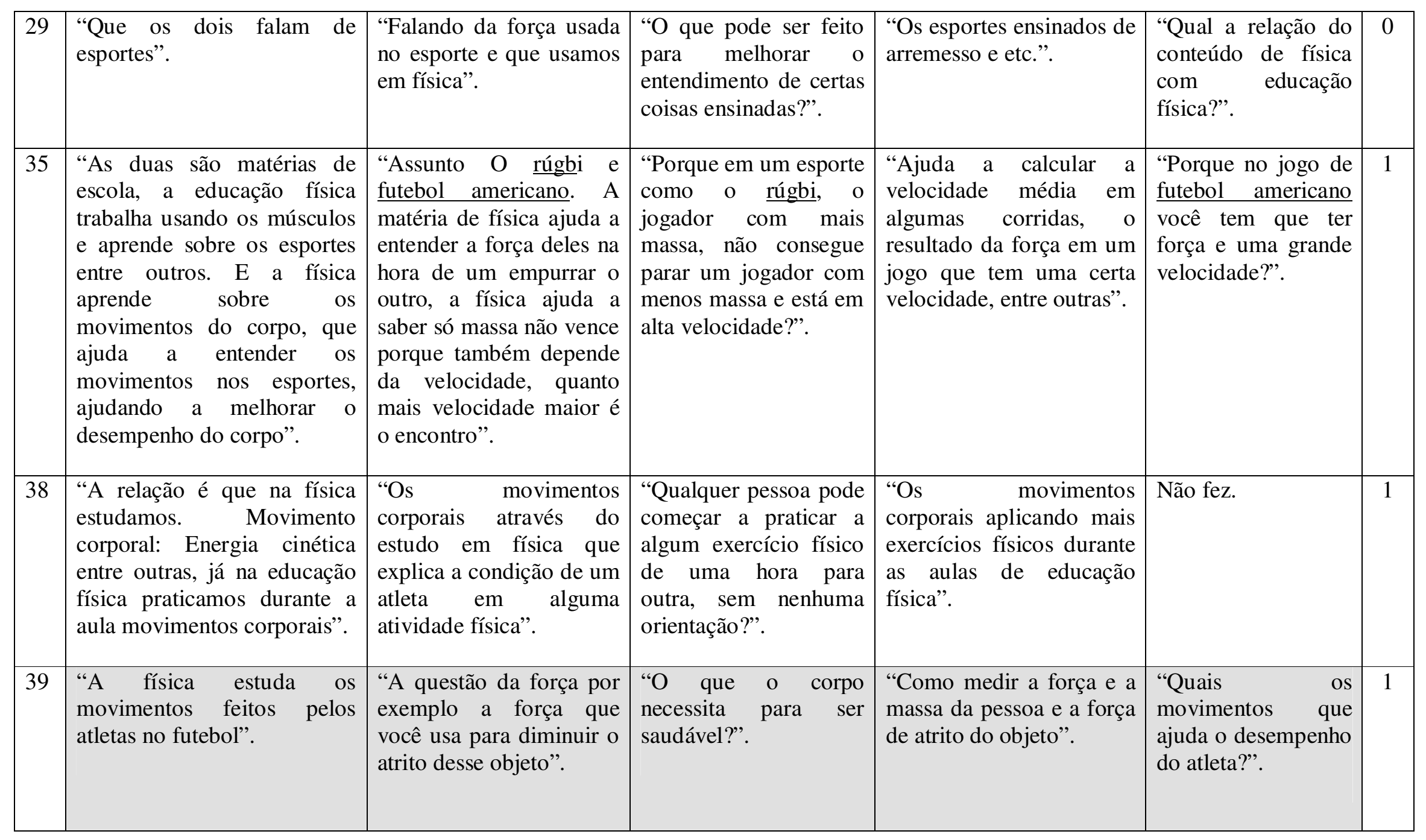




\begin{tabular}{|c|c|c|c|c|c|}
\hline 41 & $\begin{array}{l}\text { "Porque cada uma delas } \\
\text { falava um pouco do corpo } \\
\text { como: força, movimentos } \\
\text { físicos e saúde". }\end{array}$ & $\begin{array}{l}\text { "Os assuntos como força, } \\
\text { força brusca, os } \\
\text { movimentos que fazemos } \\
\text { com o corpo e outros". }\end{array}$ & $\begin{array}{l}\text { "Quando tentamos } \\
\text { mover um peso } \\
\text { bruscamente, nosso } \\
\text { corpo sofre com esse } \\
\text { movimento de peso e } \\
\text { quando pegamos este } \\
\text { mesmo peso } \\
\text { vagarosamente } \\
\text { acontece o mesmo em } \\
\text { nosso corpo?". }\end{array}$ & $\begin{array}{l}\text { "A lição de movimento de } \\
\text { pesos e o que acontece } \\
\text { com o corpo durante a } \\
\text { força que você está } \\
\text { fazendo. Indicando o jeito } \\
\text { certo para não dar mais } \\
\text { jeito no corpo e nem } \\
\text { provocar tensões bruscas } \\
\text { nos músculos". }\end{array}$ & 0 \\
\hline
\end{tabular}


Pela figura 4.29, a maioria dos estudantes conseguiu fazer a relação interdisciplinar entre física e educação física. Obtemos:

Tabela 4. 38: Graus de complexidade atingidos na turma $1^{\circ}$ A da escola G.

\begin{tabular}{|c|c|}
\hline Grau de complexidade & Porcentagem (\%) \\
\hline Grau -2 & 51,2 \\
\hline Grau -1 & 0 \\
\hline Grau 0 & 14,6 \\
\hline Grau 1 & 34,1 \\
\hline
\end{tabular}

Observe a figura 4.29:

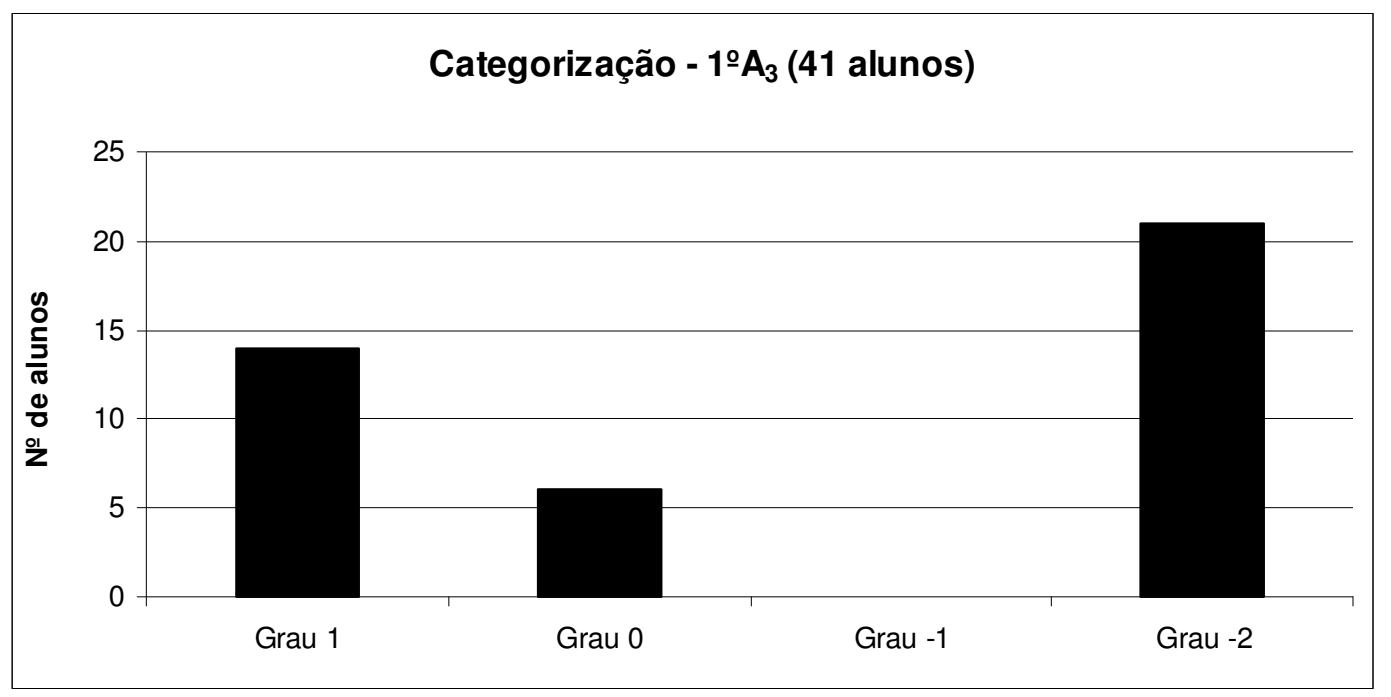

Figura 4.29: Categorização baseado em $\mathrm{Q}_{3}$.

\subsubsection{Turma $1^{\circ} B_{3}$}

Nesta turma o questionário de validação foi aplicado pela própria professora de física da sala como uma atividade extra-classe, no qual dentre os 36 alunos frequentes somente 24 alunos responderam o questionário. As respostas similares foram identificadas por cores (tabela 4.39) e mostram que são equivalentes a grupos de afinidade distribuídos pela sala de aula. Destacamos as respostas dos estudantes (16, $\left.\mathrm{B}_{3}\right),\left(30, \mathrm{~B}_{3}\right)$ que adicionam o esporte abrangido nas aulas de educação física pelo professor, o rúgbi e o futebol americano. 
Tabela 4.39: Respostas obtidas no questionário de validação $\mathrm{Q}_{3}$ - turma $1^{\circ} \mathrm{B}_{3}$.

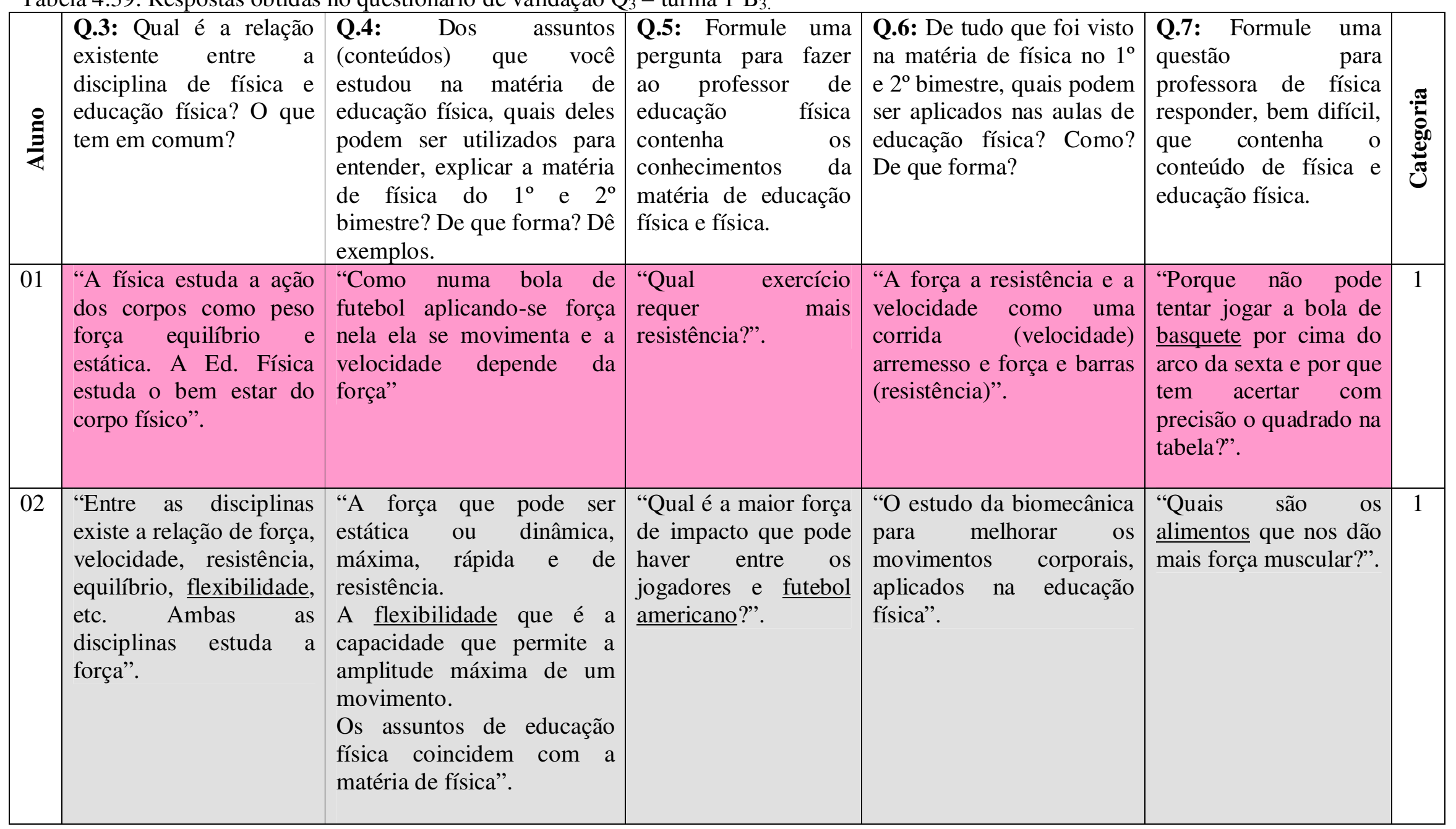




\begin{tabular}{|c|c|c|c|c|c|c|}
\hline 05 & $\begin{array}{l}\text { "O que tem em comum } \\
\text { é que a física estuda a } \\
\text { educação física, estuda o } \\
\text { esporte". }\end{array}$ & "A forma é a modalidade". & $\begin{array}{l}\text { "O que a física tem } \\
\text { que a educação física } \\
\text { não tem?". }\end{array}$ & $\begin{array}{l}\text { "A força, os atletas as } \\
\text { modalidades e também a } \\
\text { força, esporte, etc.". }\end{array}$ & $\begin{array}{l}\text { "Por que a física é } \\
\text { parecida com } a \\
\text { educação física mais } \\
\text { só umas r coisas } \\
\text { diferentes?". }\end{array}$ & 0 \\
\hline 06 & $\begin{array}{l}\text { "Relação de força, } \\
\text { velocidade, resistência, } \\
\text { equilíbrio, flexibilidade. } \\
\text { Ambas estudam a } \\
\text { força". }\end{array}$ & $\begin{array}{l}\text { "A força que pode ser } \\
\text { estática ou dinâmica, } \\
\text { máxima, rápida e de } \\
\text { resistência. A flexibilidade } \\
\text { que é a capacidade que } \\
\text { permite a amplitude máxima } \\
\text { de um movimento". }\end{array}$ & $\begin{array}{l}\text { "Qual e a maior força } \\
\text { de impacto que pode } \\
\text { haver entre os } \\
\text { jogadores de rúgbi?". }\end{array}$ & $\begin{array}{l}\text { "O estudo de biomecânica } \\
\text { aplicados na Ed. Física". }\end{array}$ & $\begin{array}{llr}\text { “Quais são } & \text { os } \\
\text { alimentos } & \text { mais } \\
\text { gordurosos?". } & \end{array}$ & 1 \\
\hline 08 & $\begin{array}{l}\text { "Nas duas matérias } \\
\text { procuramos entender as } \\
\text { movimentações, força e } \\
\text { velocidade". }\end{array}$ & $\begin{array}{l}\text { Em muitas aulas de Ed. } \\
\text { Física vemos como o uso da } \\
\text { movimentação do corpo é } \\
\text { necessário pra ter uma boa } \\
\text { saúde". }\end{array}$ & $\begin{array}{l}\text { "Quais são as } \\
\text { importantes } \\
\text { atividade física pra a } \\
\text { nossa saúde?". }\end{array}$ & "Atividades físicas". & $\begin{array}{l}\text { "Quais as importantes } \\
\text { de fazer atividades } \\
\text { físicas?". }\end{array}$ & 1 \\
\hline
\end{tabular}




\begin{tabular}{|c|c|c|c|c|c|c|}
\hline 10 & $\begin{array}{l}\text { "O que tem em comum } \\
\text { é que a física estuda a } \\
\text { educação física estuda o } \\
\text { esporte". }\end{array}$ & "A forma é a modalidade". & $\begin{array}{l}\text { "O que a física tem } \\
\text { que a educação física } \\
\text { não tem?". }\end{array}$ & $\begin{array}{l}\text { "A força, os atletas as } \\
\text { modalidades e também a } \\
\text { força, esporte, etc." }\end{array}$ & $\begin{array}{lcc}\text { "Porque a física } & \text { é } \\
\text { parecida com } & \text { a } \\
\text { educação física?". } & \end{array}$ & 1 \\
\hline 12 & $\begin{array}{l}\text { "A física estuda a ação } \\
\text { dos corpos como peso, } \\
\text { força equilíbrio, etc. A } \\
\text { Ed. Física estuda o bem } \\
\text { estar do corpo físico". }\end{array}$ & $\begin{array}{l}\text { "Como numa bola de } \\
\text { futebol, aplicando-se força } \\
\text { nela ela se movimenta e a } \\
\text { velocidade depende da } \\
\text { força". }\end{array}$ & $\begin{array}{l}\text { “Qual exercício } \\
\text { requer mais força?”. }\end{array}$ & $\begin{array}{l}\text { "A força, a resistência e a } \\
\text { velocidade, como uma } \\
\text { corrida (velocidade) } \\
\text { arremesso (força) e barras } \\
\text { (resistência)". }\end{array}$ & $\begin{array}{l}\text { "Porque não pode só } \\
\text { tentar jogar a bola de } \\
\text { basquete por cima do } \\
\text { arco da sexta, porque } \\
\text { tem que usar toda a } \\
\text { força necessária para } \\
\text { acertar com precisão o } \\
\text { quadrado na tabela?". }\end{array}$ & 1 \\
\hline 13 & $\begin{array}{l}\text { "Nas duas disciplinas } \\
\text { existe a relação de força, } \\
\text { velocidade, resistência, } \\
\text { equilíbrio, flexibilidade, } \\
\text { etc. Ambas as } \\
\text { disciplinas estuda a } \\
\text { força". }\end{array}$ & $\begin{array}{l}\text { "A força, que pode ser } \\
\text { estática ou dinâmica } \\
\text { máxima, rápida e de } \\
\text { resistência. A flexibilidade } \\
\text { que é a capacidade que } \\
\text { permite a amplitude máxima } \\
\text { de um movimento. Os } \\
\text { assuntos de Ed. Física } \\
\text { coincidem com a matéria de } \\
\text { física". }\end{array}$ & $\begin{array}{l}\text { "Qual é a maior força } \\
\text { de impacto que pode } \\
\text { haver entre os } \\
\text { jogadores de futebol } \\
\text { americano?". }\end{array}$ & $\begin{array}{l}\text { "O estudo da biomecânica, } \\
\text { para melhor os } \\
\text { movimentos corporais } \\
\text { aplicados na Ed. Física". }\end{array}$ & $\begin{array}{l}\text { “Quais são os } \\
\text { alimentos que nos dão } \\
\text { mais força muscular?". }\end{array}$ & 1 \\
\hline 16 & $\begin{array}{l}\text { "A relação é que a física } \\
\text { está presente em todos } \\
\text { os esportes da Ed. } \\
\text { Física". }\end{array}$ & $\begin{array}{l}\text { "O rúgbi, os lança mentos e } \\
\text { os chutes a física ajuda } \\
\text { explicar a força do lançador } \\
\text { ou lutador até a curva da } \\
\text { bola". }\end{array}$ & $\begin{array}{l}\text { "Um chute de um } \\
\text { jogador de futebol a } \\
198 \mathrm{~km} / \mathrm{h} \text { faz uma } \\
\text { curva ou não?". }\end{array}$ & $\begin{array}{l}\text { "A corrida } \\
\text { aproveitada no } \\
\text { para atletismo } \\
\text { desenvolvimento melhor". }\end{array}$ & $\begin{array}{l}\text { "Um jogador de } \\
\text { basquete } \\
\text { consegue fazer uma } \\
\text { enterrada só pegando } \\
\text { impulso?". }\end{array}$ & 1 \\
\hline
\end{tabular}




\begin{tabular}{|c|c|c|c|c|c|c|}
\hline 17 & $\begin{array}{lr}\text { "Os } & \text { exercícios } \\
\text { praticado, } & \text { de } \\
\text { velocidade, } & \text { os } \\
\text { movimentos, etc.". } & \end{array}$ & $\begin{array}{l}\text { "Por exemplo você precisa } \\
\text { saber a distância percorrida } \\
\text { da sua casa até a escola só } \\
\text { que você precisara a saber o } \\
\text { tempo a velocidade e } \\
\text { distância em quanto você te } \\
\text { andando vai estar praticar da } \\
\text { Ed. Física, fazendo } \\
\text { movimentos que também } \\
\text { faz parte da física". }\end{array}$ & $\begin{array}{l}\text { "Qual é a diferença } \\
\text { de física e Ed. Física } \\
\text { o que uma tem que a } \\
\text { outra não tem?". }\end{array}$ & $\begin{array}{l}\text { "O impulso você pega } \\
\text { uma bola de Ed. Física e } \\
\text { jogar bem longe, ai vai ter } \\
\text { a força que faz parte na } \\
\text { física os movimentos que } \\
\text { faz parte de Ed. Física } \\
\text { também". }\end{array}$ & $\begin{array}{l}\text { "Se eu tenho uma } \\
\text { extensão elétrica que } \\
\text { mede } 1 \mathrm{~m} \text {, eu ligo uma } \\
\text { ponta na eletricidade } \\
\text { como eu mediu a } \\
\text { velocidade dessa } \\
\text { energia até chegar ou } \\
\text { outra ponta?". }\end{array}$ & 1 \\
\hline 18 & $\begin{array}{ll} & \text { fElas } \\
\text { movimento e força". } & \end{array}$ & $\begin{array}{l}\text { "Estudamos saúde e para ter } \\
\text { saúde pode-se fazer } \\
\text { caminhadas e na física } \\
\text { estuda sobre isso também". }\end{array}$ & $\begin{array}{l}\text { "Pessoas gordas tem } \\
\text { mais força do que as } \\
\text { magras?". }\end{array}$ & "Velocidade força". & $\begin{array}{l}\text { "Força e torque são as } \\
\text { mesmas coisas?". }\end{array}$ & 1 \\
\hline 19 & $\begin{array}{l}\text { "O que tem em comum } \\
\text { é que a física estuda a } \\
\text { educação física, estuda o } \\
\text { esporte". }\end{array}$ & "A forma é a modalidade". & $\begin{array}{l}\text { “O que física tem a } \\
\text { educação física não } \\
\text { tem?". }\end{array}$ & $\begin{array}{l}\text { "A força, os atletas as } \\
\text { modalidades e também a } \\
\text { força, esporte, etc.". }\end{array}$ & $\begin{array}{lcc}\text { "Porque a física } & \text { é } \\
\text { parecida com } & \text { a } \\
\text { educação física?". } & \end{array}$ & 0 \\
\hline 23 & $\begin{array}{l}\text { "Por que as duas falam } \\
\text { sobre os movimentos } \\
\text { praticados". }\end{array}$ & $\begin{array}{l}\text { "Estudamos saúde e para ter } \\
\text { saúde pode-se fazer } \\
\text { caminhadas e na física } \\
\text { estuda sobre isso também". }\end{array}$ & $\begin{array}{l}\text { "Qual é a força } \\
\text { aplicada quando se } \\
\text { chuta a bola para o } \\
\text { gol?". }\end{array}$ & "Velocidade, força". & $\begin{array}{l}\text { "Por que a bola de } \\
\text { futebol } \\
\text { chutamos quando } \\
\text { vezes) vai em direção } \\
\text { contraria a do gol? E } \\
\text { por falta de força } \\
\text { aplicada ao chute?". }\end{array}$ & 1 \\
\hline
\end{tabular}




\begin{tabular}{|c|c|c|c|c|c|c|}
\hline 24 & $\begin{array}{l}\text { "Fala dos movimentos } \\
\text { do corpo só que na Ed. } \\
\text { Física é na pratica". }\end{array}$ & $\begin{array}{l}\text { "Aprendemos mais sobre a } \\
\text { saúde na matéria a de Ed. } \\
\text { Física e física". }\end{array}$ & $\begin{array}{l}\text { "Qual a velocidade } \\
\text { da bola quando } \\
\text { chutamos um jogo de } \\
\text { futebol?". }\end{array}$ & $\begin{array}{l}\text { "Velocidade e força a } \\
\text { velocidade para corrermos } \\
\text { mais e a força para jogar } \\
\text { mais forte a bola". }\end{array}$ & $\begin{array}{l}\text { "A saúde interfere na } \\
\text { força aplicada ou na } \\
\text { nossa velocidade? Por } \\
\text { quê?". }\end{array}$ & 1 \\
\hline 25 & $\begin{array}{l}\text { "Nas duas matérias } \\
\text { procuramos entender a } \\
\text { movimentação, força e } \\
\text { velocidade". }\end{array}$ & $\begin{array}{l}\text { "Com a boa alimentação, } \\
\text { fazendo a movimentação do } \\
\text { corpo". }\end{array}$ & $\begin{array}{l}\text { "A velocidade e a } \\
\text { força são muito } \\
\text { importantes para Ed. } \\
\text { Física igual são para } \\
\text { física?". }\end{array}$ & “Atividades físicas". & $\begin{array}{l}\text { "Se uma pessoa é } \\
\text { gorda ajuda no } \\
\text { impacto maior?". }\end{array}$ & 1 \\
\hline 26 & $\begin{array}{l}\text { "A física estuda a ação } \\
\text { dos corpos como peso, } \\
\text { força, equilíbrio, etc. A } \\
\text { Ed. Física estuda o bem } \\
\text { estar do corpo físico". }\end{array}$ & $\begin{array}{l}\text { "Como numa bola de } \\
\text { futebol, aplicando-se força } \\
\text { ela se movimenta e a } \\
\text { velocidade depende da } \\
\text { força". }\end{array}$ & $\begin{array}{lr}\text { "Qual } & \text { exercício } \\
\text { requer } & \text { mais } \\
\text { velocidade?". } & \end{array}$ & $\begin{array}{l}\text { "A força, a resistência e a } \\
\text { velocidade, como uma } \\
\text { corrida, arremesso e } \\
\text { barras". }\end{array}$ & $\begin{array}{l}\text { "Porque não pode só } \\
\text { tentar jogar a bola de } \\
\text { basquete por cima do } \\
\text { arco da sexta, porque } \\
\text { tem que usar toda a } \\
\text { força necessária para } \\
\text { acertar com precisão o } \\
\text { quadrado na tabela?". }\end{array}$ & 1 \\
\hline 28 & $\begin{array}{l}\text { "Entre essas disciplinas } \\
\text { existe a relação de força, } \\
\text { velocidade, resistência, } \\
\text { equilíbrio, flexibilidade, } \\
\text { etc. Ambas as } \\
\text { disciplinas estuda a } \\
\text { força". }\end{array}$ & $\begin{array}{l}\text { "A força, que pode ser } \\
\text { estática ou dinâmica } \\
\text { máxima, rápida e de } \\
\text { resistência. A flexibilidade } \\
\text { que é a capacidade que } \\
\text { permite a amplitude máxima } \\
\text { de um movimento. Os } \\
\text { assuntos de Ed. Física } \\
\text { coincidem com a matéria de } \\
\text { física". }\end{array}$ & $\begin{array}{l}\text { "Qual é a maior força } \\
\text { de impacto que pode } \\
\text { haver entre os } \\
\text { jogadores de futebol } \\
\text { americano?". }\end{array}$ & $\begin{array}{l}\text { "O estudo da biomecânica, } \\
\text { para melhor os } \\
\text { movimentos corporais } \\
\text { aplicados na Ed. Física". }\end{array}$ & $\begin{array}{l}\text { “Quais são os } \\
\text { alimentos que nos dão } \\
\text { mais força muscular?". }\end{array}$ & 1 \\
\hline
\end{tabular}




\begin{tabular}{|c|c|c|c|c|c|c|}
\hline 30 & 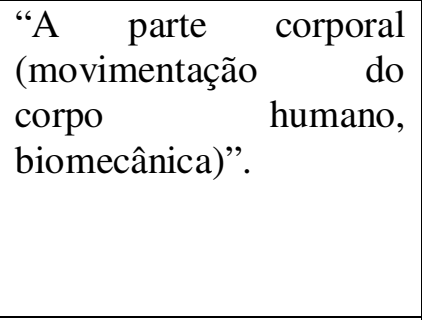 & $\begin{array}{l}\text { "A gente estudou sobre } \\
\text { rúgbi e futebol americano e } \\
\text { ambos tem muito contato } \\
\text { físico, então pode-se usar. } \\
\text { Um exemplo de dois corpos } \\
\text { em velocidade se } \\
\text { chocando". }\end{array}$ & $\begin{array}{l}\text { "Um jogador de } \\
\text { basquete de pouca } \\
\text { altura consegue fazer } \\
\text { uma enterrada só com } \\
\text { a força do impulso". }\end{array}$ & 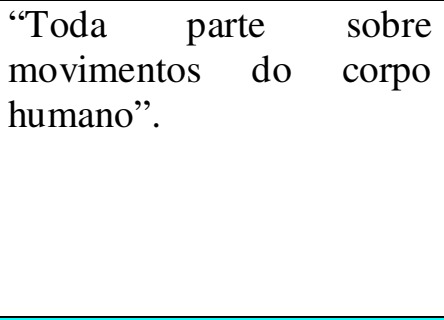 & $\begin{array}{l}\text { "Um jogador de } \\
\text { voleibol pode cair pra } \\
\text { trás ao defender uma } \\
\text { cortada do time } \\
\text { adversário? Por que?". }\end{array}$ & 1 \\
\hline 33 & $\begin{array}{l}\text { "Na física estudamos os } \\
\text { movimentos r na Ed. } \\
\text { velocidade e naticamos } \\
\text { Física rator pration } \\
\text { movimentos } \\
\text { produzimos velocidades } \\
\text { na prática esporte". }\end{array}$ & $\begin{array}{l}\text { "Em muitas aulas de Ed. } \\
\text { Física vemos com o uso da } \\
\text { movimentação do corpo é } \\
\text { necessário pra ter uma boa". }\end{array}$ & $\begin{array}{lr}\text { “A velocidade } & \text { e } \\
\text { força, } & \text { são } \\
\text { importantes } & \text { Ed. } \\
\text { Física igual são } & \text { para } \\
\text { física?". } & \end{array}$ & "Atividades físicas" & $\begin{array}{l}\text { "Se uma pessoa é } \\
\text { gorda ajuda no } \\
\text { impacto maior?". }\end{array}$ & 1 \\
\hline 34 & $\begin{array}{l}\text { "As duas disciplinas } \\
\text { envolvem estudo com o } \\
\text { corpo e procuram } \\
\text { estudar força e e } \\
\text { velocidade do corpo". }\end{array}$ & $\begin{array}{l}\text { "Em Ed. Física estudamos o } \\
\text { corpo a saúde a força, } \\
\text { velocidade e esporte isso } \\
\text { também ocorre quando } \\
\text { estudamos física. A física } \\
\text { completa a Ed. Física". }\end{array}$ & $\begin{array}{l}\text { “Qual é } \quad \text { o peso } \\
\text { máximo que uma } \\
\text { pessoa } \\
\text { levantar? } \\
\text { Alimentação tem algo } \\
\text { haver com a força?". }\end{array}$ & $\begin{array}{l}\text { "Força, velocidade, } \\
\text { esporte, alimentação. Para } \\
\text { ter uma boa saúde (estudei } \\
\text { no caderninho de física) } \\
\text { da prof. Patrícia". }\end{array}$ & $\begin{array}{l}\text { "No jogo de cada } \\
\text { jogador tem um peso } \\
\text { diferente do outro } \\
\text { exemplo os jogadores } \\
\text { da frente tem um peso } \\
\text { os de trás tem outro e } \\
\text { porque isso ocorre?". }\end{array}$ & 1 \\
\hline 36 & $\begin{array}{l}\text { "Ambos tratam de } \\
\text { atividades físicas, sendo } \\
\text { a Ed. Física tratando do } \\
\text { corpo e da saúde } \\
\text { humana e a física } \\
\text { usando como modo de } \\
\text { estudo de seus cálculos } \\
\text { e teorias". }\end{array}$ & $\begin{array}{l}\text { "A questão do exercício } \\
\text { física e do ganho e perda de } \\
\text { peso, que de certa forma se } \\
\text { relaciona com o peso a } \\
\text { massa corporal, falada na } \\
\text { diferença de peso na Terra e } \\
\text { na Lua". }\end{array}$ & $\begin{array}{l}\text { “Qual a relação } \\
\text { existente entre física } \\
\text { e Ed. Física que ajude } \\
\text { a população a ter uma } \\
\text { vida saudável?". }\end{array}$ & $\begin{array}{l}\text { "O estudo da massa corpo, } \\
\text { e a aplicação da física em } \\
\text { diferentes modalidades } \\
\text { esportivas, sendo em } \\
\text { táticas ou técnicas". }\end{array}$ & $\begin{array}{l}\text { "Quais são os pontos } \\
\text { de igualdade e } \\
\text { diferença entre Ed. } \\
\text { Física e física, ou seja, } \\
\text { qual a relação entre } \\
\text { elas?". }\end{array}$ & 1 \\
\hline
\end{tabular}




\begin{tabular}{|c|c|c|c|c|c|c|}
\hline 37 & $\begin{array}{l}\text { "Tudo. Se não entender } \\
\text { a física, não } \\
\text { conseguiremos praticar } \\
\text { Ed. Física. Afinal pela } \\
\text { física aprendemos sobre } \\
\text { as forças do corpo } \\
\text { enquanto a Ed. Física é } \\
\text { a anatomia". }\end{array}$ & $\begin{array}{l}\text { "Futebol americano, pode } \\
\text { explicar a matéria de força e } \\
\text { a de impacto". }\end{array}$ & $\begin{array}{l}\text { "Qual á a maior força } \\
\text { de impacto que pode } \\
\text { haver dentro do } \\
\text { futebol americano?". }\end{array}$ & $\begin{array}{l}\text { "É possível a bola de } \\
\text { rúgbi poder atravessar a Y } \\
\text { e sair pra fora do estádio? } \\
\text { Seria necessário quantos } \\
\text { newtons de força?". }\end{array}$ & $\begin{array}{lr}\text { "Velocidade, } & \text { a } \\
\text { resistência, } & \text { com } \\
\text { esportes que exijam } \\
\text { isso?". }\end{array}$ & 1 \\
\hline 39 & $\begin{array}{l}\text { "Em física vemos de } \\
\text { forma teórica sobre } \\
\text { força, velocidade, } \\
\text { tempo, etc. Já em física } \\
\text { nós vemos tudo isso mas } \\
\text { na prática". }\end{array}$ & $\begin{array}{l}\text { "Velocidade, força, estes } \\
\text { podem explicar a matéria de } \\
\text { física, quando jogamos } \\
\text { futebol muitas vezes } \\
\text { precisamos correr e atingir } \\
\text { uma certa velocidade para } \\
\text { alcançar a bola ao chutá-la } \\
\text { aplicamos uma força para } \\
\text { atingir o local desejado". }\end{array}$ & $\begin{array}{l}\text { "Por que o peso e } \\
\text { altura de um jogador } \\
\text { é importante em } \\
\text { determinado } \\
\text { esportes?". }\end{array}$ & $\begin{array}{l}\text { "Impulso, trajetória } \\
\text { também podem-se aplicar } \\
\text { na Ed. Física pois quando } \\
\text { precisamos correr com um } \\
\text { velocidade maior usamos } \\
\text { o impulso e fazemos um } \\
\text { trajeto determinado pelo } \\
\text { professor". }\end{array}$ & $\begin{array}{l}\text { “A matéria de } \\
\text { educação física é a } \\
\text { única que consegue } \\
\text { explicar a matéria de } \\
\text { física? Por que?". }\end{array}$ & 1 \\
\hline
\end{tabular}


Pela figura 4.30, a maioria dos estudantes conseguiu fazer a relação interdisciplinar entre física e educação física. Obtemos:

Tabela 4.40 : Graus de complexidade atingidos na turma $1^{\circ} \mathrm{B}$ da escola $\mathrm{G}$.

\begin{tabular}{|c|c|}
\hline Grau de complexidade & Porcentagem (\%) \\
\hline Grau -2 & 41,5 \\
\hline Grau -1 & 0 \\
\hline Grau 0 & 4,9 \\
\hline Grau 1 & 53,7 \\
\hline
\end{tabular}

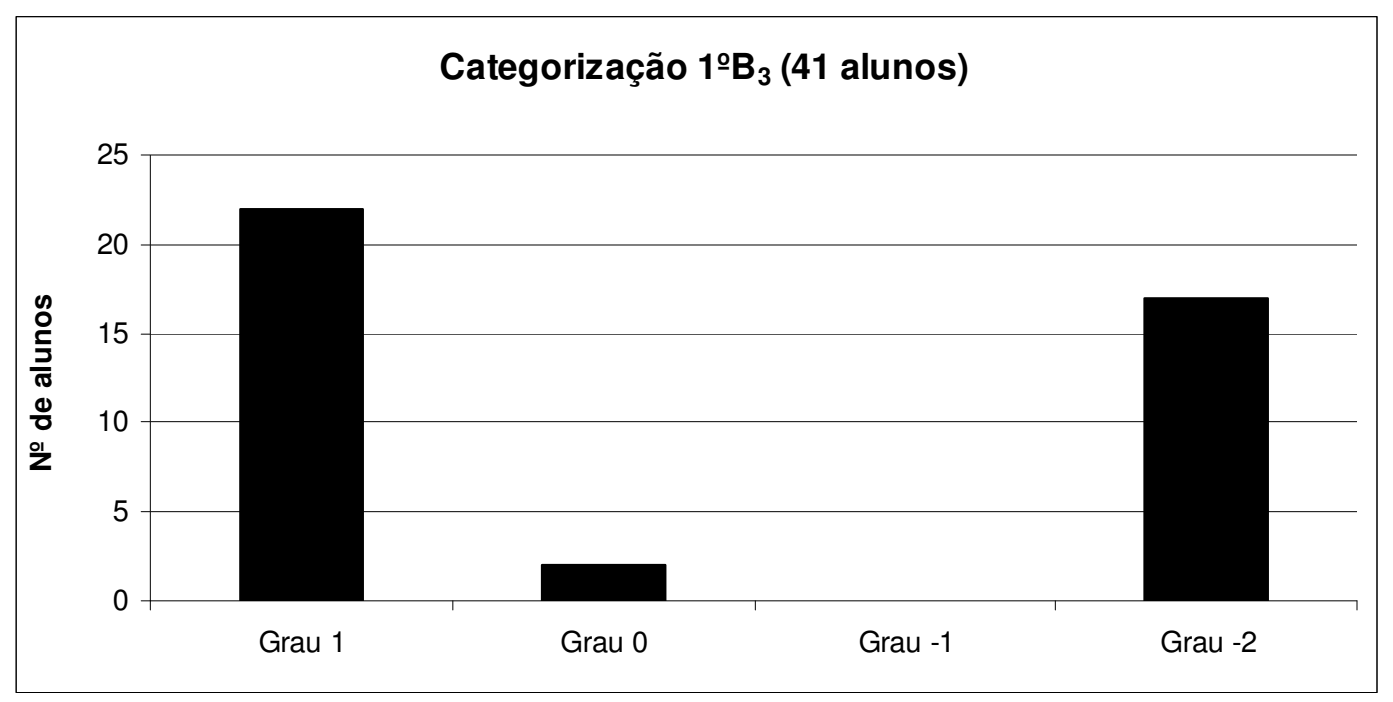

Figura 4.30: Categorização baseado em $\mathrm{Q}_{3}$.

\subsubsection{Turma $1^{\circ} \mathrm{C}_{3}$}

Nesta turma o questionário de validação foi aplicado pela própria professora, no qual dentre os 27 alunos frequentes somente 21 alunos responderam o questionário. As respostas similares foram identificadas por cores (tabela 4.41) e mostram que são equivalentes a grupos de afinidade distribuídos pela sala de aula, mas que variam em componentes. Destacamos as respostas dos estudantes:

- $\left(07, \mathrm{C}_{3}\right),\left(09, \mathrm{C}_{3}\right),\left(16, \mathrm{C}_{3}\right),\left(21, \mathrm{C}_{3}\right),\left(28, \mathrm{C}_{3}\right),\left(30, \mathrm{C}_{3}\right),\left(31, \mathrm{C}_{3}\right)$ que adicionam o esporte abrangido nas aulas de educação física pela professora em um artigo de revista o salto twist duplo carpado de Daiane dos Santos. 
- $\left(07, \mathrm{C}_{3}\right),\left(09, \mathrm{C}_{3}\right)$ que introduziram perguntas incoerentes na $\mathrm{Q} .4$ que dizem respeito ao caderno do aluno de física - vol.3, ou seja, não souberam selecionar no caderno os conceitos relacionados ao assunto do questionário.

Durante a aplicação do questionário de validação os estudantes consultaram suas anotações no caderno. 
Tabela 4.41: Respostas obtidas no questionário de validação $\mathrm{Q}_{3}$ - turma $1^{\circ} \mathrm{C}_{3}$.

\begin{tabular}{|c|c|c|c|c|c|}
\hline 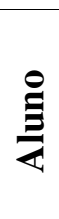 & $\begin{array}{l}\text { Q.3: O que a disciplina de física } \\
\text { tem em comum com a disciplina } \\
\text { de educação física? }\end{array}$ & $\begin{array}{l}\text { Q.4: Elabore uma pergunta que } \\
\text { contenha os conteúdos de física } \\
\text { e educação física. }\end{array}$ & $\begin{array}{l}\text { Q.5: Como você pode utilizar a } \\
\text { matéria de física nas aulas de } \\
\text { educação física? Explique, dê } \\
\text { exemplo. }\end{array}$ & 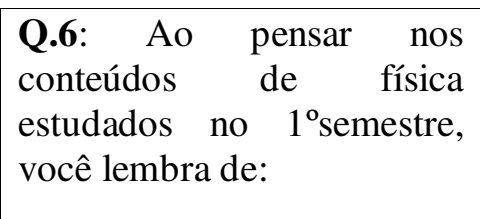 & 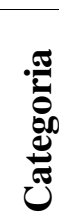 \\
\hline$\overline{0}$ & $\begin{array}{l}\text { "Em comum a força, } \\
\text { velocidade, equilíbrio, atrito, } \\
\text { precisão, etc.". }\end{array}$ & $\begin{array}{l}\text { "Um atleta de atletismo, Mário } \\
\text { realizou os } 750 \mathrm{~m} \text { rasos em } \\
\text { apenas 20,2s. Qual foi a sua } \\
\text { velocidade média?". }\end{array}$ & $\begin{array}{l}\text { "Podemos usar ao jogar futsal, } \\
\text { precisamos de agilidade, força, } \\
\text { velocidade, equilíbrio". }\end{array}$ & "Equilíbrio, força, atrito". & 1 \\
\hline 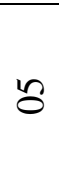 & $\begin{array}{l}\text { "Física estuda articulações e } \\
\text { saúde, e na educação física } \\
\text { estuda saúde, movimento e } \\
\text { esporte". }\end{array}$ & "O Leandro esta na fileira 3?". & $\begin{array}{l}\text { "No esporte, saúde, velocidade, } \\
\text { movimento". }\end{array}$ & $\begin{array}{lr}\text { "Velocidade, } & \text { distância, } \\
\text { articulação, } & \text { saúde, } \\
\text { deslocamento". } & \end{array}$ & 0 \\
\hline$\stackrel{0}{0}$ & $\begin{array}{l}\text { "Os dois vê a força, corre na } \\
\text { quadra e estuda na sala de aula, } \\
\text { e as duas matérias explica como } \\
\text { deve ter uma alimentação } \\
\text { saudável". }\end{array}$ & $\begin{array}{l}\text { "Como deve ter uma } \\
\text { alimentação saudável?". }\end{array}$ & $\begin{array}{l}\text { "Basquete você precisa de força } \\
\text { no arremesso e precisão". }\end{array}$ & $\begin{array}{l}\text { "Alimentação, } \\
\text { equilíbrio, } \\
\text { agilidade". }\end{array}$ & -1 \\
\hline
\end{tabular}




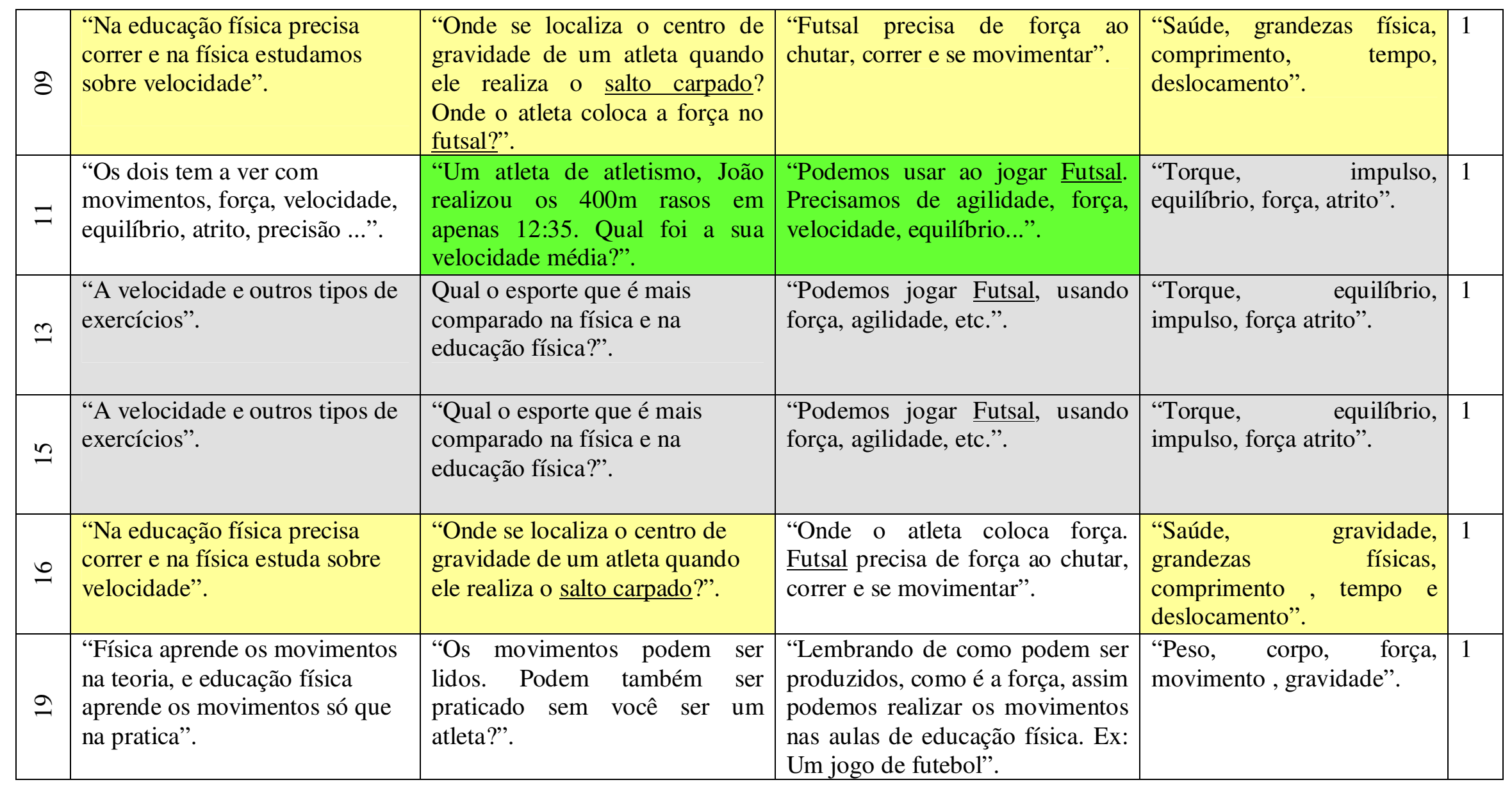




\begin{tabular}{|c|c|c|c|c|c|}
\hline$\vec{\sim}$ & $\begin{array}{l}\text { "Na educação física precisa } \\
\text { correr e na física estudamos } \\
\text { sobre a velocidade". }\end{array}$ & $\begin{array}{l}\text { "Onde se localiza o centro de } \\
\text { gravidade de um atleta quando } \\
\text { ele realiza o salto carpado? } \\
\text { Onde o atleta coloca a força no } \\
\text { futsal para chutar a bola". }\end{array}$ & $\begin{array}{l}\text { "Futsal precisa de força ao } \\
\text { chutar, correr e se movimentar". }\end{array}$ & $\begin{array}{ll}\text { "Saúde, grandezas } & \text { físicas, } \\
\text { comprimento, } & \text { tempo, } \\
\text { deslocamento". } & \end{array}$ & 1 \\
\hline ป & $\begin{array}{l}\text { "A física tem uma coisa tipo } \\
\text { exercício que é a educação } \\
\text { física, tem então parece que ela } \\
\text { se parecem". }\end{array}$ & $\begin{array}{l}\text { O que você entende por } \\
\text { velocidade?. }\end{array}$ & $\begin{array}{l}\text { "Podemos usar a velocidade, } \\
\text { massa". }\end{array}$ & $\begin{array}{l}\text { "Mecânica, corpo saudável, } \\
\text { corrida". }\end{array}$ & -1 \\
\hline ¿ & $\begin{array}{l}\text { "A física que você usa para } \\
\text { jogar, a força que você aplica } \\
\text { para chutar a bola e etc.". }\end{array}$ & $\begin{array}{l}\text { "O que é atividade física? O que } \\
\text { é constelação? Explique". }\end{array}$ & $\begin{array}{l}\text { "No seu deslocamento, na sua } \\
\text { força e etc.". }\end{array}$ & $\begin{array}{l}\text { "kg, força, deslocamento, } \\
\text { conservação de movimento, } \\
\text { leis de Newton". }\end{array}$ & -1 \\
\hline$\grave{\imath}$ & $\begin{array}{l}\text { "Tem várias coisas em comum, } \\
\text { massa, peso, beleza". }\end{array}$ & $\begin{array}{l}\text { “a) Qual tem que ser a massa de } \\
\text { um jogador?". } \\
\text { "b) A mulher em busca da } \\
\text { beleza?". }\end{array}$ & $\begin{array}{l}\text { "Pode porque as duas matérias } \\
\text { falam sobre quase tudo como: } \\
\text { peso, massa, beleza, saúde". }\end{array}$ & $\begin{array}{l}\text { "Velocidade, distância, } \\
\text { articulação, saúde". }\end{array}$ & 1 \\
\hline$\stackrel{\infty}{\sim}$ & $\begin{array}{l}\text { "Ambas lidam com o corpo e } \\
\text { com a saúde". }\end{array}$ & $\begin{array}{l}\text { "Onde se localiza o centro de } \\
\text { gravidade de um atleta quando } \\
\text { ele realiza o salto carpado? } \\
\text { Onde o atleta coloca a força no } \\
\text { futsal para chutar a bola?". }\end{array}$ & $\begin{array}{l}\text { "Para saber quanto km por } \mathrm{h} \text { um } \\
\text { corredor atinge; para medir a } \\
\text { massa corporal dos atletas etc.". }\end{array}$ & $\begin{array}{l}\text { "Saúde, centro de gravidade } \\
\text { de um atleta, contas para } \\
\text { converter Km/h r em } \\
\text { m/s,velocidade escalar e } \\
\text { impulso". }\end{array}$ & 1 \\
\hline ેे & $\begin{array}{l}\text { "Educação física é a parte } \\
\text { prática e física estuda os } \\
\text { movimentos". }\end{array}$ & $\begin{array}{l}\text { "Um atleta realizou } 10 \mathrm{~s} \text { em } \\
100 \mathrm{~m} \text { rasos. Qual é a sua } \\
\text { velocidade média?". }\end{array}$ & $\begin{array}{l}\text { "Podemos usar para explicar os } \\
\text { movimentos nos jogos de futebol, } \\
\text { por exemplo". }\end{array}$ & $\begin{array}{l}\text { "Velocidade média, força, } \\
\text { atrito". }\end{array}$ & 1 \\
\hline
\end{tabular}




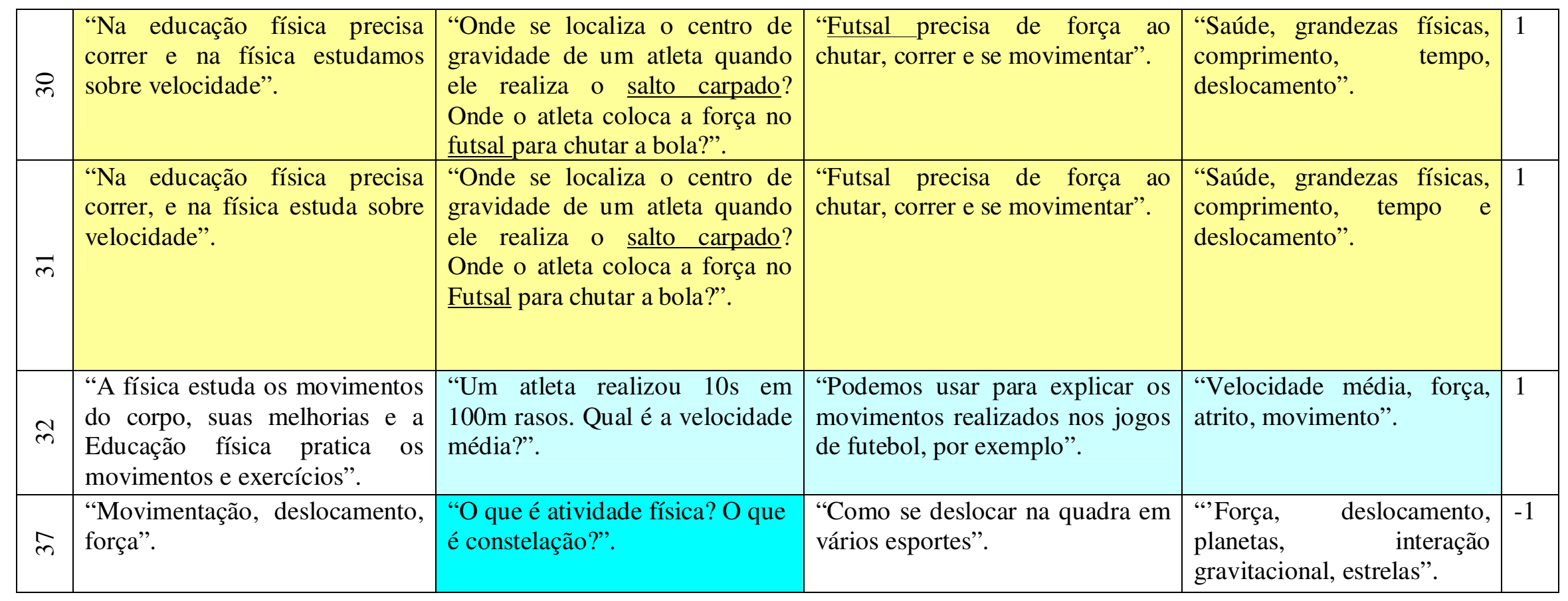


Pela figura 4.31, a maioria dos estudantes conseguiu fazer a relação interdisciplinar entre física e educação física. Obtemos:

Tabela 4.42 : Graus de complexidade atingidos na turma $1^{\circ} \mathrm{C}$ da escola $\mathrm{M}$.

\begin{tabular}{|c|c|}
\hline Grau de complexidade & Porcentagem (\%) \\
\hline Grau -2 & 43,2 \\
\hline Grau -1 & 10,8 \\
\hline Grau 0 & 2,7 \\
\hline Grau 1 & 43,2 \\
\hline
\end{tabular}

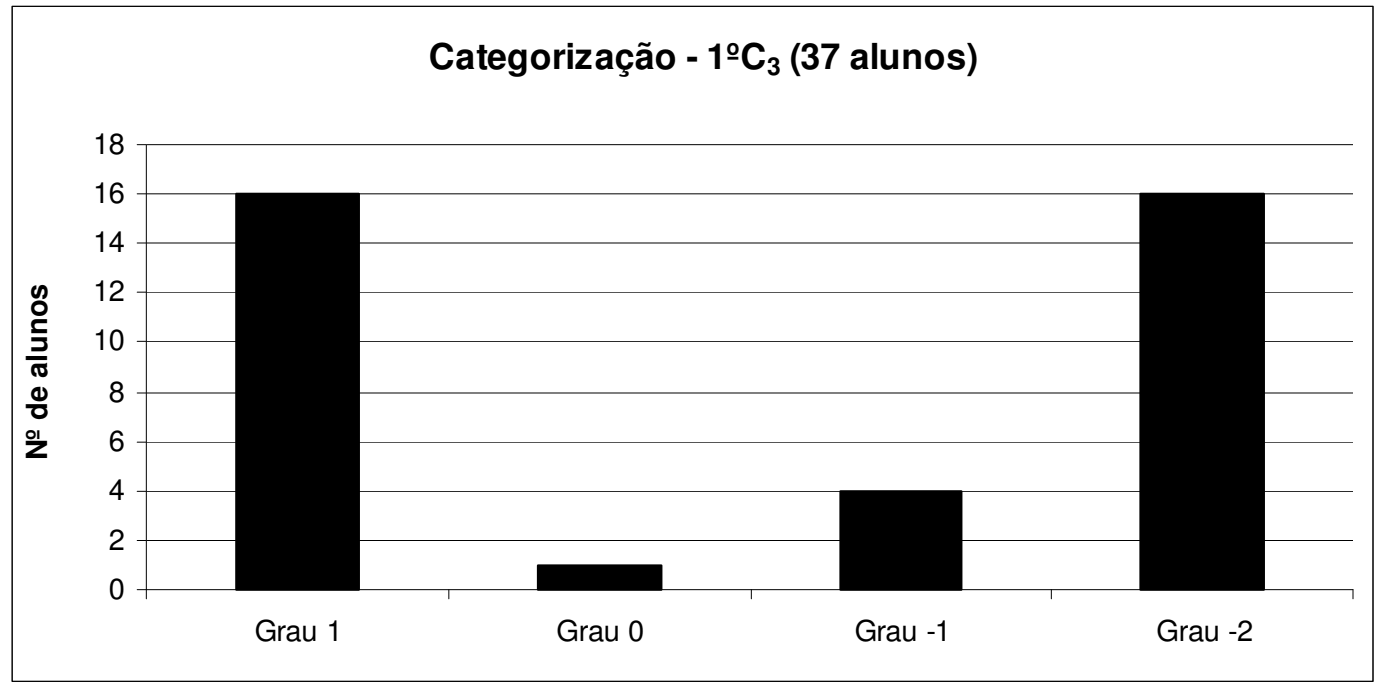

Figura 4.31: Categorização baseado em $\mathrm{Q}_{3}$.

\subsubsection{Turma $1^{\circ} D_{3}$}

Nesta turma o questionário de validação foi aplicado pela própria professora, no qual dentre os 28 alunos frequentes somente 17 alunos responderam o questionário. As respostas similares foram identificadas por cores (tabela 4.43) e mostram que são equivalentes a grupos de afinidade distribuídos pela sala de aula, mas que variam em integrantes e em posicionamento na sala de aula. Tivemos um índice grande de cópias, sendo que algumas cópias são reescritas de modos diferentes como em: $\left(05, \mathrm{D}_{3}\right),(10$, $\left.\mathrm{D}_{3}\right),\left(17, \mathrm{D}_{3}\right)$, por exemplo.

Durante a aplicação do questionário de validação os alunos consultaram constantemente o caderno e conversaram muito entre si. 
Tabela 4.43: Respostas obtidas no questionário de validação $\mathrm{Q}_{3}$ - turma $1^{\circ} \mathrm{D}_{3}$.

\begin{tabular}{|c|c|c|c|c|c|}
\hline$\stackrel{\Xi}{\Xi}$ & $\begin{array}{l}\text { Q.3: O que a disciplina de física tem em } \\
\text { comum com a disciplina de educação } \\
\text { física? }\end{array}$ & $\begin{array}{l}\text { Q.4: Como você pode utilizar a } \\
\text { matéria de física nas aulas de } \\
\text { educação física? Explique, dê } \\
\text { exemplo. }\end{array}$ & $\begin{array}{l}\text { Q.5: Ao pensar nos } \\
\text { conteúdos de física } \\
\text { estudados no } 1^{\text {os }} \text { semestre, } \\
\text { você lembra de: }\end{array}$ & $\begin{array}{l}\text { Q.6: Elabore uma } \\
\text { pergunta que contenha } \\
\text { os conteúdos de física } \\
\text { e educação física. }\end{array}$ & 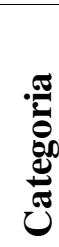 \\
\hline 02 & $\begin{array}{l}\text { "A Física e a Educação Física são matérias } \\
\text { que tem varias coisas em comum, como por } \\
\text { exemplo, estudam os movimentos, o } \\
\text { equilíbrio, velocidade de uma pessoa". }\end{array}$ & $\begin{array}{l}\text { "Na hora de medir distâncias } \\
\text { percorridas em uma corrida, a } \\
\text { velocidade que o aluno tem". }\end{array}$ & $\begin{array}{l}\text { "Velocidade, movimento, } \\
\text { horas, minutos segundos". }\end{array}$ & $\begin{array}{l}\text { "Em uma corrida de } \\
\text { alunos , qual é a } \\
\text { diferença em } \\
\text { velocidades?". }\end{array}$ & 1 \\
\hline 04 & $\begin{array}{l}\text { "Os movimentos são iguais Educação física } \\
\text { e física". }\end{array}$ & "Calcular os movimentos". & $\begin{array}{l}\text { "Sistema de medidas, } \\
\text { posição de escalar, peso de } \\
\text { um corpo, quantidade de } \\
\text { movimento, conservação } \\
\text { da quantidade de } \\
\text { movimento". }\end{array}$ & $\begin{array}{l}\text { "Física e quase toda } \\
\text { quantidade de } \text { Ed. } \\
\text { Física em...". }\end{array}$ & 1 \\
\hline 10 & $\begin{array}{l}\text { "Que as duas matérias falam sobre o corpo } \\
\text { humano e um bem estar para todas as } \\
\text { pessoas". }\end{array}$ & $\begin{array}{l}\text { "Quando for praticar um } \\
\text { exercício físico na aula de } \\
\text { Educação física você vai } \\
\text { perceber que tem tudo a ver". }\end{array}$ & $\begin{array}{l}\text { "Grandezas } \\
\text { sistemas désicas, } \\
\text { velocidade escalar medidas, } \\
\text { aceleração escalar medida, } \\
\text { conversão". }\end{array}$ & $\begin{array}{l}\text { "O que é necessária } \\
\text { para praticar alguns } \\
\text { exercícios físicos?". }\end{array}$ & 1 \\
\hline
\end{tabular}




\begin{tabular}{|c|c|c|c|c|c|}
\hline 11 & $\begin{array}{l}\text { "Entre a disciplina de Ed. Física e Física } \\
\text { tem em comum por exemplo os } \\
\text { movimentos com o material de Ed. Física, } \\
\text { forças as velocidades, as distâncias, } \\
\text { principalmente a massa". }\end{array}$ & $\begin{array}{l}\text { "Como podemos lançar a bola } \\
\text { podemos ter um calculo de } \\
\text { distância para ver a velocidade } \\
\text { que a bola vai alcançar". }\end{array}$ & $\begin{array}{l}\text { Deslocamento, velocidade, } \\
\text { movimento, impulso, } \\
\text { força". }\end{array}$ & \begin{tabular}{lrr} 
"Como & \multicolumn{2}{c}{ podemos } \\
calcular a velocidade \\
de uma bola que \\
jogamos futebol na \\
aula de & Ed. Física \\
usando a aula de \\
Física?".
\end{tabular} & 1 \\
\hline 13 & $\begin{array}{l}\text { "Muitas coisas as duas disciplinas falam } \\
\text { sobre o movimento, distância, tempo em } \\
\text { fim entre outras coisas". }\end{array}$ & $\begin{array}{l}\text { "Na hora de medir distância } \\
\text { percorridas em uma corrida, a } \\
\text { velocidade que o aluno tem". }\end{array}$ & $\begin{array}{l}\text { "Velocidade, movimento, } \\
\text { minutos, horas e } \\
\text { segundos". }\end{array}$ & $\begin{array}{l}\text { "Para chutar uma bola } \\
\text { precisa-se de força?". }\end{array}$ & 1 \\
\hline 14 & $\begin{array}{l}\text { "A física e a Educação física são matérias } \\
\text { que tem varias coisas em comum como, por } \\
\text { exemplo, estuda os movimentos, o } \\
\text { equilíbrio, velocidade e agilidade de uma } \\
\text { pessoa". }\end{array}$ & $\begin{array}{l}\text { "Na hora de medir a distância } \\
\text { percorrida em uma corrida e a } \\
\text { velocidade que o aluno tem". }\end{array}$ & $\begin{array}{l}\text { "Velocidade, movimento, } \\
\text { horas,minutos e segundos". }\end{array}$ & $\begin{array}{llr}\text { "Em uma } & \text { corrida } & \text { de } \\
\text { alunos, } & \text { qual } & \text { a } \\
\text { diferença } & \text { em } & \text { suas } \\
\text { velocidades?". }\end{array}$ & 1 \\
\hline 17 & $\begin{array}{l}\text { "As duas tem em comum que falam sobre o } \\
\text { corpo humano e ate ajudam a melhorar o } \\
\text { corpo da gente". }\end{array}$ & $\begin{array}{l}\text { "A física ajuda para quando } \\
\text { você for fazer um exercício em } \\
\text { educação física fica ate mais } \\
\text { fácil e por isso elas tem coisas } \\
\text { em comum". }\end{array}$ & $\begin{array}{l}\text { "Grandezas físicas, sistema } \\
\text { de medidas, dinâmica, } \\
\text { deslocamento e caminho } \\
\text { percorrido, teorema de } \\
\text { pitágoras, aceleração } \\
\text { escalar". }\end{array}$ & $\begin{array}{lr}\text { "O que é necessário } \\
\text { para praticar } r \text { um } \\
\text { esporte? } & \text { Cite } \\
\text { exemplos de } & \text { como } \\
\text { fazer". } & \end{array}$ & 1 \\
\hline 18 & $\begin{array}{l}\text { "A Física e a Educação Física tem muita } \\
\text { coisa em comum, porque na Educação } \\
\text { Física tem velocidade, equilíbrio, } \\
\text { movimento; E na Física estuda isso, a gente } \\
\text { faz conta para ver o quanto movimento nos } \\
\text { fazemos, contamos a velocidade e } \\
\text { estudamos o equilíbrio ( na Física nos } \\
\text { estudamos, e na Educação Física nos } \\
\text { praticamos)". }\end{array}$ & $\begin{array}{l}\text { "Quando corremos nós vemos o } \\
\text { quanto correu, quantos minutos } \\
\text { (cronometragem).r Quando } \\
\text { lançamos a bola e nós contamos } \\
\text { a distância". }\end{array}$ & "Hora, minuto, segundos". & $\begin{array}{l}\text { "Quando lançamos a } \\
\text { bola nós usamos a } \\
\text { Física para medir e a } \\
\text { Educação Física pra } \\
\text { praticar? Explique". }\end{array}$ & 1 \\
\hline
\end{tabular}




\begin{tabular}{|c|c|c|c|c|c|}
\hline 19 & $\begin{array}{l}\text { "A física e a Ed. Física são matéria que tem } \\
\text { muitas coisas em comum como por ex. } \\
\text { estudam os movimentos e o equilíbrio". }\end{array}$ & $\begin{array}{l}\text { "Na hora de medir distância } \\
\text { percorridas em uma corrida, a } \\
\text { velocidade que o aluno tem". }\end{array}$ & $\begin{array}{l}\text { "Velocidade, movimento, } \\
\text { minuto, horas, segundos". }\end{array}$ & 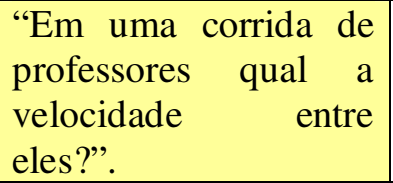 & 1 \\
\hline 23 & $\begin{array}{l}\text { "Os nomes são quase iguais Educação } \\
\text { Física e Física". }\end{array}$ & "Calcular alguns movimentos". & $\begin{array}{l}\text { "Sistema de medidas, } \\
\text { grandezas físicas, posição } \\
\text { escalar, deslocamento, } \\
\text { quantidade de movimento". }\end{array}$ & \begin{tabular}{lr}
\multicolumn{2}{l}{ "Porque os nomes são } \\
parecidos? & Porque \\
para calcular & algo \\
precisa & se \\
movimentar?". & \\
\end{tabular} & 1 \\
\hline 24 & $\begin{array}{l}\text { "As duas matérias falam sobre o corpo } \\
\text { humano e um bem estar para todas as } \\
\text { pessoas". }\end{array}$ & $\begin{array}{l}\text { "Quando for praticar um } \\
\text { exercício físico na aula de } \\
\text { Educação física você vai } \\
\text { perceber que tem...". }\end{array}$ & $\begin{array}{l}\text { "Grandeza física, sistemas } \\
\text { de medidas, velocidade, } \\
\text { aceleração escalar media, } \\
\text { conversão". }\end{array}$ & 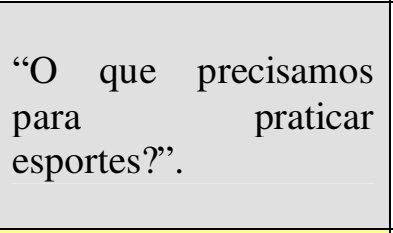 & 1 \\
\hline 25 & $\begin{array}{l}\text { "A física e a Ed. Física são matérias que } \\
\text { tem muitas coisas em comum como por } \\
\text { exemplo estudam os movimentos o } \\
\text { equilíbrio velocidade e agilidade de uma } \\
\text { pessoa". }\end{array}$ & $\begin{array}{l}\text { "Na hora de medir distâncias } \\
\text { percorridas em uma corrida, a } \\
\text { velocidade, que o aluno tem". }\end{array}$ & $\begin{array}{l}\text { "Velocidade movimento, } \\
\text { horas minutos, segundos". }\end{array}$ & $\begin{array}{l}\text { "Em uma corrida de } \\
\text { alunos, qual é } \\
\text { diferença em } \\
\text { velocidades?". }\end{array}$ & 1 \\
\hline 27 & $\begin{array}{l}\text { "A Física e a Educação física são materiais } \\
\text { que tem várias coisas em comum, como por } \\
\text { exemplo estudam os movimentos, o } \\
\text { equilíbrio, velocidade e agilidade de uma } \\
\text { pessoa". }\end{array}$ & $\begin{array}{l}\text { "Na hora de medir distâncias } \\
\text { percorridas em uma corrida, a } \\
\text { velocidade que o aluno tem". }\end{array}$ & $\begin{array}{l}\text { "Velocidade, movimento, } \\
\text { horas, minutos, segundos". }\end{array}$ & $\begin{array}{l}\text { "Em uma corrida de } \\
\text { alunos, qual é a } \\
\text { diferença em ras } \\
\text { velocidades?". }\end{array}$ & 1 \\
\hline 33 & $\begin{array}{l}\text { "A Física e a Educação Física, são matérias } \\
\text { que tem muitas coisas em comum como por } \\
\text { exemplo estudam os movimentos o } \\
\text { equilíbrio velocidade e agilidade de } \\
\text { pessoa". }\end{array}$ & $\begin{array}{l}\text { "Na hora de medir distancia } \\
\text { percorrida em uma corridas, a } \\
\text { velocidade, que o aluno tem". }\end{array}$ & $\begin{array}{l}\text { "Velocidade movimento, } \\
\text { horas, minuto, segundo". }\end{array}$ & $\begin{array}{l}\text { "Para chutar uma bola } \\
\text { precisa de muita } \\
\text { força?". }\end{array}$ & 1 \\
\hline
\end{tabular}




\begin{tabular}{|c|c|c|c|c|c|}
\hline 34 & $\begin{array}{l}\text { "Os nomes são iguais Educação física e } \\
\text { física". }\end{array}$ & "Calcular os movimentos". & $\begin{array}{l}\text { "Sistema de medida, } \\
\text { grandezas físicas, posições } \\
\text { escalar, deslocamento, } \\
\text { quantidade de movimento". }\end{array}$ & Não fez. & 1 \\
\hline 35 & $\begin{array}{l}\text { "Para mim, física tem algumas coisas em } \\
\text { comum com Ed. Física como aprendemos: } \\
\text { tudo sobre movimento, velocidade, massa, } \\
\text { distância e tudo isso se encaixa em algumas } \\
\text { aulas de Ed. Física". }\end{array}$ & $\begin{array}{l}\text { "Calculando o tempo a ser } \\
\text { percorrido, se a professora de } \\
\text { Ed. Física dar uma atividade } \\
\text { para fazermos na quadra e } \\
\text { calcular a massa corporal". }\end{array}$ & $\begin{array}{l}\text { "Gravidade, } \\
\text { distância } \\
\text { movimento". }\end{array}$ & $\begin{array}{l}\text { "Algum impulso feito } \\
\text { na aula de Ed. Física } \\
\text { pode ser medido na } \\
\text { Física? Como?". }\end{array}$ & 1 \\
\hline
\end{tabular}


Pela figura 4.32, a maioria dos estudantes conseguiu fazer a relação interdisciplinar entre física e educação física, mas obtemos:

Tabela 4. 44: Graus de complexidade atingidos na turma $1^{\circ} \mathrm{D}$ da escola $\mathrm{M}$.

\begin{tabular}{|c|c|}
\hline Grau de complexidade & Porcentagem (\%) \\
\hline Grau -2 & 54 \\
\hline Grau -1 & 0 \\
\hline Grau 0 & 0 \\
\hline Grau 1 & 46 \\
\hline
\end{tabular}

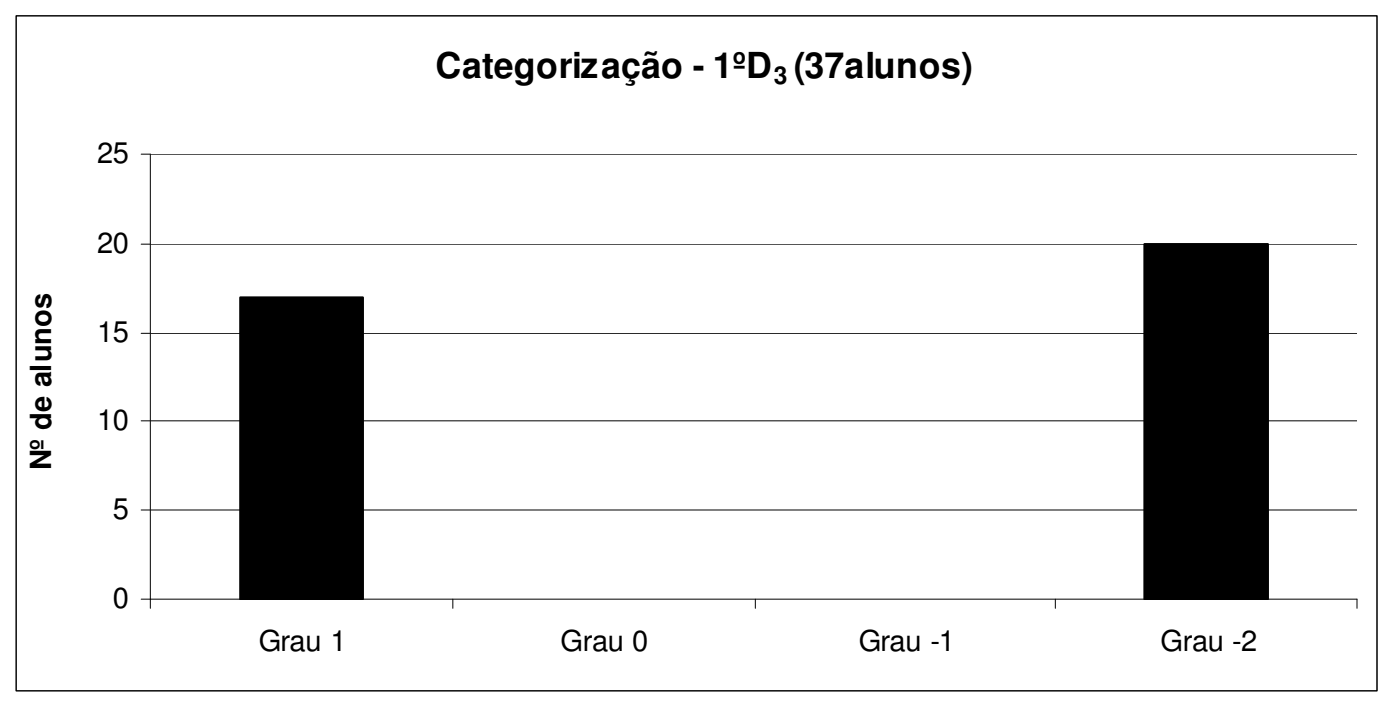

Figura 4.32: Categorização baseado em $\mathrm{Q}_{3}$.

\subsection{Análise Final}

\subsubsection{Graus de complexidade}

Analisando o questionário $\mathrm{Q}_{2}$ em conjunto com o questionário $\mathrm{Q}_{3}$, obtivemos uma visão mais completa dos dados, o que nos possibilitou classificar com mais exatidão os graus de complexidade atingida pelos estudantes, categorizado no par ordenado. Compomos uma análise mais completa da evolução das ideias dos estudantes que está baseada na análise detalhada das respostas dos alunos aos questionários acoplada à relação coerente e adequada de algumas palavras previamente selecionadas (na seção 4.1). 
Tabela 4.45: Análise Final nas duas turmas da escola G.

\begin{tabular}{|c|c|c|c|c|c|c|}
\hline$\stackrel{巳}{\Xi}$ & $\begin{array}{c}\text { Categoria } \\
\text { para } \\
1^{\circ} \mathbf{A}_{2}\end{array}$ & $\begin{array}{c}\text { Categoria } \\
\text { para } \\
\mathbf{1}^{\circ} \mathbf{A}_{3}\end{array}$ & $\begin{array}{r}\text { Categoria } \\
\text { Final - } 1^{\circ} \mathrm{A} \\
\left(\text { discurso, }^{-}\right. \\
\text {contexto) }\end{array}$ & $\begin{array}{c}\text { Categoria } \\
\text { para } \\
\mathbf{1}^{\circ} \mathbf{B}_{2}\end{array}$ & $\begin{array}{c}\text { Categoria } \\
\text { para } \\
\mathbf{1}^{\circ} \mathbf{B}_{3}\end{array}$ & $\begin{array}{c}\text { Categoria } \\
\text { Final - } 1^{\circ} \mathrm{B} \\
(\text { discurso, } \\
\text { contexto) }\end{array}$ \\
\hline 01 & 0 & 0 & 0,1 & 0 & 1 & 1,1 \\
\hline 02 & 1 & 0 & 0,1 & 1 & 1 & 2,1 \\
\hline 03 & -1 & -2 & $-1,1$ & -2 & -2 & $-2,0$ \\
\hline 04 & 1 & -2 & 1,1 & 1 & -2 & 0,2 \\
\hline 05 & 1 & 1 & 2,1 & 1 & 0 & 0,1 \\
\hline 06 & 1 & 1 & 2,1 & 1 & 1 & 2,1 \\
\hline 07 & 0 & -2 & 0,1 & 1 & -2 & 2,1 \\
\hline 08 & 1 & -2 & 1,1 & 1 & 1 & 1,1 \\
\hline 09 & 1 & 1 & 2,1 & 1 & 1 & 2,1 \\
\hline 10 & 1 & 1 & 1,1 & 1 & 1 & 1,1 \\
\hline 11 & -2 & -2 & $-2,0$ & 1 & -2 & 1,1 \\
\hline 12 & 1 & -2 & 1,2 & 1 & 1 & 2,1 \\
\hline 13 & -2 & -2 & $-2,0$ & 1 & 1 & 2,1 \\
\hline 14 & 1 & 1 & 2,1 & 1 & -2 & 1,1 \\
\hline 15 & 1 & 1 & 2,1 & -1 & -2 & $-1,1$ \\
\hline 16 & -1 & -2 & $-1,1$ & 1 & 1 & 2,1 \\
\hline 17 & 1 & -2 & 1,1 & 1 & 1 & 1,1 \\
\hline 18 & 0 & -2 & 0,1 & 1 & 1 & 1,1 \\
\hline 19 & -2 & 0 & 0,1 & 0 & 0 & 0,1 \\
\hline 20 & 1 & -2 & 1,1 & 1 & -2 & 1,1 \\
\hline 21 & 1 & 1 & 1,1 & -2 & -2 & $-2,0$ \\
\hline 22 & 1 & 1 & 1,1 & 0 & -2 & 0,1 \\
\hline 23 & 1 & 1 & 2,1 & 1 & 1 & 1,1 \\
\hline 24 & -2 & 1 & 1,1 & 1 & 1 & 1,1 \\
\hline 25 & 1 & 1 & 1,1 & 1 & 1 & 2,1 \\
\hline 26 & -2 & -2 & $-2,0$ & 1 & 1 & 2,1 \\
\hline 27 & 1 & -2 & 1,1 & -2 & -2 & $-2,0$ \\
\hline 28 & 1 & 0 & 1,2 & 1 & 1 & 2,1 \\
\hline 29 & 1 & 0 & 1,1 & -2 & -2 & $-2,0$ \\
\hline 30 & 1 & -2 & 1,1 & 1 & 1 & 2,1 \\
\hline 31 & 0 & -2 & 0,1 & 1 & -2 & 1,1 \\
\hline 32 & 0 & -2 & 0,1 & -1 & -2 & $-1,1$ \\
\hline 33 & -2 & -2 & $-2,0$ & -1 & 1 & 1,1 \\
\hline 34 & -1 & -2 & $-1,1$ & 1 & 1 & 1,1 \\
\hline 35 & 1 & 1 & 2,1 & 1 & -2 & 0,1 \\
\hline 36 & -2 & -2 & $-2,0$ & 1 & 1 & 2,1 \\
\hline 37 & -2 & -2 & $-2,0$ & 1 & 1 & 2,1 \\
\hline 38 & 1 & 1 & 1,1 & -2 & -2 & $-2,0$ \\
\hline 39 & 1 & 1 & 1,2 & 1 & 1 & 2,2 \\
\hline 40 & 1 & -2 & 1,1 & 1 & -2 & 1,1 \\
\hline 41 & -2 & 0 & 0,1 & 1 & -2 & 1,1 \\
\hline
\end{tabular}

Obs.: Embora os estudantes 2A, 18A, 22B, 31B, 35B citem termos da disciplina de educação física, não verificamos a evolução no grau de complexificação. 
Para auxiliar no entendimento da tabela 4.45 e 4.48, observe como exemplo o aluno 30 da turma B na tabela 4.18 e 4.39 enquadrado em análise separada na categoria 1 de articulação dos conceitos e na análise em conjunto (das duas tabelas) como $(2,1)$. È 2 para $x$, porque em alguma de suas respostas as questões, há esportes abrangidos nas aulas de educação física (sublinhado na tabela 4.39), e é 1 para y porque suas respostas permeiam apenas o contexto escolar. Lembrando que será 2 para y se o estudante aplicar os conceitos aprendidos na escola fora do contexto escolar.

$\mathrm{Na}$ turma $1^{\circ} \mathrm{A}$ contamos com 41 alunos para esta última análise. Para complexificação referente a coordenada $\mathrm{x}$, temos:

Tabela 4.46: Graus de complexidade atingidos na turma $1^{\circ} \mathrm{A}$ da escola $\mathrm{G}$.

\begin{tabular}{|c|c|}
\hline Grau de complexidade & Porcentagem (\%) \\
\hline Grau -2 & 14,6 \\
\hline Grau -1 & 7,3 \\
\hline Grau 0 & 17 \\
\hline Grau 1 & 39 \\
\hline Grau 2 & 19,5 \\
\hline
\end{tabular}

Lembramos que o grau zero, não significa que os estudantes passaram pelo processo de intervenção sem efeito nenhum, mas que apenas adicionaram alguns dos conceitos vistos nas atividades na sua fala com significados do cotidiano sem conexões interdisciplinares.

$\mathrm{Na}$ figura 4.33, damos o panorama geral do grau de complexidade dos estudantes da turma $1^{\circ} \mathrm{A}$, onde a cor preta corresponde a coordenada $\mathrm{x}$ (conteúdo) e a cor vermelha a coordenada y (contexto).

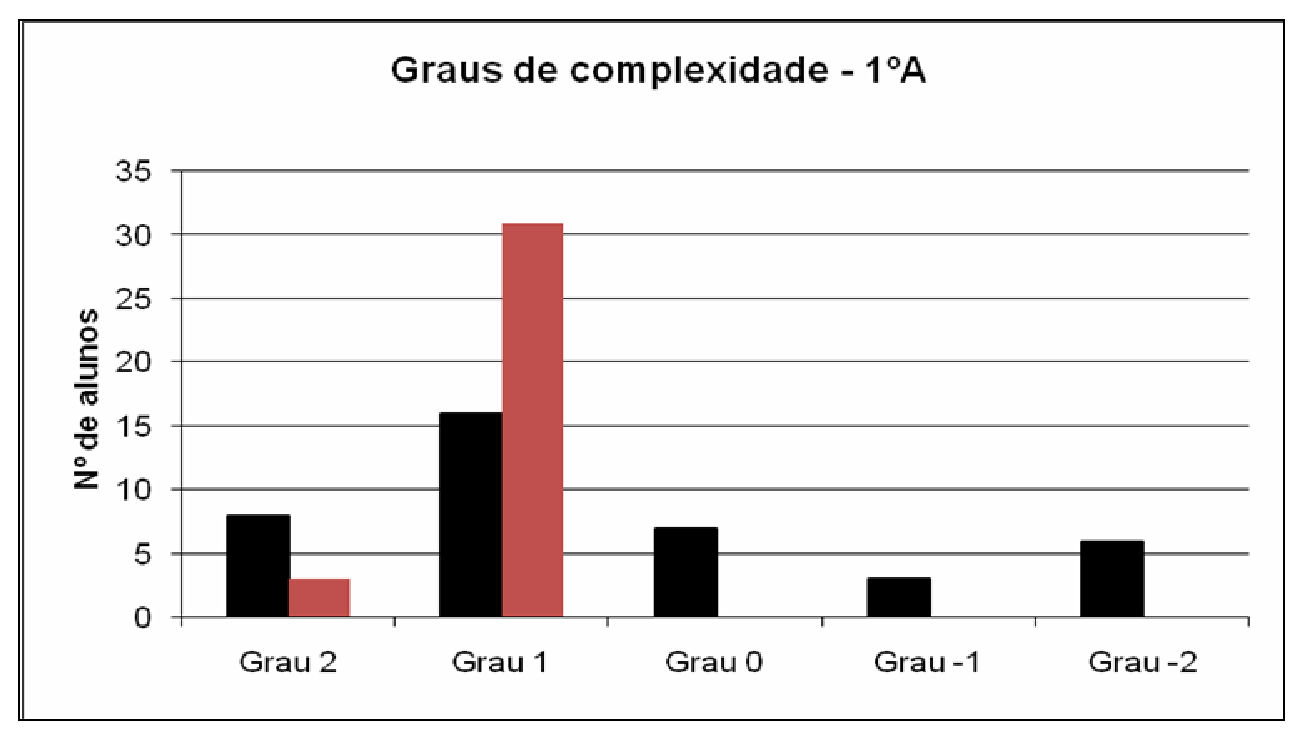

Figura 4.33: Análise dos graus de complexidade na turma $1^{\circ} \mathrm{A}$. 
$\mathrm{Na}$ turma $1^{\circ} \mathrm{B}$ contamos com 41 alunos para esta última análise. Para complexificação referente a coordenada $\mathrm{x}$, temos:

Tabela 4.47: Graus de complexidade atingidos na turma $1^{\circ} \mathrm{B}$ da escola $\mathrm{G}$.

\begin{tabular}{|c|c|}
\hline Grau de complexidade & Porcentagem (\%) \\
\hline Grau -2 & 12,2 \\
\hline Grau -1 & 4,9 \\
\hline Grau 0 & 12,2 \\
\hline Grau 1 & 36,5 \\
\hline Grau 2 & 34,1 \\
\hline
\end{tabular}

$\mathrm{Na}$ figura 4.34, damos o panorama geral do grau de complexidade dos estudantes da turma $1^{\circ} \mathrm{B}$, onde a cor preta corresponde a coordenada $\mathrm{x}$ e a cor vermelha a coordenada y.

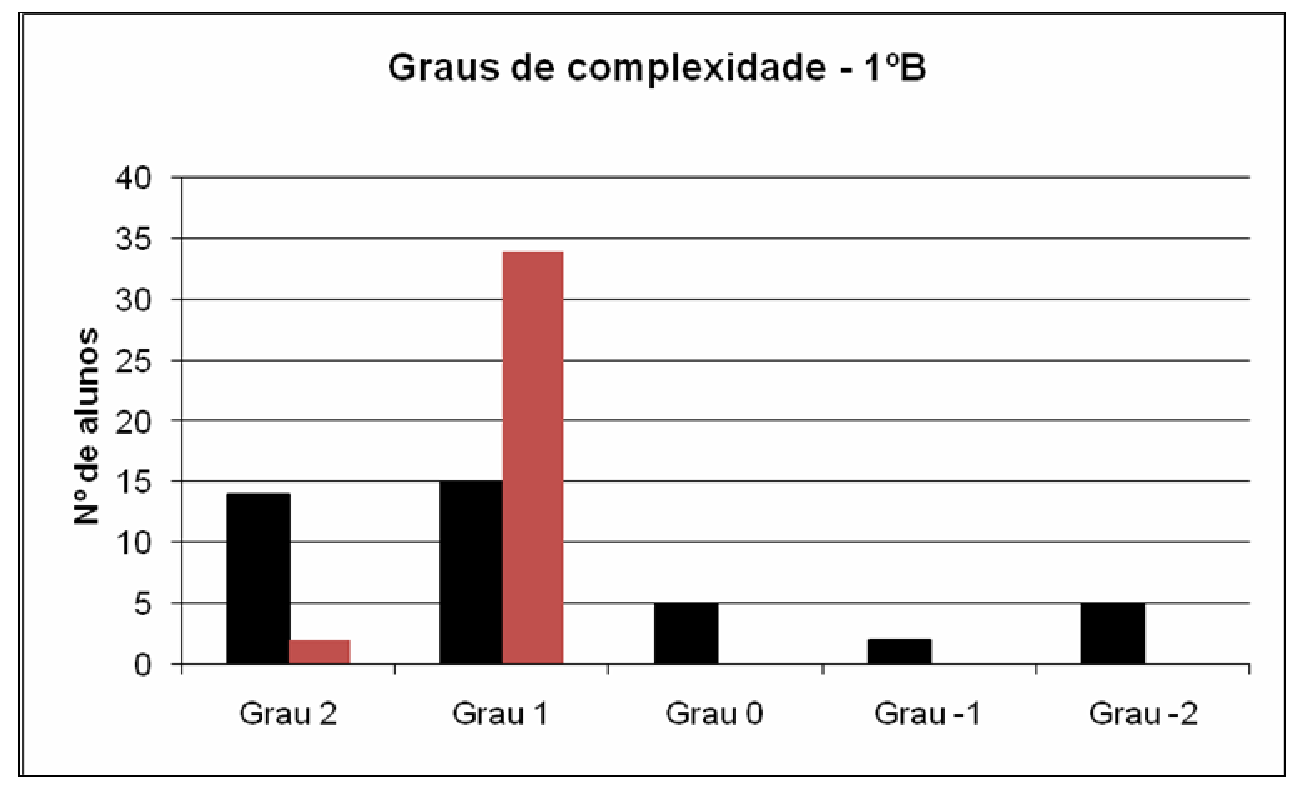

Figura 4.34: Análise dos graus de complexidade na turma $1^{\circ} \mathrm{B}$. 
Tabela 4.48: Análise Final nas duas turmas da escola M.

\begin{tabular}{|c|c|c|c|c|c|c|}
\hline$\stackrel{\varrho}{\stackrel{E}{E}}$ & $\begin{array}{c}\text { Categoria } \\
\text { para } \\
1^{\circ} \mathrm{C}_{2}\end{array}$ & $\begin{array}{c}\text { Categoria } \\
\text { para } \\
1^{\circ} \mathrm{C}_{3}\end{array}$ & $\begin{array}{c}\text { Categoria } \\
\text { Final - } 1^{\circ} \mathrm{C} \\
(\text { discurso, } \\
\text { contexto) }\end{array}$ & $\begin{array}{c}\text { Categoria } \\
\text { para } \\
\mathbf{1}^{\circ} \mathbf{D}_{2}\end{array}$ & $\begin{array}{c}\text { Categoria } \\
\text { para } \\
1^{\circ} \mathrm{D}_{3}\end{array}$ & $\begin{array}{c}\text { Categoria } \\
\text { Final - } 1^{\circ} \mathrm{D} \\
\text { (discurso, } \\
\text { contexto) }\end{array}$ \\
\hline 01 & 1 & 1 & 2,1 & -2 & -2 & $-2,0$ \\
\hline 02 & 1 & 1 & 1,1 & 1 & 1 & 2,1 \\
\hline 03 & 1 & -2 & 1,1 & -1 & -2 & $-1,1$ \\
\hline 04 & 0 & -2 & $-1,1$ & 1 & 1 & 1,1 \\
\hline 05 & -2 & 0 & 0,1 & 1 & 1 & 2,1 \\
\hline 06 & -2 & -2 & $-2,0$ & -1 & -2 & $-1,1$ \\
\hline 07 & 1 & 1 & 2,1 & 1 & -2 & 1,1 \\
\hline 08 & 1 & -1 & 2,1 & -2 & -2 & $-2,0$ \\
\hline 09 & 1 & 1 & 2,1 & 1 & -2 & 1,1 \\
\hline 10 & -2 & -2 & $-2,0$ & 0 & 1 & 1,1 \\
\hline 11 & 1 & 1 & 2,1 & 0 & 1 & 2,1 \\
\hline 12 & 0 & -2 & $-1,1$ & 1 & -2 & 1,1 \\
\hline 13 & 1 & 1 & 1,1 & 1 & 1 & 1,1 \\
\hline 14 & -2 & -2 & $-2,0$ & 1 & 1 & 1,1 \\
\hline 15 & 1 & 1 & 2,1 & 1 & -2 & 1,1 \\
\hline 16 & 1 & 1 & 2,1 & -2 & -2 & $-2,0$ \\
\hline 17 & 1 & -2 & 1,1 & 1 & 1 & 1,1 \\
\hline 18 & -2 & -2 & $-2,0$ & 1 & 1 & 1,1 \\
\hline 19 & 1 & 1 & 2,1 & 1 & 1 & 1,1 \\
\hline 20 & -2 & -2 & $-2,0$ & -2 & -2 & $-2,0$ \\
\hline 21 & 1 & 1 & 2,1 & -2 & -2 & $-2,0$ \\
\hline 22 & -1 & -1 & $-1,1$ & 1 & -2 & 1,1 \\
\hline 23 & 1 & -2 & 1,1 & 1 & 1 & 1,1 \\
\hline 24 & 1 & -1 & 1,1 & 1 & 1 & 1,1 \\
\hline 25 & 1 & -2 & 1,1 & 1 & 1 & 1,1 \\
\hline 26 & -2 & -2 & $-2,0$ & 1 & -2 & 1,1 \\
\hline 27 & 1 & 1 & 2,1 & 1 & 1 & 1,1 \\
\hline 28 & 1 & 1 & 2,1 & 1 & -2 & 1,1 \\
\hline 29 & 1 & 1 & 1,1 & -2 & -2 & $-2,0$ \\
\hline 30 & 1 & 1 & 2,1 & -2 & -2 & $-2,0$ \\
\hline 31 & 1 & 1 & 2,1 & -2 & -2 & $-2,0$ \\
\hline 32 & 1 & 1 & 1,1 & 0 & -2 & 0,1 \\
\hline 33 & 0 & -2 & 0,1 & 1 & 1 & 1,1 \\
\hline 34 & -2 & -2 & $-2,0$ & 1 & 1 & 2,1 \\
\hline 35 & -2 & -2 & $-2,0$ & 0 & 1 & 2,1 \\
\hline 36 & -2 & -2 & $-2,0$ & -2 & -2 & $-2,0$ \\
\hline 37 & 0 & -1 & 0,1 & 1 & -2 & 1,1 \\
\hline
\end{tabular}

Obs.: 33C, 3D, 6D Embora cite termos da educação física, não existe complexificação.

Na turma $1^{\circ} \mathrm{C}$ contamos com 37 alunos para esta última análise. Para complexificação referente a coordenada $\mathrm{x}$, temos: 
Tabela 4.49: Graus de complexidade atingidos na turma $1^{\circ} \mathrm{C}$ da escola $\mathrm{M}$.

\begin{tabular}{|c|c|}
\hline Grau de complexidade & Porcentagem (\%) \\
\hline Grau -2 & 24,3 \\
\hline Grau -1 & 8,1 \\
\hline Grau 0 & 8,1 \\
\hline Grau 1 & 21,6 \\
\hline Grau 2 & 37,8 \\
\hline
\end{tabular}

$\mathrm{Na}$ figura 4.35, damos o panorama geral do grau de complexidade dos estudantes da turma $1^{\circ} \mathrm{C}$, onde a cor preta corresponde a coordenada $\mathrm{x}$ e a cor vermelha a coordenada y.

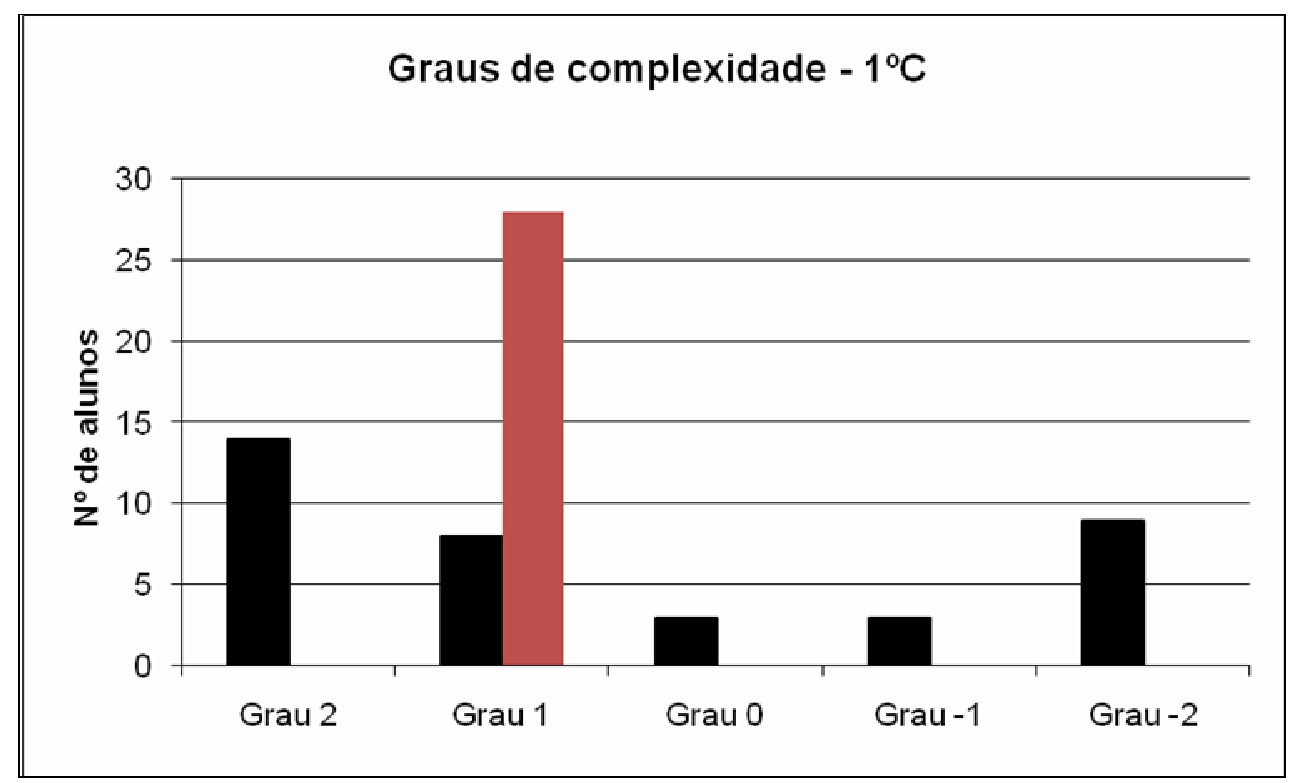

Figura 4.35: Análise dos graus de complexidade na turma $1^{\circ} \mathrm{C}$.

Na turma $1^{\circ} \mathrm{D}$ contamos com 37 alunos para esta última análise. Para complexificação referente a coordenada $\mathrm{x}$, temos:

Tabela 4.50: Graus de complexidade atingidos na turma $1^{\circ} \mathrm{D}$ da escola $\mathrm{M}$.

\begin{tabular}{|c|c|}
\hline Grau de complexidade & Porcentagem (\%) \\
\hline Grau -2 & 24,3 \\
\hline Grau -1 & 5,4 \\
\hline Grau 0 & 2,7 \\
\hline Grau 1 & 48,6 \\
\hline Grau 2 & 18,9 \\
\hline
\end{tabular}


$\mathrm{Na}$ figura 4.36, damos o panorama geral do grau de complexidade dos estudantes da turma $1^{\circ} \mathrm{D}$, onde a cor preta corresponde a coordenada $\mathrm{x}$ e a cor vermelha a coordenada y.

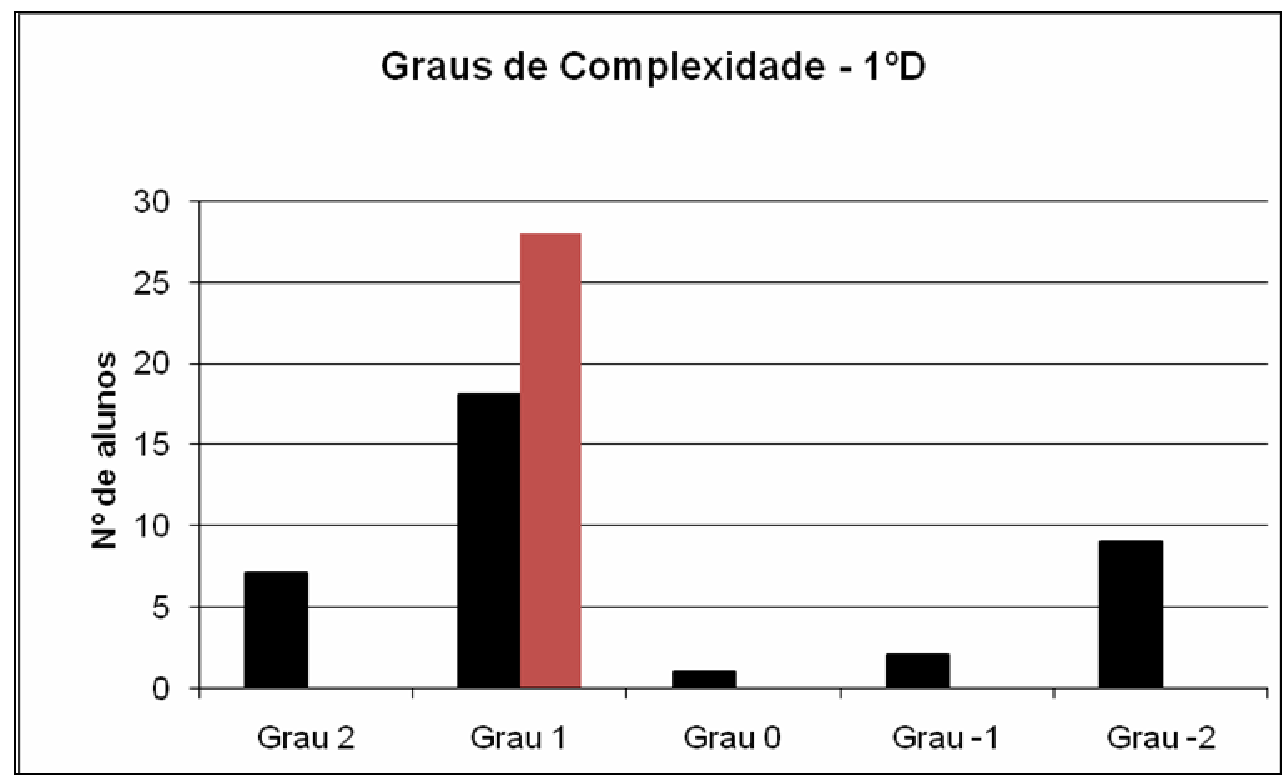

Figura 4.36: Análise dos graus de complexidade na turma $1^{\circ} \mathrm{D}$.

Lembramos que os graus -1 e -2 são de qualidade distinta dos graus 0,1 e 2, pois apenas mostram a quantia de estudantes que não responderam, ou responderam fora do perguntado nas questões selecionadas para análise.

Os resultados obtidos demonstram que a maioria dos estudantes alcançou o grau 1 de complexificação do conhecimento de esporte para articulação dos conceitos, o que é um bom índice mediante a todo contexto escolar e a atual situação da escola pública. O grau 1 para articulação dos conceitos $(x)$ vai de encontro aos objetivos da intervenção em termos da complexificação do conhecimento de esporte, mas enfatizamos que alguns estudantes vão além do esperado (grau 2) utilizando nas aulas de física, esportes e conceitos estudados nas aulas de educação física.

Além disso, pudemos analisar, mesmo que simplificadamente, qual contexto $(y)$ fora da escola (2) ou dentro da escola (1) que o estudante utiliza para responder as questões. Para pesquisas futuras, poderemos delimitar mais os contextos dentro e fora da escola, criando sub-contextos. 


\subsubsection{Considerações preliminares sobre as ordens de aprendizado}

Na tabela abaixo apresentamos um levantamento da quantidade de alunos de acordo com o par ordenado (x,y).

Tabela 4.51: Graus de complexidade das turmas da escola G e M.

\begin{tabular}{|c|c|c|c|c|}
\hline Graus de complexidade & 10A & 10B & 1C & 10D \\
\hline$(-2,0)$ & 6 & 5 & 9 & 9 \\
\hline$(-1,2)$ & 0 & 0 & 0 & 0 \\
\hline$(-1,1)$ & 3 & 2 & 3 & 2 \\
\hline$(0,1)$ & 8 & 4 & 3 & 1 \\
\hline$(0,2)$ & 0 & 1 & 0 & 0 \\
\hline$(1,1)$ & 13 & 15 & 8 & 19 \\
\hline$(2,1)$ & 8 & 13 & 14 & 6 \\
\hline$(1,2)$ & 3 & 0 & 0 & 0 \\
\hline$(2,2)$ & 0 & 1 & 0 & 0 \\
\hline TOTAL de alunos & 41 & 41 & 37 & 37 \\
\hline
\end{tabular}

Segundo a classificação da junção das ordens de aprendizado com os graus de complexidade estabelecida para categorização na seção 4.3.1, obtivemos uma grande quantia de estudantes situados na $2^{\mathrm{a}}$ ordem de aprendizado.

Tabela 4.52: Ordens de Aprendizado das turmas da escola G e M.

\begin{tabular}{|c|c|c|c|c|}
\hline Ordens de aprendizado & 1\%A & 1\%B & 19C & 1oD \\
\hline Fora da análise $=(-2,0),(-1,2),(-1,1)$ & $22 \%$ & $17 \%$ & $32,4 \%$ & $29,7 \%$ \\
\hline $1^{\mathrm{a}}=(0,1),(0,2)$ & $20 \%$ & $12,2 \%$ & $8,1 \%$ & $2,7 \%$ \\
\hline $2^{\mathrm{a}}=(1,1),(2,1),(1,2)$ & $58 \%$ & $68,3 \%$ & $59,5 \%$ & $67,6 \%$ \\
\hline $3^{\mathrm{a}}=(2,2)$ & $0 \%$ & $2,4 \%$ & $0 \%$ & $0 \%$ \\
\hline
\end{tabular}

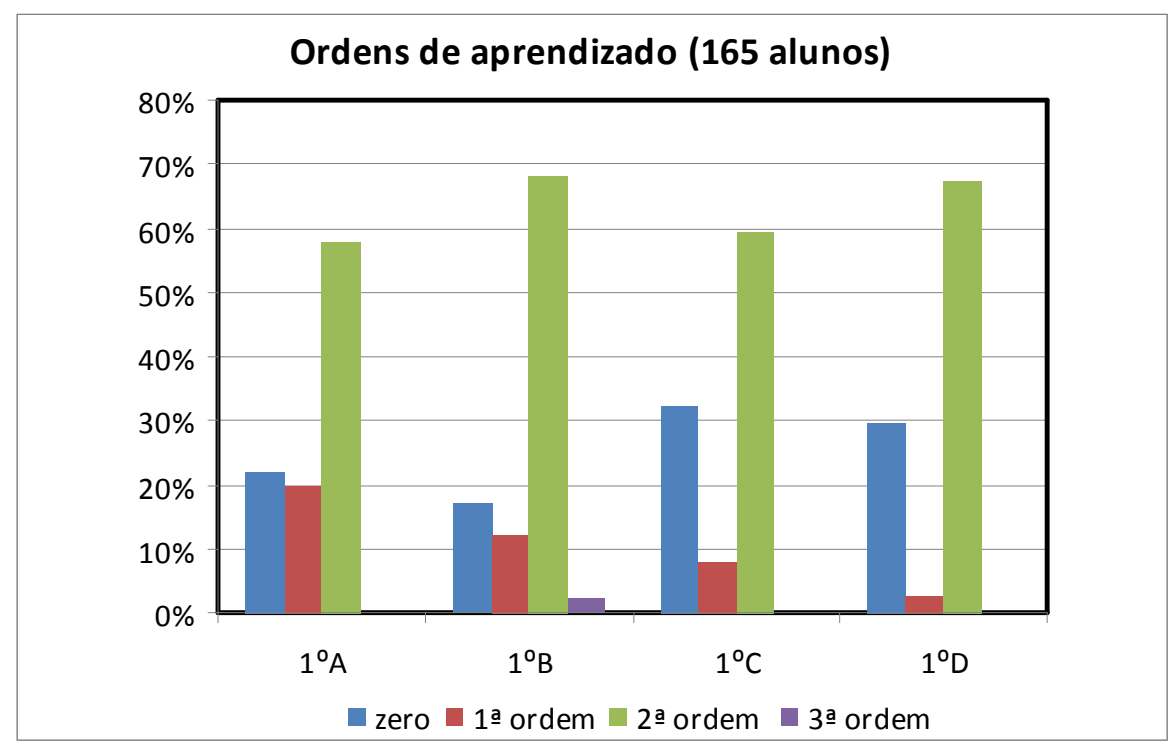

Figura 4.37: Análise das ordens de aprendizados nas turmas da escola G e M. 
Em todas as turmas obtivemos um bom índice de estudantes alcançando o grau 1 de complexificação $(1,1)$ que equivale a $2^{\mathrm{a}}$ ordem de aprendizagem, demonstrando um significativo avanço na aprendizagem dos estudantes. É claro que tínhamos como proposta que um número maior de estudantes atingisse o grau 2 de complexificação, mas mediante as características da amostra, as condições físicas de ambiente escolar e mais alguns ruídos nos dados, consideramos um bom resultado.

\subsubsection{Novos caminhos para pesquisa sobre a complexificação do conhecimento.}

Por meio da análise dos dados, percebemos duas vertentes ao tratar de complexificação. Podemos analisar a complexificação atrelada a interdisciplinaridade e a complexificação atrelada as ordens de aprendizado.

A pesquisa abre a possibilidade de futuramente podermos enfocar a complexificação via ordens de aprendizado (RODRIGUES \& MATTOS, 2007), isto cria uma perspectiva para o entendimento da dinâmica do perfil conceitual. Ao complexificar o conhecimento, novas zonas são acrescidas ao perfil conceitual, fazendo com que o estudante gradativamente evolua nas ordens de aprendizado, que por sua vez indicam a complexificação do perfil conceitual, que descreverão a evolução do estudante quanto a aplicação dos conceitos trabalhados durante este processo.

Neste trabalho escolhemos enfocar a complexificação do conhecimento por intermédio das relações interdisciplinares, embora no início da pesquisa tínhamos a intenção de estudar a evolução do perfil conceitual de esporte. Apesar de sabemos da relação existente entre complexidade e evolução do perfil conceitual, há uma grande dificuldade metodológica em realizar o levantamento do perfil conceitual de esporte, principalmente pela complexidade do conceito na forma com que foi abordado nas atividades da intervenção. Entretanto, acreditamos que a medida do perfil conceitual pode ser um dos caminhos para uma nova pesquisa.

Com as atividades da intervenção que abrangem o tema esporte de forma interdisciplinar, realizada nas duas escolas públicas verificamos a complexificação gradativa do conhecimento, pois os estudantes articularam os novos significados dado a conceitos complexos já utilizados, com o contextos diários.

O processo de complexificação envolve a dinâmica do perfil conceitual, pois novas zonas do perfil são agregadas e o estudante reconhecendo novos contextos de uso 
evolui nas ordens de aprendizado. Esta relação - complexificação e ordens de aprendizado - do ponto de vista teórico, é uma contribuição nova para a pesquisa no aprendizado de conceito.

Em trabalhos anteriores (BASTOS, 2007; BASTOS \& MATTOS, 2009), nós utilizamos categorias que evolviam os três eixos: axiológico, ontológico e epistemológico, o que nos permitiu verificar a evolução do perfil conceitual durante o processo de aprendizagem com agregação das dimensões antes inexistente. Essa transição também podemos perceber nos dados obtidos nesta pesquisa, mas que será objeto de pesquisa futura.

Entretanto mostramos a seguir algumas respostas para questão 1 da atividade avaliatória, as quais exemplificam a presença dos três eixos e permitem um indício da dinâmica do perfil conceitual dos estudantes no processo de complexificação do conhecimento de esporte. Não é possível delimitar onde começa e onde termina cada um dos três eixos, mas podemos identificá-los nas respostas dos estudantes por algumas palavras que nos remetem aos eixos. Para explicitar essas palavras escolhemos a questão 1 da atividade avaliatória que, embora exija o uso de algumas palavras teve suas respostas analisadas considerando as inter-relações entre outros termos.

Para facilitar a análise utilizamos a cor amarelo para representar o eixo axiológico, a cor azul para representar o eixo ontológico e a cor verde para o eixo epistemológico. Observe alguns exemplos na tabela 4.53:

Tabela 4.53: Respostas a questão 1 da atividade avaliatória da escola G e M.

\begin{tabular}{|c|c|}
\hline 莺 & Questão 1 (Atividade Avaliatória) \\
\hline $5, A_{2}$ & $\begin{array}{l}\text { "A biomecânica voltada para estudar o corpo humano. Para o corpo trabalhar } \\
\text { bem e ter uma boa vida, é preciso praticar esportes físicos. E com o esporte e } \\
\text { uma boa alimentação a saúde será boa. Mas para ter boa saúde é preciso praticar } \\
\text { exercício físico com moderação para que não tenha lesões". }\end{array}$ \\
\hline $6, \mathrm{~A}_{2}$ & $\begin{array}{l}\text { "A biomecânica ajuda a movimentar melhor o corpo para não sofrer lesões do } \\
\text { esporte em que o atleta está praticando. Ajuda também nas atividades físicas } \\
\text { para uma boa saúde e uma qualidade de vida melhor". }\end{array}$ \\
\hline
\end{tabular}




\begin{tabular}{|c|c|}
\hline 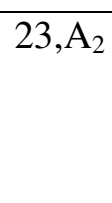 & $\begin{array}{l}\text { "A biomecânica é muito importante na vida, com ela conseguimos praticar } \\
\text { esporte assim melhorarmos a nossa saúde e nosso corpo, com isso evitamos } \\
\text { lesões, quem estuda esses movimentos é a física". }\end{array}$ \\
\hline $8, \mathrm{~A}_{2}$ & $\begin{array}{l}\text { "O esporte hoje em dia está sendo cada vez mais comum na vida das pessoas. } \\
\text { Através disso existe também a biomecânica que estuda o movimento do corpo } \\
\text { humano. Além do esporte fazer bem para o corpo humano é fundamental para a } \\
\text { saúde do ser humano, praticando de acordo com a necessidade física de cada } \\
\text { um, para que não ocorra nenhuma lesão". }\end{array}$ \\
\hline $2, B_{2}$ & $\begin{array}{l}\text { "A biomecânica tem grande importância na física e é usada para melhorar os } \\
\text { movimentos de um atleta e evitar lesõs. Assim o atleta pode praticar seus } \\
\text { esportes, ter mais saúde e vida". }\end{array}$ \\
\hline $6, B_{2}$ & $\begin{array}{l}\text { "A biomecânica faz parte da nossa vida são os nossos movimentos. Para se ter } \\
\text { saúde é preciso praticar esportes, atividade física, ter alimentação balanceada } \\
\text { entre outras coisas. Isso serve para se ter um corpo saudável e uma vida longa. } \\
\text { Só tome cuidado com o esforço na hora da prática de exercícios físicos para não } \\
\text { ter contusões e lesões". }\end{array}$ \\
\hline $11, \mathrm{~B}_{2}$ & $\begin{array}{l}\text { "Os esportes são ótimos para o corpo e a saúde, mas que se praticada } \\
\text { incorretamente pode ocasionar lesões sérias na vida da pessoa e que se tiver um } \\
\text { bom estudo da biomecânica do corpo, pode ajudar muito no condicionamento } \\
\text { físico de um atleta". }\end{array}$ \\
\hline $13, \mathrm{~B}_{2}$ & $\begin{array}{l}\text { "A biomecânica é utilizada na física e no esporte e ajuda a melhorar os } \\
\text { movimentos e evitar lesões e assim praticar esportes para ter um corpo com } \\
\text { saúde e bastante vida". }\end{array}$ \\
\hline $16, \mathrm{~B}_{2}$ & $\begin{array}{l}\text { "A biomecânica é muito importante para o atleta de qualquer esporte, mas } \\
\text { importante ter saúde, e ter uma boa condição física porque se não você esta apto } \\
\text { a ter lesão pelo corpo por isso você tem que jogar com saúde senão pode estar } \\
\text { arriscando sua vida". }\end{array}$ \\
\hline $25, B_{2}$ & $\begin{array}{l}\text { "Saúde é a chave para conseguir praticar esportes, tendo uma boa alimentação } \\
\text { você também tem uma vida saudável e um belo corpo entendendo a física você } \\
\text { entende de biomecânica que irá te prevenir de lesões". }\end{array}$ \\
\hline $37, \mathrm{~B}_{2}$ & $\begin{array}{l}\text { "A saúde de nossos corpos dependem muito da maneira que nós cuidamos } \\
\text { deles: se alimentando, praticando esportes, tentando manter sempre a calma, }\end{array}$ \\
\hline
\end{tabular}




\begin{tabular}{|c|c|}
\hline & $\begin{array}{l}\text { exercício que dê ao seu limite, senão lesões sérias podem ser causadas. Para } \\
\text { isso, saber qual exercício seria o melhor para você, por que não estudar um } \\
\text { pouco de física, hein? Assim você pode conhecer melhor a biomecânica de seu } \\
\text { corpo e seus benefícios". }\end{array}$ \\
\hline $7, \mathrm{C}_{2}$ & $\begin{array}{l}\text { "A física tem um dos seus conceitos que é a biomecânica que estuda o } \\
\text { movimento de cada atleta, independente do esporte, o esporte é muito bom, pois } \\
\text { a pessoa fica com um corpo bonito, saudável, mas pode acontecer lesões fatais } \\
\text { trazendo estragos a vida". }\end{array}$ \\
\hline $8, \mathrm{C}_{2}$ & $\begin{array}{l}\text { "O futebol é um esporte muito bom que traz uma bela aparência e ainda um } \\
\text { corpo belo e uma saúde incomparável, só que existe probabilidade de ocorrer } \\
\text { alguma lesão e também pode ser estudado a biomecânica". }\end{array}$ \\
\hline $16, C_{2}$ & $\begin{array}{l}\text { "Nosso corpo necessita de movimentos para podermos realizar determinado } \\
\text { esporte que fará bem a nossa saúde, assim podemos ter uma vida saudável. A } \\
\text { física está presente em tudo até na vida profissional dos técnico, professores, } \\
\text { etc, que devem compreender o atleta se ele está pronto para realizar alguma } \\
\text { atividade física ou se ele sofreu alguma lesão". }\end{array}$ \\
\hline $17, \mathrm{C}_{2}$ & $\begin{array}{l}\text { "A biomecânica estuda os movimentos do corpo. Na nossa vida, os esporte é } \\
\text { fundamental, pois ele ajuda não só na saúde física, quanto mental mais também } \\
\text { é preciso cuidados para não acarretar lesões". }\end{array}$ \\
\hline $23, C_{2}$ & $\begin{array}{l}\text { "O esporte é um das melhores coisas para se ter um corpo bonito e sarado uma } \\
\text { vida saudável, mas pode acontecer lesões, também a física estuda a biomecânica } \\
\text { de todos os esportes". }\end{array}$ \\
\hline $25, C_{2}$ & $\begin{array}{l}\text { "O esporte ajuda a ter saúde para nosso corpo e ficarmos de bem com a vida. Na } \\
\text { aula de física aprendi sobre a biomecânica que estuda os movimentos do corpo. } \\
\text { Para o esporte ela é muito importante, pois evita lesões". }\end{array}$ \\
\hline $32, C_{2}$ & $\begin{array}{l}\text { "A biomecânica é um estudo dos nossos movimentos, esses estudos são feitos } \\
\text { quando realizamos algum esporte. Praticando esportes nossa saúde estará } \\
\text { melhorando. A biomecânica serve para evitar que soframos alguma lesão no } \\
\text { corpo, melhorando nossa vida". }\end{array}$ \\
\hline $5, \mathrm{D}_{2}$ & $\begin{array}{l}\text { "Para ter um corpo com uma boa saúde e uma boa condição física você precisa } \\
\text { praticar esportes e estudar os movimentos que você tem que fazer com a } \\
\text { biomecânica para não ter lesões e viver uma vida saudável". }\end{array}$ \\
\hline $14, \mathrm{D}_{2}$ & coisa que \\
\hline
\end{tabular}




\begin{tabular}{|l|l|}
\hline $27, \mathrm{D}_{2}$ & $\begin{array}{l}\text { bom para o corpo e para saúde e para a vida. A biomecânica estuda tudo isso (O } \\
\text { movimento do corpo), ajuda a descobrir o que causa a lesão. Quem pratica } \\
\text { esporte é feliz e de bem coma vida". } \\
\text { saúde estável. Através da biomecânica podemos ter uma ideia de atividades } \\
\text { físicas que podemos fazer e evitar lesões". }\end{array}$ \\
\hline
\end{tabular}

*(Aluno, turma)

Embora a análise do acoplamento da complexidade as ordens de aprendizado esteja sendo realizada de forma rudimentar, podemos perceber a complexidade do processo de ensino-aprendizagem. Isso nos motiva a buscar entendimento de como se dá este processo. O objetivo seria o de elaborar um método que auxilie o professor no desenvolvimento dos conteúdos em sala de aula, de tal forma que por meio de um "mapa" que conste os três eixos: axiológico, epistemológico e ontológico, o professor consiga visualizar a dinâmica do perfil conceitual (BASTOS, 2007; BASTOS \& MATTOS, 2009) ao localizar em que ponto do mapa o estudante está, após cada aula ministrada. 


\section{CAPÍTULO 5}

\section{Considerações Finais}

Com o estudo dos graus de complexificação do conhecimento por intermédio das relações interdisciplinares, podemos conduzir melhor o processo de ensinoaprendizagem, o qual - início, meio e fim - é construído e norteado pelo professor, assim obter devolutivas mais ágeis durante o mesmo.

O processo de ensino e aprendizagem é dinâmico. Com está pesquisa obtivemos o princípio de um método que possibilite ao professor ter acesso aos graus de complexificação no qual um estudante pode se encontrar a cada aula ministrada. Isto possibilita inserções ao longo das aulas que buscarão suprir instrumentos mediadores ausentes nos estudantes.

Com um tratado interdisciplinar para complexificação do conhecimento o estudante permanece em um ciclo contínuo de aprendizado que não se finda (na sexta aula) ao soar o sinal da escola, mas contínua ao longo do dia, em suas atividades diárias.

Durante a pesquisa notamos várias similaridades entre escolas e turmas, mas também algumas diferenças gritantes, apesar disso, foi possível verificar a complexificação do conhecimento cotidiano sobre esporte. Segundo Garcia (1998), ao realizar uma intervenção não podemos apenas analisar isoladamente os indivíduos, pois há uma interdependência com o ambiente, os problemas estão atrelados ao contexto.

Nesta pesquisa pudemos realizar comparações entre quatro turmas de duas escolas estaduais. Mas sabemos que o desenvolvimento das atividades em uma intervenção (BERNSTEIN, 1990 apud MORAIS, 2007), está diretamente ligado à interação dos sujeitos nas próprias estruturas educacionais, pois é evidente que as interações são diferentes em cada turma, em cada escola. Há uma mudança de discurso pedagógico que depende do contexto específico de cada escola (discurso regulador) e da ação pedagógica de cada professor, ou seja, é um processo dinâmico.

As atividades de intervenção foram elaboradas seguindo o ciclo hipotéticopreditivo de Lawson, sendo que a finalidade não foi avaliar a eficiência do ciclo na aprendizagem, mas como se daria a complexificação do conhecimento cotidiano dos alunos com relação a física, o esporte e a prática esportiva. 
Os dados coletados durante a pesquisa são extensos e ricos. Analisamos os dados obtidos, antes e depois da intervenção, o que nos possibilitou estudar a complexificação do conhecimento dos estudantes, ou seja, como se dá a aprendizagem.

Observamos nos dados analisados que os estudantes passam a incluir os conceitos de mecânica, educação física e biomecânica se referir sobre esporte e saúde. Fundamentados no referencial teórico utilizado, entendemos que estes dados são indícios de que os estudantes passaram a representar suas situações vivenciais com novos critérios, integrados aos anteriores, elegendo, segundo o contexto, a ação comunicativa mais adequada. Isto só se torna possível, se a representação de certa complexidade do mundo, também, se complexifica, indicando, no estudo apresentado, que houve uma integração do conhecimento científico com o cotidiano.

Além disso, os estudantes passam a utilizar relações interdisciplinares entre os conceitos da física com biomecânica, esporte, saúde e educação física, mesmo que em níveis de interdisciplinaridade diferenciados, de forma a construir um conhecimento voltado para uma vida mais saudável.

Fica claro, de certa forma, que cada um destes conhecimentos, científico e cotidiano, deve estar inserido no conhecimento escolar. E, o recorte escolhido para sua apresentação, deve ser feito de forma responsável. O recorte que utilizamos foi o interdisciplinar. Como afirmamos, este recorte ao ser apresentado para os estudantes, já sintetizado pelo professor, aumenta as chance de que eles consigam complexificar seus conhecimentos anteriores, incluindo novos elementos e novas relações entre eles, tornando sua representação mais complexa.

Uma construção interdisciplinar não é uma tarefa simples de ser feita, e deixá-la exclusivamente nas mãos dos estudantes, é imaginar que eles podem, por si só, construir as relações teórico-metodológicas que fundamentam a interdisciplinaridade (MATTOS \& DRUMOND, 2004).

É necessária disponibilidade, interesse por parte do professor em se atualizar, buscar novas formas de apresentar o conhecimento que, a princípio, faça sentido para ele e, posteriormente, para o aluno. Neste trabalho, apresentamos um exemplo de complexificação do conhecimento escolar, onde não foram deixados de lado os conteúdos específicos que estavam previstos no currículo oficial do estado de São Paulo. Também não foram blocos isolados que incluíam novas metodologias, mas foram atividades que variaram as rotinas cotidianas da sala de aula, que eram intercaladas com as atividades típicas do caderno do aluno de física. 
Neste trabalho fornecemos novos caminhos de como abordar o conteúdo de mecânica de maneira interdisciplinar, auxiliando na aprendizagem dos conceitos e despertar o interesse nos alunos, além de demonstrar sua aplicabilidade em uma típica escola estadual.

Sabemos que este trabalho não é a solução para todos os problemas enfrentados pelo professor na sala de aula, mas é uma opção de como abranger o conteúdo de mecânica, juntamente com o caderno do aluno de física do $1^{\circ}$ semestre do $1^{\circ}$ ano do ensino médio. Apesar de apresentarmos todas as dificuldades encontradas na implementação dessas atividades, sabemos que serão necessários ainda muitos aprimoramentos.

Temos a esperança de que, este trabalho acadêmico, onde exemplificamos como certos referenciais teóricos podem ser utilizados para a construção e avaliação de uma intervenção, que os professores possam utilizar este material, para auxiliar no ensino de mecânica e também para se inspirar na construção de outras relações interdisciplinares, que tenham mais valor para ele, para os estudantes, para a comunidade onde está inserida a escola.

\subsection{Conclusão da pesquisa}

Ao propor uma intervenção, no qual a finalidade é analisar a complexificação do conhecimento cotidiano, observamos que sua inserção no contexto escolar gera comportamentos inusitados dos estudantes que nos levam a olhar para estrutura escolar atual, o seu significado perante a sociedade e a complexa rede hierárquica que compõem a educação.

Passamos a nos indagar, se existe alguma intervenção que consiga engajar, motivar todos os estudantes no ensino-aprendizagem, mesmo que imersos em um contexto educacional com características tão plurais. Nele nos deparamos com valores heterogêneos, que retratam uma sociedade que vive em mudanças de significados quanto a importância do conhecimento escolar para vida futura e do profissional professor. Será que uma intervenção irá resolver um problema sistêmico, que não envolve apenas uma sala de aula, ou uma escola, mas se insere em toda estrutura educacional? 
Com todas as características do sistema educacional atual, uma grande porcentagem de estudantes atingiu o grau 1 de complexificação do conhecimento, passando a integrar os conhecimentos de física, biomecânica e educação física ao falar sobre esportes, o que é favorável a intervenção. Mesmo com todos os problemas enfrentados pela professora para aplicação da intervenção, houve complexificação do conhecimento. Foram poucos estudantes que avançaram para o grau 2 de complexificação, mas este pequeno índice nos mostra grandes possibilidades de futuramente por meio de outras pesquisas abarcar mais estudantes para este grau de complexificação do conhecimento.

Aos estudantes demonstrarem a complexificação do conhecimento de esporte por meio da intervenção, percebemos que o processo de aprendizagem é dinâmico, pois complexificam gradativamente o conhecimento de esporte, por meio da utilização de um discurso construído dentro de um contexto específico - a intervenção. Isto gera um melhor entendimento e permite uma melhor argumentação ao falar sobre e praticar exercícios físicos ou um esporte, além colaborar para sua saúde.

Os resultados desta pesquisa nos levam a encontrar respostas aos inúmeros questionamentos que surgem ao ministrarmos das aulas de física. Uma destas questões é como conduzir da melhor maneira o processo de ensino-aprendizagem que não está somente ligado as relações estabelecidas entre professor e aluno, mas que sofre interferências tanto do ambiente físico (organização da sala, materiais didáticos, etc. enfim recursos) quanto do grupo de funcionários que atuam na escola (agentes de organização escolar, diretores, professores, etc.), além dos campos de poder dos órgãos superiores inseridos dentro do sistema educacional.

Todas as pessoas que permeiam o contexto escolar corroboram, mesmo que em níveis de responsabilidades diferentes para o sucesso da aprendizagem. Muitas vezes nos deparamos com má vontade em viabilizar projetos, atividades extra-curriculares, intervenções (como a que realizamos), etc., que são atípicas ao tradicional ambiente escolar, mas talvez essas atitudes, que revelam o descomprometimento com a qualidade de ensino, possam ser justificadas pela desmotivação proveniente do baixo piso salarial, das condições de trabalho, da demora para tomada de decisões urgentes, nos valores adversos que se atribui a educação, ao magistério, no comportamento dos alunos na escola, etc.

O professor atualmente no sistema educacional é um agente isolado, sobrecarregado de responsabilidades, que possui diversas funções como cuidar da parte 
burocrática, da indisciplina, da organização dos alunos nos corredores, dos baixos índices em avaliações estaduais e federais, etc., e nesta lista imensa de afazeres sobra pouco tempo para se dedicar ao primordial que é garantir aprendizagem e elevar a tão citada na mídia "qualidade de ensino", a qual que envolve vários fatores em diferentes níveis de intervenção.

O professor não pode resolver todos os inúmeros problemas da escola, é preciso um trabalho conjunto para que o sistema funcione devidamente, e que os possíveis ajustes, quando necessários, sejam feitos rapidamente. Os ajustes não podem ser realizados a longo prazo, o setor educacional precisa de atitudes imediatas, para que não se amontoem os problemas, e a qualidade de ensino diminua cada vez mais.

Ao fazer uma análise da minha carreira no magistério, percebo que no início a sede por transformar a realidade da sala de aula era intensa, mas ao cair no sistema educacional me deparei com alguns entraves que me fizeram repensar a minha atuação na sala de aula. Os valores e as prioridades no ensino se modificam, e adaptar a elas, causa frustração, que não podem tirar o alvo que é a aprendizagem e o prazer em exercer a função de professor.

Como dito anteriormente, o professor sozinho não resolve todos os problemas educacionais, mas pode contribuir para amenizá-los. Observo que são necessários novos métodos de ensino-aprendizagem que elevem a qualidade de ensino de física e propiciem aos estudantes aprendizagem. A pesquisa nesta área é ampla e muitas vezes árdua, mas os resultados obtidos são animadores. Temos retornos satisfatórios ao realizar intervenções por meio de atividades que possibilitam o estudo da complexificação do conhecimento cotidiano dos estudantes. Todos os dias aprendo a ser professora e tento incansavelmente conduzir com êxito o processo de ensinoaprendizagem.

São inúmeros fatores que causam desmotivação na carreira do magistério. Em muitos casos, percebo que o professor se perde no desenvolvimento do processo de ensino e, somente analisa se houve sucesso na aprendizagem ao final de cada conteúdo, tornando inviável o retrocesso no plano de aula devido ao cronograma bimestral. $\mathrm{O}$ fracasso na aprendizagem seria minimizado se o professor verificasse o grau de complexidade em que o estudante se encontra a cada aula ministrada (mapeamento da evolução nos graus de aprendizagem). Adotar esta dinâmica possibilita conduzir o estudante aos graus elevados de complexificação do conhecimento. 
Os graus elevados de complexidade se fazem acessíveis aos estudantes a partir do momento em que os conteúdos são tratados de forma interdisciplinar e os conceitos inseridos nele, utilizados além do contexto escolar. Isto não pode ser "despejado" de uma só vez para o estudante, mas em doses suaves para que haja êxito no entendimento da aplicação de cada um dos significados que um conceito possui de acordo com o contexto.

Relacionar complexidade com interdisciplinaridade abre um campo amplo de estudo na área de ensino de física, visto que no currículo oficial do estado de São Paulo para disciplina de física é enfatizado a importância de se fornecer durante as aulas meios para que os estudantes consigam entender os fenômenos a sua volta. Para que isso ocorra é necessário que o professor revele aos estudantes as diversas pontes interdisciplinares que podem ser construídas na abordagem do conteúdo. Algumas delas encontramos explicitadas no caderno do aluno (S.E.E., 2009), embora seja necessário complementá-las para que o estudante visualize os vários significados de um conceito. O professor ao estabelecer estas pontes utiliza-se de níveis de interdisciplinares variados para atender os objetivos prévios a cada aula que farão os estudantes a complexificar seu conhecimento gradativamente.

Como o professor está inserido atualmente em salas heterogêneas, cada estudante se encontra em diferente patamar de conhecimento, portanto os graus de complexidade alcançados são diversos, como pudemos verificar durante a análise de dados, mas são suscetíveis de modificação, pois o professor pode propor por meio de uma ou mais aulas subsídios (mais relações interdisciplinares) para que o aluno evolua na complexificação atingindo o patamar máximo $(2,2)$.

Ao abordar um novo conceito nas atividades propostas contemplamos, expomos a complexidade deste conceito pelas relações interdisciplinares explicitadas. O grau de complexidade a ser alcançado está nas mãos do professor que articula os conhecimentos de acordo com os objetivos estabelecidos no Currículo Oficial do estado de São Paulo.

Conquistamos com esse trabalho uma primeira aproximação de um método que embora ainda simplificado, revele um novo olhar ao discurso complexificado, por meios dos graus de complexidade e níveis de interdisciplinaridade.

As atividades foram um meio para verificar a funcionalidade deste método, e foram elaboradas para serem acopladas ao currículo oficial do estado de São Paulo para $1^{\circ}$ ano do ensino médio e aos recursos didáticos disponíveis em uma escola pública. Enfatizamos o fato de termos como recurso no período que esta pesquisa foi realizada o 
caderno do aluno. Não sabemos quanto tempo perdurará sua emissão pela Secretaria da Educação do estado de São Paulo, mas isto não diminui ou altera os dados obtidos nesta pesquisa, pois as atividades que compuseram a intervenção abrangeram conteúdos que estão de acordo com o currículo oficial do estado de São Paulo. Lembramos que o conjunto de nove atividades foi um artifício utilizado para o estudo da complexificação do conhecimento. 


\section{REFERÊNCIAS BIBLIOGRÁFICAS}

AMADIO, A. C., BARBANTI, V.J., (Orgs.) A biomecânica do movimento humano e suas relações interdisciplinares. $1^{\text {a }}$ edição. São Paulo: Editora Estação Liberdade Ltda, 2000.

AMADIO, A. C., COSTA, P. H. L., SACCO, I.C.N. Introdução a biomecânica para análise do movimento humano: descrição e aplicação dos métodos de medição, Revista Brasileira de Fisioterapia, v. 3, n. 2, p. 41-54, 1999.

AMADIO, A. C., Fundamentos da biomecânica do esporte. Considerações sobre análise cinética e aspectos neuro- musculares do movimento, tese de livre docência, Escola de Educação Física e Esporte - USP, 1989.

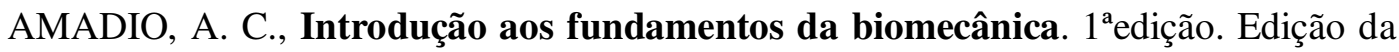
Universidade de São Paulo. São Paulo, 1996.

AMADIO, A. C.; SERRÃO, J. C. Contextualização da biomecânica para a investigação do movimento: fundamentos, métodos e aplicações para análise da técnica esportiva. Revista Brasileira de Educação Física e Esporte, v. 21, p.61-85, 2007.

BACHELARD, G.. A Filosofia do Não; In: OS PENSADORES. São Paulo: Abril Cultural, p. 01-87, 1984.

BAKHTIN, M. (VOLOCHÍNOV). Marxismo e filosofia da linguagem. $12^{\circ} \mathrm{ed}$. Ed. Hucitec - S.P., 2006 (texto de 1929).

BARDIN, L. Análise de Conteúdo. 4ªed. Ed. 70, Lda. - Lisboa/Portugal, 2010 (texto de 1977).

BASTOS, P. W. ; MATTOS, C. R. . Física para uma saúde auditiva. Revista Brasileira de Pesquisa em Educação em Ciências, v. 9, p. 1-26, 2009.

BASTOS, P. W. ; MATTOS, C. R. . Um exemplo da dinâmica do pefil conceitual como complexificação do conhecimento cotidiano. REEC. Revista Electrónica de Enseñanza de las Ciencias, v. 8, p. 1054-1078, 2009.

BASTOS, P. W. Física para uma discriminação auditiva. Dissertação de mestrado, IFUSP/FEUSP. São Paulo, 2007.

BASTOS, F. P.; GRABAUSKA, C. J. Investigação-Ação Educacional: possibilidades críticas e emancipatórias na prática educativa. In: Heuresis Revista Electrónica de Investigación Curricular y Educativa, vol.1, n.2, 1998. 
BERNSTEIN, B. Class, codes and control , vol IV: The Structuring of Pedagogic Discourse. London, Routledge, 1990.

BETTI, I. C. R. Esporte na escola: é só isso professor. Motriz, v. 1, n.1, p. 25-31, 1999.

BOGDAN, R.; BIKLEN, S. Investigação qualitativa em educação. Porto: Porto Editora, 1994.

BROWN, D. E. Students' concept force: the importance of understanding Newton's third law. Physics Education, v. 24, 1989.

CAMPOS, M. M. M. Pesquisa-participante: possibilidades para o estudo da escola. Caderno de Pesquisa, v. 49, p. 63 - 66, 1984.

CAREGNATO, R. C. A.; MUTTI R. Pesquisa qualitativa: análise de discurso versus análise de conteúdo. Texto Contexto Enfermagem: Florianópolis, out-dez., p. 679$841,2006$.

CARVAlHO, T., NOBREGA, A. C. L.,... Posição oficial da Sociedade brasileira de medicina do esporte: atividade física e saúde, Revista Brasileira de Medicina Esportiva, v.2, n. 4, 1996.

CORREA, S.C., FREIRE, E. S., Biomecânica e educação física escolar: possibilidades de aproximação, Revista Mackenzie de Educação física e esporte, n.3, 2004.

COSTA, E. M. B.; VENÂNCIO, S. Atividade física e saúde: discursos que controlam o corpo. Pensar a prática, 7(1), p.59 - 74, mar., 2004.

COSTA, M. C. O., SILVA, Estilo de vida de adolescentes: consumo alimentar de bebida alcoólica e atividade física em Teixeira Freitas/Bahia, Revista Baiana de saúde pública, v.28, n.2, p.151 - 166, 2004.

DALRI, J; RODRIGUES, A. M.; MATTOS, C. R. A relação entre a atividade de aprendizagem e a formação de conceitos no ensino de física. In: XVII SNEF São Luís -MA, 2007.

ENGEL, G. I. Pesquisa-ação. Educar, Curitiba, n.16, p. 181 - 191, 2000.

FREITAS, F. F.; COSTA, P. H. L. O conteúdo biomecânico na educação física escolar: uma análise a partir dos parâmetros curriculares nacionais. Revista Paulista de Educação Física, 14(1), p. 78 - 84, 2000.

GARCIA, J. E. Hacia uma teoria alternativa sobre los contenidos escolares, Díada Editora S. L.,1998.

GIL A. C. Como classificar as pesquisas? In: Gil, AC. Como elaborar projetos de pesquisa. $4^{\text {a }}$ edição. São Paulo: Atlas, p. 41-58, 2002. 
GÓES, M. C. R. A abordagem microgenética na matriz histórico-cultural: uma perspectiva para o estudo da constituição da subjetividade. Cadernos Cedes, v. 20, abr., 2000 .

GUEDES, D. P. Educação para saúde mediante programas de educação física escolar. Motriz. V. 5, n. 1, jun. 1999.

HAMIL, J., KNUTZEN, K. M., Bases biomecânicas do movimento humano.

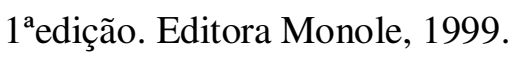

HAY, J.G., Biomecânica do esporte: Explorando ou explicando?, Boletim da Sociedade Internacional de Biomecânica, n. 9 e10, 1978.

HESTENES, D.; WELL, M.; SWACKHAMER, G. Force concept inventory. The physics teacher, v. 30, 1992.

HOLLOW, I. A.; HESTENES, D. The initial knowledge state of college physics students. American Journal Physics, 53 (11), 1985.

ITZA-ORTIZ, S. F.; REBELLO, N. S.; ZOLLMAN, D. A.; RODRIGUES-ACHACH, M. The vocabulary of introductory physics and its implications of learning physics. The physics teacher, v. 41, 2003.

KOWALSKI, M.; FERREIRA, M. B. R. Estética, corpo e cultura. Revista Conexões, Campinas, v. 5, n. 2, p. $90-111,2007$.

LAWSON, A. E. Science teaching and development of thinking. Belmont, CA: Wadsworth, 1995.

LAWSON, A. E., Abraham, M. R., Renner, J. W. A theory of instruction: Using the learning cycle to teach science concepts and thinking skills. National Association for Research in Science Teaching (monograph 1), 1989.

LAWSON, A. E. Using the learning cycle to teach biology concepts and reasoning pattern. Journal of Biological Education, http://www.IOB.ORG, v.35,4, p.165-169, 2001.

LEONTIEV, A.N. O desenvolvimento do psiquismo. Lisboa: Livros Horizonte, 1978.

LIMA, D. A.; MONSON, R. M. A relação entre educação física e esporte: alguns mitos e verdades. Revista digital. http://www.efdeportes.com/efd114/educacao-fisica-eesporte-alguns-mitos-e-verdades.htm., n.114, nov., 2007.

MATTOS, C. R; DRUMOND, A.V.N. Sensação térmica: uma abordagem interdisciplinar. Caderno Brasileiro de Ensino de Física, 21(1), 7-34, 2004.

MATTOS, C. R. ; FERRARA, N. F. . Seleção e organização de conteúdos escolares: recortes na pandisciplinaridade. In: VIII Encontro de Pesquisadores em Ensino de 
Física, 2002, Águas de Lindóia. Resumos VIII Encontro de Pesquisadores em Ensino de Física. São Paulo : SBF, p. 119-119, 2002.

MATTOS, C. R; FERRARA, N. F. Uma moldura epistemológica para seleção e organização de conteúdos escolares. Submetido à Pesquisa \& Educação to Journal of Curriculum Studies, 2006.

MAZZOTTI, T. B. Ciências da Educação em questão. Educação e Pesquisa, São Paulo, v. 32, n. 3, p. 539-550, set./dez. 2006.

MORAIS, A. M.; NEVES, I. P. A teoria de Basil Bernstein: alguns aspectos fundamentais. Práxis educativa, v.2, n. 2, p. 115 - 130, 2007.

MORTIMER, E. F. Conceptual Change or Conceptual Profile Change? Science \& Education, v.4, p.267-285, 1995.

MORTIMER, E. F. Linguagem e formação de conceitos no ensino de ciências, Editora UFMG, 2000.

MUSHENO, B. V.; LAWSON, E. L. Effects of learning cycle and traditional on comprehension of science concepts by students at differing reasoning levels, Journal of research in science teaching, v.36, n.1, p.23-37, 1999.

PARÂMETROS curriculares nacionais: educação física. Brasília, MEC/Secretaria de Educação Fundamental, 1997.

PARÂMETROS curriculares nacionais: educação física. Brasília, MEC/Secretaria de Educação Fundamental, 2002.

PARKER, K. Use of force platforms in physics and sport. Physics Education, n. 36, p. $18-22,2001$.

PAZELLO, F. P. O Conceito de Generalização a partir de um Olhar DialéticoComplexo sobre o Modelo de Perfil Conceitual. Dissertação de Mestrado. Universidade de São Paulo, 2011.

PAZELLO, F. P.; MATTOS, C. R. . O Conceito de Generalização: explorando os limites do modelo de perfil conceitual. XII Encontro de Pesquisa em Ensino de Física. Águas de Lindóia - SP, Brasil, 2010.

PEDUZZI, L. O. Q. Sobre a resolução de problemas no Ensino de Física. Caderno Catarinense de Ensino de Física, v.14, n.3: p.229-253, dez.,1997.

PEDUZZI, L. O. Q.; PEDUZZI, S. S. O conceito de força no movimento: as duas primeiras leis de Newton. Caderno Catarinense de Ensino de Física, Florianópolis, n.2 (1), p. 6 - 15, abril, 1985. 
RODRIGUES, A. M.; MATTOS, C. R. Reflexões sobre a noção de significado em contexto. In: V Encuentro Internacional sobre Aprendizaje Significativo. Madri, 2006.

RODRIGUES, A. M.; MATTOS, C. R. Theorical considerations about conceptual profile dinamic. European Science Education Research Association Congress. Malmo - Suécia, 2007.

SÃO PAULO. Proposta Curricular para Ensino Médio. São Paulo: SEE, 2008.

SÃO PAUlO. Caderno do Aluno - Física. Ensino Médio. São Paulo: SEE, 2009.

SÃO PAUlO. Caderno do Aluno - Educação Física. Ensino Médio. São Paulo: SEE, 2009.

SODRÉ, F.C.; MATTOS, C. R. Abordagens e concepções sobre alimentação do ponto de vista da física. In: VI ENPEC, Florianópolis - SC, 2007.

STOCKLMAYER, S.M.; TREAGUST, D.F. Images of electricity: how do novices and experts model electric current? International Journal of Science Education, 18(2), p. $163-178,1996$.

THIOLLENT, M. Metodologia da pesquisa-ação. Ed. Cortez, São Paulo, 1985.

UEMA, S.. Atividades curtas multi-abordagem no Ensino Médio: a dependência sensível às condições iniciais da Teoria do Caos determinístico. Dissertação de mestrado, IFUSP/FEUSP. São Paulo, 2005.

VIGOTSKI, L. S. A construção do pensamento e da linguagem, Livraria Martins Fontes Editora Ltda, 2001.

VILAS-BOAS, J. P. Biomecânica hoje: enquadramentos, perspectivas didáticas e facilidades laboratoriais. Revista Portuguesa de Ciências do desporto, v. 1, n. 1, p. 48-56, 2001.

WERTSH, J. Vygotsky and the Social Formation of Mind. Cambridge, Mass., Harvard University Press, 1985. 


\section{Universidade de São Paulo \\ Instituto de Física \\ Instituto de Química \\ Instituto de Biociências \\ Faculdade de Educação}

\section{Anexos}

\section{A CIÊNCIA COMPLEXIFICANDO O CONHECIMENTO COTIDIANO: UMA INTERVENÇÃO NA ESCOLA PÚBLICA}

\section{Patrícia Weishaupt Bastos}

Orientador: Prof. Dr. Cristiano Rodrigues de Mattos

São Paulo

2011 


\section{Sumário}

A1. Questionário Preliminar .......................................................................

A1.1. Questionário $\mathrm{Q}_{0} \quad 1$

A1.2. Questionário $\mathrm{Q}_{1}$

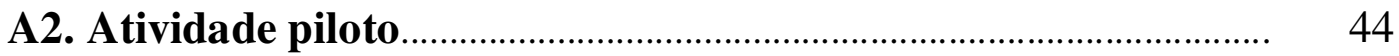

A2.1. Atividades 44

A2.2. Diário de bordo 79

A3. Intervenção + Atividade Avaliatória.................................................... 97

A3.1. Atividades 97

A3.2. Diário de Bordo 128

A3.2.1. Frequiência nas atividades $\quad 128$

A3.2.2. Diário de classe $\quad 132$

A3.2.3. Descrição das aulas 136

Observação: O uso incorreto ou incomum de pontuação, ortografia ou forma de escrita presente nas citações diretas (ipsis litteris), provém de seu autor original [sic].

\section{Introdução}

Este anexo contém todos os dados utilizados para análise no capítulo 4, como: questionários preliminares, diário de bordo, questões da atividade-piloto, questões da intervenção e da atividade avaliatória.

Lembramos que escolhemos colocar neste anexo tanto à atividade-piloto quanto a intervenção (conjunto de nove atividades) para mostrar os ajustes e as escolhas realizadas para aplicação da intervenção, que foram feitos com embasamento no diário de bordo (A2.2) - vide seção 4.2.

É de suma importância a leitura deste anexo para o entendimento do desenho de pesquisa (tabela 3.1), que está em ordem cronológica, pois traz o processo de obtenção dos dados, revelando não somente os êxitos, mas os entraves para realização desta pesquisa.

Com a leitura dos diários de bordo é possível compreender o contexto da sala de aula e da escola, além da relação estudante-estudante e professora-estudante. Observando cada classe (A3.2) percebemos a riqueza dos dados coletados, que nos revela características diferentes e com estas particularidades decidimos analisar as quatro classes.

Compreender as similaridades e diferenças no processo de aprendizagem de cada classe nos facilitou na construção de categorias (seção 4.3) que não dessem conta apenas de um grupo exclusivo de estudantes, mas que atendessem outros grupos de estudantes. 


\section{A1. Questionário Preliminar}

\section{A1.1. Questionário $Q_{0}$}

Responda todas as questões com atenção. Não coloque respostas curtas, mas argumente.

1) Na sua concepção, qual a importância do esporte na vida do ser humano? Comente.

\begin{tabular}{|c|c|}
\hline 1 & $\begin{array}{l}\text { "Bom, na minha concepção o esporte é bom para se prevenir contra doenças, deixa } \\
\text { o corpo mais flexível, e o deixa com mais disposição para realizar as atividades do } \\
\text { dia-a-dia". }\end{array}$ \\
\hline 2 & "O esporte é muito importante para a vida do ser humano por muitos motivos". \\
\hline 3 & "O esporte é importante para prevenir contra doenças". \\
\hline 4 & $\begin{array}{l}\text { "A importância do esporte é o seguinte ele ajuda a manter a forma a ter uma } \\
\text { qualidade de vida melhor e o esporte acima de tudo é um ótimo exercício para } \\
\text { qualquer idade pois existe vários para o gosto de cada um". }\end{array}$ \\
\hline 5 & "O esporte é muito importante para a saúde e além de tudo é gostoso praticar". \\
\hline 6 & $\begin{array}{l}\text { "A importância do esporte na vida do ser humano é que ajuda a viver mais anos, } \\
\text { com saúde e com mais disposição a vida". }\end{array}$ \\
\hline 7 & $\begin{array}{l}\text { "É essencial para uma vida melhor e com menor doenças e também uma vida mais } \\
\text { longa". }\end{array}$ \\
\hline 8 & $\begin{array}{l}\text { "Para mim o esporte é mais importante para o ser humano, ele ajuda não só } \\
\text { fisicamente, mas também a mente". }\end{array}$ \\
\hline 9 & $\begin{array}{l}\text { "A importância do esporte é bom para sua saúde para viver para ter mais } \\
\text { disposição em sua vida" }\end{array}$ \\
\hline 10 & $\begin{array}{l}\text { "O esporte tem extrema importância na nossa saúde. Nós temos que praticar } \\
\text { atividades físicas, é importantíssimo para vida". }\end{array}$ \\
\hline 11 & $\begin{array}{l}\text { portância do esporte é muito grande principalmente hoje que os jovens e até } \\
\text { as se aprofundando no mundo das drogas. O esporte vem ajudando essas } \\
\text { as a se desligarem disso, ocupando a cabeça com esportes, isso acaba se } \\
\text { do saudável, divertido e muitas vezes uma forma de vida". }\end{array}$ \\
\hline 12 & $\begin{array}{l}\text { "O esporte além de ser algo agradável é também muito importante para saúde } \\
\text { humana ajuda a combater problemas respiratórios, musculares entre outros } \\
\text { benefícios como também problema pulmonar". }\end{array}$ \\
\hline 13 & $\begin{array}{l}\text { "Faz bem para o corpo, para a mente, nos sentimos melhor praticando esportes, } \\
\text { ficamos mais dispostos". }\end{array}$ \\
\hline 14 & $\begin{array}{l}\text { orte é fundamental na vida de qualquer pessoa, pois esporte é sinal de saúde } \\
\text { ia. É sempre muito importante praticar alguns esportes para manter o bom } \\
\text { onamento físico". }\end{array}$ \\
\hline 15 & $\begin{array}{l}\text { orte ele contribui muito na vida de nós seres humanos, toda pessoa que tem } \\
\text { me de praticar algum esporte, com certeza ela terá uma vida mais saudável, } \\
\text { la disposição melhor, também terá mais energia em sua vida do dia-a-dia". }\end{array}$ \\
\hline 16 & $\begin{array}{l}\text { "O esporte é importante para desenvolver a criatividade, a força física e estimular o } \\
\text { crescimento saudável do praticante". }\end{array}$ \\
\hline 17 & $\begin{array}{l}\text { "O esporte tem toda a importância na vida do ser humano, pois isso faz bem a } \\
\text { saúde entre muitas coisas". }\end{array}$ \\
\hline 18 & $\begin{array}{l}\text { "O esporte tem uma importância na vida do ser humano atividade física } \\
\text { movimentação exercícios para uma boa saúde". }\end{array}$ \\
\hline 19 & "O esporte é bom para manter a saúde do ser humano. Uma pessoa que pratica \\
\hline
\end{tabular}




\begin{tabular}{|c|c|}
\hline & esporte, dificilmente vai ter problemas físicos, cardíacos". \\
\hline 20 & $\begin{array}{l}\text { "É importante para nossa saúde e também existe outros motivos como } \\
\text { campeonatos, relaxar a sua mente, etc.". }\end{array}$ \\
\hline 21 & $\begin{array}{l}\text { "O esporte na vida do ser humano é muito importante para a não atrofiação dos } \\
\text { músculos (resumindo é muito importante para perder alguns quilinhos ou não } \\
\text { engordar)". }\end{array}$ \\
\hline 22 & “O esporte não é só importante para o ser humano e sim para saúde dele”. \\
\hline 23 & $\begin{array}{l}\text { "Muita, hoje em dia principalmente, com as indústrias pensando apenas na parte } \\
\text { financeira dos alimentos e não em seus valores nutricionais. O esporte é a maneira } \\
\text { melhor de se tentar melhorar a saúde, pois se a comida não ajuda e tão pouco a } \\
\text { consciência das pessoas o jeito é pensar em seu bem estar". }\end{array}$ \\
\hline 24 & $\begin{array}{l}\text { "Não digo total, mas o esporte te ajuda na saúde, na moral, muitas vezes te tira do } \\
\text { caminho errado e fora que para quem gosta e uma emoção boa tanto assistira } \\
\text { alguém quanto praticá-lo". }\end{array}$ \\
\hline 25 & $\begin{array}{l}\text { "A importância do esporte para o ser humano é muito importante para tudo para si } \\
\text { próprio como todos atletas diz tira das ruas". }\end{array}$ \\
\hline 26 & $\begin{array}{l}\text { "O esporte é importante na vida do ser humano, porque ajuda no desenvolvimento } \\
\text { físico, mental, abre as portas para o futuro e dá uma ocupação para muitas pessoas" }\end{array}$ \\
\hline 27 & $\begin{array}{l}\text { "O esporte é fundamental na vida do ser humano, não podemos ser sedentaristas, } \\
\text { faz muito bem a saúde física, psíquica, etc. Quem não pratica esportes só corre o } \\
\text { risco de ter mais doenças, problemas cardíacos, etc.". }\end{array}$ \\
\hline 28 & $\begin{array}{l}\text { "O esporte é fundamental na vida do ser humano pois evita o sedentarismo, se você } \\
\text { tem já algum tipo de problema é só você começar a praticar algum tipo d esporte, } \\
\text { pois desta forma irá amenizar o seu problema". }\end{array}$ \\
\hline 29 & $\begin{array}{l}\text { "O esporte para mim é muito importante, tanto para o físico quanto para a saúde, eu } \\
\text { levo uma vida sedentária porque sou preguiçosa". }\end{array}$ \\
\hline 30 & "Esporte é muito importante tanto para o físico e para saúde" \\
\hline 31 & $\begin{array}{l}\text { "O esporte é muito importante na vida do ser humano. Ele tem a capacidade de } \\
\text { manter o corpo e a mente são". }\end{array}$ \\
\hline 32 & "É muito importante, previne doenças de profissão para quem não tem condições". \\
\hline 33 & $\begin{array}{l}\text { "Além de ser fundamental para saúde, ajuda a manter a forma, o esporte tem } \\
\text { função social muito grande, Muitos jovens saem da rua, das drogas, graças ao } \\
\text { esporte. O esporte ajuda a educar, ensina disciplina e convivência em grupo". }\end{array}$ \\
\hline 34 & $\begin{array}{l}\text { "É muito importante porque o esporte tem que estar na vida, quem não pratica pode } \\
\text { se prejudicar mais para frente". }\end{array}$ \\
\hline 35 & "Muito importante, porque ele te ensina muitas coisas como respeito e disciplina". \\
\hline 36 & $\begin{array}{l}\text { "O esporte ajuda várias pessoas, porque gente que poderia estar no crime roubando, } \\
\text { matando, hoje está praticando algum esporte alguma modalidade". }\end{array}$ \\
\hline 37 & $\begin{array}{l}\text { "O esporte é uma atividade que deve estar presente no dia-a-dia de todos nós. Sua } \\
\text { pratica nos mantém saudáveis, e deixa nossos corpos com maior resistência a } \\
\text { doença". }\end{array}$ \\
\hline 38 & $\begin{array}{l}\text { "O esporte em nossa vida é uma atividade que nos passa em primeiro lugar saúde, } \\
\text { nos deixa mais animados e mais vivos para o mundo". }\end{array}$ \\
\hline 39 & $\begin{array}{l}\text { "O esporte na vida do ser humano, é muito importante, pois ajuda na saúde e na } \\
\text { nossa auto-estima, e permite que nosso corpo tenha uma resistência maior". }\end{array}$ \\
\hline 40 & $\begin{array}{l}\text { "O esporte é de fundamental importância na vida do ser humano para levarmos } \\
\text { uma vida saudável, os benefícios que o esporte nos proporciona são inumeráveis". }\end{array}$ \\
\hline 41 & $\begin{array}{l}\text { "O esporte é tudo na vida do ser humano, pois com ele nós podemos desenvolver } \\
\text { nossas habilidades". }\end{array}$ \\
\hline
\end{tabular}




\begin{tabular}{|c|c|}
\hline 42 & $\begin{array}{l}\text { muito importante, pois ajuda o ser humano a se movimentar melhor, ter mais } \\
\text { hergia no dia-a-dia". }\end{array}$ \\
\hline 43 & $\begin{array}{l}\text { "Muito importante porque o esporte ajuda a melhorar a saúde das pessoas e quando } \\
\text { se trata de saúde é bom não vacilar". }\end{array}$ \\
\hline 44 & "Muito importante para viver com muita saúde e sem preocupação com a saúde". \\
\hline 45 & $\begin{array}{l}\text { "O esporte é importante para a pessoa manter uma vida mais saudável. Claro que, } \\
\text { junto com uma alimentação adequada, para que a pessoa não tenha uma vida } \\
\text { sedentária. Também é importante para integração de pessoas, e também para } \\
\text { manter o jovem fora de caminhos errados, já que, uma vez que ele pratica um } \\
\text { esporte e gosta, não vai querer estragar tudo com cigarro, bebidas, entre outras } \\
\text { coisas que possam fazer mal a o corpo". }\end{array}$ \\
\hline 46 & $\begin{array}{l}\text { "É essencial porque com a prática do esporte na vida do ser humano pode melhorar } \\
\text { nosso corpo, nossa mente". }\end{array}$ \\
\hline 47 & $\begin{array}{l}\text { te na vida do ser humano porque auxilia na saúde no } \\
\text { e no bem estar e etc.". }\end{array}$ \\
\hline 48 & $\begin{array}{l}\text { te na vida do ser humano é muito importante e porque } \\
\text { e a saúde". }\end{array}$ \\
\hline 49 & umano é muito importante os esporte, pois ajuda muito em seu \\
\hline 50 & óprio, ou necessidade Algumas pessoas fazem muitas das vezes, pratica es \\
\hline 51 & $\begin{array}{l}\text { "Na minha opinião o esporte assim como ler é fundamental em nossa vida, a leitura } \\
\text { nos traz um caráter intelectual, e os exercícios os esporte em si, nos traz } \\
\text { condicionamento e resistência física, melhora o funcionamento do nosso } \\
\text { organismo, faz bem ao coração e nos deixa com uma ótima aparência física } \\
\text { vitalidade". }\end{array}$ \\
\hline 52 & $E$ ir \\
\hline 53 & a de \\
\hline 54 & ção para realizar \\
\hline 55 & vés de uma vida \\
\hline 56 & $\begin{array}{l}\text { imo, } \\
\text { gum }\end{array}$ \\
\hline 57 & ss jovens \\
\hline 58 & físico, nos dá \\
\hline 59 & "É ml \\
\hline 60 & sporte é importante para criança praticando não tem tempo para fazer \\
\hline
\end{tabular}




\begin{tabular}{|c|c|}
\hline 61 & $\begin{array}{l}\text { É importante para uma vida saudável, para dar oportunidade as pessoas praticar } \\
\text { porte que ela mais gosta". }\end{array}$ \\
\hline 62 & $\begin{array}{l}\text { Além de ser gostoso, é bom de fazer, faz muito bem a saúde e te ajuda a prevenir } \\
\text { oenças". }\end{array}$ \\
\hline 63 & $\begin{array}{l}\text { "Existem várias coisas que o esporte pode ajudar como na saúde de algumas } \\
\text { pessoas que poderiam fazer coisas com drogas, roubos, e na vida profissional de } \\
\text { quem decide ir em frente". }\end{array}$ \\
\hline 64 & $\begin{array}{l}\text { "O esporte é importante para a saúde, quando se pratica esporte independente do } \\
\text { qual você automaticamente está ajudando um órgão do seu corpo, uma natação que } \\
\text { é bom para o coração". }\end{array}$ \\
\hline 65 & $\begin{array}{l}\text { "O esporte tem uma grande importância pois exercitamos nosso corpo nos } \\
\text { deixando mais saudáveis e nos garantindo uma boa forma física. Para mim toda } \\
\text { pessoas deveria se dedicar a algum tipo de esporte". }\end{array}$ \\
\hline 66 & $\begin{array}{l}\text { te para o ser humano pois ajuda } \\
\text { dda a prevenir algumas doenças. } \\
\text { corpo e a mente". }\end{array}$ \\
\hline 67 & nportante para manter a saúde não sofrer de obesidade e também para o \\
\hline 68 & $\begin{array}{l}\text { "A importância do esporte na vida do ser humano é que teremos saúde e uma vida } \\
\text { melhor". }\end{array}$ \\
\hline 69 & $\begin{array}{l}\text { "Muitos usam o esporte como distração, outras por prazer. A importância } \\
\text { exatamente não sei, mas por exemplo na natação para quem tem asma é muito } \\
\text { bom, pois ajuda a respirar melhor". }\end{array}$ \\
\hline 70 & $\begin{array}{l}\text { r humano porque ele se distrai com o esporte e } \\
\text { o esporte faz bem para saúde" }\end{array}$ \\
\hline 71 & $\begin{array}{l}\text { a nossa saúde faz } \\
\text { is violentos tenham } \\
\text { um futuro". }\end{array}$ \\
\hline 72 & $\begin{array}{l}\text { É muito importante } \\
\text { lo, ajuda nos ossos }\end{array}$ \\
\hline 73 & $\begin{array}{r}\text { o esporte } \\
\text { as pessoas }\end{array}$ \\
\hline 74 & e, a pessoa \\
\hline 75 & atica do esporte você pode \\
\hline 76 & "Faz b \\
\hline 77 & $\begin{array}{l}\text { nossa vida, faz bem para saúde, circulação do } \\
\text { o". }\end{array}$ \\
\hline 78 & $\begin{array}{l}\text { "A principal importância do esporte na vida do ser humano é a educação, a } \\
\text { responsabilidade e a saúde. Há várias pessoas que tem problemas de saúde, porém } \\
\text { o esporte ajuda muito na melhoria de alguns problemas. Na educação o esporte } \\
\text { influencia principalmente as crianças estudarem". }\end{array}$ \\
\hline 79 & $\begin{array}{l}\text { "O esporte é fundamental na vida do ser humano, pois esporte é sinal de saúde, } \\
\text { uma pessoa que não pratica nenhuma atividade física acaba se tornando uma }\end{array}$ \\
\hline
\end{tabular}


80 "Acredito que é benefício para sua saúde, pois a pessoa acaba adquirindo uma estabilidade com o corpo e com isso ajuda a evitar algumas doenças".

2) Qual modalidade de esporte que você pratica? (pode ser semanalmente, ou até mensalmente). Quais são as habilidades necessárias para desempenhá-lo com sucesso? Explique.

\begin{tabular}{|c|c|}
\hline 1 & $\begin{array}{l}\text { "Futsal e voley. No futsal é necessário habilidades com as pernas e no voley } \\
\text { muita atenção". }\end{array}$ \\
\hline 2 & "Futebol, se dedicando muito ou esporte". \\
\hline 3 & Caminhada, tem que fazê-la todos os dias e fazer uma refeição adequada". \\
\hline 4 & $\begin{array}{l}\text { "Vôlei para desempenhá-lo precisa de um aquecimento com exercícios para não } \\
\text { er problemas musculares, tem que ter uma certa força para que a bola passe para } \\
\text { outro lado, prestar atenção, ficar atento e acima de tudo trabalho em grupo". }\end{array}$ \\
\hline 5 & "Não pratico". \\
\hline 6 & $\begin{array}{l}\text { "Semanalmente na escola prático futsal, vôlei e queimada e as habilidades } \\
\text { necessárias é fazer um aquecimento para seu corpo". }\end{array}$ \\
\hline 7 & $\begin{array}{l}\text { "Futebol, é preciso ter habilidade nos pés, fôlego para correr, é preciso ter um } \\
\text { aquecimento antes de praticar". }\end{array}$ \\
\hline 8 & co mas pretendo". \\
\hline 9 & nto físico". \\
\hline 10 & que eu trabal \\
\hline 11 & $\begin{array}{l}\text { s vezes jogo na escola mais não acho } \\
\text { divertir". }\end{array}$ \\
\hline 12 & $\begin{array}{l}\text { ticar esporte,mas adoraria praticar futebol, seus } \\
\text { ssa saúde e devem sempre ser praticados de forma } \\
\text { fazer alongamento antes de qualquer esporte". }\end{array}$ \\
\hline 13 & te, nos sentimos melhor praticando esportes \\
\hline 14 & $\begin{array}{l}\text { "Caminhada é para desempenhá-la com sucesso é necessário estar bem alongado } \\
\text { e com uma roupa adequada". }\end{array}$ \\
\hline 15 & $\begin{array}{l}\text { "Bem particularmente pratico duas atividades físicas semanalmente, uma delas é } \\
\text { a caminhada, procuro caminhar todos os dias pelo menos } 30 \text { minutos, e para } \\
\text { desempenharmos a caminhada com êxito, temos que estar bem alongados e com } \\
\text { uma roupa bem própria para a caminhada, e outra atividade que faço é andar } \\
\text { todos os dias de bike e para exercer essa atividade com sucesso, temos que estar } \\
\text { com uma roupa adequada e procurar andar em um lugar plano". }\end{array}$ \\
\hline 16 & $\begin{array}{l}\text { uilíbrio, força, rapidez, agilidade e um pouco de malandragem para } \\
\text { versários". }\end{array}$ \\
\hline 17 & $\begin{array}{l}\text { "Na verdade não pratico nenhuma atividade física. Se no caso praticasse uma } \\
\text { caminhada acho que seria necessário um bom alongamento e aquecimento do } \\
\text { corpo". }\end{array}$ \\
\hline 18 & $\begin{array}{l}\text { "Caminhada, ciclismo, não precisa ter habilidade, só força de vontade } \\
\text { resistência" }\end{array}$ \\
\hline 19 & $\begin{array}{l}\text { "Futebol, antes de começar a jogar, deve fazer alguns exercícios físicos, como } \\
\text { alongamentos, algumas voltas". }\end{array}$ \\
\hline 20 & $\begin{array}{l}\text { "De vez enquanto eu faço caminhada, quando dá } 17 \text { e } 50 \text {, eu vou dar uma } \\
\text { caminhada de casa ao Stefano, que é de mais ou menos uns } 2 \mathrm{~km} \text {, se segunda a } \\
\text { sexta. Mas faz muito tempo que eu não pratico uma caminhada". }\end{array}$ \\
\hline
\end{tabular}




\begin{tabular}{|c|c|}
\hline 21 & $\begin{array}{l}\text { Várias modalidades, as habilidades requeridas são boa forma física e bastante } \\
\text { einamento para a modalidade desejada". }\end{array}$ \\
\hline 22 & $\begin{array}{l}\text { "Eu gosto de praticar futebol para praticá-lo é necessário equilíbrio e habilidade, } \\
\text { quanto mais rápido você for melhor e precisa de muita força nas pernas para } \\
\text { chutar". }\end{array}$ \\
\hline 23 & $\begin{array}{l}\text { "Eu gosto de praticar futebol para praticá-lo é necessário muito equilíbrio e } \\
\text { habilidade quanto mais rápido você for melhor e precisa de muita força nas } \\
\text { pernas para chutar". }\end{array}$ \\
\hline 24 & $\begin{array}{l}\text { "Vôlei são necessários reflexos, condicionamento físico, companheirismo, força } \\
\text { e raciocínio rápido". }\end{array}$ \\
\hline 25 & $\begin{array}{l}\text { No momento não estou praticando esporte mas pretendo voltar a jogar handball } \\
\text { le é necessário muita afinidade e habilidade com as mãos". }\end{array}$ \\
\hline 26 & $\begin{array}{l}\text { "Caminhada, bom condicionamento físico, boa respiração, forças nas pernas, boa } \\
\text { alimentação". }\end{array}$ \\
\hline 27 & $\begin{array}{l}\text { "Não pratico nenhum esporte, apenas exercícios diários como limpar a casa, } \\
\text { varrer o chão". }\end{array}$ \\
\hline 28 & $\begin{array}{l}\text { "Handball. Você ter disposição para os treinos, estar sempre procurando um bom } \\
\text { desempenho em tudo o que o esporte oferece para nosso benefício". }\end{array}$ \\
\hline 29 & $\begin{array}{l}\text { natação ou tênis acho muito } \\
\text { mente". }\end{array}$ \\
\hline 30 & $\begin{array}{l}\text { "O que eu mais pratico é o futsal de finais de semana e feriados, quando tenho } \\
\text { tempo". }\end{array}$ \\
\hline 31 & $\begin{array}{l}\text { "Para não dizer que eu não pratico esportes eu faço caminhada as vezes. Para } \\
\text { bem desempenhá-lo precisamos de uma roupa confortável e alongamento". }\end{array}$ \\
\hline 32 & "Eu s \\
\hline 33 & "Nen \\
\hline 34 & $\begin{array}{l}\text { "Eu p } \\
\text { fazer }\end{array}$ \\
\hline 35 & "Nata \\
\hline 36 & $\begin{array}{l}\text { "O esporte que eu pratico semanalmente é o futebol muita prática, atenção uma } \\
\text { boa visualização e um bom desempenho com o esporte, velocidade com precisão, } \\
\text { etc.". }\end{array}$ \\
\hline 37 & $\begin{array}{l}\text { xecução é necessário agilidade, força, raciocínio rápido, } \\
\text { ndicionamento físico". }\end{array}$ \\
\hline 38 & "As \\
\hline 39 & ôlei e para desempenha-lo melhor e sendo bem ágil, te \\
\hline 40 & $\begin{array}{l}\text { "Ginástica. É necessário ter disciplina, velocidade para desempenhar movimentos } \\
\text { rápidos força". }\end{array}$ \\
\hline 41 & $\begin{array}{l}\text { "Hoje em dia nenhum. Antes eu fazia natação para exercer esse esporte é preciso } \\
\text { força de vontade e preparação física". }\end{array}$ \\
\hline 42 & $\begin{array}{l}\text { "Vôlei e futsal. Para realizar com sucesso, tem que ter praticar, saber as regras } \\
\text { necessárias e ter muita concentração". }\end{array}$ \\
\hline 43 & "Não pratico \\
\hline 44 & "Futebol saber bater com o pé na bola e ter um pouco de interesse". \\
\hline 45 & 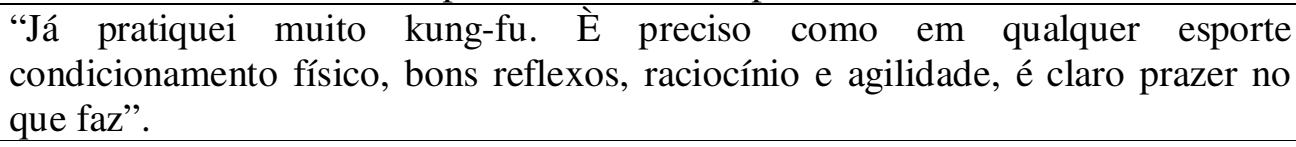 \\
\hline 46 & "Futebol estar com disposição e entender sobre o assunto". \\
\hline
\end{tabular}




\begin{tabular}{|c|c|}
\hline 47 & $\begin{array}{l}\text { Não pratico nenhuma modalidade de esporte e acho que não levo jeito para } \\
\text { uase nada, mas também não me interesso". }\end{array}$ \\
\hline 48 & $\begin{array}{l}\text { Eu pratico basquete e futebol semanalmente. È preciso ter uma habilidade e só } \\
\text { edicar se esforçar para desempenhar com sucesso". }\end{array}$ \\
\hline 49 & $\begin{array}{l}\text { Não pratico nenhum esporte. Mas gosto muito de basquete para praticar esse } \\
\text { po de esporte preciso treinar muito e ter forças nas mãos". }\end{array}$ \\
\hline 50 & $\begin{array}{l}\text { "Não pratico muito mais gosto de vôlei, saber ter passe de bola, pouca força } \\
\text { aber jogar a bola e treinar muito". }\end{array}$ \\
\hline 51 & $\begin{array}{l}\text { "Dança, ter equilíbrio ter elasticidade corporal, ter bom condicionamento e } \\
\text { resistência física". }\end{array}$ \\
\hline 52 & "Futebol, ter coordenação motora, saber criar jogadas e finalizar com perfeição". \\
\hline 53 & "Futsal e natação. Praticar e treinar regularmente". \\
\hline 54 & $\begin{array}{l}\text { "Algumas vezes eu pratico futsal. Para desenvolver o futsal você precisará ter } \\
\text { muito fôlego, correr bastante e ser esperto para montar jogadas e dribles para } \\
\text { pegar a bola e fazer gol". }\end{array}$ \\
\hline 55 & "Futsal, semanalmente, e necessário ter disposição". \\
\hline 56 & $\begin{array}{l}\text { "O meu esporte é o kung-fu, eu treino todos os dias. Para ter su } \\
\text { modalidade você apenas tem que gostar dela porque a força técnica } \\
\text { você ganha com o tempo é com muito treino". }\end{array}$ \\
\hline 57 & dos podem praticá-lo". \\
\hline 58 & m pouco de força nas pernas, ter um pouco \\
\hline 59 & la semanalmente, para ter força de vontade". \\
\hline 60 & sporte que \\
\hline 61 & "Eu g \\
\hline 62 & "Fute \\
\hline 63 & $\begin{array}{l}\text { "Eu pratico muita caminhada todos os dias não tem nenhuma habilidade, basta } \\
\text { querer e ir em frente". }\end{array}$ \\
\hline 64 & er esporte \\
\hline 65 & $\begin{array}{l}\text { ré a natação, mas somente no verão. E gosto } \\
\text { os com minha família. Para poder desempenhá- } \\
\text { rça". }\end{array}$ \\
\hline 66 & $\begin{array}{l}\text { nte apenas a caminhada do dia-a-dia } \\
\text { scola". }\end{array}$ \\
\hline 67 & "Futs \\
\hline 68 & "Não \\
\hline 69 & $\begin{array}{l}\text { ira. Uma vez por semana: } \\
\text { ico". }\end{array}$ \\
\hline 70 & "Futebol, mensalmente, \\
\hline 71 & "Não pratico". \\
\hline 72 & $\begin{array}{l}\text { "Futebol, natação, no futsal as habilidades necessárias é um bom } \\
\text { condicionamento físico, habilidade com a bola e agilidade. Já na natação é } \\
\text { necessário ter músculos bem alongados, força na hora de superar a respiração por } \\
\text { instantes e também um bom condicionamento físico." }\end{array}$ \\
\hline 73 & "O vôlei, já as habilidades necessárias é o desenvolvimento físico do atleta". \\
\hline 74 & ento físico e a altura”. \\
\hline 75 & \\
\hline
\end{tabular}




\begin{tabular}{|l|l|}
\hline & se empenhar muito nos treinamentos para desenvolver algumas habilidades". \\
\hline 76 & "Vôlei e basquete, alongar e saber jogar". \\
\hline 77 & $\begin{array}{l}\text { "Eu pratico vários esportes, adoro jogar vôlei, futebol, basquete, para } \\
\text { desempenhá-lo com sucesso tem que ter muita concentração e se entrosar, sem a } \\
\text { concentração e entrosamento, você não chega a lugar nenhum". }\end{array}$ \\
\hline 78 & $\begin{array}{l}\text { "A modalidade que eu pratico é futebol, para desempenhá-lo com sucesso tem } \\
\text { que gostar e se concentrar". }\end{array}$ \\
\hline 79 & $\begin{array}{l}\text { "Não pratico nenhum esporte, mas faço curso de dança a quatro anos duas vezes } \\
\text { por semana. É necessário flexibilidade para executar alguns movimentos, mas } \\
\text { para obter a flexibilidade é preciso fazer alongamento pelo menos três vezes por } \\
\text { semana". }\end{array}$ \\
\hline 80 & "Vôlei, um bom condicionamento físico e até habilidade com as mãos e braços". \\
\hline
\end{tabular}

3) De todas as disciplinas, coloque em ordem a que mais relaciona com esporte. Não se esqueça de nenhuma disciplina.

\begin{tabular}{|c|c|}
\hline 1 & "EF, B, F, Q, M, P, EA, H, FIL". \\
\hline 2 & "EF, EA, FIL, H, F, G, B, Q, P, M". \\
\hline 3 & “EF, F, M, Q, B, G, H, FIL, EA”. \\
\hline 4 & "EF, B, F, G, F, H, P, I, M". \\
\hline 5 & "EF, F, M, G, B, H, FIL, EA". \\
\hline 6 & "EF, B, F, M, EA, Q, G, FIL, H”. \\
\hline 7 & "EF, B, F, M, I, Q, FIL, H, EA, P, G". \\
\hline 8 & "EF,F M, G, FIL, Q, H, B, EA" \\
\hline 9 & "EF, B, EA, Q, G, FIL, Q, H, F, M". \\
\hline 10 & “EF, F, Q, FIL, H, P, M, G, I”. \\
\hline 11 & "EF,EA, M, F, P, G, B, Fil, I". \\
\hline 12 & "EF, EA, B, Q, F, H, P, M, G, FIL". \\
\hline 13 & "EF, M, F, H, B, EA, Q, FIL". \\
\hline 14 & "EF, F, H, B". \\
\hline 15 & “EF, F, B, Q, G, M, H, FIL”. \\
\hline 16 & “EF, F, Q, M, EA, FIL, H, G”. \\
\hline 17 & "EF, F, B, H". \\
\hline 18 & "EF, F, B, Q, FIL" \\
\hline 19 & "EF,H B, Q, F, G, EA, M, FIL" \\
\hline 20 & "EF, F, EA, M, Q, Q, B, P, FIL, G, I". \\
\hline 21 & "EF, F, M, B, Q, G, EA, H, FIL, P I" \\
\hline 22 & “EF, F, M, EA, H, FIL, G, B”. \\
\hline 23 & "EF, B, F, Q, G, M, H, FIL, EA, P". \\
\hline 24 & "EF, F, B, M, H, G, P, Q, I, EA, FIL". \\
\hline 25 & “EF, B, FIL, G, F, H, M, Q, EA". \\
\hline 26 & “EF, M, G, H, F, P, I, Q, EA". \\
\hline 27 & "EF, F, B, H, M, Q, G, EA, FIL". \\
\hline 28 & "EF, F, H, M, EA, Q, B, B, FIL, P”. \\
\hline 29 & “EF, F, EA, G, B, H, Q, FIL, P”. \\
\hline 30 & "EF, F, M, EA, G, B, H, Q, F, P". \\
\hline 31 & “EF, F, B, M, Q, EA, H, FIL, P”. \\
\hline 32 & “EF, F, B, Q, M, G, EA, H, FIL, P". \\
\hline
\end{tabular}




\begin{tabular}{|c|c|}
\hline 33 & "EF, B, F, Q, H, EA, M, G, I, P, FIL". \\
\hline 34 & "EF". \\
\hline 35 & "EF, F, B, Q, M, H, G, FIL, EA". \\
\hline 36 & "EF, F, G, H, EA, M, FIL, B, Q, P, I". \\
\hline 37 & "EF, F, M, B, FIL, G, EA, Q, H, P, I". \\
\hline 38 & "EF, F, M, B, FIL, G, EA, Q, Q, H, P, I". \\
\hline 39 & "EF, F, M, B, FIL, G, EA, Q, H, P,I" \\
\hline 40 & "EF, F, G, M, B, EA, Q, P, H, FIL". \\
\hline 41 & "EF, B, H, G, F, M, P, Q, FIO, I, EA". \\
\hline 42 & "EF, B, H, G, F, M, P, Q, FIL, I, EA". \\
\hline 43 & "EF, F, M, H, G, EA, FIL, B, Q, P". \\
\hline 44 & "EF, M, F, H, G, EA, FIL, Q, B, P". \\
\hline 45 & "EF, F, H, B, Q, M, G, P, FIL, EA, I". \\
\hline 46 & "EF, B, F, M, G, H, FIL, Q, I, EA, P". \\
\hline 47 & "EF, F, B, H, EA, Q, M, FIL, P". \\
\hline 48 & "EF, EA, F, Q, M, B, G". \\
\hline 49 & "EF, F, EA, FIL, B, Q, M, G, H". \\
\hline 50 & "EF, EA, F, FIL, M, Q, B, M, H". \\
\hline 51 & “EF, M, F, G, H, I, P, Q, B”. \\
\hline 52 & "EF, EA, M, F, B, FIL, H, G, Q". \\
\hline 53 & "EF, B, F, Q, M, P, G, H, EA, I". \\
\hline 54 & "EF, H, M, B, G, F, FIL, EA". \\
\hline 55 & "EF, F, B, Q, G, M, FIO, H, P, I". \\
\hline 56 & "EF, B, FIL, F, Q, EA, M, H, G". \\
\hline 57 & "EF, F, B, H, Q, M, H, FIL, EA, G". \\
\hline 58 & "EF, F, M, P, B, H, G, I, Q, FIL". \\
\hline 59 & "EF, B, F, Q, M, EA, H, FIL, G, P, I". \\
\hline 60 & "EF, H, M, B, G, Q, F, FIL, EA". \\
\hline 61 & "EF, H, M, B, G, Q, FIL, EA". \\
\hline 62 & "EF, B, G, H, FIL, EA, Q, M, P". \\
\hline 63 & "EF, M, B, EA, G, Q, F, H, FIL". \\
\hline 64 & "EF, F, Q, M, H, FIL, B, EA, G, I, F". \\
\hline 65 & "EF, B, F, Q, M, FIL, EA, H, G, P, I". \\
\hline 66 & "F, G, M, Q, B, EA, EF, FIL, H, P, I". \\
\hline 67 & "EF, F, M, B, I, P, G, Q, FIL, H, EA". \\
\hline 68 & "EF, F, M, B, G, Q, EA, FIL, P, H". \\
\hline 69 & "EF, F, M, H, G, B, Q, FIL, EA". \\
\hline 70 & "EF, M, G, F, Q, H, FIL, EA, B". \\
\hline 71 & "EF, F, Q, B, H, M, G, EA, FIL". \\
\hline 72 & "EF, F, B, Q, FIL, H, EA, M, I, G". \\
\hline 73 & "EF, B, EA, F, M, I, Q, G, FIL, H". \\
\hline 74 & "EF, B, EA, F, P, Q, M, FIL, G, I". \\
\hline 75 & "EF, EA, B, Q, M, H, G, FIL". \\
\hline 76 & "EF, F, M, B, H, Q, G, FIL, EA". \\
\hline 77 & "EF, EA, P, M, G, B, Q, I, FIL". \\
\hline 78 & "EF, M, EA, I, B, F, Q, P, H, G, FIL". \\
\hline 79 & "EF, EA, F, Q, B, G, M, P, H, I, FIL". \\
\hline 80 & “O, I, EF, FIL, B, F, M, H, EA, G, Q". \\
\hline
\end{tabular}


4) Relacionando agora o assunto "esporte" diretamente a física enumere pelo menos seis modalidades esportivas a respectiva aplicação da física nas mesmas. Para facilitar use o modelo de tabela:

\begin{tabular}{|l|l|l|l|}
\hline $1^{\mathrm{a}}$ & Modalidade esportiva & Física (conteúdo) & $\begin{array}{l}\text { Explique a relação da modalidade } \\
\text { esportiva com a física }\end{array}$ \\
\hline $2^{\mathrm{a}}$ & & & \\
\hline $3^{\mathrm{a}}$ & & & \\
\hline $4^{\mathrm{a}}$ & & & \\
\hline $5^{\mathrm{a}}$ & & & \\
\hline $6^{\mathrm{a}}$ & & & \\
\hline
\end{tabular}

\begin{tabular}{|c|c|}
\hline 1 & $\begin{array}{l}\text { "Corrida: distância, medida dos quilômetros percorridos. } \\
\text { Salto: altura, medida da altura alcançada. } \\
\text { Futebol: distância, medida da distância para se acertar o gol. } \\
\text { Ciclismo: velocidade, medida da velocidade alcançada. } \\
\text { Levantamento de peso: força. } \\
\text { Natação: força". }\end{array}$ \\
\hline 2 & -- \\
\hline 3 & $\begin{array}{l}\text { "Corrida: velocidade, velocidade. } \\
\text { Musculação: força. } \\
\text { Ciclismo: velocidade, velocidade. } \\
\text { Natação". }\end{array}$ \\
\hline 4 & $\begin{array}{l}\text { "Atletismo: cinemática, para ele ser feito é preciso uma força inicial. } \\
\text { Futebol: Dinâmica, se relaciona com a distância entre um objeto. } \\
\text { Natação: óptica, para saber a temperatura da água. } \\
\text { Caminhada: dinâmica, para sair de um ponto inicial e ir ao outro. } \\
\text { Corrida de kart: eletricidade, para ele andar tem que ter um funcionamento do } \\
\text { motor. } \\
\text { Ginástica: dinâmica, tem que ter gestos ações certas". }\end{array}$ \\
\hline 5 & $\begin{array}{l}\text { "Tiro: óptica, necessita ter visão. } \\
\text { Ginástica rítmica: acústica, estudo do corpo com o ritmo musical. } \\
\text { Dinâmica: aerodinâmica. } \\
\text { Eletricidade: carga elétrica. } \\
\text { Corrida: velocidade, você se movimenta e atinge a velocidade. } \\
\text { Salto com vara: velocidade, você corre e pega impulso". }\end{array}$ \\
\hline 6 & $\begin{array}{l}\text { "Ginástica artística: equilíbrio. } \\
\text { Salto com vara: altura. } \\
\text { Salto em distância: distância. } \\
\text { Natação: velocidade". }\end{array}$ \\
\hline 7 & $\begin{array}{l}\text { "Ciclismo: força, velocidade - equilíbrio. } \\
\text { Futsal: agilidade, velocidade- habilidade. } \\
\text { Hipismo: velocidade - equilíbrio. } \\
\text { Salto a distância: força velocidade- atrito. } \\
\text { Judô: força agilidade - atrito. } \\
\text { Ginástica: força agilidade - equilíbrio". }\end{array}$ \\
\hline 8 & $\begin{array}{l}\text { "Ginástica rítmica: acústica, trabalha o corpo com o ritmo musical. } \\
\text { Tiro: óptica, necessita ter uma boa visão e boa mira. } \\
\text { Corrida: energia, dinâmica, ele atinge o máximo de energia no seu corpo para }\end{array}$ \\
\hline
\end{tabular}




\begin{tabular}{|c|c|}
\hline & $\begin{array}{l}\text { correr e pegar velocidade. } \\
\text { Arremesso de peso: força, usa a força para lançar o objeto a distância. } \\
\text { Salto na caixa de areia: velocidade, necessita de muita velocidade para saltar e } \\
\text { ganhar com maior pulo". }\end{array}$ \\
\hline 9 & $\begin{array}{l}\text { "Salto com cavalo: altura. } \\
\text { Salto a distância, distância. } \\
\text { Salto com vara: altura. } \\
\text { futebol: condicionamento físico. } \\
\text { Ginástica olímpica: equilíbrio. } \\
\text { Levantamento de peso: força". }\end{array}$ \\
\hline 10 & ---- \\
\hline 11 & $\begin{array}{l}\text { "Ginástica olímpica: conteúdo equilíbrio, força da gravidade, ação e reação: isso } \\
\text { ocorre em quase todos os movimentos da ginástica olímpica". }\end{array}$ \\
\hline 12 & --- \\
\hline 13 & ----- \\
\hline 14 & $\begin{array}{l}\text { "Vôlei: força. } \\
\text { Basquete: força e velocidade. } \\
\text { Ginástica: equilíbrio, força. } \\
\text { Atletismo; força. } \\
\text { Futebol: velocidade. } \\
\text { Tênis de mesa: velocidade e agilidade". }\end{array}$ \\
\hline 15 & $\begin{array}{l}\text { "Futebol: velocidade, gingado. } \\
\text { Vôlei: força, atrito. } \\
\text { Handball: agilidade, agilidade com as pernas. } \\
\text { Basquete: força, para pessoa transmitir força para bola. } \\
\text { Tênis de mesa: velocidade, para tacar a bolinha. } \\
\text { Atletismo: velocidade, tem que ter velocidade". }\end{array}$ \\
\hline 16 & --- \\
\hline 17 & $\begin{array}{l}\text { "Vôlei: atrito, o jogador quando se desloca sofre atrito. } \\
\text { Ginástica: atrito e ponto de equilíbrio, o jogador necessita de força e muito } \\
\text { equilíbrio. } \\
\text { Basquete: ponto de equilíbrio, o jogador necessita de força e muito equilíbrio. } \\
\text { Futebol; força, movimento, o jogador precisa de grande movimento. } \\
\text { Futsal: força movimento, o jogador necessita de força e muito movimento no } \\
\text { corpo". }\end{array}$ \\
\hline 18 & $\begin{array}{l}\text { "Corrida: velocidade, para vencer precisa de velocidade. } \\
\text { Hipismo: dinâmica, tem posições certas para atingir altura e velocidade movimento } \\
\text { de lançamento. } \\
\text { Arremesso de peso: força, é aplicada energia. } \\
\text { Tiro: óptica, reflexo de uma visão muito boa. } \\
\text { Salto com vara: atrito, nessa modalidade o atrito da vara com muita elasticidade da } \\
\text { vara faz com que a altura seja maior. } \\
\text { Ciclismo: dinâmica, para obter velocidade, o ciclista tem que se manter em uma } \\
\text { posição para quebrar a resistência do vento". }\end{array}$ \\
\hline 19 & $\begin{array}{l}\text { "Box: força, quando acerta um soco forte. } \\
\text { Natação: força e velocidade, nos movimentos dos braços. } \\
\text { Salto a distância: rapidez e salto, quando pega uma velocidade e de um salto caindo } \\
\text { o mais longe possível. } \\
\text { Corrida: velocidade, o movimento das pernas. } \\
\text { Ginástica artística: equilíbrio, gravidade, quando fica na ponta dos pés. }\end{array}$ \\
\hline
\end{tabular}




\begin{tabular}{|c|c|}
\hline & Ciclismo: equilíbrio, velocidade, quando anda na bicicleta e movimenta as pernas". \\
\hline 20 & $\begin{array}{l}\text { "Corrida: velocidade, ao correr exerce uma velocidade . } \\
\text { Levantamento de peso: força, ao pegar um peso a força exerce energia . } \\
\text { Futebol: habilidade, ao diblar o jogador. } \\
\text { Bicicleta: atrito, entre a roda da bicicleta e o chão exerce atrito. } \\
\text { Tiro: óptica, ao mirar exerce óptica". }\end{array}$ \\
\hline 21 & $\begin{array}{l}\text { "Arremesso de peso: força, é aplicada para o arremesso. } \\
\text { Ginática olímpica: equilíbrio, introduzindo ao pé do atleta. } \\
\text { Hipismo: resistência, introduzindo o homem no cavalo. } \\
\text { Natação resistência, introduzida ao corpo. } \\
\text { Arremesso de dardo: força, força no arremesso". }\end{array}$ \\
\hline 22 & $\begin{array}{l}\text { "Karatê: força, quando dá um soco. } \\
\text { Futebol: habilidade e equilíbrio, um jogo de corpo. } \\
\text { Vôlei: atrito, quando vê pula. } \\
\text { Hipismo: equilíbrio, quando o cavalo pula. } \\
\text { Basquete: agilidade, para jogar a bola. } \\
\text { Natação: força e velocidade, para dar braçadas". }\end{array}$ \\
\hline 23 & $\begin{array}{l}\text { "Vôlei: dinâmica, estuda a bola em movimento. } \\
\text { Natação: } \mathrm{f}=\text { ma, a força empregada pelo esportista. } \\
\text { Basquete: trajetória, usa parábola e referente a bola. } \\
\text { Ginástica artística: gravidade, tudo o que sobe desce. } \\
\text { Salto: velocidade, parábola, força gravidade/correr força do atleta. } \\
\text { Atletismo: massa, aceleração, velocidade referente a massa". }\end{array}$ \\
\hline 24 & $\begin{array}{l}\text { "Futebol: velocidade, força, o jogador corre e chuta a bola com força. } \\
\text { Vôlei: pressão força, o jogador bate com força e dá pressão a bola. } \\
\text { Tênis: força, tem que ter força para bater na bolinha. } \\
\text { Basquete: velocidade, força, gravidade, tem que ter força para jogar a bola com } \\
\text { velocidade. } \\
\text { Natação: pressão e resistência, tem que agüentar a pressão em baixo da água. } \\
\text { Tiro esportivo: acústica, eles usam tampão nos ouvidos". }\end{array}$ \\
\hline 25 & $\begin{array}{l}\text { "Corrida: aceleração, os corpos em movimento. } \\
\text { Jui-jisu: ação e reação, cada coisa tem sua reação. } \\
\text { Lançamento de dardo, a diferença entre os pontos, tem que saber medida. } \\
\text { Salto em distância: um corpo em movimento, o salto. } \\
\text { Salto com vara: eletrização por indução, a vara induz a pular. } \\
\text { Triatlon: energia, precisa de muita energia". }\end{array}$ \\
\hline 26 & $\begin{array}{l}\text { "Luta livre: ação e reação, toda ação tem uma reação. } \\
\text { Corrida:aceleração, velocidade. } \\
\text { Natação: eliminação de atrito, dependendo da movimentação dos braços, maior } \\
\text { deslocamento. } \\
\text { Levantamento de peso: força, força para executar os movimentos. } \\
\text { Salto com vara: deslocamento, distância e mudar de lugar. } \\
\text { Hipismo: movimento, movimento adequado". }\end{array}$ \\
\hline 27 & $\begin{array}{l}\text { "Corrida: velocidade e resistência. } \\
\text { Volei: força e agilidade. } \\
\text { Natação: resistência. } \\
\text { Baiseball: velocidade, força e reflexo. } \\
\text { Futebol: velocidade e agilidade. } \\
\text { Tênis de mesa: velocidade, reflexo". }\end{array}$ \\
\hline 28 & "Corrida: velocidade e resistência. \\
\hline
\end{tabular}




\begin{tabular}{|c|c|}
\hline & $\begin{array}{l}\text { Volei: força e agilidade. } \\
\text { Natação: resistência. } \\
\text { Baiseball: velocidade, força e reflexo. } \\
\text { Futebol: velocidade e agilidade. } \\
\text { Tênis de mesa: velocidade, reflexo". }\end{array}$ \\
\hline 29 & $\begin{array}{l}\text { "Tênis: reflexo. } \\
\text { Vôlei: força e agilidade. } \\
\text { Basquete: velocidade e raciocínio. } \\
\text { Salto: força, precisão. } \\
\text { Tênis de mesa: velocidade e reflexo. } \\
\text { Corrida: velocidade resistência". }\end{array}$ \\
\hline 30 & $\begin{array}{l}\text { "Tênis: reflexo. } \\
\text { Vôlei: força e agilidade. } \\
\text { Basquete: velocidade e raciocínio. } \\
\text { Salto: força, precisão. } \\
\text { Tênis de mesa: velocidade e reflexo. } \\
\text { Corrida: velocidade resistência". }\end{array}$ \\
\hline 31 & $\begin{array}{l}\text { "Salto em distância: velocidade, distância. O atleta precisa calcular a força, a } \\
\text { distância e seu peso para o pulo. } \\
\text { Vôlei: velocidade e distância O atleta precisa calcular a velocidade da bola para } \\
\text { saber onde ela vai cair. } \\
\text { Futebol: força e velocidade O jogador precisa calcular o destino do chute. } \\
\text { Basquete: distância e velocidade. O jogador precisa ter mira na hora de arremessar. } \\
\text { Ginástica olímpica: gravidade. A ginasta desafia as leis da gravidade em suas } \\
\text { piruetas. } \\
\text { Natação: velocidade. Nosso corpo reage de outra forma dentro da água". }\end{array}$ \\
\hline 32 & $\begin{array}{l}\text { "Atletismo: velocidade, o praticante desta modalidade precisa de agilidade e } \\
\text { velocidade para vencer as provas. } \\
\text { Futebol: força e velocidade. O jogador precisa calcular a força para tocar na bola. } \\
\text { Basquete: velocidade e distância. O jogador precisa utilizar velocidade, além de } \\
\text { calcular a distância de seus arremessos. } \\
\text { Vôlei: velocidade. O atleta precisa ser veloz para confundir o adversário. } \\
\text { Ginástica: gravidade. O atleta precisa desafiar a gravidade } \\
\text { Handball: velocidade". }\end{array}$ \\
\hline 33 & $\begin{array}{l}\text { "Corrida: velocidade. O atleta precisa calcular o tempo em que chegará ao objetivo } \\
\text { e, assim saber a velocidade que precisará correr. } \\
\text { Natação: velocidade e distância O mesmo caso da corrida } \\
\text { Ginástica: gravidade e velocidade. Se os atletas não atingem uma boa velocidade } \\
\text { não conseguem manter no ar para realizar seus movimentos. } \\
\text { Basquete: distância e velocidade, gravidade. O jogador deve lançar a bola a uma } \\
\text { certa velocidade para cada distância para fazer as cestas. } \\
\text { Vôlei: velocidade e distância. O atleta precisa calcular a velocidade da bola para } \\
\text { fazê-la cair dentro da quadra. } \\
\text { Salto com vara: velocidade e peso. O atleta precisa saber a força a velocidade e seu } \\
\text { peso para conseguir alcançar a altura certa". }\end{array}$ \\
\hline 34 & $\begin{array}{l}\text { "Vôlei: força e agilidade. } \\
\text { Basquete: velocidade e precisão. } \\
\text { Salto: agilidade e força. } \\
\text { Tênis de mesa: raciocínio. } \\
\text { Corrida: velocidade. }\end{array}$ \\
\hline
\end{tabular}




\begin{tabular}{|c|c|}
\hline & Tênis: reflexo e raciocínio". \\
\hline 35 & $\begin{array}{l}\text { "Salto com vara: gravidade, altura adequada. } \\
\text { Natação: aceleração, aceleração das braçadas. } \\
\text { Salto triplo: velocidade, velocidade no salto. } \\
\text { Ginástica: impulso: impulso certo. } \\
\text { Futebol: energia, energia para o jogo. } \\
\text { Vôlei: força, força nos movimentos". }\end{array}$ \\
\hline 36 & $\begin{array}{l}\text { "Futebol: movimento do corpo. } \\
\text { Vôlei: movimento dos braços. } \\
\text { Basquete: visão óptica. } \\
\text { Atletismo: temperatura. } \\
\text { Natação. } \\
\text { Ginástica". }\end{array}$ \\
\hline 37 & $\begin{array}{l}\text { "Basquete: trajetória, usa a parábola. } \\
\text { Ginástica artística: gravidade, se subiu tem que descer. } \\
\text { Corrida: tração, força, aceleração velocidade. } \\
\text { Tiro ao alvo:óptica, visão para o alvo. } \\
\text { Nado sincronizado: acústica, movimento conforme a música. } \\
\text { Levantamento de peso: força, força para levantar o peso". }\end{array}$ \\
\hline 38 & $\begin{array}{l}\text { "Ginástica artística: gravidade, tudo que sobe tem que descer. } \\
\text { Basquete: trajetória, usa a parábola em relação bola. } \\
\text { Corrida: força aceleração, velocidade. } \\
\text { Tiro ao alvo: óptica, visão para o alvo. } \\
\text { Arremesso de peso: força e distância, a força com que se arremessa e a distância } \\
\text { que chegou. } \\
\text { Levantamento de peso: força distância, a força com que arremessa e a distância que } \\
\text { chegou. } \\
\text { Levantamento de peso: força, relação do peso que ele levanta". }\end{array}$ \\
\hline 39 & $\begin{array}{l}\text { "Ginástica artística: gravidade, se subir tem que descer. } \\
\text { Corrida. Tração, força aceleração velocidade. } \\
\text { Tiro ao alvo, óptica, visão para o alvo. } \\
\text { Basquete, trajetória, usa-se a parábola. } \\
\text { Nado sincronizado: acústica, fazer movimentos conforme a música. } \\
\text { Natação: movimento, espaço, minutos segundos". }\end{array}$ \\
\hline 40 & $\begin{array}{l}\text { "Corrida: velocidade, quanto mais velocidade a pessoa tiver melhor será seu } \\
\text { desempenho. } \\
\text { Levantamento de peso: força é preciso muita força para levantar pesos. } \\
\text { Ginástica: movimento e gravitação, é preciso realizar os movimentos com precisão } \\
\text { e os saltos desafiam as leis da gravidade } \\
\text { Vôlei: gravitação, não pode deixar a bola cair. } \\
\text { Tiro ao alvo: óptica, precisa-se ter uma visão precisa para acertar os tiros. } \\
\text { Arremesso: força, é preciso ter muita força para ter um bom arremesso". }\end{array}$ \\
\hline 41 & $\begin{array}{l}\text { "Natação: movimento, aceleração segundos. } \\
\text { Basquete: movimento, velocidade. } \\
\text { Atletismo: velocidade, aceleração e tempo. } \\
\text { Salto: distância, altura gravidade. } \\
\text { Vôlei: dinâmica, gravidade. } \\
\text { Salto com vara: velocidade altura, aceleração movimento gravidade". }\end{array}$ \\
\hline 42 & $\begin{array}{l}\text { "Atletismo: velocidade, velocidade massa mais aceleração. } \\
\text { Natação: movimento, espaço minutos segundos. }\end{array}$ \\
\hline
\end{tabular}




\begin{tabular}{|c|c|}
\hline & $\begin{array}{l}\text { Salto com vara: velocidade e movimento, altura velocidade. } \\
\text { Ginástica rítmica: movimento óptica acústica, os movimentos a visão o som. } \\
\text { Ciclismo: velocidade, aceleração, massa. } \\
\text { Vôlei: dinâmica, gravidade”. }\end{array}$ \\
\hline 43 & $\begin{array}{l}\text { "Salto com vara: o impulso ocorre para a prova acontecer, a física explica porque } \\
\text { este impulso ocorre. } \\
\text { Ginástica olímpica: os movimentos e impactos que são executados, a física mostra } \\
\text { os cálculos dos fatos tornando mais bela. } \\
\text { Salto a distância: a corrida para pegar velocidade e o pulo para distância, a física } \\
\text { explica porque tem que correr para poder pular longe. } \\
\text { Corrida: a aceleração do corpo, a física explica o movimento do corpo. } \\
\text { Arremesso de peso: a força do corpo e impulso dado, a física mostra ou } \\
\text { movimentos, a força calculada. } \\
\text { Futebol: a velocidade da bola, a física mostra como isso ocorre. } \\
\text { Judô, musculação, bale: a física mostra e explica cada movimento e a força que } \\
\text { ocorre". }\end{array}$ \\
\hline 44 & $\begin{array}{l}\text { "Salto a distância: a corrida par pegar velocidade, que com a velocidade você vai } \\
\text { mais longe. } \\
\text { Salto com vara: o impulso ocorre antes, explica porque este impulso. } \\
\text { Corrida: a aceleração, explica como consegue tanta velocidade. } \\
\text { Ginástica olímpica: o impacto, como a pessoa de } 60 \mathrm{~kg} \text { pode chegar a pesar } 100 \mathrm{~kg} \text {. } \\
\text { Judô: o impacto, o impulso do golpe". }\end{array}$ \\
\hline 45 & $\begin{array}{l}\text { "Salto em distância: velocidade, tem que ter muita velocidade para saltar o mais } \\
\text { longe possível. } \\
\text { Nado sincronizado: força da gravidade, para manter o equilíbrio de baixo da água } \\
\text { como se estivesse fora dela. } \\
\text { Ginástica rítmica: força da gravidade, elas precisam calcular certinho o tempo em } \\
\text { que a corda ou bambolê irá cair, e de onde virá. } \\
\text { Tiro esportivo:óptica e gravidade do ar, tem que ter uma visão aguçada para ver os } \\
\text { discos e a gravidade para se ter uma idéia de onde eles vão parar. } \\
\text { Arremesso de dardo: força velocidade, para se arremessar o dardo o mais longe } \\
\text { possível é preciso força, e deve-se levar em consideração a velocidade que o dardo } \\
\text { pega depois de lançado. } \\
\text { Handball: força gravidade, na hora em que a jogadora vai lançar para fazer o gol } \\
\text { ela tem que pular e jogar a bola antes de cair no chão". }\end{array}$ \\
\hline 46 & $\begin{array}{l}\text { "Basquete: trajetória, movimento da bola. } \\
\text { Ciclismo:aceleração, velocidade e massa. } \\
\text { Vôlei: dinâmica, estudo do movimento. } \\
\text { Atletismo: velocidade, massa + aceleração. } \\
\text { Natação: movimento, espaço minutos segundos. } \\
\text { Ginástica rítmica: movimento óptica, os movimentos a visão o som". }\end{array}$ \\
\hline 47 & $\begin{array}{l}\text { "Vôlei: dinâmica, estudo da bola em movimento. } \\
\text { Natação: f = ma, a força empregada pelo esportista. } \\
\text { Atletismo: massa e aceleração, velocidade. } \\
\text { Ginástica artística: gravidade, tudo que sobe desce. } \\
\text { Basquete: trajetória, movimento da bola. } \\
\text { Salto: parábola, força, gravidade, força do atleta". }\end{array}$ \\
\hline 48 & $\begin{array}{l}\text { "Tiro ao alvo: óptica, visão precisão. } \\
\text { Basquete: dinâmica óptica, velocidade visão precisão força. } \\
\text { Atletismo: dinâmica, velocidade força. }\end{array}$ \\
\hline
\end{tabular}




\begin{tabular}{|c|c|}
\hline & $\begin{array}{l}\text { Futebol: dinâmica óptica acústica, velocidade força visão e tem que escutar. } \\
\text { Ginástica no trampolim: dinâmica, velocidade força impulso. } \\
\text { Box: dinâmica, força velocidade". }\end{array}$ \\
\hline 49 & $\begin{array}{l}\text { "Basquete: dinâmica, distância de cada time. } \\
\text { Ginástica rítmica: gravidade, habilidades no salto. } \\
\text { Futebol: velocidade, correndo de uma distância a outra. } \\
\text { Corrida: velocidade, contar tempo percorrido. } \\
\text { Atletismo: velocidade, contar o tempo. } \\
\text { Tiro ao alvo: óptica, direção certa". }\end{array}$ \\
\hline 50 & $\begin{array}{l}\text { "Atletismo: velocidade e força, contar o tempo percorrido, como velocidade. } \\
\text { Basquete: velocidade dinâmica, a dinâmica de cada time participante. } \\
\text { Tiro ao alvo: óptica, é necessário visão direção certa. } \\
\text { Ginástica artística: gravidade, condicionamento físico e habilidades de salto. } \\
\text { Salto com vara: gravidade, habilidade de salto e corrida. } \\
\text { Natação: dinâmica e velocidade, percorrer rápido e habilidade de respiração". }\end{array}$ \\
\hline 51 & $\begin{array}{l}\text { "Corrida: aceleração, porque você precisa de muita velocidade. } \\
\text { Ginástica olímpica: força, o atleta precisa de força para executar os movimentos. } \\
\text { Salto com vara: deslocamento, ele precisa ganhar um distanciamento para saltar. } \\
\text { Karate: ação e reação, para toda ação tem um areação e no caso do karatê é } \\
\text { imediato. } \\
\text { Natação: eliminação do atrito, dependendo do movimento dos braços você se } \\
\text { desloca mais. } \\
\text { Hipismo: movimento, você tem que saber qual movimento adequado ao tipo de } \\
\text { salto". }\end{array}$ \\
\hline 52 & $\begin{array}{l}\text { "Levantamento de peso: força, cálculo da força para levantar. } \\
\text { Ginástica: velocidade, calculo das distancias de cada salto. } \\
\text { Vôlei: equilíbrio, calculo da potência de cada saque. } \\
\text { Futebol: impulso, saber o peso da bola. } \\
\text { Basquete: calcula a distância da bola até a sexta-feira . } \\
\text { Lançamento de dardo: peso, calcula a força para o lançamento". }\end{array}$ \\
\hline 53 & $\begin{array}{l}\text { "Arremesso de peso: peso, eu vejo a física no peso e na projeção e velocidade do } \\
\text { lançamento. } \\
\text { Corrida: velocidade, na velocidade dos atletas. } \\
\text { Salto em distância: velocidade, na velocidade da projeção do salto } \\
\text { Ginástica artística: equilíbrio, eu vejo a física no equilíbrio e desenvoltura do atleta } \\
\text { em barra. } \\
\text { Arremesso do disco: força e peso, na força exercida pelo atleta para o lançamento } \\
\text { do disco. } \\
\text { Judô: fica evidente a utilização da força". }\end{array}$ \\
\hline 54 & $\begin{array}{l}\text { "Ginástica artística: equilíbrio, é necessária a física para o equilíbrio. } \\
\text { Natação: resistência, é preciso ter muita resistência para nadar. } \\
\text { Corrida: velocidade, é preciso a física para medir a velocidade. } \\
\text { Academia: peso, tem que ter força. } \\
\text { Vôlei: dinâmica, por causa do movimento". }\end{array}$ \\
\hline 55 & $\begin{array}{l}\text { "Arremesso de peso, força, porque necessita da força para arremessar o peso na } \\
\text { distância desejada. } \\
\text { Corrida: velocidade, porque busca a velocidade numa certa distância buscando o } \\
\text { menor tempo possível. } \\
\text { Ginástica: equilíbrio, porque precisa de desenvoltura e equilíbrio para desempenhar } \\
\text { movimentos. }\end{array}$ \\
\hline
\end{tabular}




\begin{tabular}{|c|c|}
\hline & Taek wondo, judô, box: em todos é evidente a aplicação dos conceitos da física". \\
\hline 56 & $\begin{array}{l}\text { "Box: força, tem que usar muita força. } \\
\text { Futebol: velocidade, a velocidade é muito importante. } \\
\text { Corrida: resistência, tem que ser forte. } \\
\text { Ginástica artística: equilíbrio, para se equilibrar nas barras. } \\
\text { Basquete: dinâmica, sempre em movimento. } \\
\text { Tiro ao alvo: óptica, tem que ter uma boa visão". }\end{array}$ \\
\hline 57 & $\begin{array}{l}\text { "'Futebol, a velocidade da bola. } \\
\text { Basquete, o ângulo certo da cesta. } \\
\text { Vôlei: a altura da rede. } \\
\text { Tênis: a força jogada na bola. } \\
\text { Futsal: o peso da bola relacionada ao esporte. } \\
\text { Ginástica: equilíbrio com força". }\end{array}$ \\
\hline 58 & $\begin{array}{l}\text { "'Corrida: aceleração, velocidade. } \\
\text { Ginástica: cinemática, movimentos. } \\
\text { Tiro: óptica, precisão. } \\
\text { Arremesso de disco: deslocamento, jogar o disco. } \\
\text { Esgrima: deslocamento, deslocar e acertar". }\end{array}$ \\
\hline 59 & $\begin{array}{l}\text { "Hipismo: cinemática, tem que se concentrar no obstáculo. } \\
\text { Atletismo: velocidade, a física marca a velocidade que o atleta quer chegar. } \\
\text { Ginástica: força, tem que ter força e equilíbrio. } \\
\text { Vôlei: equilíbrio, tem que ter equilíbrio. } \\
\text { Basquete: distância, tem que saber a distância da cesta. } \\
\text { Futebol: peso, tem que ter peso da bola". }\end{array}$ \\
\hline 60 & $\begin{array}{l}\text { "Ginástica artística: equilíbrio, que precisa do equilíbrio para praticar. } \\
\text { Atletismo: resistência, tem que ter bastante força. } \\
\text { Academia: peso, tem que levantar peso. } \\
\text { Natação: agilidade, tem que ser rápido. } \\
\text { Vôlei: dinâmica, sempre no mesmo ritmo. } \\
\text { Futebol: velocidade, tem que ser bem rápido". }\end{array}$ \\
\hline 61 & $\begin{array}{l}\text { "Atletismo: equilíbrio, tem que ter muito equilíbrio. } \\
\text { Judô: peso, tem que ter um peso ideal. } \\
\text { Ginástica: acústica, ter um bol ritmo de música para apresentação. } \\
\text { Futebol: resistência, precisa ter uma boa forma. } \\
\text { Natação: velocidade, precisa ser rápido e ter um bom ar". }\end{array}$ \\
\hline 62 & $\begin{array}{l}\text { "Maratona:velocidade e tempo, precisa de muita velocidade e tempo para ser o } \\
\text { mais rápido. } \\
\text { Arremesso: força, impulso, precisa de força e impulso para lançar ou arremessar } \\
\text { muito longe. } \\
\text { Salto em altura: velocidade e impulso, precisa de velocidade e impulso para saltar. } \\
\text { Vôlei: impulso e força, precisa de impulso, força para poder fazer a bola bater na } \\
\text { quadra do adversário. } \\
\text { Tênis de mesa: velocidade, reflexo velocidade para rebater a bolinha. } \\
\text { Cama elástica: impulso e equilíbrio, para realizar todos os saltos com o máximo de } \\
\text { perfeição". }\end{array}$ \\
\hline 63 & $\begin{array}{l}\text { "Ginástica: velocidade, força, tempo, equilíbrio, precisa de força, tempo certo para } \\
\text { o passo e velocidade para o impulso. } \\
\text { Arremesso: força e impulso, o impulso para o disco pegar velocidade. } \\
\text { Salto com vara: impulso, velocidade, força e equilíbrio, velocidade para correr } \\
\text { pegar impulso e força para pular sobre a vara. }\end{array}$ \\
\hline
\end{tabular}




\begin{tabular}{|c|c|}
\hline & $\begin{array}{l}\text { Maratona: velocidade e força, velocidade para correr e força para agüentar o } \\
\text { percurso. } \\
\text { Cama elástica: impulso e equilíbrio, impulso para o pulso. } \\
\text { Ping-pong: velocidade, velocidade e agilidade para bater na bolinha". }\end{array}$ \\
\hline 64 & $\begin{array}{l}\text { "Vôlei: velocidade e altura, tem relação com o impulso que eles tomam para saltar } \\
\text { Ginástica rítmica: velocidade, coordenação motora, a relação é que os meninos tem } \\
\text { que ter agilidade. } \\
\text { Handball: velocidade, agilidade e força, a relação é que a força eles tem que } \\
\text { colocar todo o braço para arremessar a bola com força. } \\
\text { Natação: velocidade e força,a relação é que preciso de velocidade para ultrapassar } \\
\text { os outros e força para não ser puxado pela água. } \\
\text { Takendo: velocidade, coordenação motora e agilidade, a relação com a física é } \\
\text { quando o corpo sobre pressão cai par baixo. } \\
\text { Vôlei de areia: velocidade e altura e força, a relação é o impulso que eles pegam } \\
\text { para pular e atingir a bola". }\end{array}$ \\
\hline 65 & $\begin{array}{l}\text { "Ginástica artística: velocidade e altura, a velocidade que o atleta ganha para poder } \\
\text { saltar. } \\
\text { Vôlei: velocidade e força, a velocidade da bola depende da força da mão que bate } \\
\text { nela. } \\
\text { Saltos ornamentais: equilíbrio e impulso, o impulso que o atleta para poder saltar } \\
\text { mais alto, o atrito com o ar e com a água. } \\
\text { Hipismo: velocidade e equilíbrio, a velocidade do cavalo e o equilíbrio da pessoa } \\
\text { montada. } \\
\text { Natação: força e velocidade, a força da pessoa em atrito com a água e a velocidade } \\
\text { na virada. } \\
\text { Corrida: velocidade e força, a força que a pessoa fez para adquirir velocidade". }\end{array}$ \\
\hline 66 & $\begin{array}{l}\text { "Futsal: velocidade, no futsal podemos encontrar algumas coisas relacionadas a } \\
\text { física uma delas seria a velocidade. Os jogadores tem que utilizar muito a } \\
\text { velocidade para ir atrás da bola, eles precisam muito de velocidade. } \\
\text { Vôlei: peso, No vôlei também encontramos a física do peso, como o peso do } \\
\text { jogador e da bola. } \\
\text { Ginástica: movimento, o movimento de um elemento encontrado na física também } \\
\text { muito utilizado na ginástica. } \\
\text { Natação : movimento, na natação usa-se muito o movimento. Movimentos } \\
\text { constantes e diversos. } \\
\text { Salto: impulso, o impulso está muito visível no salto, o impulso esta relaciona a } \\
\text { fisicca, para o salto é preciso muito impulso. } \\
\text { Hipismo: equilíbrio, o equilíbrio esta presente na física e também no hipismo e } \\
\text { necessita de equilíbrio entre o jóquei e o cavalo". }\end{array}$ \\
\hline 67 & $\begin{array}{l}\text { "Levantamento de peso: peso, equilíbrio e força. } \\
\text { Ginástica: equilíbrio, na trave de equilíbrio. } \\
\text { Futebol: velocidade, rápido raciocínio em espaço pequeno. } \\
\text { Atletismo: velocidade e força, na hora de correr. } \\
\text { Vôlei: força, para sacar e impulso. } \\
\text { Handball: impulso, para saltar e fazer o gol". }\end{array}$ \\
\hline 68 & $\begin{array}{l}\text { "Corrida de 100m: movimento uniforme, cálculo da velocidade. } \\
\text { Arremesso de peso: cinemática, movimentos dos corpos. } \\
\text { Natação: dinâmica, movimentos. } \\
\text { Tiro ao alvo: balística, lançamento de projéteis. } \\
\text { Handball: impulso, saltar e fazer o gol. }\end{array}$ \\
\hline
\end{tabular}




\begin{tabular}{|c|c|}
\hline & Ginástica: equilíbrio, na trave do equilíbrio". \\
\hline 69 & $\begin{array}{l}\text { "Atletismo: força e velocidade, junção dos dois para o melhor desempenho. } \\
\text { Basquete: velocidade e altura, velocidade para tomar a bola e força para jogar } \\
\text { longe. } \\
\text { Futebol: velocidade, para correr. } \\
\text { Vôlei: força, para mandar a bola no lugar certo. } \\
\text { Artes marciais: velocidade e força, para derrubar o adversário. } \\
\text { Handball: força, força na mão". }\end{array}$ \\
\hline 70 & $\begin{array}{l}\text { "Ginástica: força, para se equilibrar. } \\
\text { Vôlei: dinâmica, para não se atrapalhar na posição. } \\
\text { Salto com vara: velocidade, para superar a velocidade. } \\
\text { Handball: dinâmica, força na mão. } \\
\text { Basquete: altura, força na mão. } \\
\text { Atletismo: força, velocidade". }\end{array}$ \\
\hline 71 & $\begin{array}{l}\text { "Corrida: velocidade, obter velocidade. } \\
\text { Ginástica: força e equilíbrio. } \\
\text { Salto em distância, velocidade e impulso, correr uma distância e obter impulso para } \\
\text { fazer o salto". }\end{array}$ \\
\hline 72 & $\begin{array}{l}\text { "Ginástica: equilíbrio, você usa o equilíbrio para ter concentração no salto. } \\
\text { Levantamento de peso: força, você usa a força para superar o corpo. } \\
\text { Salto em distância: velocidade, você usa velocidade para superar obstáculo. } \\
\text { Salto com vara: impulso, você usa o impulso para ter precisão em pular. } \\
\text { Ciclismo: força e equilíbrio, você usa força junto com o equilíbrio para andar de } \\
\text { bicicleta. } \\
\text { Basquete: velocidade e altura, você usa velocidade e altura para melhor } \\
\text { sustentamento envolve gravidade". }\end{array}$ \\
\hline 73 & $\begin{array}{l}\text { "Ginástica: equilíbrio e força, a ginasta tem que se equilibrar e ter força. } \\
\text { Futebol: velocidade, o jogador tem que correr. } \\
\text { Vôlei: força e velocidade;: tem que jogar com força e correr. } \\
\text { Salto com vara: velocidade, força e altitude, correr pular saltar tudo isso. } \\
\text { Arremesso de peso: força, pessoa tem que ter força e velocidade. } \\
\text { Corrida de bike: velocidade, força e equilíbrio, tem que pedalar e manter o } \\
\text { equilíbrio e manter a velocidade". }\end{array}$ \\
\hline 74 & $\begin{array}{l}\text { "'Salto em distância: concentração e impulso, você precisa pesar e ter impulso e } \\
\text { velocidade para acontecer o salto. } \\
\text { Ginástica: equilíbrio e impulso, você usa o equilíbrio para ter concentração nos } \\
\text { saltos. } \\
\text { Levantamento de peso: força, você usa para realizar os exercícios com resultado. } \\
\text { Ciclismo: força e equilíbrio, você usa o equilíbrio para andar e força também. } \\
\text { Vôlei: altura, você tem que ter o tamanho certo para jogar. } \\
\text { Handball: impulso e força, quando você corre você vai pegando impulso e ai você } \\
\text { arremessa". }\end{array}$ \\
\hline 75 & $\begin{array}{l}\text { "Salto com vara: velocidade força, tem que correr para atingir um bom salto. } \\
\text { Arremesso de peso: força, o atleta se esforça muito para arremessar. } \\
\text { Ginástica: equilíbrio e força,muito equilíbrio força e beleza. } \\
\text { Ciclismo: velocidade, exige muita velocidade do atleta. } \\
\text { Vôlei: força e velocidade, o jogador tem que ter força e agilidade. } \\
\text { Futebol: velocidade, o jogador tem que correr bastante". }\end{array}$ \\
\hline 76 & $\begin{array}{l}\text { "Vôlei: força, tem que ter força. } \\
\text { Futebol: velocidade. }\end{array}$ \\
\hline
\end{tabular}




\begin{tabular}{|l|l|}
\hline & Ginástica: equilíbrio e força. \\
& Ciclismo: velocidade. \\
& Salto com vara: velocidade e força. \\
Arremesso de peso: força".
\end{tabular}

5) Quais tipos de esportes podem ser desenvolvidos em uma academia de ginástica? Em quais deles em sua opinião é evidente aplicação dos conceitos da física?

\begin{tabular}{|l|l|}
\hline 1 & "Corrida, levantamento de peso.., nos dois" \\
\hline 2 & $\begin{array}{l}\text { "Ginástica artística, onde tem que usar a gravidade da física e relaciona sua } \\
\text { habilidade". }\end{array}$ \\
\hline 3 & "Corrida, musculação. Corrida, pois é distância". \\
\hline 4 & $\begin{array}{l}\text { "Caminhada, corrida, levantamento de peso. Para os conceitos de física eu acho, } \\
\text { quase certeza levantamento de peso, pois o corpo sustenta um peso inicial se você } \\
\text { exceder haverá problema assim como na física se houver erro pode causar sérios } \\
\text { riscos". }\end{array}$ \\
\hline 5 & "Abdominais, movimenta-se o corpo, e necessita de tempo". \\
\hline 6 & $\begin{array}{l}\text { "Barras assimétricas é evidente a aplicação da física, porque é relacionado a } \\
\text { dinâmica". }\end{array}$ \\
\hline 7 & "Artes marciais, dança, se aplicam mais a física por causa dos movimentos". \\
\hline 8 & $\begin{array}{l}\text { "A ginástica olímpica, rítmica e artística, todas devem ter conceitos da física, pois é } \\
\text { inacreditável ver como conseguem chegar a alturas inexplicáveis". }\end{array}$ \\
\hline 9 & "Musculação, porque fazemos movimentos com as mãos e todo o corpo". \\
\hline 10 & "A física está presente em tudo, cada movimento que você faz". \\
\hline 11 & "Box na ação e reação". \\
\hline 12 & "Trampolim onde se aplica a alavanca". \\
\hline 13 & $\begin{array}{l}\text { "Academia de ginástica: box, alongamento, levantamento de peso, karate, judô. Na } \\
\text { minha opinião em todos está evidente as aplicações da física" }\end{array}$ \\
\hline
\end{tabular}




\begin{tabular}{|c|c|}
\hline 14 & $\begin{array}{l}\text { "Vários entre eles são: musculação, aeróbica, capoeira, alongamento, dança e salto. } \\
\text { A musculação, porque envolve peso, força, energia que são coisas muito usadas na } \\
\text { física". }\end{array}$ \\
\hline 15 & $\begin{array}{l}\text { "Bem em uma academia pode ser feito muitas atividades uma delas são: } \\
\text { musculação, jump, rpm, aeróbica, capoeira, alongamento, dança e salto, e o que se } \\
\text { encaixa mais com a física é a musculação, pois musculaçâo, pois a musculação } \\
\text { envolve muito o peso a energia e principalmente a força que é uma das coisas } \\
\text { muito estudada na física". }\end{array}$ \\
\hline 16 & $\begin{array}{l}\text { "Box, karate, levantamento de peso, no levantamento de peso, onde o atleta aplica } \\
\text { a lei da força e da velocidade". }\end{array}$ \\
\hline 17 & $\begin{array}{l}\text { "Corrida, caminhada, levantamento de peso. O levantamento de peso devido a sua } \\
\text { movimentação". }\end{array}$ \\
\hline 18 & $\begin{array}{l}\text { "Dança, box, levantamento de peso, esteira: exerce um atrito dos pés sobre a esteira } \\
\text { conseguindo velocidade". }\end{array}$ \\
\hline 19 & $\begin{array}{l}\text { "Box, judô. No box quem tiver o soco mais forte e mais rápido tem chance de } \\
\text { vencer". }\end{array}$ \\
\hline 20 & $\begin{array}{l}\text { "Ginástica, levantamento de peso, dança. Ginástica, porque o atrito do chão com a } \\
\text { ponta do pé mantém um certo equilíbrio". }\end{array}$ \\
\hline 21 & "Aerób \\
\hline 22 & $\begin{array}{l}\text { "Musculação, karate, jui-jutsu, a musculação é a mais evidente da física porque } \\
\text { necessita de muita força". }\end{array}$ \\
\hline 23 & \\
\hline 24 & 'Halte \\
\hline 25 & "O lev \\
\hline 26 & $\begin{array}{l}\text { peso: força } \\
\text { nento". }\end{array}$ \\
\hline 27 & "Entr \\
\hline 28 & $\begin{array}{l}\text { "Ginástica artística e olímpica. A ginástica olímpica pois tem saltos corridas várias } \\
\text { coisas relacionadas a física". }\end{array}$ \\
\hline 29 & "Giná \\
\hline 30 & $\begin{array}{l}\text { "Ginástica olímpica e ritmica e muitos outros esporte coo arremesso de peso, entre } \\
\text { outros". }\end{array}$ \\
\hline 31 & $\begin{array}{l}\text { "Corrida envolve velocidade. Levantamento de peso envolve força e peso, ambos } \\
\text { podem ser desenvolvidos na academia". }\end{array}$ \\
\hline 32 & "São 1 \\
\hline 33 & $\begin{array}{l}\text { "Levantam } \\
\text { Corrida: ve }\end{array}$ \\
\hline 34 & "Só jui jitsu 1 \\
\hline 35 & sua força" \\
\hline 36 & $\begin{array}{l}\text { "O box, é um esporte que é praticado na academia. Sim é evidente a aplicação dos } \\
\text { conceitos da física, porque pratica a movimentação a visão e a energia". }\end{array}$ \\
\hline 37 & $\begin{array}{l}\text { rida, caminhada, ginástica, ginástica aeróbica, lutas etc, } \\
\text { e no levantamento de peso e nas lutas". }\end{array}$ \\
\hline 38 & $\begin{array}{l}\text { "Levantamento de peso, corrida, ginástica. A ginástica envolve gravidade, a corrida } \\
\text { velocidade, aceleração, distância e o levantamento de peso, força, mas todos os } \\
\text { esportes envolvem física". }\end{array}$ \\
\hline 39 & $\begin{array}{l}\text { "Corrida, caminhada, levantamento de peso, ginástica, ginástica aeróbica. Em todas } \\
\text { principalmente no levantamento de peso". }\end{array}$ \\
\hline
\end{tabular}




\begin{tabular}{|c|c|}
\hline 40 & $\begin{array}{l}\text { Ginástica, levantamento de peso, lutas em geral, etc. É evidente a aplicação da } \\
\text { ísica da ginástica, onde é preciso força, velocidade, movimento e outros". }\end{array}$ \\
\hline 41 & $\begin{array}{l}\text { "Corrida. Temos que considerar o movimento em uma esteira, velocidade, } \\
\text { capacidade e tempo". }\end{array}$ \\
\hline 42 & $\begin{array}{l}\text { "Levantamento de peso: temos que considerar o peso, para se ter uma força para } \\
\text { poder sustentar o peso com muito equilíbrio". }\end{array}$ \\
\hline 43 & $\begin{array}{l}\text { "Judô, karate, balé, musculação. A física mostra e explica cada movimento do } \\
\text { karate e judô e a força que ocorre". }\end{array}$ \\
\hline 44 & "Judô, karate e capoeira, a física mostra a velocidade que ocorre com os golpes". \\
\hline 45 & $\begin{array}{l}\text { "Aeróbica, musculação, halterofilismo, lutas, ginástica. Acho que dessas, a que } \\
\text { mais mostra ter física são as lutas, pois existe a acústica, óptica, resistência, pressão } \\
\text { do ar, etc.". }\end{array}$ \\
\hline 46 & $\begin{array}{l}\text { Levantamento de peso: o levantamento de peso é evidente porque temos que usar } \\
\text { ossa força para levantá-lo". }\end{array}$ \\
\hline 47 & 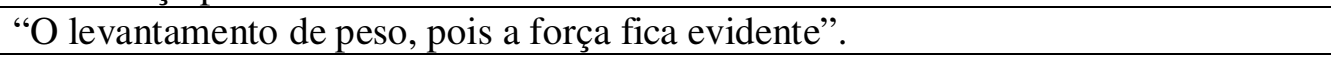 \\
\hline 48 & $\begin{array}{l}\text { "Na academia dá para desenvolver o box e o box deve ter aplicação dos conceitos } \\
\text { da física porque no box você tem que ser rápido tem que ter força e tem que ter } \\
\text { movimentação". }\end{array}$ \\
\hline 49 & $\begin{array}{l}\text { "A ginástica olímpica. Na física porque tem muita gravidade e habilidades no } \\
\text { salto". }\end{array}$ \\
\hline 50 & $\begin{array}{l}\text { "Natação, tem a ver com a física a velocidade e dinâmica habilidade de } \\
\text { respiração". }\end{array}$ \\
\hline 51 & $\begin{array}{l}\text { lismo: a aplicação na física (força). } \\
\text { plicação na física (aceleração). } \\
\text { aplicação na física( deslocamento)". }\end{array}$ \\
\hline 52 & "Giná \\
\hline 53 & exercida pelo atleta, lançamento de \\
\hline 54 & nto de peso a física se encaixa um \\
\hline 55 & --- \\
\hline 56 & ente \\
\hline 57 & "Tode \\
\hline 58 & " Gir \\
\hline 59 & "Giná \\
\hline 60 & "Gin \\
\hline 61 & de peso, entre outros o levantamento de \\
\hline 62 & "Arre \\
\hline 63 & $\begin{array}{l}\text { s. Na corrida pois temos que ter força, velocidade } \\
\text { eercurso". }\end{array}$ \\
\hline 64 & stra os movimentos do corpo e quando eles \\
\hline 65 & $\begin{array}{l}\text { a, pedalar. É evidente na corrida na esteira onde quanto } \\
\text { locidade se obtém". }\end{array}$ \\
\hline 66 & \\
\hline
\end{tabular}




\begin{tabular}{|c|c|}
\hline & física pois utiliza muito o equilíbrio". \\
\hline 67 & "Corrida, ginástica, levantamento de peso, box". \\
\hline 68 & "Pode ser o levantamento de peso, ma lei de newton para calcular a força". \\
\hline 69 & "Artes marciais, usando a força e a velocidade para o oponente". \\
\hline 70 & "O atletismo, lutas. A luta usa a física também". \\
\hline 71 & "Corrida na esteira, levantamento de peso, a própria ginástica". \\
\hline 72 & $\begin{array}{l}\text { "Qualquer tipo de ginástica, levantamento de peso, corrida, levantamento de peso, } \\
\text { pois envolve dinâmica, você precisa de impulso, força e não fica parado". }\end{array}$ \\
\hline 73 & $\begin{array}{l}\text { "A corrida além de ajudar a prevenir doenças ajuda a perder calorias. E o } \\
\text { levantamento de peso que exige força, aquela bicicleta que exige velocidade". }\end{array}$ \\
\hline 74 & $\begin{array}{l}\text { "A corrida na esteira, levantamento de peso. A aplicação da corrida, pois conforme } \\
\text { você perde calorias e faz muito bem ara movimentar o corpo". }\end{array}$ \\
\hline 75 & $\begin{array}{l}\text { "Ginástica rítmica, levantamento de peso, entre outros. O levantamento de peso } \\
\text { utiliza muito o conceito da física pois você utiliza força". }\end{array}$ \\
\hline 76 & "Corrida, levantamento de peso, ginástica, todos envolvem a física". \\
\hline 77 & $\begin{array}{l}\text { "Antes de todo o esporte é bom alongar, eu acho que todos os esportes tem a ver } \\
\text { com a física". }\end{array}$ \\
\hline 78 & $\begin{array}{l}\text { "Qualquer tipo de esporte, porém todos exigem, em primeiro lugar, bom } \\
\text { alongamento. Em todos os esportes estão aplicados os conceitos da física, pois } \\
\text { todos tem um pouco de cada coisa". }\end{array}$ \\
\hline 79 & "Levantamento de peso, ginástica aeróbica: lei da gravidade, acústica". \\
\hline 80 & $\begin{array}{l}\text { "Musculação, aeróbica, dança, ginástica. Acho que a ginástica por causa da } \\
\text { flexibilidade que o corpo tem que adquirir". }\end{array}$ \\
\hline
\end{tabular}

6) A introdução do tópico: "A física dos esportes", auxiliaria você no aprendizado dos conteúdos de física? De que forma?

\begin{tabular}{|l|l|}
\hline 1 & $\begin{array}{l}\text { "Sim, de forma que eu possa utilizar mais a física para calcular distância altura e } \\
\text { etc, quando necessitar". }\end{array}$ \\
\hline 2 & --- \\
\hline 3 & "Sim, nos auxiliando a distância de alguma coisa". \\
\hline 4 & $\begin{array}{l}\text { "Talvez, pois no esporte há por trás dele sempre um conceito de física para que ele } \\
\text { seja realizado". }\end{array}$ \\
\hline 5 & "Hipismo e dinâmica e tem movimento". \\
\hline 6 & "Sim de forma de conscientizar as pessoas a gostar e praticar esportes". \\
\hline 7 & --- \\
\hline 8 & $\begin{array}{l}\text { "Bom de forma que aprendêssemos a saber fazer cálculos sobre velocidade, como } \\
\text { conseguem fazer piruetas e outros movimentos. Daí começa a surgir a curiosidade } \\
\text { sobre tudo isso". }\end{array}$ \\
\hline 9 & "Sim de forma de conscientizar as pessoas a gostar e praticar esportes". \\
\hline 10 & "A física está presente em tudo, cada movimento que você faz". \\
\hline 11 & "Auxilia a nos entendermos a gravidade, o atrito, o equilíbrio e outras coisas mais". \\
\hline 12 & $\begin{array}{l}\text { "Auxilia a aprendizagem sobre conceitos de física, força temperatura, equilíbrio, } \\
\text { etc.". }\end{array}$ \\
\hline 13 & $\begin{array}{l}\text { "Sim porque todos gostam de esportes, mas alguns tem medo de praticar, mas com } \\
\text { a física ele saberia como praticá-lo e ficaria mais fácil para exerce-lo" }\end{array}$ \\
\hline 14 & $\begin{array}{l}\text { "De forma que em cada modalidade se usa: força, velocidade, distância tempo e na } \\
\text { física é a mesma coisa". }\end{array}$ \\
\hline 15 & "Bem me ajudará no aspecto de ver e também perceber, a força, a velocidade, a \\
\hline
\end{tabular}




\begin{tabular}{|c|c|}
\hline & $\begin{array}{l}\text { distância, o tempo, etc., pois cada esporte tem alguma dessas coisas relacionadas é } \\
\text { usado nele, e também é utilizado na física". }\end{array}$ \\
\hline 16 & $\begin{array}{l}\text { "Sim com o acréscimo do esporte na matéria ajudaria no interesse de todos, já que } \\
\text { o esporte é algo que todos nós gostamos". }\end{array}$ \\
\hline 17 & $\begin{array}{l}\text { "Sim porque relata a física em sua relação aos esportes, mostrando sua ligação e } \\
\text { seu objetivo". }\end{array}$ \\
\hline 18 & $\begin{array}{l}\text { "Sim, o exemplo dos esportes, os movimentos feitos exercem energia, velocidade, } \\
\text { tempo é modo de exemplificar um tópico". }\end{array}$ \\
\hline 19 & $\begin{array}{l}\text { "Tudo que eu faço, por exemplo, estou andando de bicicleta tenho que ter } \\
\text { equilíbrio, força, velocidade e tudo isso tem a ver com a física". }\end{array}$ \\
\hline 20 & "Sim de que se pode medir uma certa velocidade de uma corrida". \\
\hline 21 & ---- \\
\hline 22 & $\begin{array}{l}\text { "Quando estou trabalhando eu preciso de força estabilidade e isso tem a ver com a } \\
\text { física". }\end{array}$ \\
\hline 23 & ----- \\
\hline 24 & $\begin{array}{l}\text { "Ajudaria, pois seria pelo menos mais divertido para mim (pois não gosto da } \\
\text { matéria)". }\end{array}$ \\
\hline 25 & $\begin{array}{l}\text { "Eu acho que não me ajudaria no momento, mas que eu saiba depois será } \\
\text { necessário". }\end{array}$ \\
\hline 26 & $\begin{array}{l}\text { "Sim descobrindo exatamente os conceitos da física no dia-a-dia, e nos esportes } \\
\text { comuns". }\end{array}$ \\
\hline 27 & $\begin{array}{l}\text { "Não porque não entenderia se falássemos de velocidade, por exemplo no esporte } \\
\text { eu não saberia entender na física". }\end{array}$ \\
\hline 28 & $\begin{array}{l}\text { "Não, pois não porque o esporte é ligado a física que eu iria me dar bem, em } \\
\text { alguma matéria relacionada a física". }\end{array}$ \\
\hline 29 & "Acho que em muitas porque muitos esportes precisam de raciocínio e precisão". \\
\hline 30 & "Sim porque o esporte pode deixar a aula mais divertida". \\
\hline 31 & "Com certeza. Aprendemos melhor quando nos é ensinado na prática". \\
\hline 32 & "Na prática de esporte você vive o lado prático". \\
\hline 33 & "sim é muito mais fácil aprender com exemplos que estão em nosso cotidiano". \\
\hline 34 & "Acho bastante, pois todos eles tem raciocínio". \\
\hline 35 & "Sim porque serve como exemplo prático para a física". \\
\hline 36 & $\begin{array}{l}\text { "Eu acho que sim, porque eu gosto de praticar muitos esportes e saber sobre eles, } \\
\text { saber os aspectos, pesquisar, com isso certamente ajuda a desenvolver mais sobre } \\
\text { física". }\end{array}$ \\
\hline 37 & "Sim, pois assim teríamos exemplos mais claros e fáceis de entender". \\
\hline 38 & "Sim porque nós aprenderíamos na pratica e de uma forma mais visível”. \\
\hline 39 & $\begin{array}{l}\text { "Sim pois entenderíamos mais e estaríamos aprendendo na pratica coisas que } \\
\text { acontecem no nosso dia-a-dia". }\end{array}$ \\
\hline 40 & $\begin{array}{l}\text { "Sim, pois assim teríamos exemplos fáceis de como a física está presente em várias } \\
\text { atividades, e nós muitas vezes nem notamos". }\end{array}$ \\
\hline 41 & $\begin{array}{l}\text { "Sim porque você lendo "a física dos esportes", você gostaria de saber o que é } \\
\text { física". }\end{array}$ \\
\hline 42 & $\begin{array}{l}\text { "Só se for para falar de gravidade. A física influencia muito no esporte, nós que } \\
\text { não percebemos". }\end{array}$ \\
\hline 43 & $\begin{array}{l}\text { "Sim de forma que o aprendizado ocorre no momento esportivo, explicando porque } \\
\text { cada movimento acontece". }\end{array}$ \\
\hline 44 & "Sim na forma de como os movimentos ocorrem". \\
\hline 45 & "Sim acho que se fosse ensinado física com esporte, ou em qualquer outra c \\
\hline
\end{tabular}




\begin{tabular}{|c|c|}
\hline & $\begin{array}{l}\text { que envolva prática, em que os alunos participem mais do que apenas copiar lição, } \\
\text { acho que despertaria mais o interesse deles e seria fácil de aprender pois teríamos } \\
\text { exemplo e contato. Não sei se é possível, mas seria muito produtivo". }\end{array}$ \\
\hline 46 & "Sim no nosso movimento, aceleração, etc.". \\
\hline 47 & "Me auxilia no dia-a-dia através de nosso andar correr, pular, etc.". \\
\hline 48 & $\begin{array}{l}\text { "Eu acho que sim, porque seria bom para auxiliar o aprendizado dos conteúdos de } \\
\text { física com dinâmica, óptica e acústica". }\end{array}$ \\
\hline 49 & "Sim pois iria auxiliar nos esportes praticando fazendo exercícios adequados". \\
\hline 50 & "Sim a física nos esportes é pode ser um bom exemplo praticando os esportes". \\
\hline 51 & $\begin{array}{l}\text { "Sim, porque para mim os esportes são mais comuns do que os nomes que se } \\
\text { aplicam na matéria de física". }\end{array}$ \\
\hline 52 & $\begin{array}{l}\text { "Sim, buscando de maneira mais fácil para calcular as dificuldades de cada } \\
\text { esporte". }\end{array}$ \\
\hline 53 & $\begin{array}{l}\text { "Sim, porque através dos esportes pode-se observar a utilização da força, } \\
\text { velocidade, equilíbrio, peso, etc.". }\end{array}$ \\
\hline 54 & "Não". \\
\hline 55 & "Sim porque os esportes podem ser observados os conceitos da física". \\
\hline 56 & $\begin{array}{l}\text { "Comparando os esportes com a física e mostrando que os esportes também tem, } \\
\text { equilíbrio e força, etc.". }\end{array}$ \\
\hline 57 & $\begin{array}{l}\text { "Sim com assuntos de esportes relacionados a física a explicação fica mais fácil de } \\
\text { entender". }\end{array}$ \\
\hline 58 & $\begin{array}{l}\text { "Sim, pois também aprenderíamos algo sobre os esportes e tmbém os cálculos de } \\
\text { física(pacote } 2 \text { em 1)". }\end{array}$ \\
\hline 59 & $\begin{array}{l}\text { "Sim porque tem alguns esportes que você tem que saber a distância, altura, a } \\
\text { força, etc. Esporte ajuda a física". }\end{array}$ \\
\hline 60 & "Não". \\
\hline 61 & "Sim para saber algumas coisas do esporte que tem haver com a física”. \\
\hline 62 & "Sim com mais vontade de aprender usando como modelos objetos e jogos". \\
\hline 63 & $\begin{array}{l}\text { "Sim da forma que eu aprenderia a velocidade que eu vou correr, o impulso que eu } \\
\text { vou ter que fazer, ou já fiz, a força que eu tenho entre outros". }\end{array}$ \\
\hline 64 & $\begin{array}{l}\text { "Sim porque vemos como é um corpo em movimento e o que acontece para ele } \\
\text { cair". }\end{array}$ \\
\hline 65 & $\begin{array}{l}\text { "Sim, pois além de saber o conteúdo da física, veríamos na prática onde se } \\
\text { encontra a força, velocidade, etc., então conseguiríamos compreender melhor". }\end{array}$ \\
\hline 66 & $\begin{array}{l}\text { "Auxiliaria no aprendizado, pois assim talvez poderíamos ver na prática a força, o } \\
\text { equilíbrio, o movimento, etc.". }\end{array}$ \\
\hline 67 & "Sim pois nós aprenderíamos na prática onde a física é aplicada". \\
\hline 68 & $\begin{array}{l}\text { "Sim porque nas salas de aula é só teoria e na pratica é melhor pois temos mais } \\
\text { facilidade come esportes". }\end{array}$ \\
\hline 69 & $\begin{array}{l}\text { "Sim, aprendi que usando força muda a velocidade que precisa, na maioria dos } \\
\text { esportes você tem chance". }\end{array}$ \\
\hline 70 & "Na ginástica porque usa força equilíbrio e velocidade". \\
\hline 71 & "Sim pois tem força, movimento equilíbrio, velocidade etc.". \\
\hline 72 & $\begin{array}{l}\text { "Sim auxiliaria nós no aprendizado, pois envolve todo um cálculo, gravidade, } \\
\text { distância entre um atleta e outro". }\end{array}$ \\
\hline 73 & $\begin{array}{l}\text { "Nos auxiliaria muito, porque temos que usar várias coisas que envolve a física e o } \\
\text { esporte". }\end{array}$ \\
\hline 74 & $\begin{array}{l}\text { "Um pouco de forma que envolve alguns conceitos que precisa do cálculo, do } \\
\text { impulso, força, etc.". }\end{array}$ \\
\hline
\end{tabular}




\begin{tabular}{|l|l|}
\hline 75 & $\begin{array}{l}\text { "Auxiliaria muito, principalmente no meu caso, eu pratico esportes, e quanto mais } \\
\text { estudar sobre ele melhor". }\end{array}$ \\
\hline 76 & "Sim nos cálculos". \\
\hline 77 & "Sim em todo o conteúdo de física, dinâmica e eletricidade". \\
\hline 78 & "Sim passamos a ter mais conhecimentos sobre a física com os esportes". \\
\hline 79 & "Sim auxiliaria pois seria uma maneira mais interessante e mais fácil de aprender". \\
\hline 80 & "Acho que sim pois poderíamos começar a ver os exercícios por outro ângulo". \\
\hline
\end{tabular}

7) Continue a frase (com pelo menos cinco linhas). Nas minhas atividades diárias percebo que a física está sempre presente, como por exemplo, ...

\begin{tabular}{|c|c|}
\hline 1 & $\begin{array}{l}\text { uando jogo futebol e preciso ter mais ou menos uma noção a qual a distânc } \\
\text { everei chutar a bola par alcança o gol, ou um companheiro do time". }\end{array}$ \\
\hline 2 & a saúde das pessoas ...”. \\
\hline 3 & $\begin{array}{l}\text { o fazer caminhada, ou até mesmo dentro de casa ao lavar louça, ou fazer } \\
\text { lalquer outro tipo de exercícios, nós não percebemos que tudo que fazemos é em } \\
\text { lação a ela". }\end{array}$ \\
\hline 4 & $\begin{array}{l}\text { a escola como ir passear, ter um exercício a ser realizado, medir altura, a cintura, } \\
\text { também de ver que o peso, comer alguma, observar as coisas ao redor, ou } \\
\text { mplesmente assistir a um programa relacionado a física". }\end{array}$ \\
\hline 5 & $\begin{array}{l}\text { a física está praticamente relacionada a tudo porque para lavar, passar, limpar } \\
\text { ocê precisa de movimento, velocidade e força". }\end{array}$ \\
\hline 6 & $\begin{array}{l}\text { Uando ouço música é relacionado a física, porque estudamos acústica e quando } \\
\text { tou lavando louça, posso calcular a velocidade e o tempo que eu termino de } \\
\text { var". }\end{array}$ \\
\hline 7 & $\begin{array}{l}\text { o movimento que eu faço, na força, na velocidade, na temperatura, etc., todos } \\
\text { ses tópicos estão relacionados ao esporte e física, como por exemplo no ciclismo } \\
\text { velocidade, nas lutas marciais a força". }\end{array}$ \\
\hline 8 & u seja óptica. São muitos deveres \\
\hline 9 & faço \\
\hline 10 & $\begin{array}{l}\text { to de } \\
\text { der a }\end{array}$ \\
\hline 11 & na a \\
\hline 12 & $\begin{array}{l}\text {-se a força um impulso em um deterr } \\
\text { e". }\end{array}$ \\
\hline 13 & $\begin{array}{l}\text { "Seu um jogador de vôlei e aplico muita força para } \\
\text { aplicamos a teoria que tudo vai em velocidade e o }\end{array}$ \\
\hline 14 & $\begin{array}{l}\text { "porque logo que levanto tenho que ter velocidade e agilidade pois acordo sempre } \\
\text { atrasada". }\end{array}$ \\
\hline 15 & \\
\hline
\end{tabular}




\begin{tabular}{|c|c|}
\hline & caminhada, então realmente a física está presente todo o tempo em nossas vidas". \\
\hline 16 & $\begin{array}{l}\text { "na aula de educação física, no jogo d futebol, onde aplicamos a lei da velocidade, } \\
\text { a lei de que toda ação gera uma reação com o chute e a defesa do goleiro, com o } \\
\text { tempo que esse mesmo goleiro tem que calcular para pegar a bola em tempo } \\
\text { correto evitando assim o gol, ou no basquete, onde calcularmos sem perceber a } \\
\text { distância da cesta e a velocidade que temos que jogar a bola para que ela caia } \\
\text { dentro da mesma marcando pontos". }\end{array}$ \\
\hline 17 & $\begin{array}{l}\text { "na minha caminhada, pois ocorre um movimento que meu corpo, onde acho que a } \\
\text { física e a caminhada podem ser relacionadas". }\end{array}$ \\
\hline 18 & 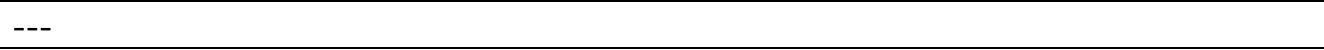 \\
\hline 19 & $\begin{array}{l}\text { "quando eu saio de casa para jogar bola, quando ando, quando estou limpando } \\
\text { alguma coisa, faço movimentos com os braços, quando estou carregando alguma } \\
\text { coisa ao levantar da cama tomar café, em trocar de roupa". }\end{array}$ \\
\hline 20 & $\begin{array}{l}\text { "na caminhada, a velocidade, quando pego um livro exerce uma energia, quando } \\
\text { subo na escada ou em cima do muro uso equilíbrio". }\end{array}$ \\
\hline 21 & 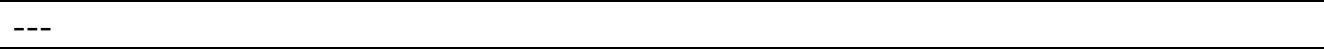 \\
\hline 22 & $\begin{array}{l}\text { "quando estou jogando bola porque estou correndo e necessito de habilidade e } \\
\text { muita força, quando estou trabalhando também preciso de muita força e } \\
\text { velocidade". }\end{array}$ \\
\hline 23 & -- \\
\hline 24 & $\begin{array}{l}\text { "quando deixo um corpo cair, pois aí a lei da gravidade entra em ação, ou então } \\
\text { quando vou tomar banho usa energia, para isso ela esquenta minha água, eu } \\
\text { também quando ligo o som ai entra acústica, geralmente ouço o rádio alto e fico } \\
\text { bem surdinha". }\end{array}$ \\
\hline 25 & $\begin{array}{l}\text { "quando eu corro muito com meu deslocamento também vem no arremesso e com } \\
\text { a atração na hora que cai e com meus saltos e analisando a distância de cada } \\
\text { jogada". }\end{array}$ \\
\hline 26 & $\begin{array}{l}\text { "ao sair de casa a caminhar, deslocamento, no trabalho movimentação, a óptica } \\
\text { sempre ao arrumar, a velocidade quando estou atrasada e a ação e reação quando } \\
\text { estou estressada". }\end{array}$ \\
\hline 27 & $\begin{array}{l}\text { "quando lavo louça, passo, limpo a casa, varro o chão, pois estou sempre em } \\
\text { movimento, assim como a física". }\end{array}$ \\
\hline 28 & $\begin{array}{l}\text { "andar, limpar a casa dançar, varrer, etc., embora sejam coisas bem simples, você } \\
\text { está se movimentando e evitando o sedentarismo, pois a todo momento você está se } \\
\text { movimentando". }\end{array}$ \\
\hline 29 & $\begin{array}{l}\text { "subir escadas, amarrar o calçado, pegar algo no alto do armário, varrer, tirar pó } \\
\text { dos móveis, escrever, escovar os dentes, lavar a louça, mesmo sendo coisas leves } \\
\text { de se fazer qu acho que ameniza um pouco o sedentarismo". }\end{array}$ \\
\hline 30 & $\begin{array}{l}\text { "quando estou ouvindo som penso muito na física, e qual volume eu posso } \\
\text { agüentar e quanto tempo". }\end{array}$ \\
\hline 31 & $\begin{array}{l}\text { "quando ando, há uma série de aplicações da física neste simples ato de me mover, } \\
\text { envolve força peso, distância, velocidade tempo gravidade, entre muitos outros } \\
\text { conceitos da física no meu dia-a-a-dia, também quando falo, quando ligo um } \\
\text { aparelho eletrônico, a física está presente em tudo o que faço". }\end{array}$ \\
\hline 32 & $\begin{array}{l}\text { "ouvindo física, preciso de eletricidade para ligar o rádio ou para sintonizar uma } \\
\text { freqüência para ouvir uma música ou fazendo escova no cabelo, ou até mesmo } \\
\text { utilizando o chuveiro". }\end{array}$ \\
\hline 33 & $\begin{array}{l}\text { "quando estou caminhando atrasada para o trabalho e tenho que aumentar a } \\
\text { velocidade porque a distância parece não diminuir, ao contrário do tempo e ao } \\
\text { mesmo tempo minha visão conseguir enxergar meu chefe voando (como se não }\end{array}$ \\
\hline
\end{tabular}




\begin{tabular}{|c|c|}
\hline & houvesse gravidade) em direção ao meu pescoço". \\
\hline 34 & "lavar louça, correr para pegar roupa, ligar a televisão, tudo ao nosso redor". \\
\hline 35 & $\begin{array}{l}\text { "nos esportes como futebol, natação atletismo ou no dia-a-dia como por exemplo, } \\
\text { um simples radar de velocidade que fica em rodovias". }\end{array}$ \\
\hline 36 & "na hora que levanto, já estou em movimento, vou lá fora a minha visão". \\
\hline 37 & $\begin{array}{l}\text { "na hora de tomar banho, quando o sabonete cai, ou quando estou me divertindo } \\
\text { em um jogo e logo chega a hora da novela, quando estou treinando artes marciais e } \\
\text { levo aquele soco no estômago, esses são alguns exemplos". }\end{array}$ \\
\hline 38 & $\begin{array}{l}\text { "quando vou trabalhar, faço uma caminhada que envolve gravidade, tempo que } \\
\text { demoro para chegar lá, distância. Quando desço de bicicleta tem a força que faço } \\
\text { para impulsionar, também tem distância e a velocidade e a força da gravidade". }\end{array}$ \\
\hline 39 & $\begin{array}{l}\text { "na caminhada que faço de casa até a casa da minha tia, quando pego algo e ele cai } \\
\text { no chão, quando faço algum jogo, quando ando de bicicleta, faço força para pegar } \\
\text { impulso, tem a velocidade e a força da gravidade que faz a gente cair". }\end{array}$ \\
\hline 40 & $\begin{array}{l}\text { "a velocidade para fazer coisas rápidas, na óptica e na acústica, na distância nos } \\
\text { lugares em que eu vou, na eletricidade dos aparelhos domésticos, nos movimentos } \\
\text { que que pratico e em muitas coisas". }\end{array}$ \\
\hline 41 & $\begin{array}{l}\text { "no atletismo com a física nós calculamos a velocidade e o percurso corrido, no } \\
\text { salto com vara, a velocidade e a altura". }\end{array}$ \\
\hline 42 & $\begin{array}{l}\text { "a distância em determinadas coisas, a serem medidas também as velocidade os } \\
\text { tempos, e com certeza o desgaste física por causa da temperatura relativo ao ar". }\end{array}$ \\
\hline 43 & $\begin{array}{l}\text { "no meu banho diário explicando como a eletricidade aquece minha água, como o } \\
\text { meu corpo esquenta e porque o meu corpo esfria ao sair do banho". }\end{array}$ \\
\hline 44 & $\begin{array}{l}\text { "aceleração, peso, impacto, eletricidade quanto tempo nos conseguimos ficar } \\
\text { correndo". }\end{array}$ \\
\hline 45 & $\begin{array}{l}\text { "quando ligo o chuveiro e percebo que a água sai quentinha, quando me olho no } \\
\text { espelho de tal ângulo e percebo que o reflexo sai de tal tamanho, quando escuto } \\
\text { rock no último volume, quando deixa cair o escorredor cheio de louça no } \\
\text { chão,minha mãe briga comigo". }\end{array}$ \\
\hline 46 & $\begin{array}{l}\text { "na caminhada porque percebo o quanto posso correr e o tempo do percurso em } \\
\text { que eu estou fazendo andar de bicicleta ajuda na hora de nossos movimentos e } \\
\text { marca quanto pedalamos" }\end{array}$ \\
\hline 47 & "a todo momento através vários fatores como a gravidade do planeta e etc" \\
\hline 48 & " no futebol e o basquete que nesses dois esportes eu uso a dinâmica e a óptica" \\
\hline 49 & $\begin{array}{l}\text { "fazendo educação física praticando esportes como vôlei ou fazendo algum } \\
\text { alongamento é muito importante para o ser humano". }\end{array}$ \\
\hline 50 & --- \\
\hline 51 & $\begin{array}{l}\text { "quando tomo banho gasto energia, quando vou me trocar preciso de velocidade } \\
\text { para não me atrasar, quando ando preciso fazer o deslocamento rápido". }\end{array}$ \\
\hline 52 & "na maneira de andar pular correr". \\
\hline 53 & $\begin{array}{l}\text { "quando utilizo um eletrodoméstico, como batedeira, máquina de lavar, de secar, } \\
\text { geladeira, utilizando eletricidade. Quando dirijo meu carro, observo a velocidade } \\
\text { com que ando, quando como algo vejo a temperatura". }\end{array}$ \\
\hline 54 & $\begin{array}{l}\text { "quando vou tomar banho, comer, ou beber, tenho que ver a temperatura, quando } \\
\text { vou assistir televisão ou ouvir música tenho que ajustar o volume, quando escurece } \\
\text { tenho que acender a luz e também utilizo eletricidade para ligar outros aparelhos } \\
\text { como secador de cabelo, maquina de lavar, etc.". }\end{array}$ \\
\hline 55 & --- \\
\hline 56 & "na hora do banho tenho que ver a temperatura da água, quando vou ouvir música, \\
\hline
\end{tabular}




\begin{tabular}{|c|c|}
\hline & tenho que modificar o volume e na academia tenho que ter força e equilíbrio". \\
\hline 57 & $\begin{array}{l}\text { "quando levanto da cama, quando ando, a distância que levo da minha casa para } \\
\text { escola, quantos km tem, o tempo que levo para chegar de um lugar para outro e a } \\
\text { velocidade". }\end{array}$ \\
\hline 58 & $\begin{array}{l}\text { "nos esportes para calcular saltos, movimentos, etc., também no cotidiano, quando } \\
\text { ando, me movimento, etc, ao derrubar algo no chão (lei de Newton), entre outras } \\
\text { coisas, resumindo, em tudo se precisa dela". }\end{array}$ \\
\hline 59 & $\begin{array}{l}\text { "corrida, saltos ornamentais, levantamento de peso, basquete, voleibol, hipismo } \\
\text { natação e ginástica artística, patinação e salto a distância". }\end{array}$ \\
\hline 60 & $\begin{array}{l}\text { "quando tomamos banho, comemos, primeiro tem que ver a temperatura, quando } \\
\text { vou assistir tv, escutar música, tem que ajustar o volume e para ligar outros } \\
\text { aparelhos como microondas, geladeira, computador, secador e etc., precisa da } \\
\text { eletricidade". }\end{array}$ \\
\hline 61 & $\begin{array}{l}\text { "quando vou ouvir uma música tenho que saber o volume certo, quando vou usar } \\
\text { algum eletrodoméstico tenho que ver se a eletricidade agüenta mais de dois } \\
\text { aparelhos ligado". }\end{array}$ \\
\hline 62 & $\begin{array}{l}\text { "no acender e apagar das luzes, abrir e fechar a torneira, varrer a casa, trocar uma } \\
\text { lâmpada, abrir a geladeira, ligar a televisão". }\end{array}$ \\
\hline 63 & $\begin{array}{l}\text { "na força que usamos para fazer os serviços de casa na eletricidade que usamos. E } \\
\text { depois de alguma aulas de física sabemos como as coisas funcionam e assim ficam } \\
\text { mais interessantes e mais fácil de ser entendida". }\end{array}$ \\
\hline 64 & $\begin{array}{l}\text { "quando nos acordamos os espreguiçamos, levantando o braço, ou quando } \\
\text { andamos porque medimos as pernas e quando agachamos e levantamos é física que } \\
\text { eu faço". }\end{array}$ \\
\hline 65 & $\begin{array}{l}\text { "quando acordamos e nos espreguiçamos, nosso corpo estava contraído e ao estica- } \\
\text { lo ele relaxa ao tomarmos banho vemos o contraste entre a temperatura do corpo } \\
\text { com a água, dependendo do tempo, se está calor queremos água mais fria, e se está } \\
\text { frio, a água mais quente, ao varrermos a casa, a força que empregamos na vassoura, } \\
\text { ao andarmos, corrermos, ao praticarmos esporte". }\end{array}$ \\
\hline 66 & $\begin{array}{l}\text { "quando caminho de casa até a escola uso o movimento, quando em meu trabalho } \\
\text { tenho que levar pilhas de coisas uso a força, quando estou atrasada com pressa uso } \\
\text { a velocidade, em todas as atividades seja no caminhar, correr, abaixar uso o } \\
\text { movimento". }\end{array}$ \\
\hline 67 & $\begin{array}{l}\text { "no futebol quando chuto a bola, nas competições de ginástica artística percebemos } \\
\text { que deve ter equilíbrio e força, assim na maioria dos esportes a física está presente } \\
\text { e podemos aprender com maior facilidade". }\end{array}$ \\
\hline 68 & "com a corrida porque assim podemos medir o tempo e velocidade". \\
\hline 69 & $\begin{array}{l}\text { "na sinuca, se eu bater com força que precisa para derrubar a bola ela cai, se for } \\
\text { menor ou maior pode sair da caçapa". }\end{array}$ \\
\hline 70 & $\begin{array}{l}\text { "em todas as modalidades, por exemplo, ginástica que leva bastante física, usa } \\
\text { força, equilíbrio, velocidade e com ajuda aprende e entende a física". }\end{array}$ \\
\hline 71 & $\begin{array}{l}\text { "correr fazer exercícios em que e relaciona com a física esteja presente, utiliza } \\
\text { força, caminhar, levantar algo puxar algo, pular subir algum objeto". }\end{array}$ \\
\hline 72 & $\begin{array}{l}\text { "quando eu corro para pegar ônibus porque estou atrasada estou envolvendo } \\
\text { velocidade, quando faço força ou trabalho com algo que não deixa eu ficar parada } \\
\text { envolve dinâmica". }\end{array}$ \\
\hline 73 & $\begin{array}{l}\text { "na minha corrida tenho que usar velocidade ou quando vou pegar alguma coisa } \\
\text { pesada, daí tenho que usar a minha força ou quando tenho que calcular a distância } \\
\text { de algum lugar tenho que usar os cálculos para saber a distância ou a força ou a } \\
\text { velocidade". }\end{array}$ \\
\hline
\end{tabular}




\begin{tabular}{|l|l|}
\hline 74 & $\begin{array}{l}\text { "quando vou caminhar eu perco calorias e quando corro também pois os } \\
\text { batimentos aumentam, a ginástica também porque você pega impulso, usa a força e } \\
\text { envolve um pouco de tudo". }\end{array}$ \\
\hline 75 & $\begin{array}{l}\text { "quando desenvolvo meus treinamentos de futsal, e em muitas outras atividades, } \\
\text { como por exemplo uma simples caminhada". }\end{array}$ \\
\hline 76 & $\begin{array}{l}\text { "quando caminho vindo para escola, quando ando de bicicleta, quando jogo vôlei, } \\
\text { quando vou a academia pratico bastante". }\end{array}$ \\
\hline 77 & $\begin{array}{l}\text { "serviço de casa, usamos a eletricidade, força, óptica, velocidade, acústica e } \\
\text { disposição". }\end{array}$ \\
\hline 78 & $\begin{array}{l}\text { "serviço de casa, usamos a eletricidade a força. No esporte que é uma das } \\
\text { atividades diárias, a física está presente no futebol, usa-se muita velocidade de } \\
\text { óptica, dinâmica, acústica e força". }\end{array}$ \\
\hline 79 & $\begin{array}{l}\text { "a eletricidade pois ela é útil em muitas ocasiões, como ouvir música, tomar banho, } \\
\text { etc.". }\end{array}$ \\
\hline 80 & ---- \\
\hline
\end{tabular}

Questionário $\mathrm{Q}_{\underline{0}}$ - ESCOLA PARTICULAR

Questão1

81 "O esporte é importante de várias formas na vida do ser humano desde o fator saúde até o fator interação até o fator educação".

82 "Sobretudo podemos analisar que o esporte se resume a lazer, os esportes saudáveis fazem bem a saúde, liberam substâncias que dão uma sensação de bem estar".

83 "O esporte é importante na vida do ser humano, pois é uma trás uma sensação de bem estar e ajuda prevenir problemas de saúde, pois a partir do momento que um indivíduo alonga seus músculos eles estão compartilhando para uma vida saudável cheia de disposição e não sedentária".

84 "O esporte para saúde física e mental. Um físico bom aumenta a auto-estima de qualquer pessoa, consequentemente, aumenta também o bem-estar psicológico".

85 "O esporte é muito importante para o ser humano, pois faz melhorar a auto-estima e seu condicionamento físico".

86 "A importância do esporte em nossa vida é muito grande, pois só através dele podemos manter boa qualidade de vida, com saúde, alegria e principalmente disposição em superar desafios".

87 "O esporte é importante na vida do ser humano porque é uma forma de lazer, trás prazer ao mesmo tempo que traz benefícios a nossa saúde, é uma maneira que você achar para descarregar energia, o estresse do dia-a-dia".

88 "O esporte é muito importante na vida do ser humano, pois quando se faz ou se pratica algum tipo de esporte assim sendo caminhada, ginástica, academia, etc., vive-se muito bem sem problemas".

89 "O esporte é muito importante para várias áreas do ser humano, como manter uma vida saudável e se livrar de várias doenças que muitas pessoas sedentárias podem ter, trazer bem estar e prazer a quem pratica".

90 "O esporte na vida do homem é necessário para a queima de gorduras para que assim não desenvolva doenças cardiovasculares".

Questão 2 


\begin{tabular}{|l|l|}
\hline 81 & $\begin{array}{l}\text { "Musculação e futebol de campo, para o desempenho é preciso uma boa } \\
\text { alimentação para obter energia, disciplina no futebol por ser um jogo coletivo e na } \\
\text { musculação para obter resultados". }\end{array}$ \\
\hline 82 & "Maratona, para se praticar maratona é necessário fôlego, resistência e velocidade". \\
\hline 83 & "Eu pratico dança contemporânea para desempenhá-la é preciso ter flexibilidade". \\
\hline 84 & $\begin{array}{l}\text { "Frequente somente a educação física e caminhada uma vez por semana. Um tênis } \\
\text { apropriado e roupas confortáveis é a melhor coisa pra se praticar esportes". }\end{array}$ \\
\hline 85 & $\begin{array}{l}\text { "Futebol, para praticá-lo antes ter um aquecimento, ter conhecimentos das regras e } \\
\text { ter times de pelo menos cinco pessoas". }\end{array}$ \\
\hline 86 & $\begin{array}{l}\text { "Eu pratico diariamente musculação (halterofilismo) onde é necessário uma } \\
\text { excelente alimentação e suplementação força, disposição, dedicação e propensão } \\
\text { genética. Pratico semanalmente futebol em fins de semana, precisando de } \\
\text { velocidade, inteligência e habilidade". }\end{array}$ \\
\hline 87 & $\begin{array}{l}\text { "Dança, natação, ambos exigem flexibilidade, muito alongamento, elasticidade dos } \\
\text { músculos, velocidade". }\end{array}$ \\
\hline 88 & $\begin{array}{l}\text { "Eu pratico musculação, para eu desempenha-la com sucesso preciso estar bem } \\
\text { descansado, bem alimentado e com um bom preparo físico para aguentar fazer bem } \\
\text { e certo os exercícios". }\end{array}$ \\
\hline 89 & "Não pratico esportes". \\
\hline 90 & $\begin{array}{l}\text { "Semanalmente pratico artes marciais, para desenvolver com maestria é preciso } \\
\text { paciência e muito treino". }\end{array}$ \\
\hline
\end{tabular}

Questão 3

\begin{tabular}{|l|l|}
\hline 81 & "EF, F, B, M, FIL, Q, H, G, EA, P" \\
\hline 82 & "EF, F, B,FIL" \\
\hline 83 & "EF, B, F, Q, M, EA, FIL, H” \\
\hline 84 & "EF, B, Q, F, M, G, FIL, EA, H” \\
\hline 85 & "EF, F, M, Q, FIL, H, G, ,P, EA, B" \\
\hline 86 & "EF, F, B, Q, G, H, P, M" \\
\hline 87 & "EF, B, F, Q, EA, H, G, FIL, M" \\
\hline 88 & "EF, F, M, FIL, EA, B, Q, G, H, P" \\
\hline 89 & "EF, F, M, B, Q, G, H, FIL” \\
\hline 90 & "EF, F, M, Q, FIL, H, G, EA, P, B" \\
\hline
\end{tabular}

Questão 4

\begin{tabular}{|c|l|}
\hline 81 & "Halterofilismo: dinâmica do movimento, pode calcular força e tração exercida \\
pelo atleta. & Corrida: cinética, calcular distância, aceleração, tempo. \\
& Musculação: acoplamento de polias, calcular o peso real exercido pelo atleta. \\
Iatismo: cinemática, velocidade barco/água, velocidade correnteza. \\
Automobilismo: tudo, tudo. \\
Lançamento de peso: lançamento, calcular rota". \\
\hline 82 & $\begin{array}{l}\text { "Formula 1: mecânica, funcionamento dos carros. } \\
\text { Arremesso de peso: força de intensidade, aplicação da força. } \\
\text { Corrida: velocidade, aplicação da velocidade, corrida". }\end{array}$ \\
\hline 83 & $\begin{array}{l}\text { "Corrida: velocidade, ao correr podemos medir a velocidade para testar a } \\
\text { resistência do corpo. } \\
\text { Natação: massa, intensidade, podemos medir a massa que está nadando. } \\
\text { Vôlei: intensidade, a intensidade da força que o jogador bate a bola". }\end{array}$ \\
\hline
\end{tabular}




\begin{tabular}{|c|c|}
\hline & $\begin{array}{l}\text { "Natação: hidrostática, o corpo lida com a densidade. } \\
\text { Velocista: cinemática, aplica a leis da velocidade. } \\
\text { Atletismo: força, força exercida nos aparelhos. } \\
\text { Vôlei: lançamento vertical, a bola é jogada para cima inúmeras vezes. } \\
\text { Futebol: trabalho, aplica conceitos do trabalho necessário para ser utilizado na } \\
\text { atividade. } \\
\text { Remo: velocidade, trabalha com a velocidade da água, do vento". }\end{array}$ \\
\hline 85 & $\begin{array}{l}\text { "Fórmula 1:cinemática, movimentação. } \\
\text { Futebol: estática, conceito de força. } \\
\text { Vôlei: estática: uma força em relação a um ponto". }\end{array}$ \\
\hline 86 & $\begin{array}{l}\text { "Maratona: cinética, calculo de velocidade e aceleração. } \\
\text { Natação: hidrostática, movimento na piscina. } \\
\text { Musculação: dinâmica dos movimentos, pesos. } \\
\text { Corrida automobilística, MHS, velocidade em circuito oval. } \\
\text { Futebol: cinética, cálculo da velocidade e movimentos em campo. } \\
\text { Golfe: MHS, movimento circular da bolinha/ Pêndulos: pendular do taco". }\end{array}$ \\
\hline 87 & $\begin{array}{l}\text { "Natação: empuxo, velocidade, a força aplicada pelo corpo sobre a densidade da } \\
\text { água. } \\
\text { Vôlei: força, força do jogador. } \\
\text { Dança: velocidade, velocidade do corpo para realizar movimentos". }\end{array}$ \\
\hline 88 & $\begin{array}{l}\text { "Natação: cinética, medir a massa que está nadando. } \\
\text { Corrida: velocidade, ao correr podemos medir. } \\
\text { Vôlei: intensidade, intensidade do jogador na bola. } \\
\text { Corrida automobilística: mhs, velocidade circuito oval. } \\
\text { Musculação: dinâmica dos movimentos, pesos. } \\
\text { Futebol: cinética, calculo das velocidades do corpo". }\end{array}$ \\
\hline 89 & $\begin{array}{l}\text { "Vôlei: cinemática, a velocidade com que a bola cai no chão. } \\
\text { Futebol: energia, intensidade de energia para chutar a bola. } \\
\text { Lançamento: trabalho, trabalho da energia potencial quando o peso chegar a } \\
\text { determinada altura". }\end{array}$ \\
\hline 90 & $\begin{array}{l}\text { "Hafiting: hidrostática, o projeto do trajeto. } \\
\text { Fórmula 1: cinemática, planejamento na pista. }\end{array}$ \\
\hline
\end{tabular}

Questão 5

\begin{tabular}{|l|l|}
\hline 81 & "Musculação, spining". \\
\hline 82 & $\begin{array}{l}\text { "Levando em consideração os halteres, peso, esteira, bicicleta, podemos citar: } \\
\text { levantamento de peso, corrida, cooper, caminhada, etc. Em todas elas há a } \\
\text { aplicação da física, mas na esteira elétrica os mostradores de velocidade, tempo, } \\
\text { distância e calorias perdidas, isso acaba sendo mais acessível ao indivíduo que } \\
\text { freqüenta a academia". }\end{array}$ \\
\hline 83 & "Leg-press, usa força e flexibilidade". \\
\hline 84 & $\begin{array}{l}\text { "Correr, musculação, leg-press. A musculação utiliza conceitos de força, trabalho, } \\
\text { dinâmica, velocidade". }\end{array}$ \\
\hline 85 & $\begin{array}{l}\text { "Futebol, para praticá-lo antes ter um aquecimento, ter conhecimentos das regras e } \\
\text { ter e ter dois times de cinco pessoas pelo menos". }\end{array}$ \\
\hline 86 & $\begin{array}{l}\text { "Musculação, artes marciais, box, corrida, bicicleta e natação, onde é mais evidente } \\
\text { a física e na musculação". }\end{array}$ \\
\hline 87 & "Musculação, os aparelhos que estimulam o corpo a força". \\
\hline
\end{tabular}




\begin{tabular}{|l|l|}
\hline 88 & "Todos: musculação, natação, hidrostática, spining, dança". \\
\hline 89 & "Levantamento de peso, bicicleta". \\
\hline 90 & ---- \\
\hline
\end{tabular}

Questão 6

\begin{tabular}{|l|l|}
\hline 81 & "É muito mais fácil aprender se você sabe onde vai aplicar". \\
\hline 82 & $\begin{array}{l}\text { "Sim, porque toda forma de aprendizagem, quando sintetizado, por exemplo, } \\
\text { tornou-se mais fácil". }\end{array}$ \\
\hline 83 & $\begin{array}{l}\text { "Pois a parte teórica não é suficiente, para sabermos onde aplicar por exemplo no } \\
\text { esporte". }\end{array}$ \\
\hline 84 & $\begin{array}{l}\text { "Sim, pois conceitos de física que são aprendidos na teoria podem ser aprendidos } \\
\text { também na prática, quando se pratica esportes". }\end{array}$ \\
\hline 85 & "Na forma como é feito o esporte". \\
\hline 86 & $\begin{array}{l}\text { "Sim auxiliaria muito, pois o aprendizado aplicado na prática que nos acompanha } \\
\text { no cotidiano sempre facilita o entendimento e compreensão". }\end{array}$ \\
\hline 87 & $\begin{array}{l}\text { "Por exemplo quando você está nadando a sua massa, sobre a densidade da água e } \\
\text { a velocidade aplicada". }\end{array}$ \\
\hline 88 & $\begin{array}{l}\text { "Ajuda muito porque na maioria fica mais fácil aprender quando colocamos a física } \\
\text { em algum esporte fica mais fácil de aprender". }\end{array}$ \\
\hline 89 & $\begin{array}{l}\text { "Porque física só na teoria não é o suficiente precisamos saber onde aplica-las no } \\
\text { dia-a-dia no caso dos esportes". }\end{array}$ \\
\hline 90 & "No estudo dos diversos esportes em que a física é aplicada". \\
\hline
\end{tabular}

Questão 7

81 "nas minhas atividades diárias".

82 "costumo calcular o tempo que percorre em uma determinada distância, assim como procuro saber em qual velocidade estou atingindo".

83 "pois corremos, nos movimentos mesmo sem querer estamos nos movimentando e usamos a física e a educação física".

84 "nas minhas atividades físicas, na utilização de aparelhos elétricos, na simples atitude de carregar alguma coisa, preparar a comida".

85 "de manhã acordo para ir a escola, de tarde pratico esportes. No dia-a-dia você faz muitas coisas de física".

86 "no cálculo das distâncias percorridas a pé ou de carro, na academia, nas questões de eletricidade e termodinâmica".

87 "nos exercícios físicos diariamente ouvindo música existe a propagação do som, por exemplo quando estamos andando de trem existe uma força atuando sobre o trem o peso a normal, em tudo se aplica a física".

88 "na academia quando eu pratico meus exercícios, assim quando calculo o tempo fazendo em conjunto com a velocidade sem conciliar as duas fazendo menos tempo com uma boa velocidade, e também calculando a força ou a quantia de peso que realizo meus exercícios".

89 "nos exercícios que pratico nas coisas ao meu redor, tudo a física é aplicada como a força a energia que aplica em algo".

90 "andando de moto o efeito centrífugo que age sobre a moto, a cinemática que está presente em trajetos feitos de carro, na academia os aparelhos que ajudam a desenvolver o princípio da tração. Em todas nossas atividades diárias está presente os conceito físicos aprendidos em sala de aula". 


\section{A1.2. Questionário $Q_{1}$}

As férias terminaram, portanto vamos retomar alguns tópicos vistos no ano anterior. Não se preocupe se está certo ou errada sua reposta, a intenção é avaliar seu poder de argumentação.

1) Dos conteúdos de física que foram abordados no ano passado, qual lhe chamou mais atenção? Dê uma explicação convincente?

\begin{tabular}{|c|c|}
\hline 1 & $\begin{array}{l}\text { "Movimento uniforme, porque ele usa quase todas as fórmulas que aprendi } V=V_{o} \\
+ \text { at e } S=S_{o}+V_{o} t+1 / 2 a t^{2} \text {." }\end{array}$ \\
\hline 2 & $\begin{array}{l}\text { "Movimento uniforme, porque usa quase todas as fórmulas (se bem que a física } \\
\text { não entra muito bem na minha cabeça)." }\end{array}$ \\
\hline 3 & “Aceleração escalar média". \\
\hline 4 & $\begin{array}{l}\text { "Cheguei a estudar muito pouco, num pequeno resumo o que é força, esse foi o } \\
\text { assunto da física que mais chamou atenção. Porque a física trata o comportamento } \\
\text { das coisas no espaço e no tempo e a força me chamou atenção porque é uma coisa } \\
\text { que está e acontece comigo, que as vezes parece obvia, mas que eu nunca tinha } \\
\text { parado pra pensar e estudar mais". }\end{array}$ \\
\hline 5 & $\begin{array}{l}\text { "Eu gostei de vários conteúdos, mas um dos que mais gostei foi energia potencial, } \\
\text { pois entendi a explicação que a professora nos seu fazendo com que eu conseguisse } \\
\text { executar os exercícios sem o menor problema". }\end{array}$ \\
\hline 6 & $\begin{array}{l}\text { "Deslocamento, pois ficamos um bom tempo estudando esse tema, e com isso me } \\
\text { acostumei e gostei de fazer esses cálculos". }\end{array}$ \\
\hline 7 & "Força e pressão porque é muito usado em nosso dia-a-dia". \\
\hline 8 & "Forçc \\
\hline 9 & "Movi \\
\hline 10 & "Força \\
\hline 11 & "Força \\
\hline 12 & "A mat \\
\hline 13 & "O conteúdo que mais gostei $\mathrm{S}=\mathrm{S}_{\mathrm{o}}+\mathrm{vt}$, pois é a fórmula do sorvete". \\
\hline 14 & $\begin{array}{l}\text { "Sobre velocidade, aceleração e desaceleração, por gostar muito de carros e } \\
\text { velocidade". }\end{array}$ \\
\hline 15 & $\begin{array}{l}\text { "Comecei a ver o conhecimento sobre o que é força essa matéria me chamou muita } \\
\text { atenção, mais não cheguei a me aprofundar nos estudos". }\end{array}$ \\
\hline 16 & $\begin{array}{l}\text { "No ano passado na escola onde eu estudava eu não tive professor de física, ele só } \\
\text { veio nas primeiras aulas, eu só aprendi a fórmula } S=S_{0}+\text { vt e uma outra que eu me } \\
\text { esqueci". }\end{array}$ \\
\hline 17 & $\begin{array}{l}\text { "O MUV, pois foi a ultima matéria que aprendi e também porque usa quase todas } \\
\text { as fórmulas". }\end{array}$ \\
\hline 18 & $\begin{array}{l}\text { "Eu não sei o nome mas o que eu mais gostei foi aquele que você se joga na } \\
\text { parede, acho que é ação e reação, depois daquela aula que eu me interessei mais } \\
\text { por aquele conteúdo". }\end{array}$ \\
\hline 19 & $\begin{array}{l}\text { "Movimento Uniformemente variado, porque ele aborda quase todas as fórmulas } \\
\text { que aprendi } V=V_{o}+\text { at e } S=S_{o}+V_{o} t+1 / 2 a t^{2} \text {." }\end{array}$ \\
\hline 20 & $\begin{array}{l}\text { "Movimento Uniformemente variado, porque ele aborda quase todas as fórmulas } \\
\text { que aprendi } V=V_{0}+\text { at e } S=S_{0}+V_{0} t+1 / 2 a t^{2} \text {." }\end{array}$ \\
\hline 21 & $\begin{array}{l}\text { "Movimento Uniformemente variado, porque ele aborda quase todas as fórmulas } \\
\text { que aprendi } V=V_{0}+\text { at e } S=S_{0}+V_{0} t+1 / 2 a t^{2} \text {." }\end{array}$ \\
\hline 22 & "Eu gostei de vários conteúdos, mas o que me chamou atenção foi a energia \\
\hline
\end{tabular}




\begin{tabular}{|l|l|}
\hline & cinética" \\
\hline 23 & $\begin{array}{l}\text { "Eu gostei de vários conteúdos, mas o que mais me chamou atenção foi a energia } \\
\text { potencial, pois a professora explica muito bem". }\end{array}$ \\
\hline 24 & $\begin{array}{l}\text { "O movimento uniformemente variado, pelo fato de a velocidade variar conforme o } \\
\text { tempo". }\end{array}$ \\
\hline 25 & $\begin{array}{l}\text { "Força e pressão porque eu acho que a gente usa no nosso dia-a-dia é bastante } \\
\text { legal" }\end{array}$ \\
\hline 26 & "Gostei mais de energia". \\
\hline 27 & $\begin{array}{l}\text { "Gostei de vários conteúdos, mais o que mais me chamou atenção foi o da } \\
\text { energia". }\end{array}$ \\
\hline
\end{tabular}

2) Dentre os conteúdos do ano passado selecione dois e descreva como cada um se relaciona com o seu dia-a-dia?

\begin{tabular}{|c|c|}
\hline 1 & $\begin{array}{l}\text { "As lições com gráficos que graças a ela nós podemos fazer qualquer gráfico que } \\
\text { podemos usar em matemática". }\end{array}$ \\
\hline 2 & "Gráficos porque com a aprendizagem dela nos podemos fazer qualquer gráfico". \\
\hline 3 & "Repouso e movimento, deslocamento". \\
\hline 4 & $\begin{array}{l}\text { Cinemática: venho de ônibus pra escola, sei qual o caminho que ele deve seguir, } \\
\text { mas não me preocupo o tempo que ele gasta, a velocidade. Força: quando estou } \\
\text { parada, para me mover para escrever por exemplo tenho ação de uma força". }\end{array}$ \\
\hline 5 & $\begin{array}{l}\text { "Potência: um aparelho de som quando é mais potente que o outro, transforma mais } \\
\text { energia elétrica em energia sonora em pouco tempo } \\
\text { Quantidade de movimento: uma pessoa empurrando um carrinho de bebe, o vento } \\
\text { empurrando um barco a vela, uma pessoa arremessando um disco". }\end{array}$ \\
\hline 6 & $\begin{array}{l}\text { "Cinemática: ir a um lugar, sabe onde fica, mas não se preocupar com o tempo e a } \\
\text { velocidade. Força: quando estou pronta pra fazer algo". }\end{array}$ \\
\hline 7 & "Força ao empurrar uma cadeira e ação e reação ao empurrar alguém". \\
\hline 8 & "Força ao empurrar algo". \\
\hline 9 & $\begin{array}{l}\text { As atividades com gráficos, porque podemos usar também com muitas outras } \\
\text { coisas por exemplo a matemática". }\end{array}$ \\
\hline 10 & $\begin{array}{l}\text { "Força ao empurrar algum objeto ou alguma outra coisa, ação e reação ao empurrar } \\
\text { uma pessoa". }\end{array}$ \\
\hline 11 & "Força para empurrar algum objeto ação e reação ao empurrar uma pessoa". \\
\hline 12 & $\begin{array}{l}\text { "Bom a professora explica muito bem a matéria, porém não me esforcei muito no } \\
\text { ano passado mas nesse ano pretendo me esforçar a aprender". }\end{array}$ \\
\hline 13 & $\begin{array}{l}\text { "Bem a senhora ensinou vários conteúdos mas não como não gosto de física } \\
\text { aprendi mas não me esforcei muito para fazer a formulas sei que elas são muito } \\
\text { importantes em nossas vidas mais não gosto". }\end{array}$ \\
\hline 14 & "Na maioria porque não sou muito bom com cálculos". \\
\hline 15 & $\begin{array}{l}\text { "Força: quando estou parada, para me mover, para escrever tenho ação de uma } \\
\text { força. Cinemática: venho de ônibus até a escola, sei qual é o seu trajeto, mais não } \\
\text { me importa com o tempo, a velocidade". }\end{array}$ \\
\hline 16 & $\begin{array}{l}\text { "Bom como a senhora já percebeu eu não tive muito conteúdo o ano passado, mas } \\
\text { acho que a fórmula do sorvete serve por exemplo para calcular a distância que um } \\
\text { carro percorre e o tempo que ele utilizou para percorrer esta determinada } \\
\text { distância". }\end{array}$ \\
\hline 17 & $\begin{array}{l}\text { "Como fazer gráficos que foi muito útil também na aula de matemática. E a } \\
\text { aceleração escalar média que tem a ver com tudo aquilo que aumenta a velocidade }\end{array}$ \\
\hline
\end{tabular}




\begin{tabular}{|l|l|}
\hline & média dos carros". \\
\hline 18 & "Acho que só ação e reação porque quase tudo que a gente faz tem uma reação". \\
\hline 19 & $\begin{array}{l}\text { "As lições com gráfico que graças a ela nos podemos fazer qualquer gráfico que } \\
\text { pudermos principalmente os de matemática. A aceleração escalar média trata de } \\
\text { quando o movimento de um corpo muda de valor no decorrer do tempo". }\end{array}$ \\
\hline 20 & $\begin{array}{l}\text { "As lições com gráfico que graças a ela nos podemos fazer qualquer gráfico que } \\
\text { pudermos principalmente os de matemática. A aceleração escalar média trata de } \\
\text { quando o movimento de um corpo muda de valor no decorrer do tempo". }\end{array}$ \\
\hline 21 & $\begin{array}{l}\text { "As lições com gráfico que graças a ela nos podemos fazer qualquer gráfico que } \\
\text { pudermos principalmente os de matemática". }\end{array}$ \\
\hline 22 & $\begin{array}{l}\text { "Quantidade uma pessoa arremessando uma lança e uma pessoa empurrando um } \\
\text { carro". }\end{array}$ \\
\hline 23 & "Potência: o meu rádio pois de transforma energia elétrica em energia sonora". \\
\hline 24 & $\begin{array}{l}\text { "O MUV quando você está andando de carro. Peso de um corpo quando se mede } \\
\text { na balança". }\end{array}$ \\
\hline 25 & $\begin{array}{l}\text { "Força para carregar um objeto para chutar a bola. Velocidade correr para pegar o } \\
\text { ônibus e para o recreio". }\end{array}$ \\
\hline 26 & $\begin{array}{l}\text { "Quantidade, uma pessoa empurra um automóvel, uma pessoa jogando algum } \\
\text { objeto". }\end{array}$ \\
\hline 27 & "Quantidade uma pessoa arremessa uma bola e uma pessoa empurra um carro". \\
\hline
\end{tabular}

3) Em quais conteúdos você teve mais dificuldade? Por quê?

\begin{tabular}{|l|l|}
\hline 1 & "Nas equações, porque eram muito difíceis". \\
\hline 2 & "Equações, dependendo da fórmula me confundo" \\
\hline 3 & $\begin{array}{l}\text { "Tive bastante dificuldade em aceleração escalar média, porque foi difícil entender } \\
\mathrm{V}_{1}, \mathrm{~V}_{2}, \mathrm{t}_{1}, \mathrm{t}_{2} \text { ". }\end{array}$ \\
\hline 4 & $\begin{array}{l}\text { "No ano passado cheguei até a cinemática vetorial, estudei bastante deslocamento, } \\
\text { velocidade média escalar, movimento uniforme. Acho que tive dificuldade mesmo } \\
\text { nas interpretações dos problemas e com as fórmulas. Porque acabavam me } \\
\text { confundindo, acho que o conteúdo que menos me atrapalhou foi o vetor oposto, } \\
\text { que estudei bem pouco". }\end{array}$ \\
\hline 5 & $\begin{array}{l}\text { "Eu tive mais dificuldades no conteúdo teorema da energia cinética, porque eu } \\
\text { confundia na hora de usar as fórmulas para montar a equação". }\end{array}$ \\
\hline 6 & $\begin{array}{l}\text { "Tive um pouco de dificuldade com alguns problemas mas não tive um tema } \\
\text { absoluto em que fiquei com dúvidas". }\end{array}$ \\
\hline 7 & "Na verdade, todos os conteúdos antes de aprender tive algumas dificuldades". \\
\hline 8 & "Alguns conteúdos, e tive algumas dificuldades antes de aprender". \\
\hline 9 & "Os conteúdos que exigem fórmulas, não entendo nada". \\
\hline 10 & "Todos os conteúdos antes de aprender tive algumas dificuldades". \\
\hline 11 & "Em quase todos, pois antes de aprender era tudo muito difícil". \\
\hline 12 & "Matemática e física, porque tem que fazer muitas contas". \\
\hline 13 & $\begin{array}{l}\text { "Física e matemática, porque eu não gosto dessas matérias, mesmo a professora } \\
\text { sendo ótima, assim como a senhora". }\end{array}$ \\
\hline 14 & "Na maioria, porque não sou bom em cálculos". \\
\hline 15 & $\begin{array}{l}\text { "Tive dificuldades na resolução de alguns problemas, mais não me lembro da } \\
\text { matéria especificamente" }\end{array}$ \\
\hline 16 & "Praticamente todos, pois eu não estudei nenhum". \\
\hline 17 & "No começo, quando tinha que interpretar o problema para montar as fórmulas". \\
\hline 18 & "Quase todos, porque eu tinha preguiça de estudar, mas se me dessem a fórmula eu \\
\hline
\end{tabular}




\begin{tabular}{|l|l|}
\hline & resolvia, mas para achar a fórmula era muito difícil". \\
\hline 19 & $\begin{array}{l}\text { "Nas equações, porque eram muito difíceis, não dependia só da fórmula, mais da } \\
\text { interpretação da pergunta". }\end{array}$ \\
\hline 20 & $\begin{array}{l}\text { "Nas equações, porque eram muito difíceis, não dependia só das fórmulas mas da } \\
\text { interpretação". }\end{array}$ \\
\hline 21 & $\begin{array}{l}\text { "Nas equações, porque eram muito difíceis, não dependia só da fórmula , mas da } \\
\text { interpretação da pergunta". }\end{array}$ \\
\hline 22 & "Na parte da energia cinética, porque eu prestei muita atenção". \\
\hline 23 & $\begin{array}{l}\text { "Eu tive dificuldade no conteúdo teorema da energia cinética, porque eu confundia } \\
\text { na hora de usar as fórmulas". }\end{array}$ \\
\hline 24 & "Energia mecânica, por causa das fórmulas e dos cálculos muito complicados". \\
\hline 25 & "Aceleração centrípeta, primeiro por ser difícil e segundo falta de prestar atenção". \\
\hline 26 & "Agora é mais fácil, mas antes eu me complicava para lembrar as fórmulas". \\
\hline 27 & "Nos conteúdos de fórmulas, pois eu me compliquei um pouco". \\
\hline
\end{tabular}

4) Construa uma frase ou uma historinha utilizando palavras relacionadas à física e aos esportes, de no mínimo 5 linhas.

\begin{tabular}{|l|l|}
\hline 1 & ---- \\
\hline 2 & $\begin{array}{l}\text { "Quando estamos fazendo alguns esportes a física está sempre presente, por } \\
\text { exemplo quando estamos jogando handball e batemos em alguém, aí entre a lei da } \\
\text { física. Dois corpos não ocupam o mesmo lugar no espaço, quando jogamos a bola } \\
\text { usamos uma enorme força física". }\end{array}$ \\
\hline 3 & "É preciso saber sobre física para praticar o esporte". \\
\hline 4 & "O esporte nos leva a física e a física nos leva ao estudo do esporte". \\
\hline 5 & $\begin{array}{l}\text { "Uma pessoa de massa 70kg prática beisebol, ao arremessar a bolas a pessoa com } \\
\text { uma velocidade de 30km/h e esbarra em outro jogador, com a força que exerceu } \\
\text { sobre ele, ele é arremessado para trás, pois toda ação tem uma reação". }\end{array}$ \\
\hline 6 & $\begin{array}{l}\text { "Um belo rapaz estava indo todo irritado para um treino de futebol. E no caminho } \\
\text { de seu treino ele começou se acalmar, e sua velocidade que estava alta, começou } \\
\text { abaixar. Com isso, ele ainda conseguiu uma carona, pois seu amigo estava em uma } \\
\text { velocidade de aproximadamente de 80km/h, que conseguiu alcançá-lo". }\end{array}$ \\
\hline 7 & ---- \\
\hline 8 & $\begin{array}{l}\text { "A física é muito presente nos esportes que praticamos. Está no contato entre } \\
\text { pessoas e objetos, por exemplo quando a gente joga bola o contato entre a bola e as } \\
\text { pessoas faz com a bola é chamado força ou explicando mais detalhadamente } \\
\text { quando a superfície dos corpos se tocam". }\end{array}$ \\
\hline 9 & $\begin{array}{l}\text { "Os esportes exigem muito contato e física, um exemplo é o vôlei que tem o } \\
\text { contato com a bola que pode se chamar de força, por exemplo num saque temos } \\
\text { que jogar a bola para cima e dá um tapa na bola causando o movimento e a } \\
\text { velocidade". }\end{array}$ \\
\hline 10 & $\begin{array}{l}\text { "A física é muito presente nos esportes que praticamos. Está no contato entre } \\
\text { pessoas e objetos, por exemplo quando a gente joga bola o contato entre a bola e as } \\
\text { pessoas faz com a bola é chamado força ou explicando mais detalhadamente } \\
\text { quando a superfície dos corpos se tocam". }\end{array}$ \\
\hline 11 & $\begin{array}{l}\text { "A física é muito presente nos esportes que praticamos. Está no contato entre } \\
\text { pessoas e objetos, por exemplo quando a gente joga bola o contato entre a bola e as } \\
\text { pessoas faz com a bola é chamado força ou explicando mais detalhadamente } \\
\text { quando a superfície dos corpos se tocam". }\end{array}$ \\
\hline 12 & ---- \\
\hline
\end{tabular}




\begin{tabular}{|c|c|}
\hline 13 & --- \\
\hline 14 & $\begin{array}{l}\text { "Corrida de carros ou motos sempre entendo porque se você encostar em outro } \\
\text { veículo dependendo da força pode ser violentamente causando acidentes". }\end{array}$ \\
\hline 15 & "A física nos envolve no esporte e o esporte nos leva ao conhecimento da física". \\
\hline 16 & ---- \\
\hline 17 & $\begin{array}{l}\text { "Em uma partida de futebol um menino mostrava muita habilidade fazendo dibles e } \\
\text { com muita energia corria em direção do gol, acelerava muito, tinha uma boa } \\
\text { arrancada, quando chegou perto do gol deu um chute com uma potência tão grande } \\
\text { que a bola viajou a uma velocidade de } 200 \mathrm{~km} / \mathrm{h} \text {, o goleiro não conseguiu parar a } \\
\text { bola em alta velocidade e foi gol". }\end{array}$ \\
\hline 18 & --- \\
\hline 19 & $\begin{array}{l}\text { "A física está muito presente nos esportes que praticamos. Ela está no contato entre } \\
\text { as pessoas e objetos, por exemplo quando a gente joga futebol o contato que a } \\
\text { gente faz com a bola é chamado força ou contato explicando detalhadamente } \\
\text { quando as superfícies dos corpos que interagem se tocam a força chamada } \\
\text { contato". }\end{array}$ \\
\hline 20 & $\begin{array}{l}\text { "A física com certeza está presente nos esportes. Quando estamos jogando futebol } \\
\text { e trombamos com alguém, entra uma lei da física: dois corpos não ocupam o } \\
\text { mesmo lugar no espaço. Quando chutamos a bola usamos força". }\end{array}$ \\
\hline 21 & $\begin{array}{l}\text { "A física com a certeza está também em nosso esporte, pois times estavam jogando } \\
\text { e um deles se trombaram ai entra a física, porque dois corpos não ocupam o } \\
\text { mesmo lugar no espaço. Quando um dos jogadores chutam a bola usamos a força } \\
\text { para chutar a bola". }\end{array}$ \\
\hline 22 & $\begin{array}{l}\text { "UM dia eu estava andando pela rua quando encontrei um velho amigo, nisso a } \\
\text { gente ficou conversando quando vinha um senhor de carro, que por infelicidade seu } \\
\text { carro acabou quebrando. E este senhor acabou nos pedindo que o ajudassem se } \\
\text { poderíamos empurrar o carro nisso nos acabamos gerando uma força ao empurrar o } \\
\text { carro para o senhor poder seguir com sua viagem". }\end{array}$ \\
\hline 23 & $\begin{array}{l}\text { "Uma pessoa de } 75 \mathrm{~kg} \text { pratica futebol e atinge uma velocidade de } 30 \mathrm{~m} / \mathrm{s} \text { e esbarra } \\
\text { em um outro jogador de } 67 \mathrm{~kg} \text { que esta parado, esse jogador é arremessado para trás } \\
\text { porque toda ação provoca uma reação, e dois corpos não ocupam o mesmo lugar no } \\
\text { espaço". }\end{array}$ \\
\hline 24 & $\begin{array}{l}\text { "Eu estava um dia saindo com meu pai de carro quando no meio da estrada não } \\
\text { havia carro nenhum, então ele resolveu correr um pouco só que ele deu uma } \\
\text { arrancada tão forte que o carro pifou, acho que a potência não agüentou". }\end{array}$ \\
\hline 25 & $\begin{array}{l}\text { "A física é nossa amiga nos ajuda a vencer nos esportes, a correr na corrida } \\
\text { impulso e fôlego na natação se não fosse pela física os médicos poderiam empregar } \\
\text { a velocidade que bate o coração". }\end{array}$ \\
\hline 26 & $\begin{array}{l}\text { "A física está relacionado nos esportes pois, temos que usar a força numa dividida, } \\
\text { para pegar impulso no pulo para cabecear a bola, usa-se a força para chutar a bola e } \\
\text { usa aceleração no atletismo". }\end{array}$ \\
\hline 27 & $\begin{array}{l}\text { "A física está relacionada aos esportes, pois temos que usar a força, em esportes de } \\
\text { contato, temos que usar a aceleração em esportes de corridas, esses são apenas } \\
\text { alguns exemplos de que a física está no esporte". }\end{array}$ \\
\hline
\end{tabular}

5) Uma área muito utilizada para avaliar o desempenho na prática esportiva é a biomecânica. Nela são utilizados muitos conceitos da Física desenvolvidos na primeira série do ensino médio. Enumere pelo menos seis atividades esportivas (lembre-se do pan 2007 e que temos nesse ano as olimpíadas).

1 "Futebol, basquete, natação, tênis vôlei". 


\begin{tabular}{|l|l|}
\hline 2 & "Vôlei, natação, basquete, handball, futebol". \\
\hline 3 & "Corrida, futebol, vôlei, judô". \\
\hline 4 & "Futebol, natação, corrida, vôlei, ciclismo e judô". \\
\hline 5 & "Voleibol, futebol feminino, natação judô, salto em distância, basquetebol". \\
\hline 6 & "Natação, voleibol, basquete, judô, futebol, atletismo". \\
\hline 7 & "Salto uma distância, natação, tênis, atletismo, vôlei e basquete" \\
\hline 8 & "Salto em distância, natação, vôlei, futebol, basquete tênis". \\
\hline 9 & "Basquete, salto em vara, natação, tênis de mesa, futebol, vôlei". \\
\hline 10 & "Natação, futebol, salto em distância, tênis, basquete". \\
\hline 11 & "Natação, futebol, tênis, vôlei, salto em distância". \\
\hline 12 & "É muito importante aprender a física por tudo que você vai fazer precisa ter pelo \\
& $\begin{array}{l}\text { menos uma noção dos cálculos. Os esportes que utilizam bastante a física é a } \\
\text { nataço, o salto, ginástica". }\end{array}$ \\
\hline 13 & "Os exercícios nas barras, ginástica, natação, corridas". \\
\hline 14 & "Atletismo, judô, taikendo, ciclismo, ginástica, natação". \\
\hline 15 & "Futebol, natação, corrida, vôlei, ciclismo e judô". \\
\hline 16 & "Natação, levantamento de peso, exercício nas barras, corrida, saltos, ginástica \\
& olímpica" \\
\hline 17 & "Tênis, atletismo, vôlei, futebol, salto triplo, salto com vara". \\
\hline 18 & "Atletismo, artes marciais, natação, ciclismo, tiro esportivo, futebol". \\
\hline 19 & "Futebol, basquete, natação, tênis, vôlei e salto em distância". \\
\hline 20 & "Futebol, basquete, natação, tênis e vôlei". \\
\hline 21 & "Futebol, basquete, natação, tênis, vôlei, salto em distância". \\
\hline 22 & "Futebol, judô, natação, basquete, vôlei e hipismo". \\
\hline 23 & "Futebol, natação, vôlei, judô, basquete e salto em vara". \\
\hline 24 & "Atletismo, natação, esgrima, boxe, ginástica, basquete". \\
\hline 25 & "Natação, atletismo, salto em distância, futebol, tênis e vôlei". \\
\hline 26 & "Futebol, jui-jitsu, natação, atletismo". \\
\hline 27 & "Karate, futebol, natação, ping-pong, judô, basquete". \\
\hline
\end{tabular}

6) Explique qual a relação dessas atividades esportivas com os conceitos aprendidos no primeiro ano.

\begin{tabular}{|l|l|}
\hline 1 & "Aceleração, força, pois tudo contém física". \\
\hline 2 & "Aceleração e força". \\
\hline 3 & "Impulso, equilíbrio, força, movimento, pressão e velocidade". \\
\hline 4 & "Todos estão relacionados com a força dos atletas". \\
\hline 5 & $\begin{array}{l}\text { "Bem como a maioria já sabe a física está relacionado ao seu dia-a-dia, então não } \\
\text { há surpresa que a física está relacionada a tudo principalmente aos esportes pois } \\
\text { tem velocidade, aceleração". }\end{array}$ \\
\hline 6 & "Que nesses esportes todos sempre haverá uma força". \\
\hline 7 & $\begin{array}{l}\text { "Já falei sobre um desses assuntos, a força e o contato, futebol, vôlei, natação tem } \\
\text { contato com a água, salto em distância, contato com o chão e usa atração da terra } \\
\text { que leva até o chão". }\end{array}$ \\
\hline 8 & $\begin{array}{l}\text { "Já falei sobre esse assunto, existe o contato, futebol, vôlei, tênis e basquete, existe } \\
\text { o contato com a bola natação é o contato com a água e salto em distância é o } \\
\text { contato com o chão com o chão que leva o pulo e usa atração da terra que vai até o } \\
\text { chão". }\end{array}$ \\
\hline 9 & $\begin{array}{l}\text { "Já falei sobre um desses assuntos, a força e o contato, futebol, basquete, tênis, } \\
\text { vôlei existe o contato com a bola, natação é o contato com a água e salto em }\end{array}$ \\
\hline
\end{tabular}




\begin{tabular}{|c|c|}
\hline & $\begin{array}{l}\text { distância é o contato com o chão que resulta no pulo e usa atração da terra que o } \\
\text { leva até o chão". }\end{array}$ \\
\hline 10 & "Força, velocidade". \\
\hline 11 & $\begin{array}{l}\text { "No tênis a força usada para bater na bola e sua velocidade, atletismo, a aceleração } \\
\text { do atleta e velocidade no vôlei a força de impacto da bola, o impulso para dar os } \\
\text { saltos, no futebol a velocidade em que os jogadores correm a bola que chutam, e } \\
\text { nas provas de salto a velocidade usada para poder saltar". }\end{array}$ \\
\hline 12 & $\begin{array}{l}\text { "A física influencia nos esportes, pois suas fórmulas ajudam a descobrir a } \\
\text { velocidade com que determinado esporte foi executado, o tempo, a distância, etc. E } \\
\text { seus conceitos ajudam no desempenho da prática esportiva". }\end{array}$ \\
\hline 13 & $\begin{array}{l}\text { "Para se saber qual velocidade que um atleta corre ou nada de um ponto a outro é } \\
\text { preciso estudar mecânica. A força entra no judô, ou até mesmo nos faz parte da } \\
\text { cinemática também usa os conceitos". }\end{array}$ \\
\hline 14 & "Força, impacto, energia". \\
\hline 15 & $\begin{array}{l}\text { "A relação dessas atividades na física é muito ligada pois usamos os cálculos para } \\
\text { saber o tempo a distância entre outras coisas". }\end{array}$ \\
\hline 16 & $\begin{array}{l}\text { "É muito importante aprender a física por tudo que você vai fazer precisa ter pelo } \\
\text { menos uma noção dos cálculos. Os esportes que utilizam bastante a física é a } \\
\text { natação, o salto, ginástica". }\end{array}$ \\
\hline 17 & "Equilíbrio, força, velocidade e movimento". \\
\hline 18 & "Equilíbrio, força, velocidade, movimento". \\
\hline 19 & $\begin{array}{l}\text { "Basquete, futsal, vôlei e tem mera exigem o contato coma bala, o salto em vara, } \\
\text { com a vara e a natação com a água". }\end{array}$ \\
\hline 20 & "Equilíbrio, força, velocidade, movimento". \\
\hline 21 & "Equilíbrio, força, velocidade, movimento". \\
\hline 22 & $\begin{array}{l}\text { "A velocidade tem muito a ver com a física na parte de velocidade pois é com essas } \\
\text { formulas físicas que conseguimos chegar a uma velocidade certa de um atleta". }\end{array}$ \\
\hline 23 & $\begin{array}{l}\text { "Sem percebermos a física está em toda parte, assim como a matemática, afinal a } \\
\text { física é uma forma de matemática, então não é surpresa que a física esteja presente } \\
\text { nos esportes, pois toda ação tem uma reação". }\end{array}$ \\
\hline 24 & $\begin{array}{l}\text { "Para se saber qual velocidade que um atleta corre ou nada de um ponto a outro é } \\
\text { preciso estudar mecânica. A força entra no judô, ou até mesmo nos seus esportes } \\
\text { colocados. Deslocamento que faz parte da cinemática também está entre os } \\
\text { conceitos". }\end{array}$ \\
\hline 25 & $\begin{array}{l}\text { "Para saber a velocidade que se percorre de um ponto a outro preciso saber sobre } \\
\text { mecânica". }\end{array}$ \\
\hline 26 & ---- \\
\hline 27 & $\begin{array}{l}\text { "Já falei sobe esse assunto a força, o contato no futebol, vôlei existe o contato com } \\
\text { a bola, natação...". }\end{array}$ \\
\hline
\end{tabular}

7) O número de medalhas da ginástica olímpica e a natação no Pan2007 foi o maior dentre todos os esportes, fazendo com que estas modalidades tivessem muito sucesso. Descreva como a Física pode ser aplicada nestes dois esportes.

\begin{tabular}{|l|l|}
\hline 1 & $\begin{array}{l}\text { "Na ginástica olímpica e a mesma coisa que explique na questão anterior vem o } \\
\text { contato com sua determinada altura e depois a força de atração da terra faz ela cair } \\
\text { na natação existe a força de atração da terra e a força da água que faz com que o } \\
\text { corpo suba isso permite que você abaixe e consiga nadar". }\end{array}$ \\
\hline 2 & ---- \\
\hline
\end{tabular}




\begin{tabular}{|c|c|}
\hline 3 & "Natação tem a ver com a força. Para ver o tempo, a força, a ação e o movimento". \\
\hline 4 & $\begin{array}{l}\text { "Eu sei que a natação tem a ver com força e a mecânica. Porque para nadar é } \\
\text { precisa a força, para se ter uma ação e também usamos a mecânica pra calcular a } \\
\text { velocidade de um ponto para outro. A ginástica eu não sei". }\end{array}$ \\
\hline 5 & "Na potência, na velocidade, distância". \\
\hline 6 & "No tempo, na potência, na velocidade". \\
\hline 7 & "Movimentação do corpo e força". \\
\hline 8 & "Movimento do corpo e força". \\
\hline 9 & $\begin{array}{l}\text { "A ginástica olímpica é a velocidade que a pessoa vai ao chão causando o impacto } \\
\text { com a terra e a natação é a força do homem contra a força da água". }\end{array}$ \\
\hline 10 & "Força e movimentação do corpo". \\
\hline 11 & "Movimentação do corpo e força". \\
\hline 12 & $\begin{array}{l}\text { "Na natação é importante a física para dar um pulo e muita velocidade pra chegar } \\
\text { rápido, e na ginástica tem que saber tempo, distância, etc.". }\end{array}$ \\
\hline 13 & $\begin{array}{l}\text { "Na natação para saber a velocidade da pessoa e na ginástica para saber o peso a } \\
\text { distância as alturas dos saltos". }\end{array}$ \\
\hline 14 & "Força, impacto, gravidade". \\
\hline 15 & $\begin{array}{l}\text { "A natação tem a ver com a força e a mecânica, porque para nadar é preciso a } \\
\text { força, pra se ver uma ação e também usamos a mecânica para calcular a velocidade } \\
\text { de um ponto para o outro". }\end{array}$ \\
\hline 16 & $\begin{array}{l}\text { "Essa pergunta é meio complicada, acho que na ginástica olímpica para realizar } \\
\text { com precisão os saltos, a distância e a velocidade que a pessoa tem que percorrer } \\
\text { para conseguir impulso para o salto. Já na natação é quase a mesma coisa, para } \\
\text { saber com que velocidade e em que tempo tal prova foi realizada". }\end{array}$ \\
\hline 17 & $\begin{array}{l}\text { "Na ginástica olímpica tem a força de impacto que o atleta no chão, que depende } \\
\text { da massa do atleta, força da gravidade da terra e o tempo que ela demora para cair } \\
\text { no chão. Na natação tem a gravidade da terra e a força da água que faz com que o } \\
\text { corpo suba, isso permite que você leve e consiga nadar com mais facilidade". }\end{array}$ \\
\hline 18 & "A ginástica é usada bastante força. A natação é usada mais força, impul \\
\hline 19 & $\begin{array}{l}\text { "Na ginástica olímpica é a mesma coisa que expliquei na questão anterior com o } \\
\text { contato com que vai a uma determinada altura e depois a força de atração da terra } \\
\text { faz ela cair na natação existe a força da atração da terra e a força da água que faz } \\
\text { com que o corpo suba isso permite que você bóie e consiga nadar com mais } \\
\text { facilidade". }\end{array}$ \\
\hline 20 & $\begin{array}{l}\text { "Na ginástica olímpica é a mesma coisa que expliquei na questão anterior como } \\
\text { contato como vai essa determinada altura e depois força da atração da terra faz ela } \\
\text { cair na natação saindo a força da atração da água faz com que o corpo sobe isso } \\
\text { permite que você bóie e consiga nadar". }\end{array}$ \\
\hline 21 & $\begin{array}{l}\text { "Na ginástica olímpica é a mesma coisa que explique na questão anterior um } \\
\text { contato com a uma determinada altura e depois a força de atração da terra faz ela } \\
\text { cair na natação existe força de atração, das terras e a força da água que faz com } \\
\text { que o corpo acha isso permite que você bóie e consiga nadar com mais facilidade". }\end{array}$ \\
\hline 22 & "Relacionando a força e aceleração". \\
\hline 23 & "Velocidade, \\
\hline 24 & $\begin{array}{l}\text { "Na ginástica - energia potencial gravitacional por causa da massa que cai no solo. } \\
\text { Na natação - energia cinética porque em um deslocamento que sofre uma ação ele } \\
\text { passa de uma velocidade Vo para velocidade V em pouco tempo". }\end{array}$ \\
\hline 25 & "Movimentação do co \\
\hline 26 & tância”. \\
\hline
\end{tabular}


\begin{tabular}{|l|l}
\hline 27 & "Ela pode ser aplicado na velocidade, força e distância".
\end{tabular}

8) Quase todo brasileiro é fanático por futebol, será que a física está presente no futebol? Faça uma breve explicação.

\begin{tabular}{|c|c|}
\hline 1 & $\begin{array}{l}\text { Pela ultima vez ao chutar a bola, o pé faz sobre ele uma força que além de } \\
\text { eformá-lo inicia o movimento". }\end{array}$ \\
\hline 2 & $\begin{array}{l}\text { "Sim pelo fato de ter aceleração. Dois corpo não ocupam o mesmo lugar no } \\
\text { espaço". }\end{array}$ \\
\hline 3 & "Sim porque tem tempo, movimento, aceleração". \\
\hline 4 & $\begin{array}{l}\text { "Sim cobrindo chutando, caindo. Sei que tem a ver com tudo o que já disse nas } \\
\text { questões anteriores. }\end{array}$ \\
\hline 5 & "Sim nos movimentos ação reação, velocidade, potência e outras mais" \\
\hline 6 & $\begin{array}{l}\text { "Sim, pois para pegar a bola, você tem que ter velocidade e existe um } \\
\text { determinado". }\end{array}$ \\
\hline 7 & "Força para correr e chutar a bola". \\
\hline 8 & "Força para chutar a bola e força para correr". \\
\hline 9 & $\begin{array}{l}\text { "Sim ao chutar uma bola o pé bate na bola causam o impacto que inicia o } \\
\text { movimento". }\end{array}$ \\
\hline 10 & "Força para correr e chutar a bola". \\
\hline 11 & "Força para correr e chut \\
\hline 12 & "Sim, porque temos que \\
\hline 13 & "Sim 1 \\
\hline 14 & "Sim velocidade utilizada pelos jogadores, tempo de reação \\
\hline 15 & $\begin{array}{l}\text { "Sim correndo chutando, caindo. Sei que tem a ver com tudo o que já disse nas } \\
\text { questões anteriores".. }\end{array}$ \\
\hline 16 & $\begin{array}{l}\text { "Acho que sim, pois futebol é um esporte e a física quase sempre está relacionada } \\
\text { com o esporte. Por exemplo quando se faz o gol, podemos saber com que } \\
\text { velocidade a bola percorreu determinada distância, até o momento em que ela } \\
\text { parar". }\end{array}$ \\
\hline 17 & $\begin{array}{l}\text { itada ela sofre uma deformação e é exercida uma força } \\
\text { nento" }\end{array}$ \\
\hline 18 & $\begin{array}{l}\text { "Acho que sim porque para você correr é preciso força, impulso velocidade, } \\
\text { deslocamento e quando você chuta a bola e o goleiro rebate ela tem a ver com ação } \\
\text { e reação, porquê você chuta a bola em tal força dá batida no goleiro e volta com a } \\
\text { mesma força" }\end{array}$ \\
\hline 19 & sim ao chutarmos uma bola o pé faz sobre ela um \\
\hline 20 & $\begin{array}{l}\text { sim ao chutar uma bola o pé faz sobre ela uma força que além de } \\
\text {-lhe movimento". }\end{array}$ \\
\hline 21 & $\begin{array}{l}\text { "Pela ultima vez sim ao chutarmos uma bola o pé faz sobre ela um a orça que além } \\
\text { de deformá-la". }\end{array}$ \\
\hline 22 & $\begin{array}{l}\text { de numa partida de futebol rola uma força e uma aceleração, quando dois } \\
\text { se trombam uma força". }\end{array}$ \\
\hline 23 & $\begin{array}{l}\text { "Sim, pois como eu disse no exercício } 4 \text { existe várias coisas relacionando ao } \\
\text { futebol a velocidade, força que você exerce sobre a bola quando você a chuta, a } \\
\text { aceleracão". }\end{array}$ \\
\hline 24 & $\begin{array}{l}\text { utarmos uma bola, o pé faz sobre ela uma força que além de deformá-la } \\
\text { ee o movimento". }\end{array}$ \\
\hline 25 & \\
\hline
\end{tabular}




\begin{tabular}{|l|l|}
\hline & marcar aquele golaço". \\
\hline 26 & "Sim pois no futebol será usado a força e a aceleração". \\
\hline 27 & $\begin{array}{l}\text { "Sim pois no futebol, pois sempre iremos usar a aceleração força entre outras } \\
\text { coisas no futebol que estão relacionados a física". }\end{array}$ \\
\hline
\end{tabular}




\section{A2. Atividade Piloto}

\section{A2.1. Atividades}

Responda:

\section{ATIVIDADE 1 Você pode ser um treinador?}

1)Qual é a função de um técnico de qualquer modalidade esportiva?

2)Mas, em sua opinião, qual é o maior desafio a ser vencido pelo técnico? Como ele pode vencer este desafio?

3)Ao assistir a prática de um esporte qualquer, você pode observar o desempenho dos atletas. É claro que para praticar algum esporte, são necessárias algumas habilidades:

a) Escolha uma modalidade esportiva de sua preferência e cite algumas habilidades necessárias para praticá-lo.

b) Agora cite alguns erros que são mais cometidos pelos atletas nesta modalidade esportiva.

c) Sugira as devidas correções aos erros citados na letra b. Dê alguns passos para que o atleta reduza os erros e melhore o seu desempenho.

4)São comuns algumas frases por parte de um torcedor, como: "bata mais fraco", "jogue com vontade", "ataque", etc. Será que estes tipos de comentários auxiliam o atleta para correção de seus movimentos? Por que?

5) Siga então os seguintes passos:

a) Escolha uma modalidade esportiva

b) Determine os objetivos desta modalidade

c) Cite algumas características especiais desta modalidade

d) Enumere algumas características que os atletas de elite desta modalidade possuem.

e) Elabore no mínimo três frases que os técnicos podem aplicar no treino dos atletas, para incentivar e corrigir alguns movimentos.

6)Depois de responder estas questões:

a) Seu conhecimento atual é suficiente para que você faça bons apontamentos (comentários) para auxiliar o atleta? Por quê?

b) Que conhecimentos estão te faltando?

c) Será que algumas das disciplinas (I, P, G, H, M, Q, B, etc.) que você tem na escola te podem auxiliar para instruir (ajudar) um atleta?

d) Cite pelo menos três disciplinas, e explique como ela será útil para análise de uma prática esportiva. Você pode seguir a tabela abaixo

\begin{tabular}{|l|l|l|}
\hline Disciplina & Conteúdo específico da disciplina & Auxilia porque.... \\
\hline & & \\
\hline & & \\
\hline & & \\
\hline
\end{tabular}

7)Será que é possível um técnico dominar as várias áreas necessárias do conhecimento para treinar um atleta adequadamente e corrigir os possíveis erros?

8)Um técnico necessita do auxilio de outros profissionais para ajudar em sua análise sobre o desempenho do atleta?

9)Cite alguns profissionais que fazem parte de uma equipe técnica e dê suas funções.

10)Você sabe qual formação acadêmica (faculdade) que um técnico deve ter? Que matérias ele deve ter feito em sua faculdade?

Atividade extra classe: Pesquise sobre a formação de um técnico no Brasil de qualquer modalidade esportiva? Verifique se há uma equipe técnica? E quais são os profissionais que a compõem? Ou será que somente há uma pessoa para dar conta de tudo isso? 


\section{ATIVIDADE 2 - SAÚDE E ESPORTE}

Responda

1) Explique e comente sobre a frase: "Corpo belo sinônimo de saúde", ou seja, "Corpo bonito significa saúde".

2) Complete a frase: Para uma pessoa para ser considerada saudável são necessários.......

3) Mas será que são suficientes para ser saudável, realizar um exercício físico e ter uma alimentação balanceada? Explique.

4) Uma pessoa dita como "saudável" necessariamente possui boa qualidade de vida? Por quê?

5) Relacione qualidade de vida com saúde.

6) Cite algumas características de uma pessoa com excelente saúde e qualidade de vida.

7) A maior parte da população está à busca um corpo perfeito (bonito). Mas para se adquirir esse corpo, essa imagem alguns fazem esforços através da alimentação, ingerem remédios, fazem cirurgias, etc, então será que todo corpo bonito é saudável? Explique.

8) Qual é a relação entre saúde e esporte? Comente.

9) Qualquer pessoa no momento em que quiser, pode praticar esporte? Por quê?

10) A prática esportiva sempre resulta em saúde? Por quê?

11) Qualquer calçado é bom para prática de esportes? Explique.

12) O que você deve analisar ao comprar um calçado para prática de esportes?

13) Você possui uma boa postura? Sente dores nas costas? Como você acha que poderia mudar esse quadro?

14) Explique a frase: "A manutenção de uma postura é pré-requisito para execução de qualquer movimento"

15) Para fechar a discussão sobre saúde, esporte, qualidade de vida e aparência física, propomos que você resuma cada texto ou elabore 6 questões sobre cada texto.

Qualidade de vida

A qualidade de vida é um termo empregado para descrever a qualidade das condições de vida levando em consideração factores como a saúde, a educação, o bem-estar físico, psicológico, emocional e mental, expectativa de vida etc. A qualidade de vida envolve também elementos não relacionados, como a família, amigos, emprego ou outras circunstâncias da vida. OMS.

A Organização Mundial da Saúde (OMS) desenvolveu um questionário para aferir a qualidade de vida. Trata-se do WHOQOL (World Health Organization Quality of Life) que possui duas versões validadas para o português, o WHOQOL 100 (composto por 100 questões) e o WHOQOL Breve, composto por 26 questões. O WHOQOL - 100 é composto por seis domínios: o físico. o psicológico, o do nível de independência, o das relações sociais, o do meio ambiente e o dos aspectos religiosos. $\mathrm{O}$ WHOQOL - Breve é composto por quatro domínios: o físico, o psicológico, o das relações sociais e o do meio ambiente.

\section{$\underline{\mathrm{IDH}}$}

O Índice de Desenvolvimento Humano (IDH) é uma medida comparativa de riqueza, alfabetização, educação, esperança média de vida, natalidade e outros fatores. É uma maneira padronizada de avaliação e medida do bem-estar de uma população, especialmente o bem-estar infantil. (http://pt.wikipedia.org/wiki/Qualidade_de_vida)

\section{Saúde}

A definição de saúde implicações legais, sociais e econômicas dos estados de saúde e doença; sem dúvida, a definição mais difundida é a encontrada no preâmbulo da Constituição da Organização Mundial da Saúde: Saúde é um estado de completo bem-estar físico, mental e social, e não apenas a ausência de doença. Quando a Organização Mundial da Saúde foi criada, pouco após o fim da Segunda Guerra Mundial, havia uma preocupação em traçar uma definição positiva de saúde, que incluiria factores como alimentação, atividade física, acesso ao sistema de saúde etc. $\mathrm{O}$ "bem-estar social" da definição veio de uma preocupação com a devastação causada pela guerra, assim como de um optimismo em relação à paz mundial - a Guerra Fria ainda não tinha começado. A OMS foi ainda a primeira organização internacional de saúde a considerar-se responsável pela saúde mental, e não apenas pela saúde do corpo. A definição adotada pela OMS tem sido alvo de inúmeras críticas desde então. Definir a saúde como um estado de completo bem-estar faz com que a saúde seja algo ideal, inatingível, e assim a definição não pode ser usada como meta pelos serviços de saúde. Alguns afirmam ainda que a definição teria possibilitado uma medicalização da existência humana, assim como abusos por parte do Estado a título de promoção de saúde.

Por outro lado, a definição utópica de saúde é útil como um horizonte para os serviços de saúde por estimular a priorização das ações. A definição pouco restritiva dá liberdade necessária para ações em todos os níveis da organização social. 
Christopher Boorse definiu em 1977 a saúde como a simples ausência de doença; pretendia apresentar uma definição "naturalista". Em 1981, Leon Kass questionou que o bem-estar mental fosse parte do campo da saúde; sua definição de saúde foi: "o bemfuncionar de um organismo como um todo", ou ainda "uma actividade do organismo vivo de acordo com suas excelências específicas." Lennart Nordenfelt definiu em $\underline{2001}$ a saúde como um estado físico $e$ mental em que é possível alcançar todas as metas vitais, dadas as circunstâncias.

As definições acima têm seus méritos, mas provavelmente a segunda definição mais citada também é da OMS, mais especificamente do Escritório Regional Europeu: A medida em que um indivíduo ou grupo é capaz, por um lado, de realizar aspirações e satisfazer necessidades $e$, por outro, de lidar com o meio ambiente. A saúde é, portanto, vista como um recurso para a vida diária, não o objetivo dela; abranger os recursos sociais e pessoais, bem como as capacidades físicas, é um conceito positivo.

Essa visão funcional da saúde interessa muito aos profissionais de saúde pública, incluindo-se aí os médicos, enfermeiros, fisioterapeutas e os engenheiros sanitaristas, e de atenção primária à saúde, pois pode ser usada de forma a melhorar a eqüidade dos serviços de saúde e de saneamento básico, ou seja prover cuidados de acordo com as necessidades de cada indivíduo ou grupo. (http://pt.wikipedia.org/wiki/Sa\%C3\%BAde)

\section{Valores estéticos}

Muitos críticos dos valores estéticos do corpo basicamente acham imoral que poderosos esforços da alimentação, atividade corporal, ingestão de produtos químicos, uso de cosméticos, realização de cirurgias entre outros, sejam realizados pelos indivíduos e especialmente pelas mulheres para atingirem padrões corporais esteticamente valorizados. O corpo torna-se lugar da salvação sendo uma forma de não passar despercebido, uma maneira de destacar-se na cena social corpo - imagem, o corpo é a moda.(http://polaris.bc.unicamp.br/seer/fef/includ e/getdoc.php?id=662\&article $=254 \&$ mode $=$ pdf $)$

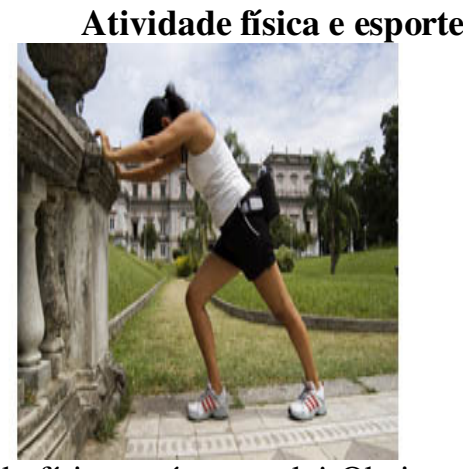

Atividade física está na moda! Obviamente isto é um bom sinal; seus benefícios estão mais do que descritos e comprovados. Existe, porém grande desconhecimento da população em geral sobre o assunto. Afinal o que é atividade física? $\mathrm{O}$ que é esporte? O que faz bem para saúde? Para responde tais perguntas precisamos recorrer a alguns conceitos científicos consensuais.

Segundo o Consenso Biomédico Latino Americano (2000), a atividade física é qualquer movimento do corpo produzido pela musculatura esquelética que resulta em um incremento do gasto energético, ou seja, são as atividades que promovem um gasto energético acima do básico para manutenção do metabolismo (termoregulação, digestão, respiração etc..). Andar, subir escadas, correr, pedalar, lavar roupas, lavar carro, são exemplos típicos de atividade física.

Já exercício físico é toda atividade física planejada e estruturada com o propósito de melhoria do condicionamento físico e saúde. E finalmente, esporte também é uma atividade física, porém que envolve a busca da performance devido à competição.

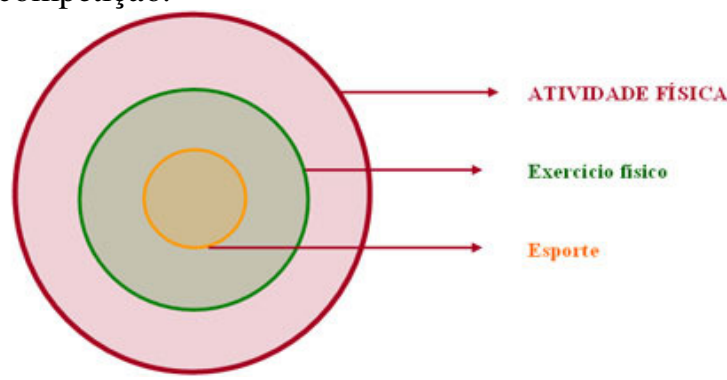

Conhecendo estes conceitos básicos podemos evitar desconfortos tais como nos obrigarmos a fazer uma atividade física que não gostamos, ou ingressar num esporte competitivo, quando muitas vezes o que mais desejamos é melhorar a saúde. Ninguém precisa ser atleta para fazer atividade física, e muito menos se seu objetivo for condicionamento e qualidade de vida.

Ninguém deve ser obrigado a fazer algo que não gosta ou não possui afinidade, ou seja, se alguns praticam natação e se identificam, outros, por outro lado, preferem corrida, alguns praticam esporte, outros não.

Temos que estabelecer nossos objetivos e para isso devemos conhecer o mínimo do assunto de interesse. Se o objetivo for melhoria da saúde e condição física, devemos procurar um programa de exercícios que mais nos agrade, por outro lado se, além disso, desejarmos participar de competições e atingir performance podemos procurar o esporte mais interessante (em ambos os casos, é imprescindível o acompanhamento de um profissional especializado). http://bbel.uol.com.br/artigo/esporte/atividade_fisica _e_esporte.aspx

Extra - classe: Você pode acessar os seguintes vídeos:

Estética saúde:

http://www.youtube.com/watch?v=qu_rXW 1 u8z8

Esporte e lesões:

http://www.youtube.com/watch?v=H10QAMm4XJM 
Calçados:

http://www.youtube.com/watch?v=1NJjDBjYgbM\&f

eature=related

\section{ATIVIDADE 3 - INTERAGINDO COM NOVOS CAMPOS DO CONHECIMENTO}

Responda:

1) Cite áreas do conhecimento (ou profissionais) que nos ajudam a conhecer o nosso corpo.

2) O corpo humano pode ser comparado a uma máquina? Em que situações? Explique.

3) Elabore uma frase contendo as palavras: humano, corpo, máquina, mecânico(a), vida

4) Para entender o funcionamento, o movimento, do corpo humano precisamos de várias áreas do conhecimento, complete a tabela abaixo:

\begin{tabular}{|l|l|}
\hline Área do conhecimento & Aplica a que movimento ou parte do corpo humano \\
\hline & \\
\hline
\end{tabular}

5) Será que é alguém já pensou em utilizar a física (conteúdo de mecânica) para estudar o movimento dos seres vivos. Você acha que é possível? Leia o texto abaixo:

Os cientistas que trabalham no campo da mecânica estudam os efeitos das forças (como gravidade, atrito e resistência do ar) sobre objetos vivos e não-vivos. Eles usam seu conhecimento de mecânica para ajudar a desenhar prédios, pontes, automóveis, barcos e aviões de modo a prever e medir o movimento de uma máquina. Além disso, avaliam o efeito das forças sobre pessoas e, vice-versa, o efeito de forças aplicado por pessoas. (Biomecânica dos esportes Gerry Carr - p.4)

Foi uma transição natural usar as ferramentas da mecânica e aplicá-las nos organismos vivos. Assim desenvolveu-se a biomecânica, o estudo da aplicação da mecânica aos sistemas biológicos.

A biomecânica avalia o movimento de um organismo vivo e o efeito da força - seja empurrando ou tracionando - sobre esse organismo. A abordagem biomecânica para análise dos movimentos pode ser qualitativa, com o movimento observado e descrito, ou quantitativa, significando que está sendo feita alguma medida do movimento. As características de movimento de um humano serão descritas usando parâmetros do tipo velocidade e direção, a quantidade de movimento que é criada pela aplicação das forças dentro e fora do corpo, e as posições de ações corporais ideais para movimentos eficientes e efetivos em humanos e objetos.

Para avaliar biomecanicamente o movimento de levantar-se uma cadeira, por exemplo, pode tentar-se medir e identificar as forças articulares que agem no quadril, joelho e tornozelo, assim como a força entre o pé e o solo, tudo isso interagindo para produzir o movimento de levantar-se a cadeira (Bases biomecânicas do movimento humano - HAMIL \& KNUTZEN - p.5)

6) Após a leitura do texto abaixo escolha 5 cientistas envolvidos com o estudo da biomecânica e cite suas contribuições.

\section{HISTÓRIA DA BIOMECÂNICA}

O estudo do movimento humano se inicia antes de Cristo, veja uma breve síntese histórica:

Aristóteles (384 - 322 a.C.): Com apenas 17 anos, apresentava um talento notável para observação e era fascinado pela a anatomia e estrutura de seres vivos. Ele foi considerado como o primeiro Biomecânico. Ele escreveu um livro sobre o movimento dos animais, considerando seus corpos como sistemas mecânicos. Foi quem introduziu o termo "mecânica" pela primeira vez, descrevendo alavancas e outros mecanismos

simples.

Claudius Galeno (130 - 201 d.C.): Médico que escreveu "De motu musculorum" onde teve as primeiras considerações de como o músculo funciona. Sem conhecer a macroestrutura do músculo, fez uma tentativa de explicação de como ocorre o encurtamento das fibras. Também foi considerado como o primeiro Médico Desportivo. Leonardo da Vinci (1452 - 1519):Era um homem da Renascença que fazia tudo através de desenhos para explorar o mundo das ciências. Seus estudos se baseiam fundamentalmente em sua formação de engenharia. Contribuiu substancialmente para a área da mecânica ao longo do desenvolvimento de seus inúmeros projetos de engenharia civil e invenções imaginativas: de skis aquáticos à planadores manuais. Ele estudou anatomia humana e analisou forças musculares e funções articulares. Da Vinci qualifica a mecânica como a mais nobre e útil ciência pelo fato de que todos os corpo vivos que possuem capacidade de movimentar-se, agem de acordo com as leis desta ciência. Escreveu a "Mecânica do movimento".

Andreas Vesalius (1514 - 1564): Anatomista que deu início a era moderna da anatomia. Livro: "Estrutura do Corpo Humano".

Giovanni Alfonso Borelli (1608 - 1679): escreveu um livro que foi o primeiro a esclarecer que as alvancas do sistema musculoesquelético aumentam / ampliam o movimento muito mais do que a força. Borelli desvendou as forças requeridas para equilibrar articulações no corpo humano muito mais rápido do que qualquer outro. Ele determinou o centro de gravidade do corpo humano e, demonstrou 
que a inspiração dependia de ação muscular e a expiração dependia da elasticidade dos tecidos. É considerado o pai da Biomecânica. Escreveu "De motu animalium" e "De motu musculorum".

Isaac Newton (1643 - 1727): Estabeleceu as leis da mecânica - leis de movimento.

Luigi Galvani (1737 - 1798): Aplicou conceitos de eletricidade em sistemas biológicos.

Irmãos Weber - Eduard (1795-1881) e Wilhelm Weber (1804-1891): Estudaram a marcha humana a partir de leis simples da mecânicas. Compararam o movimento dos membros inferiores com o movimento de um pêndulo. Utilizaram a cronofotografia como método de análise. A moderna pesquisa sobre marcha humana deve-se em parte às contribuições dos dois irmãos Eduard (1795-1881) e Wilhelm Weber (1804-1891), e sua obra "On the Mechanics of the Human Gait Tools". Esta obra foi predominantemente baseada em observações, considerações teóricas e bom senso e intuição dos pesquisadores.

Étienne-Jules Marey (1830-1904): As contribuições de Marey passam pelos campos da cardiologia, instrumentação física, aviação, cinematografia e ciência da fotografia. Pioneiro da cinematografia (cronociclo). Estudou locomoção animal e humana através da cronofotografia e através de seus inventos.

Eadweard Muybridge (1830 - 1904): Realizou importantes estudos fotográficos sobre padrões de movimento que foram marcos na cinemetria biomecânica.

Eadweard Muybridge (1830 - 1904) Christian Wilhelm Braune (1831-1892) e Otto Fischer (1889 - 1906): Estudaram a marcha humana a partir de leis simples da mecânica. Compararam o movimento dos membros inferiores com o movimento de um pêndulo. Utilizaram a cronofotografia como método de análise. A moderna pesquisa sobre marcha humana deve-se em parte às contribuições dos dois irmãos Eduard (1795-1881) e Wilhelm Weber (1804-1891), e sua obra "On the Mechanics of the Human Gait Tools". Esta obra foi predominantemente baseada em observações, considerações teóricas e bom senso e intuição dos pesquisadores.

$\frac{\text { Du Bois Reymond }}{\text { Beniamin Amand }}$ (1818-1922) e $\frac{\text { Guillaume }}{\text { Duchenne }}$ Duchenne é conhecido pelo mundo como o Pai da Biomecânica Moderna. Seu livro entitulado "Fisiologia do Movimento" é considerado uma das mais importantes obras da literatura. Ele era fascinado pela investigação das respostas musculares produzidas pela estimulação elétrica. Estabeleceu os fundamentos da eletromiografia. Muito embora ele tenha reconhecido que ação muscular isolada não existe na natureza, ele classificou funções de músculos isolados em relação ao movimento do corpo humano.

Archibald Vivian Hill (1886-1977): Estabeleceu os princípios da contração muscular. Prêmio Nobel. Nikolai Bernstein (1940): Obra que contribuiu para o estudo da coordenação e regulação do movimento humano. Um dos primeiros a considerar e estabelecer a Biomecânica como ciência. Kotikowa (1930): Elaborou o primeiro programa de Biomecânica em Escola de Educação Física em Leningrado. E depois disso, a Biomecânica foi instituída como disciplina em Leipizig.

Donskoi (1969): "Biomecânica dos movimentos corporais"- "Princípios Biomecânicos"

http://www.fm.usp.br/fofito/fisio/pessoal/isabel/biom ecanicaonline/elementar/historia.php

7) Na figura abaixo identifique alguns termos científicos que você conhece.

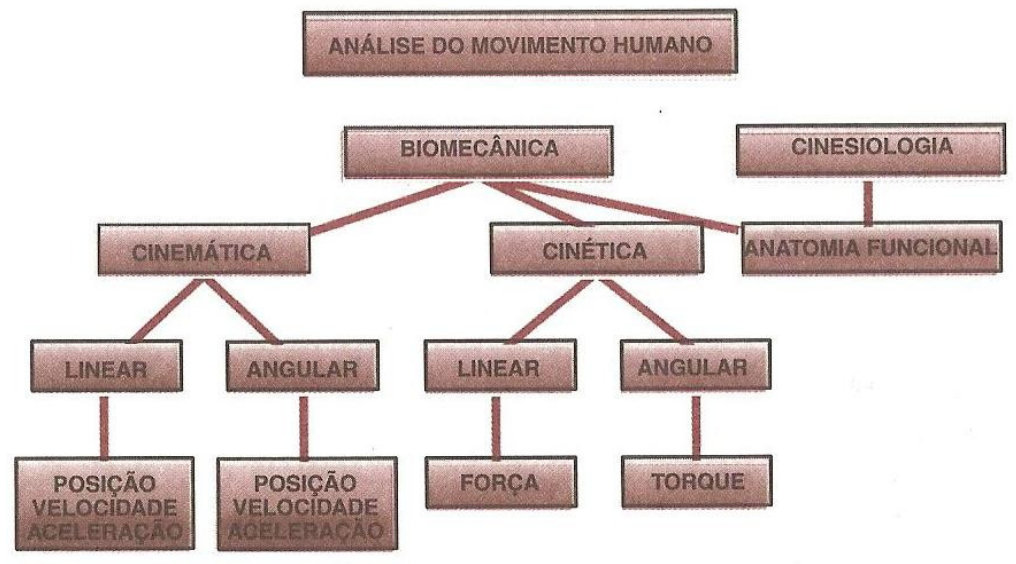

Figura 1 : Tipos de análise do movimento (Bases biomecânicas do movimento humano - HAMIL \& KNUTZEN - p.5) Cinesiologia: estuda o sistema músculo-esquelético, através da anatomia funcional, que é o estudo dos componentes do corpo necessários para desempenhar um movimento.

8) Complete a frase: A biomecânica pode ajudar a....

9) Durante a leitura do texto abaixo relacione as palavras que você não entendeu 


\section{MÉTODOS DA BIOMECÂNICA}

Os métodos utilizados pela biomecânica para abordar as diversas formas de movimento são: antropometria, cinemetria, dinamometria e eletromiografia.

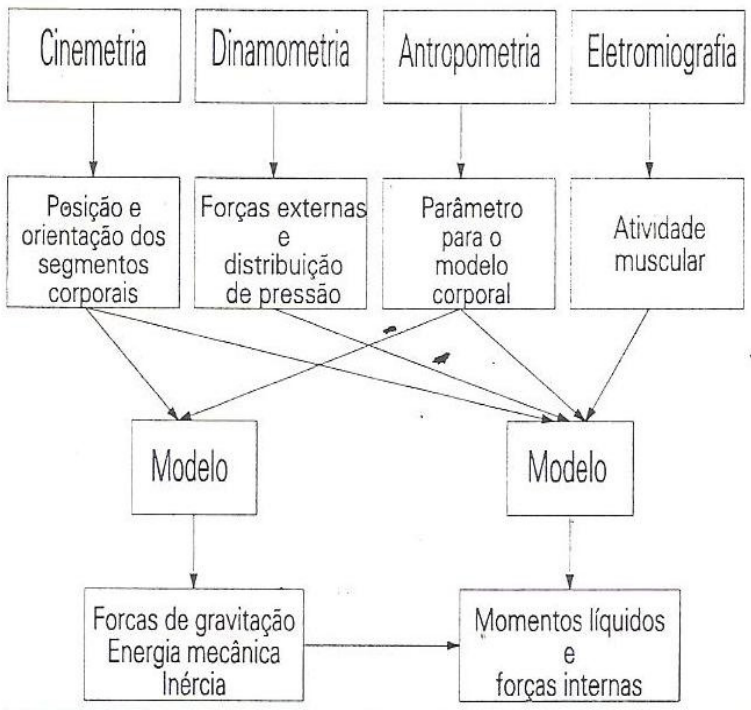

Figura 2: Áreas para complexa análise biomecânica do movimento humano

\section{MÉTODOS DA BIOMECÂNICA}

Cinemetria: consiste em um conjunto de métodos que busca medir os parâmetros cinemáticos do movimento, isto é, a partir de imagens durante a execução do movimento, realiza-se o cálculo das variáveis dependentes dos dados observados nas imagens, como posição, orientação, velocidade e aceleração do corpo ou de seus segmentos.

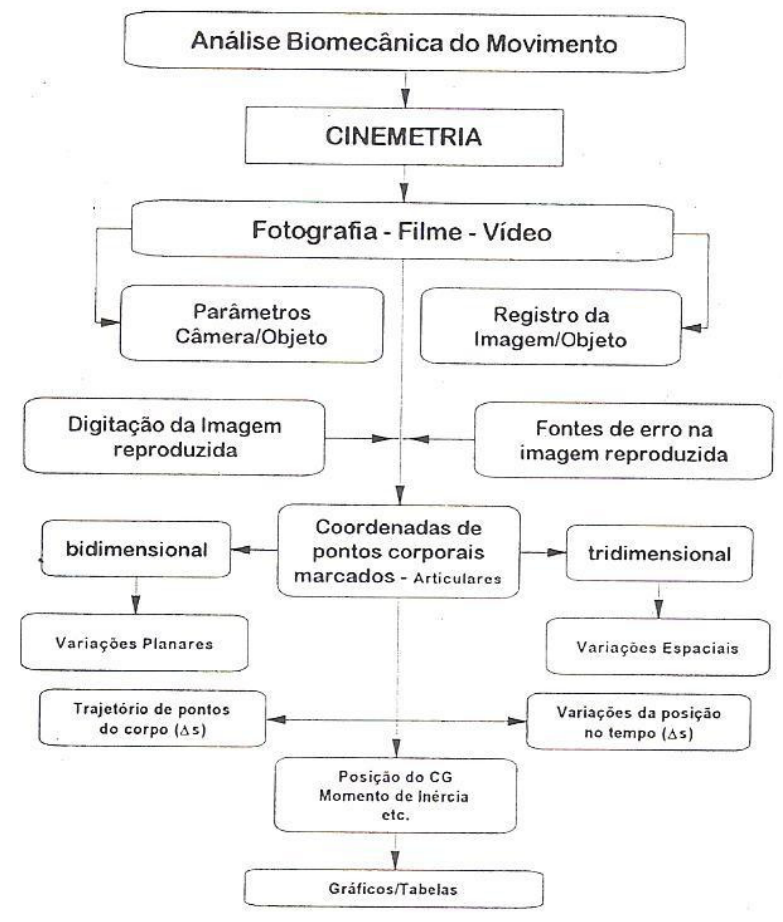

Figura 3: Etapas em processamento na cinemetria

Dinamometria: engloba todos os tipos de medida de força e ainda distribuição de pressão, o que possibilita interpretar respostas de comportamentos dinâmicos do movimento humano. O instrumento básico usado na dinamometria é a plataforma de força, que mede fundamentalmente a força de reação do solo e o ponto de aplicação desta força.

Eletromiografia: é o método de registro da atividade elétrica de um músculo quando realiza contração. A utilização da eletromiografia tem como propósitos fundamentais ser um: indicador de estresse, indicador de padrões de movimentos e parâmetros de controle do sistema nervoso. 
Antropometria: se preocupa em determinar características e propriedades do aparelho locomotor como as dimensões e as formas geométricas de segmentos corporais, distribuição de massa, braços de alavanca, etc., definindo então, um modelo antropométrico contendo parâmetros necessários para construção de um modelo biomecânico da estrutura analisada, ou seja, a antropometria busca modelos que possam ser utilizados para representar o corpo humano.

Independente do modelo adotado, este de permitir o cálculo da: massa, posição do centro de massa do corpo ou do segmento e momento de inércia. Podemos classificar os modelos biomecânicos em modelos físicos (em escala e manequins antropométricos) e modelos matemáticos (corpos rígidos e elementos deformáveis).

A formulação de modelos físicos matemáticos é atualmente uma das principais tarefas da biomecânica. A cada simulação do movimento é feita uma simplificação esquemática do movimento complexo do corpo humano a fim de mensurá-lo e interpretá-lo.

(Fundamentos biomecânicos para análise do movimento humano - Alberto Carlos Amadio - p.21)

\section{Resumo da Atividade}

A biomecânica aplicada aos esportes te ajudará, a saber, como e porque as coisas funcionam no mundo dos esportes:

10) Você aprenderá a observar, analisar e corrigir erros no desempenho.

11) Você estará mais capacitado para avaliar a eficácia de inovações em equipamentos esportivos

12) Você estará mais bem preparado para avaliar métodos de treinamento em relação a problemas de segurança

13) Você estará mais capacitado a avaliar o valor de inovações no modo como às habilidades esportivas são desempenhadas

14) Você saberá o que esperar de diferentes biótipos corporais e diferentes níveis de maturidade Com a biomecânica você concluirá que a compreensão de princípios mecânicos básicos o ajudará se tornar melhor conhecedor e apreciador daquilo que produz os melhores desempenhos, além disso você saberá se proteger contra lesões, através de conhecimentos de equilíbrio, alavanca, torque, etc.

(Biomecânica dos esportes - Gerry Carr - p.7)

\section{ATIVIDADE 4 - O MOVIMENTO}

A prova de 100 metros rasos é uma modalidade olímpica de atletismo, considerada a prova rainha das corridas de velocidade. Dura pouco mais de 10 segundos e os respectivos vencedores são muitas vezes apelidados de homem / mulher mais rápido do mundo.

1. Então qual será a velocidade de um atleta na prova de 100m rasos? Explique seu raciocínio.

2. Qual seria a velocidade de uma pessoa comum nesta prova?

3. Com esta velocidade que você sugeriu então em quanto tempo esta pessoa completaria a prova dos $100 \mathrm{~m}$ rasos? Explique seu raciocínio.

4. Uma pessoa que completa uma prova de $100 \mathrm{~m}$ rasos com velocidade de $22,5 \mathrm{~km} / \mathrm{h}(6,25 \mathrm{~m} / \mathrm{s})$, levou quanto tempo para completar a prova? Explique seu raciocínio

5. Leia o texto que está no quadro:

A maratona é a mais longa, desgastante e uma das mais difíceis e emocionantes provas do atletismo olímpico. Ela é disputada na distância de 42,195 km desde 1908 A Corrida Internacional de São Silvestre é a mais famosa corrida de rua no Brasil, realizada anualmente na cidade de São Paulo, no dia 31 de dezembro, dia de São Silvestre (data de morte do papa da Igreja Católica, canonizado também neste dia, anos depois, no quarto século da Era Cristã) e de onde vem o seu nome. A corrida tem um percurso atual de $15 \mathrm{~km}$, menos da metade de uma maratona

http://pt.wikipedia.org/wiki/Maratona

6. Desafio: Preciso fazer uma comparação da velocidade entre três atletas em provas diferentes para saber qual dos atletas obteve maior velocidade durante o percurso. Frank Caldeira em 2005 completou a Maratona de São Silvestre em 44min06s e Ronaldo Costa em 1998 completou a Maratona em Berlim em 2h06min05s. O queniano Eliud Kipchoge na Corrida Espanhola de São Silvestre em Madri $(10 \mathrm{~km})$ completou a prova em 26min54s. Qual deles teve maior velocidade? Explique seu raciocínio.

7. Como você explicaria seu raciocínio para uma criança. Descreva.

8. Um atleta em uma maratona mantêm a mesma velocidade durante todo o percurso?

9. O que indica então a velocidade estimada por você na questão desafio? 
10. Objetivo: analisar o raciocínio dos alunos e o conceito de velocidade média.

11. Analise o gráfico da fig. 1 abaixo e compare os recordes dos atletas em 1980 e 2000, o que podemos dizer a respeito da velocidade média?

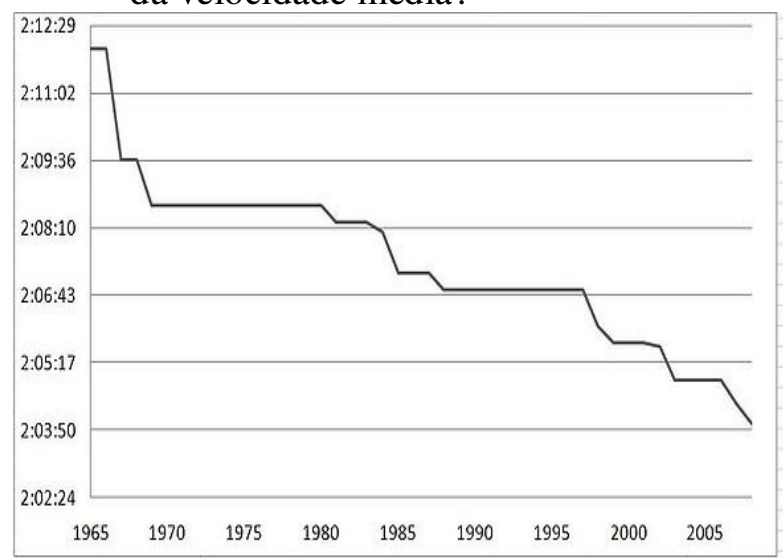

Figura 1: Evolução do recorde do mundo em Maratona (Homens) 1965-2008

(http://pt.wikipedia.org/wiki/Maratona)

12. Observe um exemplo de gráfico (fig. 2) gerado a partir dos dados coletados em um treino de $5 \mathrm{~km}$ por um relógio esportivo que mede, em tempo real, tempo, velocidade, passos, distância, calorias, batimentos cardíacos,

13. Leia com atenção o texto abaixo

\section{Mesmo agredido, brasileiro conquista o bronze na maratona}

Um manifestante roubou a cena e ajudou a afastar a medalha de ouro de Vanderlei Cordeiro de Lima na maratona, a tradicional prova que encerrou a $28^{\mathrm{a}}$ edição dos Jogos da Era Moderna, neste domingo. $\mathrm{O}$ brasileiro teve que se conformar - e comemorar muito - com a de bronze.

Veterano de outras duas Olimpíadas, o fundista de 33 anos tinha vantagem de meio minuto sobre o segundo colocado por volta dos $36 \mathrm{~km}$ dos $42,195 \mathrm{~km}$, quando o torcedor fantasiado com traje típico irlandês de saia, boina e meias compridas verdes e laranjas, invadiu o trajeto, agarrou e tirou o maratonista da pista.

$\mathrm{O}$ infrator foi rapidamente detido pelos policiais, mas o paranaense demorou cerca de 20 segundos para se livrar dele e retornou abalado para a rua. Vanderlei manteve a liderança por alguns quilômetros, mas foi superado pelo italiano

14. Vamos comparar as velocidades dos maratonistas: Stefano Baldini, Mebrahtom Keflezighi e Vanderlei Cordeiro, para isso complete a tabela abaixo:

\begin{tabular}{|l|l|l|}
\hline Maratonistas & Tempo de prova & Velocidade \\
\hline Stefano Baldini & $2 \mathrm{~h} 10 \min 55 \mathrm{~s}=2,18 \mathrm{~h}$ & \\
\hline
\end{tabular}

segmentados por volta ou média e total. No eixo Y a linha em azul significa batimentos cardíacos por minuto (b.p.m.) e a linha em vermelho indica velocidade em $\mathrm{km} / \mathrm{h}$. No eixo X está sinalizada a distância percorrida. Faça a leitura da velocidade e dos batimentos cardíacos por minuto do corredor na distância de $2,5 \mathrm{~km}$

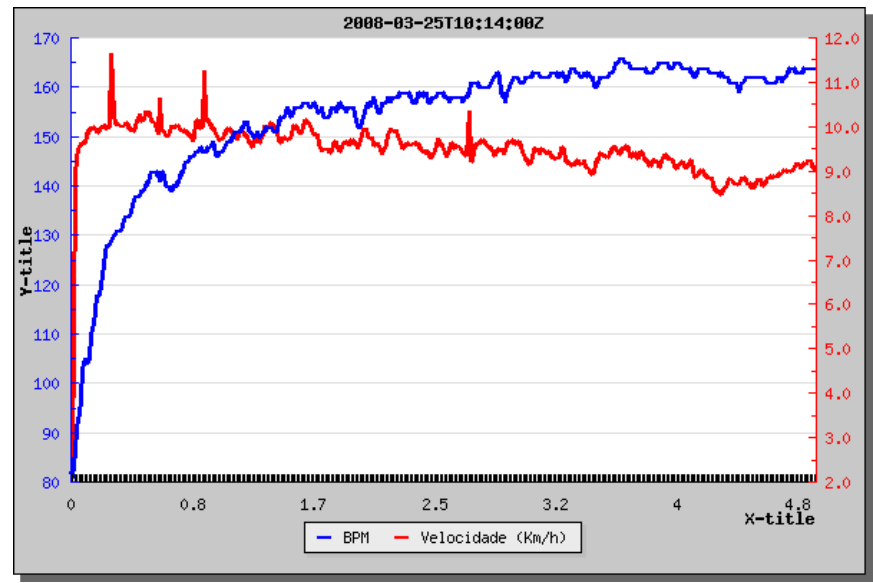

Figura 2: Treino de $5 \mathrm{~km}$ corredor.com.br/blog/?tag=forerunner)

Stefano Baldini e pelo norte-americano Mebrahtom Keflezighi e terminou em terceiro lugar, com o tempo de $2 \mathrm{~h} 12 \mathrm{~min} 11 \mathrm{~s}$ a $1 \min 16 \mathrm{~s}$ do vencedor e 42 s do segundo.

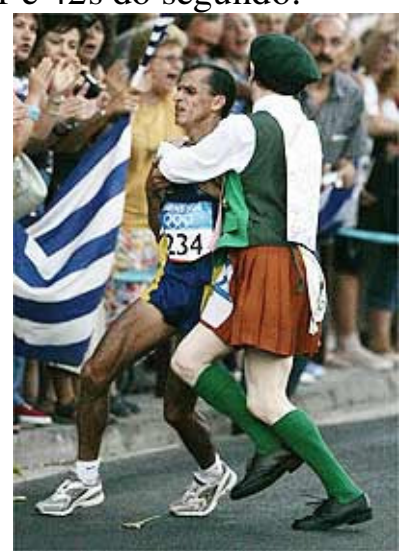

Figura 3: Manifestante agarra Vanderlei Cordeiro, então na liderança, no fim da prova

http://esporte.uol.com.br/olimpiadas/ultimas/ 2004/08/29/ult2247u452.jhtm 


\begin{tabular}{|l|l|l|}
\hline Mebrahtom Keflezighi & $2 \mathrm{~h} 11 \min 29 \mathrm{~s}=2,19 \mathrm{~h}$ & \\
\hline Vanderlei Cordeiro & $2 \mathrm{~h} 12 \min 11 \mathrm{~s}=2,20 \mathrm{~h}$ & \\
\hline
\end{tabular}

15. O que indica os valores encontrados de velocidade para cada um dos maratonistas?

16. Estes valores de velocidade indicam a mínima e a máxima do atleta? Então para que servem?

17. Somente a partir da velocidade calculada do maratonista Vanderlei você poderia prever a parada dele por 20s? Por quê?

18. Então os valores que colocamos na tabela indicam a velocidade $m$

19. Para efetuar estes cálculos foi necessário levar em consideração a direção e o sentido do corredor?

20. Represente de alguma forma o percurso da maratona feito por Vanderlei, não se esqueça do imprevisto ocorrido para que qualquer pessoa ao visualizar o gráfico entenda o que aconteceu durante a corrida.

21. Em termos de colisão (choque), qual deles sai perdendo Vanderlei ou o fantasiado? Explique.

22. A massa $(\mathrm{kg})$ de cada um deles interfere? E a velocidade? Por quê?

23. Há recuo (movimento para trás)? Represente em um desenho a colisão.

24. Vamos supor que Vanderlei tenha $60 \mathrm{~kg}$ e esteja com uma velocidade de $19,3 \mathrm{~km} / \mathrm{h}$ e o fantasiado tenha $80 \mathrm{~kg}$ e uma velocidade de $8 \mathrm{~km} / \mathrm{h}$. Quem sai perdendo na colisão Vanderlei ou o fantasiado? Explique.

25. Vamos aplicar o conceito de velocidade média em outras situações, leia o texto abaixo.

CORRIDA DE REVEZAMENTO: Há corridas de revezamento de 4 x 100 m e 4 x 400 m para homens e para mulheres nas Olimpíadas.

- Durante uma corrida de revezamento, quatro atletas de uma equipe se revezam correndo partes de um circuito.

- Os corredores devem passar um bastão de metal ou de madeira ao próximo corredor dentro de uma zona determinada. Nas Olimpíadas, as trocas de bastão são obrigatórias dentro de uma zona de passagem de 20 metros.

- A estratégia comum para uma equipe de revezamento composta por 4 pessoas é a seguinte: a primeira pessoa é o segundo atleta mais rápido, o segundo corredor é o terceiro mais rápido, o terceiro corredor é o menos rápido e o quarto corredor (âncora) é o mais rápido.

- Os revezamentos começam em raias com uma largada por etapas. O primeiro competidor começa nos blocos de largada; o segundo, terceiro e quarto corredores largam correndo.

Recordistas mundiais: Mike Marsh, Leroy Burrel, Dennis Mitchell e Carl Lewis, dos Estados Unidos, são os recordistas mundiais na corrida de revezamento 4 x $100 \mathrm{~m}$ masculino com o tempo de 37s40centésimos (37,4s) (http://esporte.hsw.uol.com.br/resumo-corrida-revezamento-olimpiada.htm).

Vídeo:http://www.youtube.com/watch?v=pQLSu8eITcU\&feature=PlayList\&p=D4DCAC66FC12C5BE \&playnext=1\&playnext_from=PL\&index $=69$

26. Numa competição de revezamento em corrida de 4 x $100 \mathrm{~m}$ a equipe completa a prova em 40 s. $\mathrm{O}$ primeiro corredor parte da largada e entrega o bastão para o segundo quando o cronômetro indica 10 s, e este por sua entrega ao terceiro corredor no tempo de 20 s, que entrega ao quarto no tempo de 31s. Represente de alguma forma essa situação.

27. Qual a velocidade média do segundo corredor da equipe? Do terceiro? E no percurso todo?

28. Como você explicaria a um colega como calcular velocidade, pense em algo geral, será que dá para representar matematicamente?

29. Agora você sabe que durante uma corrida e em várias situações do dia-a-dia é muito difícil conseguir manter uma velocidade constante (que não muda, não varia). Percebemos que durante um percurso podemos aumentar e diminuir a velocidade, ou até parar. Comparando com um carro, o que você faz quando quer aumentar a velocidade? E diminuir?

30. Agora temos mais um conceito físico importante à aceleração. Durante uma corrida podemos ter vários valores de aceleração. Alguns disparam na largada e têm uma aceleração enorme nos primeiros $40 \mathrm{~m}$. Depois a aceleração diminui (desaceleram) e, perto da fita de chegada, podem até acelerar novamente.

CURIOSIDADE: Atletas que competiram com o campeão olímpico Carl Lewis sabiam que ele era capaz de estar acelerando na marca de $70 \mathrm{~m}$ na corrida de $100 \mathrm{~m}$. Seu índice de aceleração podia ser menor do que seus oponentes no início, mas sua aceleração continuava por mais tempo. Nos últimos 30m, Carl, frequentemente alcançava e passava atletas que estavam empatando e lutando para manter suas posições. 
É importante notar que um atleta pode reduzir o índice da aceleração e ainda assim, aumentar a velocidade escalar. Enquanto houver aceleração mesmo que seja mínima, a velocidade escalar aumentará. O quanto a velocidade escalar de um atleta diminui depende dos índices de aceleração e desaceleração. (Biomecânica dos esportes - Gerry Carr - p.13)

31. Mas como podemos calcular a desaceleração e aceleração de um atleta?

32. Imagine um tobogã quádruplo (para quatro pessoas) descendo uma rampa. Este tobogã acelera a uma velocidade de $4,5 \mathrm{~m} / \mathrm{s}$ no primeiro segundo, $9 \mathrm{~m} / \mathrm{s}$ no segundo e $13,5 \mathrm{~m} / \mathrm{s}$ no terceiro segundo. Qual o aumento da velocidade do tobogã a cada segundo? Então qual a aceleração do tobogã durante o percurso? Ela varia? Explique seu raciocínio.

33. Se a unidade de medida de velocidade $(\mathrm{km} / \mathrm{h}, \mathrm{m} / \mathrm{s})$ é a unidade de comprimento $(\mathrm{m}, \mathrm{km}, \mathrm{cm}$, etc.) pela unidade de tempo (s, h, m), então qual é a unidade de aceleração?

34. Será que nos esportes a aceleração de um atleta se mantém constante (a mesma)? Por quê?

35. A direção interfere no cálculo da aceleração tanto faz se o movimento é na horizontal ou na vertical?

36. No caso da corrida de revezamento $4 \times 100 \mathrm{~m}$, a aceleração se manteve constante durante a prova?

37. Na modalidade esportiva dos saltos ornamentais um atleta salta de uma plataforma bem alta, a $78 \mathrm{~m}$ de altura. Após $1 \mathrm{~s}$ de queda, o atleta está se deslocando a uma velocidade de $9,8 \mathrm{~m} / \mathrm{s}$ $(34,8 \mathrm{~km} / \mathrm{h})$. Após $2 \mathrm{~s}$, a velocidade do atleta alcançou $19,6 \mathrm{~m} / \mathrm{s}(69,76 \mathrm{~km} / \mathrm{h})$. Na marca dos $3 \mathrm{~s}$, o atleta alcançou $29,4 \mathrm{~m} / \mathrm{s}(104,6 \mathrm{~km} / \mathrm{h})$. Finalmente na marca dos $4 \mathrm{~s}$, a velocidade do atleta alcançou os inacreditáveis $39,2 \mathrm{~m} / \mathrm{s}(139,5 \mathrm{~km} / \mathrm{h})$. Descubra o que se mantêm constante neste caso.

38. Então qual é o valor da aceleração? Explique seu raciocínio.

39. Dê a direção (horizontal, vertical, etc.) e o sentido (para esquerda, para cima, etc.) do movimento do atleta.

40. Represente de alguma forma a queda do atleta.

41. Por que o atleta cai para baixo?

42. O que a Terra exerce sobre o atleta?

43. Portanto o que podemos dizer do valor de aceleração que encontramos de um atleta em um salto ornamental?

44. Nas competições de saltos ornamentais a plataforma se encontra a 10m da superfície da água. Você é capaz de estimar através dos dados de velocidade citados acima quanto tempo o atleta demora a atingir a superfície da água?

45. Descreva ou desenhe o movimento de um atleta no início, durante e no fim do salto?

46. Será que há alguma explicação do por que destes movimentos? Tente explicar.

47. Desafio: Explique o que foi feito na situação acima para afirmar que $9,8 \mathrm{~m} / \mathrm{s}=34,8 \mathrm{~km} / \mathrm{h}, 19,6 \mathrm{~m} / \mathrm{s}$ $=69,76 \mathrm{~km} / \mathrm{h}, 29,4 \mathrm{~m} / \mathrm{s}=104,6 \mathrm{~km} / \mathrm{h}, 39,2 \mathrm{~m} / \mathrm{s}=139,5 \mathrm{~km} / \mathrm{h}$. Como se chegou a esses valores? Lembre-se que: $1 \mathrm{~km}=1000 \mathrm{~m}, 1 \mathrm{~h}=60 \mathrm{~min}, 1 \mathrm{~min}=60 \mathrm{~s}$.

Vídeo: http://www.youtube.com/watch?v=uZKP6gS7hVE\&feature=related

48. Após analisar gráficos que representam passadas (figura 4 e 5), tente explicar os gráficos.

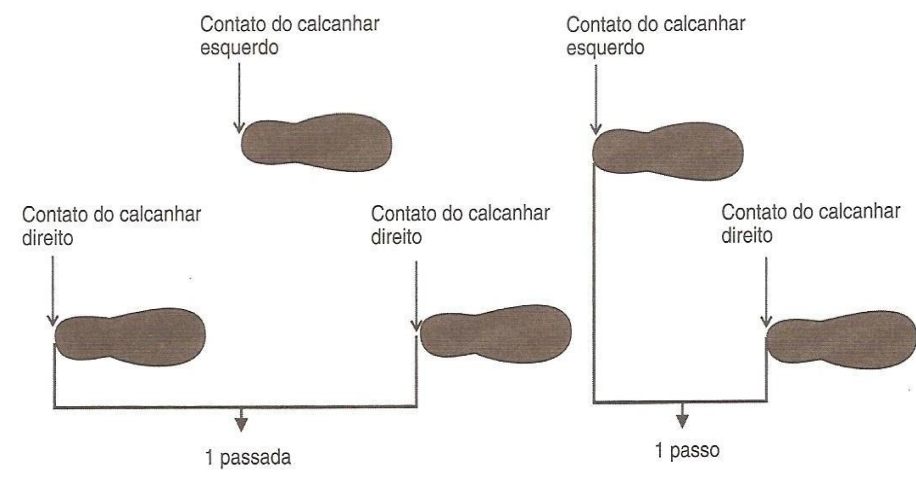

Figura 4: Ilustração dos parâmetros da passada durante o andar (Bases biomecânicas do movimento humano HAMIL \& KNUTZEN).

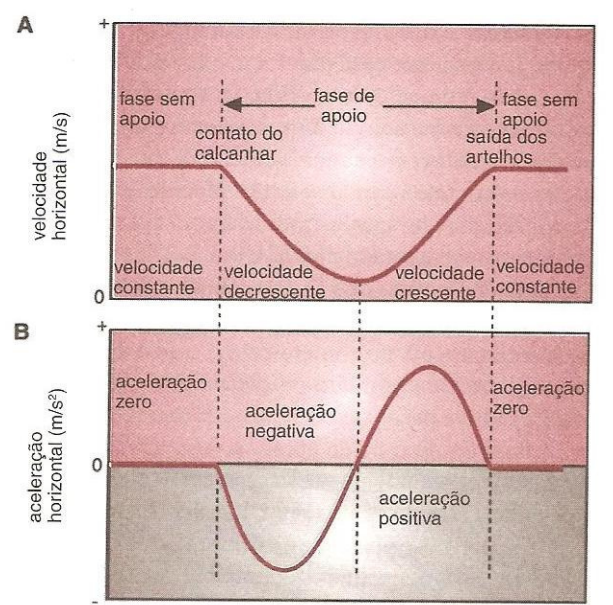

Figura 5: Mudanças na (Ampquelocidade e (B) aceleração durante a fase de apoio de uma passada na corrida (Bases biomecânicas do movimento humano - HAMIL \& KNUTZEN) 
Vídeo: http://www.youtube.com/watch?v=mUIc_Jnr2B8\&feature=related

LANÇAMENTO DE PROJÉTEIS: Nos esportes existem muitas modalidades em que atletas e objetos são projetados ao ar. Os projéteis podem ser bolas de golfe, bolas de basquete, dardos; ou em modalidades de salto, ginastas e saltos ornamentais, os próprios atletas. Todos esses esportes requerem que o atleta manipule, controle ou avalie o trajeto de vôo que ocorre. Por exemplo: Um goleiro de futebol avalia a velocidade e vôo da bola para fazer uma defesa bem sucedida, um saltador em altura está interessado em altura, distância e rotação de modo que ele possa ultrapassar a barra com sucesso.

Em modalidade que incorporam o vôo, vários fatores influenciam a característica de seu caminho: trajetória e ângulo, velocidade e trajetória de lançamento.

Quando um atleta executa uma habilidade esportiva, geralmente, várias forças agem ao mesmo tempo. Vamos atentar para essas forças em ação no arremesso de peso. Pense em atletas de elite arremessando um peso, a um ângulo de arremesso de cerca de $42^{\circ} \mathrm{com}$ a horizontal. Para fazer o peso de deslocar para cima, os atletas devem aplicar força naquela direção. Portanto eles aplicam alguma (mas não toda) força na direção vertical. Para fazer o peso se deslocar horizontalmente, eles aplicam força naquela direção também. A combinação de forças horizontais e verticais dá ao peso sua trajetória de $42^{\circ}$.

Obviamente, os arremessadores não vão aplicar toda sua força somente em uma direção vertical ou horizontal. Se os atletas fossem tolos o suficiente para por toda sua força em uma direção vertical, o peso iria direto para cima e direto para baixo! Isso não é a melhor coisa a se fazer em uma competição que dá prêmio ao atleta que alcança a maior distância horizontal! Por outro lado, se toda a força do arremessador for direcionada horizontalmente, o peso atingirá o solo muito antes de ter tempo para percorrer a distância ideal. Portanto utiliza-se um ângulo de trajetória que está entre o horizontal e o vertical (Biomecânica dos esportes - Gerry Carr - p.23 e 27).

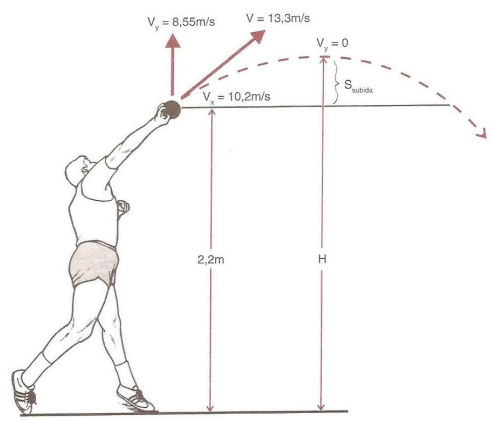

Figura 6: Bases biomecânicas do movimento humano HAMIL \& KNUTZEN - p.354 


\section{ATIVIDADE 5 - O PESO IDEAL}

1. Leia o texto abaixo e sublinhe todos os conceitos relacionados à física

Por exemplo, o saltador de trampolim sabe que a gravidade age perpendicularmente a superfície da Terra tem uma melhor compreensão de qual trajetória proporciona melhor trajeto para o salto. De maneira semelhante, lutadores aprenderão que a gravidade é amiga quando eles desequilibram seus adversários. Por outro lado, se eles não mantêm sua própria estabilidade, a gravidade muda de lado e ajuda o adversário! Os saltadores com esqui entendem que, quando estendem as pernas e se inclinam para frente, ao descerem a rampa, reduzem a resistência do ar. Essa posição do corpo permite que a gravidade os acelere em preparação para decolagem. Uma vez voando, os saltadores com esqui reagem à força da gravidade fazendo uso da resistência do ar. Eles estendem as pernas e se inclinam para frente, simulando a asa de um avião. Dessa forma, ela oferece uma força para cima. É essa variação no uso da gravidade e resistência do ar que ajuda os saltadores de esqui a realizar longos saltos planadores.

Biomecânica dos esportes - Gerry Carr

Geralmente utilizamos o valor aproximado de $10 \mathrm{~m} / \mathrm{s}^{2}$ para aceleração da gravidade, mas isto depende do que queremos calcular, e da precisão que necessitamos. Para representar a aceleração da gravidade utilizamos a letra $\mathrm{g}$.

2. Por que os atletas que querem desempenhar bem suas modalidades monitoram o peso de seus corpos?

3. Cite 4 esportes e relacione a massa ideal para o atleta desempenhá-lo. Complete a tabela:

\begin{tabular}{|l|l|l|}
\hline Modalidade esportiva & Massa & Por que esta massa? \\
\hline & & \\
\hline & & \\
\hline & & \\
\hline & & \\
\hline
\end{tabular}

4. Será que existe alguma diferença em termos de desempenho ou habilidade esportiva quando o atleta vai a competições perto da linha do equador ou perto do pólo Sul ou Norte? Explique.

5. A massa do atleta muda ao se deslocar do Pólo Sul ao Pólo Norte? Então o que muda?

6. Por que as pessoas que estão no vídeo estão flutuando?

http://www.youtube.com/watch?v=FInOkiFVQkU\&feature=related

http://www.youtube.com/watch?v=N6ZJnIJRUCI\&feature=related

7. Leia o texto abaixo

Peso corporal: Os atletas que querem desempenhar bem suas modalidades monitoram o peso de seus corpos. Eles sabem que muito ou pouco peso pode afetar o desempenho. Para todos nós a verificação do peso do corpo é um meio de avaliar nossa saúde e condicionamento geral. Quando subimos em uma balança, o mostrador fornece uma leitura que associamos com a massa corporal (isto é, ossos, músculos, gordura, tecidos) que possuímos. Geralmente pensamos que o peso corporal de um atleta comprime as molas da balança, já que a leitura do mostrador representa o quanto elas são comprimidas. Isso é verdade, mas o que acontece, na realidade, é um pouco mais complexo.

Em termos mecânicos, o peso de um atleta representa a força de atração gravitacional da Terra puxando seu corpo sobre a Terra! A leitura da balança representa quanta atração existe entre ambos. A Terra puxa o atleta para baixo e, inversamente, o atleta puxa a Terra para cima.

O grau de atração, ou puxão, entre o atleta e a Terra depende de quanta massa a Terra possui e quanta massa corporal o atleta possui. Quanto maior atração, maior a compressão das molas da balança. Portanto um atleta com mais massa corporal comprime mais as molas do que um atleta com menos massa corporal. Consequentemente, a agulha na balança se move adiante do mostrador.

Um atleta que pesa $90,8 \mathrm{~kg}$ nos pólos pesará cerca de $90,3 \mathrm{~kg}$ ao nível do mar no Equador, e um atleta que pesa $90,8 \mathrm{~kg}$ ao nível do mar pesará, aproximadamente $90,7 \mathrm{~kg}$ a uma altitude de $3600 \mathrm{~m}$. Essas pequenas mudanças de peso nos dizem que o peso corporal de um atleta é uma função das variações na atração gravitacional da Terra sobre a massa do atleta. A massa corporal de um atleta pode permanecer constante, porém, o peso corporal da mesma pessoa pode alterar, dependendo de onde o atleta estiver no planeta. $\mathrm{O}$ mesmo se aplica a um dardo, a um peso ou a qualquer tipo de equipamente usado em uma competição esportiva (Biomecânica dos esportes - Gerry Carr - p.11).

8. Peso corporal e massa corporal são iguais? Explique.

9. Explique então o que é massa corporal. 
Atletas são constituídos de músculos, ossos, gordura, tecidos e fluidos, todos são substância ou matéria e tem massa. Portanto um atleta, tendo massa, puxa a Terra e a Terra, também tendo massa, puxa o atleta. Um lutador na categoria peso-pesado possui mais massa do que um ginasta peso-leve. A atração entre a Terra e o lutador peso-pesado é maior do que aquela entre a Terra e o ginasta. Isso é demonstrado na balança. A agulha na balança pode marcar 100kg para o lutador e $36,2 \mathrm{~kg}$ para o ginasta.

Biomecânica dos esportes - Gerry Carr - p.11

CURIOSIDADE:No corpo humano, ossos e músculos são menos densos do que gordura. Portanto é possível para um atleta pequeno e musculoso ter mais massa e pesar mais do que um atleta que parece maior, mas tem menos músculo e mais gordura. Como músculo é mais denso do que gordura, culturistas que gastam tempo desproporcional desenvolvendo seu tronco, aumentarão a massa muscular nessa área de seus corpos (Biomecânica dos esportes - Gerry Carr - p.20).

O esqueleto é uma estrutura mecânica constituída de ossos e cartilagens e articulações. Suas principais funções são: sustentação do corpo, locomoção, proteção de órgãos importantes como o cérebro, olho e ouvido interno, coração, pulmões etc. e armazenamento de substâncias químicas, sendo a mais importante delas, o cálcio. Em um adulto há 206 ossos de diferentes formas e tamanhos, dos quais a metade faz parte das mãos e dos pés. Devido a sua composição, os ossos são extraordinariamente leves, principalmente por causa da porosidade. Em um adulto padrão, a massa de todos os ossos equivale a $18 \%$ da massa corporal (Desvendando a física do corpo humano - Okuno \& Fratin - p. 142)

10. Como peso e massa estão relacionados? Explique.

11. Por na Terra nós andamos normalmente, e na Lua como vemos em filmes e reportagens os astronautas flutuam?

12. É possível um atleta sem alteração na massa corporal ter um peso em um lugar da superfície da Terra e outro peso em outro lugar?

\section{CURIOSIDADE JOGOS OLÍMPICOS DE VERÃO DE 1968}

Os Jogos Olímpicos de 1968 foram realizados na Cidade do México entre 12 e 27 de outubro de 1968. Pela primeira vez os Jogos foram sediados na América Latina e a altitude de $2.300 \mathrm{~m}$ acima do nível do mar da capital mexicana gerou controvérsias sobre os danos que o ar mais rarefeito poderia causar no desempenho dos atletas. Realmente, a altitude prejudicou o desempenho dos atletas nas provas de resistência e de longa distância, como o ciclismo, a natação e a maratona, mas em compensação ajudou a provocar uma chuva de recordes mundiais e olímpicos nos eventos mais curtos e de esforço mais rápido como as corridas de menos de $800 \mathrm{~m}$, halterofilismo, lançamento de dardo e outros.

O norte-americano Bob Beamon ganha a medalha de ouro no salto em distância com aquela que por muitos é considerada a mais espetacular marca já atingida no atletismo. Ajudado pelo ar rarefeito dos $2.300 \mathrm{~m}$ de altura da capital mexicana, Beamon conseguiu um salto de 8,90m de extensão, mais de meio metro acima do recorde então vigente, marca tão fantástica que até hoje se mantém como recorde olímpico e durante mais de vinte anos foi o recorde mundial.

(http://pt.wikipedia.org/wiki/Jogos_Ol\%C3\%ADmpicos_de_Ver\%C3\%A3o_de_1968).

A atração gravitacional da Terra irradia de seu núcleo de maneira semelhante as ondulações causadas por uma pedra atirada na água. Quanto mais perto você estiver do núcleo da Terra, maior será a atração. Como a Terra não é perfeitamente redonda, um atleta está mais longe do núcleo se estiver na linha do equador do que se estiver no pólo Sul.

Consequentemente, um atleta, ou um implemento como um dardo, pesará um pouco menos no equador do que nos pólos. Se o atleta subir ao topo de uma montanha no Equador, ele estará ainda mais longe do núcleo e seu peso se reduzirá ainda mais (Biomecânica dos esportes - Gerry Carr - p.11).

CURIOSIDADE: A cada pulsação, o coração bombeia sangue para os demais órgãos do corpo por meio de tubos chamados artérias. Ao ser bombeado, o sangue é empurrado contra a parede dos vasos sanguíneos, gerando o que conhecemos mais comumente como pressão arterial.

Essa pressão varia ao longo do dia, dependendo de suas atividades. Quando por exemplo, você se exercita, ela aumenta; quando relaxa, ela diminui. 
Mas, além das atividades físicas, também a postura (sentado ou em pé) influencia a pressão arterial. Quando uma pessoa se encontra em pé, o sangue é lançado para cima, fazendo com que o resto do corpo, devido à ação correspondente, seja "empurrado" um pouco mais contra o chão.

Se você quiser comprovar esse fato, suba em uma balança mecânica de farmácia e observe atentamente a marcação do ponteiro. Você verá que ele não se fixa exatamente em torno dele. Isso acontece porque essa oscilação acompanha as batidas do coração. Quando o coração se contrai, lançando o sangue para cima (na sístole), o ponteiro tende a marcar um valor maior, indicando o aumento da força aplicada para baixo na balança. Da mesma maneira, quando o coração relaxa (na diástole), o ponteiro tende a marcar um valor menor, indicando a diminuição da força aplicada na balança.

Coleção Nova Geração - Física - Mecânica 1 - Talavera \& Pozzani - p. 17

13. Imagine-se praticando sumô, o milenar esporte japonês. Será que lhe faltaria força? Afinal, para pratica do sumo, força física é fundamental. Mesmo que não seja no sumo, você utiliza força no seu dia-a-dia: ao puxar uma cadeira, abrir a janela, etc. Afinal, quanto de força será necessário para apertar o botão do controle remoto da TV? Enfim utilizamos a palavra força para movimentar ou mudar a forma daquilo que estamos interagindo. Observe que no tênis, a força aplicada a bolinha pode movimentá-la e deformá-la momentaneamente.

Vídeos: http://www.youtube.com/watch?v=UxhKb-zZoWE\&feature=fvst

http://www.youtube.com/watch?v=jjE8SQG8AwI

http://www.youtube.com/watch?v=-99QU0i-XTg

http://www.youtube.com/watch?v=0KfD-v23isA

14. Complete a frase: Quando medimos força estamos medindo

A massa da Terra é $5,97 \cdot 10^{24} \mathrm{~kg}$, e cada um desses quilogramas atrai um quilograma de massa do seu corpo, portanto a força de atração que ela exerce sobre os corpos não é desprezível, como por exemplo, quando uma pessoa se aproxima de nós, ou quando seguramos um livro. $\mathrm{O}$ valor que nos informa qual é a força com que a Terra atrai cada $1 \mathrm{~kg}$ de massa situado em sua superfície ou nas proximidades dela é simbolizado pela gravidade g, que é aproximadamente $10 \mathrm{~N} / \mathrm{kg}$. Antes utilizamos a unidade de $\mathrm{m} / \mathrm{s}^{2}$ para aceleração da gravidade e agora apareceu N/kg.

15. Você pode me dizer o que significa a unidade $\mathrm{N}$ ? Observe que $\mathrm{N} / \mathrm{kg}=\mathrm{m} / \mathrm{s}^{2}$.

CURIOSIDADE: Quando alguém nos pergunta quanto pesamos, respondemos um valor em quilogramas. Só que essa unidade corresponde a medida de massa. E agora? Você continua acreditando que mediu o peso. Você sabia que seu peso é maior em São Paulo do em Fortaleza? Mas isso não tem nada a ver com a leveza de espírito que a gente sente nas belas praias cearenses, mas com a relação de peso.Satélites em torno do planeta Terra permitem medir a aceleração da gravidade em praticamente qualquer ponto da superfície, com extrema exatidão. Veja alguns valores:

\begin{tabular}{|l|l|}
\hline Rio de Janeiro & $9,788 \mathrm{~N} / \mathrm{kg}$ \\
\hline Buenos Aires & $9,797 \mathrm{~N} / \mathrm{kg}$ \\
\hline Fortaleza & $9,780 \mathrm{~N} / \mathrm{kg}$ \\
\hline Pólo Norte & $9,832 \mathrm{~N} / \mathrm{kg}$ \\
\hline Porto Alegre & $9,789 \mathrm{~N} / \mathrm{kg}$ \\
\hline Recife & $9,781 \mathrm{~N} / \mathrm{kg}$ \\
\hline Salvador & $9,782 \mathrm{~N} / \mathrm{kg}$ \\
\hline São Paulo & $9,788 \mathrm{~N} / \mathrm{kg}$ \\
\hline Uberlândia & $9,786 \mathrm{~N} / \mathrm{kg}$ \\
\hline
\end{tabular}

Coleção Nova Geração - Física - Mecânica 1 - Talavera \& Pozzani - p. 48

16. Qual é o seu peso e a sua massa na cidade de São Paulo? Explique seu raciocínio.

17. Elabore uma fórmula para que uma pessoa (por exemplo, a inspetora da escola) consiga calcular o seu peso facilmente em qualquer parte do planeta. Faça uma explicação sobre sua fórmula. Observação: não se esqueça de explicar a diferença entre massa corporal e peso.

18. Nas atividades 4 e 5 vocês entraram em contato com várias unidades de medida, então complete a tabela abaixo:

\begin{tabular}{|l|l|l|}
\hline Grandeza & Unidade & Por extenso \\
\hline Velocidade & & \\
\hline
\end{tabular}




\begin{tabular}{|l|l|l|}
\hline & $\mathrm{kg}$ & quilograma \\
\hline Aceleração & & \\
\hline & $\mathrm{N}$ & newton \\
\hline
\end{tabular}

\section{ATIVIDADE 6: O PAPEL DA FORÇA NO ESPORTE}

Responda:

1. O que é força?

2. O que significa a palavra interação?

3. Será que há uma forma de saber o que acontece quando dois corpos interagem?

4. Você é capaz de ver uma força? E senti-la? Explique.

5. Você lembra que na atividade 4, iniciamos uma discussão sobre colisões (choque) quando foram introduzidas algumas questões sobre o choque entre o maratonista Vanderlei Cordeiro e o fantasiado. Em uma colisão o que devemos levar em conta?

6. Cite 4 exemplos de colisões que acontecem nos esportes, completando a tabela abaixo:

\begin{tabular}{|l|l|}
\hline Esporte & Tipo de Colisão \\
\hline & \\
\hline & \\
\hline & \\
\hline & \\
\hline
\end{tabular}

Exemplo de colisão no vídeo: http://www.youtube.com/watch?v=pZqkaJDaz2A

7. Ao empurrar um carrinho de supermercado vazio, por exemplo, você é capaz de tirá-lo do repouso e colocá-lo em movimento com uma velocidade que vai depender, em parte do quanto é intenso o "empurrão" que você dá. Como podemos chamar este "empurrão"?

8. Se o carrinho estiver cheio vai ser mais difícil para tirá-lo do lugar. Para ele ganhar a mesma velocidade do carrinho vazio, o que você fará? Explique.

9. Será que dar um empurrão mais forte resolve? O quanto mais forte?

10. Os dois carrinhos terão acelerações diferentes ou iguais? Por quê?

Experiência ou vídeo: Colisão entre carrinhos ou bolinhas, vídeo: http://www.youtube.com/watch?v=pEzILbXJjZE

http://www.youtube.com/watch?v=CHTqw5kW57k

11. Destaque os pontos mais importantes do vídeo ou da experiência.

12. Quais são as grandezas envolvidas e suas unidades de medida?

13. O tempo do "empurrão" interfere nas colisões? E na aceleração adquirida pelos corpos?

Um atleta movimentando-se é um exemplo de massa em movimento. Porque a massa corporal do atleta está se movendo, dizemos que esse atleta tem certa quantidade de movimento. O momento descreve a quantidade de movimento que ocorre. Um atleta enorme e com muita massa, correndo na mesma velocidade de um atleta com menos massa corporal, tem mais momento. Da mesma forma com massa corporal mínima, correndo a uma velocidade fenomenal, pode ter mais momento do que o atleta que tenha mais massa. Para compensar uma tremenda diferença de massa, atletas com pouca massa corporal têm de correr uma velocidade muito grande para alcançar um atleta com maior massa.

Biomecânica dos esportes - Gerry Carr

14. Se um atleta de $136 \mathrm{~kg}$ corre $100 \mathrm{~m}$ em $20 \mathrm{~s}$, quanto tempo um outro atleta de $68 \mathrm{~kg}$ deve ter para produzir o mesmo momento?

O momento ocorre sempre que um atleta ou um objeto se movimenta e tem papel particularmente importante em esportes em que há colisões e impactos.

Ex.: 1) Um disco batido com imensa velocidade por um jogador de hóquei, pode ter um momento suficiente para derrubar um goleiro. Quando o disco atinge o goleiro, o disco e o goleiro por um instante, tornam-se uma massa combinada. O disco diminui sua velocidade e perde um pouco do seu momento. Ele mantém um pouco de momento, mas a maior parte é dada ao goleiro, que, por ser jogado para trás, ganha momento naquela direção, 2) Um jogador que arremessa a bola de basquete na linha dos três metros 
almeja colocar a bola na cesta, e não fazê-la ricochetear para o meio da quadra, o momento dado a bola deve ser exato (Biomecânica dos esportes - Gerry Carr).

Retomando o exemplo do carrinho:

15. Analisando o tempo, o que aconteceria se empurrasse o carrinho por mais tempo?

16. Analise a frase: "Para medir o empurrão temos que levar em conta o quanto tempo ele dura, determinar o impulso, que também está relacionado a quantidade de movimento e a força aplicada ao carrinho". Esta afirmação é verdadeira ou falsa, explique.

Quando um atleta deseja movimentar-se ou acelerar um objeto e dar a ele momento, tem de ser produzida força muscular. A força que o atleta aplica sempre demanda tempo. Quando um atleta aplica certa força em um objeto sobre um período de tempo, dizemos que o atleta aplicou um impulso no objeto. Como força e tempo são combinados, depende das capacidades físicas do atleta. Algumas habilidades requerem que uma tremenda força seja aplicada em um curto espaço de tempo, outras requerem menor força aplicada durante um espaço de tempo maior (Biomecânica dos esportes - Gerry Carr).

17. Fale um pouco sobre o impulso em alguma modalidade esportiva de sua preferência. Por exemplo, em um golpe de caratê ao destruir um bloco de concreto.

Curiosidade: Os ossos podem resistir 40 vezes mais ao estresse ou força por unidade de área do que o concreto

18. Leia o texto abaixo e elabore 5 questões.

O Salto em altura é semelhante ao dardo no sentido em que ambas as modalidades requerem que o atleta crie uma tremenda velocidade de saída. No salto em altura, o atleta é um projétil propelido para cima, no ar, pela força muscular. No lançamento de dardo, o dardo é um projétil lançado pelo atleta. Porque o saltador em altura deseja ir o mais alto possível, você poderia pensar que seria uma boa idéia, na subida aplicar o máximo de força possível sobre o maior período de tempo disponível. Portanto, por que não fazer o atleta começar o impulso para cima, na subida, a partir de um agachamento completo e continuar se impulsionando até que a perna do salto esteja totalmente estendida? Certamente, começar com um agachamento completo maximiza o tempo que a força é aplicada pela musculatura das pernas. Infelizmente, não é esse caso. Em um agachamento completo, um atleta não é capaz de desenvolver força máxima porque os músculos das pernas estão em uma má posição para lançá-lo para cima. Antes o que você observará é que todos os grandes saltadores em altura aplicam uma tremenda força por um tempo mais curto e iniciam seu impulso para cima, a partir de uma posição que lembra um quarto de agachamento. Se saltadores em altura não podem usar uma posição totalmente fletida, existe alguma outra maneira de eles aumentarem o período de tempo de aplicação da força? Sim. Exatamente como um lançador de dardo de elite, todos os grandes saltadores inclinam-se para trás ao apoiarem o pé do salto, antes da subida. O endireitamento, a partir da inclinação para trás, permite que o atleta passe mais tempo aplicando força ao solo, o qual em reação o impulsiona para cima. A mesma técnica é usada para jogadores de voleibol quando lês saltam para cortar e bloquear, por jogadores de futebol quando eles pulam para cabecear a bola, e por jogadores de basquete quando eles saltam para bloquear ou fazer uma bandeja. O uso de uma inclinação para trás antes da decolagem, ajuda a todos os atletas a subirem mais alto no ar (Biomecânica dos esportes - Gerry Carr, p.34). 
19. Relacione as grandezas impulso, força e quantidade de movimento.

20. Analise o gráfico abaixo e tente diferenciar o impulso do salto e impulso do peso corporal?

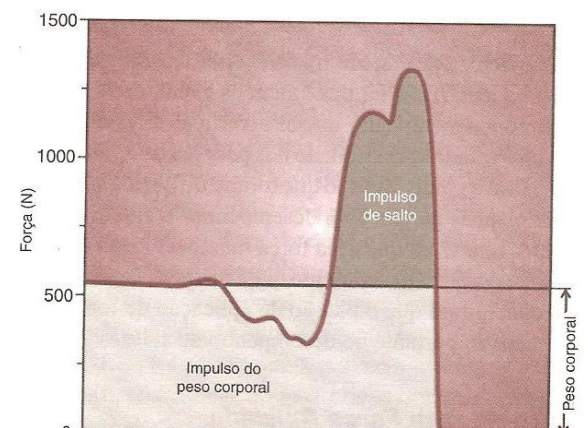

Figura 1: O componente vertical da força de reação do solo de um salto contramovimento (Bases biomecânicas do movimento humano - HAMIL \& KNUTZEN - p.479)

21. Vamos interpretar os gráficos da figura 2 para salto com contramovimento e com agachamento. Descubra qual o gráfico para salto com agachamento. Por que é justamente este?
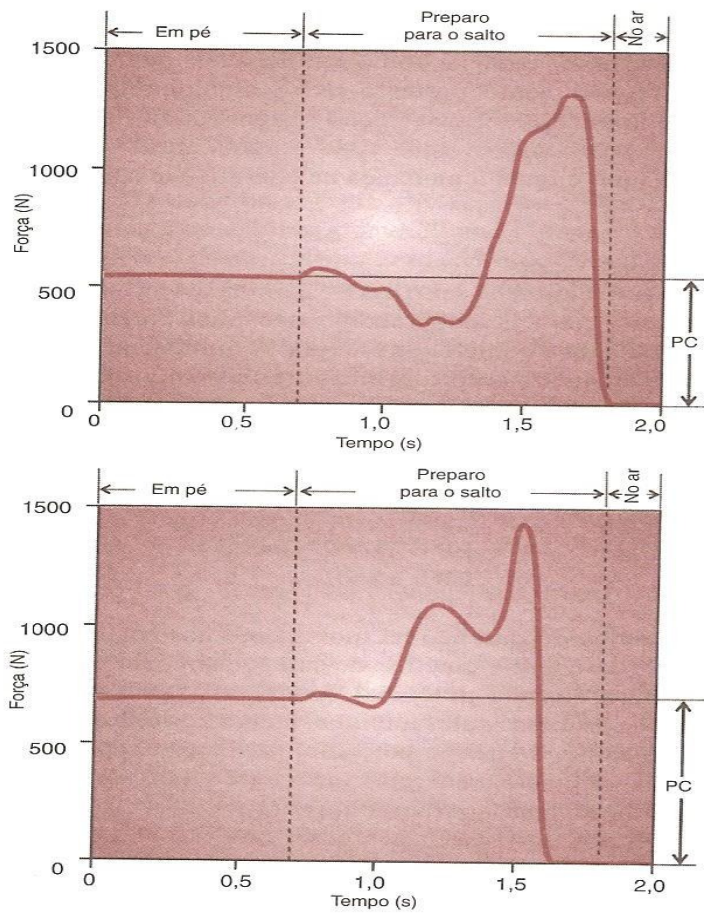

Figura 2: O componente vertical da força de reação do solo de dois tipos de saltos verticais: salto em contramovimento e salto com agachamento (Bases biomecânicas do movimento humano - HAMIL \& KNUTZEN - p.479).

\section{ATIVIDADE 7 - AS TRÊS LEIS DE NEWTON}

Recordando:

1. A massa corporal do atleta depende da modalidade esportiva que ele pratica. No sumô seus praticantes devem ter grandes massas e na ginástica olímpica baixa massa. Tente explicar esta frase através da relação força/peso.

2. Para se derrubar um lutador de sumo o que se deve fazer?

3. Como é difícil colocar um corpo em movimento! O que é necessário vencermos para colocarmos um corpo em movimento?

4. Qual o significado da palavra inércia?

5. Observe o vídeo do futebol americano

Vídeo: http://www.youtube.com/watch?v=CNRWEKDGX5s

No futebol americano temos os quarterbacks que são protegidos por offensive linemem, que são homens imensos com uma grande massa. È necessário uma força inacreditável para tirar esses homens do caminho. Mas os offensive linemen enfrentam defensive limenen igualmente grandes cuja tarefa é romper a linha protetora e perseguir o quarterback. 
6. Explique este trecho: "Considere dois caçadores de emoção que decidem saltar de bungee jump de uma ponte. Um tem duas vezes a massa do outro. Eles saltam ao mesmo tempo da ponte. De um modo surpreendente, ambos aceleram em direção ao solo, aproximadamente no mesmo índice".

Experiência: cd + balão

7. Cite exemplos de pros e contras da inércia escolhendo uma modalidade esportiva? Use para explicar tanto a inércia de repouso quanto a de movimento.

Inércia descreve o "desejo" de um objeto de continuar a fazer o que estava fazendo - mesmo quando ele está se movendo. Todos os objetos (quer sejam atletas ou equipamentos como tacos, bastões ou bolas) desejam permanecer imóveis. Mas se uma força for grande suficiente para fazê-los se mover em uma determinada direção, eles desejarão continuar se movendo na mesma direção, a uma velocidade constante (Biomecânica dos esportes Gerry Carr - p.12).

RECORDANDO: Devido a atração de massas a outros objetos que têm massa, atletas em pé, no chão puxam a Terra para cima, ao mesmo tempo que são puxados pela força gravitacional. Quanto mais massa o atleta tiver, mais forte a atração. Isso significa que um atleta pressiona a Terra com uma força igual ao seu peso. Por estranho que pareça a Terra reage ao peso do atleta, empurrando-o para cima com uma força igual e oposta. A força empurrando o atleta é chamada força reação do solo (Biomecânica dos esportes - Gerry Carr - p.20).

8. Em cada figura 1 e 2 abaixo:

- Represente de alguma forma nos desenhos as forças de ação e reação exercidas.

- Explique porque você adotou esta forma para representar as forças que atuam.

a) saída de uma corrida de sprint.

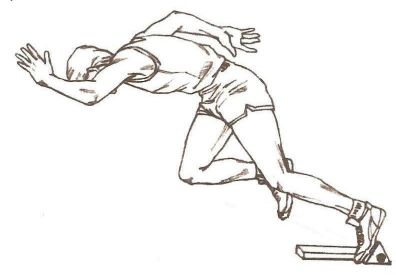

Figura 1: Saída de uma corrida de sprint (Biomecânica dos esportes - Gerry Carr - p.31)

b) salto a distância

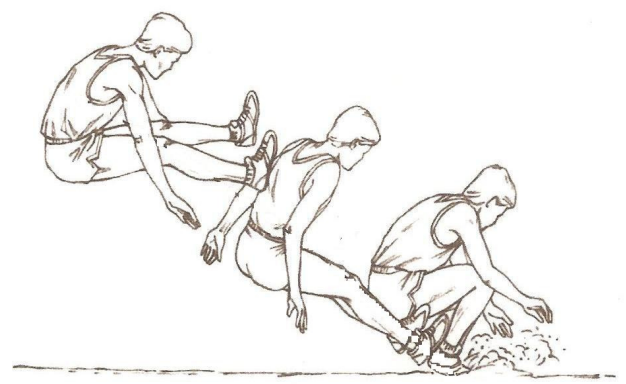

9. Escolha mais duas outras modalidades esportivas para representar as forças de ação e reação.

10. De alguma forma nos desenhos sua intenção foi a de representar o sentido e a direção da força. Observe que dependendo do que estamos analisando precisamos dar mais características às grandezas. No levantamento de peso, imaginemos dois levantadores combinando suas forças musculares para elevar uma barra na direção vertical. A combinação de suas forças totalizou certo valor e foi orientada para certa direção e sentido. Quando a direção, o sentido e o valor da força aplicada são conhecidos, a combinação desses dois itens é chamada vetor força.

11. Cite outras grandezas físicas, no qual podemos atribuir direção e sentido.

12. Na figura 3 abaixo nomeie os vetores força representados:
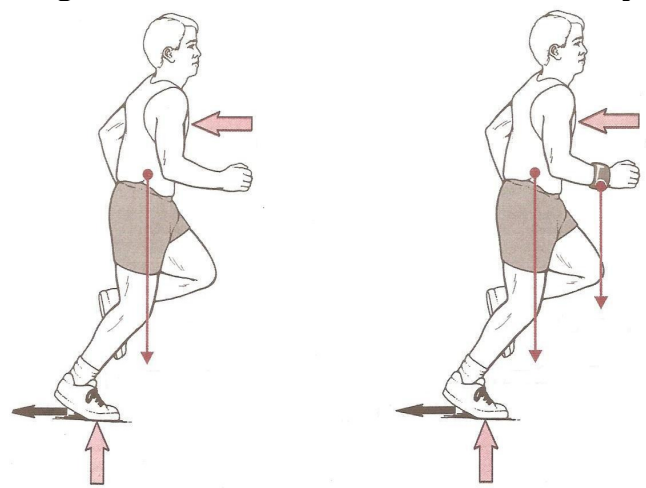

Figura 3: Corrida (Bases biomecânicas do movimento humano - HAMIL \& KNUTZEN- p.413)

13. Durante suas explicações apareceu a palavra atrito? Bom não importa, mas agora tente explicar o que é atrito. 
14. Você caminha com mais facilidade no asfalto ou em uma pista lotada de óleo? Explique.

15. Leia o texto com atenção:

As demandas por atrito variam acentuadamente, de um esporte para outro e de um grupo de condições climáticas a outro. Um atleta pode desejar muito atrito em um momento e apenas um atrito mínimo em outro. Técnicos e atletas precisam saber como fazer o melhor uso de todas as condições de atrito que ocorrem em um esporte - quais estratégias usar quando as condições mudam e quais inovações técnicas adotar quando novos materiais e desenhos entram no cenário esportivo. O conhecimento das características de atrito é requisito para produzir desempenhos ideais (Biomecânica dos esportes - Gerry Carr - p.20).

16. Cite 2 exemplos em que o atrito facilita o desempenho do atleta e explique.

17. Cite 2 exemplos em que o atrito prejudica o desempenho do atleta e explique Experiência sobre atrito

18. Observe abaixo na figura uma pessoa levantando uma barra de $100 \mathrm{~kg}$ em um agachamento. Quanta força foi aplicada? Como a força não pode ser vista, não existe um meio de avaliar a força com precisão a menos que possa ser medida usando instrumentos de registro. Uma análise cinética (tenta definir as forças que provocam o movimento) pode proporcionar informações importantes sobre como o movimento é produzido ou como uma posição é mantida, além de identificar aspectos de uma habilidade ou movimento que tornam o atleta propenso à lesão. Essa informação pode direcionar o condicionamento e treinamento para um esporte ou movimento. Você já viu alguma vez algum tipo de máquina que mede força? Nem em uma loja de tênis?
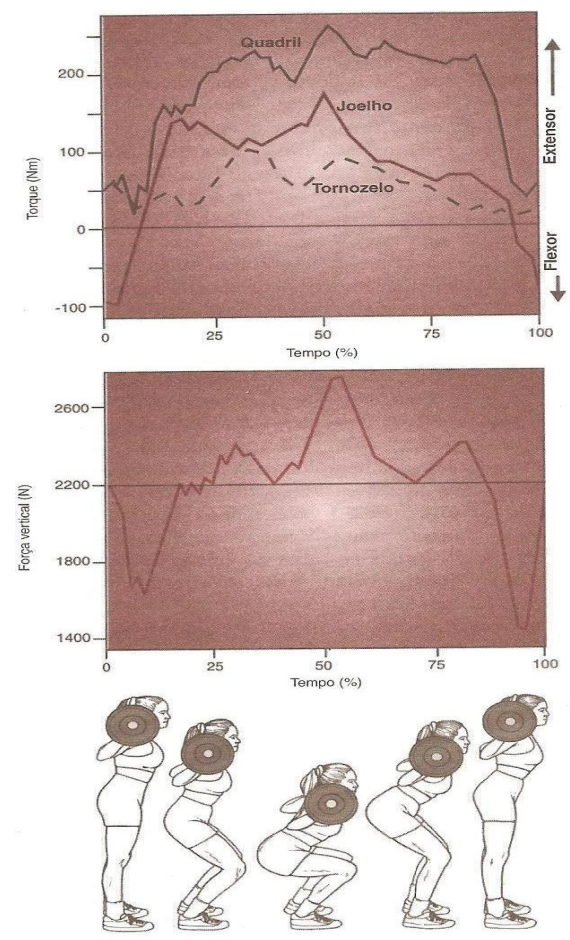

Figura 4: Análise cinemática (lado esquerdo) e análise cinética (lado direito) - Figura: Corrida (Bases biomecânicas do movimento humano - HAMIL \& KNUTZEN, p.9)

Experiência: Plataforma de força

Uma plataforma de força é uma escala de medida muito sofisticada geralmente embutida no solo, com sua superfície nivelada com a superfície do solo onde o individuo está. Esse dispositivo pode medir a força de colisão da sola com o pé do individuo sobre a superfície, ou medir a força de um indivíduo apenas em pé sobre a plataforma (Bases biomecânicas do movimento humano - HAMIL \& KNUTZEN, p.401). 
Gráficos de força

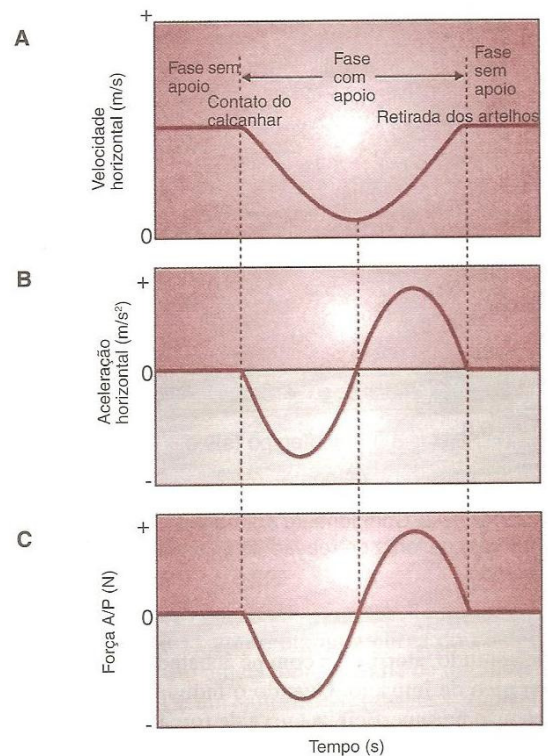

Figura 5: a)Velocidade horizontal do centro de massa de um corredor (Bases biomecânicas do movimento humano - HAMIL \& KNUTZEN- p. 404)

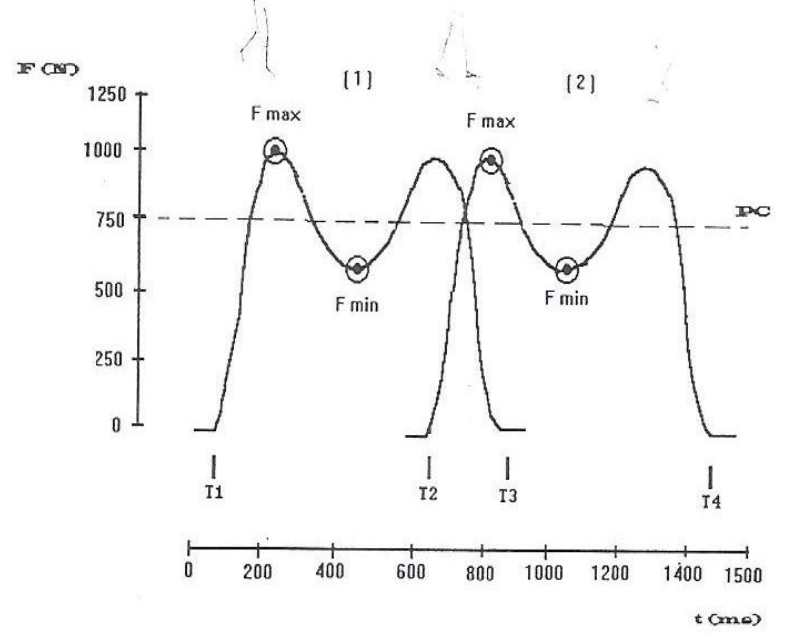

Figura 6: (Fundamentos biomecânicos para análise do movimento humano - Alberto Carlos Amadio, p.122)

19. Leia o texto e defina o que é trabalho para a física

TRABALHO: No treinamento com peso, o levantamento de uma barra é um bom exemplo de trabalho mecânico. O atleta aplica força na barra e, como resultado, eleva-a a certa distância. Por outro lado, se a barra for colocada sobre um suporte, à altura do tórax, e um atleta pressioná-la ou puxá-la com uma contração estática de 10 segundos, nenhum trabalho será feito. Razão mecânica porque nada se moverá. Não importa quão vigorosamente os músculos do atleta se contraem ou quanto trabalho fisiológico é feito. Se nada se move, seja um dardo, uma bola de hóquei de campo ou uma barra, nenhum trabalho mecânico é feito (Biomecânica dos esportes - Gerry Carr - p.38).

20. Escolha três modalidades esportivas e elabore uma frase para cada uma delas que envolva trabalho, força e distância. Veja um exemplo:

O lançador de dardo aplicou uma força ao dardo por uma certa distância e, fazendo isso realizou trabalho sobre o dardo.

21. Complete: Se a unidade de força é dada em e a unidade de distância em A unidade de trabalho será em

22. Quais as principais características que distinguem os atletas bem sucedidos e os atletas de desempenho médio?

23. Imagine dois atletas levantando uma barra. Um leva 1s para elevá-la acima da cabeça e o outro 2 s. Ambos elevam a barra a uma mesma distância. Nessa comparação o primeiro atleta é mais potente? Por quê?

24. Então o que indica a grandeza potência? 
25. Pense em um aparelho de som, a unidade de potência é dada em Pense em um carro, a potência é dada na unidade de Para um carro funcionar ele precisa de Um atleta precisa de

26. Represente em um desenho a modalidade esportiva do salto com vara, e explique cada um dos passos para completar o salto utilizando os conceitos de energia cinética, energia potencial gravitacional e energia potencial elástica.

27. Complete com as palavras: cinética ou potencial elástica ou potencial gravitacional.

28. Dobrar um arco no arco-e-flecha ou movimentar um trampolim no salto ornamental são exemplos de trabalho sendo feito em um objeto para dar a ele energia Na ginástica uma saltadora de cama elástica utiliza força muscular para alongar as molas da cama elástica. As molas alongadas em energia . Essa energia realiza trabalho, impulsionando a atleta para o ar. A atleta tem energia zero quando por um breve momento, está imóvel no ponto mais alto de seu salto. Nesse ponto a energia é máxima. Na subida e quando ela toca a cama elástica novamente, no caminho de volta, sua velocidade e energia___ são máximas e sua energia mínima. A energia gerada durante a queda em direção a cama elástica é combinada com a força aplicada pelos músculos da atleta. Ambas realizam trabalho para alongar as molas da cama elástica novamente.

29. Após a leitura do texto, cite unidades de potencia diferentes.

Em geral quase toda energia que necessitamos é convertida em calor. Para se ter uma idéia mais clara de nossas exigências diárias de energia e potência, um jogador de futebol consome cerca de 750 cal numa partida (ou seja, o jogador deve dispor em média de uma potência próxima a $0,75 \mathrm{HP}$ ), o que corresponde aproximadamente $40 \%$ da energia requerida para assegurar o funcionamento do corpo humano a nível basal (1800 cal/dia). Os seres humanos podem dispor de potências mais elevadas do que esta, desde que em tempos mais reduzidos. Assim um adulto poderá dispor de uma potência máxima de 1,09HP durante $1 \mathrm{~min}$, e de uma potência de 1,87 HP durante 10 segundos.

Uma das constantes fisiológicas mais importantes é a potência específica máxima disponível para um ser humano, ela vale 3,9HP para um indivíduo de $70 \mathrm{~kg}$. Tal nível de potência só é mantido por no máximo 1 segundo. Essa potência limite é empregada usualmente nas largadas de corridas de 100 e 200 metros rasos, e no momento de arranque das provas de levantamento de peso (nas quais o levantador tem apenas 1 segundo para levantar uma massa de $140 \mathrm{~kg}$ a uma altura acima da cabeça com os braços esticados). Desnecessário dizer que despender energia a essa taxa é uma atividade de altíssimo risco para maior parte das pessoas podendo facilmente levar a morte.

A perda de $0,01 \mathrm{~kg}$ de gordura do corpo através de oxidação requer $10 \mathrm{cal}$ de trabalho muscular. Portanto se uma pessoa deseja perder $\mathrm{m}(\mathrm{kg})$ de gordura através de malhação a uma potência média de $700 \mathrm{~W}$ ela deverá investir cerca de $\mathrm{t}$ (horas $)=17 . \mathrm{m}(\mathrm{kg})$ nos exercícios, ou seja, cerca de 17 horas de malhação para $1 \mathrm{~kg}$ de gordura. Conclui-se que a melhor forma de se livrar da gordura, é controlar a ingestão de alimentos. No andar a força é provida pelos músculos das pernas. No caso, a perna de um adulto corresponde a $35 \%$ de seu peso total $(\mathrm{P}=686 \mathrm{~N}$ para uma pessoa de $70 \mathrm{~kg})$ e adotando uma velocidade do andar de $4 \mathrm{~km} / \mathrm{h}$, temos que a potência exigida no andar de ser próxima de $264 \mathrm{~W}$ (A física dos esportes, GOMES, 2001).

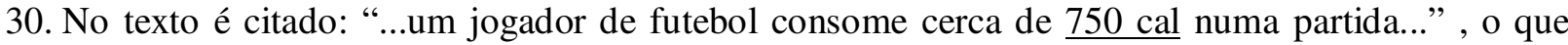
representa a unidade $\underline{\mathrm{cal}}$ ?

\section{ATIVIDADE 8 - ESTÀTICA}

1. Complete com a palavra repouso ou movimento

Imagine que você esteja parado na calçada e passe pela rua um ônibus com vários passageiros. Eles, sem dúvida, estão em movimento. Se estivermos, porém, dentro do ônibus e olharmos para os outros passageiros, diremos que eles estão parados ou em movimento? Nós os vemos parados, mas eles podem afirmar que estão em movimento.

Para resolver essa questão sem risco de engano, podemos dizer: em relação ao ônibus eles estão em mas em relação ao chão estão em

Suponha que um avião, voando horizontalmente, solte uma bomba. Se você observar a queda da bomba de dentro do avião, você verá que ela cai ao longo de uma reta vertical. Entretanto, se você estivesse em 
sobre a superfície da Terra, observando a queda da bomba, você veria que ela, ao cair, descreveria uma trajetória curva. No primeiro caso, dizemos que o movimento da bomba estava sendo observado com o referencial no avião e, no segundo caso, com o referencial na Terra. Este exemplo nos mostra que o movimento de um corpo, visto por um observador, depende do referencial no qual o observador está situado.

O movimento de qualquer objeto sempre é observado em relação a algum ponto de referência. A escolha de um referencial é fundamental para a compreensão, de qualquer tipo de movimento. Esse referencial pode ser um objeto, uma estrela, uma pessoa etc.

http://br.geocities.com/saladefisica6/cinematica/referencial.htm

2. Para estudar os movimentos do corpo humano precisamos adotar um sistema de referência? Mas que sistema? Será que é fora ou dentro do corpo? Qual é a sua opinião sobre isso?

\section{PLANOS E EIXOS}

O sistema de referência é estabelecido arbitrariamente, e pode se localizar dentro ou fora do corpo. O método universalmente usado para descrever os movimentos humanos em três dimensões básicas baseia-se num sistema de planos e eixos. Qualquer posição pode ser descrita identificando a distância entre o objeto e cada um dos três eixos.

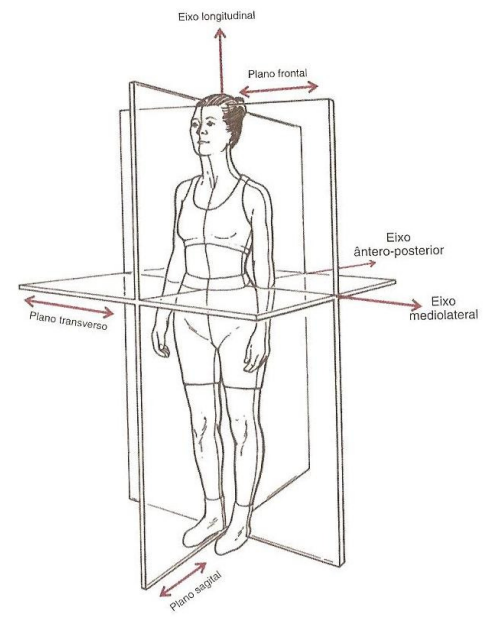

Figura 1: Planos e eixos no corpo humano (Bases biomecânicas do movimento humano - HAMIL \& KNUTZEN- p. 20).

A maioria dos movimentos emprega movimentos nos três eixos. Os esportes como ginástica, salto ornamental, esqui aéreo e patinação combinam saltos mortais e parafusos que são realizados em torno do eixo transversal (de quadril a quadril) e

3. Leia o texto abaixo:

a) Cite todos os conceitos físicos que aparecem

b) Quais os tipos de movimento que são citados? se torcem ao redor do seu eixo longitudinal (da cabeça aos pés). Os ginastas também dão estrelas e saltos mortais laterais ao redor de seu eixo frontal. Classifique os movimentos da figura abaixo segundo os planos: sagital, frontal e transverso.
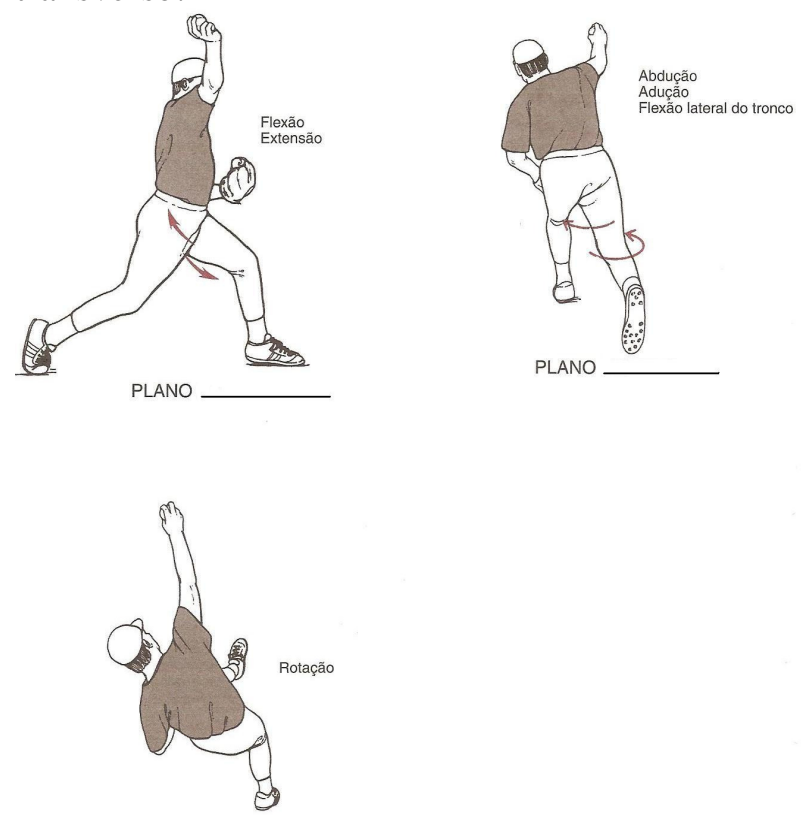

PLANO

Figura 2: Movimentos nos três planos (Bases biomecânicas do movimento humano - HAMIL \& KNUTZEN- p. 24).

\section{Chutar uma bola o mais distante possível}

A intenção do chute é fazer sólido contato entre a trajetória do pé, deslocado em alta velocidade linear e movida na direção correta, e uma bola de modo a mandar a bola na direção linear desejada. O movimento linear de interesse é o caminho real e o movimento da bola após deixar o solo. Para criar altas velocidades na direção certa, os movimentos angulares na perna com a qual está chutando são seqüenciais e extraem velocidade uns dos outros, de modo que a velocidade do pé é determinada pela soma das velocidades individuais dos segmentos que se conectam. A perna é jogada para trás sob a coxa muito rapidamente à medida que a coxa começa a mover-se para frente para iniciar o chute. Na fase de potência do chute, a 
coxa move-se vigorosamente para frente e rapidamente entende a perna e o pé para frente em velocidades angulares muito rápidas. Quando é feito o contato com a bola, o pé está se movendo muito rápido, porque as velocidades da coxa e da perna se transferiram para o pé. Pela observação cuidadosa do movimento humano, a relação entre movimento angular e linear, mostrada neste exemplo do chute, serve como base para as técnicas usadas para corrigir ou facilitar um padrão de movimento ou habilidade.

4. Abaixo temos algumas figuras que exemplificam o movimento linear e o angular de uma habilidade em uma modalidade esportiva, cite mais dois exemplos de cada um dos movimentos.

Você pode desenhar ou descrever.

\section{MOVIMENTOS}

O movimento linear pode ser chamado de movimento de translação, que é o movimento ao longo de uma via curva ou reta. Exemplos: exame da velocidade de um corredor velocista, a trajetória de uma bola de beisebol, o movimento de uma barra em um supino ou o movimento do pé em um chute sem pulo.
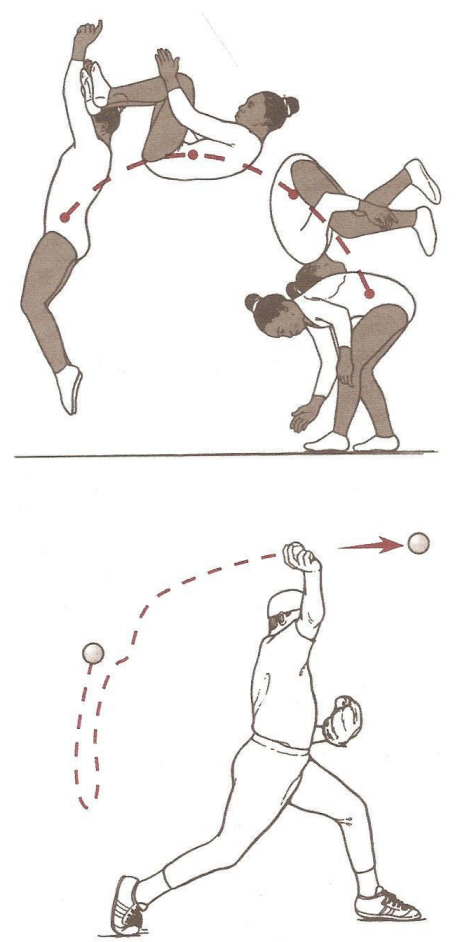

Figura 3: Exemplos de movimento linear (Bases biomecânicas do movimento humano - HAMIL \& KNUTZEN- p. 6).

Movimento angular: ocorre ao redor de algum ponto em que diferentes regiões do mesmo segmento corporal (é o ponto pela qual a massa do objeto fica equilibrada, e representa o ponto onde o efeito total da gravidade age sobre o corpo) ou objeto não se movem pela mesma distância. Os Movimentos angulares ocorrem ao redor de uma linha imaginária chamada eixo de rotação (ex: abaixar o corpo fazendo um agachamento total), ou ao redor de um eixo que passa pelo centro de massa (ex: giro vertical na patinação artística), ou ao redor de um eixo externo fixo (ex: balançar numa barra)
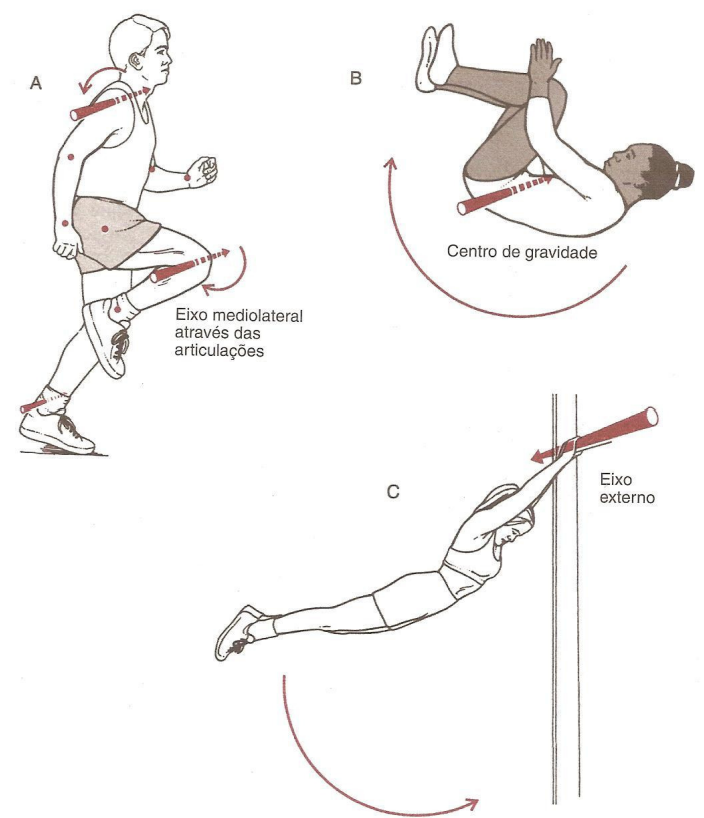

Figura 4: Exemplos de movimento angular (Bases biomecânicas do movimento humano - HAMIL \& KNUTZEN- p. 7).

5. Observe a figura e responda:

\section{Estática}

6. A corda está em movimento? Por quê?

7. Explique a situação utilizando a matemática? 


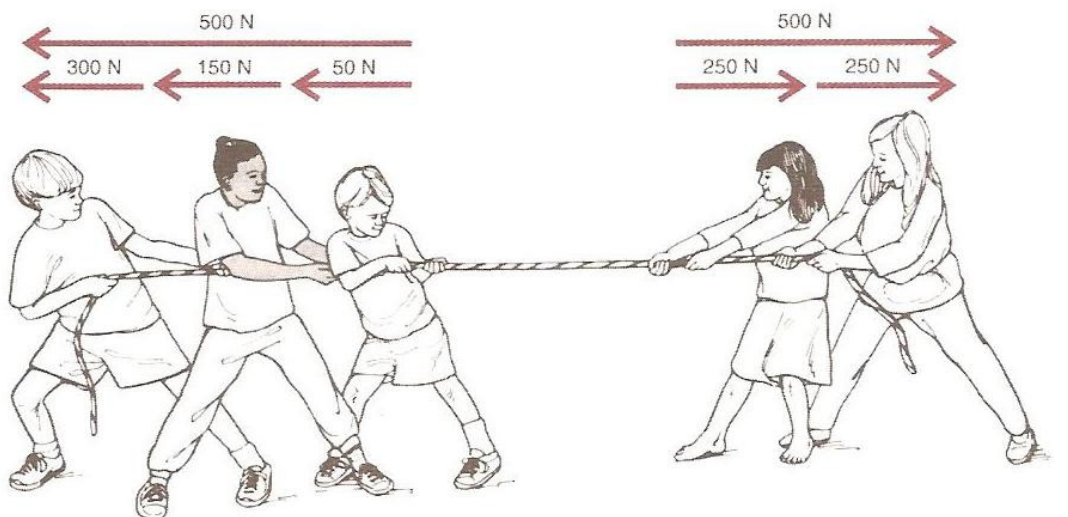

Figura 5: Análise estática (Bases biomecânicas do movimento humano - HAMIL \& KNUTZEN- p. 463).

\section{Equilíbrio}

\section{CURIOSIDADE $O$ efeito zero da gravidade}

O que acontece com nossos corpos quando não há gravidade? No espaço, os ossos de um astronauta sofrem perda mineral e ficam mais fracos. O sangue se concentra mais na parte superior do corpo causando uma mudança no seu centro da gravidade. O equilíbrio do estudante também é perturbado. $\mathrm{O}$ sistema cardiovascular se enfraquece e os músculos, acostumados a reagir a gravidade, perdem força. Quando cosmonautas russos retornaram a Terra, após um ano no espaço, eles tiveram de ser ajudados a sair da cápsula, porque não podiam ficar de pé. Os cosmonautas acharam até o peso dos cobertores desconfortável. E demorou muito tempo para eles se acostumarem com a força gravitacional da Terra.

8. Já vimos em atividades anteriores como calcular o nosso peso em qualquer lugar do planeta, pois apenas necessitamos da nossa massa corporal e da aceleração da gravidade local, mas em que ponto se aplica o peso? Em todo corpo? Ou podemos reduzir a um ponto?

Experiência: Experiência do João bobo, de estática com papéis.

9. Agora que você já fez a experiência, existe um ponto onde se aplica o peso? Onde está localizado? Existe alguma relação com a massa do corpo?

10. Identifique nas figuras abaixo onde está o ponto de aplicação do peso.
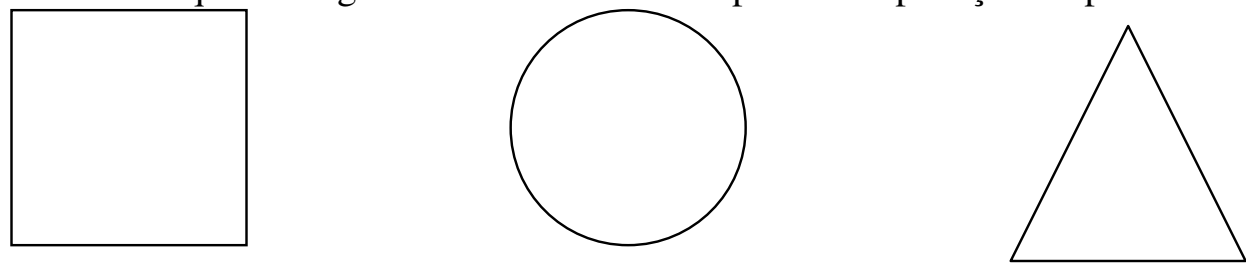

11. Quando a distribuição de massa de um corpo é irregular, onde estará o centro de massa? Como faremos para descobrir?

12. Observe as figuras abaixo:

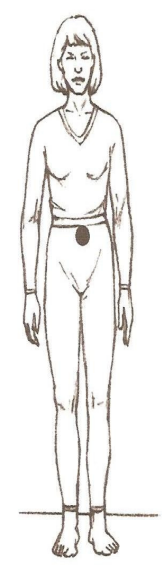

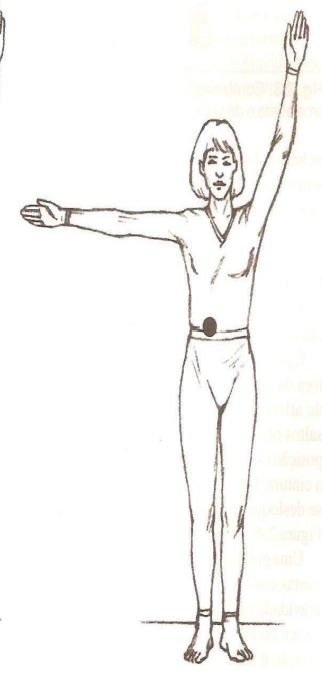

Figura 6: O centro de gravidade da atleta muda com a mudança de posição do corpo (Biomecânica dos esportes Gerry Carr - p.17)

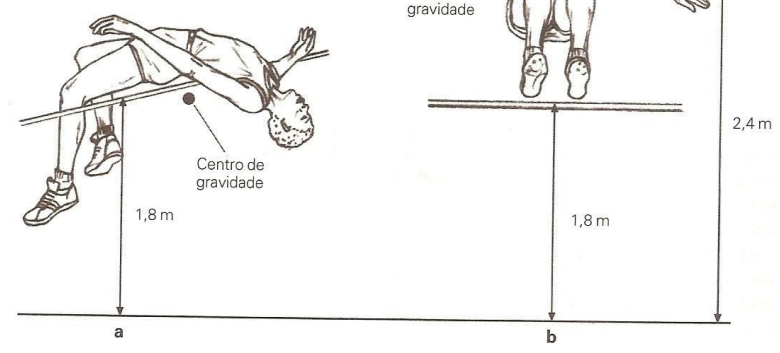


Figura 7: Altura no qual o centro de gravidade de um atleta precisa ser elevado (Biomecânica dos esportes - Gerry Carr - p.19)
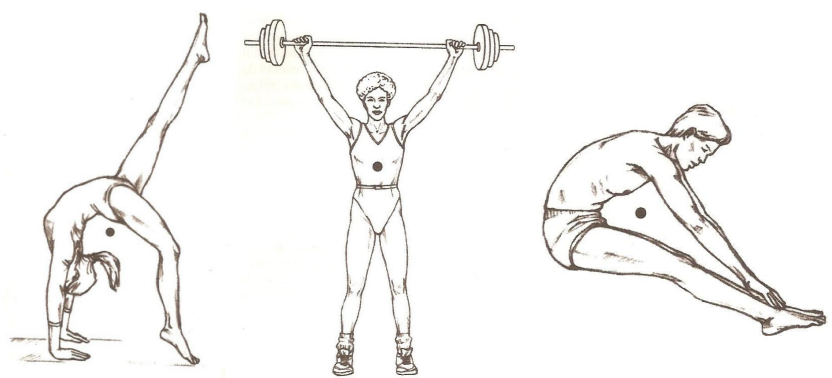

Figura 8: Centro de gravidade (Biomecânica dos esportes Gerry Carr)

No corpo humano, ossos e músculos são menos densos do que gorduras, culturistas que gastam um tempo desproporcional desenvolvendo seu corpo, aumentarão a massa muscular nessa área de seus corpos. Isso também significa que eles elevarão seu centro de gravidade. Atletas que têm um centro de gravidade alto podem estar em desvantagem em esportes (judô e luta) onde a estabilidade está em jogo. Não é diferente para um levantador de peso, com uma barra de $90 \mathrm{~kg}$ eleva o centro de gravidade combinado do levantador de peso e da barra muito acima do que se uma barra de $45 \mathrm{~kg}$ fosse elevada na mesma posição. Atletas com um centro de gravidade mais alto, incluindo o levantador de peso, têm de lutar mais para manter o equilíbrio.

\section{ALAVANCAS}

13. A utilização de alavancas ocorre em todos os esportes. O que é uma alavanca? Descreva ou represente através de um desenho.

14. Para que serve uma alavanca?

15. Leia o texto:

Em um sistema de alavancas, uma força é aplicada em um ponto de alavanca e uma resistência aplica sua própria força em outro ponto. No corpo de um atleta, força é produzida, primariamente pela contração muscular. O peso dos membros do atleta mais o peso do que quer que seja que ele esteja tentando mover produzam resistência. A distância perpendicular de onde a força é aplicada ao ponto de apoio é denominada braço. Da mesma forma, a distância perpendicular de onde a resistência aplica sua própria força ao ponto de apoio é o braço de resistência. Uma alavanca é uma máquina simples que transforma e modifica a energia mecânica de um lugar para outro.

16. Observe algumas figuras que representam alguns tipos de alavancas e faça comparações destacando os aspectos semelhantes em cada uma delas.

a)
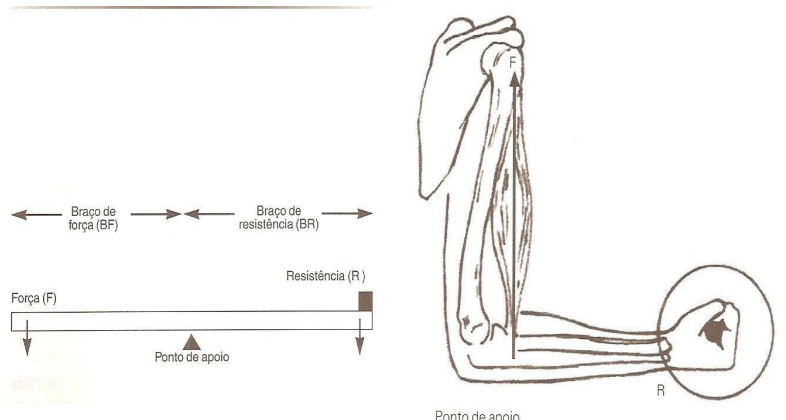

Ponto de apoio
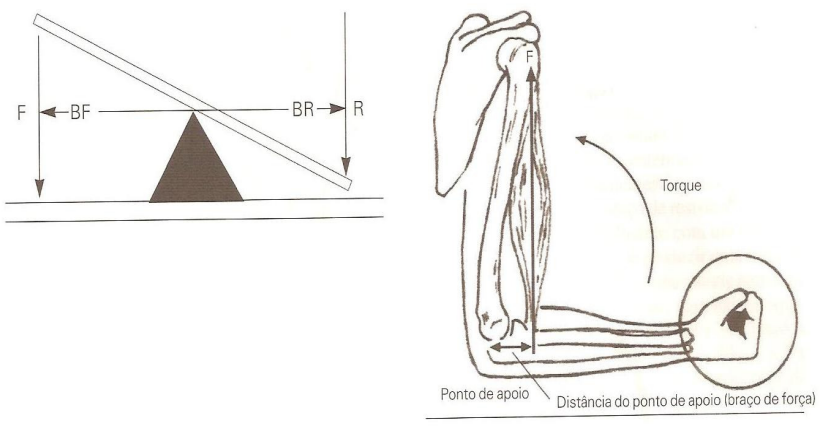

Figura 9: Sistema de alavanca no corpo humano (Biomecânica dos esportes - Gerry Carr - p.53)

b) 


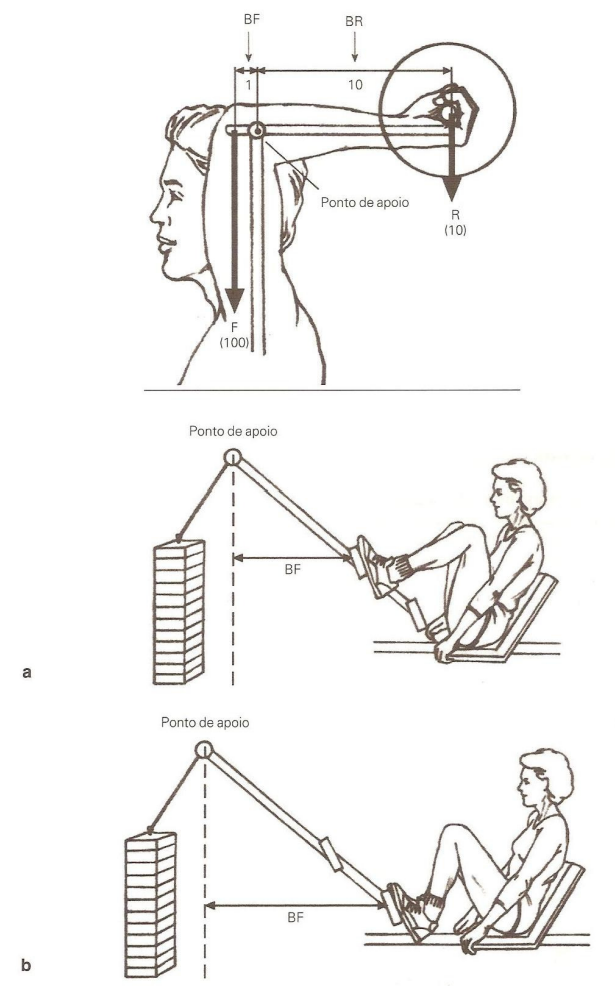

Figura 10: Sistema de alavanca no corpo humano (Biomecânica dos esportes - Gerry Carr - p.55)

c)

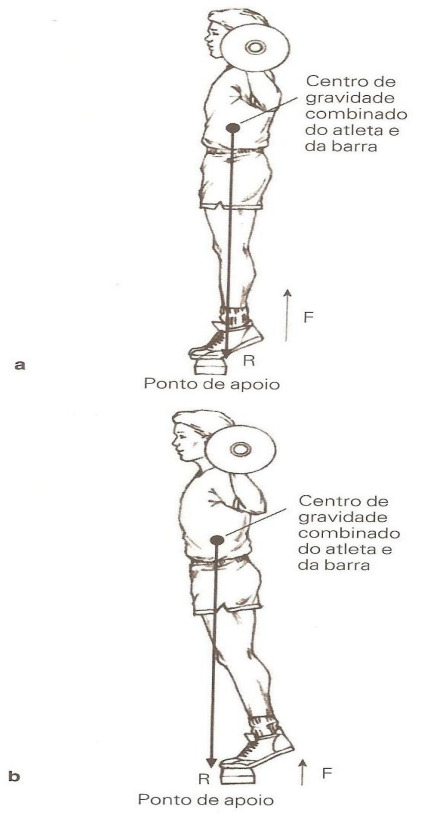

Figura 11: Sistema de alavanca no corpo humano (Biomecânica dos esportes - Gerry Carr - p.56)

d)
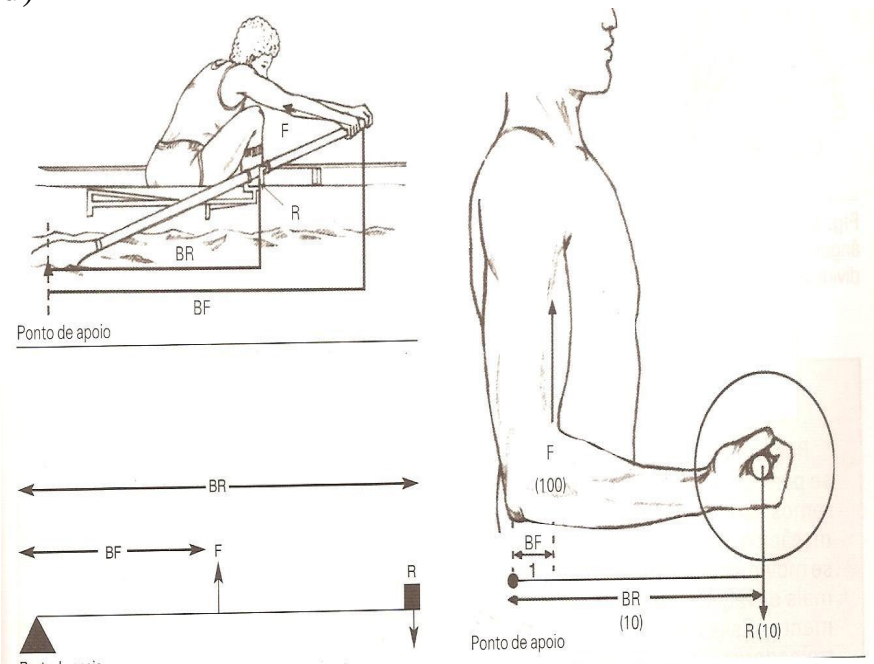

Ponto de apoio

Figura 12: Sistema de alavanca no corpo humano (Biomecânica dos esportes - Gerry Carr - p.57)

17. Determine o ponto de apoio para o movimento em cada uma das figuras $9,10,11$ e 12 . Aliás qual o significado de ponto de apoio.

18. Na figura da letra a apareceu à palavra torque. Você sabe o que é torque? Explique.

19. Tente representar matematicamente o que diz o texto

Como todas as alavancas oscilam ou giram ao redor de um ponto de apoio, elas sempre produzem um efeito rotativo, o qual denomina torque. Em um treinamento com peso, uma barra faz com que o músculo bíceps puxe o antebraço e produza um efeito rotativo direcionado para cima. A quantidade de torque que ocorre depende da quantidade de força produzida pelo bíceps multiplicada pelo braço de força. O braço de força é a distância perpendicular desde a fixação do bíceps no antebraço até o ponto de apoio.

(Biomecânica dos esportes - Gerry Carr - p.53)

20. As alavancas são divididas em três grupos:

Alavanca de primeira classe: o ponto de apoio está localizado entre a força e a resistência. Os braços de força podem ser do mesmo tamanho ou de tamanhos diferentes.

Alavanca de segunda classe: possui tanto a força como a resistência do mesmo lado do ponto de apoio, com o braço de força sempre maior do que o braço de resistência. 
Alavanca de terceira classe: o ponto de apoio está em uma ponta da alavanca e a resistência está em outra ponta. Classifique as alavancas das figuras a, b, c e d.

\begin{tabular}{|l|l|}
\hline $\mathrm{a}$ & Alavanca de \\
\hline $\mathrm{b}$ & Alavanca de \\
\hline $\mathrm{c}$ & Alavanca de \\
\hline $\mathrm{d}$ & Alavanca de \\
\hline
\end{tabular}

21. Quando você vai abrir uma porta, onde você aplica a força para abrir?

22. Tente aplicar mais perto da dobradiça? O que acontece?

23. Complete: Quanto a distância da dobradiça ao ponto de aplicação da força mais fácil fica de abrir a porta.

24. Explique as vantagens e desvantagens do comprimento dos membros do corpo humano, observe novamente as figuras acima.

25. Como podemos iniciar uma rotação?

26. Onde devo aplicar a força para que a bola de vôlei inicie a rotação no sentido e na direção indicada na figura abaixo? Represente na figura 13.

a
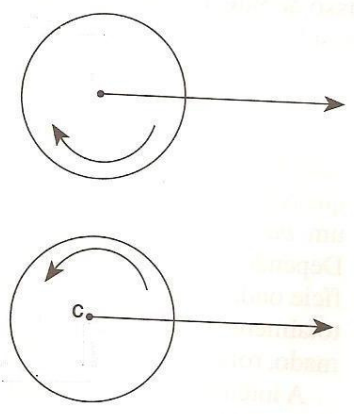

b

Figura 13: Bola de vôlei girando (Biomecânica dos esportes - Gerry Carr - p.61)

27. Como uma ginasta consegue girar a si mesmo, na habilidade de giro girante da ginástica olímpica? Será que a gravidade ajuda no movimento? Como?

28. Indique na figura o ponto de apoio

29. Em termos de velocidade angular, coloque em ordem crescente as seguintes velocidade angulares: dos quadris, das mãos, dos pés

\begin{tabular}{|l|l|}
\hline 1 & \\
\hline 2 & \\
\hline 3 & \\
\hline
\end{tabular}

30. Na figura 14 e 15 , temos um ginasta de cerca de $1,67 \mathrm{~m}$ e peso corporal de $59 \mathrm{~kg}$. Seria possível um jogador de basquetebol (um gigante) que tem $136 \mathrm{~kg}$ de peso corporal praticar essa habilidade da ginástica olímpica?

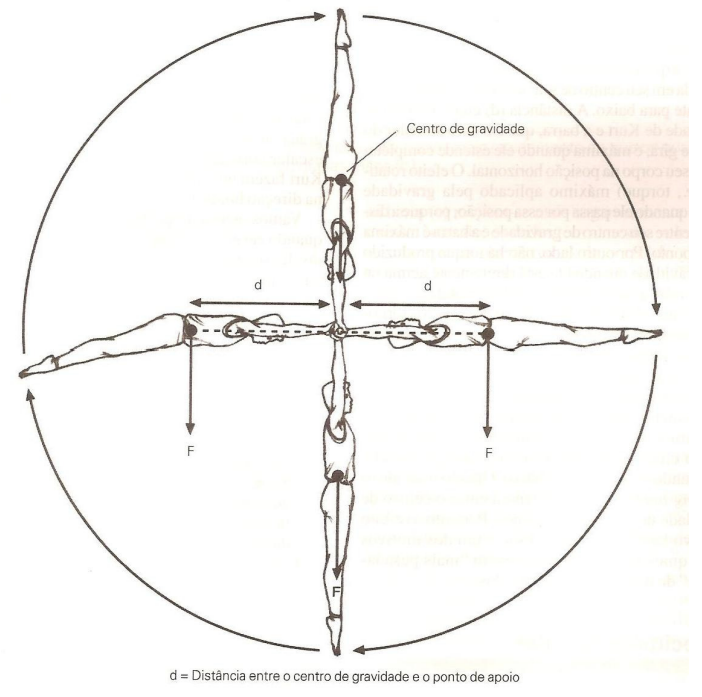

Figura 14: Giro gigante (Biomecânica dos esportes - Gerry Carr - p.63)

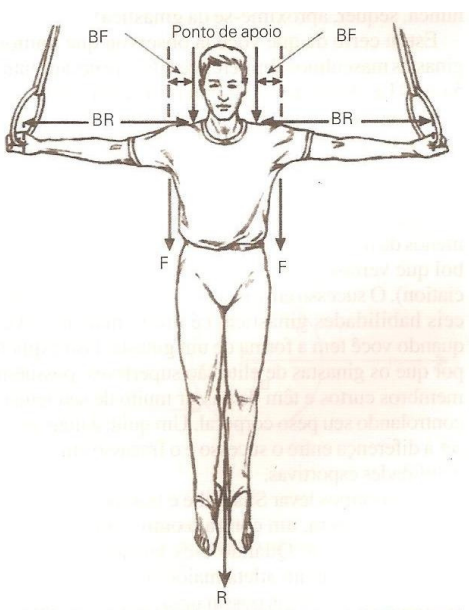

Figura 15: Crucifixo (Biomecânica dos esportes - Gerry Carr - p59)

31. Inércia da Rotação, o que seria? Tente relacionar com a primeira lei de newton.

32. Leia o texto:

\section{Manipulação da inércia de rotação no Salto Ornamental}

Quando grandes saltadores dão um mortal no ar se movem de uma posição corporal estendida para uma encolhida, eles flexionam seus troncos, 
pernas e braços e encolhem suas cabeças. Algumas partes de seu corpo (braços e pernas) movem-se a uma grande distância em direção a seus eixos transversais (quadril a quadril). Outras partes, como suas cabeças, deslocam-se a uma distância pequena. Não obstante ainda há uma diferença dramática na inércia da rotação, entre a posição corporal estendida e encolhida. As pernas e os braços de um saltador são relativamente pesados e constituem muito da massa corporal. Eles se movem a uma grande distância em direção ao eixo do saltador, de forma a ter um grande efeito na redução da resistência do corpo do saltador contra a rotação. Quando o saltador está no ar e numa posição corporal estendida, você pode perceber que ele gira vagarosamente. Se ele puxar seu corpo e ficar encolhido, gira muito mais rápido. Quanto mais massa ele puxar em direção ao seu eixo de rotação (que passa no centro de gravidade), mais rápido ele gira. Isso significa que um corpo esbelto, conjugado com grande flexibilidade, desempenha um papael importante na determinação da velocidade de giro dos saltadores quando eles se encolhem. Atletas

34. No início da atividade falamos em equilíbrio. Leia o texto e descreva a diferença entre equilíbrio e estabilidade.

\section{Equilíbrio e estabilidade}

São dois termos que estão estreitamente relacionados, mas tem três diferentes significados. Equilíbrio (ou balanço) implica coordenação e controle. Um atleta com grande balanço é capaz de manter um estado de equilíbrio e neutralizar aquelas forças que iriam perturbar seu desempenho. A estabilidade está relacionada especificamente a quantidade de resistência que os atletas colocam contra o distúrbio de seu equilíbrio.

Estabilidade linear: Um atleta pode resistir a ser movimentado em uma determinada direção e resistir a ficar parado ou ter sua direção mudada, uma vez em movimento.

Estabilidade rotatória: É a resistência de um atleta ou objeto contra ser inclinado, tombado ou posto em peou girado em círculo. Há alguns fatores que determinam a estabilidade rotatória:

- Atletas aumentam sua estabilidade quando aumentam o tamanho de sua base de sustentação (área do solo englobada pelos pontos de contato do corpo do atleta).

- Atletas aumentam sua estabilidade quando sua linha de gravidade cai dentro do perímetro de sua base de sustentação

- Atletas aumentam sua estabilidade quando abaixam seu cento de gravidade.

- Atletas aumentam sua estabilidade quando aumentam sua massa corporal

- Atletas aumentam sua estabilidade quando estendem sua base de direção de uma força vindo contra eles.

- Atletas aumentam sua estabilidade quando deslocam sua linha de gravidade em direção à força.

Biomecânica dos esportes - Gerry Carr - p.89

Ex: Ginasta executando uma parada de mãos com uma mão só. 


\section{ATIVIDADE 9 - APLICANDO DIRETAMENTE A VÁRIOS ESPORTES}

1. Para cada uma das figuras onde estão representadas algumas modalidades esportivas, explique cada um dos passos ( $\mathrm{a}, \mathrm{b}, \mathrm{c}, \mathrm{d}, \mathrm{e} . .$.$) utilizando todos os conceitos físicos vistos nas atividades$ anteriores.

1) Corrida de velocidade

Todos os atletas utilizam corridas de velocidade como forma de locomoção. É a mais dinâmica vigorosa de todas as técnicas de corrida. A caminhada e as corridas de média e longa distância obedecem às mesmas leis mecânicas que a corrida de velocidade, mas empregam menos movimentos vigorosos.

\section{Corrida de Velocidade}
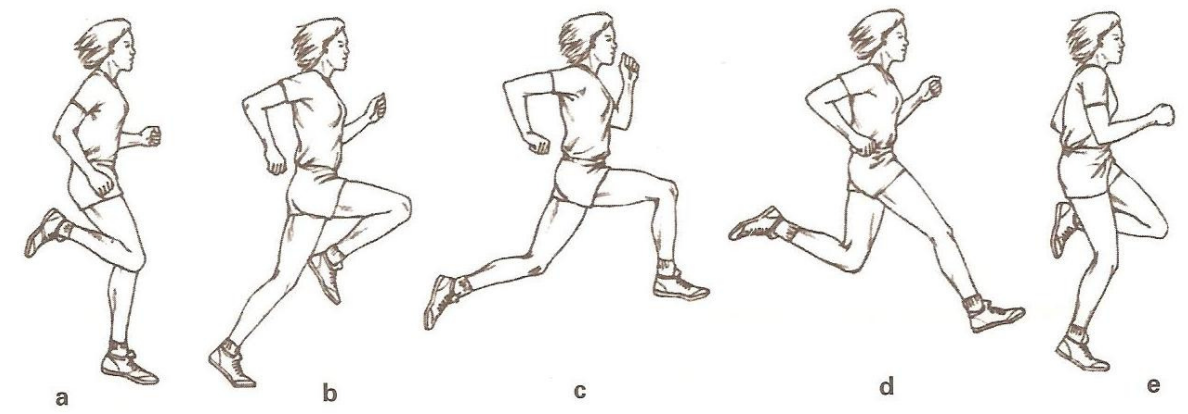

2) Salto em altura

Os princípios mecânicos que controlam como um atleta sobe no ar, no salto $\mathrm{m}$ altura, também se aplicam as outras habilidades de salto. Uma vez no ar, as mesmas leis da mecânica aplicam-se ao atleta de salto em distância, como o fazem para com o atleta de salto em altura.

\section{Salto em Altura Flop}

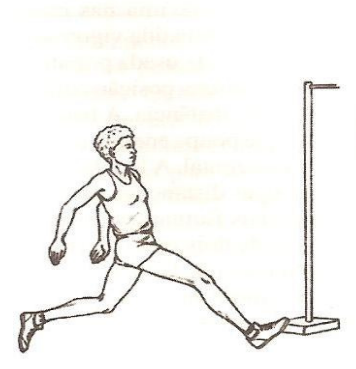

a

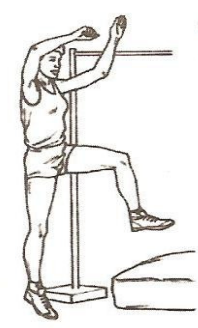

b
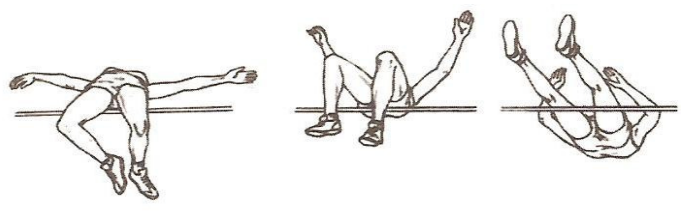

3)Lançamento de dardo

Exige que o atleta gere alta velocidade, o lançador deseja que a mão de lançamento desloque o mais
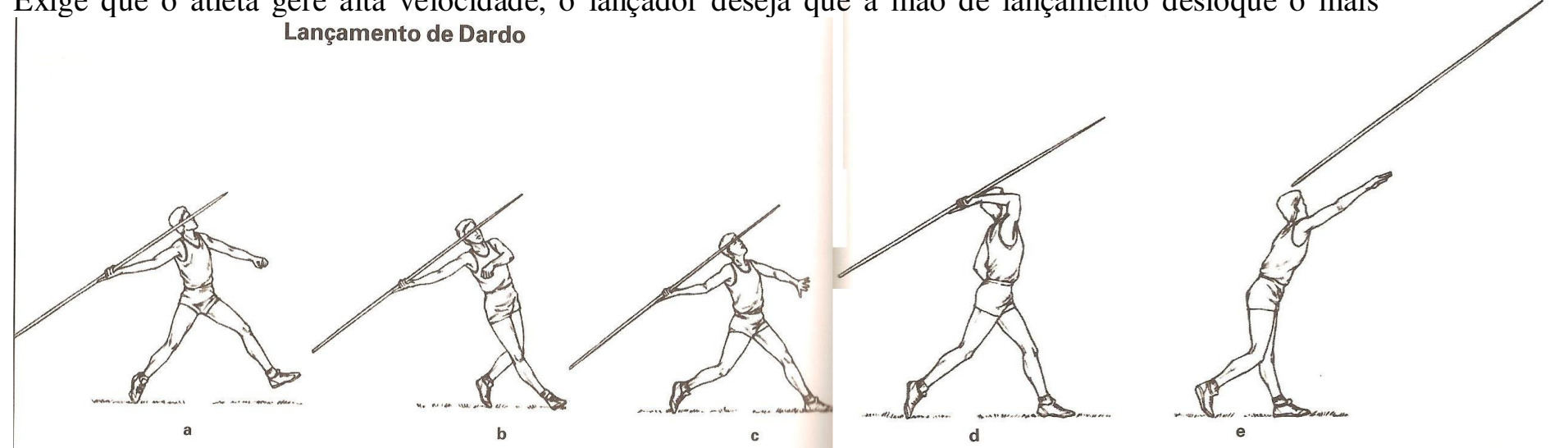
rápido possível.

\section{4) Arremesso}

O encaixe é um movimento de elevar e puxar o arremesso é um movimento de empurrar. Movimentos de carregar ocorrem quando o atleta faz uma pausa com a barra no tórax e, novamente, quando a barra está acima da cabeça, a altura dos braços esticados. Os princípios mecânicos envolvidos no arremesso aplicam-se a todas as técnicas de elevação, carregamento e assistência. As leis que controlam a estabilidade também têm grande papel no arremesso.

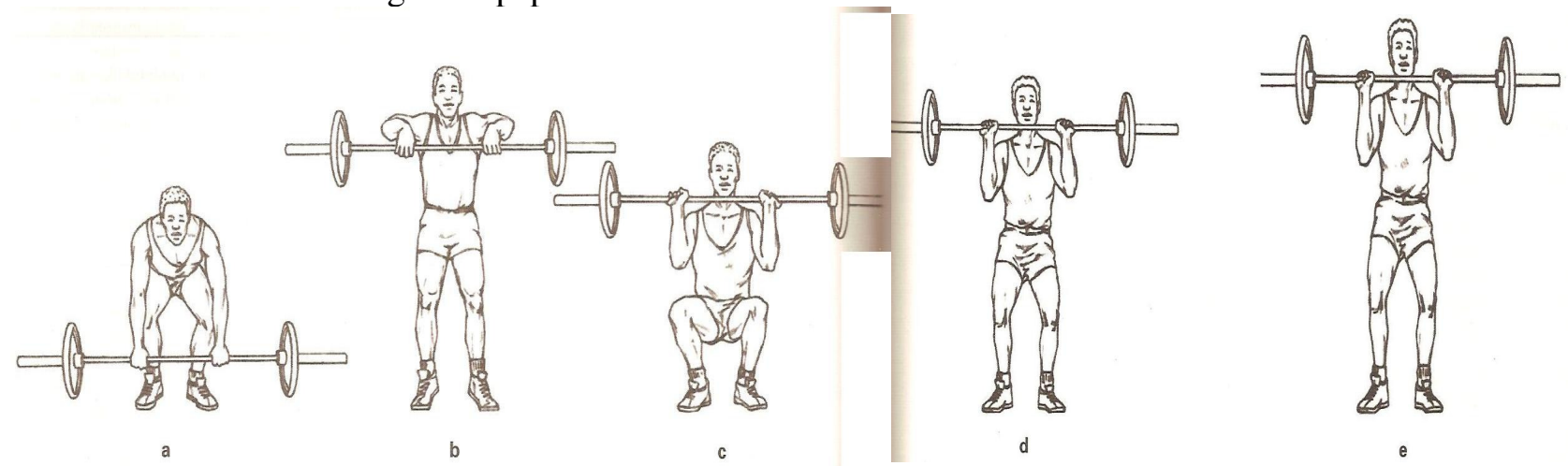

5) Ginástica olímpica

a) Giro girante

Tanto no giro gigante quanto no salto mortal de frente utilizamos a oscilação e rotação.

A oscilação é um a habilidade rotacional controlada por muitos dos princípios mecânicos que governam o salto mortal de frente. Entretanto existem algumas diferenças.

$\mathrm{O}$ giro girante ao redor de uma barra elevada age como um eixo externa ao corpo do atleta.

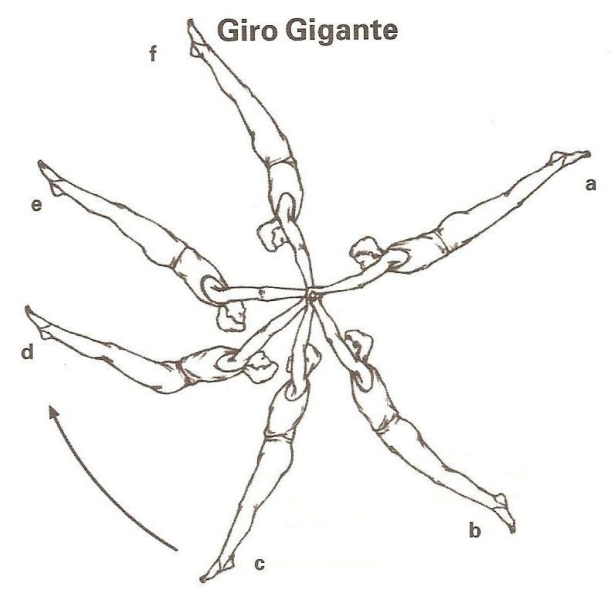

b) Salto mortal

Em contraste, o eixo para o salto mortal de frente passa pelo corpo do atleta de um quadril a outro. Existem semelhanças e diferenças na mecânica dessas duas habilidades

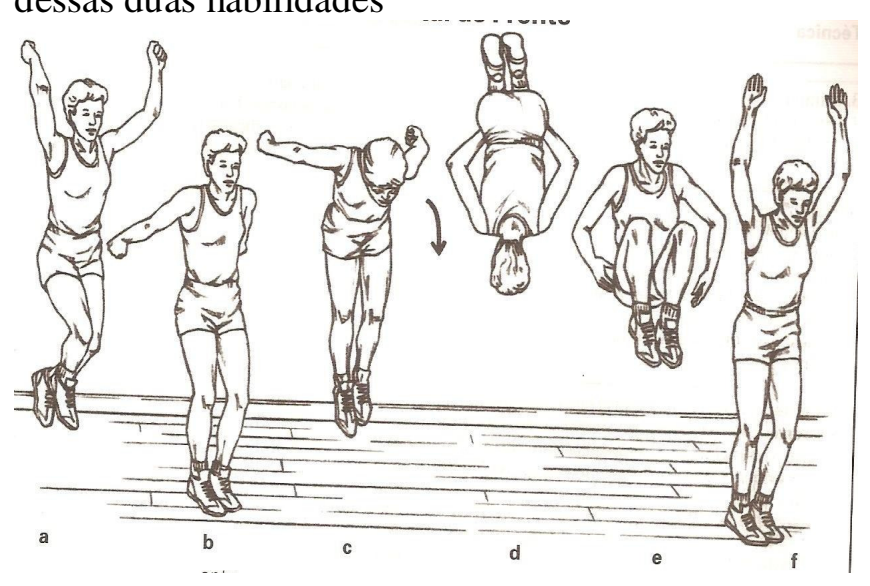




\section{ATIVIDADE 10 - ESPORTES x LESÕES}

Todos os atletas diferem no físico, temperamento e capacidade física e o que funciona para um, não funcionará necessariamente para outro (Biomecânica dos esportes - Gerry Carr - p. 7).

1. Praticar alguma modalidade esportiva ou fazer exercício físico é sinônimo de saúde? Por quê?

2. Que cuidados devemos ter ao iniciar uma atividade física?

3. Qual a importância da biomecânica para prática esportiva?

4. Por que uma compreensão básica dos princípios mecânicos básicos ajudará o atleta a ter um melhor desempenho?

Uma lesão é um termo não-específico usado para descrever um tecido anormal num organismo vivo.Tais anomalias podem ser causadas por doenças, traumas ou simplesmente pela prática de desporto, por exemplo (http://pt.wikipedia.org/wiki/Les\%C3\%A3o).

Tipos de Lesões

\begin{tabular}{|llcc|}
\hline \multicolumn{1}{|c}{ Modalidade } & Tipo de Lesão & $n$ & $\%$ \\
\hline Atletismo & & & \\
$\quad$ Lançamentos & Condromalácia Patelar & 35 & 51.3 \\
Fundo & Tendinite Patelar & 52 & 58.7 \\
Saltos & "Shin - Splints" & 35 & 35 \\
$\quad$ Velocidade & Tendinite Patelar & 44 & 34.1 \\
Basquetebol & Tendinites do Ombro & 41 & 12.2 \\
Canoagem & Pubalgias & 50 & 53.3 \\
Futebol & Epicondilites & 34 & 9.1 \\
Ginástica Desportiva & Dorso-Lombalgias & 90 & 31 \\
Handebol & Tendinite Patelar e & 75 & 19.2 \\
& Dorso-Lombalgias & & \\
Judo & Lombalgias & 30 & 10.8 \\
Remo & Lombalgias & 30 & 96 \\
Tênis & Tendinite Patelar & 18 & 40.7 \\
Voleibol & Dorso-Lombalgias & 36 & 50 \\
TOTAL & Tendinite Patelar & 570 & 38.7 \\
\hline
\end{tabular}

Figura 1: Lesões de sobrecarga em atletas portugueses (Fundamentos biomecânicos para análise do movimento humano Alberto Carlos Amadio, p. 135)

- Leia os textos e faça comentários LESÕES DE SOBRECARGA NOS JOVENS ATLETAS

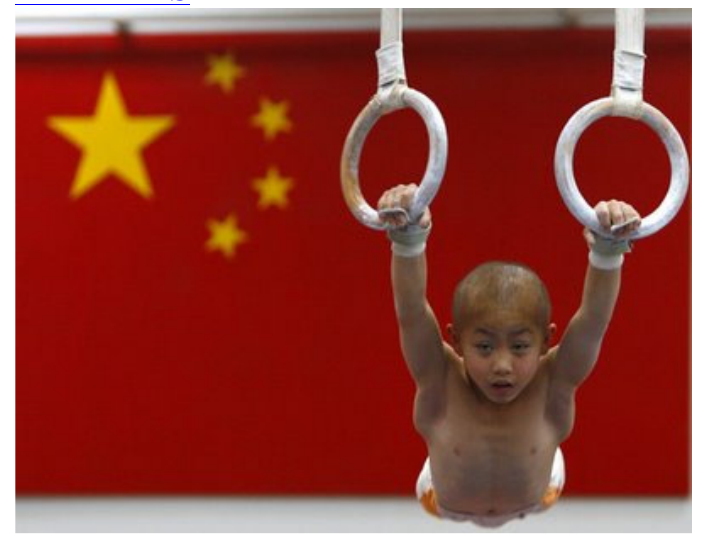

Lesões de sobrecarga mais comuns nos jovens atletas e fatores relacionados com o crescimento e maturidade biológica do sistema osteo-articular Há uma susceptibilidade da cartilagem de crescimento a esforços repetitivos que excedem a sua capacidade de resistência e absorção particularmente no tornozelo, joelho, cotovelo e punho. Em casos extremos mais graves podem surgir lesões da cartilagem articular (osteocondrite dissecante) que podem ter repercussões graves na morfologia anatômica da articulação podendo necessitar de intervenção cirúrgica. Estes tipos de lesão nas articulações do membro superior acontecem, por exemplo, nas ginastas que trabalham desde muito novas com os apoios invertidos, onde essas articulações passam a suportar o peso corporal durante muito tempo e com muitas repetições.

Outro tipo de consequências igualmente graves se não forem despistadas precocemente as lesões na cartilagem de crescimento é a perturbação no processo de crescimento ósseo em si mesmo (paragem parcial ou total desse crescimento). Também são comuns as fracturas de fadiga nos locais de intensa e repetitiva carga como os ossos metatársicos, a tíbia, o perônio (nos corredores, p.ex), vértebras lombares - nos istmos articulares que podem levar a situações de instabilidade articular onde o tecido ósseo é substituído por tecido fibroso: espondilólise - (nos tenistas, ginastas e patinadores que realizam movimentos repetitivos e extremos em hiperextensão da coluna lombar associada à rotação - mecanismos desencadeantes desta situação). Existem também as lesões nos locais de inserção óssea dos músculos mais potentes do membro 
inferior onde também está a ocorrer o crescimento ósseo (salto pubertário). A inserção do tendão patelar na tíbia (Doença de OsgoodSchlatter) ou do tendão de Aquiles na calcâneo (doença de Sever) são os exemplos mais comuns no jovem entre os 10/11 e os 14/16 anos. Pode variar a idade de ocorrência destas lesões em função do sexo, do índice maturacional e dos desportos praticados.

O desfazamento entre o pico de crescimento ósseo e o pico de crescimento músculotendinoso, a reduzida flexibilidade desses músculos, a relativa fraqueza destes locais de inserção e o aumento das solicitações mecânicas (forças de tração) que o jovem atleta é sujeito (p.ex multi-saltos, deslocamentos defensivos, mudanças bruscas de direção e velocidade) com um esqueleto em crescimento acelerado, explicam o porquê da elevada prevalência destes problemas entre os jovens.

Por último as tendinopatias (lesões nos tendões) também são um bom exemplo das lesões de sobrecarga sendo mais comuns no tendão patelar - "jumpers knee"- (basquetebol, voleibol. salto em altura e em comprimento), no tendão de Aquiles (atletas de fundo e meio fundo), nos tendões da coifa dos rotadores do ombro (natação, tênis, badminton, voleibol, andebol) e nos tendões do punho (tênis, tênis de mesa). Lesões nos jovens atletas - fatores psicossociais Mas não podemos esquecer que existem outros fatores - psicossociais e sócio-desportivos - que em interação com os descritos atrás, potenciam o risco de lesão e podem comprometer a saúde do atleta. Ora vejamos:

- O desporto de competição e de rendimento nas camadas jovens implica um tempo de exposição ao risco de lesão muito elevado que testa continuamente os seus limites de resistência e de adaptabilidade física, psicológica e mental - A valorização social no desporto de rendimento cria expectativas, ilusões e desejos de afirmação individual e coletiva que só é atingida por reduzida minoria de atletas. Este fator é potenciado pelo papel que os media têm atualmente na divulgação do fenômeno desportivo.

- A pressão social (família, clube, colegas e pares, treinadores) mesmo que de forma subtil e indireta centrado nos resultados (vitórias, recordes, medalhas) projeta-se no jovem que se quer afirmar e ter sucesso, o que leva que em algumas situações se corram riscos dos quais nem sempre os atletas conhecem totalmente, ou se os conhecem resolvem desafiá-los.
A frase "no pain, no gain" que se ajusta para descrever o espírito de sacrifício, disciplina e capacidade de trabalho que estes jovens devem ter, pode servir para explicar situações em que ou por desconhecimento dos profissionais envolvidos ou por estarem excessivamente focados nos objetivos competitivos se vão ignorando ou desvalorizando sinais de alerta que o corpo do jovem vai dando. Por outro lado também no treino desportivo a quantidade de trabalho (volume e intensidade) nem sempre são sinônimos de qualidade.

Os jovens desportistas não são "adultos em ponto pequeno". Têm uma dinâmica fisiológica própria, um controle neuro-endócrino e metabólico também específicos e vivem uma realidade psicológica única. Neste contexto todos os profissionais envolvidos de alguma forma no treino de jovens atletas deveriam ter uma formação pedagógico - cientifica sólida e promover a multidisciplinaridade da intervenção. O conhecimento dos padrões de crescimento e de maturação neurobiológica de cada jovem atleta, a avaliação das suas características físicas e psicossociais, o domínio dos fatores de risco de lesão (extrínsecos e intrínsecos) associados à prática da cada modalidade devem constituir os pilares fundamentais da intervenção multidisciplinar para que os jovens atletas possam praticar um melhor desporto num contexto de maior prazer, segurança e afirmação individual e coletiva.

http://requilibrius.blogspot.com/2009/01/lesesde-sobrecarga-nos-jovens-atletas.html 


\section{Biomecânica do Calçado, \\ por Marcelo Luiz de Souza}

Considerações atuais sobre a escolha do tênis para treinamento e atividade física.

Todo praticante de atividade física, desportistas e atletas, que façam da corrida ou caminhada seu instrumento de condicionamento, devem se preocupar com o uso correto do tênis. Correm riscos de lesões se algumas questões não forem observadas adequadamente. $\mathrm{O}$ avanço tecnológico nos últimos anos com a indústria dos calçados permite adequar o tipo de pisada e, principalmente, a biomecânica da marcha e da corrida, ao tênis, permitindo não só a prevenção de lesões, mas também melhor eficiência do movimento produzindo, assim, um melhor rendimento. Fazse necessário, porém, apontar algumas características fundamentais para às quais o atleta/desportista deve estar atento.

1) Biomecânica: É comum que as lesões por sobrecarga sejam provocadas por uma combinação de fatores intrínsecos e extrínsecos.

Dentre os fatores intrínsecos, posso destacar: desalinhamento do pé (pé plano, hiperpronação, pé cavo, tíbia vara, geno valgum, geno varum, patela alta, anteversão da cabeça femoral); discrepância de comprimento dos membros inferiores; fraqueza muscular; flexibilidade reduzida; composição e tamanho corporal; sexo e tipo de pé.

O fator extrínseco mais considerável é à força de reação do solo (FRS). No caso da corrida, o contato do pé com o solo, produz uma elevação muito aguda das forças verticais de reação que certamente se constituem, no fator mais importante para as lesões por sobrecarga. Neste sentido, os tênis para treinamento/atividade física são construídos objetivando dar suporte funcional ao pé, evitar movimentos rotacionais excessivos e evitar forças excessivas em geral.

Assim são observados alguns princípios: Limitar as forças de impacto durante o apoio (amortecimento), dar suporte ao pé durante o apoio médio (estabilização) e conduzir o pé durante a fase final de apoio (orientação). Posso afirmar que os principais objetivos em relação à biomecânica do calçado são, de maximizar o rendimento, prevenir lesões e controlar sobrecarga no aparelho locomotor.

Destacarei a seguir alguns procedimentos importantes que devem ser observados na escolha do tênis específico.

2) Avaliar pisada: Continua sendo fundamental para a escolha do tênis. Os modelos são adaptados em função das características dos pés e da pisada.

Um dos modelos de avaliação encontrado, prático, rápido, porém pouco funcional, pois não avalia dinâmica da corrida, são encontrados nas lojas especializadas em tênis esportivo trata-se dos "SCANS". Um dos mais utilizado é o Robot Pexam, que através de células ultrasensíveis capta as pressões exercidas no pé e se verifica onde estas pressões são maiores. O problema, entretanto, reside no fato de que o vendedor, apesar de saber qual a pisada do cliente, nem sempre indicará o tênis mais adequado.

$\mathrm{Na}$ avaliação que fazemos, observamos o tipo de pisada, angulação dos joelhos e quadril, se possui retro-pé valgo ou varo e, em seguida, a pessoa será filmada em diversos ângulos de movimento para observarmos efetivamente qual melhor modelo indicar.

Outro exame interessante para avaliar a dinâmica da marcha e da corrida, é a baropodometria, exame extremamente funcional que permite observar em vários ângulos o movimento articular e, sobretudo as pressões exercidas sobre cada parte do pé, em função da força de reação do solo. Algumas clínicas já adotam este modelo. Ocorre que nem sempre o profissional que avalia tem o conhecimento sobre o tênis a indicar. Conhecem o procedimento de avaliação e as pressões efetivamente exercidas, mas conhecer os diferentes modelos e as estruturas tecnológicas inovadoras que as indústrias procuram efetivar nos tênis é outra questão.

No teste do "pé molhado" ou da "cartolina com talco", observa-se apenas o arco pé (normal, cavo e plano), não dando dinâmica à avaliação. Podem ser utilizados, pois em geral existe compatibilidade do pé cavo com a pisada supinada e do pé plano com a pisada pronada. Mas, repito, é necessária uma avaliação dinâmica para efetivação do processo. Para lembrar, relacionamos os tipos de pisadas:

a) Neutra: Inicia o contato com o solo do lado externo do calcanhar e, então, ocorre uma rotação moderada para dentro, terminando a passada no centro da planta do pé. Calçado ideal, entre amortecimento e estabilidade

b) Supinada: A pisada inicia no calcanhar do lado externo e se mantém o contato do pé com o solo do lado externo, terminando a pisada entre o $4^{\circ}$ e $5^{\circ}$ metatarso (dedinho do pé). Pé supinado é, em geral, muito rígido. Calçado ideal, aumento do amortecimento e da flexibilidade.

c) Pronada: Aquela em que a pisada também se inicia do lado externo do calcanhar, ou algumas vezes um pouco mais para a parte interna, para então ocorrer uma rotação acentuada do pé para dentro, terminando a passada perto do hálux (dedão do pé). A pronação é um problema de hipermobilidade. Calçado ideal, menos flexível, mais estabilidade, e controle do movimento (retropé).

3) Como usar o tênis adequadamente: A indústria utiliza principalmente, EVA (acetato vinil etileno), P.U(poliuretano), MoGo (uma liga plástica), SPEVA, SOLYTE e o X10(carbono), entre outros, na confecção da entressola do tênis. Este material é deformado de acordo com as pressões exercidas na marcha e na corrida. E necessita-se de pelo menos 24 horas para este material se "recuperar" das pressões exercidas, devendo assim considerar, quem corre todos os dias, a relevância da aquisição de um segundo modelo. Um modelo para treino longo, outro para treino de intensidade, por exemplo. 
4) Amortecimento ou estabilidade? O tema é polêmico e requer algumas reflexões. A grande justificativa das indústrias que fabricam tênis é exatamente o amortecimento como sendo o diferencial na escolha do calçado. Entretanto, estudos recentes nos mostram que é a ESTABILIDADE a característica mais importante na escolha do tênis para o treinamento ou atividade física, no que se refere à prevenção de lesões, funcionamento biomecânico correto dos membros inferiores e a performance. E assim, deve ser dada preferência se o indivíduo não for um supinador excessivo ou um pronador excessivo, usar tênis da categoria ESTABILIDADE. Veremos abaixo como os tênis são divididos por categorias.

5) Como escolher o tênis em função de sua pisada: Estes são divididos pelas seguintes categorias: a) Controle do Movimento (pronadores excessivos): São os mais rígidos. Geralmente, são mais pesados, mas muito duráveis, e têm solado plano para oferecer maior estabilidade e suporte. Você deve preferir este tipo de tênis caso tenha um grau de pronação muito acentuada. b) Estabilidade (pronadores leves a moderados, corredores neutros e supinadores leves a moderados podem optar por tênis desta categoria): Estes tênis possuem uma boa estabilidade, sem deixar de lado o amortecimento. Apresentam solado semi-curvo. Em geral a grande maioria de atletas e ou desportistas vão se enquadrar nesta categoria.

c) Amortecimento. (Supinadores moderados a severos): Tem como principal objetivo amortecer o impacto com o solo. Os supinadores, que normalmente têm o pé mais rígido, encontrarão aqui os modelos mais adequados. Solado curvo ou semicurvo para estimular os movimentos dos pés.

d) Performance (competição): são tênis mais leves indicados para as competições ou até mesmo treino de intensidade.

e) Trilha: Tracking, caminhadas em montanhas, terrenos arenosos e etc.

6) Quando devemos trocar de tênis: Devemos considerar que as deformações ocorridas devido às forças de reação do solo, variam de acordo com a tecnologia empregada no tênis, material utilizado, e até mesmo as compensações biomecânicas. Com isso, estima-se que em geral, um tênis vá ter sua eficiência biomecânica compensada, e um bom amortecimento prevenindo assim as lesões, dependendo do modelo, entre 500 e $800 \mathrm{~km}$ de uso. Acima disto, o tênis perde muito sua eficiência biomecânica e não é garantido que o tênis tenha sua função preservada.

A durabilidade, então, dependerá do modelo, da tecnologia empregada, dos materiais utilizados na confecção do tênis e das características biomecânicas da pisada em função da marcha e da corrida.

Quanto ao preço, os bons modelos, com variação de recursos tecnológicos, giram em torno de $\mathrm{R} \$ 300,00$ a $\mathrm{R} \$ 550,00$. E a durabilidade será, sem dúvida, maior, naqueles modelos de maior investimento tecnológico, ou seja, paga-se mais, mas em compensação, o desgaste do material é menor é o tênis, certamente durará mais tempo.

7) Principais Lesões por supinação e pronação excessivas: Todo movimento de pronação e supinação ocorre na articulação subtalar (tálus e calcâneo), abaixo da articulação do tornozelo, e assim, consideramos como fisiológico o movimento de pronação e supinação da articulação subtalar. A biomecânica da marcha ou corrida inicia-se com pressão na parte externa do calcâneo, portanto em leve supinação, terminando com pressão maior em nível do Hálux (dedão do pé), com leve pronação.

As lesões ocorrerão quando a supinação e pronação forem EXCESSIVAS na articulação subtalar, e daí a necessidade de um modelo de tênis que minimize o impacto, estabilize a articulação subtalar, sendo adequada a um determinado tipo de pisada. Dentre as lesões por supinação e pronação EXCESSIVAS, destaco:

Lesões por supinação excessiva: - Entorses por inversão do tornozelo - Síndrome do estresse tibial medial (canelite) $\bullet$ Tendinite dos fibulares - Síndrome do atrito no trato iliotibial $\bullet$ Bursite trocantérica $\bullet$ Fratura por estresse do $5^{\circ}$ metatarso (fratura de Jones) $\bullet$ Neuroma de Morton.

Lesões por pronação excessiva: • Fratura por estresse do navicular • Fratura por estresse do $2^{\circ}$ metatarso (fratura de March) • Joanete $\bullet$ Fascí́te plantar $\bullet$ Tendinite do tibial posterior $\bullet$ Tendinite do Tendão de Aquiles $\bullet$ Síndrome do estresse tibial medial (canelite) $\bullet$ Dor na parte medial do joelho $\bullet$ Subluxação do cubóide $\bullet$ Síndrome do túnel do tarso.

8) Conclusão: Na hora de escolher um modelo de tênis, não deixe de considerar os aspectos aqui levantados. Desta forma, seu rendimento estará melhorando na medida em que as lesões estejam sendo prevenidas. As grandes marcas Asics, Mizuno, Adidas, Nike, e que já foram absolutas em termos de tecnologia, hoje, recebem a concorrência de outras marcas, inclusive de marcas que estão chegando ao Brasil como a Brooks Trance, Avia e etc.

Portanto, não deixe de fazer uma avaliação com um especialista na hora de escolher um tênis adequado às suas características biotipológicas. Assim, observando este aspecto, o atleta/desportista estará dando salto de qualidade no seu planejamento, respeitando princípios fundamentais que, hoje, norteiam o desenvolvimento da preparação física no Brasil e no Mundo, que é, a maximização da performance diminuindo o risco de lesões.

http://www.cartaovermelho.esp.br/index.php?name=Sections\&req=viewarticle\&artid=425\&page=1

Sugestão: http://www.encontroaaarl.com.br/artigo.php?id=9

5. Agora você pode dizer qual é a maior responsabilidade de um treinador? 
6. Depois destas atividades você é capaz de analisar mais criticamente o desempenho de um atleta? Você consegue dizer qual movimento é mais eficiente ou não?

7. Escolha uma modalidade esportiva (não pode ser o que já vimos) e enumere as habilidades necessárias para seu desempenho.

Lembre-se que quando você observa um atleta de elite executando uma habilidade, você tem um quadro de velocidade, ritmo, potência, posições corporais e outras características que compõem um desempenho de qualidade, isso o ajuda a entender os padrões básicos de movimentos na técnica da habilidade escolhida.

8. Como você pode identificar e corrigir os erros do atleta nesta modalidade que você escolheu. 


\section{A2.2. Diário de Bordo}

Foi entregue aos grupos em cada aula uma cópia da atividade do dia, e pedido para que respondessem em uma folha de caderno e não rabiscassem a cópia, pois usaria em outras salas para economizar no custo das cópias, sendo uma folha de resposta por grupo.

Notação: A: aluno, P: professora

\section{Escola M}

\section{$1^{\circ} A_{1}-3^{a}$ aula - 14/09}

Expliquei que se tratava de 10 avaliações que valerão nota do $4^{\circ}$ bimestre. Propus grupos de no máximo 4 alunos que não poderão mudar durante as avaliações.

Inicialmente pedi para escreverem 10 palavras relacionadas a força e depois iniciei a atividade 1.

P: Você pode colocar o que vem a mente.

A: Pode consultar o livro? Tem caderno? Já sei! Fazer necessidades - faz força ué. Também força elétrica.

Muitos alunos ficaram confusos (achando esquisito) outros com celular "zoando", alguns desenhando, outros preocupados em copiar a lição do caderno do aluno de física, mas também houve alunos preocupados em responder e com o tempo de aula.

Há grupos que funcionaram bem (todos participando), mas há grupos em que alguns alunos ficam isolados, calados.

Muitos diziam: Ah eu não sei, mas vou colocar sim, pois aí não precisa dizer o por quê?

Durante a aula toda fiquei sentada, apenas me levantei quando algum grupo me chamava, não interferi, não comentei nada.

Na questão $6 \mathrm{~d}-\mathrm{A}$ : Coloca física seu tonto, se a professora está aplicando.

O primeiro grupo a entregar foi em 44 minutos.

A: E a atividade extra-classe é para fazer?

P: Não é obrigatório, somente se você tiver curiosidade

A: Então terminei, para que isso?

A: A questão 6d eu acho que só tem uma disciplina, pois as outras não servem!

P: Então tudo bem.

A: Acho que o treinador faz educação física e depois algum curso igual ao que o bandeirinha faz. Se bem que para ser jogador não precisa de nada é só saber jogar.

$1^{\circ} B_{1}-5^{a}$ aula $-14 / 09$

Iniciei explicando como fazer uma maquete do sistema solar, coloquei a regra de três do caderno de física do aluno 3 e depois comecei a atividade 1. Expliquei que seriam 10 provas e que o grupo de quatro pessoas não poder ser mudado, e em seguida pedi para escreverem 10 palavras relacionadas a força.

A: Veio na minha cabeça o Huck.

P: Pode ser.

A: Não vai dar para terminar nesta aula.

P: Não tem problema continuamos na próxima aula.

Percebi que sempre há um aluno que responde e os outros integrantes se isolam.

Também por poder terminar em outra aula, só enrolaram. 


\section{$1^{\circ} \mathrm{C}_{1}-6^{\mathrm{a}}$ aula $-14 / 09$}

Expliquei que seriam 10 provas. Apresentaram-se confusos para fazer os grupos de quatro, ficaram assustados com a apalavra prova, pois não costumo aplicar prova.

A: Pode consultar o caderno?

P: Não haverá necessidade, mas enfim...è sua opinião!

A: Tem certeza?

A: Professora o treinador é o técnico, né?

A: Não sei nada! Não assisto jogo nenhum!

P: De qualquer forma eu respeito sua opinião.

Me desanimei, pois tem aluno que não se anima com nada, não faz contas, não escreve, não desenha, etc. Como era a última aula, deixei o restante da atividade 1 para próxima aula, pois a última aula é sempre complicada.

Após recolher as folhas com as respostas dos grupos, um aluno me questionou sobre o objetivo desta prova.

P: Você irá entender nas aulas seguintes.

A: Vi na TV o nadador Phelphs e a análise dos seus movimentos na água falaram de energia cinética e potencial que já vimos nas aulas.

P: Você está começando a entender o propósito das provas.

$1^{\circ} B_{1}-2^{a}$ aula $-15 / 09$

Dei a folha das perguntas da atividade 1, e não devolvi a folha de respostas da aula anterior.

A: Por que você não vai devolver a folha de repostas?

P: Para assegurar que não será copiado pelos grupos atrasados. Pode deixar que eu falo em que questão vocês pararam.

Tive que interromper um grupo, pois ao invés de fazer a atividade ficavam conversando sobre assuntos pessoais. Alguns alunos apresentaram dificuldade em interpretar as questões. Durante a aula, os alunos que iam terminando a atividade, vinham a minha mesa para esclarecer dúvidas do caderno de física do aluno 3.

Os alunos me chamaram poucas vezes, sendo que um grupo questionou sobre a tabela da questão $6 \mathrm{~d}$, dei um exemplo utilizando a disciplina de português, mas não sei se fiz certo.

Os alunos que deixaram de responder as questões ficaram dura te a aula brincando com o celular, desenhando, conversando, etc.

\section{$1^{\circ} A_{1}-4^{a}$ aula $-15 / 09$}

Iniciei a aula explicando algumas coisas do caderno de física do aluno 3.

A: Professora, não terminei ontem, você vai devolver?

P: Sim, mas no final da aula.

A: Eu faltei.

P: Responde sozinho.

A: Ai credo! Não gosto de esportes.

Nesta aula até que funcionou, havia alunos que estavam terminando a atividade 1 e outros fazendo as lições do caderno de física do aluno3 e claro que outros não fazendo nada.

$1^{\circ} \mathrm{C}_{1}-1^{\mathrm{a} a u l a}-21 / 09$ 
Hoje estou confusa, mas logo que entrei, fui para lousa colocar o diâmetro, distância ao sol, período orbital dos planetas e planetas anões, pois é necessário terminar o caderno física do aluno3 para entregar as médias do $3^{\circ}$ bimestre, mas uma aluna disse que precisava terminar a atividade1.

Falei em voz alta a questão em que cada grupo parou na aula anterior e pedi para que os alunos que faltaram na aula anterior formassem um grupo juntos.

Foi uma aula agitada, pois uns alunos terminavam a atividade, outros copiavam a matéria da lousa, enquanto eu aplicava visto no caderno e no caderno do aluno de física 3, é claro que havia também alunos não fazendo nada e outros copiando a lição de educação física que era para aula seguinte.

A: Na questão 10 vai matemática mesmo? Coloquei, pois ele disse que vai.

A: Porque a gente faz o calculo do ICM em educação física.

$1^{\circ} A_{1}-4^{\text {a }}$ aula - 21/09

Após o intervalo, tudo fica mais difícil, bom iniciei a aula pedindo para montarem os grupos para a atividade 2. Houve confusão, pois queriam adicionar outros colegas no lugar do que havia faltado. Havia alunos que iniciaram ainda a atividade 1 , pois faltaram nas duas últimas aulas.

Fiquei sentada não interferi em nada e apliquei visto no caderno de física do aluno3. Enquanto isso, alguns alunos respondiam a atividade 2, outros grupos apenas conversavam, outros mexiam no celular, etc.

$\mathrm{Na}$ questão 5, troquei a palavra relacionar por: "Tem algo a ver" para que entendessem a questão. Muitos questionaram sobre os textos - A: Lê e depois responde, ou responde e depois lê.

A: Eu sou magra, mas só como merda.

A: Esqueci qual alimento é saudável, mesmo...verdura é?

A aula foi interrompida pelo coordenador da escola para recolher alguns cadernos do alunos de algumas disciplinas para ele dar visto - começou o tumulto novamente.

A turma é um "vuco-vuco", onde se faz a tarefa conversa, conversa e faz a tarefa e assim vai...

$1^{\circ} \mathrm{C}_{1}-6^{\text {a aula }}-21 / 09$

Iniciei pedindo pra formarem os mesmos grupos para prova 2

A: Você quer matar a gente? Pode mudar de grupo?

P: Não faz drama e responde!

Vários grupos tiveram dificuldade com a questão 2, devido a má formulação da questão. Houve confusão com os textos - lê e responde ou responde e lê?

Durante a aula apliquei visto no caderno e no caderno física do aluno3.

Na questão 5 - A: è tudo a mesma coisa.

A: O que é auto-estima professora? Essas perguntas são parecidas com as do caderno de educação física.

A: Professoras as minhas respostas estão todas iguais, o que mais eu respondo?

$\mathrm{P}$ : Se você acha igual então repete as respostas, as questões podem estar mal formuladas.

$1^{\circ} B_{1}-4^{a}$ aula $-21 / 09$

Como sempre é uma demora para que todos entrem. Iniciei colocando alguns recados na lousa e pedi para que formassem os mesmos grupos da atividade 1, enfatizando que só teriam 1 aula para responder.

A: Ah professora! É só nesta aula mesmo? 
P: Ou termina hoje, ou fica sem nota.

A: Lê o texto e responde?

P: Quero sua opinião.

A: Mas como assim qualidade de vida? É quem tem dinheiro né.

P: Se você tem essa definição, $\mathrm{OK}$, quero saber o que você pensa a respeito.

Fiquei sentada corrigindo o caderno do aluno de física 3, mas tive que interferir em um grupo que ria muito e não produzia nada.

Há grupos que discutem bem e o tempo fica escasso, mas maioria enrola...

A: Que saco! É saudável, saudável, a mesma coisa.

Estou nervosa, pois nunca param com o celular, com as revistinhas, etc.

Questão 9 - A: Quem tem aids vai levantar peso, seu "trouxa".

$1^{\circ} A_{1}-4^{a}$ aula $-22 / 09$

Depois do intervalo...é só Deus...

A aula estava confusa, pois havia alunos discutindo entre si (acho que a confusão já começou no intervalo), então tive que fazer uma pequena ameaça: Se vocês não se comportarem adequadamente terão que fazer as atividades individualmente.

Na questão 4 - A: Se é parte do corpo humano então poder ser o coração e na área o cardiologista.

A: Coloca sempre a resposta mais curta, seu tonto! você deu.

Na questão 7 - A: É para colocar a definição também? Torque é, eu me lembro, A aula depois do intervalo é mais curta e nenhum grupo terminou.

$1^{\circ} B_{1}-22 / 09-2^{a}$ aula

Que confusão, muitos copiavam as lições do caderno de física sobre o caderno do aluno de física 3 um do outro para me entregar, então interrompi: Ou respondem a atividade ou zero. Escolhe!

A: Como assim faculdade?

P: Profissão: engenheiro, médico, etc.

A: O que é mesmo inércia?

P: Lembra da $1^{\mathrm{a}}$ lei de Newton, parada ou em movimento contínuo.

Parece que gostaram da atividade, ficaram calmos respondendo.

$1^{\circ} \mathrm{C}_{1}-28 / 09-1^{\mathrm{a} a u l a}$

Estavam muitos calmos, não houve problemas de comportamento, fizeram os grupos e começaram a responder, enquanto isso eu corrigia as lições no caderno de física do aluno3.

A: Do que o otorrino cuida mesmo?

A: Vou ficar com azul né, respondi tudo?

\section{$1^{\circ} A_{1}-3^{a}$ aula - 28/09}

Muito barulho! Pedi para terminarem todas as atividades atrasadas - senão nota baixa (devido aos alunos "enrolões" e faltosos). Na atividade 4 permiti que mudassem o grupo, pois achei melhor em dupla, acho que dá menos confusão, demoraram para formas as duplas, mas depois de 20 minutos foi...

A: Não entendi a questão 1 . 
P: Vamos ler juntos e devagar.

A: Ah entendi então são $10 \mathrm{~m} / \mathrm{s}$, na questão 2 acho que $5 \mathrm{~m} / \mathrm{s}$, mas e a questão 3 ?

P: Então se você faz com velocidade de $5 \mathrm{~m} / \mathrm{s}$, significa que você faz 5 metros em 1 segundo, então 100 metros em ....

A: Ah entendi.

Tive que fazer algumas interferências para encaminhar o raciocínio.

A: Na questão 1 é 100.

P: Leia com calma.

A: Ah são 10.

A: Professora quanto é $100 \mathrm{~m}$ ?

P: Pense um passo tem aproximadamente $0,5 \mathrm{~m}$.

A: Na questão 2 seria o dobro.

P: Então temos um cara super- power, pois ele é mais rápido que um corredor de elite?

A: Ah entendi é menos, então é regra de três?

P: Quero saber como você fez para responder, não necessariamente precisa de conta.

A: Professora na questão 6 são distâncias diferentes, então não dá para dizer a velocidade.

P: pense, será?

A: Vou transforma em segundos...

A aula passou rapidamente e a maioria parou na questão 6 .

$1^{\circ} B_{1}-4^{\text {a aula } 28 / 09}$

Tumulto grande, pedi para que formassem duplas, mas queriam continuar em quatro, então expliquei que era mais fácil para eu poder ver o raciocínio. Li a questão 1 da atividade 4 várias vezes, associei com o velocímetro do carro, até entenderem e responderem sozinhos.

Tinha alunos indo muito bem e outros somente copiando.

Como havia vários grupos não entendendo a questão 1 , encenei com passos por segundo e dei exemplo da corrida de aleluia da cidade, no qual eu participo.

P: Eu fiz $8 \mathrm{~km}$ em 40 minutos e outro $10 \mathrm{~km}$ em $50 \mathrm{~min}$, quem foi o mais rápido?

Surgiram várias respostas até chegar nos valores de velocidade.

$1^{\circ} \mathrm{C}_{1}-6^{\mathrm{a} a u l a}-28 / 09$

Foi muito tranqüilo, iniciaram a atividade 4 sem muitos problemas, apenas exemplifiquei eu na corrida de aleluia para encaminhar a questão 6.

$1^{\circ} B_{1}-2^{a}$ aula $-29 / 09$

Propus terminar até a questão 29, e coloquei encaminhamentos na folhas que me entregaram na aula anterior e a transformação de tempo na lousa.

A: Não sei explicar meu raciocínio, como faço? Está certo?

$\mathrm{P}$ : Como você pensou? Ah, s/km representa o que? Massa?

A: Ah, é km/s

P: Então...

P: Ah já sei. Mil (1000) é diferente de 1,000.

A: Mas na calculadora tem ponto, mas então o ponto é a vírgula! 
Se empenharam em fazer, mas percebi que é necessário incentivar: Vocês estão indo bem, sabem física, agora está vendo onde aplica, coragem, isso mesmo, calma, raciocinar leva tempo e vontade, é isso aí, parabéns. Enfim são crianças grandes!

\section{$1^{\circ} A_{1}-4^{a}$ aula $-29 / 09$}

Que bagunça. Sermão para começar: Silêncio posso falar? Até acalmar demorou. Vocês tem crédito e não sabem utilizar...

Sentei o comecei a olhar os cadernos, até começarem a me chamar para tirar duvidas sobre a atividade 4, pois na folha de respostas, havia colocado alguns encaminhamentos.

A: Professora fiz a questão 1 de novo e deu $10 \mathrm{~m} / \mathrm{s}$, não é pouco?

P: Pense meu braço tem $0,5 \mathrm{~m}$.

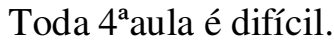

A: Professora dividi, está certo?

P: Sei lá, explique seu raciocínio... então...

Coloquei na lousa as transformações das unidades de tempo. Há duplas que negociam - você faz isso, eu faço aquilo.

Uns são muito rápidos para responder, outros que nunca fizeram nada na minha aula, me surpreenderam com o raciocínio.

$1^{\circ} C_{1}-1^{a}$ aula $-05 / 10$

Iniciei entregando a folha de resposta e esperando me chamarem para tirar as dúvidas. Que confusão parece que esqueceram tudo o que fizeram na última aula (passou apenas 1 semana). Muitos alunos preferem tirar as dúvidas com outros alunos do que comigo. Também há alunos inseguros que a todo momento querem confirmar suas respostas comigo.

A: Professora, não sei a questão 14.

P: Por que?

A: Não entendi nada.

P: Leu o texto?

A: Não.

P: Então leia.

A: Não entendi.

$\mathrm{P}: \mathrm{O}$ que você não entendeu?

A: Ele chegou atrasado porque o fantasiado o segurou.

P: Isso agora eu quero saber a velocidade de cada um, lembra do velocímetro do carro? No radar da cidade a velocidade máxima é $50 . .$.

A: $\mathrm{km} / \mathrm{h}$

P: Então o que você faz?

A: divide $42 \mathrm{~km}$ da maratona pelo tempo.

$1^{\circ} A_{1}-05 / 10-3^{a}$ aula

P: Vocês devem terminar toda a atividade 4 hoje, não enrole e acelere. Como sempre temos alunos que não fazem nada.

A: Professora como é mesmo que faz para transformar minutos para segundos?

P: 1 minuto tem quantos segundos?

A: 60 s

P: Então.

A: Ah, multiplica. 
Havia alunos que nem abriram a mochila, mas que nas aulas anteriores foram bem participativos, vá saber né.

A: Não sei a questão 14.

P: Qual a distância de uma maratona?

A: $42 \mathrm{~km}$

P: A velocidade do carro devido ao radar não pode ultrapassar $50 \ldots$

A: Não sei.

$\mathrm{P}: \mathrm{km} / \mathrm{h}$

A: Então eu multiplico né?

P: è por hora. O que significa o por na matemática?

A: Não sei.

$\mathrm{P}$ : significa dividir.

Conclusão os alunos não conseguiram terminar a atividade.

\section{$1^{\circ} B_{1}-5^{a}$ aula $-05 / 10$}

Entreguei as folhas de resposta da atividade 4 e pedi para que terminassem. É complicado controlar os grupos, os que faltaram nas atividades anteriores querem fazer com os alunos que já tem o grupo fechado. Há alunos que monitoram os grupos, dizendo: quem copia, quem faz, etc., e como é $4^{\circ}$ bimestre muitos já atingiram a nota para passar para série seguinte, então não fazem nada.

P: Terminem rápido é fácil.

A: Ah professora, as questões não são tão simples assim, temos que pensar!

P: Estou aqui para ajudar.

A: Estou com preguiça.

A: Como faço um gráfico sem números?

P: Pense, em matemática, o gráfico da função do $1^{\circ}$ grau é uma...veja não precisou de números.

Logo em seguida o aluno me mostrou uma reta, não seu certo.

A: Professora se eu colidir com você eu te machuco.

P: Por quê?

A: Não sei explicar.

P: Se um carro colide com uma moto, um caminhão como um carro.

A: Acho que agora eu sei explicar.

A: Professora vai bater o sinal e eu não terminei.

P: Depois eu vejo o que eu faço.

$1^{\circ} C_{1}-6^{a}$ aula $-05 / 10$

A aula iniciou tumultuada, mas assim mesmo entreguei as folhas de respostas, para que aos poucos se acalmassem, mas começaram a discutir entre si, sobre uma garrafa de água, enfim...

A: Professora o que vou colocar no eixo x e no eixo y?

P: Use o que você achar melhor para representar o Vanderley e o fantasiado, é um esboço.

Alguns alunos conseguem fazer inconscientemente análise dimensional, outros não conseguem estabelecer raciocínio.

$1^{\circ} B_{1}-06 / 05$ 
Iniciei colocando na lousa as duplas da ativ. 4 e os exercícios que deveriam ser terminados em casa para me entregar na próxima aula.. Então iniciei a ativ.5.
A: Professora o que é perpendicular?
P: Um ângulo de $90^{\circ}$.
A: Professora não entendi a questão 3.
P: Qual é a sua massa?
A: $60 \mathrm{~kg}$
P: isso

P: por exemplo, os jogadores vão disputar uma partida de futebol na Bolívia, Chile, o desempenho dos atletas é o mesmo?

A: Professora a linha de capricórnio passa na praça né.

Estão calmos e fazendo as atividades, mas não posso dizer que fazem apenas em dupla, a sala é um grupão, no qual se interferir gera conflitos desnecessários.
A: Professora o que é N?
P: Abreviação do nome de um cientista que já mencionei.
A: Newton.

$1^{\circ} A_{1}-4^{\text {a aula }}-06 / 10$

Nesta aula repeti incansavelmente: Não enrole. Tudo ocorreu calmamente.

\section{$1^{\circ} B_{1}-2^{a}$ aula $-13 / 10$}

Iniciei pedindo para terminarem rapidamente a ativ 5 e para começar a ativ.6.

Passei como lição de casa algumas páginas do caderno de física do aluno 4 e sentei para preencher meus diários, enquanto os alunos respondiam a atividade.

A: Professora N é Newton?

P: Isso.

A: Como acho o meu peso em SP?

P: Observe a unidade da gravidade, é N/kg, então...

A: multiplica ué.

A: Qual é a diferença entre peso e massa corporal?

P: Você leu o texto?

A: Não.

P: Qual é sua massa em kg? Para encontrar o seu peso é só multiplicar pela gravidade.

A: Na questão 17, como faço?

P: Como você respondeu a questão 16 ?

A: Professora me confundo toda, o que é massa? E peso? Massa é em Newton né?

P: è o que você lê na balança.

A: Ah em kg, então peso é em Newton.

Estranho alguns alunos começaram a retirar os livros das prateleiras (os livros didáticos ficam disponíveis em uma prateleira na sala de aula) para completar a tabela da questão 18.

A: professora eu posso ver a força? Numa luta né.

P: pode ser

A: Como assim, que tipo de colisão?

P: De lado, de frente, etc. 
A: O empurrão pode ser aceleração? Ou força?

\section{$1^{\circ} A_{1}-13 / 10-4^{a}$ aula}

Haviam poucos alunos na sala, entreguei as folhas da atividade 5 e 6

A: Professora, vou entregar, não sei fazer as questões 16, 17 e 18

P: Tente, qual é sua massa na balança?

A: $50 \mathrm{~kg}$

P: Então termine.

A: Não sei a 16 e 17.

P: que tal ler o texto.

A: Ah, então qual a unidade de peso?

P: Você multiplicou então cancelou $\mathrm{kg}$ com $\mathrm{kg}$ e sobrou.

A: $\mathrm{N}$

$\mathrm{P}: \mathrm{N}$ é a unidade de força.

A: Professora a definição de força está no livro.

P: Sim, mas o que é interação.

$1^{\circ} B_{1}-27 / 10-2^{a}$ aula

Muitos alunos faltaram, mas isso fez com que ficassem calmos. Iniciaram a ativ. 6 e começaram de repente a pegar os livros de física, claro que para responder o que é força, pois não sabiam.

A: Na questão 4 depende se for de contato ou de movimento.

P: Coloque as duas e explique.

Enquanto faziam a ativ. coloquei na lousa o dia do visto nas lições do caderno do aluno de física 4, mas sempre incentivando. Hoje estão respondendo em grupões, interessante que estavam organizados, sem copiar, apenas discutindo as questões.

A: Professora não entendi o momento na questão 14.

$\mathrm{P}: \mathrm{O}$ que você colocou na anterior?

A: Massa.

P: O que mais? Se eu fosse de encontro a você com maior velocidade, vou lhe causar prejuízo? Mas se eu tiver maior massa e menor velocidade?

A: Pode usar as fórmulas do caderno.

Fiz simulação do agachamento e do salto para que entendessem os gráficos e para atividade 7 soltei um livro e uma folha lisa e depois o livro e a folha amassada.

\section{$1^{\circ} A_{1}-27 / 10-4^{a}$ aula}

Complicado, muita bagunça. Pequeno sermão: Falta entregar o fim da atividade 4, a atividade 5 está incompleta e a ativ. 6 vocês devem terminar hoje!

A: Estou em dúvida entre força e impulso quando empurro o carrinho.

P: Coloque.

A: O empurrão é a força de atrito?

P: O que é força de atrito?

A: Não sei só lembrei do nome.

P: Como você coloca uma coisa que você não sabe o significado.

A: Professora não acho outra palavra.

P: Fiz o gesto do empurrão. 


\section{A: Ah, impulso.}

A: Professora no texto está errado, não seria movimento ao invés de momento?

P: É momento mesmo. Leia o texto.

A: Professora pelas contas o de $68 \mathrm{~kg}$ deu a velocidade de $2,5 \mathrm{~m} / \mathrm{s}$, mas não seria a metade do tempo, pois ele tem o dobro da massa.

\section{$1^{\circ} B_{1}$ - aula de reposição no sábado}

A: Professora entreguei as provas, assim nós vamos adiantando para acabar logo.

P: Não como estamos em um pequeno número é melhor continuar o caderno do aluno de física 4.

\section{$1^{\circ} B_{1}-2^{a}$ aula $-03 / 11$}

Entrei dizendo: Quem terminou as lições do caderno do aluno de física 4, por favor deixe na minha mesa. Hoje vocês devem terminar a ativ.6 e iniciou a ativ.7 sem enrolar. Só poderei dispensá-los para as férias se vocês terminarem as 10 provas. Coragem.

P: Terminem as lições, estão meio mortos, acho que é o calor.

Estranho, estão tirando o livro da estante para responder a ativ.7, o que será?

Hoje não estão perguntando nada..., estranho!

Na questão 20 e 21 da ativ.6 exemplifiquei o movimento para os alunos.

faço?

Alguns alunos ao invés de me perguntar estão deixando de responder - o que eu

A: Professora de onde você tira essas questões?

P: De alguns livros de esporte (pensei em dizer que fui eu que fiz, mas achei ruim).

A: Há muito tempo li um livro de atletismo.

P: Qual é o nome?

A: Regras do atletismo, e é o que eu quero fazer educação física, depôs posso xerocar as atividades.

P: Me lembre no final delas.

Na atividade 7

A: Professora me explica a questão 3.

P: Para colocar um guarda-roupa em movimento o que você faz? Por que?

A: Empurro.

P: E se colocar um tapete embaixo fica mais difícil ou mais fácil? Pense.

\section{$1^{\circ} A_{1}-03 / 11-4^{\mathrm{a} a u l a}$}

Demoraram para chegar do intervalo, mas enquanto chegavam coloquei alguns recados de tarefas do caderno de física do aluno 4 e marquei: Termine a ativ. 6 e 7.

P: Pessoal agilize, enquanto vocês não terminarem até a prova 10 , não libero vocês de férias!

A: Misericórdia de nós.

P: Não vou discutir, se quiserem me perguntar muito bem, senão está bom também!

A: O que é inércia?

P: Tendência do corpo em ficar parado ou em movimento contínuo.

A: Mas qual é o significado? 
P: Sai da inércia menino.

A: Parado.

Acabei dando a definição, isto gerou cópia, acho que não deu certo!

A: Professora não entendi a 10.

P: Mas você fez a 8.

A: Fiz.

P: Desenhou.

A: Não.

P: Precisa desenhar.

A: Ah, os vetores?

Estão conversando muito sobre diversos assuntos, menos sobre as atividades.

$1^{\circ} A_{1}-3^{a}$ aula $-16 / 11$

Ficamos muito tempo sem aula e os alunos já estão em clima de férias, o calendário está justo então marquei a última aula para 30/11, ou seja, responder da ativ.7 a 10.

P: Bom agora vocês devem agilizar para terminar, sem enrolar.

Durante a aula confirmei as atividades feitas do bimestre para confirmar as notas.

Que confusão, chamar atenção não resolve dura pouco tempo o silêncio, ameaçar com nota também não, o que fazer? Estou cansada.

$1^{\circ} B_{1}-5^{a}$ aula $-16 / 11$

Coloquei o calendário na lousa e disse que se encerra o dia 30/11.

A: O que é inércia?

P: Pense: Sai da inércia menino!

A: sei lá.

P: É a tendência do corpo em ficar parado ou em movimento.

A: Professora não entendi a 1.

P: Ué, por que um atleta de sumo precisa de muita massa e um ginasta de pouca massa?

Se confundem com a definição de atrito e depois fica confuso em dar exemplos sobre sua aplicação.

A:Professora não entendi a questão 19.

P: No supino você permanece com a barra parada, você está fazendo uma força muscular elevada, mas não está deslocando a barra, portanto embora tenha um trabalho fisiológico, não há o mecânico, pois lembre que vimos que trabalho é força vezes o deslocamento.

A: Professora não entendi a 22.

P: Por que? O que você acha?

A: Ah um teste.

P: E o teste mede o que?

A: força e resistência.

P: Então o que mais?

$1^{o} B_{1}-1^{a}$ aula - 17/11 
Começaram a atividade 8 , mas muitos grupos começaram a dividir as tarefas, como por exemplo: Você termina a 7 e eu faço a 8.

A: Como referência?

P: Veja se eu estou observando aquele menino na quadra ele está em movimento, mas se eu estiver correndo com ele?

A: Ai, que pergunta tonta, mas não consigo explicar o porquê.

\section{$1^{\circ} A_{1}-17 / 11-4^{\mathrm{a}}$ aula}

Entrei na sala e como sempre muitos não chegaram do intervalo e os outros bagunçando, coloquei as atividades na mesa e na lousa escrevi: Vocês só têm até o dia 30/11 para responder tudo. Fiquei calada. Uns bagunçam outros fazem e assim vai.

A: Professora o que é potência?

P: O que é?

A: Resistência.

P: E o que é resistência, forme uma frase.

A: A pedra é resistente, por isso não quebra.

P: Faça a frase usando pessoa.

A: Uma pessoa é mais resistente que a outra.

A: Acho que potência é realização de trabalho em um tempo determinado.

P: Isso.

$1^{\circ} C_{1}-1^{\text {a aula }}-23 / 11$

Confusão, uns terminam o caderno de física do aluno 4, outros fazem a atividade

5 .

A: Professora, o que eu faço na 3.

P: Estime a massa do atleta e explique o porque deste valor.

A: Professora na 4 é possível eu pesar diferente?

P: A gravidade depende da altitude.

A: Professora se uma fica magra fica sem resistência e uma pessoa gorda fica sem desenvolvimento.

Muitos terminaram em 1 aula.

\section{$1^{\circ} A_{1}-23 / 11-3^{a}$ aula}

A: Professora não entendi a prova 9.

P: De acordo com o que já vimos explique esta modalidade.

A: Como assim?

P: Já vimos velocidade, força, aceleração, etc.

A: Ah!

A: Professora não entendi a prova 9.

P: Use os conceitos físicos para explicar a modalidade.

A: Professora é só colocar massa, força.

P: Mas você deve explicar o porque.

Estou com medo de não estarem entendo as coisas, sempre dizem que não sabem se expressar.

\section{$1^{\circ} B_{1}-23 / 11-4^{\mathrm{a}}$ aula}


Passei o nome dos alunos que me deviam atividades do bimestre e muitos alunos disseram que não iam fazer mais nada, pois já tinham nota para serem promovidos, mas insisti.

A: Mas professora é muita coisa.

P: Viu o que deu ficar enrolando.

Há alunos que estão utilizando o dicionário, que bom. Muitos se recusaram em fazer as atividades, deixei como estava, não falei nada, para que criar conflito se não vai resolver.

A: Professora como assim vantagem e desvantagem do comprimento dos membros.

P: Para algumas modalidades esportivas é bom ter o braço comprido para outros não

Uma aluna que já praticou ginástica, se identificou com as perguntas da ativ.9.

O que faço quando os alunos não querem fazer nada?

$1^{\circ} C_{1}-6^{a}$ aula $-24 / 11$

Como havia deixado a folha de perguntas na $1^{\mathrm{a} a u l a}$ muitos já entregaram a ativ.5 pronta. Pedi para que iniciassem a prova 6. Ao estimar a massa nas modalidades esportivas, muitos alunos diziam que este esporte tem categorias em peso pena e pesado.

De uma forma geral foi tudo bem.

\section{$1^{\circ} B_{1}-24 / 11-2^{a}$ aula}

Entreguei as provas 9 e 10 e iniciaram, pois avisei que só iria passar as médias para os alunos que fizessem até a 10.

A: Professora o que é biomecânica?

P: É a ciência que estuda o movimento do corpo humano.

$\mathrm{Na}$ ativ. 10 muitos alunos reclamaram do tamanho do texto. Acho que pressionei demais estão fazendo de qualquer jeito.

A: Como eu vou saber nunca fiz esse esporte.

Muitos estão copiando um dos outros, acho que apressei demais.

\section{$1^{\circ} A_{1}-24 / 11-4^{\mathrm{a}}$ aula}

Até decidirem fazer a lição demora...

A: Professora o que para fazer na ativ.10?

P: Explicar os movimentos através dos conceitos físicos que já vimos.

A: Professora o que é biomecânica?

A: Professora a maior responsabilidade do técnico é manter o atleta em forma.

P: Ah e tudo isso que você viu nas atividades anteriores não serve.

A: Mas aqui está perguntando a maior e não as maiores.

Tudo bem me descontrolei, estou cansada, pelo menos estão fazendo, mas sempre tem alunos copiando, final de ano é difícil.

\section{$\underline{\text { Escola G }}$}

As dúvidas foram praticamente às mesmas dos alunos da outra escola. Mas devido a problemas internos na escola tive que me ausentar em algumas aulas e quando isto aconteceu deixei os alunos com a inspetora fazendo as atividades. Todas as atividades forma feitas em dupla.

$1^{\circ} E_{1}-24 / 09-1^{a}$ aula e $2^{\mathrm{a}}$ aula 
Propus as 10 provas e entreguei a primeira, no começo ficaram assustados mas quando disse que eu queria a opinião fizeram tranquilamente. Não perguntaram nada.

\section{$1^{0} E_{1}-1 / 10-1^{a}$ aula e $2^{a}$ aula}

Entreguei a atividade 2 e 3 e deixei tranqüilos fazendo com a inspetora.

\section{$1^{0} D_{1}-01 / 10-3^{a}$ aula e $4^{\mathrm{a} a u l a}$}

Expliquei sobre as 10 provas e entreguei a atividade 1 e 2, fizeram calmos e sem problemas, apenas um aluno me questionou sobre a palavra estado, pois tinha vários sentidos.

\section{$1^{0} E_{1}-08 / 10-1^{a}$ aula e $2^{a}$ aula}

Iniciei verificando se todos terminaram a atividade 3 e propus irmos ao pátio para fazer mos algumas medidas para atividade 4. Medimos as lajotas do pátio com uma régua e medidos o tempo de corrida com um cronômetro para distância de 18 lajotas de $97 \mathrm{~cm}$ com um único aluno correndo.

Após a coleta dos dados, voltamos para sala e coloquei os resultados na lousa, fazendo as transformações de unidades para encontrar a velocidade em $\mathrm{m} / \mathrm{s}$. $\mathrm{O}$ valor da velocidade foi de $4,3 \mathrm{~m} / \mathrm{s}$ e aproveitei para colocar em $\mathrm{km} / \mathrm{h}$.

Na questão 2, muitos alunos estavam colocando $20 \mathrm{~m} / \mathrm{s}$ e eu não entendia porque, mas pensando bem acho que estão tomando o tempo e confundindo as grandezas.

Uns alunos tentavam copiar do outro, pois estavam sem paciência para fazer, e outros reclamavam por não saber explicar o raciocínio. Confundiram muito as unidades de medida para as grandezas.

A: Professora então divide.

P: Não sei, o que você acha?

A: Então multiplica.

P: Por quê?

A: Então divide, não sei, não entendi.

P: Tenha paciência leia o texto.

Hoje estavam muito indisciplinados. Errei ao colocar na lousa a velocidade em $\mathrm{km} / \mathrm{h}$, pois em todas as questões queriam converter para $\mathrm{km} / \mathrm{h}$.

\section{$1^{\circ} D_{1}-08 / 10-3^{a}$ aula e $4^{\text {a }}$ aula}

Muitos terminaram a atividade 2 e começaram a atividade 3 . Alguns alunos me perguntaram o que era antropometria, eletromiografia e fiquei contente porque pela primeira vez leram o texto.

\section{$1^{\circ} D_{1}-22 / 10-3^{\text {a }}$ aula e $4^{\text {a aula }}$}

Entrei na sala pedindo uma régua emprestada e elegi dois alunos para correr no pátio, e pedi para usarem o cronômetro do celular. $\mathrm{N}$ pátio escolhemos a distância de 17 lajotas de $96 \mathrm{~cm}$. Foi tumultuado no pátio, pois alguns alunos aproveitaram para fugir.

Na lousa coloquei:

Distância $=96 \mathrm{~cm} \times 17$ lajotas $=1632 \mathrm{~cm} / 100=16,32 \mathrm{~m}$

Corredor 1: tempo $=4,5 \mathrm{~s}$, velocidade $16,32 / 4,5 \mathrm{~s}=3,6 \mathrm{~m} / \mathrm{s}$

Corredor 2: tempo $=2,7 \mathrm{~s}$, velocidade $16,32 \mathrm{~m} / 2,7 \mathrm{~s}=6 \mathrm{~m} / \mathrm{s}$

Expliquei e começaram a discutir quem da sala faria em menos tempo

Entreguei a atividade 4 e começaram a fazer

A: Professora temos a distância de $16,32 \mathrm{~m}$ para $100 \mathrm{~m}$ é a mesma velocidade de $3,6 \mathrm{~m} / \mathrm{s}$ ?

P: Calma, não importa a distância a velocidade continuará em $\mathrm{m} / \mathrm{s}$ 
Na questão 6: A: Professora é o corredor...

P: Mas por quê?

A: Ah é só olhar o tempo.

P: E a Distância não influencia?

Expliquei para toda sala: Eu professora estou na corrida de aleluia (da cidade) e faço $8 \mathrm{~m}$ em $40 \mathrm{~min}$ e o outro corredor $10 \mathrm{~km}$ em $50 \mathrm{~min}$, quem é o mais rápido?

A: Claro que é o de $10 \mathrm{~km}$, pois é $2 \mathrm{~km}$ em $10 \mathrm{~min}$.

P: E daí? E o outro é quantos $\mathrm{km}$ em 10min?

A: Sei lá

Expliquei a questão 6 e logo após.

A: Como faz a questão 6.

P: Leia o texto e acompanhe na lousa.

A: Ah é que eu estava conversando.

P: Eu explico de novo.

A: Professora é muito difícil.

P: Estou aqui para ajudar.

A: Que saco!

A: Professora, não entendi está errada a unidade, não é so $\mathrm{m} / \mathrm{s}$ ou $\mathrm{km} / \mathrm{h}$.

P: Não, é que são as mais conhecidas, mas veja $1 \mathrm{~km}$ tem $1000 \mathrm{~m}$.

A: Entendi, mas não sei explicar o raciocínio.

$1^{0} E_{1}-22 / 10-1^{a}$ aula e $2^{\text {a }}$ aula

Entrei na sala e todos me perguntaram se iriam terminar a ativ.4, respondi que sim, distribui as folhas e coloquei os dados da corrida no pátio novamente e expliquei de novo

A: Quem sai perdendo o Vanderley ou o fantasiado?

P: Eu vou de encontro a você e você a mim com a mesma velocidade, quem sai perdendo? Eu de encontro com um lutador de sumo com a mesma velocidade? Entendeu?

A: Ah

A: Professora não entendi velocidade $m$

P: Imagine: O Vanderley numa maratona teve velocidade de $19 \mathrm{~km} / \mathrm{h}$, você conseguiria descobrir que houve a parada com o fantasiado? Então a velocidade de $19 \mathrm{~km} / \mathrm{h}$ é uma velocidade $\mathrm{m}$

A: média

A: Como uma pessoa mergulha a $78 \mathrm{~m}$, se eu escutei na TV que a $37 \mathrm{~m}$ a água vira concreto para nós?

P: Sim, mas você já viu a técnica no salto ornamental para penetrar na água?

A: Professora, como eu calculo a aceleração e a desaceleração do atleta?

P: Como?

A: Não sei me expressar

P: Tente 
A: Ah, devo levar em conta a velocidade

P: Isso, agora como?

A: Professora no tobogã encontrei que a velocidade aumenta $4,5 \mathrm{~m} / \mathrm{s}$ a cada segundo e qual é a aceleração?

P: Vamos escrever matematicamente o que você disse (na lousa).

A: Ah entendi.

A: Professora qual é a aceleração no salto?

P: Um objeto cai para baixo por quê?

A: Pela gravidade.

P: Então leia a questão novamente.

A: Professora em $4 \mathrm{~s}$ olha o tamanho da velocidade, o esportista não se machuca?

P: Há técnicas para penetrar na água.

A: Mas não sei aceleração.

P: O que ocorre com a velocidade?

A: Aumenta eu dividi um pelo outro.

P: Isso significa em quanto uma velocidade é maior que a outra, mas em quanto aumenta.

A: Então subtrai.

P: isso. perdendo.

Na questão da quantidade de movimento os alunos discutiram entre si quem sai A: O Vanderley, pois o fantasiado é gordo.

A: Mas o Vanderley está correndo.

A: Mas foi de lado.

A: Bom, mas devido a camada de ozônio.

A: Ah e a flexibilidade do rabo da lagartixa.

P: Estava indo tão bem.

$1^{\circ} E_{1}-29 / 10-1^{a}$ aula e $2^{a}$ aula

Tinham poucos alunos, mas pedi para que iniciassem a atividade 6. Somente tiveram dificuldade para completar a tabela de unidades, tiveram que olhar no caderno.

$1^{\circ} E_{1}-12 / 11-1^{a}$ aula e $2^{a}$ aula

Entreguei as folhas e começaram a fazer sem problemas.

A: Professora, o que é força?

P: É isso que estou perguntando.

A: Posso pegar o dicionário?

P: Por que? Estou perguntando para você.

A: Professora o que é interação.

P: O que você acha?

A: Não faço a mínima idéia.

P: Tem certeza.

A: Tenho.

P: Então coloque que não sabe.

A: Mas vai estar errado.

P: Por que? Se você não sabe. 
A: Mas e a 3 como vou responder?

P: Coloca que a professora esta doida, pois se não sei a 2 como irei fazer a 3.

Um aluno entregou a folha e percebi que havia questões em branco.

A: Professora só fiz isso.

P: Quer me perguntar alguma coisa?

A: Não.

P: Posso te ajudar.

A: Deixa assim mesmo.

\section{$1^{\circ} D_{1}-12 / 11-3^{a}$ aula e $4^{a}$ aula}

Depois de quatro semanas sem aula retomamos a atividade 4, tive que relembrar o dados coletados no pátio. Para alguns alunos as perguntas são fáceis e por isso a todo momento me perguntam se está correto.

A: Professora é só pegar $42,195 \mathrm{~km}$ e dividir por horas né?

P: E isso aí.

Estranho me perguntaram poucas coisas e estão indo bem.

\section{$1^{\circ} E_{1}-19 / 11-1^{a}$ aula e $2^{a}$ aula}

Entreguei a prova 7, se organizaram sozinhos e começaram a responder.

A: O que é inércia?

P: Quando falo, menino sai da inércia.

A: Não sei

P: Mas falei nisso nos bimestres anteriores.

A: Falou é, não sei.

Bom repensei e acabei dando a definição de inércia.

Como alguns alunos não estavam entendendo a questão 6, utilizei para representar uma folha amassada e um caderno e larguei, até chegarem a gravidade.

Hoje está muito quente, estão todos moles, até eu estou.

A: Professora tem uma máquina na loja de tênis.

P: Sim.

A: Só vi no pânico uma maquina de medir socos.

A: Professora que esporte é bom sem atrito?

P: Qual? Pense.

A: Natação, pois eles raspam o corpo.

A: Professora o torquímetro mede força também. Lá a gente põe o peso e gira.

P: Fiquei em dúvidas, pois nunca vi um torquímetro.

Muitos preferem perguntar uns para os outros, é esquisito.

A: Professora não entendi a 24.

P: O que é potência?

A: Professora veja o som, se eu tenho um de 50 e o meu colega de 100 o dele é mais potente.

P: E em termos de atletas, quando um é mais potente que o outro?

\section{$1^{0} D_{1}-19 / 11-3^{a}$ aula e $4^{\mathrm{a}}$ aula}

Distribui as folhas e pedi para terminarem a ativ 4.

A: Professora não entendi a 37. 
P: Veja em quanto aumenta.

A: 9,8

P: E isso é o que?

A: Ah a gravidade.

Estavam indo bem, mas depois do intervalo virou confusão.

$1^{\circ} E_{1}-26 / 11-1^{a}$ aula e $2^{a}$ aula

Deixei todas as atividades na mesa e pedi para que fossem fazendo

A: Professora alavanca é aquilo que amplia a força?

Muitos alunos me perguntaram o que é biomecânica e alavanca?

A: Professora o que faço se não tem dados para calcular.

P: Estime. 


\section{A3. Intervenção + Atividade Avaliatória}

\section{A3.1. Atividades}

\section{ATIVIDADE 1 Você pode ser um técnico?}

Responda todas as questões com atenção, exponha com sinceridade suas idéias.

1) Quais são as maiores responsabilidades de um técnico de qualquer modalidade esportiva?

2)Mas, em sua opinião, qual é o maior desafio a ser vencido pelo técnico? Como ele pode vencer este desafio?

3)Ao assistir a prática de um esporte qualquer, você pode observar o desempenho dos atletas. É claro que para praticar algum esporte, são necessárias algumas habilidades:

a)Escolha uma modalidade esportiva de sua preferência e cite algumas habilidades necessárias para praticá-la.

b)Agora, cite alguns erros que são mais cometidos pelos atletas nesta modalidade esportiva.

c)Sugira as devidas correções aos erros citados na letra b. Dê alguns passos para que o atleta reduza os erros e melhore o seu desempenho.

4)São comuns algumas frases por parte de um torcedor, como: "bata mais fraco", "jogue com vontade", "ataque", etc. Será que estes tipos de comentários auxiliam o atleta para correção de seus movimentos? Por quê?

5) Escolha qualquer modalidade esportiva e responda:

a)Como é esta modalidade (suas características)? Quais são seus objetivos?

b)Nesta modalidade que você escolheu, cite um atleta bom (de elite). Descreva algumas características que faz este atleta de elite ser diferente dos outros atletas.

c)Elabore no mínimo três frases que os técnicos podem aplicar no treino dos atletas, para corrigir alguns movimentos de seus atletas.

6)Seu conhecimento atual é suficiente para que você faça bons apontamentos (comentários) para auxiliar um atleta? Que conhecimentos estão te faltando?

7)Será que algumas das disciplinas (I, P, G, H, M, Q, B, F, EF, EA, Fil, So) que você tem na escola podem ajudar um atleta a ter um bom desempenho? Cite pelo menos quatro disciplinas (coloque em ordem de importância), e explique como ela será útil para análise de uma prática esportiva. Para facilitar complete a tabela abaixo:

\begin{tabular}{|l|l|l|l|}
\hline & Disciplina & $\begin{array}{l}\text { Conteúdo (matéria) específico } \\
\text { da disciplina }\end{array}$ & Auxilia ... \\
\hline Exemplo & Artes & Técnicas de Pintura & Dar harmonia as cores no quadro \\
\hline $1^{\mathrm{a}}$ & & & \\
\hline $2^{\mathrm{a}}$ & & & \\
\hline $3^{\mathrm{a}}$ & & & \\
\hline $4^{\mathrm{a}}$ & & & \\
\hline
\end{tabular}

8)Quais áreas do conhecimento um técnico deve dominar para treinar um atleta adequadamente e corrigir os possíveis erros? Será que é possível um técnico saber tudo isso? De que forma?

9)Um técnico necessita do auxílio de outros profissionais para ajudar em sua análise sobre o desempenho do atleta. Cite 4 profissionais que fazem parte da equipe (comissão) técnica e dê suas funções. (Obs.: não é a equipe de arbitragem e nem os componentes do time!).

10)Você sabe qual formação acadêmica (faculdade) que um técnico deve ter? Que matérias ele deve ter feito em sua faculdade?

11) Qual esporte você pratica? Há quanto tempo?

12)Complete:

a) Ao dizer a palavra esporte, eu penso em:

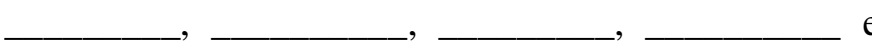

b) Ao dizer a palavra saúde, eu penso em: e

c) Ao dizer a palavra força, eu penso em: $\mathrm{e}$ 
Opcional: Atividade extra-classe

Pesquise sobre a formação de um técnico no Brasil de qualquer modalidade esportiva? Quais profissionais fazem parte de uma equipe técnica? É possível apenas uma pessoa dar conta de tudo isso? Então qual é a verdadeira função de um técnico?

\section{ATIVIDADE 2 - SAÚDE E ESPORTE}

1) Comente a frase: "Corpo bonito significa saúde".

2) Quais são os requisitos necessários para que uma pessoa seja considerada saudável?

3) Para uma pessoa ser saudável é suficiente apenas realizar um exercício físico ou ter uma alimentação balanceada? Explique.

4) Praticar alguma modalidade esportiva ou fazer exercício físico resulta em saúde? Por quê?

5) A maior parte da população está à busca um corpo perfeito (bonito). Mas para se adquirir esse corpo (essa imagem) algumas pessoas fazem esforços através da alimentação, outros preferem ingerir remédios para emagrecer, outros fazem cirurgias, etc. Então, será que todo corpo bonito é saudável? Explique.

6) Leia o texto abaixo, e explique o significa:
a) bem - estar físico
b) bem - estar mental
c) bem - estar social

\section{Qualidade de vida}

A qualidade de vida é um termo empregado para descrever a qualidade das condições de vida levando em consideração factores como a saúde, a educação, o bem-estar físico, psicológico, emocional e mental, expectativa de vida etc. A qualidade de vida envolve também elementos não relacionados, como a família, amigos, emprego ou outras circunstâncias da vida. OMS.

A Organização Mundial da Saúde (OMS) desenvolveu um questionário para aferir a qualidade de vida. Trata-se do WHOQOL (World Health Organization Quality of Life) que possui duas versões validadas para o português, o WHOQOL 100 (composto por 100 questões) e o WHOQOL Breve, composto por 26 questões. O WHOQOL - 100 é composto por seis domínios: o físico. o psicológico, o do nível de independência, o das relações sociais, o do meio ambiente e o dos aspectos religiosos. O WHOQOL - Breve é composto por quatro domínios: o físico, o psicológico, o das relações sociais e o do meio ambiente (http://pt.wikipedia.org/wiki/Qualidade_de_vida).

A definição de saúde segundo a Constituição da Organização Mundial da Saúde é um estado de completo bem-estar físico, mental e social, e não apenas a ausência de doença. Quando a Organização Mundial da Saúde foi criada, pouco após o fim da Segunda Guerra Mundial, havia uma preocupação em traçar uma definição positiva de saúde, que incluiria factores como alimentação, atividade física, acesso ao sistema de saúde etc. O "bem-estar social" da definição veio de uma preocupação com a devastação causada pela guerra, assim como de um optimismo em relação à paz mundial - a Guerra Fria ainda não tinha começado. A OMS foi ainda a primeira organização internacional de saúde a considerar-se responsável pela saúde mental, e não apenas pela saúde do corpo.

A definição adotada pela OMS tem sido alvo de inúmeras críticas desde então. Definir a saúde como um estado de completo bem-estar faz com que a saúde seja algo ideal, inatingível, e assim a definição não pode ser usada como meta pelos serviços de saúde. Alguns afirmam ainda que a definição teria possibilitado uma medicalização da existência humana, assim como abusos por parte do Estado a título de promoção de saúde.

Por outro lado, a definição utópica de saúde é útil como um horizonte para os serviços de saúde por estimular a priorização das ações. A definição pouco restritiva dá liberdade necessária para ações em todos os níveis da organização social.

Christopher Boorse definiu em 1977 a saúde como a simples ausência de doença; pretendia apresentar uma definição "naturalista". Em 1981, Leon Kass questionou que o bem-estar mental fosse parte do campo da saúde; sua definição de saúde foi: "o bemfuncionar de um organismo como um todo", ou ainda "uma actividade do organismo vivo de acordo com suas excelências específicas." Lennart Nordenfelt definiu em 2001 a saúde como um estado físico $e$ mental em que é possível alcançar todas as metas vitais, dadas as circunstâncias.

As definições acima têm seus méritos, mas provavelmente a segunda definição mais citada também é da OMS, mais especificamente do Escritório Regional Europeu: A medida em que um indivíduo ou grupo é capaz, por um lado, de realizar aspirações e satisfazer necessidades e, por outro, de lidar com o meio ambiente. A saúde é, portanto, vista como um recurso para a vida diária, não o objetivo dela; abranger os recursos sociais e pessoais, bem como as capacidades físicas, é um conceito positivo. 
Essa visão funcional da saúde interessa muito aos profissionais de saúde pública, incluindo-se aí os médicos, enfermeiros, fisioterapeutas e os engenheiros sanitaristas, e de atenção primária à saúde, pois pode ser usada de forma a melhorar a eqüidade dos serviços de saúde e de saneamento básico, ou seja prover cuidados de acordo com as necessidades de cada indivíduo ou grupo. (http://pt.wikipedia.org/wiki/Sa\%C3\%BAde)

7) Uma pessoa dita como "saudável" necessariamente possui boa qualidade de vida? Explique.

8) Qual é a ligação entre qualidade de vida e saúde?

9) Cite algumas características de uma pessoa com excelente saúde e qualidade de vida.

10) Leia o texto abaixo e responda:

a) Qual é a ligação entre saúde e esporte? Comente.

b) Qualquer pessoa no momento em que quiser, pode praticar esporte? Por quê?

c) Quais os cuidados que devemos ter ao praticar exercícios físicos?

\section{Atividade física e esporte}

Atividade física está na moda! Obviamente isto é um bom sinal; seus benefícios estão mais do que descritos e comprovados. Existe, porém grande desconhecimento da população em geral sobre o assunto. Afinal o que é atividade física? O que é esporte? O que faz bem para saúde? Para responde tais perguntas precisamos recorrer a alguns conceitos científicos consensuais.

Segundo o Consenso Biomédico Latino Americano (2000), a atividade física é qualquer movimento do corpo produzido pela musculatura esquelética que resulta em um incremento do gasto energético, ou seja, são as atividades que promovem um gasto energético acima do básico para manutenção do metabolismo (termoregulação, digestão, respiração etc..). Andar, subir escadas, correr, pedalar, lavar roupas, lavar carro, são exemplos típicos de atividade física.

Já exercício físico é toda atividade física planejada e estruturada com o propósito de melhoria do condicionamento físico e saúde. E finalmente, esporte também é uma atividade física, porém que envolve a busca da performance devido à competição.

Conhecendo estes conceitos básicos podemos evitar desconfortos tais como nos obrigarmos a fazer uma atividade física que não gostamos, ou ingressar num esporte competitivo, quando muitas vezes o que mais desejamos é melhorar a saúde. Ninguém precisa ser atleta para fazer atividade física, e muito menos se seu objetivo for condicionamento e qualidade de vida.

Temos que estabelecer nossos objetivos e para isso devemos conhecer o mínimo do assunto de interesse. Se o objetivo for melhoria da saúde e condição física, devemos procurar um programa de exercícios que mais nos agrade, por outro lado se, além disso, desejarmos participar de competições e atingir performance podemos procurar o esporte mais interessante (em ambos os casos, é imprescindível o acompanhamento de um profissional especializado). http://bbel.uol.com.br/artigo/esporte/atividade_fisica e_esporte.aspx

11) Qualquer calçado é bom para prática de esportes? O que você deve analisar ao comprar um calçado para prática de esportes? Explique.

12) Escolha uma modalidade esportiva e descreva o calçado ideal para sua prática.

13) Explique a frase: "Cuidados com a postura é pré-requisito para execução de qualquer movimento"

14) Que cuidados você deve ter com sua postura ao ficar sentado para fazer lições ou pesquisar no computador, ao levantar um objeto, etc. Você possui uma boa postura?

Opcional: Atividade extra-classe

Você pode acessar os seguintes vídeos:

Estética e saúde: http://www.youtube.com/watch?v=qu_rXW1u8z8

Esporte e lesões: http://www.youtube.com/watch?v=H10QAMm4XJM

Calçados: http://www. youtube.com/watch?v=1NJjDBjYgbM\&feature=related

\section{ATIVIDADE 3 - INTERAGINDO COM NOVOS CAMPOS DO CONHECIMENTO}

1) O corpo humano pode ser comparado a uma máquina? Em que situações? Explique.

2) Elabore uma frase que contenha as palavras: humano, corpo, máquina, mecânico(a), vida. Obs.: Sua frase deve conter todas as palavras.

3) Cite quatro áreas do conhecimento (pode ser profissões) e explique de que forma nos ajudam a conhecer e entender o nosso corpo. Para facilitar complete a tabela 


\begin{tabular}{|l|l|}
\hline Área do conhecimento & Esta área do conhecimento me auxilia a entender o meu corpo, porque... \\
\hline 1 & \\
\hline 2 & \\
\hline 3 & \\
\hline 4 & \\
\hline
\end{tabular}

4) De que forma a "ciência" pode ajudar um técnico a melhorar o desempenho de um atleta?

5) Leia o texto abaixo e responda:

a) Será que alguém já pensou em utilizar a física (conteúdo de mecânica) para estudar o movimento dos seres vivos? Você acha que é possível? Por quê?

b) O que a biomecânica estuda?

c) Complete a frase: A biomecânica pode ajudar a....

d) A biomecânica pode ajudar a corrigir os movimentos de um atleta para melhorar seu desempenho? De que forma?

Os cientistas que trabalham no campo da mecânica estudam os efeitos das forças (como gravidade, atrito e resistência do ar) sobre objetos vivos e não-vivos. Eles usam seu conhecimento de mecânica para ajudar a desenhar prédios, pontes, automóveis, barcos e aviões de modo a prever e medir o movimento de uma máquina. Além disso, avaliam o efeito das forças sobre pessoas e, vice-versa, o efeito de forças aplicado por pessoas. (Biomecânica dos esportes Gerry Carr - p.4)

Foi uma transição natural usar as ferramentas da mecânica e aplicá-las nos organismos vivos. Assim desenvolveu-se a biomecânica, o estudo da aplicação da mecânica aos sistemas biológicos.

A biomecânica avalia o movimento de um organismo vivo e o efeito da força - seja empurrando ou tracionando - sobre esse organismo. A abordagem biomecânica para análise dos movimentos pode ser qualitativa, com o movimento observado e descrito, ou quantitativa, significando que está sendo feita alguma medida do movimento. As características de movimento de um humano serão descritas usando parâmetros do tipo velocidade e direção, a quantidade de movimento que é criada pela aplicação das forças dentro e fora do corpo, e as posições de ações corporais ideais para movimentos eficientes e efetivos em humanos e objetos.

Para avaliar biomecanicamente o movimento de levantar-se uma cadeira, por exemplo, pode tentar-se medir e identificar as forças articulares que agem no quadril, joelho e tornozelo, assim como a força entre o pé e o solo, tudo isso interagindo para produzir o movimento de levantar-se a cadeira (Bases biomecânicas do movimento humano - HAMIL \& KNUTZEN - p.5).

6) Após a leitura do texto abaixo, escolha 5 cientistas envolvidos com o estudo da biomecânica e cite suas maiores descobertas com relação ao estudo do movimento do corpo humano.

\section{HISTÓRIA DA BIOMECÂNICA}

$\mathrm{O}$ estudo do movimento humano se inicia antes de Cristo, veja uma breve síntese histórica:

Aristóteles (384 - 322 a.C.): Com apenas 17 anos, apresentava um talento notável para observação e era fascinado pela a anatomia e estrutura de seres vivos. Ele foi considerado como o primeiro Biomecânico. Ele escreveu um livro sobre o movimento dos animais, considerando seus corpos como sistemas mecânicos. Foi quem introduziu o termo "mecânica" pela primeira vez, descrevendo alavancas e outros mecanismos

simples.

Claudius Galeno (130 - 201 d.C.): Médico que escreveu "De motu musculorum" onde teve as primeiras considerações de como o músculo funciona. Sem conhecer a macroestrutura do músculo, fez uma tentativa de explicação de como ocorre o encurtamento das fibras. Também foi considerado como o primeiro Médico Desportivo. Leonardo da Vinci (1452 - 1519):Era um homem da Renascença que fazia tudo através de desenhos para explorar o mundo das ciências. Seus estudos se baseiam fundamentalmente em sua formação de engenharia. Contribuiu substancialmente para a área da mecânica ao longo do desenvolvimento de seus inúmeros projetos de engenharia civil e invenções imaginativas: de skis aquáticos à planadores manuais. Ele estudou anatomia humana e analisou forças musculares e funções articulares. Da Vinci qualifica a mecânica como a mais nobre e útil ciência pelo fato de que todos os corpo vivos que possuem capacidade de movimentar-se, agem de acordo com as leis desta ciência. Escreveu a "Mecânica do movimento".

Andreas Vesalius (1514 - 1564): Anatomista que deu início a era moderna da anatomia. Livro: "Estrutura do Corpo Humano". 
Giovanni Alfonso Borelli (1608 - 1679): escreveu um livro que foi o primeiro a esclarecer que as alvancas do sistema musculoesquelético aumentam / ampliam o movimento muito mais do que a força. Borelli desvendou as forças requeridas para equilibrar articulações no corpo humano muito mais rápido do que qualquer outro. Ele determinou o centro de gravidade do corpo humano e, demonstrou que a inspiração dependia de ação muscular e a expiração dependia da elasticidade dos tecidos. É considerado o pai da Biomecânica. Escreveu "De motu animalium" e "De motu musculorum".

Isaac Newton (1643 - 1727): Estabeleceu as leis da mecânica - leis de movimento.

Luigi Galvani (1737 - 1798): Aplicou conceitos de eletricidade em sistemas biológicos.

Irmãos Weber - Eduard (1795-1881) e Wilhelm Weber (1804-1891): Estudaram a marcha humana a partir de leis simples da mecânicas. Compararam o movimento dos membros inferiores com o movimento de um pêndulo. Utilizaram a cronofotografia como método de análise. A moderna pesquisa sobre marcha humana deve-se em parte às contribuições dos dois irmãos Eduard (1795-1881) e Wilhelm Weber (1804-1891), e sua obra "On the Mechanics of the Human Gait Tools". Esta obra foi predominantemente baseada em observações, considerações teóricas e bom senso e intuição dos pesquisadores.

Étienne-Jules Marey (1830-1904): As contribuições de Marey passam pelos campos da cardiologia, instrumentação física, aviação, cinematografia e ciência da fotografia. Pioneiro da cinematografia (cronociclo). Estudou locomoção animal e humana através da cronofotografia e através de seus inventos.

Eadweard Muybridge (1830 - 1904): Realizou importantes estudos fotográficos sobre padrões de movimento que foram marcos na cinemetria biomecânica.

Eadweard Muybridge $\quad(1830 \quad$ - 1904$)$
Christian Wilhelm Braune (1831-1892) e Otto Fischer (1889 - 1906): Estudaram a marcha humana a partir de leis simples da mecânica. Compararam o movimento dos membros inferiores com $\mathrm{o}$ movimento de um pêndulo. Utilizaram a cronofotografia como método de análise. A moderna pesquisa sobre marcha humana deve-se em parte às contribuições dos dois irmãos Eduard (1795-1881) e Wilhelm Weber (1804-1891), e sua obra "On the Mechanics of the Human Gait Tools". Esta obra foi predominantemente baseada em observações, considerações teóricas e bom senso e intuição dos pesquisadores.

Du Bois Reymond (1818-1922) e Guillaume Benjamin Amand Duchenne (1806-1875): Duchenne é conhecido pelo mundo como o Pai da Biomecânica Moderna. Seu livro entitulado "Fisiologia do Movimento" é considerado uma das mais importantes obras da literatura. Ele era fascinado pela investigação das respostas musculares produzidas pela estimulação elétrica. Estabeleceu os fundamentos da eletromiografia. Muito embora ele tenha reconhecido que ação muscular isolada não existe na natureza, ele classificou funções de músculos isolados em relação ao movimento do corpo humano. Archibald Vivian Hill (1886-1977): Estabeleceu os princípios da contração muscular. Prêmio Nobel. Nikolai Bernstein (1940): Obra que contribuiu para o estudo da coordenação e regulação do movimento humano. Um dos primeiros a considerar e estabelecer a Biomecânica como ciência.

Kotikowa (1930): Elaborou o primeiro programa de Biomecânica em Escola de Educação Física em Leningrado. E depois disso, a Biomecânica foi instituída como disciplina em Leipizig.

Donskoi (1969): "Biomecânica dos movimentos corporais"- "Princípios Biomecânicos"

http://www.fm.usp.br/fofito/fisio/pessoal/isabel/biom ecanicaonline/elementar/historia.php

7) Leia o texto com atenção e tente explicar de que forma a biomecânica aplicada aos esportes pode nos ajudar, a saber, como e porque as coisas funcionam no mundo dos esportes. Como a biomecânica pode ajudar a um técnico melhorar o desempenho de um atleta? 


\section{MÉTODOS DA BIOMECÂNICA}

Os métodos utilizados pela biomecânica para abordar as diversas formas de movimento são: antropometria, cinemetria, dinamometria e eletromiografia.

Cinemetria: consiste em um conjunto de métodos que busca medir os parâmetros cinemáticos do movimento, isto é, a partir de imagens durante a execução do movimento, realiza-se o cálculo das variáveis dependentes dos dados observados nas imagens, como posição, orientação, velocidade e aceleração do corpo ou de seus segmentos.

Dinamometria: engloba todos os tipos de medida de força e ainda distribuição de pressão, o que possibilita interpretar respostas de comportamentos dinâmicos do movimento humano. O instrumento básico usado na dinamometria é a plataforma de força, que mede fundamentalmente a força de reação do solo e o ponto de aplicação desta força.

Eletromiografia: é o método de registro da atividade elétrica de um músculo quando realiza contração. A utilização da eletromiografia tem como propósitos fundamentais ser um: indicador de estresse, indicador de padrões de movimentos e parâmetros de controle do sistema nervoso.

Antropometria: se preocupa em determinar características e propriedades do aparelho locomotor como as dimensões e as formas geométricas de segmentos corporais, distribuição de massa, braços de alavanca, etc., definindo então, um modelo antropométrico contendo parâmetros necessários para construção de um modelo biomecânico da estrutura analisada, ou seja, a antropometria busca modelos que possam ser utilizados para representar o corpo humano.

Independente do modelo adotado, este de permitir o cálculo da: massa, posição do centro de massa do corpo ou do segmento e momento de inércia. Podemos classificar os modelos biomecânicos em modelos físicos (em escala e manequins antropométricos) e modelos matemáticos (corpos rígidos e elementos deformáveis).

A formulação de modelos físicos matemáticos é atualmente uma das principais tarefas da biomecânica. A cada simulação do movimento é feita uma simplificação esquemática do movimento complexo do corpo humano a fim de mensurá-lo e interpretá-lo.

(Fundamentos biomecânicos para análise do movimento humano - Alberto Carlos Amadio - p.21)

\section{ATIVIDADE 4 - O MOVIMENTO}

\section{$\mathbf{1}^{\text {a }}$ PARTE}

1) Complete a tabela e responda:

\begin{tabular}{|l|l|lr|}
\hline Tempo & 1 hora $=\ldots$ minutos & 1 minuto $=\ldots$ segundos \\
\hline Distância & 1 quilômetro $=\ldots$ metros & 1 metro $=\ldots$ centímetros \\
\hline
\end{tabular}

a) 5000 metros equivale (é igual) a distância de 50 quilômetros? Por quê?

b) 120 minutos equivale (é igual) ao tempo de 3 horas? Por quê?

2) Reúna-se na quadra ou no pátio com o professor e sua turma e simule uma corrida com três colegas para disputar quem é o mais rápido. Antes de iniciar a corrida determine a distância, não se esqueça de marcar o tempo.

\begin{tabular}{|l|l|l|}
\hline Nome & Tempo & Velocidade \\
\hline & & \\
\hline & & \\
\hline & & \\
\hline & & \\
\hline
\end{tabular}

3) A prova de $\mathbf{1 0 0}$ metros rasos é uma modalidade olímpica de atletismo, considerada a prova rainha das corridas de velocidade. Dura pouco mais de 10 segundos e os respectivos vencedores são muitas vezes apelidados de homem / mulher mais rápido do mundo. De acordo com estes dados responda:

a) Qual é velocidade de um atleta que leva 10 segundos para completar a prova de 100 metros rasos? Explique seu raciocínio.

b) Estime (chute) a velocidade de uma pessoa comum em uma prova de $100 \mathrm{~m}$ rasos? Com esta velocidade que você sugeriu, em quantos segundos esta pessoa completaria a prova dos $100 \mathrm{~m}$ rasos? Explique seu raciocínio. 
c) Uma pessoa com velocidade de $22,5 \mathrm{~km} / \mathrm{h}$, ou seja, $6,25 \mathrm{~m} / \mathrm{s}$ em uma prova de $100 \mathrm{~m}$ rasos demora quantos segundos para completar a prova? Explique seu raciocínio.

4) Frank Caldeira em 2005 completou a Maratona Internacional de São Silvestre $(15 \mathrm{~km})$ na cidade de São Paulo em 44min06s. Ronaldo Costa em 1998 completou a Maratona em Berlim $(42,195 \mathrm{~km})$ em 2h06min05s. O queniano Eliud Kipchoge na Corrida Espanhola de São Silvestre em Madri $(10 \mathrm{~km})$ completou a prova em 26min54s. Responda:

a) Qual deles é o mais rápido? Explique seu raciocínio. Deixe as contas na folha.Lembre que são percursos diferentes!

b) Um atleta em uma maratona mantêm a mesma velocidade durante todo o percurso? Então, o que indicam as velocidades dos corredores que você encontrou?

5) Analise o gráfico abaixo e compare os recordes dos atletas em 1980 e 2000, o que podemos dizer a respeito da velocidade média? Aumentou ou diminuiu? Por quê?

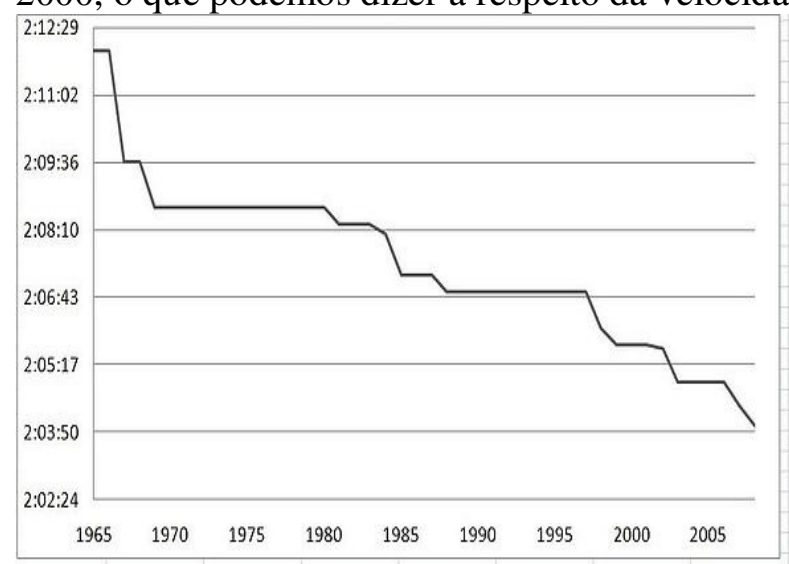

Figura 1: Evolução do recorde do mundo em Maratona (Homens) 1965-2008 (http://pt.wikipedia.org/wiki/Maratona)

6) Leia com atenção o texto abaixo

\section{Mesmo agredido, brasileiro conquista o bronze na maratona}

Um manifestante roubou a cena e ajudou a afastar a medalha de ouro de Vanderlei Cordeiro de Lima na maratona, a tradicional prova que encerrou a $28^{a}$ edição dos Jogos da Era Moderna, neste domingo. O brasileiro teve que se conformar - e comemorar muito - com a de bronze.

Veterano de outras duas Olimpíadas, Vanderlei de 33 anos tinha vantagem de meio minuto sobre o segundo colocado por volta dos $36 \mathrm{~km}$ dos $42,195 \mathrm{~km}$, quando o torcedor fantasiado com traje típico irlandês de saia, boina e meias compridas verdes e laranjas, invadiu o trajeto, agarrou e tirou o maratonista da pista. $\mathrm{O}$ infrator foi rapidamente detido pelos policiais, mas o paranaense demorou cerca de 20 segundos para se livrar dele e retornou abalado para a rua. Vanderlei manteve a liderança por alguns quilômetros, mas foi superado pelo italiano Stefano Baldini e pelo norte-americano Mebrahtom Keflezighi e terminou em terceiro lugar, com o tempo de $2 \mathrm{~h} 12 \mathrm{~min} 11 \mathrm{~s}$ a 1 min $16 \mathrm{~s}$ do vencedor e $42 \mathrm{~s}$ do segundo. (vídeo: http://www.youtube.com/watch?v=gvIcw3shUGU e http://www.youtube.com/watch?v=0roYKrf6HKk\&NR=1 )

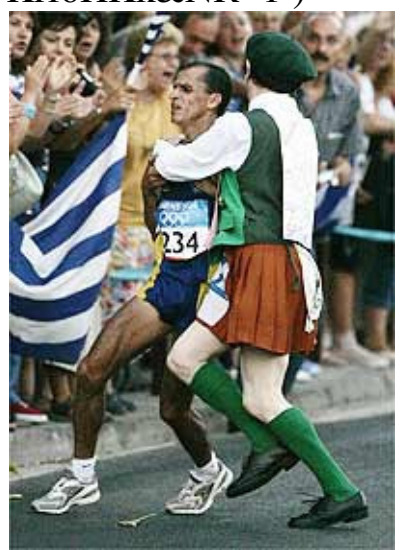

Figura 2: Manifestante agarra Vanderlei Cordeiro, então na liderança, no fim da prova 
http://esporte.uol.com.br/olimpiadas/ultimas/2004/08/29/ult2247u452.jhtm

Responda:

a) Determine as velocidades dos maratonistas (preencha a tabela): Stefano Baldini, Mebrahtom Keflezighi e Vanderlei Cordeiro.

\begin{tabular}{|l|l|l|}
\hline Maratonistas & Tempo de prova & Velocidade Mé__ \\
\hline Stefano Baldini & $2 \mathrm{~h} 10 \min 55 \mathrm{~s}=2,18 \mathrm{~h}$ & \\
\hline Mebrahtom Keflezighi & $2 \mathrm{~h} 11 \min 29 \mathrm{~s}=2,19 \mathrm{~h}$ & \\
\hline Vanderlei Cordeiro & $2 \mathrm{~h} 12 \min 11 \mathrm{~s}=2,20 \mathrm{~h}$ & \\
\hline
\end{tabular}

b) Somente a partir da velocidade do maratonista Vanderlei você poderia prever a parada dele por 20s? Por quê?

c) O que indica as velocidades dos maratonistas? Para que servem? Será que indicam a velocidade mínima e a máxima do atleta?

d) Para efetuar os cálculos de velocidade foi necessário levar em consideração a direção e o sentido dos corredores?

e) Represente o percurso da maratona feito por Vanderlei. Não se esqueça do imprevisto ocorrido, para que qualquer pessoa ao visualizar o gráfico ( $\mathrm{v} \times \mathrm{t}$ ou $\mathrm{s} \times \mathrm{t}$ ) ou o desenho entenda o que aconteceu durante a corrida.

f) Em termos de colisão (batida, "encontrão"), qual deles sai perdendo Vanderlei ou o fantasiado? A massa $(\mathrm{kg})$ de cada um deles interfere? E a velocidade? Explique em detalhes.

g) $\mathrm{Na}$ colisão do Vanderlei com o fantasiado há recuo (movimento para trás)? Represente em um desenho a colisão.

h) Vamos supor que Vanderlei tenha $60 \mathrm{~kg}$ e esteja com uma velocidade de $19,3 \mathrm{~km} / \mathrm{h}$ e o fantasiado tenha $80 \mathrm{~kg}$ e uma velocidade de $8 \mathrm{~km} / \mathrm{h}$. Quem sai "perdendo" na colisão, Vanderlei ou o fantasiado? Explique.

\section{$2^{\text {a }}$ PARTE}

Leia o texto e assista ao vídeo:

http://www.youtube.com/watch?v=pQLSu8eITcU\&feature=PlayList\&p=D4DCAC66FC12C5BE\&playn ext=1\&playnext_from=PL\&index=69

CORRIDA DE REVEZAMENTO: Há corridas de revezamento de 4 x 100 m e 4 x 400 m para homens e para mulheres nas Olimpíadas.

- Durante uma corrida de revezamento, quatro atletas de uma equipe se revezam correndo partes de um circuito.

- Os corredores devem passar um bastão de metal ou de madeira ao próximo corredor dentro de uma zona determinada. Nas Olimpíadas, as trocas de bastão são obrigatórias dentro de uma zona de passagem de 20 metros.

- A estratégia comum para uma equipe de revezamento composta por 4 pessoas é a seguinte: a primeira pessoa é o segundo atleta mais rápido, o segundo corredor é o terceiro mais rápido, o terceiro corredor é o menos rápido e o quarto corredor (âncora) é o mais rápido.

- Os revezamentos começam em raias com uma largada por etapas. O primeiro competidor começa nos blocos de largada; o segundo, terceiro e quarto corredores largam correndo.

Recordistas mundiais: Mike Marsh, Leroy Burrel, Dennis Mitchell e Carl Lewis, dos Estados Unidos, são os recordistas mundiais na corrida de revezamento 4 x $100 \mathrm{~m}$ masculino com o tempo de 37s40centésimos (37,4s) (http://esporte.hsw.uol.com.br/resumo-corrida-revezamento-olimpiada.htm).

7) Numa competição de revezamento em corrida de 4 x $100 \mathrm{~m}$ a equipe completa a prova em $40 \mathrm{~s}$. $\mathrm{O}$ primeiro corredor parte da largada e entrega o bastão para o segundo quando o cronômetro indica 10 s, e este por sua entrega ao terceiro corredor no tempo de 20 s, que entrega ao quarto no tempo de 31s. Qual a velocidade média:

a) no percurso todo?

b) do segundo corredor da equipe?

c) do terceiro corredor da equipe?

8) Durante uma corrida e em várias situações do dia-a-dia é muito difícil conseguir manter uma velocidade constante (que não muda, não varia). Percebemos que durante um percurso podemos 
aumentar e diminuir a velocidade, ou até parar. O que você faz quando quer aumentar a velocidade? E diminuir?

CURIOSIDADE: Atletas que competiram com o campeão olímpico Carl Lewis sabiam que ele era capaz de estar acelerando na marca de $70 \mathrm{~m}$ na corrida de $100 \mathrm{~m}$. Seu índice de aceleração podia ser menor do que seus oponentes no início, mas sua aceleração continuava por mais tempo. Nos últimos 30m, Carl, frequentemente alcançava e passava atletas que estavam empatando e lutando para manter suas posições. É importante notar que um atleta pode reduzir o índice da aceleração e ainda assim, aumentar a velocidade escalar. Enquanto houver aceleração mesmo que seja mínima, a velocidade escalar aumentará. O quanto a velocidade escalar de um atleta diminui depende dos índices de aceleração e desaceleração. (Biomecânica dos esportes - Gerry Carr - p.13)

9) Durante uma corrida podemos ter vários valores de aceleração (leia o texto acima). Alguns disparam na largada e têm uma aceleração enorme nos primeiros $40 \mathrm{~m}$. Depois a aceleração diminui, ou seja, desaceleram (a velocidade diminui no decorrer do tempo) e, perto da fita de chegada, podem até acelerar novamente (a velocidade aumenta no decorrer do tempo). Como podemos calcular a desaceleração e aceleração de um atleta?

10) Imagine um tobogã quádruplo (para quatro pessoas) descendo uma rampa. Este tobogã acelera a uma velocidade de $4,5 \mathrm{~m} / \mathrm{s}$ no primeiro segundo, $9 \mathrm{~m} / \mathrm{s}$ no segundo e $13,5 \mathrm{~m} / \mathrm{s}$ no terceiro segundo. Qual o aumento da velocidade do tobogã a cada segundo? Então qual a aceleração do tobogã durante o percurso? Ela varia? Explique seu raciocínio.

11)É comum nos esportes a aceleração de um atleta se manter constante (a mesma)? Explique. É mais provável obter a aceleração constante na direção horizontal ou na vertical, ou tanto faz? Explique.

12) Um atleta deseja superar seus índices saltando de uma plataforma bem alta, a 78m (altura equivalente aproximadamente a um edifício de 25 andares) de altura para efetuar um salto ornamental (vídeo: http://www.youtube.com/watch?v=Ri5_faU-c_Q e http://www.youtube.com/watch?v=uZKP6gS7hVE\&feature=related). Após 1s de queda, o atleta está se deslocando a uma velocidade de $9,8 \mathrm{~m} / \mathrm{s}$. Após $2 \mathrm{~s}$, a velocidade do atleta alcançou 19,6m/s. $\mathrm{Na}$ marca dos $3 \mathrm{~s}$, o atleta alcançou $29,4 \mathrm{~m} / \mathrm{s}$. Finalmente na marca dos $4 \mathrm{~s}$, a velocidade do atleta alcançou os inacreditáveis 39,2 m/s. Qual é o aumento de velocidade a cada segundo? O que se mantêm constante? Qual é o valor da aceleração? Explique seu raciocínio.

13)Qual é a direção (horizontal, vertical, etc.) e o sentido (para esquerda, para cima, etc.) do movimento do atleta em um salto ornamental. Represente de alguma forma a queda do atleta no salto ornamental.

14) Por que o atleta em um salto ornamental cai para baixo? O que a Terra exerce sobre o atleta? Portanto o que podemos dizer do valor de aceleração que encontramos de um atleta em um salto ornamental?

15) Nas competições de saltos ornamentais a plataforma se encontra a $10 \mathrm{~m}$ da superfície da água. Como sabemos no movimento na vertical temos constante sempre a aceleração da gravidade, a partir disso em quanto tempo o atleta irá atingir a superfície da água?

16) Explique este trecho: "Considere dois caçadores de emoção que decidem saltar de bungee jump de uma ponte. Um tem duas vezes a massa do outro. Eles saltam ao mesmo tempo da ponte. De um modo surpreendente, ambos aceleram em direção ao solo, aproximadamente no mesmo índice".

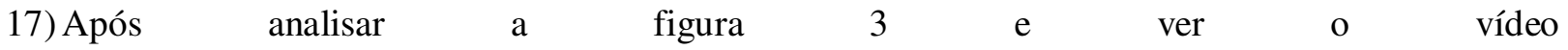
(http://www.youtube.com/watch?v=mUIc_Jnr2B8\&feature=related), tente explicar o gráfico 4.
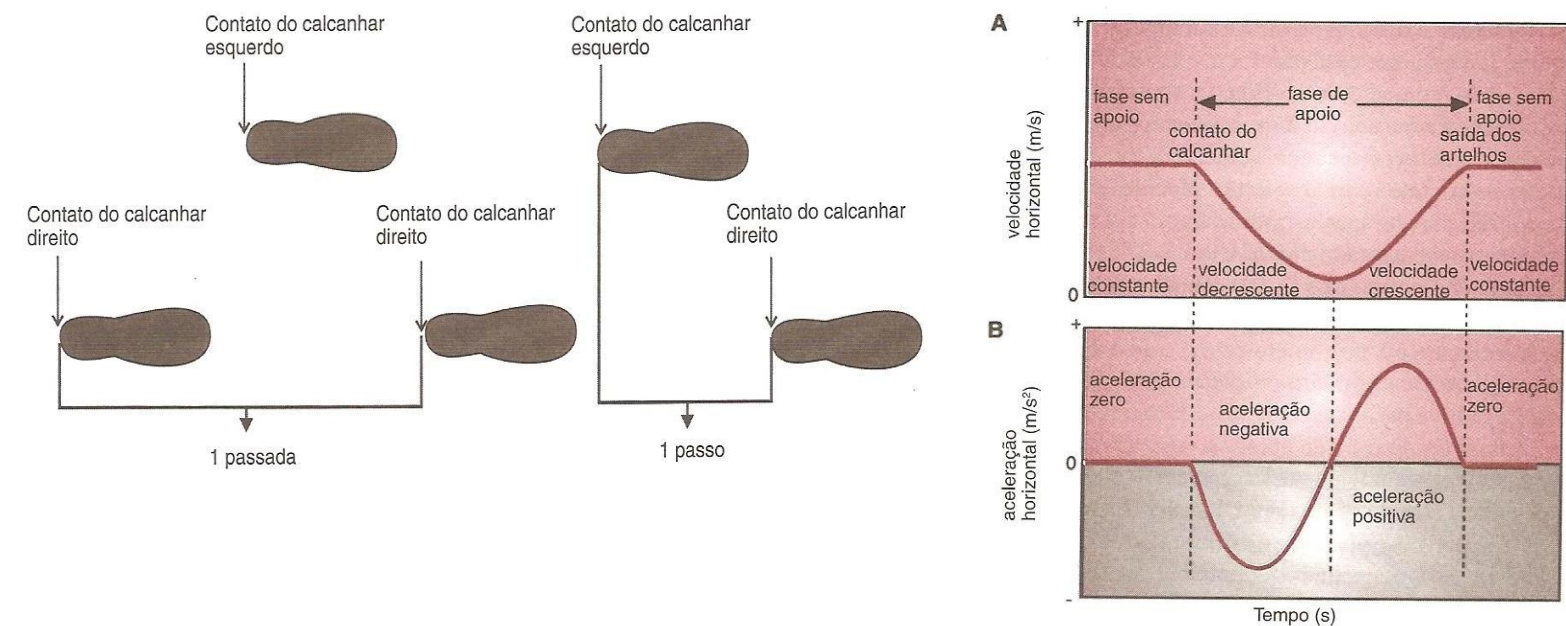
Figura 3: Ilustração dos parâmetros da passada durante o andar (Bases biomecânicas do movimento humano HAMIL \& KNUTZEN).

18) Leia o texto e elabore três questões.

LANÇAMENTO DE PROJÉTEIS: Nos esportes existem muitas modalidades em que atletas e objetos são projetados ao ar. Os projéteis podem ser bolas de golfe, bolas de basquete, dardos; ou em modalidades de salto, ginastas e saltos ornamentais, os próprios atletas. Todos esses esportes requerem que o atleta manipule, controle ou avalie o trajeto de vôo que ocorre. Por exemplo: Um goleiro de futebol avalia a velocidade e vôo da bola para fazer uma defesa bem sucedida, um saltador em altura está interessado em altura, distância e rotação de modo que ele possa ultrapassar a barra com sucesso.

Em modalidade que incorporam o vôo, vários fatores influenciam a característica de seu caminho: trajetória e ângulo, velocidade e trajetória de lançamento.

Quando um atleta executa uma habilidade esportiva, geralmente, várias forças agem ao mesmo tempo. Vamos atentar para essas forças em ação no arremesso de peso. Pense em atletas de elite arremessando um peso, a um ângulo de arremesso de cerca de $42^{\circ}$ com a horizontal. Para fazer o peso de deslocar para cima, os atletas devem aplicar força naquela direção. Portanto eles aplicam alguma (mas não toda) força na direção vertical. Para fazer o peso se deslocar horizontalmente, eles aplicam força naquela direção também. A combinação de forças
Figura 4: Mudanças na (A) velocidade e (B) aceleração durante a fase de apoio de uma passada na corrida (Bases biomecânicas do movimento humano - HAMIL \& KNUTZEN)

horizontais e verticais dá ao peso sua trajetória de $42^{\circ}$.

Obviamente, os arremessadores não vão aplicar toda sua força somente em uma direção vertical ou horizontal. Se os atletas fossem tolos o suficiente para por toda sua força em uma direção vertical, o peso iria direto para cima e direto para baixo! Isso não é a melhor coisa a se fazer em uma competição que dá prêmio ao atleta que alcança a maior distância horizontal! Por outro lado, se toda a força do arremessador for direcionada horizontalmente, o peso atingirá o solo muito antes de ter tempo para percorrer a distância ideal. Portanto utiliza-se um ângulo de trajetória que está entre o horizontal e o vertical (Biomecânica dos esportes - Gerry Carr - p.23 e 27).

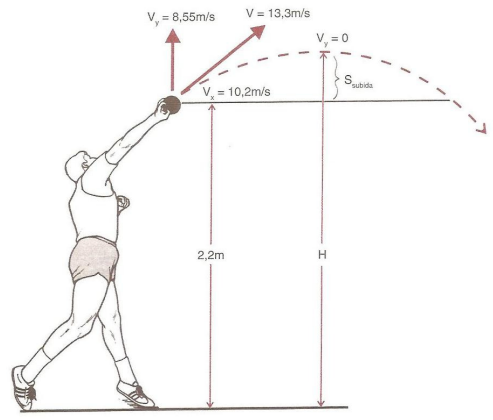

Figura 5: Bases biomecânicas do movimento humano HAMIL \& KNUTZEN - p.354 


\section{ATIVIDADE 5 - O PESO IDEAL}

1. Leia o texto abaixo e anote todas as palavras relacionadas à física.

Por exemplo, o saltador de trampolim sabe que a gravidade age perpendicularmente a superfície da Terra tem uma melhor compreensão de qual trajetória proporciona melhor trajeto para o salto. De maneira semelhante, lutadores aprenderão que a gravidade é amiga quando eles desequilibram seus adversários. Por outro lado, se eles não mantêm sua própria estabilidade, a gravidade muda de lado e ajuda o adversário! Os saltadores com esqui entendem que, quando estendem as pernas e se inclinam para frente, ao descerem a rampa, reduzem a resistência do ar. Essa posição do corpo permite que a gravidade os acelere em preparação para decolagem. Uma vez voando, os saltadores com esqui reagem à força da gravidade fazendo uso da resistência do ar. Eles estendem as pernas e se inclinam para frente, simulando a asa de um avião. Dessa forma, ela oferece uma força para cima. É essa variação no uso da gravidade e resistência do ar que ajuda os saltadores de esqui a realizar longos saltos planadores.

Biomecânica dos esportes - Gerry Carr

2. Por que os atletas que querem desempenhar bem suas modalidades monitoram sua massa corporal? Dê exemplos.

3. Cite 4 esportes e determine a massa ideal que o atleta deve ter para desempenhá-lo. Complete a tabela:

\begin{tabular}{|l|l|l|}
\hline Modalidade esportiva & Massa $(\mathrm{kg})$ & Por que esta massa para este esporte? \\
\hline 1 & & \\
\hline 2 & & \\
\hline 3 & & \\
\hline 4 & & \\
\hline
\end{tabular}

4. Leia o texto abaixo e responda

\section{CURIOSIDADE JOGOS OLÍMPICOS DE VERÃO DE 1968}

Os Jogos Olímpicos de 1968 foram realizados na Cidade do México entre 12 e 27 de outubro de 1968. Pela primeira vez os Jogos foram sediados na América Latina e a altitude de $2.300 \mathrm{~m}$ acima do nível do mar da capital mexicana gerou controvérsias sobre os danos que o ar mais rarefeito poderia causar no desempenho dos atletas. Realmente, a altitude prejudicou o desempenho dos atletas nas provas de resistência e de longa distância, como o ciclismo, a natação e a maratona, mas em compensação ajudou a provocar uma chuva de recordes mundiais e olímpicos nos eventos mais curtos e de esforço mais rápido como as corridas de menos de $800 \mathrm{~m}$, halterofilismo, lançamento de dardo e outros.

O norte-americano Bob Beamon ganha a medalha de ouro no salto em distância com aquela que por muitos é considerada a mais espetacular marca já atingida no atletismo. Ajudado pelo ar rarefeito dos $2.300 \mathrm{~m}$ de altura da capital mexicana, Beamon conseguiu um salto de $8,90 \mathrm{~m}$ de extensão, mais de meio metro acima do recorde então vigente, marca tão fantástica que até hoje se mantém como recorde olímpico e durante mais de vinte anos foi o recorde mundial.

(http://pt.wikipedia.org/wiki/Jogos O1\%C3\%ADmpicos de Ver\%C3\%A3o de 1968).

A atração gravitacional da Terra irradia de seu núcleo de maneira semelhante às ondulações causadas por uma pedra atirada na água. Quanto mais perto você estiver do núcleo da Terra, maior será a atração. Como a Terra não é perfeitamente redonda, um atleta está mais longe do núcleo se estiver na linha do equador do que se estiver no pólo Sul.

Consequentemente, um atleta, ou um implemento como um dardo, pesará um pouco menos no equador do que nos pólos. Se o atleta subir ao topo de uma montanha no Equador, ele estará ainda mais longe do núcleo e seu peso se reduzirá ainda mais (Biomecânica dos esportes - Gerry Carr - p.11).

a) Será que existe alguma diferença em termos de desempenho ou habilidade esportiva quando o atleta vai a competições perto da linha do equador ou perto do pólo Sul ou Norte? Explique.

b) A massa corporal do atleta muda ao se deslocar do Pólo Sul ao Pólo Norte? Então o que muda? Explique.

5. Leia o texto abaixo e após assistir os vídeos, responda:

(http://www.youtube.com/watch?v=FInOkiFVQkU\&feature=related e http://www.youtube.com/watch?v=N6ZJnIJRUCI\&feature=related) 


\section{PESO CORPORAL}

Os atletas que querem desempenhar bem suas modalidades monitoram o peso de seus corpos. Eles sabem que muito ou pouco peso pode afetar o desempenho. Para todos nós a verificação do peso do corpo é um meio de avaliar nossa saúde e condicionamento geral. Quando subimos em uma balança, o mostrador fornece uma leitura que associamos com a massa corporal (isto é, ossos, músculos, gordura, tecidos) que possuímos. Geralmente pensamos que o peso corporal de um atleta comprime as molas da balança, já que a leitura do mostrador representa o quanto elas são comprimidas. Isso é verdade, mas o que acontece, na realidade, é um pouco mais complexo.

Em termos mecânicos, o peso de um atleta representa a força de atração gravitacional da Terra puxando seu corpo sobre a Terra! A leitura da balança representa quanta atração existe entre ambos. A Terra puxa o atleta para baixo e, inversamente, o atleta puxa a Terra para cima.

O grau de atração, ou puxão, entre o atleta e a Terra depende de quanta massa a Terra possui e quanta massa corporal o atleta possui. Quanto maior atração, maior a compressão das molas da balança. Portanto um atleta com mais massa corporal comprime mais as molas do que um atleta com menos massa corporal. Consequentemente, a agulha na balança se move adiante do mostrador. Geralmente utilizamos o valor aproximado de $10 \mathrm{~m} / \mathrm{s}^{2}$ para aceleração da gravidade, mas isto depende da precisão que necessitamos. Para representar a aceleração da gravidade utilizamos a letra $\mathrm{g}$.

Um atleta que pesa $90,8 \mathrm{~kg}$ nos pólos pesará cerca de $90,3 \mathrm{~kg}$ ao nível do mar no Equador, e um atleta que pesa $90,8 \mathrm{~kg}$ ao nível do mar pesará, aproximadamente $90,7 \mathrm{~kg}$ a uma altitude de $3600 \mathrm{~m}$. Essas pequenas mudanças de peso nos dizem que o peso corporal de um atleta é uma função das variações na atração gravitacional da Terra sobre a massa do atleta. A massa corporal de um atleta pode permanecer constante, porém, o peso corporal da mesma pessoa pode alterar, dependendo de onde o atleta estiver no planeta. $\mathrm{O}$ mesmo se aplica a um dardo, a um peso ou a qualquer tipo de equipamente usado em uma competição esportiva (Biomecânica dos esportes - Gerry Carr - p.11).

a) Peso corporal e massa corporal são iguais? Explique então o que é massa corporal e peso corporal.

b) Como podemos calcular o peso corporal de um atleta? Explique.

c) É possível um atleta (sem alteração de massa corporal) ter um peso corporal $\mathbf{x}$ em um lugar da superfície da Terra e $\mathbf{y}$ em outro planeta, ou seja, diferentes? Por quê?

d) Por que na Terra nós andamos normalmente, e na Lua como vemos em filmes os astronautas flutuam?

6. A massa da Terra é $5,97.10^{24} \mathrm{~kg}$, e cada um desses quilogramas atraem um quilograma de massa do seu corpo, portanto a força de atração que ela exerce sobre os corpos não é desprezível, como por exemplo, quando uma pessoa se aproxima de nós, ou quando seguramos um livro.O valor que nos informa qual é a força com que a Terra atrai cada $1 \mathrm{~kg}$ de massa situado em sua superfície ou nas proximidades dela é simbolizado pela gravidade g, que é aproximadamente $10 \mathrm{~N} / \mathrm{kg}$ (igual a $10 \mathrm{~m} / \mathrm{s}^{2}$ ). O que significa a unidade $\mathrm{N}$ ? Observe que $\mathrm{N} / \mathrm{kg}=\mathrm{m} / \mathrm{s}^{2}$.

7. Leia o texto e responda:

Quando alguém nos pergunta quanto pesamos, respondemos um valor em quilogramas. Só que essa unidade corresponde à medida de massa. E agora? Você continua acreditando que mediu o peso. Você sabia que seu peso é maior em São Paulo do em Fortaleza? Mas isso não tem nada a ver com a leveza de espírito que a gente sente nas belas praias cearenses, mas com a relação de peso. Satélites em torno do planeta Terra permitem medir a aceleração da gravidade em praticamente qualquer ponto da superfície, com extrema exatidão. Veja alguns valores:

\begin{tabular}{|l|l|}
\hline Rio de Janeiro & $9,788 \mathrm{~N} / \mathrm{kg}$ \\
\hline Buenos Aires & $9,797 \mathrm{~N} / \mathrm{kg}$ \\
\hline Fortaleza & $9,780 \mathrm{~N} / \mathrm{kg}$ \\
\hline Pólo Norte & $9,832 \mathrm{~N} / \mathrm{kg}$ \\
\hline Porto Alegre & $9,789 \mathrm{~N} / \mathrm{kg}$ \\
\hline Recife & $9,781 \mathrm{~N} / \mathrm{kg}$ \\
\hline Salvador & $9,782 \mathrm{~N} / \mathrm{kg}$ \\
\hline
\end{tabular}




\begin{tabular}{|l|l|}
\hline São Paulo & $9,788 \mathrm{~N} / \mathrm{kg}$ \\
\hline Uberlândia & $9,786 \mathrm{~N} / \mathrm{kg}$ \\
\hline
\end{tabular}

(Coleção Nova Geração - Física - Mecânica 1 - Talavera \& Pozzani - p. 48)

a) Qual é a sua massa corporal e seu peso corporal na cidade de São Paulo? Explique seu raciocínio.

b) Explique como uma pessoa pode calcular o seu peso corporal em qualquer parte do planeta. Observação: não se esqueça de explicar a diferença entre massa corporal e peso corporal.

8. Já utilizamos várias unidades de medida, como por exemplo, a grandeza de tempo em s (segundos). Complete a tabela abaixo:

\begin{tabular}{|l|l|l|}
\hline Grandeza & Unidade no S.I.* & Por extenso \\
\hline Velocidade & & \\
\hline & $\mathrm{kg}$ & Quilograma \\
\hline Aceleração & & \\
\hline & $\mathrm{N}$ & Newton \\
\hline
\end{tabular}

* S.I. = sistema internacional de unidades

9. Leia os textos abaixo e formule quatro questões

"Atletas são constituídos de músculos, ossos, gordura, tecidos e fluidos, todos são substância ou matéria e tem massa. Portanto um atleta, tendo massa, puxa a Terra e a Terra, também tendo massa, puxa o atleta.

Um lutador na categoria peso-pesado possui mais massa do que um ginasta peso-leve. A atração entre a Terra e o lutador peso-pesado é maior do que aquela entre a Terra e o ginasta. Isso é demonstrado na balança. A agulha na balança pode marcar 100kg para o lutador e 36,2kg para o ginasta" (Biomecânica dos esportes - Gerry Carr - p.11).

"No corpo humano, ossos e músculos são menos densos do que gordura. Portanto é possível para um atleta pequeno e musculoso ter mais massa e pesar mais do que um atleta que parece maior, mas tem menos músculo e mais gordura. Como músculo é mais denso do que gordura, culturistas que gastam tempo desproporcional desenvolvendo seu tronco, aumentarão a massa muscular nessa área de seus corpos" (Biomecânica dos esportes - Gerry Carr - p.20).

"O esqueleto é uma estrutura mecânica constituída de ossos e cartilagens e articulações. Suas principais funções são: sustentação do corpo, locomoção, proteção de órgãos importantes como o cérebro, olho e ouvido interno, coração, pulmões etc. e armazenamento de substâncias químicas, sendo a mais importante delas, o cálcio. Em um adulto há 206 ossos de diferentes formas e tamanhos, dos quais a metade faz parte das mãos e dos pés. Devido a sua composição, os ossos são extraordinariamente leves, principalmente por causa da porosidade. Em um adulto padrão, a massa de todos os ossos equivale a $18 \%$ da massa corporal" (Desvendando a física do corpo humano - Okuno \& Fratin - p. 142).

"A cada pulsação, o coração bombeia sangue para os demais órgãos do corpo por meio de tubos chamados artérias. Ao ser bombeado, o sangue é empurrado contra a parede dos vasos sanguíneos, gerando o que conhecemos mais comumente como pressão arterial. Essa pressão varia ao longo do dia, dependendo de suas atividades. Quando, por exemplo, você se exercita, ela aumenta; quando relaxa, ela diminui. Mas, além das atividades físicas, também a postura (sentado ou em pé) influencia a pressão arterial. Quando uma pessoa se encontra em pé, o sangue é lançado para cima, fazendo com que o resto do corpo, devido à ação correspondente, seja "empurrado" um pouco mais contra o chão. Se você quiser comprovar esse fato, suba em uma balança mecânica de farmácia e observe atentamente a marcação do ponteiro. Você verá que ele não se fixa exatamente em torno dele. Isso acontece porque essa oscilação acompanha as batidas do coração. Quando o coração se contrai, lançando o sangue para cima (na sístole), o ponteiro tende a marcar um valor maior, indicando o aumento da força aplicada para baixo na balança. Da mesma maneira, quando o coração relaxa (na diástole), o ponteiro tende a marcar um valor menor, indicando a diminuição da força aplicada na balança" (Coleção Nova Geração - Física - Mecânica 1 Talavera \& Pozzani - p. 17). 


\section{ATIVIDADE 6: O PAPEL DA FORÇA NO ESPORTE}

1. Imagine-se praticando sumô, o milenar esporte japonês. Será que lhe faltaria força? Afinal, para a pratica do sumo, força física é fundamental. Mesmo que não seja no sumô, você utiliza força no seu dia-adia: ao puxar uma cadeira, abrir a janela, etc. Afinal, quanto de força será necessário para apertar o botão do controle remoto da TV? Enfim utilizamos a palavra força para movimentar ou mudar a forma daquilo que estamos interagindo. Observe que no tênis, a força aplicada à bolinha pode movimentá-la e deformála momentaneamente.

Vídeos: http://www.youtube.com/watch?v=UxhKb-zZoWE\&feature=fvst http://www.youtube.com/watch?v=jjE8SQG8AwI

http://www.youtube.com/watch?v=-99QU0i-XTg $\mathrm{http}: / / \mathrm{www}$.youtube.com/watch?v=0KfD-v23isA

2. Complete: Interação é a ação recíproca (mútua) de dois ou mais corpos uns nos outros, portanto quando medimos força estamos medindo..........

3. Você é capaz de ver uma força? E senti-la? Explique.

4. Após ler o texto responda:

Um atleta movimentando-se é um exemplo de massa em movimento. Porque a massa corporal do atleta está se movendo, dizemos que esse atleta tem certa quantidade de movimento. O momento descreve a quantidade de movimento que ocorre. Um atleta enorme e com muita massa, correndo na mesma velocidade de um atleta com menos massa corporal, tem mais momento. Da mesma forma com massa corporal mínima, correndo a uma velocidade fenomenal, pode ter mais momento do que o atleta que tenha mais massa. Para compensar uma tremenda diferença de massa, atletas com pouca massa corporal têm de correr uma velocidade muito grande para alcançar um atleta com maior massa.

Biomecânica dos esportes - Gerry Carr

a) $\mathrm{Na}$ atividade 4, iniciamos uma discussão sobre a colisão ("encontrão") entre o maratonista Vanderlei Cordeiro e o fantasiado. Em uma colisão o que devemos levar em consideração para analisar quem sai "perdendo" ou "ganhando"? Opcional: vídeo sobre colisões: http://www.youtube.com/watch?v=pZqkaJDaz2A

b) Cite 4 esportes e seus respectivos exemplos de colisões (pode ser na lateral, de frente, de costas, etc.) que podem acontecer nestes esportes. Complete a tabela abaixo:

\begin{tabular}{|l|l|}
\hline Esporte & Exemplo de Colisão \\
\hline & \\
\hline & \\
\hline & \\
\hline
\end{tabular}

c) O que você deve analisar em uma colisão? Que grandezas estão envolvidas em uma colisão?

d) Você já deve ter observado que um jogador de vôlei movimenta o braço para dar uma cortada na bola, que um tenista movimenta a raquete para bater na bola. Para que fazem isso?

e) Ao empurrar um carrinho de supermercado vazio, por exemplo, você é capaz de tirá-lo do repouso e colocá-lo em movimento com uma velocidade que vai depender, em parte do quanto é intenso o seu "empurrão" ao carrinho. Em outras palavras como nós podemos chamar este "empurrão"?

f) O tempo do "empurrão" interfere nas colisões? E na aceleração adquirida pelos corpos?

g) Se o carrinho estiver cheio vai ser mais difícil para tirá-lo do lugar. Para que o carrinho cheio ganhe a mesma velocidade do carrinho vazio, o que você faz? Explique.

h) Analisando o tempo, o que aconteceria se empurrasse o carrinho cheio por mais tempo?

i) Destaque os pontos mais importantes do vídeo: http://www.youtube.com/watch?v=pEzILbXJjZE http://www.youtube.com/watch?v=CHTqw5kW57k

5. Com base no texto abaixo, se um atleta de $136 \mathrm{~kg}$ corre $100 \mathrm{~m}$ em $20 \mathrm{~s}$ (que corresponde a velocidade de $5 \mathrm{~m} / \mathrm{s}$ ), quanto tempo um outro atleta de $68 \mathrm{~kg}$ deve ter, para produzir o mesmo momento? (ou seja, para ninguém sair perdendo ou ganhando na colisão).

Momento ocorre sempre que um atleta ou um objeto se movimenta e tem papel particularmente importante em esportes em que há colisões e impactos. Por exemplo, um disco batido com imensa velocidade por um jogador de hóquei, pode ter um momento suficiente para derrubar um goleiro. Quando 
o disco atinge o goleiro, o disco e o goleiro por um instante, tornam-se uma massa combinada. O disco diminui sua velocidade e perde um pouco do seu momento. Ele mantém um pouco de momento, mas a maior parte é dada ao goleiro, que, por ser jogado para trás, ganha momento naquela direção.

Quando um atleta deseja movimentar-se ou acelerar um objeto e dar a ele momento, tem de ser produzida força muscular. A força que o atleta aplica sempre demanda tempo. Quando um atleta aplica certa força em um objeto sobre um período de tempo, dizemos que o atleta aplicou um impulso no objeto. Como força e tempo são combinados, depende das capacidades físicas do atleta. Algumas habilidades requerem que uma tremenda força seja aplicada em um curto espaço de tempo, outras requerem menor força aplicada durante um espaço de tempo maior (Biomecânica dos esportes - Gerry Carr).

6. "Para medir o "empurrão" temos que levar em conta o quanto tempo ele dura, determinar o impulso, que também está relacionado a quantidade de movimento (ao momento) e a força aplicada ao carrinho". Descreva a utilização do impulso em alguma modalidade esportiva de sua preferência (por exemplo, em um golpe de caratê ao destruir um bloco de concreto - Curiosidade: Os ossos podem resistir 40 vezes mais ao estresse ou força por unidade de área do que o concreto).

7. A partir do texto abaixo, enumere as semelhanças e as diferenças entre o salto em altura e o lançamento de dardo.

O Salto em altura é semelhante ao dardo no sentido em que ambas as modalidades requerem que o atleta crie uma tremenda velocidade de saída. No salto em altura, o atleta é um projétil propelido para cima, no ar, pela força muscular. No lançamento de dardo, o dardo é um projétil lançado pelo atleta. Porque o saltador em altura deseja ir o mais alto possível, você poderia pensar que seria uma boa idéia, na subida aplicar o máximo de força possível sobre o maior período de tempo disponível. Portanto, por que não fazer o atleta começar o impulso para cima, na subida, a partir de um agachamento completo e continuar se impulsionando até que a perna do salto esteja totalmente estendida? Certamente, começar com um agachamento completo maximiza o tempo que a força é aplicada pela musculatura das pernas. Infelizmente, não é esse caso. Em um agachamento completo, um atleta não é capaz de desenvolver força máxima porque os músculos das pernas estão em uma má posição para lançá-lo para cima. Antes o que você observará é que todos os grandes saltadores em altura aplicam uma tremenda força por um tempo mais curto e iniciam seu impulso para cima, a partir de uma posição que lembra um quarto de agachamento. Se saltadores em altura não podem usar uma posição totalmente fletida (agachada), existe alguma outra maneira de eles aumentarem o período de tempo de aplicação da força? Sim. Exatamente como um lançador de dardo de elite, todos os grandes saltadores inclinam-se para trás ao apoiarem o pé do salto, antes da subida. O endireitamento, a partir da inclinação para trás, permite que o atleta passe mais tempo aplicando força ao solo, o qual em reação o impulsiona para cima. A mesma técnica é usada para jogadores de voleibol quando lês saltam para cortar e bloquear, por jogadores de futebol quando eles pulam para cabecear a bola, e por jogadores de basquete quando eles saltam para bloquear ou fazer uma bandeja. O uso de uma inclinação para trás antes da decolagem, ajuda a todos os atletas a subirem mais alto no ar (Biomecânica dos esportes - Gerry Carr, p.34). 


\section{ATIVIDADE 7 - AS TRÊS LEIS DE NEWTON E OS ESPORTES}

\section{$\mathbf{1}^{\text {a }}$ PARTE}

1) Explique esta afirmação: "A massa corporal de um atleta depende da modalidade esportiva que ele pratica. No sumô seus praticantes devem ter grandes massas e na ginástica olímpica baixa massa".

2) Como é difícil colocar um corpo em movimento! O que fazer para derrubar um lutador de sumô? Qual "obstáculo" é necessário vencer, para colocarmos qualquer objeto ou pessoa em movimento?

3) Observe o vídeo do futebol americano

Vídeo: http://www.youtube.com/watch?v=CNRWEKDGX5s

No futebol americano temos os quarterbacks que são protegidos por offensive linemem, que são homens imensos com uma grande massa. È necessário uma força inacreditável para tirar esses homens do caminho. Mas os offensive linemen enfrentam defensive limenen igualmente grandes cuja tarefa é romper a linha protetora e perseguir o quarterback.

4)Leia o texto e explique o que é inércia.

Inércia descreve o "desejo" de um objeto de continuar a fazer o que estava fazendo - mesmo quando ele está se movendo (inércia de movimento). Todos os objetos (quer sejam atletas ou equipamentos como tacos, bastões ou bolas) desejam permanecer imóveis (inércia de repouso). Mas se uma força for grande suficiente para fazê-los se mover em uma determinada direção, eles desejarão continuar se movendo na mesma direção, a uma velocidade constante (Biomecânica dos esportes - Gerry Carr - p.12).

5. Cite um exemplo em que a inércia é favorável (ajuda) e um exemplo em que a inércia é desfavorável (atrapalha) em uma modalidade esportiva de sua preferência? Use para explicar tanto a inércia de repouso quanto a de movimento.

6. Leia o texto abaixo e responda:

Devido a atração de massas a outros objetos que têm massa, atletas em pé, no chão puxam a Terra para cima, ao mesmo tempo que são puxados pela força gravitacional. Quanto mais massa o atleta tiver, mais forte a atração. Isso significa que um atleta pressiona a Terra com uma força igual ao seu peso. Por estranho que pareça a Terra reage ao peso do atleta, empurrando-o para cima com uma força igual e oposta. A força empurrando o atleta é chamada força reação do solo (Biomecânica dos esportes - Gerry Carr - p.20).

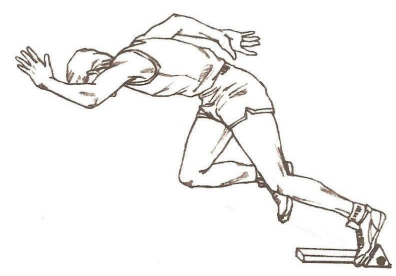

Figura 1: Saída de uma corrida de sprint (Biomecânica dos esportes - Gerry Carr - p.31)

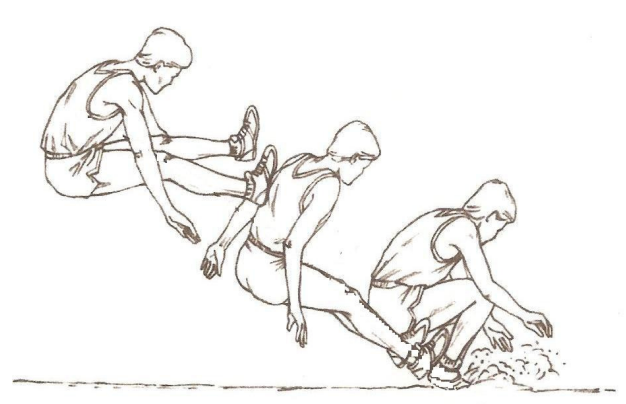

Figura 2: Salto a distância (Biomecânica dos esportes Gerry Carr - p.21)

a) Represente nas figuras 1 e 2 as forças de ação e reação exercidas pelos atletas.

b) Por que você representou as forças de ação e reação desta forma?

c) Nas figuras sua intenção foi representar o sentido e a direção da força? Observe que dependendo do que estamos analisando precisamos dar mais características às grandezas. No levantamento de peso, imaginemos dois levantadores combinando suas forças musculares para elevar uma barra na direção vertical. A combinação de suas forças totalizou certo valor e foi orientada para certa direção e sentido. Quando a direção, o sentido e o valor da força aplicada são conhecidos, a combinação desses dois itens é chamada vetor força. Cite três grandezas físicas, no qual podemos atribuir direção e sentido. A grandeza física massa possui direção e sentido? Posso dizer que tenho uma massa de $60 \mathrm{~kg}$ na horizontal de baixo para cima? 
7. Na figura 3 abaixo, nomeie os vetores força (as setas) representados. Temos vários tipos de força: força de ação, força de contato, força peso, etc.
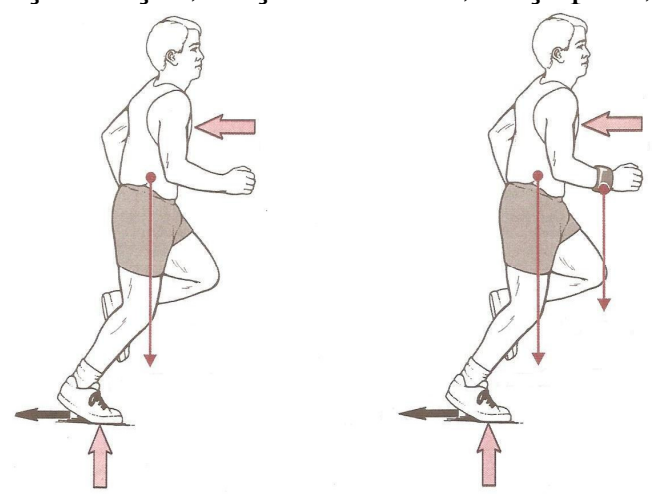

Figura 3: Corrida (Bases biomecânicas do movimento humano - HAMIL \& KNUTZEN- p.413)

8. Você caminha com mais facilidade no asfalto ou em uma pista lotada de óleo? Por quê?

9. Leia o texto com atenção, e cite dois exemplos em que o atrito prejudica o desempenho do atleta e dois exemplos em que o atrito facilita o desempenho do atleta.

As demandas por atrito (resistência) variam acentuadamente, de um esporte para outro e de um grupo de condições climáticas a outro. Um atleta pode desejar muito atrito em um momento e apenas um atrito mínimo em outro. No futebol americano, as mudanças bruscas de direção dependem do atrito para uma boa tração. Em piso artificial, o atrito entre o tênis do atleta e o piso pode, algumas vezes, ser bom demais! Técnicos e atletas precisam saber como fazer o melhor uso de todas as condições de atrito que ocorrem em um esporte - quais estratégias usar quando as condições mudam e quais inovações técnicas adotar quando novos materiais e desenhos entram no cenário esportivo. O conhecimento das características de atrito é requisito para produzir desempenhos ideais (Biomecânica dos esportes - Gerry Carr - p.20).

10. Como a força não pode ser vista, não existe um meio de avaliar a força com precisão a menos que possa ser medida usando instrumentos de registro. Geralmente é utilizada uma plataforma de força que é uma escala de medida muito sofisticada geralmente embutida no solo, com sua superfície nivelada com a superfície do solo onde o individuo está. Esse dispositivo pode medir a força de colisão da sola com o pé do individuo sobre a superfície, ou medir a força de um indivíduo apenas em pé sobre a plataforma (Bases biomecânicas do movimento humano - HAMIL \& KNUTZEN, p.401) Você já viu alguma vez algum tipo de máquina que mede força? Nem em uma loja de tênis? Observe que na figura 4 temos uma pessoa levantando uma barra de $100 \mathrm{~kg}$ em um agachamento. A partir do gráfico da figura 4, qual é o valor máximo de força que a pessoa aplicou para levantar a barra de $100 \mathrm{~kg}$ ?

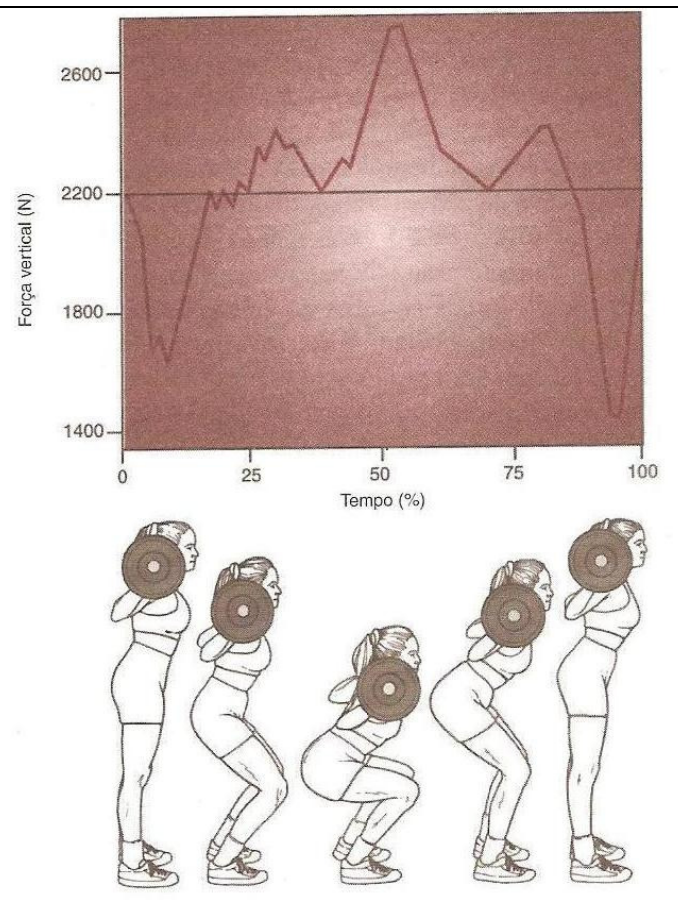

Figura 4: Análise cinemática (lado esquerdo) e análise cinética (lado direito) - Figura: Corrida (Bases biomecânicas do movimento humano - HAMIL \& KNUTZEN, p.9)

\section{$2^{\text {a }}$ PARTE}

11. Leia o texto e defina o que é trabalho para a física

No treinamento com peso, o levantamento de uma barra é um bom exemplo de trabalho mecânico. $\mathrm{O}$ atleta aplica força na barra e, como resultado, eleva-a a certa distância. Por outro lado, se a barra for colocada sobre um suporte, à altura do tórax, e um atleta pressioná-la ou puxá-la com uma contração estática de 10 segundos, nenhum trabalho 
será feito. Razão mecânica porque nada se moverá. Não importa quão vigorosamente os músculos do atleta se contraem ou quanto trabalho fisiológico é feito. Se nada se move, seja um dardo, uma bola de hóquei de campo ou uma barra, nenhum trabalho mecânico é feito (Biomecânica dos esportes - Gerry Carr - p.38).

12. Escolha três modalidades esportivas e elabore uma frase para cada uma delas que envolva trabalho, força e distância. Veja um exemplo: O lançador de dardo aplicou uma força ao dardo por uma certa distância e, fazendo isso realizou trabalho sobre o dardo.

13. Imagine dois atletas levantando uma barra a uma mesma distância. $\mathrm{O}$ atleta $\mathrm{A}$ leva $1 \mathrm{~s}$ para elevar a barra acima da cabeça e o atleta B leva 2s. O atleta A é mais potente que o atleta B. Por quê? O que indica a grandeza potência?

14. Após a leitura do texto abaixo, responda:

a. No texto é citado: “...um jogador de futebol consome cerca de 750 calorias numa partida...”, o que representa a unidade calorias?

b. Formule 3 questões sobre o texto.

c. Complete: Pense em um aparelho de som, a unidade de potência é dada em

Pense em um carro, a potência é dada na unidade de funcionar ele precisa de . Um atleta precisa de Para um carro

Em geral quase toda energia que necessitamos é convertida em calor. Para se ter uma idéia mais clara de nossas exigências diárias de energia e potência, um jogador de futebol consome cerca de 750 calorias (cal) numa partida (ou seja, o jogador deve dispor em média de uma potência próxima a 0,75 HP- horse power), o que corresponde aproximadamente $40 \%$ da energia requerida para assegurar o funcionamento do corpo humano a nível basal (1800 cal/dia). Os seres humanos podem dispor de potências mais elevadas do que esta, desde que em tempos mais reduzidos. Assim um adulto poderá dispor de uma potência máxima de 1,09HP durante 1 minuto, e de uma potência de 1,87 HP durante 10 segundos.

Uma das constantes fisiológicas mais importantes é a potência específica máxima disponível para um ser humano, ela vale 3,9HP para um indivíduo de $70 \mathrm{~kg}$. Tal nível de potência só é mantido por no máximo 1 segundo. Essa potência limite é empregada usualmente nas largadas de corridas de 100 e 200 metros rasos, e no momento de arranque das provas de levantamento de peso (nas quais o levantador tem apenas 1segundo para levantar uma massa de 140kg a uma altura acima da cabeça com os braços esticados). Desnecessário dizer que despender energia a essa taxa é uma atividade de altíssimo risco para maior parte das pessoas podendo facilmente levar a morte.

A perda de $0,01 \mathrm{~kg}$ de gordura do corpo através de oxidação requer $10 \mathrm{cal}$ de trabalho muscular. Portanto se uma pessoa deseja perder $\mathrm{m}(\mathrm{kg})$ de gordura através de malhação a uma potência média de $700 \mathrm{~W}$ ela deverá investir cerca de $\mathrm{t}($ horas $)=17 . \mathrm{m}(\mathrm{kg})$ nos exercícios, ou seja, cerca de 17 horas de malhação para $1 \mathrm{~kg}$ de gordura. Concluise que a melhor forma de se livrar da gordura, é controlar a ingestão de alimentos. No andar a força é provida pelos músculos das pernas. No caso, a perna de um adulto corresponde a $35 \%$ de seu peso total $(\mathrm{P}=686 \mathrm{~N}$ para uma pessoa de $70 \mathrm{~kg}$ ) e adotando uma velocidade do andar de $4 \mathrm{~km} / \mathrm{h}$, temos que a potência exigida no andar de ser próxima de 264W (A física dos esportes, GOMES, 2001).

15. Represente em um desenho as 4 fases da modalidade esportiva do salto com vara (Fase 1: corrida com a vara, Fase 2: salto - vara envergando, Fase 3: atleta no ar por cima da barra, Fase 4: momento em chega ao colchão).

16. Explique as quatro fases do salto com vara indicados na questão anterior utilizando os conceitos de: energia cinética, energia potencial gravitacional e energia potencial elástica.

17. Complete: Dobrar um arco no arco-e-flecha ou movimentar um trampolim no salto ornamental são exemplos de trabalho sendo feito em um objeto para dar a ele energia___. Na ginástica uma saltadora de cama elástica utiliza força muscular para alongar as molas da cama elástica. As molas alongadas tem energia ___. Essa energia realiza trabalho, impulsionando a atleta para o ar. A atleta tem energia ___ zero quando por um breve momento, está imóvel no ponto mais alto de seu salto. Nesse ponto a energia

máxima. Na subida e quando ela toca a cama elástica novamente, no caminho de volta, sua velocidade e energia são máximas e sua energia , mínima. A energia __ gerada durante a queda em direção a cama elástica é combinada com a força aplicada pelos músculos da atleta. Ambas realizam trabalho para alongar as molas da cama elástica novamente. 


\section{ATIVIDADE 8 - DO MOVIMENTO AO EQUILÍBRIO: ALAVANCAS NO CORPO HUMANO}

\section{$1^{\text {a }}$ PARTE}

1. Complete com a palavra repouso ou movimento

Imagine que você esteja parado na calçada e passe pela rua um ônibus com vários passageiros. Eles, sem dúvida, estão em movimento. Se estivermos, porém, dentro do ônibus e olharmos para os outros passageiros, diremos que eles estão parados ou em movimento? Nós os vemos parados, mas eles podem afirmar que estão em movimento.

Para resolver essa questão sem risco de engano, podemos dizer: em relação ao ônibus eles estão em mas em relação ao chão estão em

Suponha que um avião, voando horizontalmente, solte uma bomba. Se você observar a queda da bomba de dentro do avião, você verá que ela cai ao longo de uma reta vertical. Entretanto, se você estivesse em sobre a superfície da Terra, observando a queda da bomba, você veria que ela, ao cair, descreveria uma trajetória curva. No primeiro caso, dizemos que o movimento da bomba estava sendo observado com o referencial no avião e, no segundo caso, com o referencial na Terra. Este exemplo nos mostra que o movimento de um corpo, visto por um observador, depende do referencial no qual o observador está situado.

O movimento de qualquer objeto sempre é observado em relação a algum ponto de referência. A escolha de um referencial é fundamental para a compreensão, de qualquer tipo de movimento. Esse referencial pode ser um objeto, uma estrela, uma pessoa etc.

http://br.geocities.com/saladefisica6/cinematica/referencial.htm

2. Com base no texto abaixo, responda:

a. Para estudar os movimentos do corpo humano precisamos adotar um sistema de referência? Mas que sistema? Será que é fora ou dentro do corpo? Qual é a sua opinião sobre isso?

b. Classifique os movimentos da figura 2 abaixo segundo os planos: sagital, frontal e transverso.

\section{PLANOS E EIXOS}

O sistema de referência é estabelecido arbitrariamente, e pode se localizar dentro ou fora do corpo. O método universalmente usado para descrever os movimentos humanos em três dimensões básicas baseia-se num sistema de planos e eixos. Três planos imaginários são posicionados pelo corpo em ângulos retos de modo que façam intersecção no centro de massa do corpo. Qualquer posição pode ser descrita identificando a distância entre o objeto e cada um dos três eixos.

O plano sagital bissecciona o corpo nas metades direita e esquerda, o plano frontal ou coronário bissecciona o corpo nas metades da frente e de trás, o plano transverso ou horizontal bissecciona o corpo em partes inferior e superior.

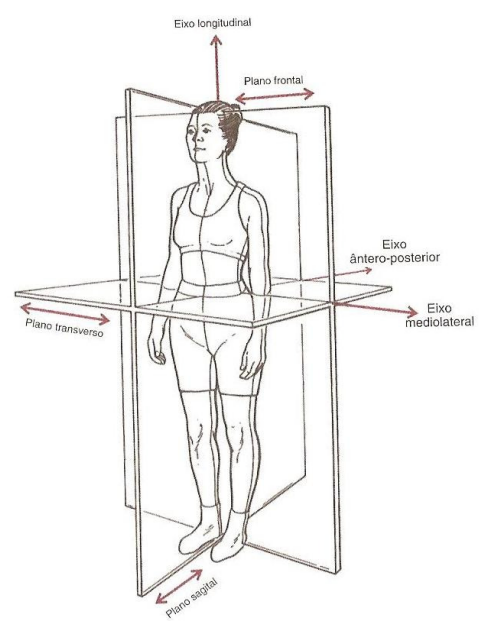

Figura 1: Planos e eixos no corpo humano (Bases biomecânicas do movimento humano - HAMIL \& KNUTZEN- p. 20).

A maioria dos movimentos emprega movimentos nos três eixos. Os esportes como ginástica, salto ornamental, esqui aéreo e patinação combinam saltos mortais e parafusos que são realizados em torno do eixo transversal (de quadril a quadril) e se torcem ao redor do seu eixo longitudinal (da cabeça aos pés). Os ginastas também dão estrelas e saltos mortais laterais ao redor de seu eixo frontal. 

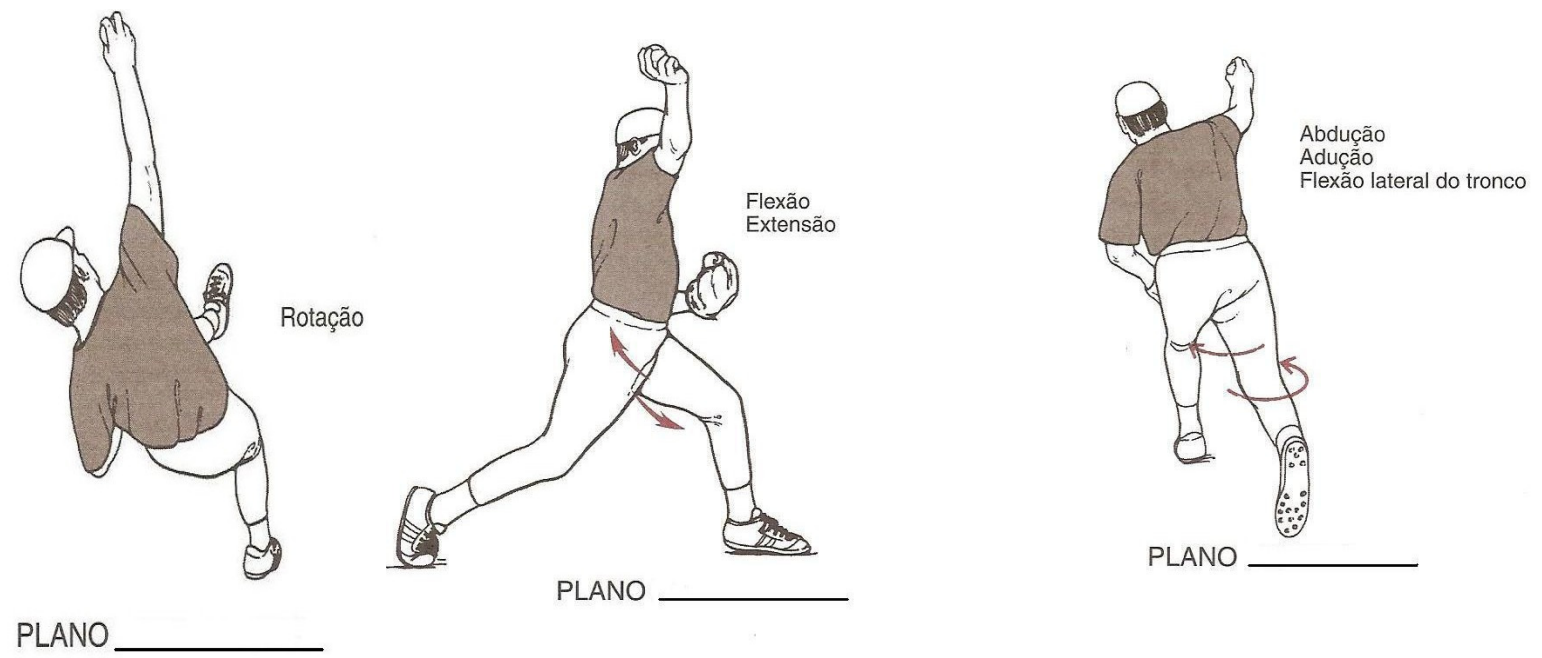

Figura 2: Movimentos nos três planos (Bases biomecânicas do movimento humano - HAMIL \& KNUTZEN- p. 24).

3. Após ler o texto abaixo, escreva as palavras que são utilizadas na física.

\section{Chutar uma bola o mais distante possível}

A intenção do chute é fazer sólido contato entre a trajetória do pé, deslocado em alta velocidade linear e movida na direção correta, e uma bola de modo a mandar a bola na direção linear desejada. O movimento linear de interesse é o caminho real e o movimento da bola após deixar o solo. Para criar altas velocidades na direção certa, os movimentos angulares na perna com a qual está chutando são seqüenciais e extraem velocidade uns dos outros, de modo que a velocidade do pé é determinada pela soma das velocidades individuais dos segmentos que se conectam. A perna é jogada para trás sob a coxa muito rapidamente à medida que a coxa começa a mover-se para frente para iniciar o chute. Na fase de potência do chute, a coxa move-se vigorosamente para frente e rapidamente entende a perna e o pé para frente em velocidades angulares muito rápidas. Quando é feito o contato com a bola, o pé está se movendo muito rápido, porque as velocidades da coxa e da perna se transferiram para o pé. Pela observação cuidadosa do movimento humano, a relação entre movimento angular e linear, mostrada neste exemplo do chute, serve como base para as técnicas usadas para corrigir ou facilitar um padrão de movimento ou habilidade.

4. Temos na figura 3 e 4 algumas habilidades esportivas utilizadas em modalidades esportivas que exemplificam o movimento linear e o movimento angular. Desenhe ou descreva uma habilidade esportiva para o movimento linear e uma para o movimento angular de qualquer modalidade esportiva de sua preferência.

\section{MOVIMENTOS}

O movimento linear pode ser chamado de movimento de translação, que é o movimento ao longo de uma via curva ou reta. Exemplos: exame da velocidade de um corredor velocista, a trajetória de uma bola de beisebol, o movimento de uma barra em um supino ou o movimento do pé em um chute sem pulo.
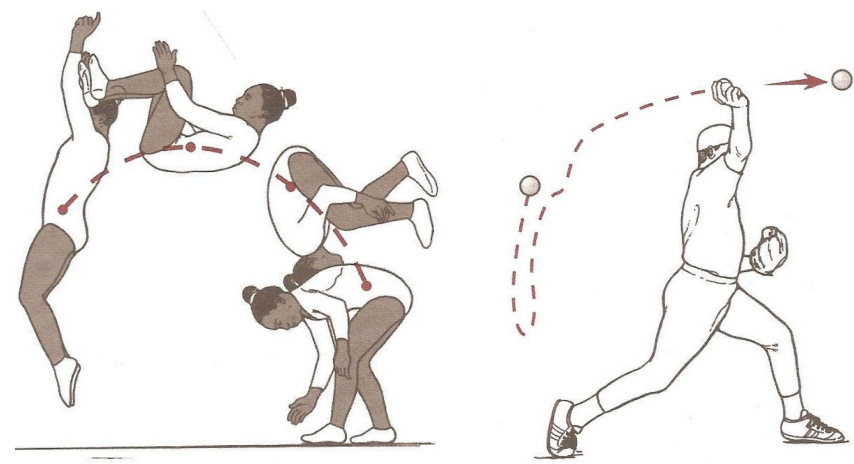

Figura 3: Exemplos de movimento linear (Bases biomecânicas do movimento humano - HAMIL \& KNUTZEN- p. 6). 
Movimento angular: ocorre ao redor de algum ponto em que diferentes regiões do mesmo segmento corporal (é o ponto pela qual a massa do objeto fica equilibrada, e representa o ponto onde o efeito total da gravidade age sobre o corpo) ou objeto não se movem pela mesma distância. Os movimentos angulares ocorrem ao redor de uma linha imaginária chamada eixo de rotação (ex: abaixar o corpo fazendo um agachamento total), ou ao redor de um eixo que passa pelo centro de massa (ex: giro vertical na patinação artística), ou ao redor de um eixo externo fixo (ex: balançar numa barra)

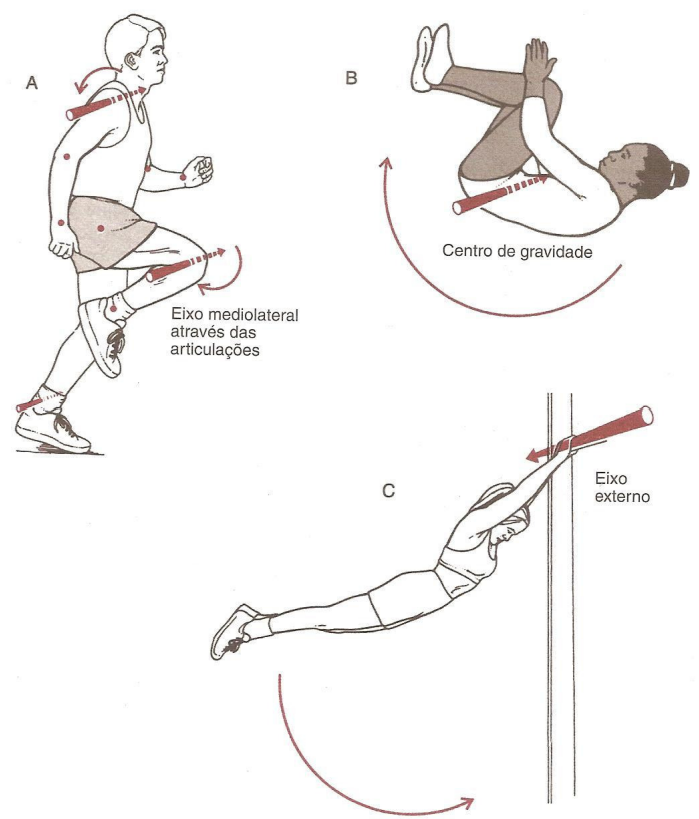

Figura 4: Exemplos de movimento angular (Bases biomecânicas do movimento humano - HAMIL \& KNUTZEN- p. 7).

\section{$2^{\text {a }}$ PARTE}

5. Na figura 5 a corda está em movimento ou equilíbrio? Por quê?

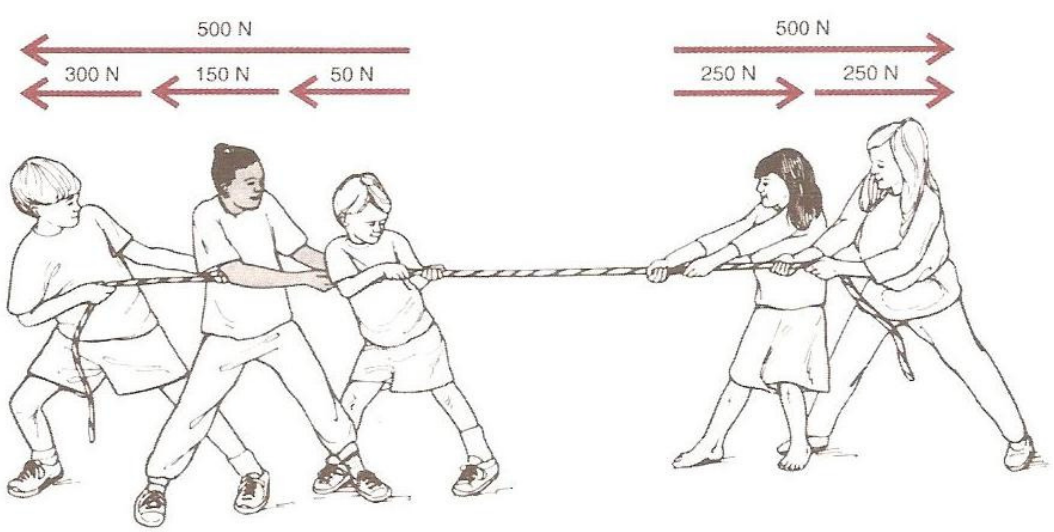

Figura 5: Análise estática (Bases biomecânicas do movimento humano - HAMIL \& KNUTZEN- p. 463).

6. O que você faz para tirar o João Bobo do equilíbrio? Ele sempre balança em torno de um ponto? Este ponto está ligado a massa do João Bobo?

7. O que acontece com nossos corpos quando não há gravidade? No espaço, os ossos de um astronauta sofrem perda mineral e ficam mais fracos. O sangue se concentra mais na parte superior do corpo causando uma mudança no seu centro da gravidade. $\mathrm{O}$ equilíbrio do estudante também é perturbado. $\mathrm{O}$ 
sistema cardiovascular se enfraquece e os músculos, acostumados a reagir a gravidade, perdem força. Quando cosmonautas russos retornaram a Terra, após um ano no espaço, eles tiveram de ser ajudados a sair da cápsula, porque não podiam ficar de pé. Os cosmonautas acharam até o peso dos cobertores desconfortável. E demorou muito tempo para eles se acostumarem com a força gravitacional da Terra.

8. Já vimos em atividades anteriores como calcular o nosso peso corporal em qualquer lugar do planeta, pois apenas necessitamos da nossa massa corporal e da aceleração da gravidade local, mas em que ponto do corpo se aplica o peso? Em todo corpo? Ou podemos reduzir a um ponto?

9. Leia o texto abaixo e observe nas figuras 6,7 e 8 o centro de gravidade (que pode estar dentro ou fora) dos corpos mediante as posições em que se encontram, e responda:

a) Qual é a diferença entre equilíbrio e estabilidade.

b) Indique nas figuras o centro de gravidade.
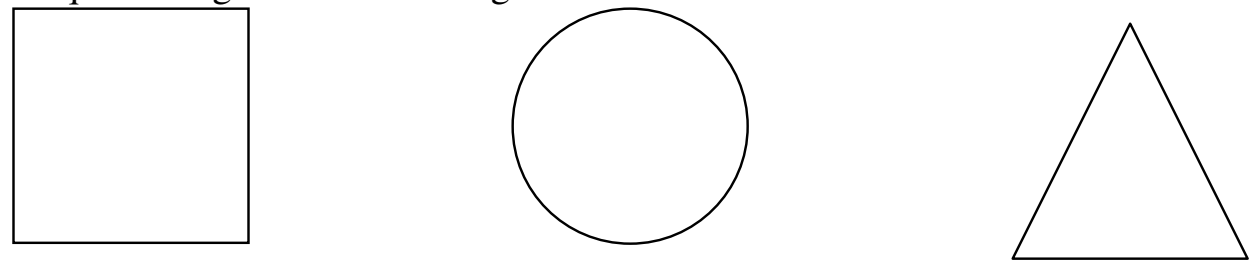

\section{Centro de gravidade}

No corpo humano, ossos e músculos são menos densos do que gorduras, culturistas que gastam um tempo desproporcional desenvolvendo seu corpo, aumentarão a massa muscular nessa área de seus corpos. Isso também significa que eles elevarão seu centro de gravidade. Atletas que têm um centro de gravidade alto podem estar em desvantagem em esportes (judô e luta) onde a estabilidade está em jogo. Não é diferente para um levantador de peso, com uma barra de $90 \mathrm{~kg}$ eleva o centro de gravidade combinado do levantador de peso e da barra muito acima do que se uma barra de $45 \mathrm{~kg}$ fosse elevada na mesma posição. Atletas com um centro de gravidade mais alto, incluindo o levantador de peso, têm de lutar mais para manter o equilíbrio.
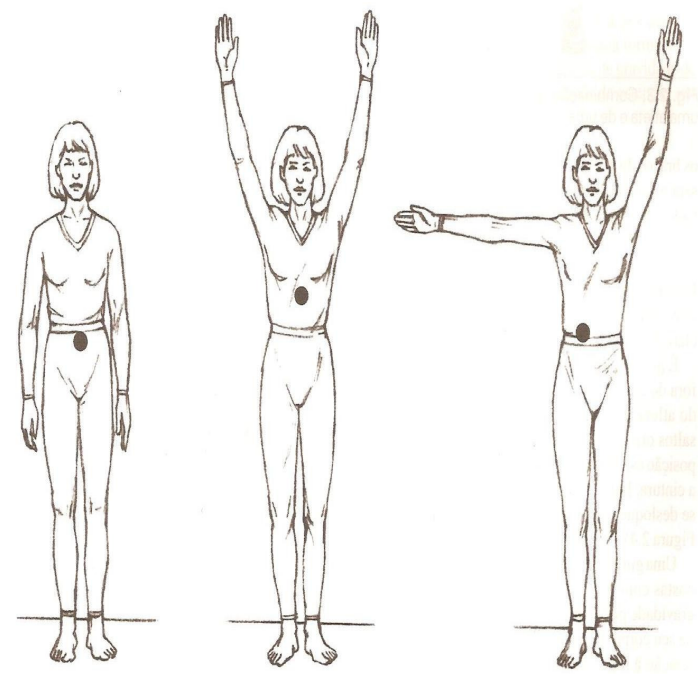

Figura 6: O centro de gravidade da atleta muda com a mudança de posição do corpo (Biomecânica dos esportes - Gerry Carr p. 17) 


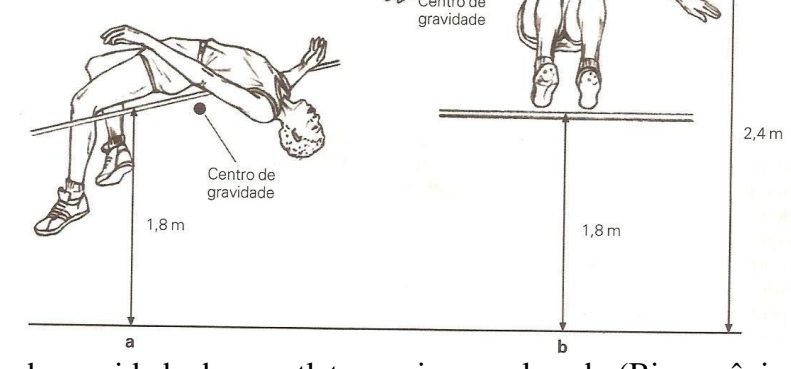

Figura 7: Altura no qual o centro de gravidade de um atleta precisa ser elevado (Biomecânica dos esportes - Gerry Carr - p.19)
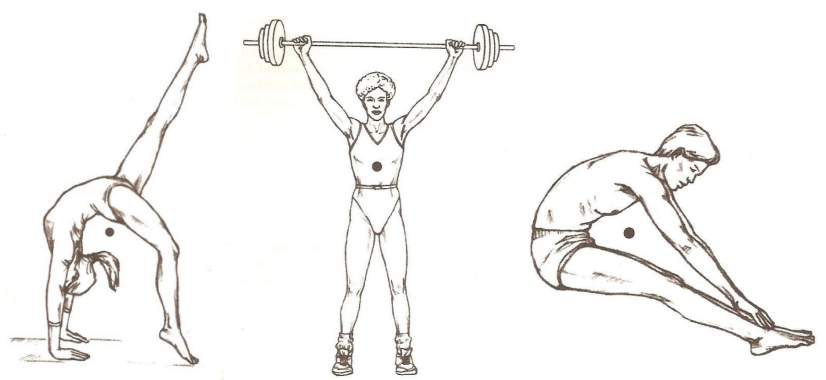

Figura 8: Centro de gravidade (Biomecânica dos esportes - Gerry Carr)

\section{Equilíbrio e estabilidade}

São dois termos que estão estreitamente relacionados, mas tem três diferentes significados. Equilíbrio (ou balanço) implica coordenação e controle. Um atleta com grande balanço é capaz de manter um estado de equilíbrio e neutralizar aquelas forças que iriam perturbar seu desempenho. A estabilidade está relacionada especificamente a quantidade de resistência que os atletas colocam contra o distúrbio de seu equilíbrio.

Estabilidade linear: Um atleta pode resistir a ser movimentado em uma determinada direção e resistir a ficar parado ou ter sua direção mudada, uma vez em movimento.

Estabilidade rotatória: É a resistência de um atleta ou objeto contra ser inclinado, tombado ou posto em pé ou girando em círculo. Há alguns fatores que determinam a estabilidade rotatória:

- Atletas aumentam sua estabilidade quando aumentam o tamanho de sua base de sustentação (área do solo englobada pelos pontos de contato do corpo do atleta).

- Atletas aumentam sua estabilidade quando sua linha de gravidade cai dentro do perímetro de sua base de sustentação

- Atletas aumentam sua estabilidade quando abaixam seu cento de gravidade.

- Atletas aumentam sua estabilidade quando aumentam sua massa corporal

- Atletas aumentam sua estabilidade quando estendem sua base de direção de uma força vindo contra eles.

- Atletas aumentam sua estabilidade quando deslocam sua linha de gravidade em direção à força.

Biomecânica dos esportes - Gerry Carr - p.89

10. Leia o texto, observe as figuras $9,10,11$ e 12 e responda:

Em um sistema de alavancas, uma força é aplicada em um ponto de alavanca e uma resistência aplica sua própria força em outro ponto. No corpo de um atleta, força é produzida, primariamente pela contração muscular. O peso dos membros do atleta mais o peso do que quer que seja que ele esteja tentando mover produzam resistência. A distância perpendicular de onde a força é aplicada ao ponto de apoio é denominada braço. Da mesma forma, a distância perpendicular de onde a resistência aplica sua própria força ao ponto de apoio é o braço de resistência. Uma alavanca é uma máquina simples que transforma e modifica a energia mecânica de um lugar para outro.

Como todas as alavancas oscilam ou giram ao redor de um ponto de apoio, elas sempre produzem um efeito rotativo, o qual denomina torque. Em um treinamento com peso, uma barra faz com que o músculo bíceps puxe o antebraço e produza um efeito rotativo direcionado para cima. A quantidade de torque que 
ocorre depende da quantidade de força produzida pelo bíceps multiplicada pelo braço de força. O braço de força é a distância perpendicular desde a fixação do bíceps no antebraço até o ponto de apoio.

As alavancas são divididas em três grupos e frequentemente utilizadas no desempenho de habilidades esportivas:

- Alavanca de primeira classe: o ponto de apoio está localizado entre a força e a resistência. Os braços de força podem ser do mesmo tamanho ou de tamanhos diferentes. Por exemplo, no corpo esse sistema de alavancas é frequentemente usado para manter posturas ou equilíbrio.

- Alavanca de segunda classe: esse sistema proporciona vantagem mecânica e é pouco encontrado no corpo humano, possui tanto a força como a resistência do mesmo lado do ponto de apoio, com o braço de força sempre maior do que o braço de resistência.

- Alavanca de terceira classe: é muito comum no corpo humano, o ponto de apoio está em uma ponta da alavanca e a resistência está em outra ponta.

(Biomecânica dos esportes - Gerry Carr - p.53 e Desvendando a física do corpo humano - Okuno \&

Fratin - p. 106)

a) A utilização de alavancas ocorre em todos os esportes. O que é uma alavanca? Descreva ou represente através de um desenho.

b) Para que serve uma alavanca?

c) Classifique as alavancas das figuras 9,10 e 11.

\begin{tabular}{|l|lc|}
\hline 9 & Alavanca de & classe \\
\hline 10 & Alavanca de & classe \\
\hline 11 & Alavanca de & classe \\
\hline 12 & Alavanca de & classe \\
\hline
\end{tabular}

1)

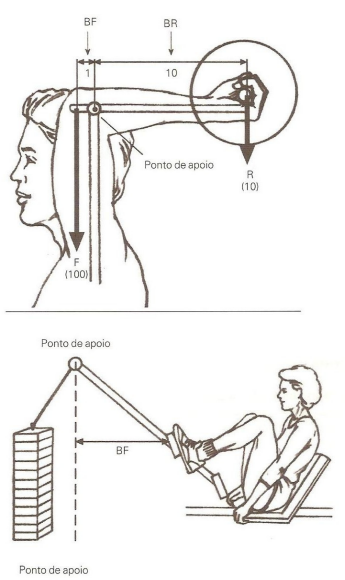

Figura 9: Sistema de alavanca no corpo humano (Biomecânica dos esportes - Gerry Carr - p.55)

2)

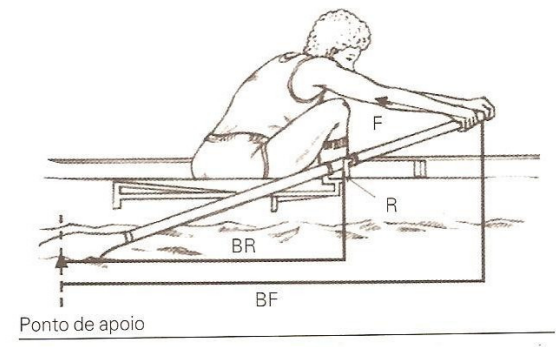

d) O que é torque? Explique.

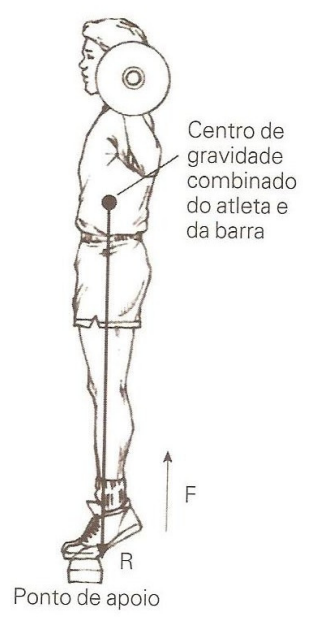

Figura 10: Sistema de alavanca no corpo humano (Biomecânica dos esportes - Gerry Carr - p.56)

3)

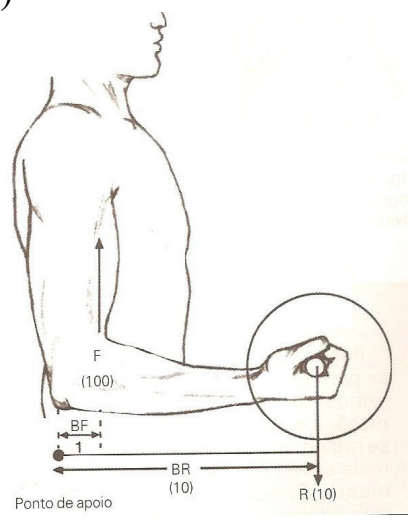

Figura 11: Sistema de alavanca no corpo humano (Biomecânica dos esportes - Gerry Carr - p.57) 
e) Aplicamos força para abrir uma porta, na maçaneta. Deveríamos aplicar mais ou menos força para abrir a porta se a maçaneta fosse mais perto da dobradiça? Complete: Quanto a distância da dobradiça ao ponto de aplicação da força, mais fácil fica de abrir a porta.

f) $\mathrm{Na}$ figura 12 , temos um ginasta de $1,67 \mathrm{~m}$ e peso corporal de $59 \mathrm{~kg}$. Seria possível um jogador de basquetebol (um gigante) que tem $136 \mathrm{~kg}$ de peso corporal praticar essas habilidades da ginástica olímpica? Por quê? Observe o comprimento dos membros do corpo humano.
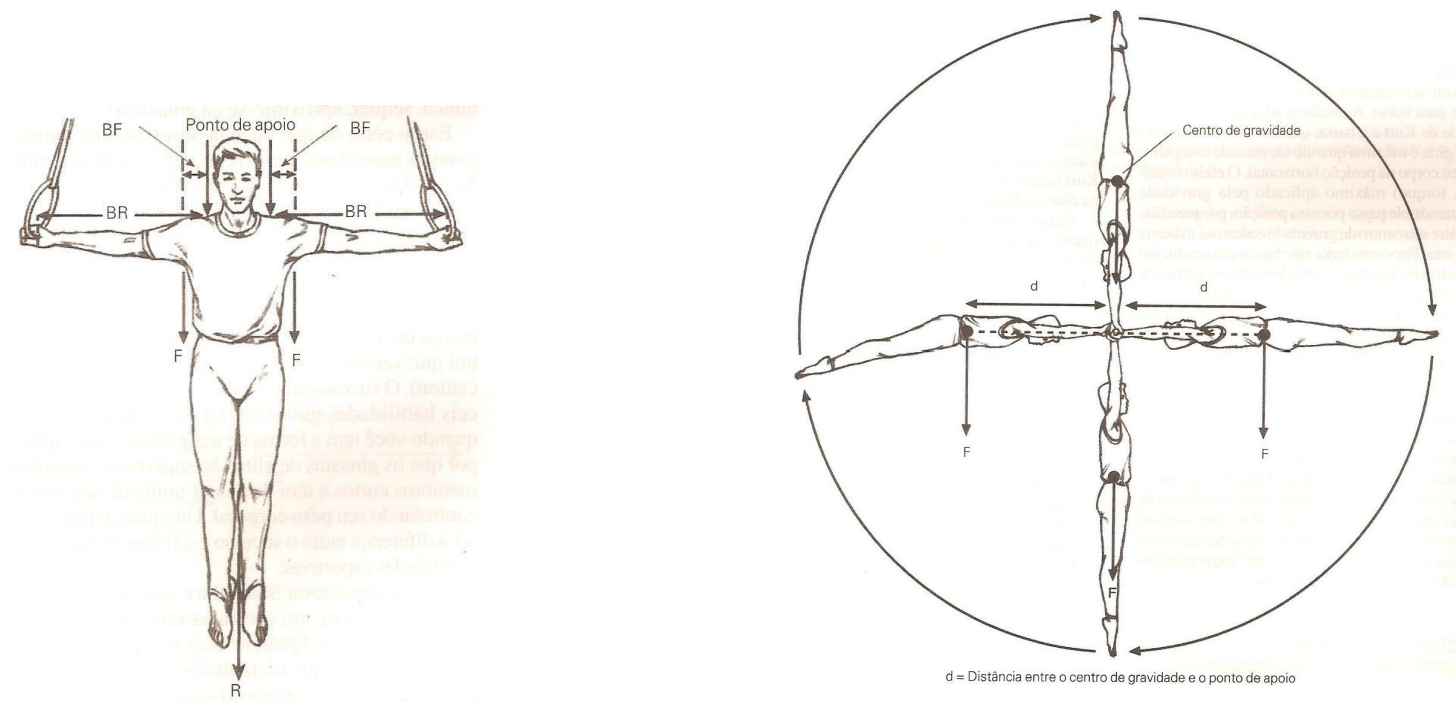

Figura 12: Crucifixo e Giro gigante (Biomecânica dos esportes - Gerry Carr - p. 59 e 63)

11. Leia o texto e responda:

a) O que é Inércia da Rotação?

b) Como podemos iniciar uma rotação (giro)?

c) Onde devo aplicar a força para que a bola de vôlei inicie a rotação no sentido e na direção indicada na figura abaixo? Represente na figura 13.

a
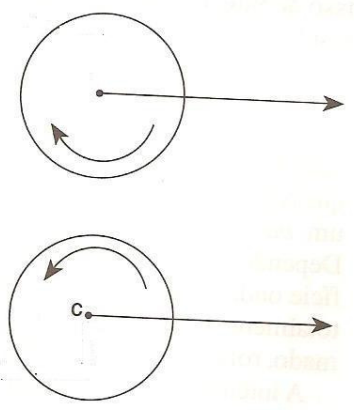

b

Figura 13: Bola de vôlei girando (Biomecânica dos esportes - Gerry Carr - p.61)

d) Como uma ginasta consegue girar a si mesmo, na habilidade de giro girante (figura 12) da ginástica olímpica? Será que a gravidade ajuda no movimento? Como?

e) Em termos de velocidade angular, coloque em ordem crescente (do menor valor para o maior) as seguintes velocidades angulares: dos quadris, das mãos, dos pés, para isso observe a figura 12

\begin{tabular}{|l|l|}
\hline 1 & \\
\hline 2 & \\
\hline 3 & \\
\hline
\end{tabular}

f) Indique na figura 14 em qual das posições a velocidade de giro é maior?

\section{Manipulação da inércia de rotação no Salto Ornamental}

Quando grandes saltadores dão um mortal no ar se movem de uma posição corporal estendida para uma encolhida, eles flexionam seus troncos, pernas e braços e encolhem suas cabeças. Algumas partes de seu 
corpo (braços e pernas), movem-se a uma grande distância em direção a seus eixos transversais (quadril a quadril). Outras partes, como suas cabeças, deslocam-se a uma distância pequena. Não obstante ainda há uma diferença dramática na inércia da rotação, entre a posição corporal estendida e encolhida. As pernas e os braços de um saltador são relativamente pesados e constituem muito da massa corporal. Eles se movem a uma grande distância em direção ao eixo do saltador, de forma a ter um grande efeito na redução da resistência do corpo do saltador contra a rotação.

Quando o saltador está no ar e numa posição corporal estendida, você pode perceber que ele gira vagarosamente. Se ele puxar seu corpo e ficar encolhido, gira muito mais rápido. Quanto mais massa ele puxar em direção ao seu eixo de rotação (que passa no centro de gravidade), mais rápido ele gira. Isso significa que um corpo esbelto, conjugado com grande flexibilidade, desempenha um papel importante na determinação da velocidade de giro dos saltadores quando eles se encolhem. Atletas musculosos e grandes têm dificuldade para se encolher, pois seu excesso de massa corporal atrapalha. Para multiplicar os saltos mortais os saltadores agarram firmemente suas pernas e puxam seus joelhos o mais alto possível em direção aos seus ombros para girar mais rápido (Biomecânica dos esportes - Gerry Carr - p.72).

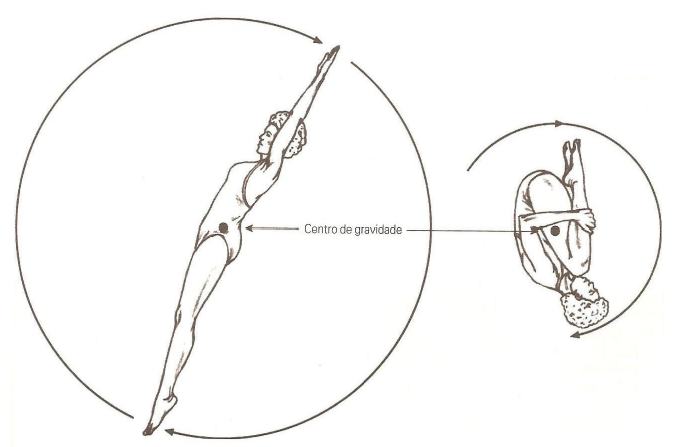

Figura 14: Salto ornamental (Biomecânica dos esportes - Gerry Carr - p.71)

122 


\section{ATIVIDADE 9 - LESÕES E ESPORTES}

1. Uma lesão é um termo não-específico usado para descrever um tecido anormal num organismo vivo.Tais anomalias podem ser causadas por doenças, traumas ou simplesmente pela prática de desporto, por exemplo (http://pt.wikipedia.org/wiki/Les\%C3\%A3o).

\section{Tipos de Lesões}

\begin{tabular}{|llcc|}
\hline \multicolumn{1}{|c}{ Modalidade } & Tipo de Lesão & $n$ & $\%$ \\
\hline Atletismo & & & \\
\multicolumn{1}{c}{ Lançamentos } & Condromalácia Patelar & 35 & 51.3 \\
Fundo & Tendinite Patelar & 52 & 58.7 \\
Saltos & "Shin - Splints" & 35 & 35 \\
$\quad$ Velocidade & Tendinite Patelar & 44 & 34.1 \\
Basquetebol & Tendinites do Ombro & 41 & 12.2 \\
Canoagem & Pubalgias & 50 & 53.3 \\
Futebol & Epicondilites & 34 & 9.1 \\
Ginástica Desportiva & Dorso-Lombalgias & 90 & 31 \\
Handebol & Tendinite Patelar e & 75 & 19.2 \\
& Dorso-Lombalgias & & \\
Judo & Lombalgias & 30 & 10.8 \\
Remo & Lombalgias & 30 & 96 \\
Tênis & Tendinite Patelar & 18 & 40.7 \\
Voleibol & Dorso-Lombalgias & 36 & 50 \\
TOTAL & Tendinite Patelar & 570 & 38.7 \\
\hline
\end{tabular}

Figura 1: Lesões de sobrecarga em atletas portugueses (Fundamentos biomecânicos para análise do movimento humano Alberto Carlos Amadio, p. 135)

Escolha um atleta de qualquer modalidade esportiva que tenha se lesionado durante uma competição. Conte em detalhes como ocorreu lesão? Esta lesou poderia ser evitada? Como?

2. Todos os atletas diferem no físico, temperamento e capacidade física e o que funciona para um, não funcionará necessariamente para outro (Biomecânica dos esportes - Gerry Carr - p. 7). Que cuidados devemos ter ao iniciar uma atividade física?

3. Qual é a ligação entre saúde e esporte? Comente.

4. Praticar alguma modalidade esportiva ou fazer exercício físico resulta em saúde? Por quê?

5. Qual a importância da biomecânica para prática esportiva?

6. Qualquer pessoa no momento em que quiser, pode praticar esporte? Por quê?

7. Quais os cuidados que devemos ter ao praticar exercícios físicos?

8. Por que uma compreensão básica dos princípios mecânicos básicos ajudará o atleta a ter um melhor desempenho?

9. Escolha uma das seis modalidades esportivas representadas nas figuras abaixo e explique biomecanicamente cada um dos passos ( $\mathrm{a}, \mathrm{b}, \mathrm{c}, \mathrm{d}, \mathrm{e} . .$.$) ou o movimento como um todo, utilizando todo$ conteúdo de física visto nas atividades anteriores.

1) Corrida de velocidade

Todos os atletas utilizam corridas de velocidade como forma de locomoção. É a mais dinâmica vigorosa de todas as técnicas de corrida. A caminhada e as corridas de média e longa distância obedecem às mesmas leis mecânicas que a corrida de velocidade, mas empregam menos movimentos vigorosos. 


\section{Corrida de Velocidade}
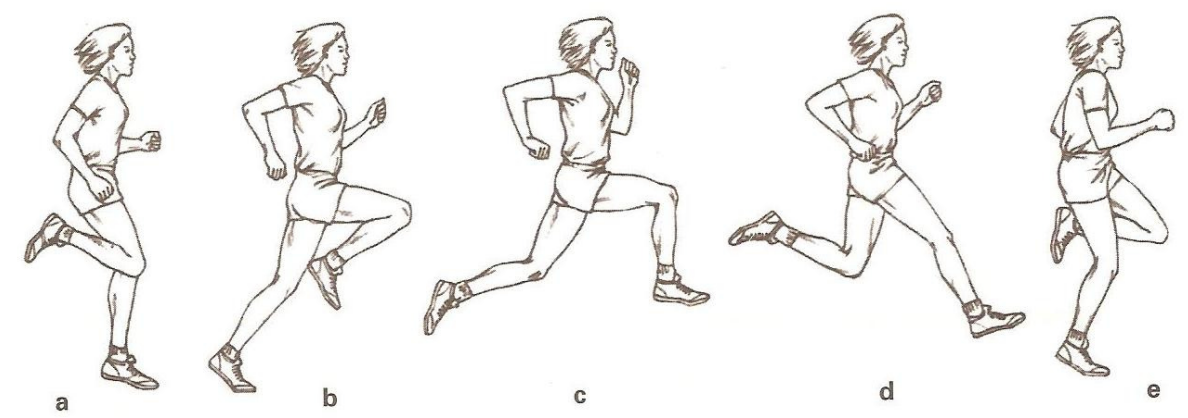

2) Salto em altura

Os princípios mecânicos que controlam como um atleta sobe no ar, no salto $\mathrm{m}$ altura, também se aplicam as outras habilidades de salto. Uma vez no ar, as mesmas leis da mecânica aplicam-se ao atleta de salto em distância, como o fazem para com o atleta de salto em altura.

\section{Salto em Altura Flop}

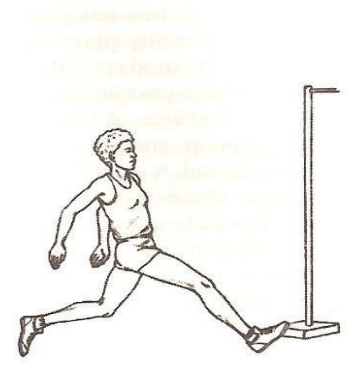

a

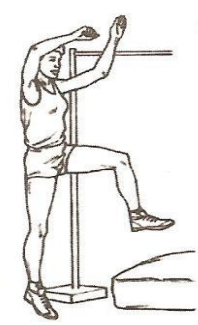

b
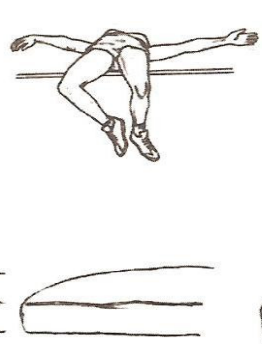

c
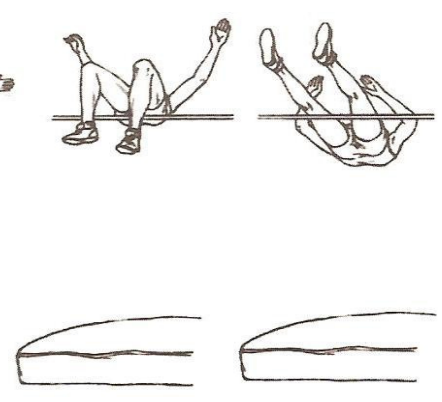

d

e

3)Lançamento de dardo

Exige que o atleta gere alta velocidade, o lançador deseja que a mão de lançamento desloque o mais rápido possível.
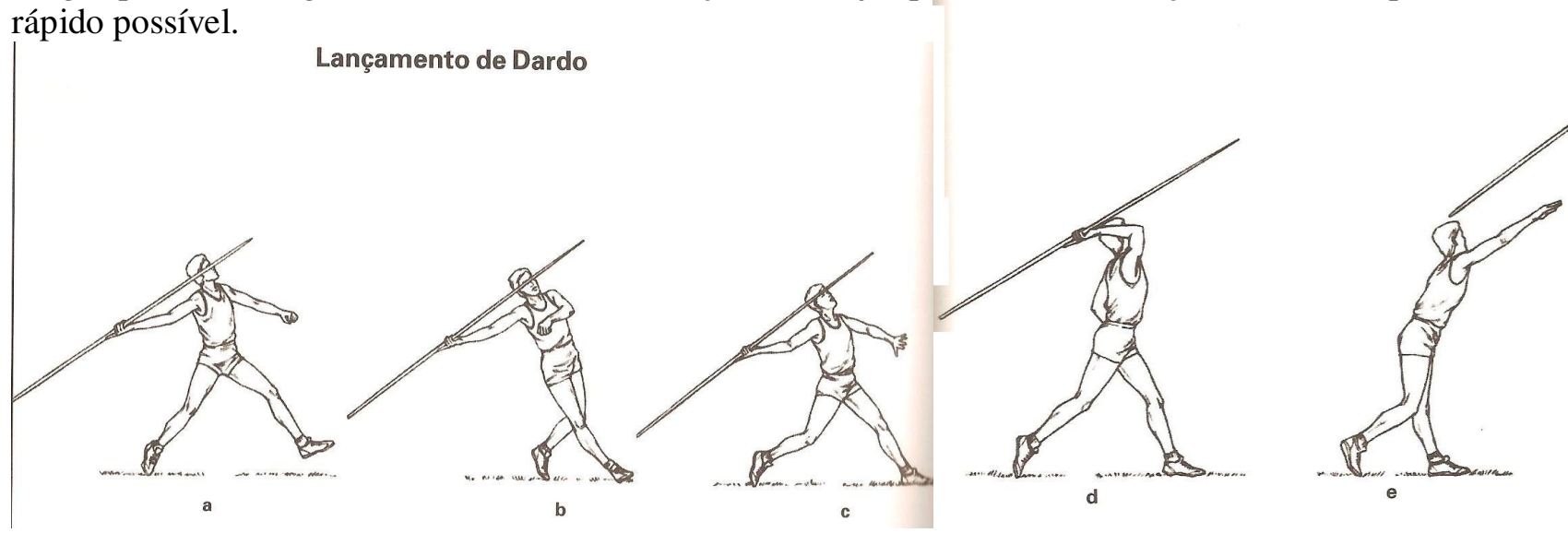

\section{4) Arremesso}

O encaixe é um movimento de elevar e puxar o arremesso é um movimento de empurrar. Movimentos de carregar ocorrem quando o atleta faz uma pausa com a barra no tórax e, novamente, quando a barra está acima da cabeça, a altura dos braços esticados. Os princípios mecânicos envolvidos no arremesso aplicam-se a todas as técnicas de elevação, carregamento e assistência. As leis que controlam a estabilidade também têm grande papel no arremesso. 


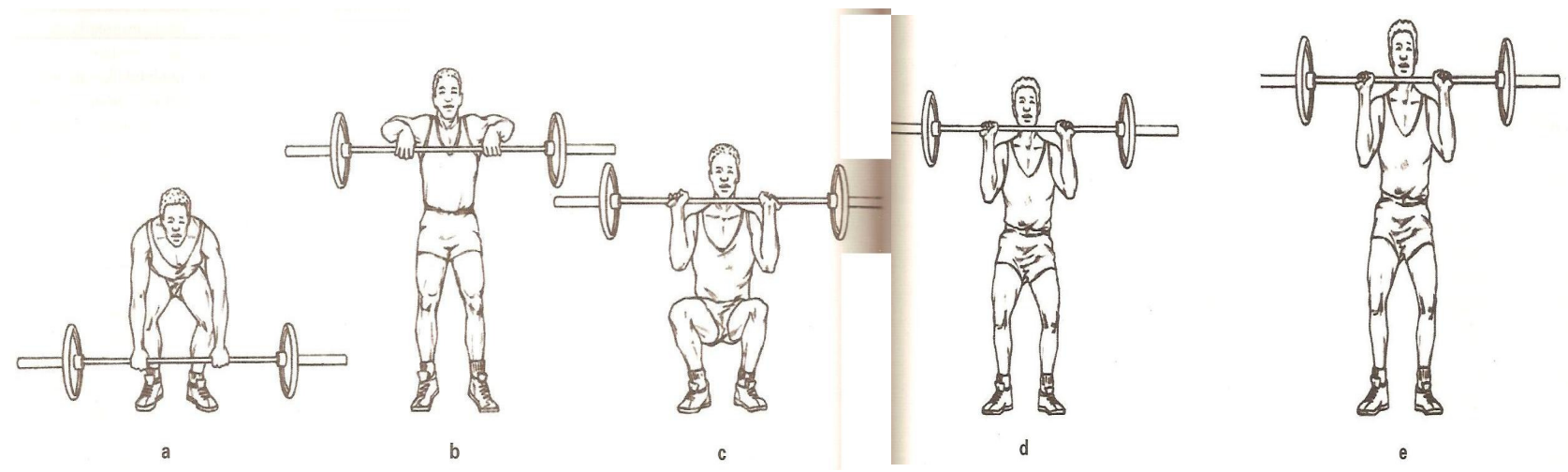

5) Ginástica olímpica

a) Giro girante

Tanto no giro gigante quanto no salto mortal de frente utilizamos a oscilação e rotação.

A oscilação é um a habilidade rotacional controlada por muitos dos princípios mecânicos que governam o salto mortal de frente. Entretanto existem algumas diferenças.

$\mathrm{O}$ giro girante ao redor de uma barra elevada age como um eixo externa ao corpo do atleta.

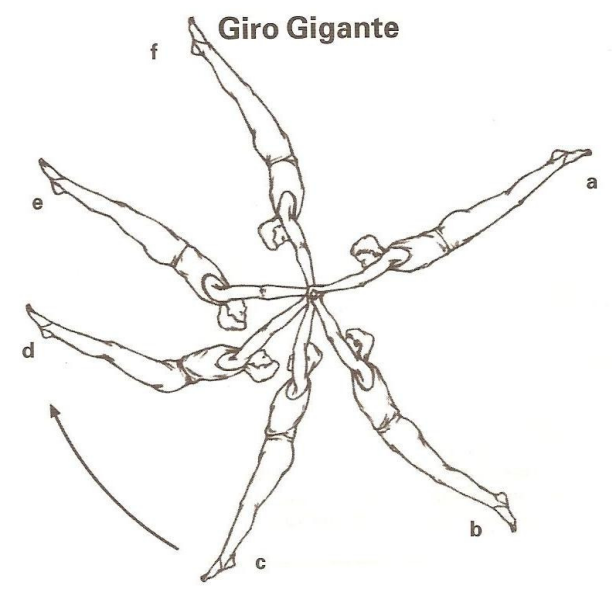

b) Salto mortal

Em contraste, o eixo para o salto mortal de frente passa pelo corpo do atleta de um quadril a outro. Existem semelhanças e diferenças na mecânica dessas duas habilidades

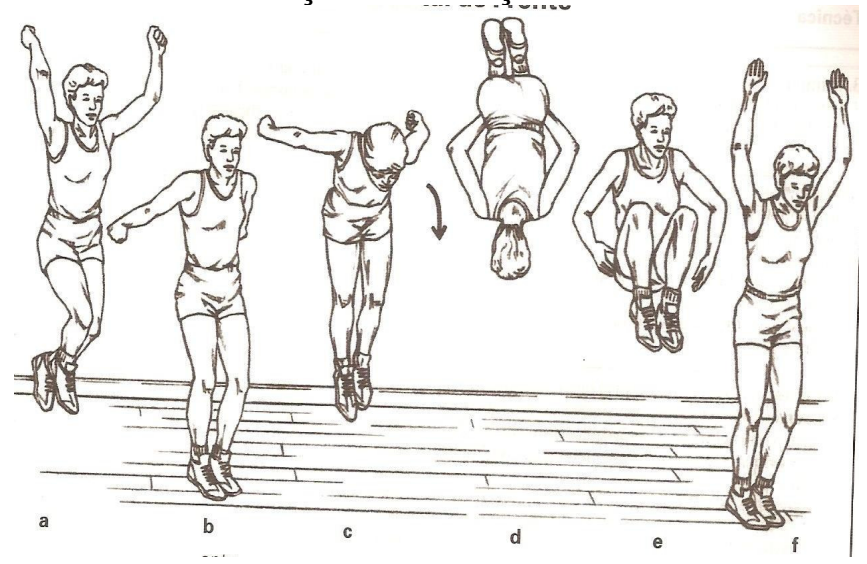


10. Quando você observa um atleta de elite executando uma habilidade, você tem um quadro de velocidade, ritmo, potência, posições corporais e outras características que compõem um desempenho de qualidade, isso o ajuda a entender os padrões básicos de movimentos na técnica da habilidade escolhida. Escolha uma modalidade esportiva (não pode ser o que já vimos) e enumere as habilidades necessárias para seu desempenho.

11. Como você pode identificar e corrigir os erros do atleta nesta modalidade que você escolheu na questão 9?

12. Quais são as maiores responsabilidades de um técnico de qualquer modalidade esportiva?

13. Depois destas atividades você é capaz de analisar mais criticamente o desempenho de um atleta? Você consegue dizer qual movimento é mais eficiente ou não?

14. Complete:

a) Ao dizer a palavra esporte, eu penso em: $\mathrm{e}$

b) Ao dizer a palavra saúde, eu penso em: $\mathrm{e}$

c) Ao dizer a palavra força, eu penso em: e

BIBLIOGRAFIA DOS LIVROS:

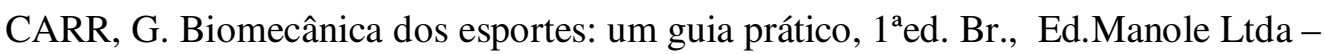
S.P.- BR., 1998.

OKUNO, E.; FRATIN, L. Desvendando a física do corpo humano, $1^{\mathrm{a} e d .} \mathrm{Br}$., Ed.Manole Ltda - Barueri, S.P. - BR., 2003.

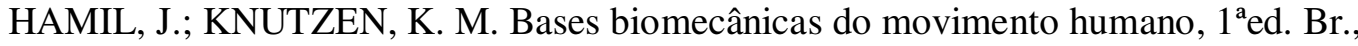
Ed.Manole Ltda - S.P.- BR., 1999

TALAVERA, A. C.; POZZANI, L. Coleção Nova Geração - Física - Mecânica 1.Ed. Nova Geração - S.P. - BR., 2002. 


\section{Atividade Avaliatória}

1 - Formule um texto, uma frase ou uma história que contenha obrigatoriamente (no singular ou plural) as palavras: biomecânica, esporte, saúde, física, lesão, corpo e vida.

2 - Coloque-se no lugar de um técnico de qualquer modalidade esportiva de sua escolha, e dê instruções a um atleta para melhorar seu desempenho (performance) em alguma habilidade desta modalidade esportiva. Você deve abranger em sua instrução não somente o psicológico, a alimentação, etc., mas principalmente o desenvolvimento de movimentos corretos que evitam lesões no atleta e proporcionam melhor desempenho. Utilize para isso conceitos da física e da biomecânica.

3 - Observe nas figuras abaixo, algumas habilidades na modalidade esportiva futebol, e explique cada uma delas utilizando os conceitos físicos vistos nas atividades.

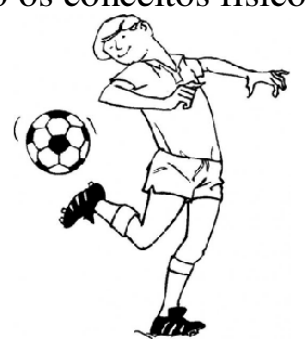

Figura 1: (http://pequenopolis.files.wordpress.com/2009/08/futebol.gif)

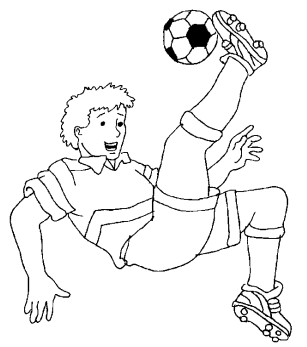

Figura 2: (http://www.portalsaofrancisco.com.br/alfa/futebol-paracolorir/imagens/futebol-4.gif)

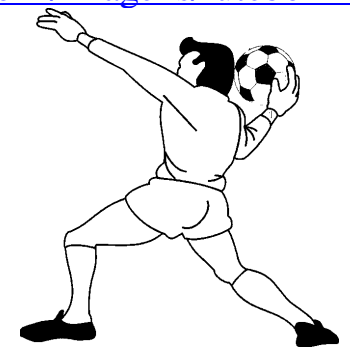

Figura 3: (http://www.portalsaofrancisco.com.br/alfa/futebol-paracolorir/imagens/futebol-5.gif)

4 - Selecione um trecho do vídeo e o explique através de conceitos físicos

1 - http://www.youtube.com/watch?v=Fut2GVWwJD4\&feature=fvsr

2 - http://www.youtube.com/watch?v=AdoEwnCoEVk\&NR=1

3 - http://www.youtube.com/watch?v=JMri3UIPOCU\&feature=related

Física e o futebol

http://www.youtube.com/watch?v=V_6WmiFg-wo

BOA PROVA! 


\section{A3.2. Diário de Bordo}

\section{A3.2.1. Frequência nas atividades}

Tabela 1: Frequiência da turma $-1^{\circ} \mathrm{A}_{2}$

\begin{tabular}{|c|c|c|c|c|c|c|c|c|c|c|c|}
\hline \multicolumn{2}{|c|}{ Alunos } & \multicolumn{9}{|c|}{ Atividades da intervenção } & \multirow[b]{2}{*}{ A.V. } \\
\hline $\mathbf{1}^{\circ} \mathbf{A}_{2}$ & $\mathbf{1}^{\circ} \mathbf{A}_{3} *$ & 1 & 2 & 3 & 4 & 5 & 6 & 7 & 8 & 9/até & \\
\hline 1 & & $\mathrm{OK}$ & $\mathrm{OK}$ & $\mathrm{OK}$ & $\mathrm{OK}$ & $\mathrm{OK}$ & $\mathrm{OK}$ & $\mathrm{OK}$ & $\mathrm{OK}$ & & $\mathrm{OK}$ \\
\hline 2 & & OK & OK & $\mathrm{OK}$ & $\mathrm{OK}$ & $\mathrm{OK}$ & OK & OK & & $\mathrm{OK} / 14$ & OK \\
\hline 3 & & $\mathrm{OK}$ & $\mathrm{OK}$ & & & & $\mathrm{OK}$ & & & & $\mathrm{OK}$ \\
\hline 4 & & $\mathrm{OK}$ & OK & $\mathrm{OK}$ & $\mathrm{OK}$ & $\mathrm{OK}$ & OK & $\mathrm{OK}$ & $\mathrm{OK}$ & $\mathrm{OK} / 14$ & $\mathrm{OK}$ \\
\hline 5 & & $\mathrm{OK}$ & $\mathrm{OK}$ & $\mathrm{OK}$ & $\mathrm{OK}$ & $\mathrm{OK}$ & OK & OK & $\mathrm{OK}$ & $\mathrm{OK} / 14$ & OK \\
\hline 6 & & $\mathrm{OK}$ & OK & $\mathrm{OK}$ & $\mathrm{OK}$ & $\mathrm{OK}$ & OK & $\mathrm{OK}$ & & $\mathrm{OK} / 14$ & $\mathrm{OK}$ \\
\hline 7 & & OK & OK & OK & $\mathrm{OK}$ & OK & & $\mathrm{OK}$ & & & OK \\
\hline 8 & & $\mathrm{OK}$ & OK & $\mathrm{OK}$ & $\mathrm{OK}$ & $\mathrm{OK}$ & $\mathrm{OK}$ & $\mathrm{OK}$ & $\mathrm{OK}$ & & $\mathrm{OK}$ \\
\hline 9 & & $\mathrm{OK}$ & OK & $\mathrm{OK}$ & $\mathrm{OK}$ & $\mathrm{OK}$ & OK & $\mathrm{OK}$ & $\mathrm{OK}$ & $\mathrm{OK} / 14$ & $\mathrm{OK}$ \\
\hline 10 & & & & & $\mathrm{OK}$ & $\mathrm{OK}$ & OK & $\mathrm{OK}$ & $\mathrm{OK}$ & $\mathrm{OK} / 14$ & OK \\
\hline 11 & & OK & OK & & $\mathrm{OK}$ & & & & & & \\
\hline 12 & & $\mathrm{OK}$ & OK & $\mathrm{OK}$ & $\mathrm{OK}$ & $\mathrm{OK}$ & OK & $\mathrm{OK}$ & $\mathrm{OK}$ & $\mathrm{OK} / 14$ & $\mathrm{OK}$ \\
\hline 13 & & $\mathrm{OK}$ & $\mathrm{OK}$ & $\mathrm{OK}$ & $\mathrm{OK}$ & $\mathrm{OK}$ & OK & $\mathrm{OK}$ & OK & & \\
\hline 14 & & $\mathrm{OK}$ & OK & $\mathrm{OK}$ & $\mathrm{OK}$ & $\mathrm{OK}$ & OK & $\mathrm{OK}$ & & $\mathrm{OK} / 14$ & OK \\
\hline 15 & & $\mathrm{OK}$ & $\mathrm{OK}$ & $\mathrm{OK}$ & $\mathrm{OK}$ & $\mathrm{OK}$ & & $\mathrm{OK}$ & & $\mathrm{OK} / 14$ & $\mathrm{OK}$ \\
\hline 16 & & $\mathrm{OK}$ & $\mathrm{OK}$ & & & & & & & & OK \\
\hline 17 & & $\mathrm{OK}$ & $\mathrm{OK}$ & $\mathrm{OK}$ & $\mathrm{OK}$ & $\mathrm{OK}$ & $\mathrm{OK}$ & $\mathrm{OK}$ & & & OK \\
\hline 18 & & $\mathrm{OK}$ & OK & & $\mathrm{OK}$ & & & & & & $\mathrm{OK}$ \\
\hline 19 & & $\mathrm{OK}$ & OK & $\mathrm{OK}$ & $\mathrm{OK}$ & $\mathrm{OK}$ & OK & OK & & & \\
\hline 20 & & $\mathrm{OK}$ & $\mathrm{OK}$ & $\mathrm{OK}$ & $\mathrm{OK}$ & $\mathrm{OK}$ & OK & $\mathrm{OK}$ & $\mathrm{OK}$ & $\mathrm{OK} / 14$ & \\
\hline 21 & & $\mathrm{OK}$ & OK & $\mathrm{OK}$ & $\mathrm{OK}$ & & $\mathrm{OK}$ & $\mathrm{OK}$ & $\mathrm{OK}$ & $\mathrm{OK} / 14$ & $\mathrm{OK}$ \\
\hline 22 & & $\mathrm{OK}$ & OK & $\mathrm{OK}$ & $\mathrm{OK}$ & $\mathrm{OK}$ & $\mathrm{OK}$ & $\mathrm{OK}$ & & $\mathrm{OK} / 14$ & OK \\
\hline 23 & & OK & $\mathrm{OK}$ & $\mathrm{OK}$ & $\mathrm{OK}$ & OK & OK & $\mathrm{OK}$ & $\mathrm{OK}$ & $\mathrm{OK} / 14$ & OK \\
\hline 24 & & $\mathrm{OK}$ & $\mathrm{OK}$ & $\mathrm{OK}$ & $\mathrm{OK}$ & $\mathrm{OK}$ & $\mathrm{OK}$ & $\mathrm{OK}$ & $\mathrm{OK}$ & & \\
\hline 25 & & $\mathrm{OK}$ & $\mathrm{OK}$ & $\mathrm{OK}$ & $\mathrm{OK}$ & $\mathrm{OK}$ & OK & $\mathrm{OK}$ & $\mathrm{OK}$ & $\mathrm{OK} / 14$ & $\mathrm{OK}$ \\
\hline 26 & 27 & OK & & & & & & & & & \\
\hline 27 & 26 & $\mathrm{OK}$ & $\mathrm{OK}$ & $\mathrm{OK}$ & $\mathrm{OK}$ & OK & $\mathrm{OK}$ & OK & OK & $\mathrm{OK} / 14$ & OK \\
\hline 28 & & & OK & $\mathrm{OK}$ & $\mathrm{OK}$ & $\mathrm{OK}$ & $\mathrm{OK}$ & & & $\mathrm{OK} / 14$ & OK \\
\hline 29 & & $\mathrm{OK}$ & $\mathrm{OK}$ & $\mathrm{OK}$ & $\mathrm{OK}$ & $\mathrm{OK}$ & $\mathrm{OK}$ & $\mathrm{OK}$ & $\mathrm{OK}$ & $\mathrm{OK} / 14$ & $\mathrm{OK}$ \\
\hline 30 & & OK & $\mathrm{OK}$ & $\mathrm{OK}$ & $\mathrm{OK}$ & $\mathrm{OK}$ & OK & $\mathrm{OK}$ & $\mathrm{OK}$ & $\mathrm{OK} / 14$ & \\
\hline 31 & & $\mathrm{OK}$ & $\mathrm{OK}$ & $\mathrm{OK}$ & $\mathrm{OK}$ & $\mathrm{OK}$ & OK & $\mathrm{OK}$ & $\mathrm{OK}$ & $\mathrm{OK} / 14$ & \\
\hline 32 & & $\mathrm{OK}$ & $\mathrm{OK}$ & & $\mathrm{OK}$ & $\mathrm{OK}$ & $\mathrm{OK}$ & $\mathrm{OK}$ & $\mathrm{OK}$ & $\mathrm{OK} / 8$ & $\mathrm{OK}$ \\
\hline 33 & & & & $\mathrm{OK}$ & & & & & & & \\
\hline 34 & & $\mathrm{OK}$ & OK & & $\mathrm{OK}$ & & & & & & OK \\
\hline 35 & & $\mathrm{OK}$ & OK & $\mathrm{OK}$ & $\mathrm{OK}$ & $\mathrm{OK}$ & $\mathrm{OK}$ & $\mathrm{OK}$ & $\mathrm{OK}$ & $\mathrm{OK} / 14$ & $\mathrm{OK}$ \\
\hline 36 & 35 & $\mathrm{OK}$ & $\mathrm{OK}$ & & $\mathrm{OK}$ & & OK & OK & & & OK \\
\hline 37 & 36 & $\mathrm{OK}$ & $\mathrm{OK}$ & & & & & & & & \\
\hline 38 & 37 & $\mathrm{OK}$ & $\mathrm{OK}$ & $\mathrm{OK}$ & $\mathrm{OK}$ & $\mathrm{OK}$ & $\mathrm{OK}$ & $\mathrm{OK}$ & & $\mathrm{OK} / 14$ & $\mathrm{OK}$ \\
\hline 39 & 38 & $\mathrm{OK}$ & $\mathrm{OK}$ & $\mathrm{OK}$ & $\mathrm{OK}$ & $\mathrm{OK}$ & $\mathrm{OK}$ & OK & $\mathrm{OK}$ & $\mathrm{OK} / 8$ & $\mathrm{OK}$ \\
\hline 40 & 39 & OK & & & & OK & & OK & & & OK \\
\hline
\end{tabular}




\begin{tabular}{|l|l|l|l|l|l|l|l|l|l|l|l|}
\hline 41 & 40 & OK & OK & OK & OK & & & OK & OK & & \\
\hline TOTAL & 39 & 38 & 29 & 36 & 30 & 30 & 30 & 22 & 23 & 30 \\
\hline
\end{tabular}

*Como os números para pesquisa são diferentes dos contidos no diário de classe houve alguns problemas para o mapeamento da sala, por isso colocamos o número correspondente.

Tabela 2: Freqüência da turma $-1^{\circ} \mathrm{B}_{2}$

\begin{tabular}{|c|c|c|c|c|c|c|c|c|c|c|c|c|}
\hline \multicolumn{2}{|c|}{ Alunos } & \multicolumn{10}{|c|}{ Atividades da intervenção } & \multirow[b]{2}{*}{$\mathbf{A V}$} \\
\hline $1^{\circ} B_{2}$ & $1^{\circ} B_{3} *$ & 1 & 2 & 3 & 4 & 5 & 6 & 7A & 7B & 8 & 9/até & \\
\hline 1 & & OK & $\mathrm{OK}$ & $\mathrm{OK}$ & OK & & OK & OK & OK & $\mathrm{OK}$ & $\mathrm{OK} / 7$ & \\
\hline 2 & & $\mathrm{OK}$ & $\mathrm{OK}$ & $\mathrm{OK}$ & & $\mathrm{OK}$ & $\mathrm{OK}$ & $\mathrm{OK}$ & $\mathrm{OK}$ & $\mathrm{OK}$ & OK/11 & $\mathrm{OK}$ \\
\hline 3 & & & $\mathrm{OK}$ & & $\mathrm{OK}$ & $\mathrm{OK}$ & & & & & & \\
\hline 4 & & $\mathrm{OK}$ & OK & $\mathrm{OK}$ & OK & $\mathrm{OK}$ & $\mathrm{OK}$ & $\mathrm{OK}$ & & $\mathrm{OK}$ & $\mathrm{OK} / 14$ & $\mathrm{OK}$ \\
\hline 5 & & $\mathrm{OK}$ & & & OK & $\mathrm{OK}$ & $\mathrm{OK}$ & & $\mathrm{OK}$ & $\mathrm{OK}$ & OK/7 & $\mathrm{OK}$ \\
\hline 6 & & OK & $\mathrm{OK}$ & $\mathrm{OK}$ & OK & $\mathrm{OK}$ & OK & OK & $\mathrm{OK}$ & $\mathrm{OK}$ & OK/11 & $\mathrm{OK}$ \\
\hline 7 & & OK & OK & $\mathrm{OK}$ & OK & OK & OK & OK & & $\mathrm{OK}$ & OK/11 & OK \\
\hline 8 & & OK & & & OK & $\mathrm{OK}$ & $\mathrm{OK}$ & OK & $\mathrm{OK}$ & $\mathrm{OK}$ & OK/8 & $\mathrm{OK}$ \\
\hline 9 & & $\mathrm{OK}$ & $\mathrm{OK}$ & & $\mathrm{OK}$ & $\mathrm{OK}$ & OK & & & $\mathrm{OK}$ & $\mathrm{OK} / 9$ & $\mathrm{OK}$ \\
\hline 10 & & OK & $\mathrm{OK}$ & & $\mathrm{OK}$ & $\mathrm{OK}$ & $\mathrm{OK}$ & & & $\mathrm{OK}$ & $\mathrm{OK} / 7$ & $\mathrm{OK}$ \\
\hline 11 & & OK & OK & $\mathrm{OK}$ & OK & & OK & OK & & & $\mathrm{OK} / 9$ & OK \\
\hline 12 & & $\mathrm{OK}$ & $\mathrm{OK}$ & $\mathrm{OK}$ & $\mathrm{OK}$ & $\mathrm{OK}$ & $\mathrm{OK}$ & $\mathrm{OK}$ & $\mathrm{OK}$ & $\mathrm{OK}$ & $\mathrm{OK} / 9$ & $\mathrm{OK}$ \\
\hline 13 & & OK & OK & $\mathrm{OK}$ & $\mathrm{OK}$ & & OK & OK & OK & $\mathrm{OK}$ & OK/11 & $\mathrm{OK}$ \\
\hline 14 & & & OK & $\mathrm{OK}$ & OK & $\mathrm{OK}$ & OK & OK & & $\mathrm{OK}$ & $\mathrm{OK} / 10$ & OK \\
\hline 15 & & OK & $\mathrm{OK}$ & $\mathrm{OK}$ & $\mathrm{OK}$ & $\mathrm{OK}$ & OK & OK & & $\mathrm{OK}$ & $\mathrm{OK} / 10$ & $\mathrm{OK}$ \\
\hline 16 & & $\mathrm{OK}$ & $\mathrm{OK}$ & $\mathrm{OK}$ & $\mathrm{OK}$ & $\mathrm{OK}$ & $\mathrm{OK}$ & $\mathrm{OK}$ & & & OK/9 & $\mathrm{OK}$ \\
\hline 17 & & & & $\mathrm{OK}$ & OK & $\mathrm{OK}$ & & $\mathrm{OK}$ & & & OK/9 & $\mathrm{OK}$ \\
\hline 18 & & $\mathrm{OK}$ & $\mathrm{OK}$ & $\mathrm{OK}$ & OK & $\mathrm{OK}$ & OK & $\mathrm{OK}$ & $\mathrm{OK}$ & $\mathrm{OK}$ & OK/14 & $\mathrm{OK}$ \\
\hline 19 & & $\mathrm{OK}$ & $\mathrm{OK}$ & & $\mathrm{OK}$ & $\mathrm{OK}$ & $\mathrm{OK}$ & & $\mathrm{OK}$ & $\mathrm{OK}$ & OK/7 & $\mathrm{OK}$ \\
\hline 20 & & OK & & & OK & $\mathrm{OK}$ & $\mathrm{OK}$ & $\mathrm{OK}$ & & & $\mathrm{OK} / 9$ & $\mathrm{OK}$ \\
\hline 21 & & OK & $\mathrm{OK}$ & & OK & & & & & & & \\
\hline 22 & & $\mathrm{OK}$ & $\mathrm{OK}$ & $\mathrm{OK}$ & $\mathrm{OK}$ & $\mathrm{OK}$ & & $\mathrm{OK}$ & $\mathrm{OK}$ & & $\mathrm{OK} / 10$ & $\mathrm{OK}$ \\
\hline 23 & 24 & $\mathrm{OK}$ & & $\mathrm{OK}$ & $\mathrm{OK}$ & $\mathrm{OK}$ & OK & $\mathrm{OK}$ & $\mathrm{OK}$ & $\mathrm{OK}$ & $\mathrm{OK} / 10$ & $\mathrm{OK}$ \\
\hline 24 & 23 & $\mathrm{OK}$ & $\mathrm{OK}$ & $\mathrm{OK}$ & $\mathrm{OK}$ & $\mathrm{OK}$ & $\mathrm{OK}$ & $\mathrm{OK}$ & $\mathrm{OK}$ & $\mathrm{OK}$ & OK/14 & $\mathrm{OK}$ \\
\hline 25 & & $\mathrm{OK}$ & OK & $\mathrm{OK}$ & $\mathrm{OK}$ & $\mathrm{OK}$ & OK & OK & $\mathrm{OK}$ & $\mathrm{OK}$ & $\mathrm{OK} / 3$ & $\mathrm{OK}$ \\
\hline 26 & & $\mathrm{OK}$ & $\mathrm{OK}$ & $\mathrm{OK}$ & $\mathrm{OK}$ & & $\mathrm{OK}$ & $\mathrm{OK}$ & $\mathrm{OK}$ & $\mathrm{OK}$ & OK/10 & $\mathrm{OK}$ \\
\hline 27 & & $\mathrm{OK}$ & & $\mathrm{OK}$ & & $\mathrm{OK}$ & OK & $\mathrm{OK}$ & & & & \\
\hline 28 & & OK & $\mathrm{OK}$ & $\mathrm{OK}$ & $\mathrm{OK}$ & $\mathrm{OK}$ & $\mathrm{OK}$ & OK & $\mathrm{OK}$ & $\mathrm{OK}$ & $\mathrm{OK} / 11$ & $\mathrm{OK}$ \\
\hline 29 & & $\mathrm{OK}$ & $\mathrm{OK}$ & & $\mathrm{OK}$ & $\mathrm{OK}$ & $\mathrm{OK}$ & $\mathrm{OK}$ & & & & \\
\hline 30 & & $\mathrm{OK}$ & & $\mathrm{OK}$ & & $\mathrm{OK}$ & OK & $\mathrm{OK}$ & & & OK/9 & $\mathrm{OK}$ \\
\hline 31 & & OK & $\mathrm{OK}$ & $\mathrm{OK}$ & $\mathrm{OK}$ & & $\mathrm{OK}$ & OK & & $\mathrm{OK}$ & OK/10 & $\mathrm{OK}$ \\
\hline 32 & & $\mathrm{OK}$ & $\mathrm{OK}$ & $\mathrm{OK}$ & $\mathrm{OK}$ & $\mathrm{OK}$ & $\mathrm{OK}$ & OK & $\mathrm{OK}$ & & $\mathrm{OK} / 3$ & $\mathrm{OK}$ \\
\hline 33 & & $\mathrm{OK}$ & $\mathrm{OK}$ & & $\mathrm{OK}$ & $\mathrm{OK}$ & OK & $\mathrm{OK}$ & $\mathrm{OK}$ & $\mathrm{OK}$ & $\mathrm{OK} / 3$ & $\mathrm{OK}$ \\
\hline 34 & & OK & $\mathrm{OK}$ & $\mathrm{OK}$ & & $\mathrm{OK}$ & OK & OK & & $\mathrm{OK}$ & $\mathrm{OK} / 14$ & $\mathrm{OK}$ \\
\hline 35 & & $\mathrm{OK}$ & $\mathrm{OK}$ & $\mathrm{OK}$ & & & $\mathrm{OK}$ & $\mathrm{OK}$ & & & $\mathrm{OK} / 8$ & $\mathrm{OK}$ \\
\hline 36 & & $\mathrm{OK}$ & $\mathrm{OK}$ & $\mathrm{OK}$ & $\mathrm{OK}$ & $\mathrm{OK}$ & $\mathrm{OK}$ & $\mathrm{OK}$ & $\mathrm{OK}$ & $\mathrm{OK}$ & OK/6 & $\mathrm{OK}$ \\
\hline 37 & & $\mathrm{OK}$ & $\mathrm{OK}$ & $\mathrm{OK}$ & $\mathrm{OK}$ & $\mathrm{OK}$ & $\mathrm{OK}$ & $\mathrm{OK}$ & $\mathrm{OK}$ & $\mathrm{OK}$ & OK/11 & $\mathrm{OK}$ \\
\hline 38 & & $\mathrm{OK}$ & $\mathrm{OK}$ & $\mathrm{OK}$ & $\mathrm{OK}$ & & $\mathrm{OK}$ & $\mathrm{OK}$ & & $\mathrm{OK}$ & & \\
\hline 39 & & $\mathrm{OK}$ & $\mathrm{OK}$ & & $\mathrm{OK}$ & $\mathrm{OK}$ & $\mathrm{OK}$ & $\mathrm{OK}$ & $\mathrm{OK}$ & $\mathrm{OK}$ & $\mathrm{OK} / 8$ & $\mathrm{OK}$ \\
\hline 40 & & $\mathrm{OK}$ & $\mathrm{OK}$ & $\mathrm{OK}$ & $\mathrm{OK}$ & $\mathrm{OK}$ & $\mathrm{OK}$ & $\mathrm{OK}$ & $\mathrm{OK}$ & $\mathrm{OK}$ & $\mathrm{OK} / 10$ & \\
\hline
\end{tabular}




\begin{tabular}{|l|l|l|l|l|l|l|l|l|l|l|l|l|}
\hline 41 & & OK & OK & OK & OK & OK & OK & OK & & OK & OK/9 & OK \\
\hline TOTAL & 38 & 36 & 32 & 37 & 34 & 38 & 36 & 21 & 29 & 36 & 34 \\
\hline
\end{tabular}

*Como os números para pesquisa são diferentes dos contidos no diário de classe houve alguns problemas para o mapeamento da sala, por isso colocamos o número correspondente.

Tabela 3: Freqüiência da turma $-1^{\circ} \mathrm{C}_{2}$

\begin{tabular}{|c|c|c|c|c|c|c|c|c|c|c|c|c|}
\hline \multicolumn{2}{|c|}{ Alunos } & \multicolumn{10}{|c|}{ Atividades da intervenção } & \multirow[b]{2}{*}{$\mathrm{AV}$} \\
\hline $1^{\circ} \mathrm{C}_{2}$ & $1^{\circ} \mathrm{C}_{3} *$ & 1 & 2 & 3 & 4 & 5 & 6 & $7 \mathrm{~A}$ & $7 \mathrm{~B}$ & 8 & 9/até & \\
\hline 1 & & $\mathrm{OK}$ & OK & & $\mathrm{OK}$ & OK & OK & OK & OK & OK & $\mathrm{OK} / 14$ & $\mathrm{OK}$ \\
\hline 2 & & OK & OK & & $\mathrm{OK}$ & $\mathrm{OK}$ & OK & OK & $\mathrm{OK}$ & OK & $\mathrm{OK} / 14$ & $\mathrm{OK}$ \\
\hline 3 & & & $\mathrm{OK}$ & $\mathrm{OK}$ & $\mathrm{OK}$ & $\mathrm{OK}$ & & & & & & $\mathrm{OK}$ \\
\hline 4 & & $\mathrm{OK}$ & $\mathrm{OK}$ & $\mathrm{OK}$ & $\mathrm{OK}$ & $\mathrm{OK}$ & & & $\mathrm{OK}$ & $\mathrm{OK}$ & $\mathrm{OK} / 14$ & $\mathrm{OK}$ \\
\hline 5 & & & OK & $\mathrm{OK}$ & $\mathrm{OK}$ & $\mathrm{OK}$ & $\mathrm{OK}$ & & & & $\mathrm{OK} / 13$ & \\
\hline 6 & 7 & $\mathrm{OK}$ & OK & & & & & & & & & \\
\hline 7 & 8 & OK & & & $\mathrm{OK}$ & & & $\mathrm{OK}$ & & $\mathrm{OK}$ & $\mathrm{OK} / 14$ & $\mathrm{OK}$ \\
\hline 8 & 9 & $\mathrm{OK}$ & OK & $\mathrm{OK}$ & $\mathrm{OK}$ & & & $\mathrm{OK}$ & & $\mathrm{OK}$ & $\mathrm{OK} / 14$ & $\mathrm{OK}$ \\
\hline 9 & 10 & $\mathrm{OK}$ & OK & $\mathrm{OK}$ & $\mathrm{OK}$ & & $\mathrm{OK}$ & & & $\mathrm{OK}$ & $\mathrm{OK} / 14$ & $\mathrm{OK}$ \\
\hline 10 & & OK & & & & & & & & & & \\
\hline 11 & & $\mathrm{OK}$ & OK & $\mathrm{OK}$ & OK & $\mathrm{OK}$ & $\mathrm{OK}$ & $\mathrm{OK}$ & $\mathrm{OK}$ & $\mathrm{OK}$ & $\mathrm{OK} / 14$ & OK \\
\hline 12 & & $\mathrm{OK}$ & OK & & OK & OK & & OK & & OK & $\mathrm{OK} / 14$ & OK \\
\hline 13 & & OK & OK & $\mathrm{OK}$ & OK & OK & OK & & & OK & $\mathrm{OK} / 14$ & $\mathrm{OK}$ \\
\hline 14 & & $\mathrm{OK}$ & OK & & $\mathrm{OK}$ & & & & & & & \\
\hline 15 & & $\mathrm{OK}$ & OK & $\mathrm{OK}$ & $\mathrm{OK}$ & $\mathrm{OK}$ & $\mathrm{OK}$ & $\mathrm{OK}$ & $\mathrm{OK}$ & OK & $\mathrm{OK} / 14$ & $\mathrm{OK}$ \\
\hline 16 & & $\mathrm{OK}$ & OK & $\mathrm{OK}$ & $\mathrm{OK}$ & $\mathrm{OK}$ & OK & OK & OK & OK & $\mathrm{OK} / 14$ & $\mathrm{OK}$ \\
\hline 17 & & $\mathrm{OK}$ & OK & $\mathrm{OK}$ & OK & $\mathrm{OK}$ & OK & OK & & OK & $\mathrm{OK} / 14$ & $\mathrm{OK}$ \\
\hline 18 & & OK & OK & & OK & & OK & & & OK & & \\
\hline 19 & & OK & OK & OK & $\mathrm{OK}$ & $\mathrm{OK}$ & OK & OK & OK & OK & $\mathrm{OK} / 14$ & $\mathrm{OK}$ \\
\hline 20 & & OK & OK & & & & & & & & & \\
\hline 21 & 20 & OK & OK & OK & $\mathrm{OK}$ & OK & OK & OK & OK & OK & $\mathrm{OK} / 14$ & $\mathrm{OK}$ \\
\hline 22 & 21 & $\mathrm{OK}$ & OK & OK & OK & OK & OK & OK & OK & OK & $\mathrm{OK} / 14$ & \\
\hline 23 & 22 & OK & OK & OK & OK & & & & OK & $\mathrm{OK}$ & $\mathrm{OK} / 14$ & $\mathrm{OK}$ \\
\hline 24 & 23 & & OK & & $\mathrm{OK}$ & & $\mathrm{OK}$ & & $\mathrm{OK}$ & OK & $\mathrm{OK} / 14$ & $\mathrm{OK}$ \\
\hline 25 & 24 & OK & OK & $\mathrm{OK}$ & $\mathrm{OK}$ & $\mathrm{OK}$ & $\mathrm{OK}$ & OK & & OK & $\mathrm{OK} / 14$ & $\mathrm{OK}$ \\
\hline 26 & 25 & $\mathrm{OK}$ & OK & & $\mathrm{OK}$ & & & OK & & & & \\
\hline 27 & 26 & & OK & $\mathrm{OK}$ & OK & OK & & & & OK & $\mathrm{OK} / 14$ & OK \\
\hline 28 & 27 & OK & OK & & OK & & & OK & $\mathrm{OK}$ & OK & $\mathrm{OK} / 14$ & Ok \\
\hline 29 & 28 & OK & OK & & OK & OK & OK & OK & & OK & $\mathrm{OK} / 14$ & $\mathrm{OK}$ \\
\hline 30 & 29 & OK & OK & $\mathrm{OK}$ & $\mathrm{OK}$ & $\mathrm{OK}$ & $\mathrm{OK}$ & OK & $\mathrm{OK}$ & $\mathrm{OK}$ & $\mathrm{OK} / 14$ & $\mathrm{OK}$ \\
\hline 31 & 30 & OK & OK & $\mathrm{OK}$ & OK & OK & OK & OK & OK & OK & $\mathrm{OK} / 14$ & OK \\
\hline 32 & 38 & & & & & & & & & & $\mathrm{OK} / 14$ & OK \\
\hline 33 & 31 & & OK & & OK & $\mathrm{OK}$ & & & OK & & $\mathrm{OK} / 14$ & $\mathrm{OK}$ \\
\hline 34 & 32 & OK & OK & OK & $\mathrm{OK}$ & & & & & & & \\
\hline 35 & 34 & & OK & & & & & & & & & \\
\hline 36 & 33 & $\mathrm{OK}$ & OK & $\mathrm{OK}$ & $\mathrm{OK}$ & & $\mathrm{OK}$ & & & & & \\
\hline 37 & 35 & & OK & $\mathrm{OK}$ & $\mathrm{OK}$ & & $\mathrm{OK}$ & & OK & $\mathrm{OK}$ & $\mathrm{OK} / 14$ & \\
\hline TOT & & 30 & 35 & 22 & 32 & 18 & 20 & 18 & 16 & 25 & 27 & 25 \\
\hline
\end{tabular}

*Como os números para pesquisa são diferentes dos contidos no diário de classe houve alguns problemas para o mapeamento da sala, por isso colocamos o número correspondente. 
Tabela 4: Freqüência da turma $-1^{\circ} \mathrm{D}_{2}$

\begin{tabular}{|c|c|c|c|c|c|c|c|c|c|c|c|c|}
\hline \multicolumn{2}{|c|}{ Alunos } & \multicolumn{10}{|c|}{ Atividades da intervenção } & \multirow[b]{2}{*}{ AV } \\
\hline $1^{\circ} \mathrm{D}_{2}$ & $1^{\circ} \mathrm{D}_{3} *$ & 1 & 2 & 3 & 4 & 5 & 6 & $7 \mathrm{~A}$ & $7 \mathrm{~B}$ & $8 \mathrm{~A}$ & 9/até & \\
\hline 1 & & $\mathrm{OK}$ & $\mathrm{OK}$ & $\mathrm{OK}$ & $\mathrm{OK}$ & & & & & & & \\
\hline 2 & & $\mathrm{OK}$ & & $\mathrm{OK}$ & $\mathrm{OK}$ & & $\mathrm{OK}$ & & & $\mathrm{OK}$ & $\mathrm{OK} / 14$ & $\mathrm{OK}$ \\
\hline 3 & & $\mathrm{OK}$ & $\mathrm{OK}$ & $\mathrm{OK}$ & & $\mathrm{OK}$ & $\mathrm{OK}$ & $\mathrm{OK}$ & $\mathrm{OK}$ & OK & OK & OK \\
\hline 4 & & $\mathrm{OK}$ & $\mathrm{OK}$ & $\mathrm{OK}$ & & $\mathrm{OK}$ & $\mathrm{OK}$ & $\mathrm{OK}$ & $\mathrm{OK}$ & & OK/14 & $\mathrm{OK}$ \\
\hline 5 & & $\mathrm{OK}$ & OK & $\mathrm{OK}$ & & $\mathrm{OK}$ & $\mathrm{OK}$ & $\mathrm{OK}$ & & & $\mathrm{OK} / 14$ & $\mathrm{OK}$ \\
\hline 6 & & $\mathrm{OK}$ & OK & $\mathrm{OK}$ & & & $\mathrm{OK}$ & $\mathrm{OK}$ & $\mathrm{OK}$ & $\mathrm{OK}$ & OK/14 & OK \\
\hline 7 & & & & $\mathrm{OK}$ & OK & & $\mathrm{OK}$ & $\mathrm{OK}$ & $\mathrm{OK}$ & & OK/14 & OK \\
\hline 8 & & $\mathrm{OK}$ & $\mathrm{OK}$ & $\mathrm{OK}$ & & $\mathrm{OK}$ & $\mathrm{OK}$ & $\mathrm{OK}$ & $\mathrm{OK}$ & & & \\
\hline 9 & & & & & & & & & & & OK/14 & $\mathrm{OK}$ \\
\hline 10 & 9 & $\mathrm{OK}$ & $\mathrm{OK}$ & & OK & & $\mathrm{OK}$ & $\mathrm{OK}$ & & & & OK \\
\hline 11 & 10 & $\mathrm{OK}$ & $\mathrm{OK}$ & & & & $\mathrm{OK}$ & & & & & $\mathrm{OK}$ \\
\hline 12 & & $\mathrm{OK}$ & OK & & & & $\mathrm{OK}$ & $\mathrm{OK}$ & & & OK/14 & OK \\
\hline 13 & & & $\mathrm{OK}$ & $\mathrm{OK}$ & OK & & $\mathrm{OK}$ & $\mathrm{OK}$ & $\mathrm{OK}$ & OK & OK/14 & OK \\
\hline 14 & & $\mathrm{OK}$ & & & & & & $\mathrm{OK}$ & & & OK & $\mathrm{OK}$ \\
\hline 15 & & $\mathrm{OK}$ & OK & $\mathrm{OK}$ & OK & OK & $\mathrm{OK}$ & $\mathrm{OK}$ & $\mathrm{OK}$ & OK & OK/14 & OK \\
\hline 16 & & & & & $\mathrm{OK}$ & & & & & & & \\
\hline 17 & & $\mathrm{OK}$ & OK & $\mathrm{OK}$ & & & $\mathrm{OK}$ & $\mathrm{OK}$ & & & OK/14 & $\mathrm{OK}$ \\
\hline 18 & & $\mathrm{OK}$ & $\mathrm{OK}$ & $\mathrm{OK}$ & $\mathrm{OK}$ & & $\mathrm{OK}$ & $\mathrm{OK}$ & & & $\mathrm{OK} / 14$ & $\mathrm{OK}$ \\
\hline 19 & & $\mathrm{OK}$ & $\mathrm{OK}$ & $\mathrm{OK}$ & $\mathrm{OK}$ & & $\mathrm{OK}$ & $\mathrm{OK}$ & & $\mathrm{OK}$ & OK/14 & $\mathrm{OK}$ \\
\hline 20 & & $\mathrm{OK}$ & & & OK & & & & & & & \\
\hline 21 & & & $\mathrm{OK}$ & & & & & & & & & \\
\hline 22 & & $\mathrm{OK}$ & $\mathrm{OK}$ & $\mathrm{OK}$ & $\mathrm{OK}$ & $\mathrm{OK}$ & $\mathrm{OK}$ & $\mathrm{OK}$ & $\mathrm{OK}$ & OK & $\mathrm{OK} / 14$ & $\mathrm{OK}$ \\
\hline 23 & & OK & OK & $\mathrm{OK}$ & & OK & OK & $\mathrm{OK}$ & $\mathrm{OK}$ & OK & $\mathrm{OK} / 14$ & OK \\
\hline 24 & & $\mathrm{OK}$ & $\mathrm{OK}$ & $\mathrm{OK}$ & OK & & $\mathrm{OK}$ & $\mathrm{OK}$ & $\mathrm{OK}$ & $\mathrm{OK}$ & OK/14 & $\mathrm{OK}$ \\
\hline 25 & & $\mathrm{OK}$ & OK & & $\mathrm{OK}$ & & $\mathrm{OK}$ & $\mathrm{OK}$ & $\mathrm{OK}$ & & & $\mathrm{OK}$ \\
\hline 26 & & $\mathrm{OK}$ & OK & $\mathrm{OK}$ & & & & & & $\mathrm{OK}$ & $\mathrm{OK} / 14$ & \\
\hline 27 & & $\mathrm{OK}$ & OK & $\mathrm{OK}$ & OK & OK & $\mathrm{OK}$ & $\mathrm{OK}$ & $\mathrm{OK}$ & OK & OK/14 & $\mathrm{OK}$ \\
\hline 28 & & $\mathrm{OK}$ & $\mathrm{OK}$ & $\mathrm{OK}$ & $\mathrm{OK}$ & $\mathrm{OK}$ & $\mathrm{OK}$ & $\mathrm{OK}$ & $\mathrm{OK}$ & & OK/14 & $\mathrm{OK}$ \\
\hline 29 & & $\mathrm{OK}$ & OK & & OK & & & & & & & \\
\hline 30 & & OK & OK & $\mathrm{OK}$ & & & & & & & & \\
\hline 31 & & $\mathrm{OK}$ & $\mathrm{OK}$ & & $\mathrm{OK}$ & & & & & & & \\
\hline 32 & & $\mathrm{OK}$ & OK & $\mathrm{OK}$ & OK & & $\mathrm{OK}$ & $\mathrm{OK}$ & $\mathrm{OK}$ & & OK/12 & \\
\hline 33 & & $\mathrm{OK}$ & OK & & OK & $\mathrm{OK}$ & OK & $\mathrm{OK}$ & $\mathrm{OK}$ & $\mathrm{OK}$ & OK/14 & $\mathrm{OK}$ \\
\hline 34 & & $\mathrm{OK}$ & $\mathrm{OK}$ & $\mathrm{OK}$ & $\mathrm{OK}$ & $\mathrm{OK}$ & $\mathrm{OK}$ & $\mathrm{OK}$ & $\mathrm{OK}$ & $\mathrm{OK}$ & OK/14 & $\mathrm{OK}$ \\
\hline 35 & & $\mathrm{OK}$ & $\mathrm{OK}$ & & & & $\mathrm{OK}$ & & & & & $\mathrm{OK}$ \\
\hline 36 & & $\mathrm{OK}$ & OK & & $\mathrm{OK}$ & & & $\mathrm{OK}$ & $\mathrm{OK}$ & $\mathrm{OK}$ & & \\
\hline 37 & & $\mathrm{OK}$ & OK & $\mathrm{OK}$ & $\mathrm{OK}$ & $\mathrm{OK}$ & $\mathrm{OK}$ & $\mathrm{OK}$ & $\mathrm{OK}$ & OK & OK/14 & $\mathrm{OK}$ \\
\hline TOT & & 32 & 32 & 23 & 24 & 12 & 26 & 25 & 18 & 15 & 24 & 26 \\
\hline
\end{tabular}

*Como os números para pesquisa são diferentes dos contidos no diário de classe houve alguns problemas para o mapeamento da sala, por isso colocamos o número correspondente. 


\section{A3.2.2. Diário de classe da professora}

Conteúdo do caderno do aluno aplicados nas turmas de ambas as escolas:

Cad. 1 - p. 3 a 13, 16 a 20, 22 a 34, 36 a 38, 40, 42 e 43.

Cad. 2 - p. 7 a 10, 10 a 16, 20 a 29, 41, 42, 44 a 46. (todos experimentos para casa)

\section{$\underline{\text { Escola G }}$}

Tabela 5 : Freqüência dos alunos nas aulas

\begin{tabular}{|l|l|l|}
\hline AULAS & $\mathbf{1}^{\mathbf{0}} \mathbf{A}_{\mathbf{2}}$ ( alunos) & $\mathbf{1}^{\mathbf{0}} \mathbf{B}_{\mathbf{2}}$ ( alunos) \\
\hline $22 / 02$ & 36 & 39 \\
\hline $01 / 03$ & 37 & 38 \\
\hline $08 / 03$ & 35 & 35 \\
\hline $15 / 03$ & 28 & 29 \\
\hline $22 / 03$ & 30 & 30 \\
\hline $29 / 03$ & 32 & 34 \\
\hline $05 / 04$ & 34 & 35 \\
\hline $12 / 04$ & 33 & 39 \\
\hline $19 / 04$ & 36 & 38 \\
\hline $26 / 04$ & 33 & 34 \\
\hline $03 / 05$ & 32 & 30 \\
\hline $10 / 05$ & s/ aula & s/ aula \\
\hline $17 / 05$ & s/ aula & s/ aula \\
\hline $24 / 05$ & 32 & 38 \\
\hline $31 / 05$ & 36 & 39 \\
\hline $07 / 06$ & s/ aula & s/ aula \\
\hline $14 / 06$ & 29 & 38 \\
\hline $21 / 06$ & 35 & 37 \\
\hline $28 / 06$ & s/ aula & s/ aula \\
\hline $05 / 07$ & 13 & 23 \\
\hline $02 / 08$ & 33 & 35 \\
\hline $09 / 08$ & 30 & 36 \\
\hline $16 / 08$ & s/aula & s/aula \\
\hline $23 / 08$ & 30 & 35 \\
\hline$* 2^{\mathrm{a}}$ feira -2 aulas $-1^{\circ} \mathrm{A}\left(5^{\mathrm{a}}\right.$ e $6^{\mathrm{a}}$ aula) e $1^{\circ} \mathrm{B}\left(3^{\mathrm{a}}\right.$ e $4^{\mathrm{a}}$ aula $)$ \\
\hline
\end{tabular}

Tabela 6: Conteúdo das aulas

\begin{tabular}{|l|l|}
\hline DATA - No de AULAS & \multicolumn{1}{|c|}{ CONTEÚDO - $\mathbf{1}^{\mathbf{0}}$ A e 1 $\mathbf{1}^{\mathbf{}} \mathbf{B}$} \\
\hline $22 / 02$ & Apresentação \\
\hline $01 / 03$ & Ativ. 1 + cad. 1 (p. 3 a 5) \\
\hline $08 / 03$ & Ativ. 2 + cad. 1 (p. 6 e 7) \\
\hline $15 / 03$ & Vm + cad. 1 (p. 8 a 11) \\
\hline $22 / 03$ & Ex. Vm + ativ.3 \\
\hline $29 / 03$ & Ativ. $4+$ pátio \\
\hline $05 / 04$ & Ativ. 4 \\
\hline $12 / 04$ & Colisões + ativ. 4 \\
\hline $19 / 04$ & cad. 1 (p. 17 a 20) + Am + Ativ. 4 \\
\hline $26 / 04$ & cad. 1 (p. 21 a 23) + Ativ. 5 \\
\hline $03 / 05$ & cad. 1 (p. 24 a 27) + Ativ. 5 \\
\hline
\end{tabular}




\begin{tabular}{|l|l|}
\hline $10 / 05$ & Conselho de Classe e série \\
\hline $17 / 05$ & Reunião de Pais \\
\hline $24 / 05$ & cad. 1 (p. 32 a 37, 40 a 43) \\
\hline $31 / 05$ & Ativ. 6 + cad. 2 (p. 7 a 10) \\
\hline $07 / 06$ & Prova interna \\
\hline $14 / 06$ & cad. 2 (p. 10 a 16, 20 a 26) + Em + Pot \\
\hline $21 / 06$ & cad. 2 (p. 44 a 47) + Ativ. 7 \\
\hline $28 / 06$ & Copa: Jogo do Brasil \\
\hline $05 / 07$ & Ativ. 8 \\
\hline férias & \multicolumn{2}{|l|}{} \\
\hline $02 / 08$ & Cad. 3 + término Ativ. 8 + Ativ. 9 \\
\hline $09 / 08$ & Cad. 3 + término Ativ. 9 \\
\hline $16 / 08$ & Feriado municipal \\
\hline $23 / 08$ & Cad.3+ Ativ. Av. \\
\hline Eventual & Ativ. Pessoal \\
\hline
\end{tabular}

\section{Escola M}

Tabela 7 : Freqüência dos alunos nas aulas

\begin{tabular}{|l|l|l|}
\hline AULAS & $\mathbf{1}^{\circ} \mathbf{C}_{\mathbf{2}}(\mathbf{3 5}$ ALUNOS) & $\mathbf{1}^{\mathbf{0}} \mathbf{D}_{\mathbf{2}}$ (37 ALUNOS) \\
\hline $18 / 02$ & 25 & 19 \\
\hline $23 / 02$ & & 31 \\
\hline $25 / 02$ & 32 & 31 \\
\hline $02 / 03$ & & 35 \\
\hline $04 / 03$ & 34 & 30 \\
\hline $09 / 03$ & & 28 \\
\hline $11 / 03$ & 26 & 19 \\
\hline $16 / 03$ & & 32 \\
\hline $18 / 03$ & 30 & 29 \\
\hline $23 / 03$ & & 30 \\
\hline $25 / 03$ & 25 & 29 \\
\hline $30 / 03$ & & 26 \\
\hline $01 / 04$ & 20 & 6 \\
\hline $06 / 04$ & & 24 \\
\hline $08 / 04$ & 31 & 20 \\
\hline $13 / 04$ & & 30 \\
\hline $15 / 04$ & 24 & 19 \\
\hline $20 / 04$ & & 27 \\
\hline $22 / 04$ & 20 & 6 \\
\hline $27 / 04$ & & 27 \\
\hline $29 / 04$ & 22 & 13 \\
\hline $04 / 05$ & & 27 \\
\hline $06 / 05$ & 24 & 26 \\
\hline $11 / 05$ & & conselho \\
\hline $13 / 05$ & 20 & 24 \\
\hline $18 / 05$ & & 25 \\
\hline $20 / 05$ & 25 & 26 \\
\hline $24 / 05$ & & 30 \\
\hline $27 / 05$ & 29 & 29 \\
\hline & & \\
\hline & & \\
\hline
\end{tabular}




\begin{tabular}{|l|l|l|}
\hline $01 / 06$ & & 27 \\
\hline $03 / 06$ & feriado & \\
\hline $08 / 06$ & Olimpíada: matemática & \\
\hline $10 / 06$ & 17 & 17 \\
\hline $15 / 06$ & copa & \\
\hline $17 / 06$ & 29 & 24 \\
\hline $22 / 06$ & & 24 \\
\hline $24 / 06$ & 28 & 23 \\
\hline $29 / 06$ & & 22 \\
\hline $01 / 07$ & 16 & 11 \\
\hline FÉRIAS & & \\
\hline $03 / 08$ & & 26 \\
\hline $05 / 08$ & 29 & 25 \\
\hline $10 / 08$ & & 20 \\
\hline $12 / 08$ & 21 & 18 \\
\hline $17 / 08$ & & reunião \\
\hline $19 / 08$ & 26 & 23 \\
\hline $24 / 08$ & & 24 \\
\hline
\end{tabular}

Tabela 8: Conteúdo das aulas

\begin{tabular}{|c|c|c|}
\hline $\begin{array}{l}\text { DATA - No de } \\
\text { AULAS }\end{array}$ & CONTEÚDO - $1^{\circ} \mathrm{C}_{2}$ & CONTEÚDO - $1^{\circ} \mathrm{D}_{2}$ \\
\hline $18 / 02-2$ & Apresentação & Apresentação \\
\hline $23 / 02-1$ & & Atividade 1 \\
\hline $25 / 02-2$ & Ativ. 1 + cad. 1 (p. 3, 4 e 5) & \\
\hline $25 / 02-1$ & & $\begin{array}{l}\text { Término ativ. } 1+\text { cad. } 1 \text { (p. 3, } 4 \text { e } \\
\text { 5) }\end{array}$ \\
\hline $02 / 03-1$ & & Atividade 2 \\
\hline $04 / 03-2$ & Ativ. 2 + SI + cad. 1 (p. 6 e 7$)$ & \\
\hline $04 / 03-1$ & & SI+ cad. 1 (p. 6 e 7) \\
\hline $09 / 03-1$ & & Ex. sobre unidades e desloc \\
\hline $11 / 03-2$ & $\begin{array}{l}\text { Ativ. } 3+\text { Ex. sobre unidades e } \\
\text { desloc }\end{array}$ & \\
\hline $11 / 03-1$ & & Ativ. 3 \\
\hline $16 / 03-1$ & & $\mathrm{Vm}$ \\
\hline $18 / 03-2$ & $\mathrm{Vm}+\mathrm{ex}$. & \\
\hline $18 / 03-1$ & & Ex. Vm \\
\hline $23 / 03-1$ & & Lições atrasadas \\
\hline $25 / 03-2$ & Ativ.4 (quadra) + cálculos & \\
\hline $25 / 03-1$ & & Ativ.4 (quadra) \\
\hline $30 / 03-1$ & & Ativ. 4 + cad. 1 (p. 16) \\
\hline $01 / 04-2$ & Ativ. $4+$ cad. 1 (p. 3 a 12, 16) & \\
\hline $01 / 04-1$ & & cad. 1 (p. 8 e 12$)+$ ex. $V m$ \\
\hline $06 / 04-1$ & & Ativ. 4 \\
\hline $08 / 04-2$ & Ativ. 4 & \\
\hline $08 / 04-1$ & & Ativ. 4 \\
\hline $13 / 04-1$ & & $\mathrm{Am}+\mathrm{ex}$ \\
\hline $15 / 04-2$ & Ativ. $4+$ Am + ex. & \\
\hline $15 / 04-1$ & & Ativ. 4 \\
\hline
\end{tabular}




\begin{tabular}{|c|c|c|}
\hline $20 / 04-1$ & & cad. 1 (p. 17 a 20) \\
\hline $22 / 04-2$ & $\begin{array}{l}\text { cad. } 1(\text { p. } 17 \text { a } 20,22 \text { e } 23)+P= \\
\text { m.g }\end{array}$ & \\
\hline $22 / 04-1$ & & Lições atrasadas \\
\hline $27 / 04-1$ & & cad. 1 (p. 21 a 24) $+\mathrm{P}=\mathrm{m} . \mathrm{g}$ \\
\hline $29 / 04-2$ & Ex. peso + ativ. 5 & \\
\hline $29 / 04-1$ & & Ativ. 5 \\
\hline $04 / 05-1$ & & Ativ. 5 \\
\hline $06 / 05-2$ & cad. 1 (p. 24 a 26, 32 a 37) & \\
\hline $06 / 05-1$ & & cad. 1 (p. 24 a 26) \\
\hline $11 / 05-1$ & & Sem aula \\
\hline $13 / 05-2$ & cad. 1 (p. 27,38 a 43) + 3 leis & \\
\hline $13 / 05-1$ & & cad. 1 (p. 32 a 37) \\
\hline $18 / 05-1$ & & 3 leis \\
\hline $20 / 05-2$ & Ativ. $6+$ Ativ. 7 & \\
\hline $20 / 05-1$ & & Ativ. 6 \\
\hline $24 / 05-1$ & & Ativ. 7 \\
\hline $27 / 05-2$ & Ativ. 7 & \\
\hline $27 / 05-1$ & & Ativ. 7 \\
\hline $01 / 06-1$ & & cad. 2 (p. 7 a 10) \\
\hline $03 / 06-2$ & & feriado \\
\hline $03 / 06-1$ & & feriado \\
\hline $08 / 06-1$ & & Olimpíada de matemática \\
\hline $10 / 06-2$ & Em + cad. 2 (p. 7 a 16) & \\
\hline $10 / 06-1$ & & $\mathrm{Em}+\mathrm{cad} .2$ (p. 11 a 16$)$ \\
\hline $15 / 06-1$ & & Copa \\
\hline $17 / 06-2$ & $\begin{array}{l}\text { Pot. + cad. } 2 \text { (p. } 24 \text { a 27) + Ativ. } \\
7\end{array}$ & \\
\hline $17 / 06-1$ & & Pot. + cad. 2 (p. 24 a 27) \\
\hline $22 / 06-1$ & & Torque + cad. 2 (p. 42 a 46) \\
\hline $24 / 06-2$ & $\begin{array}{l}\text { Torque }+ \text { cad. } 2 \text { (p. } 42 \text { a } 46)+ \\
\text { Ativ. } 7\end{array}$ & \\
\hline $24 / 06-1$ & & Ativ. 7 \\
\hline $29 / 06-1$ & & Ativ. $7+$ Ativ. 8 \\
\hline $01 / 07-2$ & Ativ. 8 & \\
\hline $01 / 07-1$ & & Ativ. 8 \\
\hline \multicolumn{3}{|l|}{ FÉRIAS } \\
\hline $03 / 08-1$ & & $\begin{array}{l}\text { Cad. } 3+\text { Exp. Cad. } 2 \text { p/ entregar } \\
\text { em setembro + Ativ. } 9\end{array}$ \\
\hline $05 / 08-2$ & $\begin{array}{l}\text { Cad. } 3+\text { Exp. Cad. } 2 \text { p/ entregar } \\
\text { em setembro + Ativ. } 9\end{array}$ & \\
\hline $05 / 08-1$ & & Ativ. 9 \\
\hline $10 / 08-1$ & & Ativ. avaliatória \\
\hline $12 / 08-2$ & Ativ. Avaliatória + Ativ. pessoal & \\
\hline $12 / 08-1$ & & Cad. 3 \\
\hline $17 / 08$ & & REUNIÃO \\
\hline $19 / 08-2$ & Cad. 3 & \\
\hline $19 / 08-1$ & & Cad. 3 \\
\hline $24 / 08-1$ & & Cad. 3 + Ativ. pessoal \\
\hline
\end{tabular}




\section{A3.2.3. Descrição das aulas}

\section{$\underline{1^{\circ} \text { dia de aula }}$}

Comumente, no primeiro dia de aula faço alguns acertos e combinados com os alunos, inicialmente marco os trabalhos e resumos de reportagens científicas do ano todo e detalhadamente comento sobre cada um deles. Além disso, faço um contrato de comportamento que deve ser seguido o ano inteiro. Sempre digo: Temos uma aula de $50 \mathrm{~min}$, e $5 \mathrm{~min}$ são exclusivos meus, quem desobedecer as ordens fará a sala toda pagar a penalidade. Como sempre há alunos que querem "pagar para ver", ou seja, testar os limites do professor, sempre acabo aplicando uma provinha para verem que não é brincadeira e, é claro que insiro na nota do bimestre.

Há aulas que não costumo nem utilizar os $5 \mathrm{~min}$ para exposição de algum tópico, prefiro sempre distribuir a tarefa do dia primeiro, para que aos poucos se acalmem e organizem. Os estudantes geralmente quando há troca de professores ficam "alvoroçados" e demoram retornar a sala, então não adiantar gritar ou pedir para ficarem quietos, aos poucos com a tarefa eles vão se acalmando e percebendo que precisam fazer a atividade, embora sempre tenha alguns estudantes que não querem saber de nada, mas pelo menos não ficam andando pela sala de aula. Como são agitados não agüentam ficar na sala de aula calmamente então precisam "passear" pela escola e usam sempre a desculpa do sanitário, mas já no primeiro dia combinamos que a sinceridade é essencial, pois prefiro que falem o que vão fazer (ir a cantina ir a quadra, passear no pátio, ir em outra sala, etc.) para mapeá-los caso haja algum problema.

\section{Distincão entre as escolas}

Como trabalho nas duas escolas há dez anos, percebo algumas mudanças de comportamento nos estudantes de ano para ano. Nos últimos anos a violência aos poucos tem entrado na escola, nas duas já houve casos de agressão corporal com objetos de corte (além da agressão verbal que é constante) e o interessante é que essa "maré" vem e volta e neste ano se instalou na escola $\mathrm{M}$, que corrobora com a falta de recursos didáticos tecnológicos para trabalhar em sala de aula. Uns anos atrás a violência estava mais aflorada na escola $\mathrm{G}$, mas enfim trabalhamos na escola da melhor maneira possível e tentamos lidar com as diferentes condições sociais e valores morais dos estudantes que freqüentam a escola. Muitas vezes percebo que o meio físico em que se ensina interfere na aprendizagem (mexe com a motivação do estudante em aprender), tanto quanto trabalhar com um conteúdo dentro de um tema que não chame atenção do estudante. $\mathrm{E}$ dentro desta esfera que estou tentando introduzir algumas atividades na perspectiva de causar mudanças que melhorem o aprendizado dos estudantes.

\section{$\underline{\text { Escola G }}$}

$1^{\circ} \mathrm{A}_{2}-5^{\mathrm{a}}$ e $6^{\mathrm{a}}$ aula - segunda-feira

$1^{\circ} B_{2}-3^{a}$ e $4^{a}$ aula - segunda-feira

\section{$22 / 02-1^{\circ} A_{2}$ e $1^{\circ} B_{2}$}

Como é de praxe no primeiro dia de aula falei sobre o meu sistema de avaliação, a regras a serem seguidas, inclusive a dos aparelhos eletrônicos (lei federal). Coloquei as datas dos resumos e dos trabalhos e todo conteúdo dos quatro bimestres. Mostrei o caderninho de atividades e falei sobre o conteúdo bem vagamente e que termos que realizar medidas na quadra. Enfatizei o visto no caderno e nas apostilas. Nas duas aulas não tive problemas quanto ao comportamento dos estudantes. 
Apenas no $1^{\circ} \mathrm{A}$ tive um aluno falante que adora interromper a minha fala e questionar sobre tudo, acho que ele deve ter deficit de atenção no lar.

\section{$01 / 03-1^{\circ} \mathbf{A}_{2}$}

Iniciei a aula colocando o recado: desligue os aparelhos eletrônicos e expliquei dizendo: "iremos discutir sobre esporte, saúde e física para compreender algumas modalidades esportivas, já que tivemos as olimpíadas recentemente e estamos vendo as olimpíadas de inverno e teremos a copa. Nesta primeira atividade avaliatória quero a opinião sincera de vocês, só não pode dizer: sim, não, talvez sem justificar. A avaliação já vale dez com tudo respondido, não deixe nada sem responder, coloque nome, número e esérie e responda de 1 a 12 da atividade 1: é só a respostas, dúvidas me perguntem, não rabisquem o caderninho, irei utilizar também em outras salas. Vocês tem duas para responder a atividade 1 e as pág. 3, 4 e 5 da apostila.

Na segunda parte da aula estavam quietos respondendo, tirando dúvidas sobre as questões que não conseguiam interpretar. Expliquei a questão 7 da tabela a todos para evitar a repetição, e enfatizei que queria a opinião, e que opinião não se copia um do outro. No fim da aula estavam bem agitados, pois já tinham terminado as lições. Surpreendi-me com a fala de um aluno que me perguntou: Professora você vai descontar nota ou ficar diferente comigo porque eu coloquei tudo o que penso?

\section{$1^{\circ} B_{2}-01 / 03$}

Iniciei a aula colocando na lousa: desligue os aparelhos eletrônicos e explicando que iríamos fazer a primeira atividade avaliatória que abrangerá esporte, saúde e física, para que possamos falar com mais propriedade das olimpíadas e da copa.

Pedi para colocarem nome e a série em folha avulsa para responder as questões do caderninho e expliquei que a atividade 1 como as outras já valem dez com as 12 questões respondidas.

Essa turma de uma forma geral me pareceu calma e interessada, durante as duas aulas responderam em silêncio a atividade e quando necessário me chamaram e as vezes discutiram entre si a melhor resposta. Na questão 7 um aluno me surpreendeu, pois perguntou se era para colocar as disciplinas que o ajudariam no intelecto ou na compreensão dos movimentos. Muitos alunos não conheciam os integrantes da comissão técnica e estavam receosos em escrever que não sabiam ou que odiavam esporte, por exemplo. No final da aula pedi para a medida que terminassem a atividade 1 respondessem as pag. 4,3 e 5 da apostila.

\section{$\mathbf{1}^{\circ} \mathbf{A}_{2}-08 / 03$}

A situação na escola estava conturbada, pois os professores estavam discutindo sobre uma possível greve, mas mesmo assim quando entrei na sala tinham muitos alunos, então pedi para que respondessem a atividade 2 sem enrolar e que se apressassem e antemão disse que lessem o texto se achassem necessidade, e devido a isto começaram a me indagar sobre a diferença de saúde e qualidade de vida e novamente muitos alunos me questionaram se realmente era para colocar o que pensavam sem restrição. Na segunda parte da aula escrevi na lousa o conteúdo de sistema de medidas e conversões, além de distância e tempo.

Fiz alguns exemplos na lousa, solucionei dúvidas e pedi para resolverem alguns exercícios e responderem p. 6 e 7 da apostila.

$1^{\circ} B_{2}-08 / 03$ 
Pedi para que colocassem o nome em folha avulsa para entregar a atividade $2 \mathrm{e}$ que seria para uma aula apenas. Iniciaram a atividade 2 , uns conversaram muito até começar mas depois tudo OK. Muitos alunos não entenderam a questão 7 e 8.Expliquei a toda sala que no texto não há as respostas e que apenas é um encaminhamento para o raciocínio, mas mesmo assim fizeram algumas confusões com os conceitos de saúde e qualidade de vida. Durante a atividade os alunos discutiram entre si sobre anabolizantes e lipoaspiração para obter um "corpão".

Terminaram tranquilamente a atividade.

\section{$1^{\circ} A_{2}-15 / 03$}

Na primeira parte da aula coloquei um exercício sobre deslocamento e caminho percorrido e expliquei algumas conversões de unidades de velocidade e pedi para responderem a p. 8 a 11 da apostila.

$\mathrm{Na}$ segunda parte da aula distribui os caderninhos e pedi para responderem a atividade 2. Percebi que os alunos já se acostumaram a responder o caderninho e ficaram motivados, pois alguns alunos do dito "fundão" iniciaram uma disputa de quem formaria a melhor frase, mas também devido a isto não conseguiram terminar a atividade em uma aula.

\section{$1^{\circ} B_{2}-15 / 03$}

Estava indecisa se aplicaria a atividade 3 pela quantidade de alunos que havia na sala, então na primeira parte da aula passei alguns exercícios sobre velocidade média e também conversões de medidas. Na segunda parte da aula pedi para que fizessem a atividade 3. Muitos alunos tiveram dificuldade em responder a questão 3, sendo que alguns passaram a copiar as respostas um dos outros, então intervi dizendo que cada pessoa tem uma opinião diferente.

É interessante observar que nesta sala tenho um aluno "diferente" dos demais, pois ele adora se comportar como monitor e tirar dúvidas dos colegas a respeito da lição, mas mesmo com toda esta interação a maioria dos alunos não conseguiu terminar a atividade 3 em uma aula

\section{$1^{\circ} B_{2}-22 / 03$}

Iniciei a aula propondo cinco exercícios sobre velocidade média, recolhi as apostilas para olhar da p. 1 a 11, para justamente corrigir os exercícios de velocidade média, então observei que estava tudo incompleto, portanto fui obrigada a deixar as duas aulas para os alunos colocarem em dia as lições do caderno, caderninho e apostila.

\section{$1^{\circ} A_{2}-22 / 03$}

Propus cinco exercícios de velocidade média e recolhi as apostilas para olhar, mas estava toda incompleta, então decidi usar as duas aulas para que solucionassem dúvidas e colocassem em ordem as atividades da apostila, do caderno e caderninho. Com tudo isso, percebi que apresentam bastante dificuldade com o conceito de velocidade média.

\section{$1^{\circ} B_{2}-29 / 03$}

Iniciei a aula colocando um pequeno roteiro da atividade que iríamos desenvolver no pátio. Pedi para formarem grupos para medirmos a velocidade de cada integrante do grupo em uma marcação escolhida para corrida. Como estavam muito lentos, pressionei e iniciou a coleta de dados, medidos com os pés a distância e voltamos a sala de aula para fazer os cálculos. Utilizei o meu tempo de corrida e a 
distância medida por eles e comparei com a velocidade de um corredor de elite. Todos os alunos calcularam a velocidade de cada um do grupo, a velocidade média do grupo e finalmente da sala, além de colocar o mais rápido e o mais lento. É interessante destacar que os alunos mais rápidos demoraram entender porque o grupo deles não havia ganhado a competição, o que foi uma excelente oportunidade para enfatizar o conceito de velocidade média.

\section{$1^{\circ} \mathrm{A}_{2}-29 / 03$}

Iniciei a aula dizendo que faríamos algumas medições no pátio e que era necessário fazer algumas notações para efetuarmos alguns cálculos de velocidade. A maioria dos alunos estava com vergonha de correr, mas como iniciei comigo ficaram mais a vontade, e fizeram todas as medições de tempo e distância. Fomos a sala e expliquei os cálculos e comparei a minha velocidade com a de um corredor de elite e pedi para que verificassem o mais lento e o mais rápido grupo e fizessem a média do grupo, isto foi muito produtivo pois perceberam que para ganhar é necessário que todos da equipe sejam bons corredores, isto foi muito bom para o entendimento do conceito de velocidade média. Nesta sala havia uma menina com problemas cardíacos, então fiz participar da atividade do mesmo jeito, ela caminhou e medimos o tempo e comparamos com os outros. Como terminaram rapidamente os cálculos pedi que respondessem a p.16 da apostila, mas me surpreendi, pois parece que não entenderam o conceito de velocidade, mas insisti e por final realizaram os cálculos.

\section{$1^{\circ} B_{2}-05 / 04$}

Comecei colocando na lousa a correção da p.16 da apostila e propondo a entrega das p. 7 e 8 da atividade 4 do caderninho. No final da terceira aula levei os alunos na sala de vídeo para assistirem a maratona de 2008 e a corrida 4x100m, fiz uma analise dos movimentos e comparamos com os nossos movimentos na corrida no pátio. $\mathrm{Na}$ maratona pude enfatizar novamente o conceito de velocidade média com o Vanderlei devido a sua parada. A questão 4 deu mais trabalho para que efetuassem os cálculos, mas foi um ótimo exemplo de conversões e treino. A maioria dos alunos conseguiu terminar apenas até a questão 5.

Desta vez tive que interferir nas atitudes do aluno monitor, pois não estava ainda com os conceitos firmados para explicar, se confundia muito. Como sempre permaneço sentada na mesa solucionando dúvidas, pois percebi que circular entre as carteiras, deixa os alunos acuados. Nesta atividade foi necessário corrigir a primeira parte para dar uma devolutiva, para que consertassem os cálculos e pudessem iniciar a segunda parte da atividade na próxima aula.

\section{$1^{\circ} A_{2}-05 / 04$}

Iniciei a aula dizendo que fariam um a prova que seria a atividade 4, mas antes de iniciar a resolução, os levei a sala de vídeo para assistir um trecho da maratona de 2008 e uma corrida 4x100m, fiz algumas analises e enfatizei o conceito de velocidade média e voltamos a sala. Durante a aula tive que intervir com explicações no quadro para relembrar novamente transformações de unidades, mas acho que desta vez entenderam. Tive que usar de estratégia para que duas alunas continuassem a responder a atividade, pois apresentavam muita dificuldade. Alguns alunos passaram aula inteira conversando e não fizeram a atividade, mas faz parte. No final da aula recolhi as atividades para fazer as correções e dar um retorno na próxima aula, pois acho que facilitará o aprendizado dos cálculos. 
$1^{\circ} B_{2}-12 / 04$

Comecei escrevendo no quadro a teoria de aceleração média e alguns exercícios, após explicar pedi que resolvessem os exercícios. Na segunda parte da aula os alunos prosseguiram respondendo a atividade 4 , reclamaram um pouco, mas foi...Hoje estavam dispersos o que deixou a aula tumultuada, mas mesmo assim insisti para que terminassem e terminei a aula fornecendo alguns exemplos de colisões para facilitar o entendimento de algumas questões da atividade 4

\section{$1^{\circ} \mathrm{A}_{2}-\mathbf{1 2} / 04$}

Iniciei explicando aceleração média e propondo alguns exercícios, após a finalização desta parte, os alunos continuaram a fazer atividade 4. Durante a aula percebi que os alunos que me procuravam para solucionar dúvidas muitas vezes esqueceram tudo da aula anterior, mas era apenas citar os cálculos feitos com os dados obtidos no pátio que iniciavam os cálculos, claro que com dificuldade em matemática, mas devagar vai, o importante é entender mais os conceito.

\section{$\mathbf{1}^{\circ} \mathbf{B}_{2}-19 / 04$}

Comecei com a apostila p.17 a 20, explicando colisões e força, levei-os a sala de vídeo para assistirem alguns trechos de alguns esportes como sumo, salto ornamental, futebol americano, taco, tênis, etc. para que facilitasse responder o restante da atividade 4. Então pressionei para que terminassem toda ativ. 4 naquela aula. Solucionei muitas duvidas quanto a matemática. A aula foi produtiva, pois me consultavam, consultavam os colegas, estavam meio desesperados para terminar logo, mas como sempre havia alunos desinteressados, que estavam atrapalhando o bom andamento da aula.

\section{$1^{\circ} B_{2}-26 / 04$}

Iniciei a aula colocando na lousa a teoria de peso de um corpo, expliquei e pedi para que fizessem alguns exercícios que propus e as pags. 21, 22 e 23 da apostila, e após terminar que iniciassem a atividade 5 do caderninho. Durante a atividade 5 fizeram algumas confusões com massa e peso corporal, mas aos poucos foram se acertando, claro que muitos alunos se atrasaram, mas mesmo assim recolhi as folhas para pressionar, pois mais conversam do que fazem as atividades.

\section{$1^{\circ} \mathrm{A}_{2}-26 / 04$}

Expliquei peso de um corpo e passei alguns exercícios e as pags.21,22 e 23 da apostila. Após terminarem a lição liberei para que fizessem a atividade 5. Hoje estão calmos, me perguntaram muitas vezes sobre massa corporal e peso corporal e percebi que há uma dificuldade em enquadrar ao cotidiano.

\section{$1^{0} B_{2}-03 / 05$}

Nesta aula fiz um resuminho sobre as 3leis de Newton e enfatizei alguns cálculos da 2a lei. Nas duas aulas ficaram terminando a atividade 5 da aula anterior e as p. 24 a 27 da apostila. Novamente muitos alunos vieram indagar sobre peso e massa corporal, mas acho que agora foi....

$1^{\circ} \mathrm{A}_{2}-03 / 05$

Como sempre estão agitados, a maioria dos meninos hoje não querem fazer nada, mas insisto e acabam fazendo. Expliquei resumidamente as três leis de Newton e passei alguns exercícios na lousa e pedi para responderem p. 24 a 27 da apostila e para finalizarem a atividade 5. Bom desta vez funcionou. 
$\mathbf{1}^{\circ} \mathbf{B}_{2}-17 / 05$

Coloquei na lousa a teoria de quantidade de movimento e impulso, expliquei e passei alguns exercícios, olhei as apostilas e na segunda parte da aula houve reunião de pais

$\mathbf{1}^{\mathbf{0}} \mathbf{A}_{2}$ - 17/05 - Reunião de pais

\section{$1^{\circ} B_{2}-24 / 05$}

Expliquei conservação da quantidade de movimento através do exemplo da p.38 da apostila e pedi para que finalizassem as p. 32 a 37 e 40 a 43 apostila 1, para eu corrigir. Simulei uma colisão minha com um lutador de sumo e discuti massa e velocidade. $\mathrm{Na}$ segunda parte da aula iniciaram a atividade 6 do caderninho e apresentaram muita dificuldade em entender a palavra interação. No inicio estavam falantes, mas depois começaram a conversar sobre colisões no esporte, mas foi um sufoco para trocarem a palavra empurrão por impulso.

\section{$\mathbf{1}^{\circ} \mathrm{A}_{2}-\mathbf{2 4 / 0 5}$}

Escrevi no quadro a teoria de quantidade de movimento e impulso, passei algumas paginas da apostila para responderem e pressionei-os para terminar rapidamente toda a atividade da apostila que havia passado nas aulas anteriores. Simulei uma colisão minha com um lutador de sumô e discuti massa e velocidade. Na segunda parte da aula iniciaram a atividade 6, estavam muito calmos e discutindo e argumentando sobre colisões nos esportes. Apresentaram dificuldade em entender a palavra interação e ficaram a todo tempo perguntando: posso colocar o que realmente acho, mesmo que seja um absurdo?

\section{$\mathbf{1}^{0} \mathbf{B}_{2}-31 / 05$}

Iniciei colocando na lousa vários tipos de energia, expliquei a p. 7 da apostila e pedi para responderem a p. 7 a 10 da cad. 2 e em seguida iniciar a ativ. 7 - ex. 1 ao 10. Mesmo com o texto explicando inércia na atividade e a explicação das aulas anteriores, tiveram dificuldade em entender o conceito de inércia. Durante a aula tive que exemplificar arrastando o armário da sala a força de atrito para que todos entendessem melhor.

\section{$1^{\circ} A_{2}-31 / 05$}

Coloquei na lousa os vários tipos de energia e suas transformações exemplificando com situações do cotidiano, pedi para responderem a p. 7 a 10 da apostila 2 e depois iniciarem a atividade 7 do ex. 1 ao 10. Apresentaram dificuldade em exemplificar situações em que houvesse inércia e nas questões que apareceram a palavra grandeza, tive que explicar o que significava, embora já tivesse tratado disso em aulas anteriores. A sala estava tumultuada, bastante conversa, mas mesmo assim conseguiram terminar a atividade.

$\mathbf{1}^{\circ} \mathbf{A}_{2} \mathbf{e} \mathbf{1}^{\circ} \mathbf{B}_{2}$ - 07/06 - Prova Semestral da Escola

\section{$1^{\circ} B_{2}-14 / 06$}

Coloquei a teoria sobre energia mecânica e fiz alguns exercícios dados na apostila e pedi para que resolvessem os outros da p. 10 a 16, 20 a 22. Coloquei também a teoria sobre potência e suas conversões de unidades $(\mathrm{CV}, \mathrm{HP})$ e pedi para fazerem em 
casa p. 25 a 29. Como sempre fiquei sentada atendendo as dúvidas, muitos alunos fizeram as atividades, mas claro que outros só conversaram a aula toda e depois copiaram tudo do colega, e com a copa a solta o celular com TV também ficou a solta.

\section{$1^{\circ} A_{2}-14 / 06$}

Coloquei na lousa a teoria sobre energia mecânica, e fiz alguns exercícios da apostila 2 para exemplificar e pedi para que fizessem todos os exercícios da p. 10 a 16 , 20 a 22. Hoje estão calmos e solucionando dúvidas, muitos alunos faltaram para assistir o futebol da copa. No final da aula expliquei potências e suas conversões e utilizações no cotidiano e pedi para iniciarem a p.26 a 29 da cad. 2. Durante a aula tinha alguns alunos assistindo o jogo pelo celular, não estressei, pois não adianta, depois passa.

\section{$1^{\circ} B_{2}-21 / 06$}

Iniciei a aula colocando na lousa a teoria sobre torque e dando alguns exemplos. Fiz com os alunos a p.42 da cad. 2 e pedi para que finalizassem toda a apostila exceto as experiências que passei para fazerem nas férias. Na segunda parte da aula pedi para que respondessem a segunda parte da ativ. 7 e a primeira parte da atividade 8, enquanto isso, fiquei olhando as apostilas e os cadernos, pois já está em época de fechar as médias novamente. A bagunça está reinando hoje, alguns estão fazendo as lições, mas a maioria parece que está em ritmo de férias. Muitos alunos são inseguros e a todo o momento vem a minha mesa para que eu confirme a resposta, apenas digo: é sua opinião.

\section{$1^{\circ} A_{2}-21 / 06$}

Iniciei colocando a teoria sobre torque e apresentando alguns exemplos com contas e fiz a p.42 da cad. 2. Na segunda parte da aula pedi para que respondessem o restante a atividade 7 e a primeira parte da atividade 8 . Estavam falantes e agitados, mas rendeu terminaram a ativ. 7 e iniciaram a 8 , sendo que no final recolhi todas as folhas, muitos alunos vinham confirmar as respostas para potência e calorias, sendo que já estava correta, estão muito inseguros. Os meninos estavam agitados, por causa do jogo da copa, mas até que deu para suportar tranquilamente.

$1^{\circ} \mathbf{A}_{2}$ e $1^{\circ} B_{2}-28 / 06$ - Jogo da copa

\section{$1^{\circ} B_{2}-05 / 07$}

Muitos alunos não vieram, pois já declararam férias antecipadamente, mesmo eu pedindo para não faltarem para terminar a atividade 8. Como na aula anterior não terminaram a ativ. 7 e 8 , pressionei os poucos alunos que havia e pedi para terminarem imediatamente a atividade 7 e 8 , todos fizeram as lições e solucionaram as dúvidas, tiveram dificuldades em entender os planos de referência no corpo e o significado de inércia da rotação. Lembrei alguns tópicos do final da apostila de alavancas e terminaram tranquilamente as atividades.

\section{$\mathbf{1}^{\mathbf{0}} \mathbf{A}_{\mathbf{2}}-\mathbf{0 5 / 0 7}$}

Havia poucos alunos, então devolvi as folhas da atividade 8 e pedi para que terminassem, estavam muitos quietos, e rendeu, achei muito estranho, pois ninguém perguntou absolutamente nada, até o final das duas aulas todos haviam terminado.

$1^{\circ} B_{2}-02 / 08$ 
Coloquei na lousa o planejamento para o $2^{\circ}$ semestre e as datas dos resumos e trabalhos. Decidi começar a cad. 3 - p. 3 a 8 para dar margem para os alunos faltosos terminarem a ativ. 8 .

Coloquei também na lousa os números dos alunos que faltavam entregar a ativ. 8, enquanto alguns alunos faziam a cad. 3. Para um primeiro dia depois das férias estavam calmos fazendo a lição, mas depois do intervalo ficaram agitadíssimos, mas foram fazendo aos poucos. Um grupo pediu ajuda para o estudante "monitor", que se irritou pelo nível das perguntas como:

A 1: O que é alavanca?

A2: Mas não entendi nada da cad. 2

A1: Claro, você falta muito nas aulas

A2: É, e agora vou chutar

Insistiram tanto que ele passou todas as respostas.

$\mathbf{1}^{\circ} \mathrm{A}_{2}-02 / 08$

Fiz o planejamento, revisei as datas de trabalhos e resumos e iniciei a cad. 3 - p. 3 a 8. Coloquei na lousa o números dos alunos que precisavam terminar a ativ.8. Mas, logo em seguida iniciaram a ativ. 9. Estavam muito agitados e reclamando da quantidade de lições. Observe algumas perguntas que surgiram:

Profa. O que é epicondilites? (sabe que eu não tinha reparado nesta palavra, não soube responder)

Profa. O que é biomecânica?

Profa. É a última atividade né, que bom.

$1^{\circ} B_{2}-09 / 08$

Iniciei as aulas com a cad. 3, explicando alguns cálculos e como sempre muita dificuldade em matemática. Após isso pedi para responderem a ativ. 9, mas a maioria dos alunos não lembravam da definição de biomecânica e de conceitos físicos. Por dentro fiquei irritada, mas pensando melhor, falei a palavra biomecânica com ênfase apenas na ativ. 3 e não tratei os conceitos vistos com o termo "conceitos físicos".

$1^{\circ} A_{2}-09 / 08$

Iniciei as aulas com a cad. 3, explicando alguns cálculos e como sempre muita dificuldade em matemática. Em seguida pedi para terminarem finalmente a ativ.9, mas aos foram se organizando e terminarem tanto a ativ.9 quanto as lições da cad. 3.

$1^{\circ} B_{2}-23 / 08$

Fomos para sala de data-show, assistir inicialmente um vídeo sobre a comparação das dimensões dos planetas e algumas estrelas. Depois passei quatro vídeos de pequena duração sobre algumas habilidades no futebol. Acharam muito divertidos, então pedi em seguida para que fizessem a avaliação final. Tudo ocorreu calmamente.

\section{$1^{\circ} A_{2}-23 / 08$}

Levei-os para sala do data-show, assistimos um vídeo sobre as dimensões dos planetas. Em seguida passei os vídeos de futebol, mas no último a internet caiu, mas mesmo assim os alunos responderam a atividade de avaliação calmamente, mas surgiram algumas perguntas como: O que é biomecânica mesmo profa.? O que é conceito físico? Respirei fundo e respondi calmamente. È preciso ter paciência.

\section{$\underline{\text { Escola M }}$}


$1^{\circ} \mathrm{C}_{2}-3^{\mathrm{a}}$ e $5^{\mathrm{a}}$ aula - segunda-feira

$1^{\circ} \mathrm{D}_{2}-1^{\mathrm{a}}$ aula - segunda-feira, $4^{\mathrm{a}}$ aula - quinta-feira

\section{8/02 - $1^{\circ} \mathrm{C}_{2}$ e $1^{\circ} \mathrm{D}_{2}$ - Primeiro dia de aula}

No primeiro dia deixei para me apresentar e colocar algumas regras para o ano, além de atividades que se repetirão durantes todos os bimestres, inclusive a feitura dos exercícios da apostila e a utilização do caderninho de atividades englobando esporte e saúde. Comentei sobre as olimpíadas de inverno que estava passando na Record e da copa do mundo que se aproxima.

Como era o primeiro dia estavam bem comportados, embora houvesse poucos alunos, também as aulas começaram em uma quinta-feira. Foram duas aulas no mesmo dia, coloquei no quadro as datas de entrega dos resumos de reportagens científicas e as datas de entrega e os conteúdos das pesquisas bimestrais. Coloquei um resumo na lousa sobre grandezas físicas e escalares e expliquei, além de listar os tópicos que seriam vistos durante os bimestres, reclamaram um pouco da quantidade de matéria.

Como o uso de aparelhos eletrônicos foi proibido através de lei federal e por ordem da diretora, comentei por cima que talvez fosse utilizar máquina fotográfica e notebook.

Durante a aula fui surpreendida pela diretora que trouxe mais um aluno para fazer parte da turma. Fiquei metade da aula conversando com ela que me explicava como trabalhar com este aluno portador de deficiência auditiva, mas não adiantou, pois não sei me comunicar em libras, mas enfim espero que tudo dê certo, ambas as salas foram receptivas.

\section{3/02 - $\mathbf{1}^{\mathrm{o}} \mathrm{D}_{2}$}

A sala estava com mais alunos, coloquei no canto da lousa a frase: "Desligue os aparelhos eletrônicos, por favor," e solicitei a cópia dos textos da aula anterior para aplicar visto no caderno.

Apresentei-me novamente e disse que iriam começar a aula fazendo uma atividade avaliatória, aí começaram as indagações dos alunos: Você está louca? Que merda! Da onde saiu esse ser? Isto partiu dos alunos que não estavam na primeira aula, enfim foram muito agressivos.

Expliquei que iríamos realizar algumas atividades avaliatórias sobre esportes, saúde e física e que a atividade não tinha caráter de testar as habilidades em contas, mas que, era apenas necessário que expressassem a sua opinião sinceramente, imediatamente um aluno A exclamou: que saco, posso ir ao banheiro? Delicadamente respondi que já havia um aluno fora, que era para aguardar.

Mostrei os caderninhos de atividade e expliquei que não haveria motivos para estresse, apenas seria necessário colocar o nome em uma folha de caderno, o número da questão e responder individualmente. Enfatizei que não poderiam rabiscar o caderninho, pois seriam utilizados por outros alunos também. Avisei que na atividade 1 deveriam responder as 12 questões e me chamar ou vir até a minha mesa caso houvesse dúvidas.

$\mathrm{O}$ aluno A me interrompeu novamente me perguntando se o aluno tinha ido "cagar", pois estava demorando para voltar, ignorei as provocações. Expliquei aos alunos que nunca daria algo que fosse impossível de ser respondido, acelerem e respondam. Ao tirar da minha bolsa a máquina para filmar a aula, os alunos me interromperam dizendo que era proibido utilizar aparelhos eletrônicos.

Diante desta situação não houve meio de argumentar e para não estender a polêmica e não perder a aula recuei, e iniciaram a atividade. 
Vários alunos me chamaram para solucionar dúvidas a respeito das questões, muitos não sabiam o significado da palavra desafio. Houve dois alunos que entregaram a atividade rapidamente, mas também observei que estavam incoerentes, os dois estavam alterados, então permiti que fossem ao banheiro e sumiram.

A maioria dos alunos respondeu tranquilamente, me chamando para ajudar a interpretar as questões, nesta atividade tiveram bastante dificuldade em entender o preenchimento da tabela então fui explicando de carteira em carteira.

Faltando cinco minutos para finalizar a aula recolhi os caderninhos de atividade e pedi para que ficassem com a folha de respostas para que pudessem terminar na aula posterior. É interessante relatar que a aluna A que havia sido desagradável durante a aula foi pressionada pelas amigas a responder, fiz questão de ir em sua carteira perguntar se havia alguma dúvida e permaneceu o restante da aula tranquila.

Não estou a vontade na sala de aula, pois não conheço os aluno, mas pelas suas conversas, percebo que é uma sala problemática, talvez tenha iniciado precocemente as atividades. Para que respondessem com empenho e rapidez. Expliquei que cada atividade inteira respondida vale 10 para compor a nota bimestral.

\section{$25 / 02-1^{\circ} D_{2}$}

Anotei no quadro para terminarem a atividade 1 e iniciarem as páginas 3 , 4 e 5 da apostila de física para evitar muito barulho, pois muitos alunos já tinham terminado a atividade 1 e outros ainda estavam respondendo. Nesta aula estavam mais receptivos, a todo o momento me chamavam para ajudá-los a interpretar as questões, principalmente a questão sete da tabela. Durante a aula uma aluna se queixou que não poderia responder a questão sete, pois nunca tinha tido biologia, química e física. Diante disso expliquei que deveria recorrer aos conhecimentos que já possuía.

Alguns alunos que tinham faltado nas aulas anteriores, iniciaram a atividades hoje. No restante da aula fiquei solucionando dúvidas das questões da apostila.

\section{$25 / 02-1^{\circ} \mathrm{C}_{2}$}

Escrevi na lousa o tema: Esporte, saúde e física, entreguei o caderninho e pedi para que respondessem a atividade 1 inteira, expliquei que se trata da parte introdutória de esportes e a opinião deles é muito importante.

Encontrei dificuldades em me comunicar com o aluno deficiente auditivo, que durante toda aula ficou praticamente olhando, pois ele não é letrado em português. Durante a aula fui interrompida pela inspetora para entrega das apostilas. Fiz na lousa uma explicação sobre a questão sete e comentei sobre a copa e as olimpíadas de inverno.

Algumas alunas alegaram não saber nada sobre esportes, imaginando que haveria questões dificílimas sobre o assunto na atividade. Durante a aula enfatizei que por estar respondendo todas as questões da atividade já possuem dez, pois por enquanto tanto nesta atividade, quanto da apostila não há contas, somente preciso das opiniões.

Alguns alunos reclamaram que a atividade estava muito difícil, pois não sabiam muito bem o nome dos jogadores e nem explicar como corrigir os movimentos, mas intervi dizendo que se não souberem não há problemas, pois a intenção é que ao final do curso consigam responder todas essas questões.

No final da aula foi uma bagunça, um comportamento insuportável, pois já haviam terminado a atividade do caderninho e da apostila (p. 3, 4e 5).

\section{$02 / 03-1^{\circ} \mathrm{D}_{2}$}


Iniciei a aula perguntando se todos haviam feito as p. 3, 4 e 5 da apostila. Pedi para que respondessem a atividade 2 e caso terminassem indicassem a p.6 e 7 da apostila, durante a aula foram vários questionamentos:

Aluno 1: Professora o que é pré-requisito

Aluno2: Aí, não gosto de ler, precisa ler para responder?

Aluno3: Professora, "o loco" precisa ler tudo isso, credo!

Aluno4: Essa qualidade de vida é o dinheiro? O texto está complicado

Durante a aula me mantive sentada, fazendo anotações no diário de classe e solucionando as duvidas dos alunos. A medida que iam terminando a atividade a bagunça também aumentava.

$04 / 03-1^{\circ} \mathrm{C}_{2}$

Já iniciei escrevendo na lousa: Responda a atividade 2 do caderninho, e disse: sem enrolação, é para esta aula! Não se atrasem, qualquer dúvida é só me chamar. Muitos alunos me questionaram sobre a leitura dos textos, pois estavam com preguiça de ler. Após terminarem a atividade 2, pedi para escreverem no caderno o conteúdo que estava na lousa sobre S.I., unidades e conversões de unidades de tempo e distância, expliquei detalhadamente, passei exercícios e pedi para responderem p. 6 e 7 da apostila.

\section{$04 / 03-1^{\circ} D_{2}$}

Nesta aula escrevi no quadro e expliquei S.I. e unidades e conversões de tempo e distância e após passei alguns exercícios, muitos alunos disseram que precisariam terminar a atividade 2 do caderninho que não deu tempo e que é bem melhor o caderninho do que fazer estas contas de transformação.

$09 / 03-1^{\circ} D_{2}$

Esta semana estava conturbada, pois muitos professores estavam aderindo a greve, então vários alunos pararam de vir a escola. Interrompi as atividades do

caderninho e da apostila e passei vários exercícios sobre tempo e distância percorrida e fiquei a aula toda atendendo as dúvidas dos poucos alunos que fizeram os exercícios.

\section{$11 / 03-1^{0} D_{2}$}

A escola estava muito tumultuada pela greve, mas até que tinha muitos alunos, então apliquei a atividade 3 , os alunos responderam tranquilamente em silêncio, estavam concentrados e apenas reclamaram do tamanho dos textos e da questão 3 devido a tabela.

\section{$11 / 03-1^{\circ} \mathrm{C}_{2}$}

Iniciei a aula propondo alguns exercícios sobre distância e tempo, pressionandoos para tirarem as dúvidas, bom tive que relembrar alguns tópicos de matemática, mas mesmo assim vários alunos ficaram conversando, bagunçando e reclamando da quantidade de exercícios.

Na segunda parte da aula pedi para que entregassem a atividade 3 do caderninho, reclamaram alegando que estavam cansados, mas depois acabaram fazendo e até gostaram, discutiram entre si as questões e após terminaram, começou novamente a bagunça

\section{$16 / 03-1^{\circ} D_{2}$}


Nesta aula expliquei e deixei alguns exercícios sobre velocidade média e conversões de unidades, para que tentassem resolver e solucionassem dúvidas, além de pedir para responderem a p.8 da apostila.

$18 / 03-1^{\circ} \mathrm{C}_{2}$

Iniciei a aula dizendo que iria olhar o caderno e a apostila, bom houve desespero. Expliquei e propus alguns exercícios sobre velocidade média e transformações de unidades, solucionaram durante a aula poucas dúvidas e pedi para responderem a p.8 da apostila.

$18 / 03-1^{\circ} D_{2}$

Depois do intervalo é sempre difícil, mas passei na lousa 5 exercícios sobre velocidade média, a maioria dos alunos não fizeram, olhei todos os cadernos e apostilas, dei um sermão, cobrei as atividades atrasadas, enfim...

\section{$18 / 03-1^{\circ} \mathrm{C}_{2}$}

Ao entrar na sala, os alunos começaram agressivamente reclamar que dou muitas lições, então intervi cortando a reclamação. Hoje fiquei aliviada, pois me deparei com uma interprete na sala para o aluno deficiente auditivo, fiquei um tempo conversando com a mesma, para entender como trabalhar com o aluno. Olhai os cadernos e apostilas, pedi para os alunos atrasados terminarem a atividade três.

\section{$23 / 03-1^{0} D_{2}$}

Deixei esta aula para que terminassem as lições atrasadas, tanto do caderninho, quanto da apostila e do caderno.

\section{5/03 - $1^{\circ} \mathrm{C}_{2}$}

Expliquei aos alunos que iríamos na quadra fazer algumas medidas, escrevi no quadro o que teriam que medir e pedi para se organizarem em grupos. Fiquei surpresa, pois ao invés de ficarem contentes, ficaram reclamando que estava muito Sol para correr, bom não dei atenção, fomos a quadra, marquei os pontos de corrida e marcação para o tempo. Demoraram iniciar, pois estavam com vergonha, então iniciei comigo correndo e pedi para marcarem o tempo, depois pegaram o jeito e anotaram tudo. Pedi para alterarem o jeito de correr e verificar se havia diferença no tempo e assim foi...

Esticaram um barbante para ver a distância, após isso voltamos a sala de aula, e dividi o barbante em três pedaços e pedi que medissem o seu comprimento e me surpreendi, porque mesmo utilizando a régua de $30 \mathrm{~cm}$ forneceram os valores em metros, confirmei a medida fazendo algumas perguntas sobre as unidades de comprimento.

Na lousa fiz os cálculos de velocidade média com o meu tempo de corrida e pedi para que fizessem de cada integrante do grupo para avaliarmos o mais rápido, o mais lento dentro do grupo e depois verificarmos o grupo mais rápido. A partir disso, começaram a entender velocidade média e a conseguir comparar com um corredor de elite. Algumas questões apareceram como: Ele pegou impulso antes, por isso foi mais rápido. Não adianta eu ser o mais rápido, o grupo perdeu assim mesmo. Que esquisito o mais rápido é aquele que fez em menos tempo.

Confirmamos o valor da distância através das passadas de alguns alunos e todos se alegraram pois acertaram a medida. No final da aula olhei todos os cadernos e conferi as contas. 
$1^{\circ} D_{2}-25 / 03$

Como sempre chegam atrasados do intervalo, então rapidamente expliquei que iríamos fazer algumas medidas na quadra e o que precisariam anotar e quais cálculos faríamos depois.

Ficaram alegres por sair da sala, marquei a distância que iriam correr e se organizaram em grupos e começaram a medir de todos. Pedi para que cada integrante do grupo contassem quantos pés cabia na distância determinada para corrida. Havia alguns alunos que não queriam correr então pedi para que medissem o tempo da caminhada e assim foi...

Na sala de aula ensinei como fazer os cálculos, utilizei as minhas marcações, calculamos a distância com o pé de cada aluno que mediu e como deu diferente, fizemos a média.

Pedi para analisarem o aluno mais rápido e lento do grupo e depois comparem com a classe e com um corredor de elite para que eles percebam a importância do conceito de velocidade média.

\section{$\mathbf{1}^{\circ} \mathrm{D}_{2}-\mathbf{3 0 / 0 3}$}

Iniciei a aula colocando na lousa para entregar a folha do grupo com as contas, visto no caderno e na apostila. Para a folha do grupo tive que relembrar as instruções do que fazer, pois não haviam feito em casa, para variar. Propus para casa a p.16. Era um vuco, vuco, uns faziam o caderno, outros cálculos, outros apostila, e outros nada.Então pedi para os que terminaram tudo iniciarem a atividade 4. Apresentaram problemas com as unidades, mas depois que viram no caderno as transformações faziam. Muitos alunos que faltaram queriam ir correr, então tive que usar do jogo de cintura.

\section{$1^{\circ} D_{2}-01 / 04$}

Expliquei novamente velocidade média em detalhes, não sei mais como me expressar para entenderem. Fizemos novamente a p. 8, 16 e 12, e como estávamos em pouco número, fui com eles na rua para medir a velocidade dos carros. Acharam excelente, marcaram com o cronômetro do celular e agora acho que entenderam. Marcamos a distância com os pés e convertemos para metros, mas veja bem isso foi porque tinham poucos alunos

\section{$1^{\circ} \mathrm{C}_{2}-01 / 04$}

Iniciei colocando na lousa a p.8 e 16, fazendo a correção e explicando novamente velocidade média em detalhes. Falamos um pouco sobre o funcionamento de radares e pedi para que zerassem todas as páginas da apostila que havia passado para eu poder olhar. Na segunda parte da aula iniciamos a atividade 4. Como já haviam feito os cálculos com os dados da quadra, apenas se embaraçaram com as transformações de tempo, então fui para lousa para relembrar as transformações. Tiveram bastante dificuldade com a matemática, mas percebi que começaram a entender melhor o conceito. Para alguns alunos o conceito está difícil, mas acho que com o tempo vai.

\section{$1^{\circ} \mathrm{D}_{2}-06 / 04$}

Coloquei na lousa que era obrigatório entregar sem falta os primeiros exercícios da atividade 4, mas não deu certo estavam preocupados com a prova de biologia que seria na próxima aula, não adiantou lutar contra este fato. Alguns alunos disseram que foi muito boa a aula na rua que deveríamos repetir mais vezes. Poucos alunos fizeram a atividade 4 , estavam apáticos 
$1^{\circ} D_{2}-08 / 04$

Iniciei a aula devolvendo as folhas da atividade 4 corrigidas e pedi para que continuassem. Expliquei novamente como fazer a transformação de tempo, enfatizei o conceito de velocidade média exemplificando o que aconteceu com o corredor Vanderley na maratona de 2008, mas durante toda a aula preferiram conversar e apenas dois alunos se interessaram.

\section{$1^{\circ} \mathrm{C}_{2}-08 / 04$}

Iniciei pedindo para que terminassem a atividade 4. Coloquei na lousa um lembrete de transformações de tempo e exemplifiquei como proceder fazendo os cálculos para o Frank Caldeira, mas a dúvida que apareceu foi estranha, pois achavam que o que teria velocidade maior, faria em tempo maior também, então exemplifiquei para sala a situação do Vanderley novamente comparando velocidade com o tempo de corrida. Nesta aula estava previsto para eu passar o vídeo da corrida, mas mesmo agendando a sala de vídeo com uma semana de antecedência a coordenação fingiu que não tinha feito nada, então desisti, pois é melhor não mexer sem supervisão, vai que quebra. Todos os alunos se empenharam para realizar a atividade, solucionaram suas dúvidas. No final da aula coloquei várias situações nos esportes em que há colisões e os alunos começaram a dar importância não somente a massa, mas também a velocidade. Com os alunos deficientes auditivos (ah! entrou mais um) fiquei tentando explicar juntamente claro que com a interprete as unidades de tempo.

\section{$1^{\circ} D_{2}-13 / 04$}

Que confusão, como sempre cheguei na sala e somente tinha 3 alunos (a maioria chega atrasado). Comecei a passar aceleração escalar média e alguns exercícios, expliquei e pedi para resolver alguns exercícios que havia passado, e fiquei aguardando na minha mesa algum aluno interessado em solucionar dúvidas.

\section{$1^{\circ} \mathrm{C}_{2}-\mathbf{1 5 / 0 4}$}

Iniciei a aula colocando na lousa a teoria e alguns exercícios sobre aceleração escalar média. na segunda parte da aula liberei a atividade 4 para terminarem, pois estavam ansiosos para terminar, mas antes expliquei algumas modalidades esportivas, já o vídeo seria impossível de passar. Durante o desenvolvimento da atividade, me surpreendi com alguns alunos, pois esqueceram totalmente o conceito de velocidade média, mas ao exemplificar a acorrida na quadra lembravam dos cálculos. Ao fazer os exercícios de aceleração me perguntaram como fazer, aí me descontrolei: acabamos de ver isso a $30 \mathrm{~min}$, já esqueceram? Mas percebi que era pura preguiça, pois depois resolviam as questões tranquilamente. Não estou dando conta dos alunos que faltam, pois a todo o momento ficam me interrompendo, é difícil conciliar tudo, mas dou um jeito, o importante é não desestimular o aluno que quer fazer as tarefas.

\section{$1^{\circ} \mathrm{D}_{2}-\mathbf{1 5 / 0 4}$}

Como sempre entro na sala e há apenas dois alunos, mas já acostumei depois de 20 min estavam todos na sala, então deixo escrito na lousa para terminarem a atividade 4, mas é muito difícil estão em uma fase em que não se interessam por nada e não querem fazer nada, além do que fica difícil pois também perdem pontos importantes das explicações e das atividades por faltar ou ficar conversando na sala de aula, mas com paciência acho que vai, uma hora sai...

$1^{\circ} D_{2}-20 / 04$ 
Desta vez estou cansada, entrei calada e sai muda, apenas coloquei o que deveriam fazer na lousa (apostila p. 17 a 20). Poucos alunos vieram tirar dúvidas, a maioria ficou badernando. Saliento que não adianta dar "pit", as coisas só pioram, pois a maioria sempre vence, espero que tenhamos dias melhores.

$1^{\circ} D_{2}-22 / 04$

Não há quase alunos, e os que estão presentes, somente está o corpo, mas mesmo assim passei exercícios e expliquei: Peso de um corpo e dei visto em algumas apostilas.

$1^{\circ} \mathrm{C}_{2}-22 / 04$

Pedi para terminarem a p. 17 a 20 da apostila, pois necessitava fechar as médias, claro que fizeram direitinho. Na segunda parte da aula coloquei na lousa a teoria e alguns exercícios sobre Peso de um corpo e pedi que respondessem também a p. 22 e 23 da apostila. Mesmo com um número pequeno de alunos iniciei a atividade 5. Com os alunos deficientes auditivos tentei explicar e pedi para que fizessem outra atividade.

\section{$1^{\circ} D_{2}-24 / 04$}

Iniciei a aula colocando na lousa para responder p. 21 a 23 da apostila e para terminarem os exercícios da aula anterior, mas é raro quem me entregou alguma coisa.

\section{$1^{\circ} \mathrm{C}_{2}-29 / 04$}

Iniciei a aula com poucos alunos, mas mesmo assim pedi para que terminassem a atividade 5, re-expliquei peso e massa corporal e enfatizei a unidade de força, discutimos a massa de atletas e suas modalidades, os peso de gordura e músculo, enfim ficaram as duas aulas terminando a atividade 5 e colocando o caderno em ordem. Com os alunos deficientes auditivos comecei a explicar quantidade de movimento, claro que tudo visualmente sem cálculos.

\section{$1^{\circ} D_{2}-29 / 04$}

Muitos alunos faltaram por imprevistos na escola, mas mesmo assim decidi pedir para terminar a atividade 5, como sempre poucos fizeram, relembrei a diferença de massa e peso corporal.

\section{$1^{\circ} D_{2}-04 / 05$}

É uma "enrolação" para entrar na sala de aula, parece quanto mais pressiono pior é. Pedi novamente para terminarem a atividade 5 , mas continuam a fazer muita bagunça e devido a isso quando olham massa corporal querem calcular o IMC, mas enfim pelo menos lembram de algo.

\section{$1^{\circ} \mathrm{C}_{2}-06 / 05$}

Iniciei colocando na lousa a teoria e alguns exemplos sobre quantidade de movimento e impulso relacionados com o esporte e pedi para responderem p. 24 a 26. $\mathrm{Na}$ segunda parte da aula expliquei conservação da quantidade de movimento, resolvi com eles a p.37 e pedi para responderem p. 32 a 37 da apostila e novamente discutimos colisões pelo exemplo da maratona 2008. Articulei alguns exemplos simulando colisões entre eu (professora) e um aluno, um ginasta e um lutador de sumo.

\section{$1^{\circ} D_{2}-06 / 05$}

Expliquei rapidamente quantidade de movimento e impulso e já pedi para responder a p. 24 a 26 e fiquei sentada observando a falta de consideração com o 
professor, que bagunça, graças a Deus que não é somente na minha aula que se comportam desta maneira, mas em todas as aulas.

$1^{\circ} D_{2}-11 / 05$

Conselho de classe e série.

$1^{\circ} \mathrm{C}_{2}-13 / 05$

Passei na lousa um resumo das três leis de Newton, expliquei e fiz em detalhes a p.27 da apostila. Como havia poucos alunos estava uma paz e prestaram atenção. Na segunda parte da aula passei vários exercícios e pedi para responderem p. 27, 38, 40 a 43 da apostila.

$1^{\circ} D_{2}-13 / 05$

É tudo sempre igual chegam atrasados depois do intervalo, enquanto chegam passei na lousa a teoria e exercícios sobre conservação de movimento e expliquei como proceder para resolver as p. 32 a 37 da apostila, novamente poucos fizeram a atividade, pois a maioria só quer saber de conversar.

\section{$1^{0} D_{2}-18 / 05$}

Finalmente estão calmos hoje, consegui explicar resumidamente as três leis de Newton e fazer os exercícios da p. 27

\section{$1^{\circ} \mathrm{C}_{2}-20 / 05$}

Coloquei no canto da lousa um resumo da aula anterior e re-expliquei novamente a matéria, pois ao responderem a atividade 6 parece que não lembravam de mais nada, mas isso é porque estavam muito agitados falando muito e como tenho que tirar um tempo grande para explicar a matéria para os alunos deficientes auditivos eles se aproveitam disso para me burlar. Ah agora também tenho que cuidar de uma aluna que cumpre dependência de matéria.

\section{$1^{\circ} \mathrm{D}_{2}-20 / 05$}

Relembrei o conteúdo de algumas aulas anteriores e pedi para que fizessem a atividade 6 , hoje me procuraram bastante na minha mesa, solucionei várias dúvidas, mas também eles não prestam atenção nas aulas, mas assim não sei como tive paciência, mas tive.

\section{$1^{\circ} D_{2}-24 / 05$}

Iniciei a aula cobrando as lições atrasadas, fui interrompida várias vezes pelo coordenador, que deu um grande sermão na sala, claro que não resolveu, enfim esta aula não foi proveitosa.

\section{$1^{\circ} \mathrm{D}_{2}-27 / 05$}

Iniciei a aula explicando transformação de energia e pedi para responderem p.7 a 10 da apostila 2 e para finalmente terminar a atividade 7. Muitos alunos se queixaram sobre a questão 6, mas pacientemente expliquei a todos o que era para ser feito, também tiveram dúvidas no significado da palavra grandeza.

\section{$1^{\circ} \mathrm{C}_{2}-27 / 05$}

$\mathrm{Na}$ primeira parte da aula os alunos foram ao cinema assistir um filme da secretaria da educação. 
Na segunda parte da aula expliquei transformação de energia e pedi para responderem $\mathrm{p}$. 7 a 10 da apostila 2 e terminar a atividade 7 do caderninho. Muitos alunos não conseguiam interpretar as questões, mas de uma forma ou outra encaminhava as questões e pedia para lerem os textos. Exemplifiquei utilizando a loja de tênis e a plataforma e dei alguns exemplos de inércia nos esportes, pois não consegui fazer com que eles lessem o texto.

\section{$1^{\circ} D_{2}-01 / 06$}

Iniciei colocando transformação de energia e pedindo novamente a p. 7 a 10. Expliquei e passei alguns exercícios sobre trabalho de uma força e pedi para que terminassem de uma vez a atividade 7, mas tinha alguns alunos que haviam faltado nas aulas anteriores e acabaram copiando dos que não terminaram no prazo.

$1^{\circ} \mathbf{D}_{2}-03 / 06$ - Feriado

$1^{\circ} \mathrm{C}_{2}-\mathbf{0 3 / 0 6}$ - Feriado

$\mathbf{1}^{0} \mathbf{D}_{2}$ - 08/06 - Olimpíada de matemática

$1^{\circ} \mathrm{C}_{2}-10 / 06$

Havia poucos alunos, pois a maioria não veio para assistir a abertura da copa. Iniciei a aula colocando a teoria e alguns exercícios sobre trabalho de uma força e energia mecânica. Resolvi alguns exercícios da apostila a respeito e pedi para que finalizassem a tarefa da apostila da p.11 a 16.

$1^{\circ} D_{2}-20 / 06$

Coloquei na lousa a teoria sobre energia mecânica e pedi para que respondessem todos os exercícios das p. 11 a 16 da apostila.

$1^{\circ} \mathbf{D}_{2}$ - 15/06 - Jogo: copa

$1^{\circ} \mathrm{C}_{2}-17 / 06$

Expliquei potência e conversões de unidades e pedi para responderem os exercícios das p. 24 a 27 da apostila 2, enquanto isso fiquei explicando a matéria para os alunos deficientes auditivos. Na segunda parte da aula pedi para entregarem a segunda parte da atividade 7, mas no inicio reclamaram das frases, mas depois fizeram tranquilamente. Fiz também um apanhado geral da matéria das aulas anteriores.

$1^{\circ} \mathrm{D}_{2}-17 / 06$

Passei a teoria e fiz alguns exemplos sobre potência e pedi para responderem p.24 a 27 e deixei como tarefa p 29 e 42.

$1^{\circ} D_{2}-22 / 06$

Iniciei a aula com apenas 3 alunos, então decidi colocar na lousa a teoria e alguns exercícios sobre torque na lousa, depois de algum tempo quando todos finalmente chegaram resolvi a p.42 da apostila com eles e pedi para que finalizassem toda apostila exceto os experimentos que seriam entregues depois das férias.

$1^{\circ} \mathrm{C}_{2}-24 / 06$ 
Iniciei a aula colocando a teoria sobre torque e explicando alguns exercícios inclusive da p.42 e 44 da apostila 2 e pedi para que completassem toda a apostila 2.

$\mathrm{Na}$ segunda parte da aula pedi para terminarem a parte 2 da atividade do caderninho e fazer a atividade 8. Interessante, hoje estavam muito empenhados terminaram a sete sem problemas e iniciaram a atividade 8 , no qual discutiram sobre alavancas com os colegas e deram muitos exemplo já que haviam acabado de responder os exercícios da apostila sobre este assunto.

\section{$1^{\circ} D_{2}-24 / 06$}

Iniciei colocando na lousa que era obrigatório terminar a atividade 7 do caderninho, mas estava uma bagunça, e nem deram atenção, fizeram um pique-nique na sala e fingiram que eu não estava presente, não dei atenção para não gerar conflitos desnecessário. Apenas dois alunos fizeram as atividades, pois também estavam preocupados com as notas.

\section{$1^{\circ} \mathrm{D}_{2}-20 / 06$}

Bom comecei pedindo para terminarem a atividade 8 para que eu pudesse fechar as médias, muitos alunos se desesperaram, mas não adiantou pois não conseguiram terminar nada. Os alunos que se empenharam em fazer apresentaram bastante dúvidas, pois como sempre não prestam atenção na aula não há uma continuidade. Muitos da sala copiaram a atividade dos que estavam mais adiantados. Percebi que nunca conseguiriam terminar a atividade 8 então para não faltarem na próxima aula para que eu pudesse finalizar o bimestre.

\section{$1^{\circ} \mathrm{C}_{2}-01 / 07$}

Muitos alunos faltaram, pois declararam férias antecipadas, mas com os poucos alunos pedi para que finalizassem a atividade 8, terminaram sem dúvidas todas as questões em uma aula e na outra ficaram impacientes querendo saber das médias. Decidi por não aplicar a atividade 9 , pois tinham poucos alunos

\section{$1^{\circ} D_{2}-01 / 07$}

Tinha pouquíssimos alunos então entreguei o caderninho mesmo assim para terminarem a atividade 8 , mas nem deram atenção continuaram sem fazer nada.

\section{$1^{\circ} D_{2}-03 / 08$}

Iniciei colocando na lousa o planejamento do $2^{\circ}$ semestre, comentei e respondi com os alunos as páginas iniciais da cad.3. pedi para que fizessem as experiências da cad. 2 (p. 5, 6, 31, 32, 33, 34, 37, 38, 39 e 40) que restaram. Passei na lousa a relação dos alunos que precisavam entregar a ativ.8 e para os outros passei a ativ.9, mas como sempre é um tumulto só, mas algumas questões foram comuns a todos, o que é biomecânica? Expliquei e expliquei com calma, mas não sei se entenderam, embora tenha alguns alunos que sabiam o significado e apenas confirmavam comigo.

\section{$1^{\circ} \mathrm{C}_{2}-05 / 08$}

Iniciei a aula colocando na lousa o conteúdo para o $2^{\circ}$ semestre, cobrando as atividades de resumo e pesquisa, acertando notas e iniciando a cad.3 - p. 3 e 4. Pretendia fazer a post. 3 nesta aula, mas a maioria esqueceu, então resolvi distribuir a ativ. 9 que intitulei como prova do $3^{\circ}$ bimestre.

Rapidamente se organizaram e começaram a responder. Muitos alunos me perguntaram sobre o que é conceitos de biomecânica, tiveram dificuldade com essas palavras (devia 
ter usado mais nas aulas). Tiveram problemas em interpretar algumas questões, me chamaram muitas vezes, mas como sempre tive dificuldades em atender a todos, pois tenho que dar atenção aos deficientes auditivos.

\section{$1^{\circ} \mathrm{D}_{2}-05 / 08$}

Esta sala é difícil já depois do intervalo que bagunça, então só me resta dar o recado por escrito: "Termine a ativ. 9 ou ficará sem nota!". Demorou prestarem atenção, mas depois se organizaram e sossegaram. O problema é que um copia do outro, não importa o que eu diga. Parece que não lembram de nada.

$1^{\circ} D_{2}-10 / 08$

Iniciei cobrando as atividades da cad.3. Pedi para finalizarem a ativ. 9 e a atividade avaliatória do ex. 1 ao 3. É um milagre estavam muito calmos.

$1^{\circ} \mathrm{C}_{2}-12 / 08$

Iniciei colocando na lousa uma tabela gigantesca com algumas medidas de alguns planetas e fiz alguns cálculos, mas um aluno comentou que finalmente não haveria mais o caderninho (atividades). Mas aproveitei para aplicar a atividade avaliatória e a atividade pessoal (pedi para não colocarem o nome). Alguns alunos estão lentos e não conseguiram terminar, insisti mas...

$1^{\circ} D_{2}-19 / 08$

Expliquei os assuntos referentes a cad.3.

$1^{\circ} \mathrm{C}_{2}-19 / 08$

Expliquei os assuntos da cad. 3, esperando que alguns lembrassem de terminar a atividade avaliatória, mas achei melhor não insistir, já está ficando cansativo.

$1^{\circ} D_{2}-24 / 08$

Expliquei alguns dos assuntos da cad.3 e em seguida apliquei a avaliação pessoal (pedi para colocarem o nome e responderem com sinceridade), como sempre não terminarem, então pedi para que entregassem pronto na próxima aula. 